\author{
UNIVERSIDADE DE SÃO PAULO \\ MUSEU DE ARQUEOLOGIA E ETNOLOGIA \\ PROGRAMA DE PÓS-GRADUAÇÃO EM ARQUEOLOGIA
}

\title{
ESTUDO SOBRE A ICONOGRAFIA DE ÁPIS DURANTE O PERÍODO FARAÔNICO
}

\section{CORPUS I}

\author{
Cássio de Araújo Duarte
}

Orientador: Prof ${ }^{a} \operatorname{Dr}^{a}$ Maria Isabel D’Agostino Fleming

Linha de Pesquisa: Representações Simbólicas em Arqueologia

Tese apresentada ao programa de

Pós-Graduação em Arqueologia do Museu de Arqueologia e Etnologia da Universidade de São Paulo para obtenção do título de Doutor em Arqueologia.

São Paulo 


\section{Introdução ao Corpus}

Diante do diversificado leque de objetos correspondentes a uma ampla datação que selecionamos para o presente estudo, optamos por torná-la menos confusa ao público em geral evitando inúmeras subclassificações, e dividimos o presente corpus em dois blocos principais.

O primeiro, relativo aos monumentos de origem e cronologia diversas (MONdiv) corresponde a toda série de fontes iconográficas cuja procedência não é o Serapeum datadas do período faraônico, acrescidas de outras dos Período Ptolemaico e Romano, as quais utilizamos como apoio. Embora aí encontremos desde artefatos de pequenas dimensões e artigos funerários de túmulos privados até cenas provenientes de edifícios da realeza, achamos que seccionar esta parte, pela variedade de objetos da qual ela trata, só traria inconvenientes no momento de sua consulta. Por esta razão, e baseados na idéia de

que Ápis só ganhou um status de divindade no período em que passou a ser sepultado no Serapeum de Mênfis, acreditamos que esta seria uma linha demarcatória razoável para os fins de uma classificação menos barroca. Assim, na segunda parte, dedicada aos monumentos do Serapeum, cada subclassificação é precedida do termo "SE", e aqui procuramos agrupar os artefatos de acordo com a sua categoria.

Em virtude de sua heterogeneidade, a primeira subdivisão foi nomeada de “monumentos diversos do Serapeum”, e compreende vestígios arquitetônicos, de estatuária privada e as ilustrações que Mariette fez dos afrescos de duas sepulturas individuais. As partes seguintes estão dedicadas aos shabtis (SEsh) e às esculturas de Ápis que não são de bronze (SEesc). Por fim, temos as estelas (SEest) e os bronzes (SEbr), cuja proveniência não é necessariamente do Serapeum, mas são suposta ou comprovadamente originários da necrópole de Saqqara. 


\section{Códigos utilizados no Corpus}

$(!)$

Palavras em itálico
Não há ou não está presente.

Característica não mencionada, mas com possibilidade de constar. Um exemplo freqüente é o triângulo normalmente visto na fronte dos Ápis. Também vale para as ocasiões em que um detalhe não é observável na foto ou no artefato, que por motivo de oxidação ou má conservação pode ter perdido certas características, como as gravações do dorso, o triângulo na fronte, manchas etc.

Não mencionada na bibliografia ou nas fichas de museus, mas que podem estar presentes, uma vez que outras características ou símbolos que são vistos na fotografia não foram descritos.

Decoração não mencionada na bibliografia ou nas fichas de museus mas que estão presentes, mesmo que não seja possível perceber suas particularidades. Por exemplo, nota-se uma figura alada mas não é possível saber de qual se trata (disco, escaravelho, abutre).

Há indícios de representação, mas não muito precisos, por exemplo:

Imagem alada I: escaravelho alado (?) - neste caso, e pelo motivo das informações não serem sempre precisas nas fichas e na bibliografia, sendo a única fonte direta uma fotografia de perfil, supõe-se com base em algum indício que, por mais frágil que seja, deve ser mencionado. No caso citado, pela observação de traços que lembram as pernas de um escaravelho, supõe-se assim que se trate desse inseto, embora não possa ser de todo afirmado.

No texto descritivo, (?) pode exprimir a dúvida sobre uma particularidade não mencionada e não visível nas fotografias, mas que, dado as estatísticas, pode estar presente: por exemplo, cauda unida à perna posterior direita (?).

Exprime dúvida sobre uma suposição fundamentada em outros indícios que os apresentados pela fonte, por exemplo: Serapeum ? (indica a dúvida sobre essa proveniência, embora haja possibilidade do artefato ter vindo desse local como tantos outros de uma coleção).

Para termos especiais, como "uraeus", e observações contidas nas fichas ou na bibliografia. 


\section{MONUMENTOS DE ORIGEM E \\ CRONOLOGIA \\ DIVERSAS}

(MONdiv) 


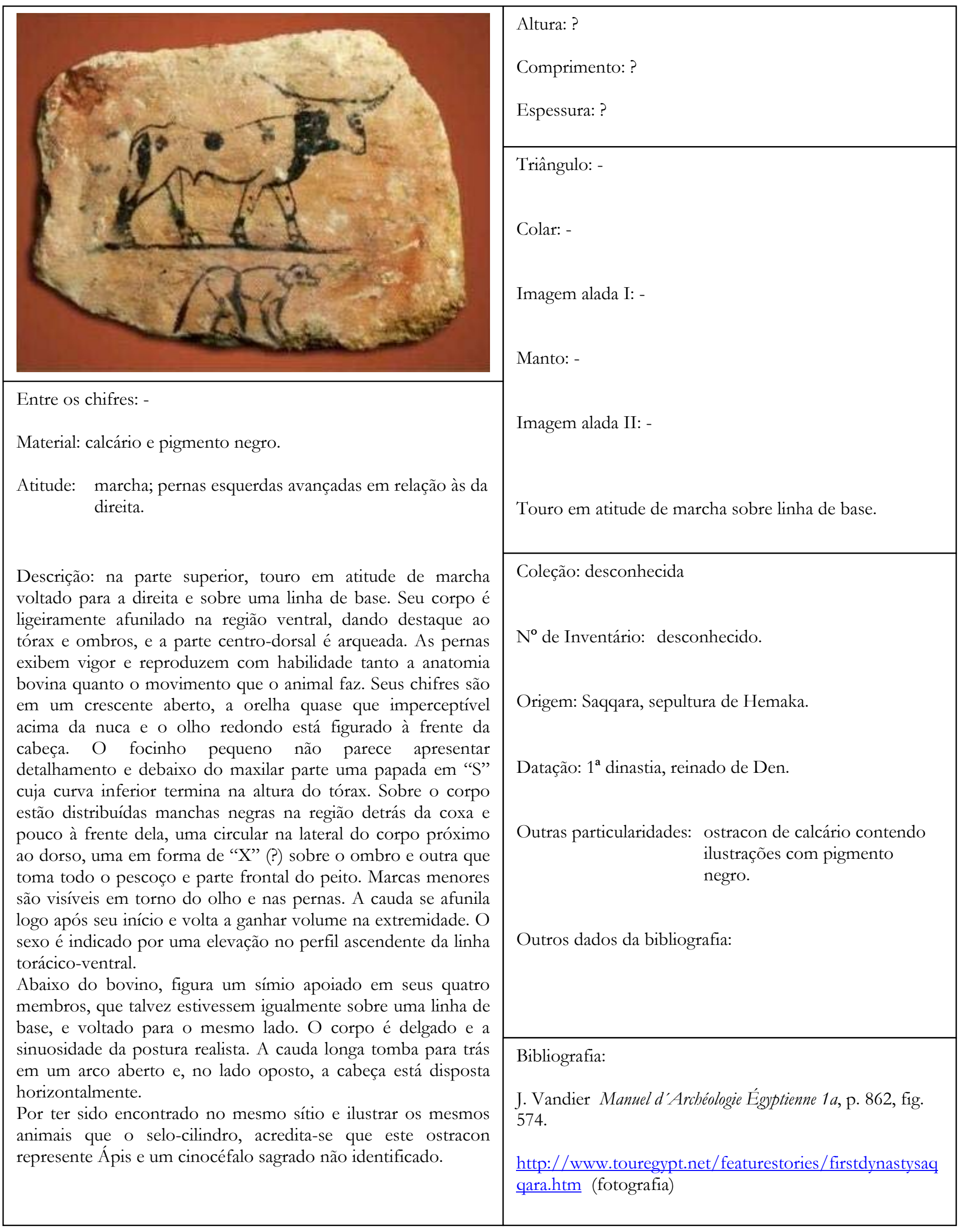




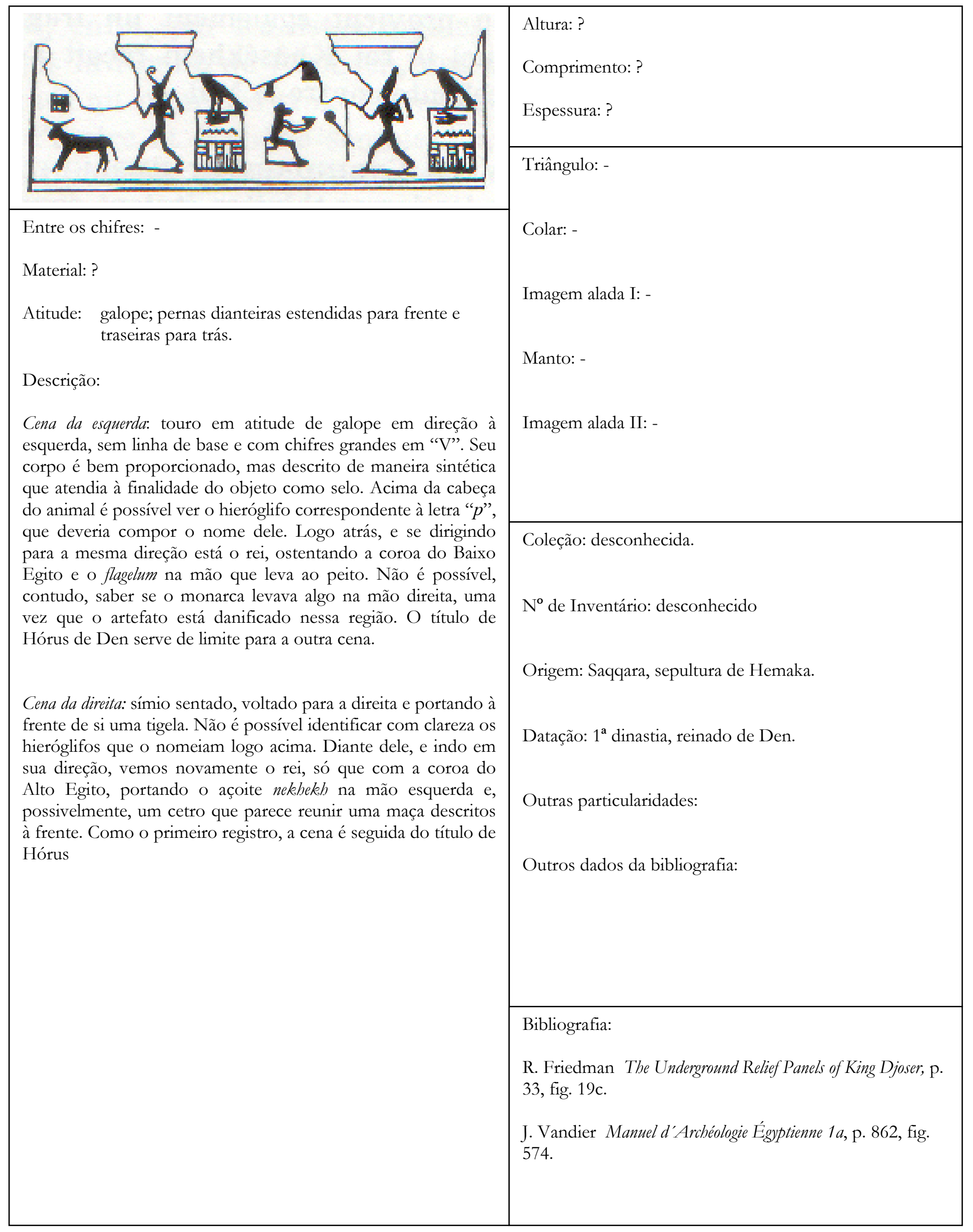




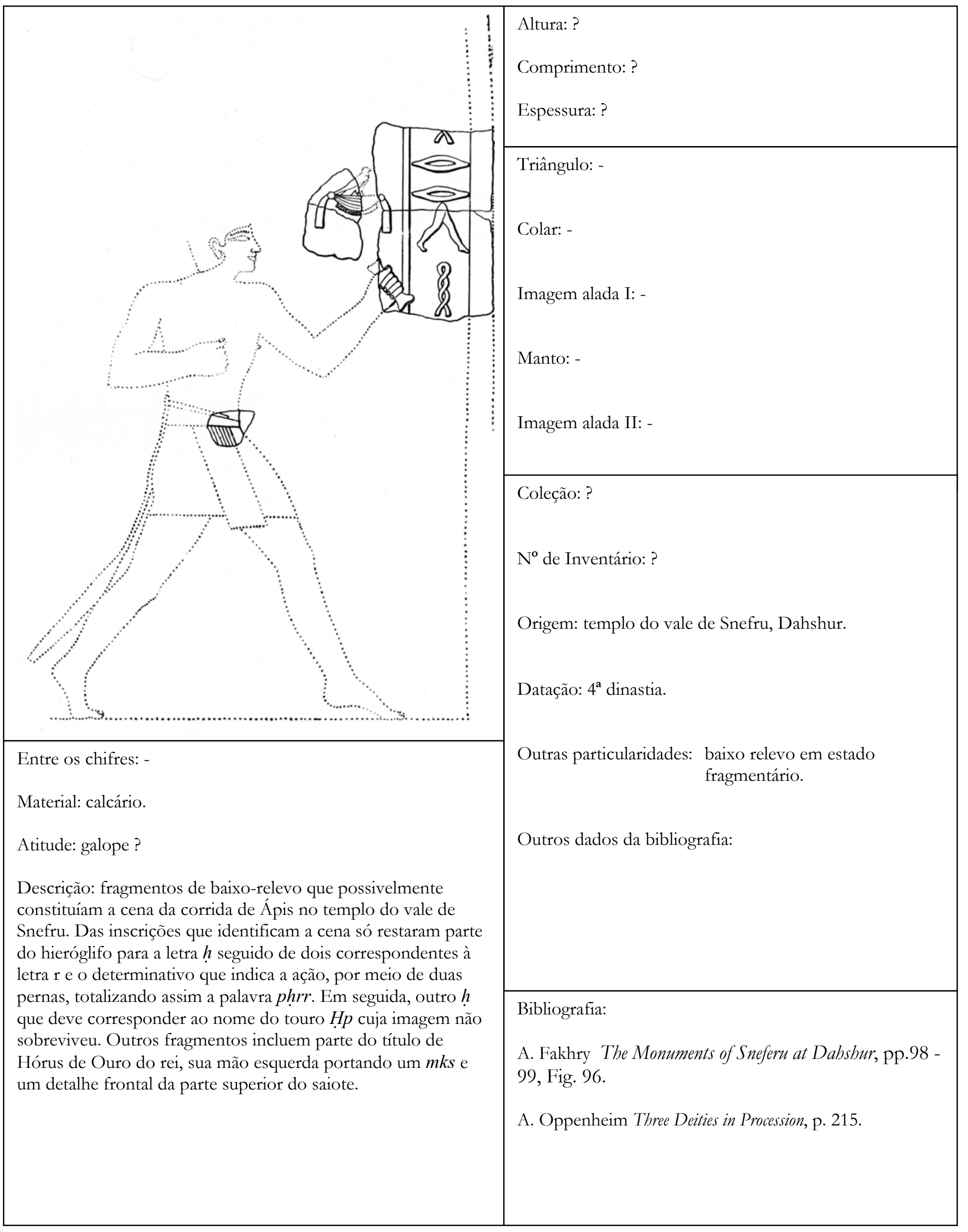




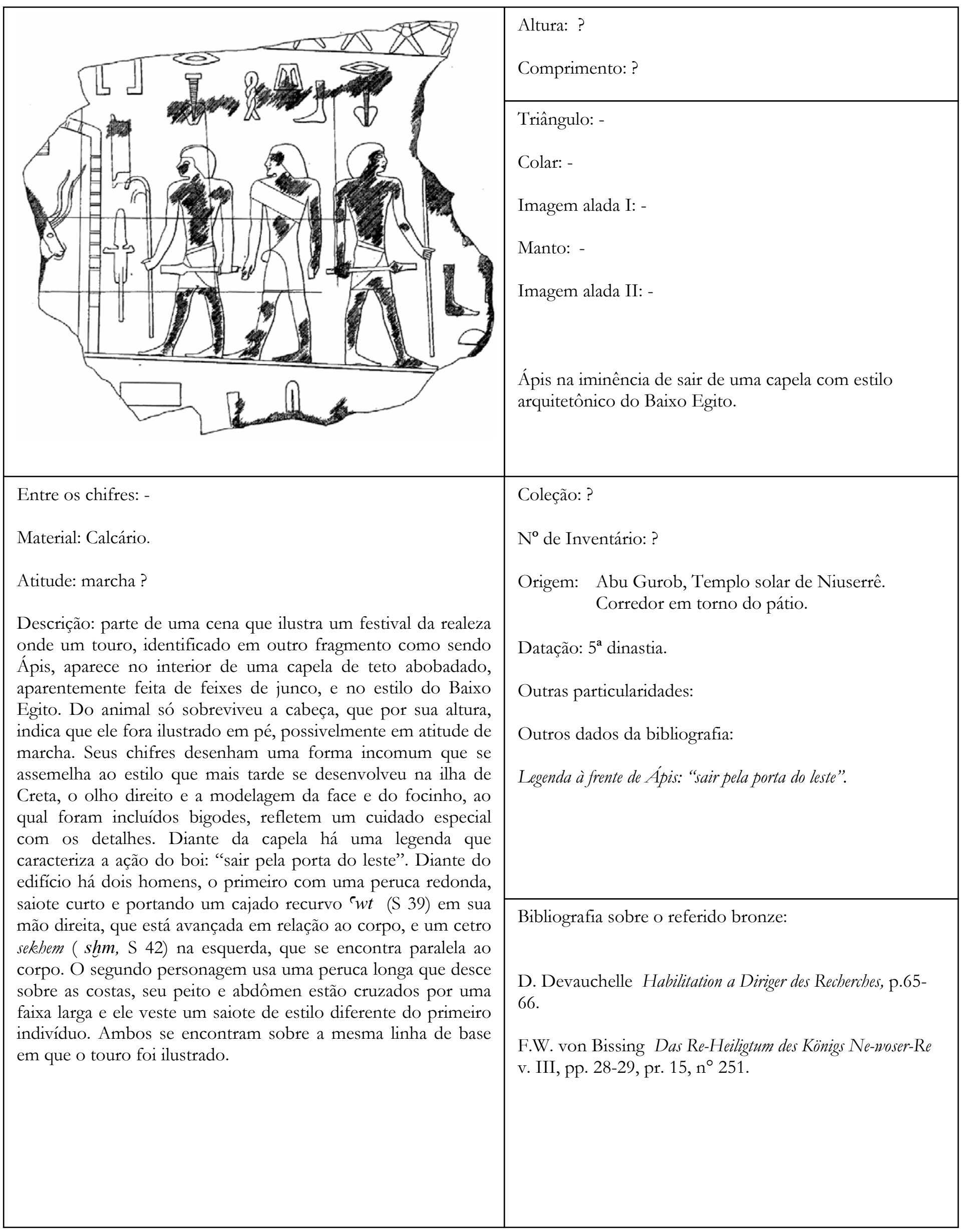




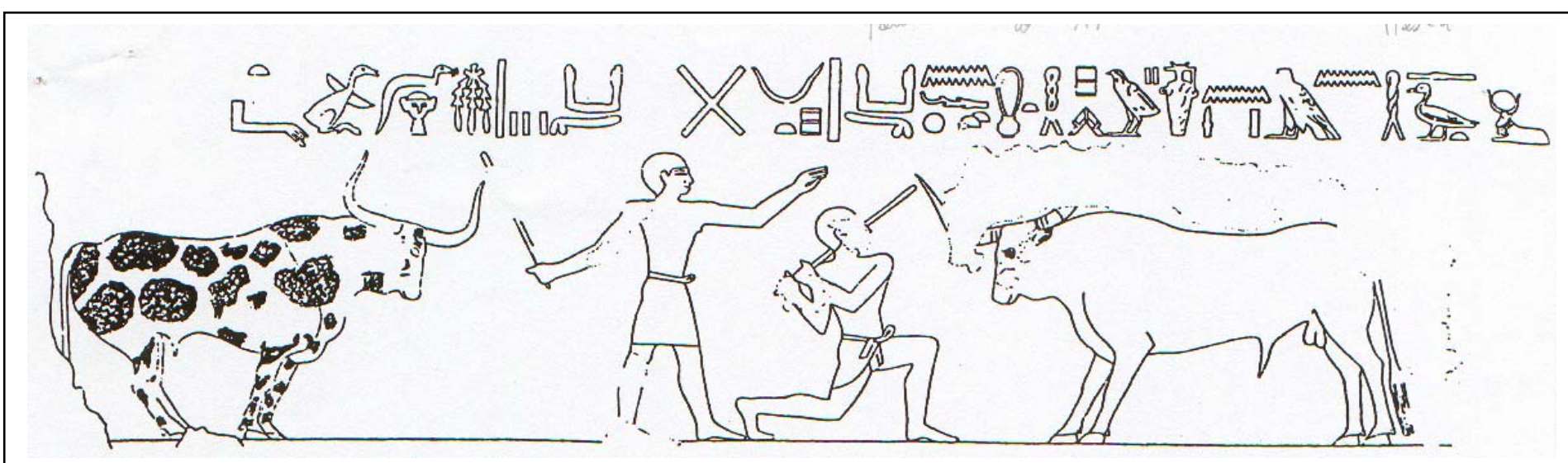

Altura: ?

Comprimento: ?

Entre os chifres: -

Material: afresco.

Atitude: galope; pernas dianteiras estendidas para frente e traseiras para trás.

Descrição: cena de tauromaquia composta por dois touros que se enfrentam, localizados nas extremidades esquerda e direita da imagem, e intermediados por dois homens ao centro dirigidos para o animal da direita. $\mathrm{O}$ touro à sinistra, ilustrado em pleno galope, tem as pernas direcionadas para uma mesma região no solo abaixo de seu peito, postura esta que transmite mais vivacidade do que aquela do animal do lado oposto, que parece estar na retaguarda. Mesmo desempenhando tamanha força para movimentar-se, a cauda parece estar inabalada em sua inércia. O corpo grande e em plena maturidade exibe manchas negras grandes espalhadas por sua pelagem alva, característica que lhe deu sua denominação como "o manchado rival". A cabeça é tratada com uma serenidade que contrasta com o aspecto agressivo da cena e dos chifres amplos e pontiagudos. A sinuosidade dorsal imprime com grande fidelidade a anatomia do movimento desenvolvido pelo animal. $\mathrm{O}$ primeiro personagem se encontra em pé, vestido com um saiote curto e liso, e seus braços abertos refletem a atitude de atiçar os animais com uma vara na mão direita. $\mathrm{O}$ outro, desempenhando a mesma função, está agachado, veste um saiote ainda mais curto que contém uma amarra, e suas mãos, que seguram um bastão, estão posicionadas na altura do ombro direito. Ambos têm suas cabeças raspadas ou cobertas com um toucado e acima deles a legenda diz: "arbitrando touros". O outro bovino, que parece ligeiramente superior em sua massa corporal e cujo órgão sexual foi ilustrado com maior destaque, exibe as mesmas qualidades na modelagem de sua anatomia, a pelagem é alva e os chifres são consideravelmente grandes. As pernas, no entanto, configuram a atitude de galope com menos maestria que as do rival. Acima dele o texto diz: "touro poderoso, semelhante a Ápis, amamentado por Hesat”.
Triângulo: -

Colar: -

Imagem alada I: -

Manto: -

Imagem alada II: -

Touro em atitude de galope em cena de tauromaquia.

Localização: in situ, capela da tumba de Senbi, filho de Ukhhotep, em Meir.

$\mathrm{N}^{0}$ de Inventário: -

Datação: reinado de Amenemhat I, $12^{\mathrm{a}}$ dinastia.

Outras particularidades: desenho de afresco.

Outros dados da bibliografia:

Bibliografia:

D. Devauchelle Habilitation à Diriger des Recherches, p. 63.

J. M. Galán Tauromaquía en el Antiguo Egipto, pp.43-44 


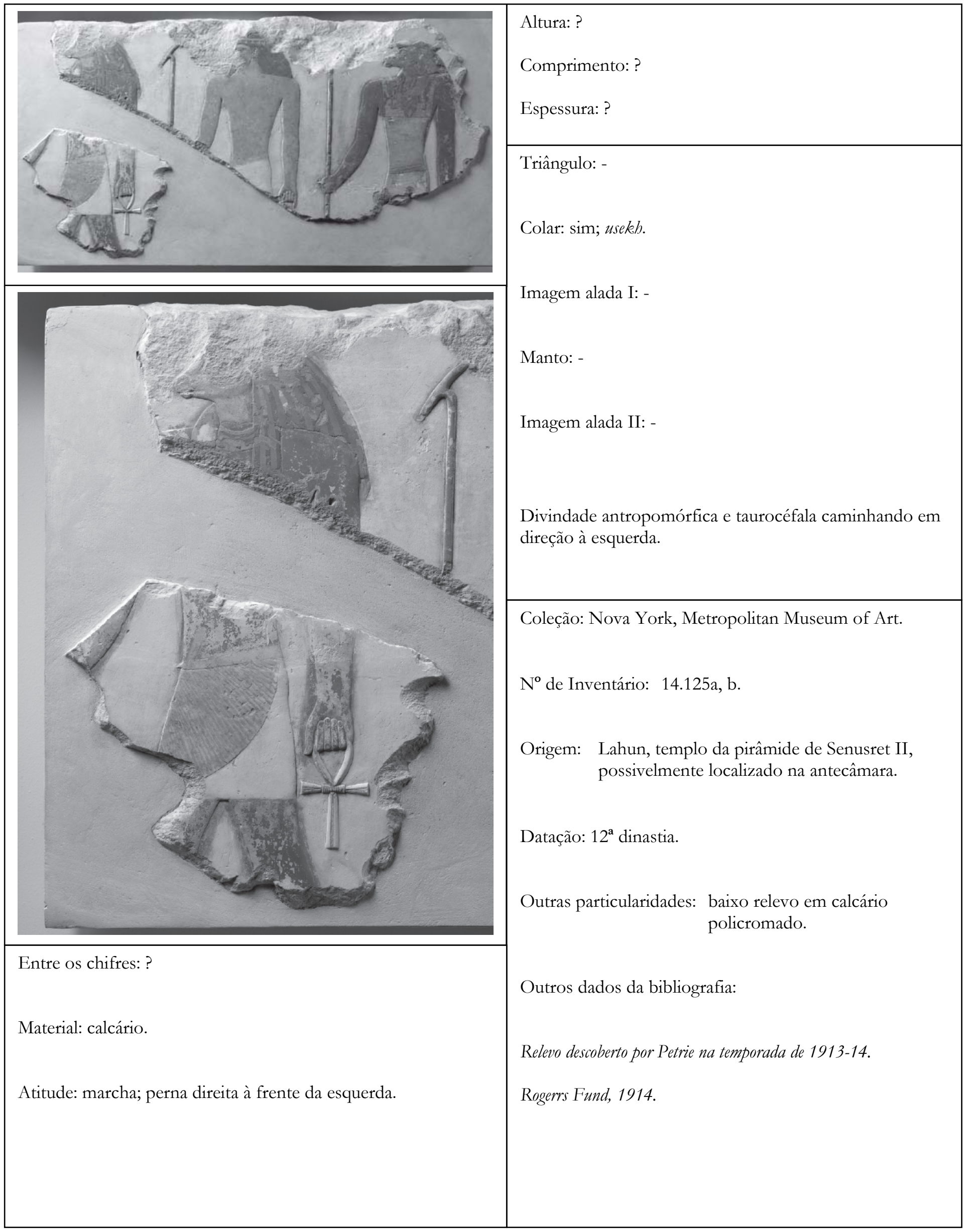


Descrição: procissão de três divindades voltadas para a esquerda e cujo registro se encontra bastante danificado e anepígrafo. Da primeira, que representa uma divindade taurocéfala, só restaram a parte superior, que compreende a cabeça e parte dos ombros e braço esquerdo, e a inferior, na qual se observa uma porção dos braços direito e esquerdo, e a região que engloba o abdômen, o saiote e o início das pernas. Sua cabeça, pintada de amarelo e muito desgastada na parte de cima, revela os contornos precisos do focinho e do maxilar, além da modelagem em relevo dessas partes que inclui a boca e a narina, tratadas com grande discrição. Do olho, nota-se parcialmente o seu contorno inferior e tanto a orelha como os chifres foram apagados. Uma peruca klaft pesada e com cachos verdes e azuis cobre-lhe a zona posterior da cabeça, descendo sobre as costas e peito. A transição para o corpo humano, o qual é pintado de vermelho, se faz por intermédio de um colar com carreiras verdes e azuis. A mão esquerda, curiosamente tratada como se fosse a direita, é caprichosamente moldada, exibe as unhas e porta um ankh. Um saiote shendyt com cinturão plissado na sua parte frontal, que é pintada de amarelo, é a única peça de vestuário do deus.

O segundo personagem, que tem uma tez vermelha e é identificado como Sopdu pelo tipo de peruca e barba em estilo asiático, foi mais afortunado do que o anterior pela sobrevivência de uma maior parte de seu registro, embora as particularidades de sua face estejam igualmente destruídas. O olho amendoado ainda guarda traços da maquiagem verde, a orelha é realista e tanto a barba quanto o cabelo estão pintados de uma tonalidade marrom-avermelhada. Em torno da cabeça há um aro pintado de amarelo onde se observa, na direção do olho, parte de uma das duas plumas que estavam associadas ao diadema. Sopdu não exibe colar e veste somente um saiote, que é inteiramente branco. Sua mão esquerda recebeu o mesmo tratamento que a da divindade taurocéfala e carrega parte de um ankh. O braço direito está avançado, ligeiramente flexionado, e a mão correspondente ostenta um cetro was, visível somente em sua parte superior.

Por fim, temos uma divindade criocéfala que exibe um vestuário mais completo, constituído de um tipo de colete com alças triangulares atadas na parte superior por nós e um saiote branco com cauda de touro e um nó tjet à frente, abaixo do cinturão. O pescoço está ornado de um colar com bandas verdes e azuis alternadas e a cabeça recoberta de uma peruca tripartite como a da primeira divindade. A tez do corpo humano é vermelha enquanto a da cabeça e pescoço é verde. Como nas demais representações, um tratamento atencioso foi dado à cabeça, que ilustra cornos horizontais espiralados, olho alongado com duto lacrimal, a orelha tombada para frente e um focinho afeiçoado com boca e narina indicados. A frente de si porta um cetro was (?) verde e na mão esquerda, como as demais divindades, possivelmente segurava um ankh.

Bibliografia:

W. C. Hayes The Scepter of Egypt v.1, p. 200.

A. Oppenheim Three Deities in Procession, pp. 207-218. 

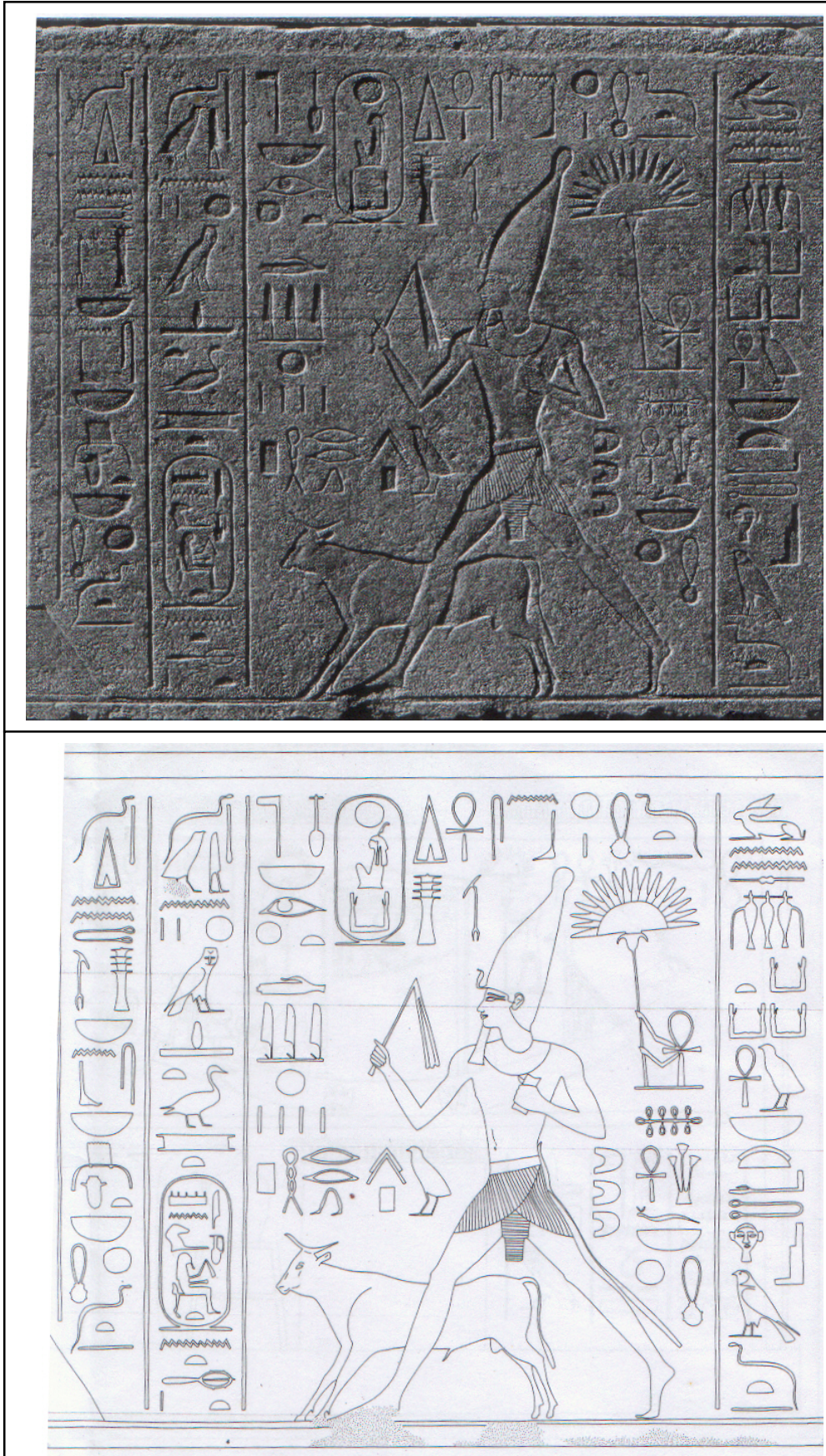

Entre os chifres: -

Material: Granito.

Atitude: galope; pernas frontais estendidas para frente e traseiras para trás.
Altura: ?

Comprimento:?

Espessura: ?

Triângulo: -

Colar: -

Imagem alada I: -

Manto: -

Imagem alada II: -

Ápis em atitude de galope em cerimônia da realeza.

Localização: in situ, Capela Vermelha de Hatshepsut, Templo de Karnak.

$\mathrm{N}^{0}$ de Inventário: ? bloco 102.

Datação: $18^{\text {a }}$ dinastia, reinado de Hatshepsut.

Outras particularidades: textos e imagens escavados.

Outros dados da bibliografia:

Parada na capela de celcita de Amenhotep I, "Firme é a fuindação de Amon". Hatshepsut, ofertando os campos, corre ao lado do touro Apis. 
Descrição: parte da cena que ilustra a corrida de Ápis na Capela Vermelha de Hatshepsut, em Karnak. No presente registro, a monarca trajada como faraó desempenha a corrida diante da capela de calcita de Amenhotep I, tendo atrás de si três dos seis marcos territoriais que simbolizavam as Duas Terras. Voltada para a esquerda, ela veste um shendyt plissado com cauda taurina, o pescoço está ornado de um colar usekh e à cabeça ostenta a coroa do Alto Egito com uraeus e uma barba postiça no queixo. Os braços se encontram flexionados e nas mãos Hatshepsut porta um flagelum e um mks - o primeiro na direita e o outro na esquerda junto ao peito. Ao lado dela, em segundo plano, menores dimensões e voltado para a mesma direção há uma representação de Ápis em galope, com suas pernas frontais estendidas para frente e as traseiras para trás, com os cascos pousados na mesma linha de base que define a composição. $O$ corpo do animal exibe boas proporções, a modelagem da cabeça e demais partes refletem um cuidado atencioso com a anatomia, mas observa-se pela descrição dos cascos e pernas a busca por linhas mais leves. A face do animal apresenta suaves contornos e desníveis que reproduzem as saliências naturais da cabeça, como a fossa orbital que se desenvolve abaixo do olho marcando o focinho. A orelha localiza-se atrás da nuca e os chifres pequenos são configurados em "V. Acima de sua cabeça está escrito:"a corrida de Ápis" e na coluna vertical "dar os campos quatro vezes", intitulando assim o tema ilustrado.

Bibliografia:

F. Burgos, F. Larché La Chapelle Rouge v.1, p. 63.

D. Devauchelle Habilitation à Diriger des Recherches, p.57. 


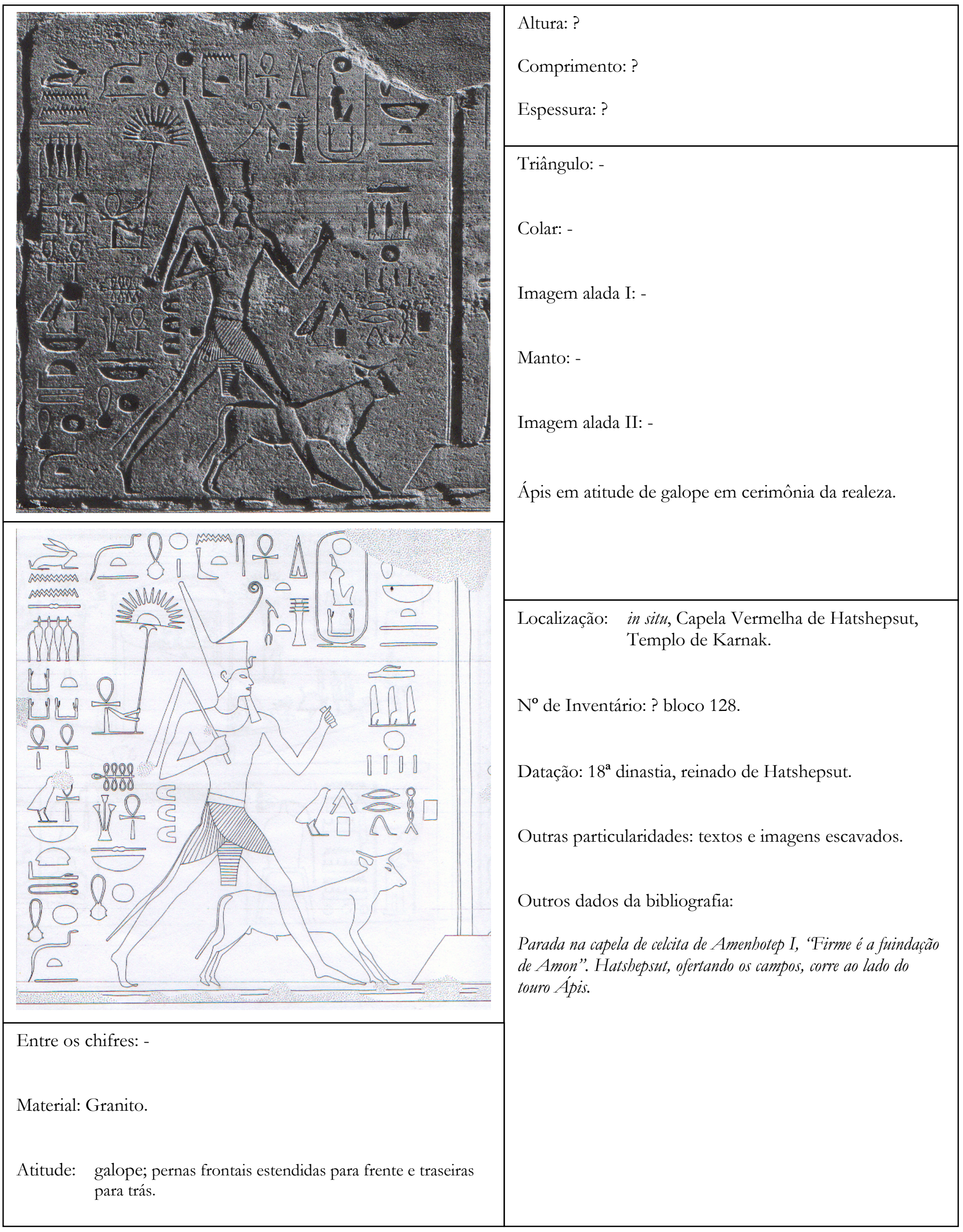


Descrição: Descrição: parte da cena que ilustra a corrida de Ápis na Capela Vermelha de Hatshepsut, em Karnak. No presente registro, a monarca trajada como faraó desempenha a corrida diante da capela de calcita de Amenhotep I, tendo atrás de si três dos seis marcos territoriais que simbolizavam as Duas Terras. Voltada para a direita, ela veste um shendyt plissado com cauda taurina, o pescoço está ornado de um colar usekh e à cabeça ostenta a coroa do Baixo Egito com uraeus e uma barba postiça no queixo. Os braços se encontram flexionados e nas mãos Hatshepsut porta um flagelo nekhekh e um mks - o primeiro na direita e o segundo na esquerda. Ao lado dela, em segundo plano, menores dimensões e voltado para a mesma direção há uma representação de Ápis em galope, com suas pernas frontais estendidas para frente e as traseiras para trás, com os cascos quase que flutuando sobre a linha de base que define a composição. O corpo do animal exibe boas proporções, a modelagem da cabeça e demais partes refletem um cuidado atencioso com a anatomia, mas observa-se pela descrição dos cascos e pernas a busca por linhas mais leves. A face do animal apresenta suaves contornos e desníveis que reproduzem as saliências naturais da cabeça, como a fossa orbital que se desenvolve abaixo do olho marcando o focinho. A orelha localiza-se atrás da nuca e os chifres pequenos são configurados em "V. Acima de sua cabeça está escrito:"a corrida de Ápis" e na coluna vertical "dar os campos quatro vezes", intitulando assim o tema ilustrado.

Bibliografia:

F. Burgos, F. Larché La Chapelle Rouge v.1, p. 110. 


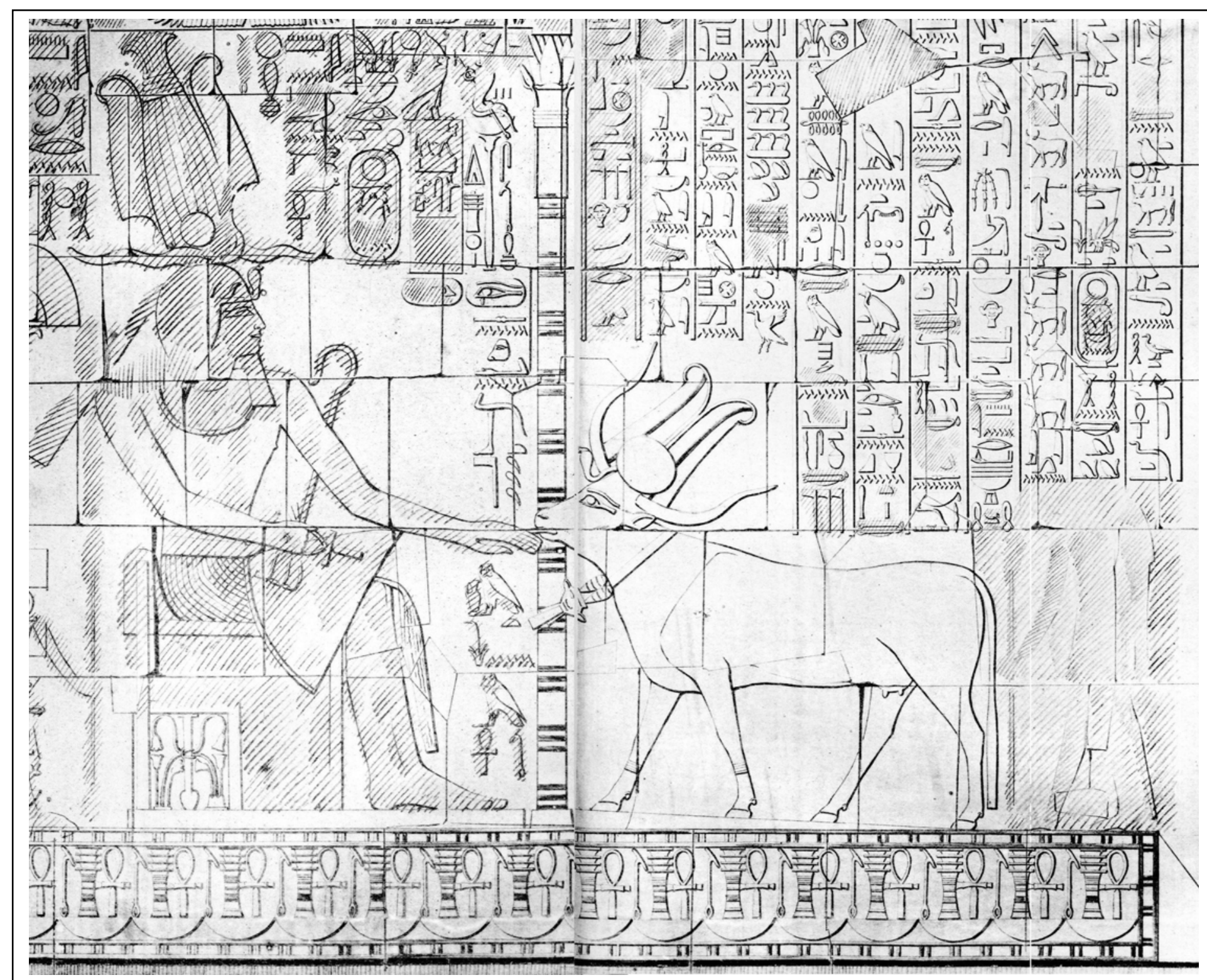

Triângulo: ? apagado

Colar: ? apagado

Imagem alada I: -

Manto: -

Imagem alada II: -

Suposta representação antropomórfica e taurocéfala de Ápis.
Altura: ?

Comprimento: ?

Entre os chifres: ? apagado

Material: calcário

Atitude: marcha; perna direita avançada em relação à da esquerda. 
Descrição: À esquerda, sentada em um trono cúbico sobre uma base baixa e no interior de um pavilhão encontra-se Hatshepsut, cuja imagem está severamente destruída. Trajada como um rei, ela vestia um saiote plissado com projeção triangular ornado de um cinturão com cauda, uma barba postiça e uma peruca globular sobre a qual ostentava uma coroa atef. Um diadema com uma banda traseira e uma uraeus na fronte contornava a cabeça e um colar usekh enfeitava o pescoço. $\mathrm{O}$ braço esquerdo se estendia à frente e a mão lambida pela vaca Háthor. O punho direito repousava sobre o colo, e outrora portava um ankh e um cetro heka. A vaca, cuja imagem não foi depredada, exibe boas proporções e as linhas que compõem seu corpo tratam a anatomia bovina com traços precisos e o úbere foi descrito com sutileza ímpar. No pescoço ela leva um colar com um pingente grande semelhante às representações de sistros, com uma cabeça humana provida de orelhas bovinas, mas com uma barba trapezoidal e longa. Entre os chifres longos a deusa apresenta uma coroa com um par de plumas e um disco com ureaus, a qual desce sobre a fronte da deusa. A cabeça foi tratada com cuidado especial, com um focinho que exibe formas afeiçoadas e narinas e boca discretas. O olho e sobrancelha maquiados transmitem uma caracterização humanizada à vaca. Atrás dela, e voltada para a mesma direção distinguem-se vestígios da representação de uma divindade, portando à sua frente um cetro was (?) na mão direita e, possivelmente, um ankh na esquerda. Traços da cauda do saiote são visíveis, mas a porção superior do corpo está completamente apagada. Sua identificação à forma antropomórfica de Ápis é sugerida pelo texto da terceira coluna contando da direita, aqui representado incompleto.

Os três personagens estão sobre uma base retangular alta, decorada repetidamente com os símbolos ankh, djed e was sobre o hieróglifo neb, significando "toda a vida, estabilidade e poder".
Localização: in situ, Templo de Deir el Bahari

$\mathrm{N}^{0}$ de Inventário: -

Datação: reinado de Hatshepsut, $18^{\mathrm{a}}$ dinastia.

Outras particularidades:

Outros dados da bibliografia:

Bibliografia:

C. Desroches-Noblecourt La Reine Mystérieuse Hatshepsout, pp. 320-321.

D. Devauchelle Habilitation à Diriger des Recherches, pp. 6465.

E. Naville The Temple of Deir el Bahari v. IV, pr. 94R. 


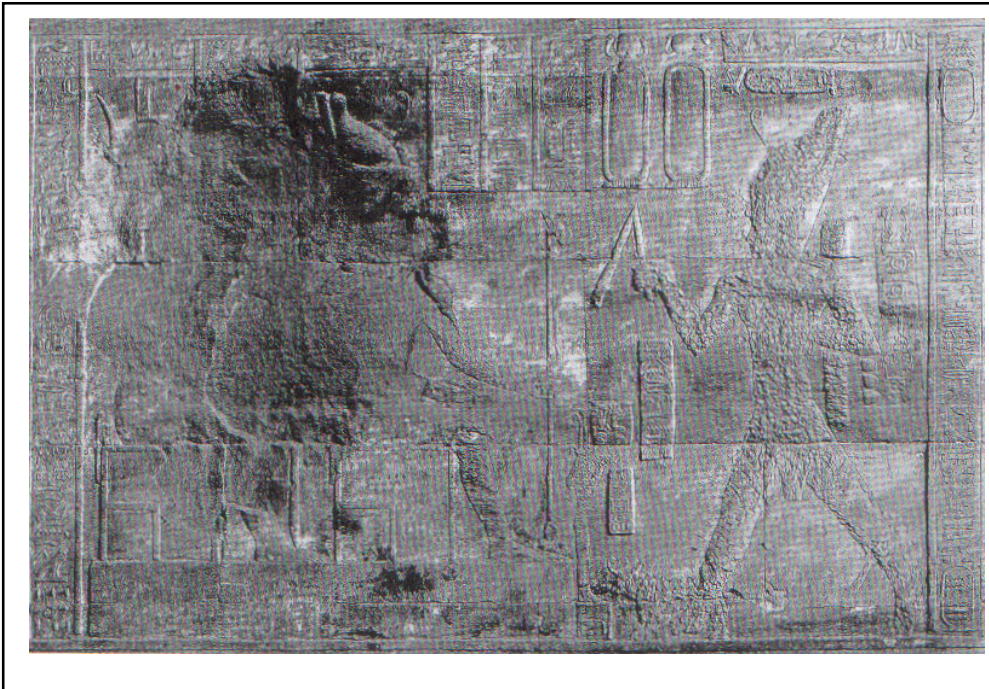

Entre os chifres: -

Material: arenito.

Atitude: galope; pernas dianteiras estendidas paralelamente para frente e as traseiras para trás.

Descrição: Cena em que o rei faz a oferta do açoite nekhekh para Hórus, o qual está acompanhado de Ísis. O monarca está ilustrado correndo com a coroa do Alto e Baixo Egito, o pschent, $e$ os deuses estão sentados em tronos cúbicos sobre uma base retangular longa e alta, mas tanto os detalhes de sua representação quanto os do rei estão severamente comprometidos. Das divindades se distinguem suas coroas: a de Hórus, semelhante à do governante, e a de Ísis, composta de um par de chifres de vaca que emoldura um disco solar. Ao lado do pé direito do rei, em pequenas proporções, é possível distinguir a imagem de Ápis em galope com seus chifres modelados em "V", mas como as demais particularidades do registro, seus pormenores estão muito prejudicados e não é possível notar a presença de símbolos.
Altura: ?

Comprimento: ?

Triângulo: -

Colar: -

Imagem alada I: -

Manto: -

Imagem alada II: -

Ápis em atitude de galope.

Localização: in situ, Templo de Dendera, Egito.

$\mathrm{N}^{0}$ de Inventário: -

Datação: Período Ptolemaico.

Outras particularidades: figuras e textos gravados em baixo relevo.

Outros dados da bibliografia:

Bibliografia:

S. Cauville Dendara I, pp.162-164, pr. XLV.

D. Devauchelle, Le Taurean Apis, p. 103-105. 


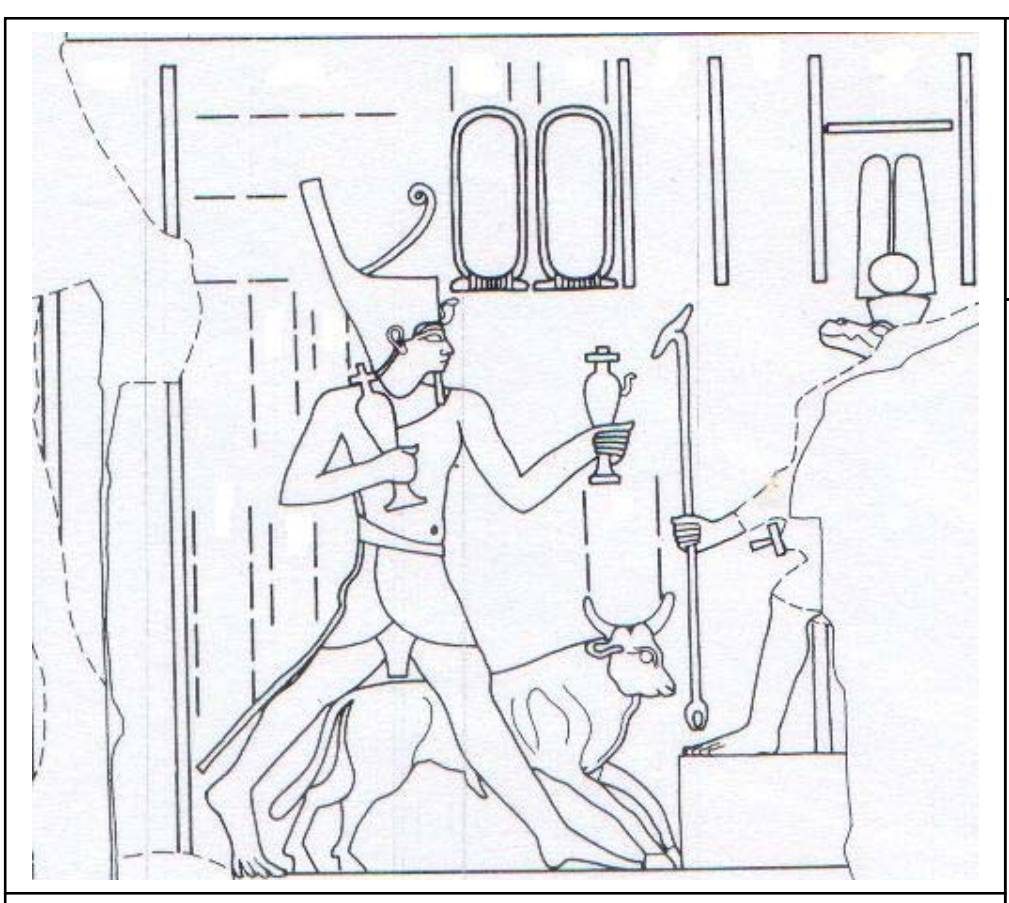

Entre os chifres: -

Material: arenito.

Atitude: galope; pernas frontais estendidas para frente e traseiras para trás.

Descrição: rei ilustrado em atitude de corrida, com saiote shendyt com cauda de touro, ostentando a coroa vermelha do Baixo Egito e portando dois vasos para libação - o da mão esquerda contendo um bico. Ele se dirige para a Sobek, o deus crocodilo, que está sentado em um trono cúbico que se encontra sobre uma base retangular alta. $\mathrm{Na}$ mão direita o deus apresenta um cetro was e na esquerda um ankh. Ao lado do monarca está Ápis, em atitude de galope e com o corpo desprovido de seus símbolos característicos. $\mathrm{O}$ animal apresenta boas proporções, ao seu movimento foi dado um toque de realismo e as particularidades de sua anatomia estão destacadas. Os chifres em crescente não trazem o característico disco solar e o triângulo que aparece em sua fronte pode ser um detalhe anatômico da cabeça. Os olho grande e arredondado tem pálpebras, o focinho bem modelado traz narina e boca discretas e a orelha direita está bem configurada. Tanto o touro quanto o rei estão descritos sobre a mesma linha de base, mas como em outras cenas similares o animal apresenta menores dimensões.
Altura: ?

Comprimento: ?

Espessura: ?

Triângulo: sim?

Colar: -

Imagem alada I: -

Manto: -

Imagem alada II: -

Ápis em atitude de galope com o corpo aparentemente desprovido de todos os seus símbolos sagrados.

Localização: in situ, Templo de Kom Ombo.

$\mathrm{N}^{0}$ de Inventário: -

Datação: Período Ptolemaico-Romano.

Outras particularidades:

Outros dados da bibliografia:

O rei corre ao lado de um touro (o nome não é dado) portando dois vasos qebeh; o título da cena é "apresentar o vaso-qebeh à seu pai".

Bibliografia:

D. Devauchelle, Le Taurean Apis, p. 104

A. Gutbub Kôm Ombo I, pp.238-241. 


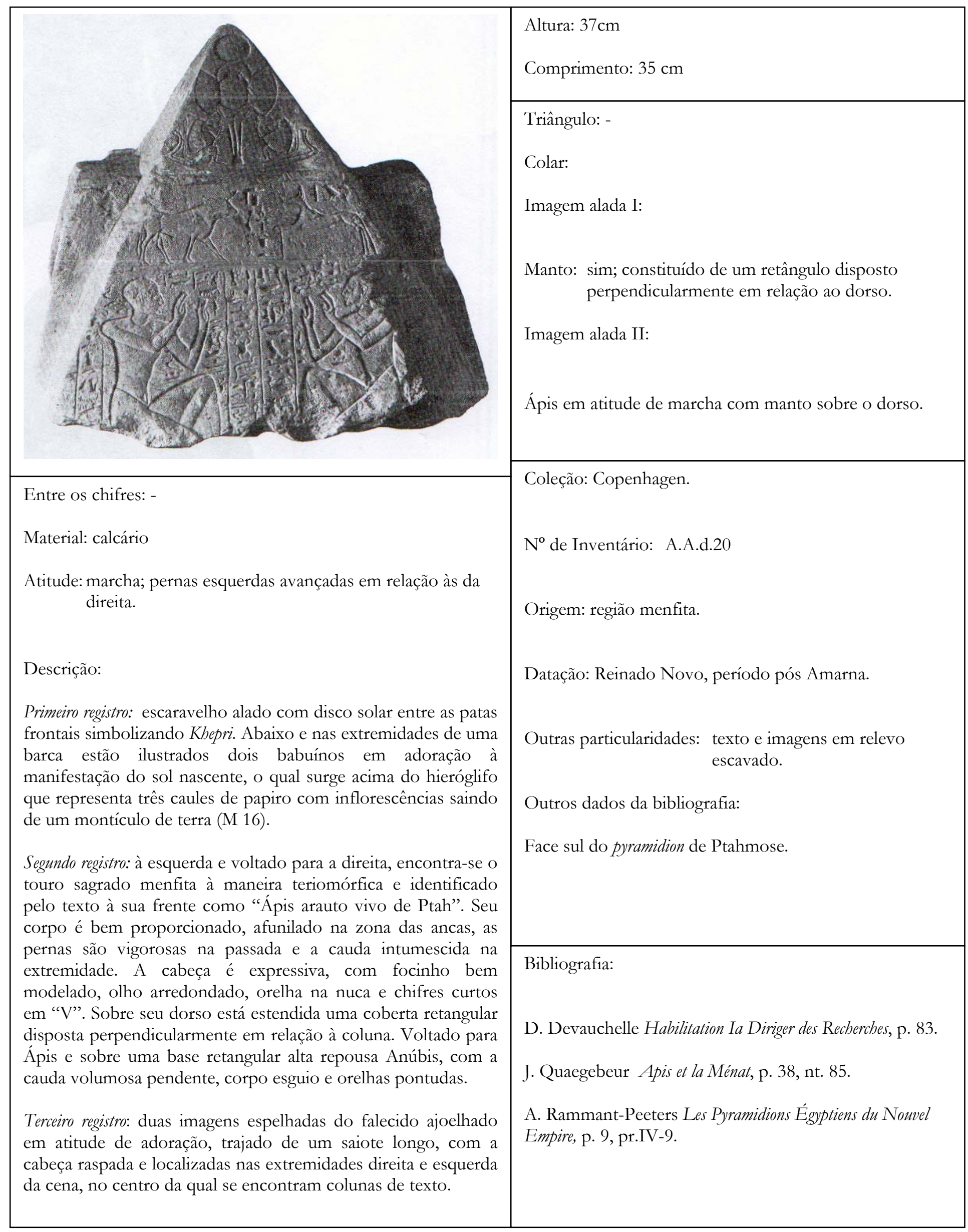




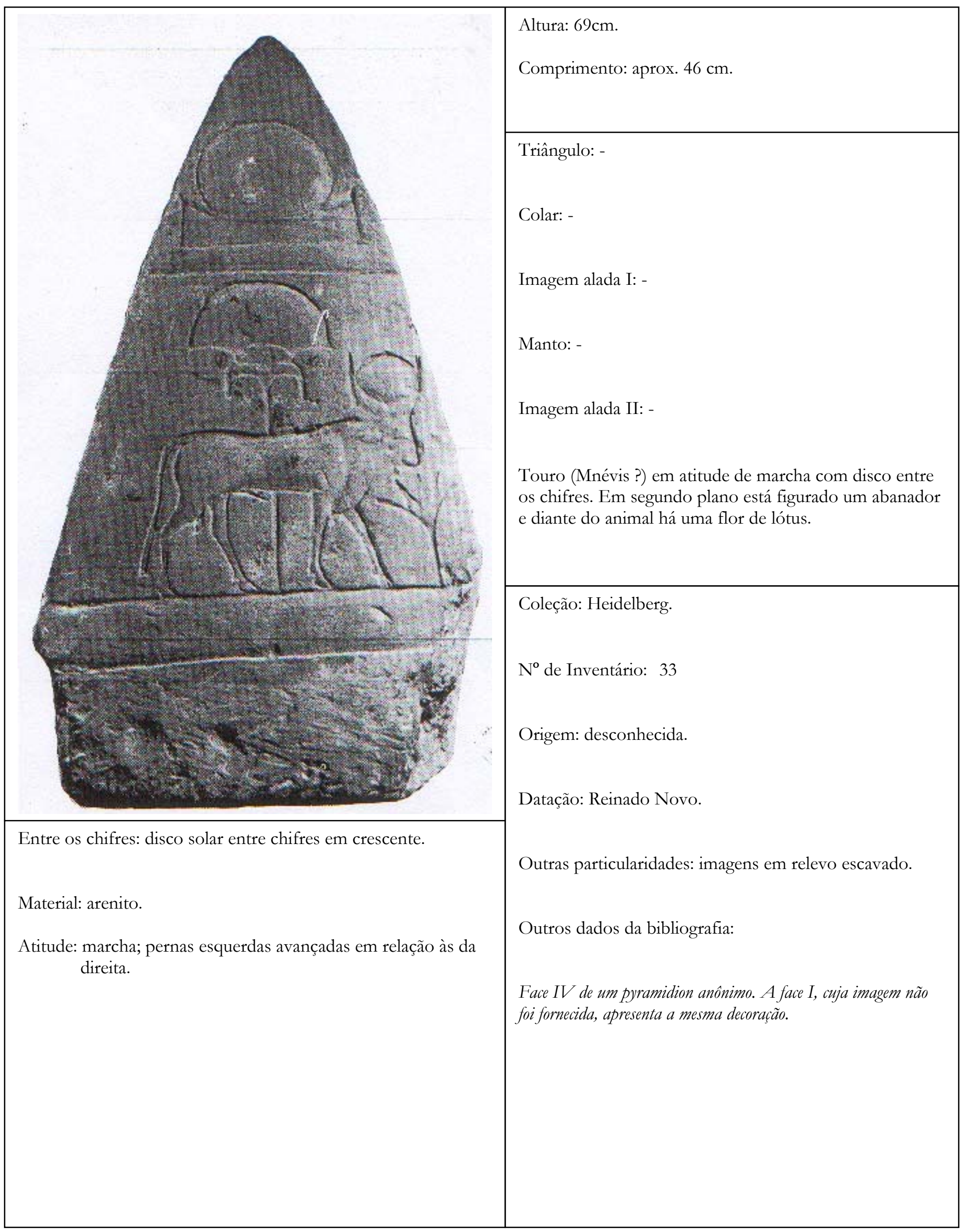




\section{Descrição:}

Primeiro registro: símbolo de um disco solar entre duas colinas, correspondente ao hieróglifo N 27.

Segundo registro: touro em atitude de marcha sobre linha de base e voltado para a direita. O animal é bem proporcionado, a linha torácico-ventral é aproximadamente paralela à dorsal - que possui um suave arqueamento no centro - e a papada desce abaixo da altura do peito. As pernas foram descritas de maneira precisa, a extremidade da cauda foi ilustrada com discrição da mesma forma que o sexo. A cabeça, que não exibe muitos detalhes, apresenta o olho amendoado e a orelha acima da nuca. Os chifres, semelhantes a um "U" emolduram um disco solar. Brotando do chão e abaixo do focinho há uma flor de lótus aberta e em segundo plano, encoberto pelo animal, há um abanador descrito como o hieróglifo S 35.

Bibliografia:

D. Devauchelle Habilitation Ia Diriger des Recherches, p. 83.

J. Quaegebeur Apis et la Ménat, p. 38, nt. 85.

A. Rammant-Peeters Les Pyramidions Égyptiens du Nouvel Empire, p. 16, pr. IX-26. 


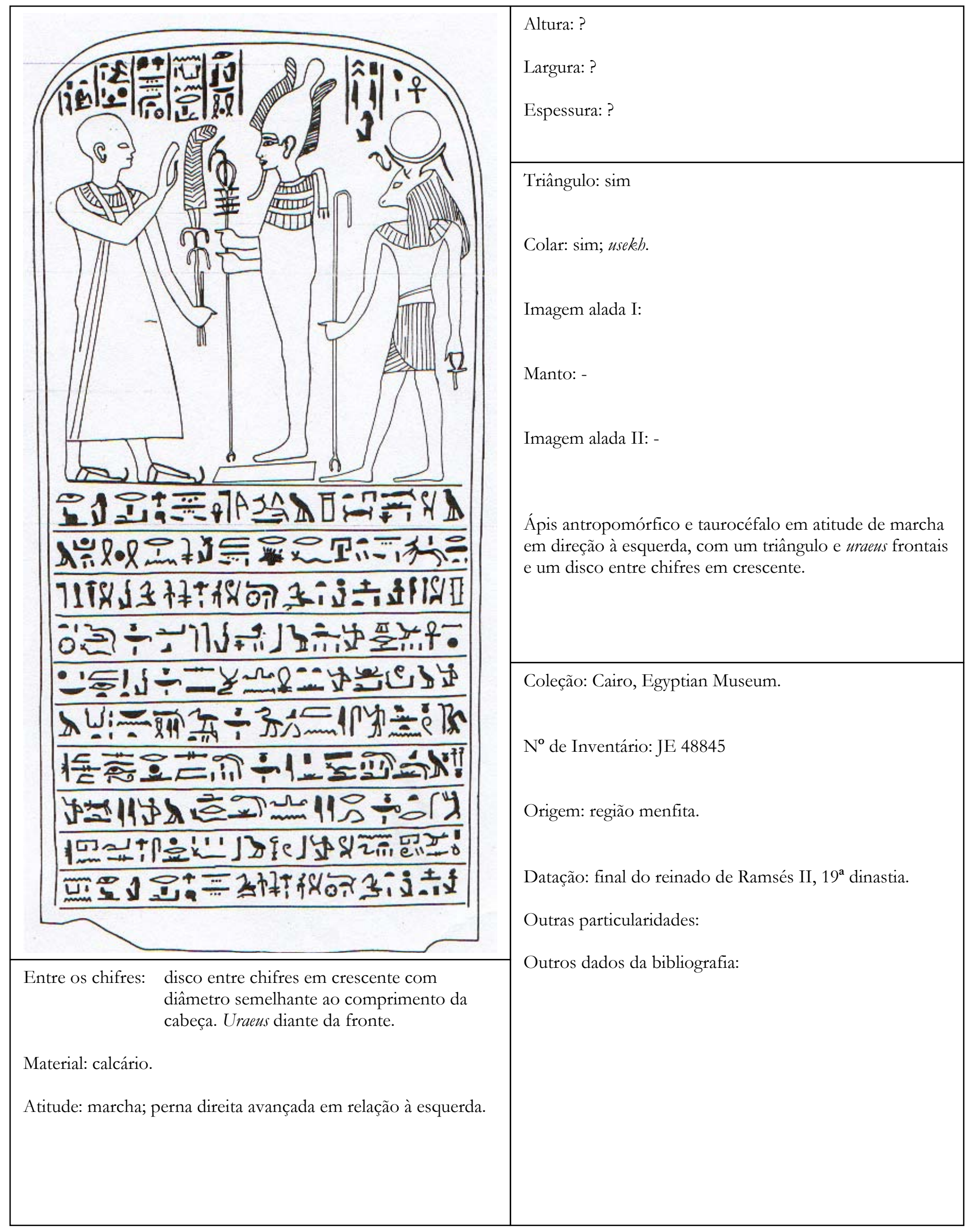


Descrição: no centro, deus Osíris mumificado em pé sobre uma plataforma no modelo do símbolo Aa 11 com as mãos projetadas para frente segurando o cetro was e os símbolos para vida ankh e estabilidade djed. Uma coroa atef enfeita sua cabeça, usa uma barba recurva na extremidade do queixo e um colar estriado que contém um contrapeso. Atrás dele está Ápis, à maneira antropomórfica e taurocéfala, voltado para esquerda em atitude de marcha sobre uma linha de base. A cabeça está coberta por uma peruca volumosa com os cachos indicados que esconde parcialmente o colar usekh, mas deixa descobertos as orelhas e os chifres em crescente, os quais guardam um disco solar de tamanho aproximadamente igual ao da cabeça do deus. $\mathrm{Na}$ fronte distingue-se um triângulo invertido e mais à frente, descendo do chifre, uma uraeus com a cauda pendente na extremidade do outro corno. O braço esquerdo desce acompanhando o corpo, com a mão correspondente segurando um ankh, e a direita, ligeiramente avançada, carrega um cetro composto cuja parte inferior é similar a de um cetro was e a superior modelada como a de um cajado $a u t\left({ }^{`} w t\right)$. A única peça de vestuário de Ápis, assim identificado pela coluna de texto logo acima dele, é um saiote plissado com cinturão desprovido de cauda. No lado esquerdo, voltado para as divindades, com a mão direita erguida em adoração e a esquerda baixada segurando um abanador (S 37), está o vizir Rahotep, trajado com o costume característico de um vizir, com a cabeça raspada, usando sandálias e com o pescoço ornado por um colar usekh.

Bibliografia:

M. Moursi Die Stele des Vezirs Re-hotep, MDAIK 37, pp. 321-329.

D. Devauchelle Habilitation à Diriger des Recherches, pp. 81-82. 


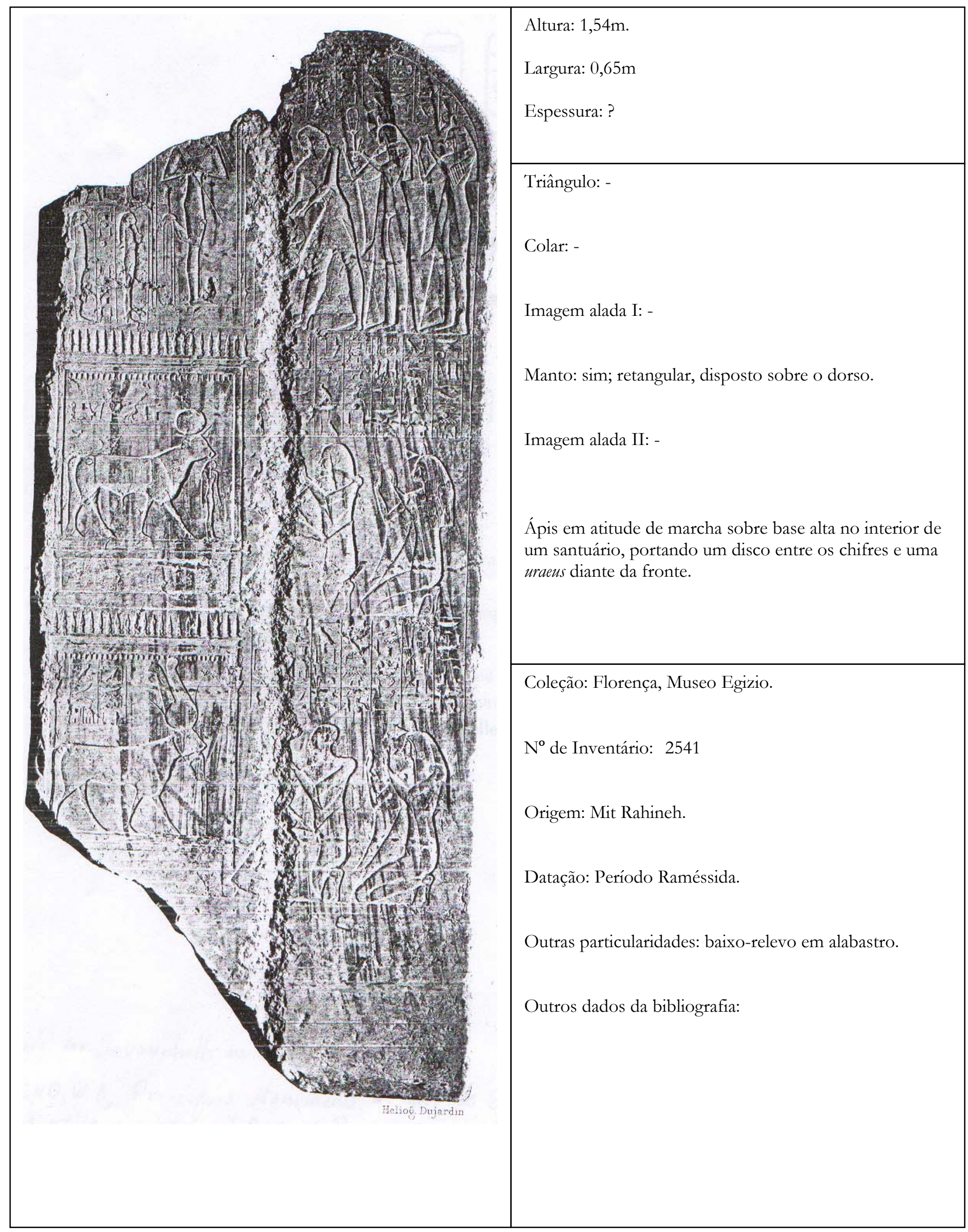


Entre os chifres: disco entre chifres em "V" com diâmetro similar ao comprimento da cabeça.

Material: alabastro.

Atitude: marcha; pernas do lado esquerdo avançadas em relação às do lado direito.

Descrição:

Primeiro registro: três personagens em pé à direita e voltados para a esquerda prestam louvores ao deus Osíris, localizado no interior de uma capela situada à esquerda. O primeiro personagem é o defunto, Seba, vestido de uma túnica longa com mangas curtas, e com uma peruca longa. Seus braços estão flexionados para frente assim como seu torso, como que realizando uma ação sobre as oferendas diante dele. As duas mulheres que o seguem usam vestidos longos, largos e transparentes similares e perucas espessas e compridas sobre as quais repousam cones odoríferos e flores de lótus. Ambas estão com as mãos elevadas à altura do rosto, mas a primeira tem só uma mão (direita) ilustrada em atitude de adoração enquanto que a esquerda segura um sistro. A imagem do deus está incompleta pelo fato do monumento estar destruído na parte superior. Osíris repousa em pé e mumiforme sobre uma base alta e tem suas pernas abraçadas por uma representação personificada do símbolo para o ocidente (R 14). As mãos ostentam um açoite nekhekh e possivelmente um cetro heka. Atrás dele estão dispostas imagens mumiformes que retratam os filhos de Hórus.

Segundo registro: dois personagens ajoelhados, o falecido Seba e sua mulher, vestidos de forma similar à primeira cena, mantém as mãos elevadas em adoração a Ápis, localizado no interior de uma capela ornada na parte superior com um friso $h k r$ (Aa 30). O deus aparece em atitude de marcha para a direita e exibe um porte elegante e proporcional. A linha torácicoabdominal mantém uma orientação ascendente - interrompida brevemente pelo sexo - enquanto que a dorsal é aproximadamente paralela à base até o início dos ombros, de onde sobe até a nuca. As pernas exibem firmeza na passada, a cauda descreve uma linha perpendicular até próximo ao chão e a papada, após duas ondulações muito sutis, desce abaixo do peito para encontrá-lo na área entre as pernas. A cabeça está bem moldada, com focinho e orelha discretos e o olho descrito com esmero. Entre os chifres curtos em "V" repousa um disco com diâmetro similar ao comprimento da cabeça e diante da fronte nota-se a uraeus. Um manto retangular cobre-lhe as costas e diante dele há uma imagem feminina não identificada, mas que pode se tratar de uma personificação do "ocidente", presente nos demais registros.

Terceiro registro: o escultor Mes e sua esposa, na mesma atitude e trajados de forma similar aos personagens do registro anterior, com exceção de que o homem aparece com a cabeça raspada. Diante deles, e dentro de um santuário semelhante ao da imagem superior, está ilustrada a vaca Háthor com a modelagem do corpo aparentada à de Ápis. Seus longos chifres em lira também guardam um disco solar sobre o qual elevam-se duas plumas. No pescoço, a deusa porta um colar com uma face humana e orelhas bovinas modelado à semelhança do símbolo para vida ankh. À frente da vaca há uma representação do símbolo do ocidente (R 14).

Bibliografia:

W. B. Berend Principaux Monuments du Musée Égyptien de Florence, pp. 52-53, pr. VII.

D. Devauchelle Habilitation à Diriger des Recherches, p. 84 


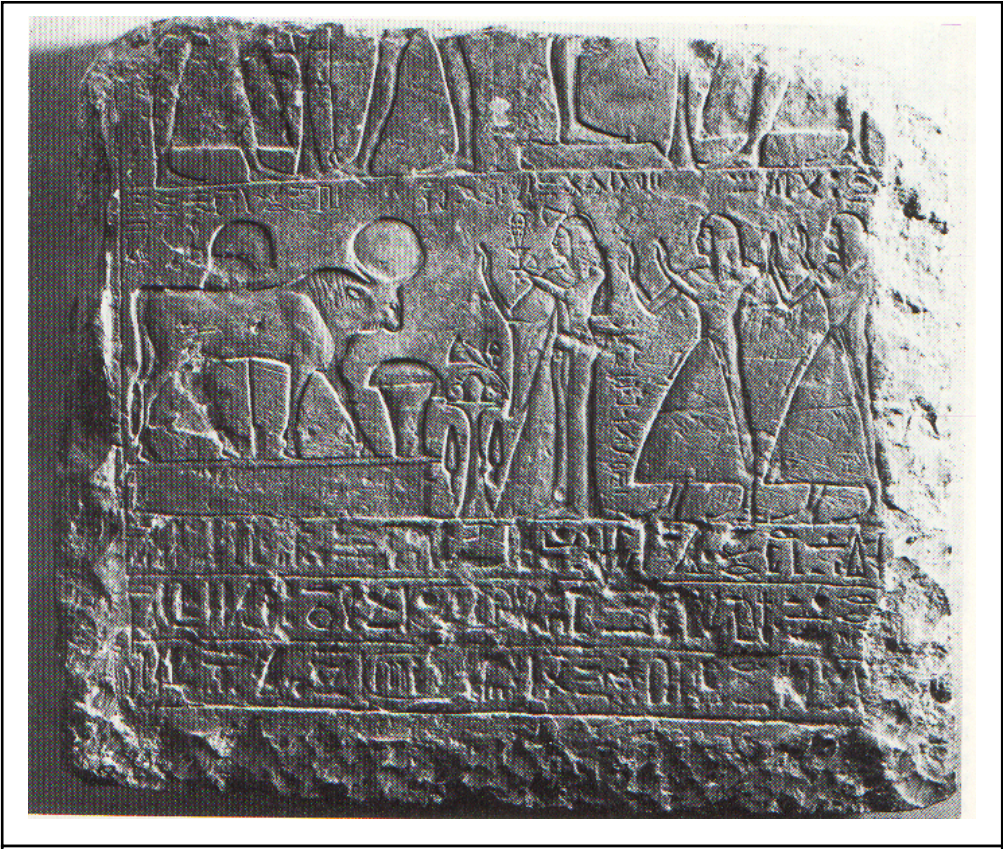

Entre os chifres: disco entre chifres em crescente.

Material: calcário

Atitude: marcha; pernas esquerdas avançadas em relação às da direita.

Primeiro registro: deste só restaram partes das pernas e pés dos personagens. Da esquerda para a direita é possível distinguir um homem vestido de um longo saiote diante de um altar e uma imagem divina masculina portando um cetro was. Em seguida, uma divindade mumiforme sobre uma base com forma alusiva ao hieróglifo para maat (Aa 11), um outro altar de oferendas e as pernas de um homem.

Segundo registro: à esquerda e voltado para a direita, se encontra o touro Mnévis sobre uma base retangular alta com uma estreita cornija. Á frente dele há um recipiente alto para alimentação e encoberto por seu corpo, em segundo plano, o símbolo para um abanador (S 36). Como é habitual, o touro é ilustrado com grande habilidade e atenção à anatomia. As pernas transmitem segurança no movimento, ainda que a cena em questão se refira a uma escultura em um pedestal, e os volumes da musculatura estão sutilmente indicados, especialmente nos ombros. A cauda desce perpendicularmente e termina com um intumescimento indicando a pelagem característica dessa área. A linha do peito descreve uma suave inclinação até o início do abdômen, para daí rumar paralelamente em relação à base. O perfil dorsal assume a mesma orientação até o início dos ombros, onde adquire uma súbita ascensão que termina no início do pescoço para daí descer até a cabeça. Tanto nessa área quanto na papada foram traçadas linhas onduladas que indicam a pelagem. A cabeça exibe um focinho pequeno e bem moldado no qual se nota o orifício da narina, e o olho arredondado tem suas extremidades posicionadas diagonalmente e a orelha está bem indicada atrás da cabeça com o pavilhão auditivo escavado. Os
Altura: $78,3 \mathrm{~cm}$.

Comprimento: $91 \mathrm{~cm}$.

Espessura: $13 \mathrm{~cm}$.

Triângulo: -

Colar:

Imagem alada I:

Manto: -

Imagem alada II:

Mnévis em atitude de marcha sobre linha de base, com disco solar entre os chifres.

Coleção: Paris, Musée du Louvre.

$\mathrm{N}^{\text {o }}$ de Inventário: C $292=$ AF 749

Origem: Heliópolis.

Datação: $19^{\mathrm{a}}$ dinastia, possivelmente reinado de Ramsés II.

Outras particularidades: Imagens e textos em relevo escavado.

Outros dados da bibliografia:

Não é possivel saber se é uma estela ou decoração mural. 
chifres em crescente aberto emolduram parte de um grande disco solar. Diante do boi e sobre a linha de base está posicionado um altar repleto de oferendas seguido de três personagens: uma mulher com vestido longo e amplo, com peruca comprida sobreposta de uma flor de lótus portando um sistro na mão esquerda e a outra elevada na altura da face, e dois homens com saiotes volumosos longos em atitude de adoração com perucas que descem até pouco abaixo dos ombros.

Bibliografia:

C. Desroches-Noblecourt, J. Vercoutter Un Siècle de Fouilles Françaises en Égypte 1880-1980, pp. 268-269.

http: $/ /$ cartelfr.louvre.fr $/$ cartelfr $/$ visite? srv $=$ car not frame\&idNotice $=20353$ 


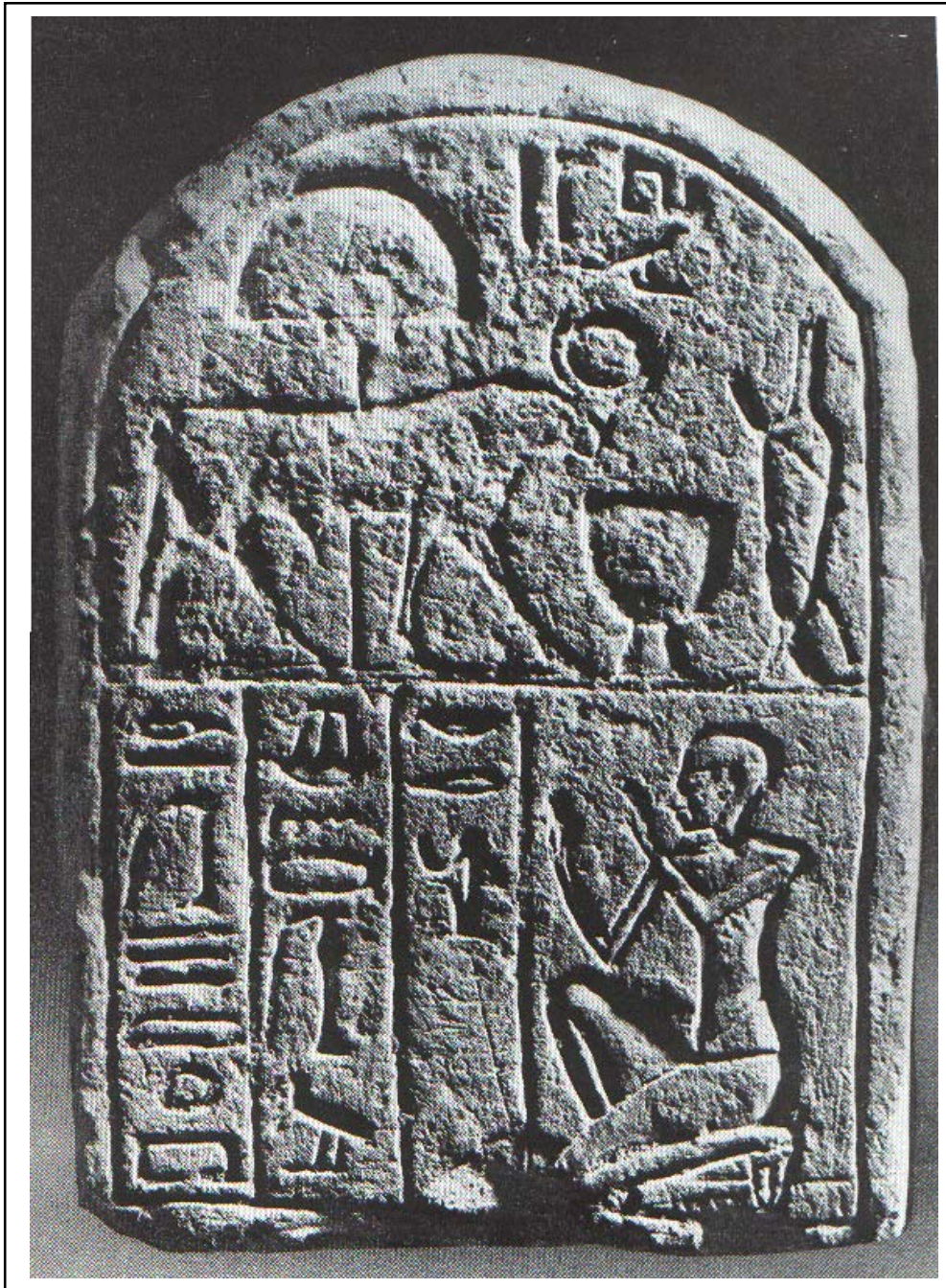

Entre os chifres: disco entre chifres em crescente.

Material: calcário

Atitude: marcha; pernas esquerdas avançadas em relação às da direita.
Altura: $15,5 \mathrm{~cm}$.

Largura: $10,75 \mathrm{~cm}$.

Triângulo: -

Colar: -

Imagem alada I:

Manto: sim (?); constituído por uma faixa perpendicular ao dorso e que se estende até a linha torácicoventral.

Imagem alada II:

Mnévis em atitude de marcha sobre linha de base, com disco solar entre os chifres e manto (?) sobre o dorso.

Coleção: Moscou, Pushkin Museum of Fine Arts.

$\mathrm{N}^{0}$ de Inventário: I.1.a.5611 (3568)

Origem: Heliópolis.

Datação: $19^{\mathrm{a}}$ dinastia.

Outras particularidades: texto e imagens em relevo escavado.

Outros dados da bibliografia: 


\section{Descrição:}

Primeiro registro: Mnévis em atitude de marcha sobre linha de base e voltado para a direita. À frente do touro e sobre o chão estão um recipiente em forma de cálice, logo abaixo do focinho, e um cântaro de vinho serpenteado por um caule de lótus com botão. Em segundo plano e parcialmente encoberto pela imagem taurina há um abanador, correspondente ao hieróglifo S 35. A constituição física do touro é a de um animal maduro, com a genitália bem evidenciada e porte viril. Embora a superfície da estela apresente rugosidades, percebe-se o cuidado com a representação dos membros e das sinuosidades do corpo. A cabeça, contudo, é pequena em proporção a este, e mal se distingue a orelha pouco abaixo da linha superior do pescoço e o olho, retratado por um traço. Os chifres grandes em crescente emolduram um disco solar e um manto parece ter sido figurado cobrindo parte do dorso e a lateral do bovino. A legenda acima de sua cabeça o identifica como o touro sagrado de Heliópolis.

Segundo registro: à direita e voltado para as colunas de texto no lado oposto, está o ofertante Baker ajoelhado com cabeça raspada, vestido de um saiote até os joelhos com cinturão elevado e as mãos erguidas em atitude de adoração.

Bibliografia:

S. Hodjash, O. Berlev The Egyptian Reliefs and Stelae in the Pushkin Museum of Fine Arts, Moscow, pp. 144-145. 


\begin{tabular}{|c|c|}
\hline 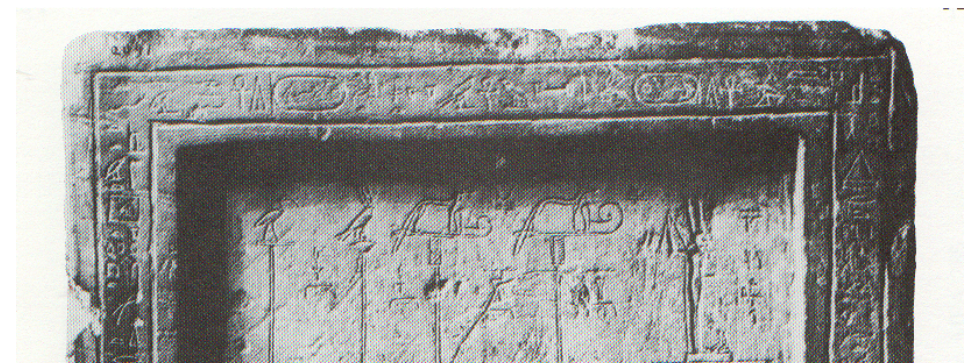 & $\begin{array}{l}\text { Altura: } 70 \mathrm{~cm} . \\
\text { Largura: } 42 \mathrm{~cm} . \\
\text { Comprimento da "mesa de oferendas" talhada no mesmo } \\
\text { bloco e na parte inferior da estela: } 10 \mathrm{~cm} \text {. } \\
\text { Altura da "mesa de ofernedas": } 17,5 \mathrm{~cm} \text {. }\end{array}$ \\
\hline 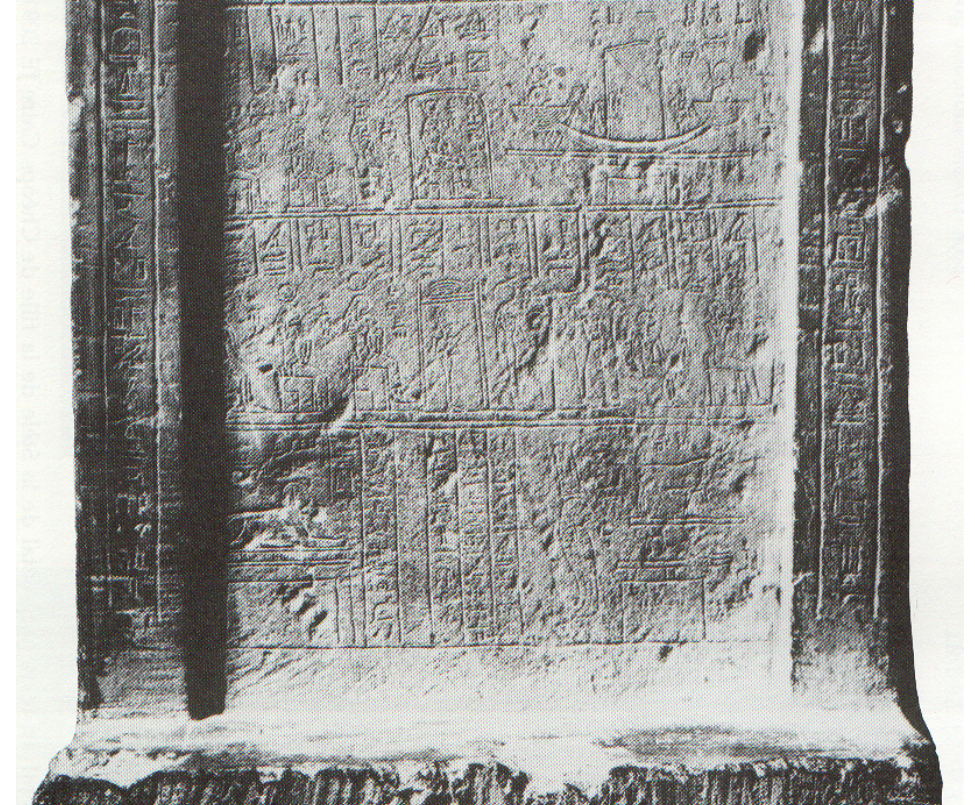 & $\begin{array}{l}\text { Triângulo: - } \\
\text { Colar: - } \\
\text { Imagem alada I: - } \\
\text { Manto: - } \\
\text { Imagem alada II: - } \\
\text { Ápis em atitude de marcha sobre base baixa e portando } \\
\text { um disco entre os chifres. Seu corpo parece apresentar } \\
\text { demarcadas as regiões das manchas negras comumente } \\
\text { vistas nas estelas do Serapeum, ao menos na parte } \\
\text { anterior das coxas e um semicírculo sobre o dorso - que } \\
\text { também pode ser um manto com parte inferior } \\
\text { arredondada. }\end{array}$ \\
\hline 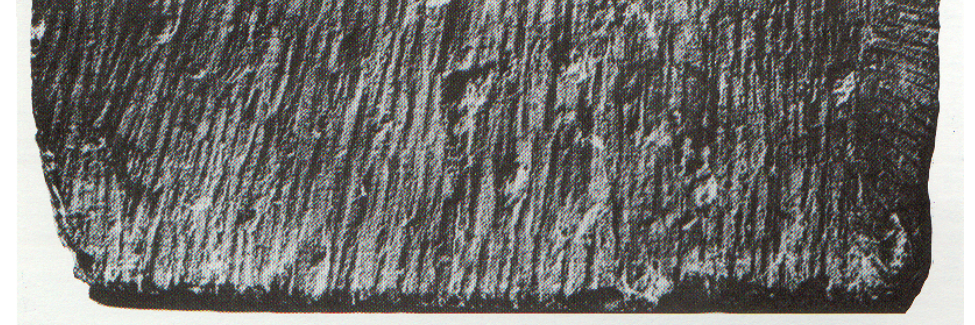 & $\begin{array}{l}\text { Coleção: Cairo, Egyptian Museum. } \\
\text { No de Inventário: JE } 2091 . \\
\text { Origem: Giza, templo de Ísis. } \\
\text { Datação: } 26^{\text {a dinastia. }}\end{array}$ \\
\hline $\begin{array}{ll}\text { Entre os chifres: } & \text { disco com diâmetro aproximadamente igual } \\
& \text { ao comprimento da cabeça. }\end{array}$ & $\begin{array}{l}\text { Outras particularidades: } \\
\text { Outros dados da bibliografia: }\end{array}$ \\
\hline $\begin{array}{l}\text { Atitude: marcha; pernas esquerdas avançadas em relação às da } \\
\text { direita. }\end{array}$ & \\
\hline \multicolumn{2}{|l|}{ Bibli } \\
\hline \multicolumn{2}{|l|}{ O. Perdu in M. Desti Des Dieux, des Tombeaux, un Savant, pp.164-165. } \\
\hline C. Zivie-Coche Giza au Premier Millenaire, pp. 216-246, prs. 39-40. & \\
\hline
\end{tabular}


Descrição: Nos registros horizontais do centro da estela há uma série de representações de estátuas de culto de divindades ou de seus estandartes, com legendas informando suas dimensões e material. Somente nos casos de Ápis e Harmakhis não há qualquer menção quanto a isso, mas é de se supor de que se trate mais de um esquecimento do que de uma falta de coerência interna do monumento.

Primeiro registro: deus Min mumiforme e itifálico em pé sobre uma base baixa pousada sobre um andor. À sua cabeça uma coroa com um par de plumas longas e uma barba recurva no queixo, e seu braço direito voltado para trás e flexionado para cima em ângulo reto portando um açoite nekhekh. À sua frente e sobre a linha de base há um pequeno personagem ajoelhado que possivelmente ilustra o rei em atitude de adoração ou apresentando uma oferenda. Atrás do deus há quatro estandartes com imagens divinas apoiados sobre bases pequenas. Os dois primeiros representam o deus canídeo Wepwawet em pé, com as caudas esticadas para baixo e à frente dos quais há uma protuberância recurva chamada de shedshed que possivelmente simbolizava a placenta real. Logo atrás uma imagem de Hórus como falcão, com duas plumas no cimo da cabeça e pousado sobre um suporte à imagem de uma coluna com capitel papiriforme. Por fim, uma representação de Thot como uma íbis.

Segundo registro: a primeira imagem à direita é a de uma barca sagrada da deusa Ísis pousada sobre um andor, decorada em suas extremidades de figuras hathóricas em forma de égides com o disco solar entre os chifres. A cabine constitui um naos com o modelo canônico de um santuário do Alto Egito, com uma uraeus com um disco solar à cabeça na parte superior, e com teto sustentado por colunas papiriformes atrás e lotiformes à frente. À frente do santuário, uma esfinge em pé e, atrás, um personagem que com duas cordas comanda um leme duplo que termina com duas cabeças de Hórus. Logo atrás da embarcação, outro santuário com arquitetura similar, mas com menos detalhes, sobre uma base baixa e contendo em seu interior uma imagem da deusa Ísis sentada sobre um trono cúbico arcaico. Sobre a peruca tripartite ela ostenta um par de chifres hathóricos emoldurando um disco solar, o pescoço está adornado com um colar usekh, seu corpo vestido de um vestido longo colante com alças, e suas mãos repousam sobre os joelhos. Atrás dela, sentada e vestida de forma similar, está a deusa Néftis com seu emblema característico sobre a cabeça (O 9). Em seguida, duas outras representações de Ísis: Ísis-Meskhenet e Ísis-escorpião. Ambas estão trajadas como as imagens que as precedem e assentam-se sobre o mesmo tipo de trono. A primeira está prestes a amamentar um deus-criança nu, com cabeça raspada e uma trança lateral que está sobre suas pernas. Quanto à outra, que está com as mãos sobre os joelhos como as duas primeiras deusas, o único elemento diferente nela é o símbolo de um escorpião com cauda recurva sobre sua cabeça.

Terceiro registro: Este contém as representações de oito divindades. À direita, dois deuses-criança nus, Harendotes e Harpocrates, com a cabeça raspada e uma trança lateral. O primeiro está sentado sobre um trono cúbico, e com o indicador da mão direita à boca e a mão esquerda sobre o joelho. O outro está em pé e com os braços abaixados junto ao corpo. Em seguida está o deus Ptah, mumificado em pé dentro de um naos no estilo do Alto Egito, com um uma touca colante, barba recurvada na extremidade e portando o cetro was junto ao peito. Atrás de Ptah vem Sekhmet, trajada de uma túnica colante, com um disco solar sobre sua cabeça leonina, braço direita acompanhando verticalmente o corpo e o esquerdo avançado portando à mão um cetro wadj em forma de papiro. Osíris sucede a deusa dentro de um santuário de teto abobadado no estilo do baixo Egito. Mumificado como Ptah, ostenta a coroa atef e, junto ao peito, os cetros heka e nekhekh. O deus está acompanhado da deusa Ísis em duas versões: uma com coroa hathórica, vestida da mesma maneira que no registro superior e sentada sobre o mesmo trono enquanto amamenta seu filho, e a outra, que é ilustrada de forma idêntica, mas sem uma coroa. Por fim, uma imagem de Hórus como criança nu, em posição de estar sentado sem, no entanto, estar sobre qualquer assento. Seus braços acompanham o corpo e sobre a cabeça tem um pschent, ou coroa dupla do Alto e Baixo Egito.

Quarto registro: à direita e acima, Ápis em atitude de marcha sobre uma base baixa e voltado para o lado direito. Disco entre chifres em "V". Seu corpo apresenta vigor, é bem proporcionado e as pernas bem modeladas sugerem segurança na passada. A cabeça, pequena como é usual, é pequena, mas detalhada (particularidades não visíveis na fotografia). A cauda desce volumosa perpendicularmente. Abaixo e sobre uma grande base retangular, um emblema deitado de Nefertum. Logo atrás vem uma deusa serpente - possivelmente Uraeus (Iarret) - com cabeça humana e peruca, sobre a qual repousa um modius com duas plumas e um disco solar. Por fim, deitada sobre uma base alta emoldurada em seu interior e com uma cornija, está uma representação de Harmakhis, a Grande Esfinge de Giza. Um toucado nemes com uma uraeus à fronte lhe cobre a cabeça e sob o queixo porta uma barba recurva na extremidade. Contrariamente em relação ao resto da estela, a esfinge recebeu muito mais atenção aos seus detalhes, cujos cânones remontam à $18^{\text {a }}$ dinastia, que as demais imagens citadas. 


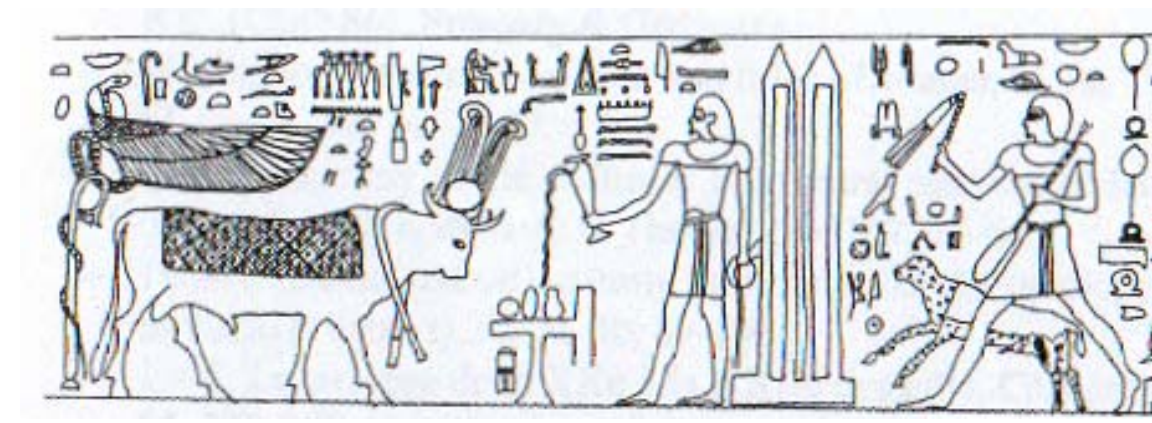

Altura: ?

Comprimento:?

Espessura: ?

Imagem da esquerda

Triângulo: -

Colar: sim; na forma do hieróglifo *(V 7).

Imagem alada I: -

Manto: sim; constituído de um retângulo disposto longitudinalmente em relação ao dorso e decorado com uma tela com pontos no interior de cada quadrilátero formado por ela.

Imagem alada II: -

Touro em marcha (possivelmente Mnévis), com um manto sobre o dorso e um pequeno disco sobreposto de duas plumas entre os chifres em crescente.

\section{Imagem da direita}

Triângulo: -

Colar: -

Imagem alada I: -

Manto: sim; a parte frontal possui extremidades em ângulo reto e à medida em que se aproxima das ancas a coberta torna-se mais estreita e parece terminar com uma cauda que se confunde com aquela do animal.

Imagem alada II: -

Ápis em atitude de galope com manto sobre o dorso e sem chifres.

\section{Imagem da esquerda}

Entre os chifres: um pequeno disco solar sobreposto por um par de plumas entre chifres em crescente.

Material: madeira estucada e policromada.(?)

Atitude: marcha; pernas do lado esquerdo avançadas em relação às do lado direito.
Imagem da direita

Entre os chifres: -

Material: madeira estucada e policromada.(?)

Atitude: galope; pernas traseiras apoiadas no solo e as dianteiras erguidas. 
Coleção: Berlim, Ägyptisches Museum.

Nº de Inventário: 11978 (Möller), 119780 (Niwiński).

Origem: região tebana (?).

Datação: $21^{\text {a }}$ dinastia.

Outras particularidades:

Outros dados da bibliografia:

Descrição: a imagem que se localiza à direita ilustra um personagem associado a Osíris, correndo em direção a um par de obeliscos, segurando um açoite nekhekh ( $\mathrm{S} 45$ ) em sua mão direita e um remo (P 8) na esquerda, com ambos os braços flexionados. Ele veste um saiote curto com uma faixa frontal vertical, uma peça de vestimenta como um colete sem faixas sobre os ombros, um colar usekh e uma peruca redonda. Em segundo plano e em menores dimensões, vemos um bovino saltitante desprovido de chifres e com aparência de um bezerro cheio de vitalidade. Seu corpo alvo está recoberto de múltiplas manchas escuras pequenas e seu dorso com um longo manto estendido longitudinalmente e cuja parte inferior é irregular, lembrando uma pele cuja cauda se confunde com aquela do jovem touro. Somente suas patas traseiras estão apoiadas sobre a linha de base, que é a mesma que organiza a presente cena e as demais do registro. Acima da cabeça do animal lemos a expressão hrrp Hp que significa "conduzindo Ápis", e logo à frente, $m$ st in $R^{e}$ "em direção ao lugar de Rê", uma referência ao sítio de Heliópolis. O registro à esquerda ilustra o mesmo homem, só que com uma peruca mais alongada, vertendo libações sobre um altar diante de um touro com um par de plumas e um disco solar entre os chifres Sobre o dorso do animal há um manto retangular disposto longitudinalmente, decorado com uma tela cujo centro de cada losango formado pela trama ilustra um enfeite circular, e o pescoço está adornado com um colar em forma do hieróglifo (V 7). Seu porte é o de um touro no auge de sua força e fecundidade, apresenta boas proporções e sua anatomia é descrita com linhas precisas. Acima de sua parte traseira estendem-se as assas de uma uraeus que se apóia em um suporte em forma de lírio (?) cuja flor está recurvada para baixo. Embora o touro não esteja propriamente nomeado, há na parte superior da cena um texto que o descreve como "touro, Ba do Grande Deus de Heliópolis (?)" aludindo assim à representação de Mnévis.

Bibliografia:

G. Möller Das $H b-s ́ d$ des Osiris nach Sargedarstellungen des neues Reiches, Z ̈̈S 39, pp. 71-74, pr.IV.

A. Niwiński Iconography of the $21^{\text {st }}$ Dynasty, OBO 175, pp.40-41, fig. 16. 


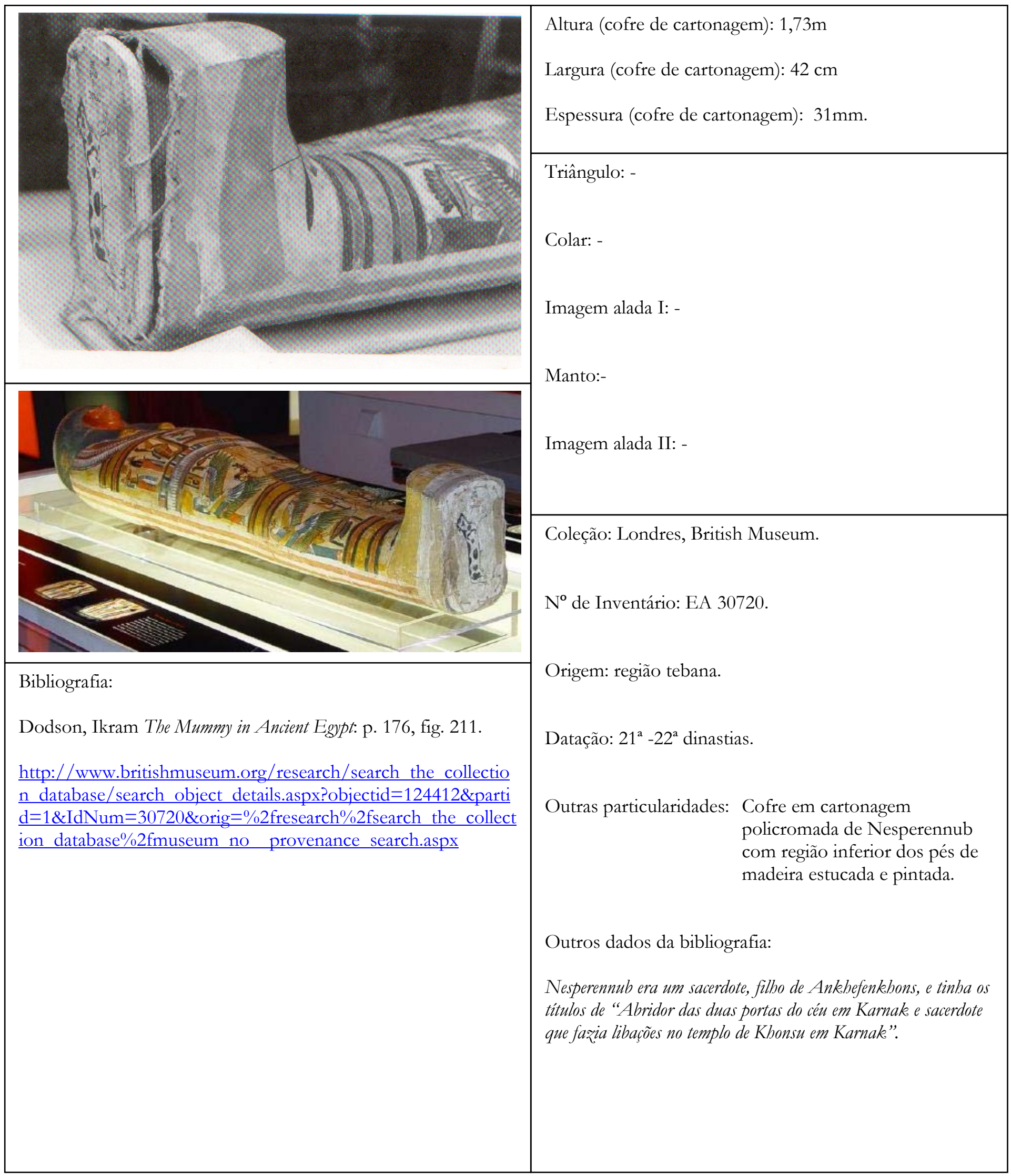


Entre os chifres: -

Material: madeira estucada e pintada (pés).

Atitude: galope; pernas frontais estendidas para frente e as traseiras para trás.

Descrição: a imagem, que não nomeia o personagem ilustrado, representa o touro Ápis em atitude de galope representado em outros sarcófagos do Terceiro Período Intermediário e Período Tardio. Aqui, o animal, ao contrário das cenas em outros gêneros de artefatos, apresenta o corpo do deus coberto de manchas negras espalhadas de forma irregular, sem a intenção de formar padrões simbólicos específicos da pelagem. O corpo é bem proporcionado e o mamífero, talvez com o objetivo de expressar sua juventude e vitalidade, foi representado sem chifres. 


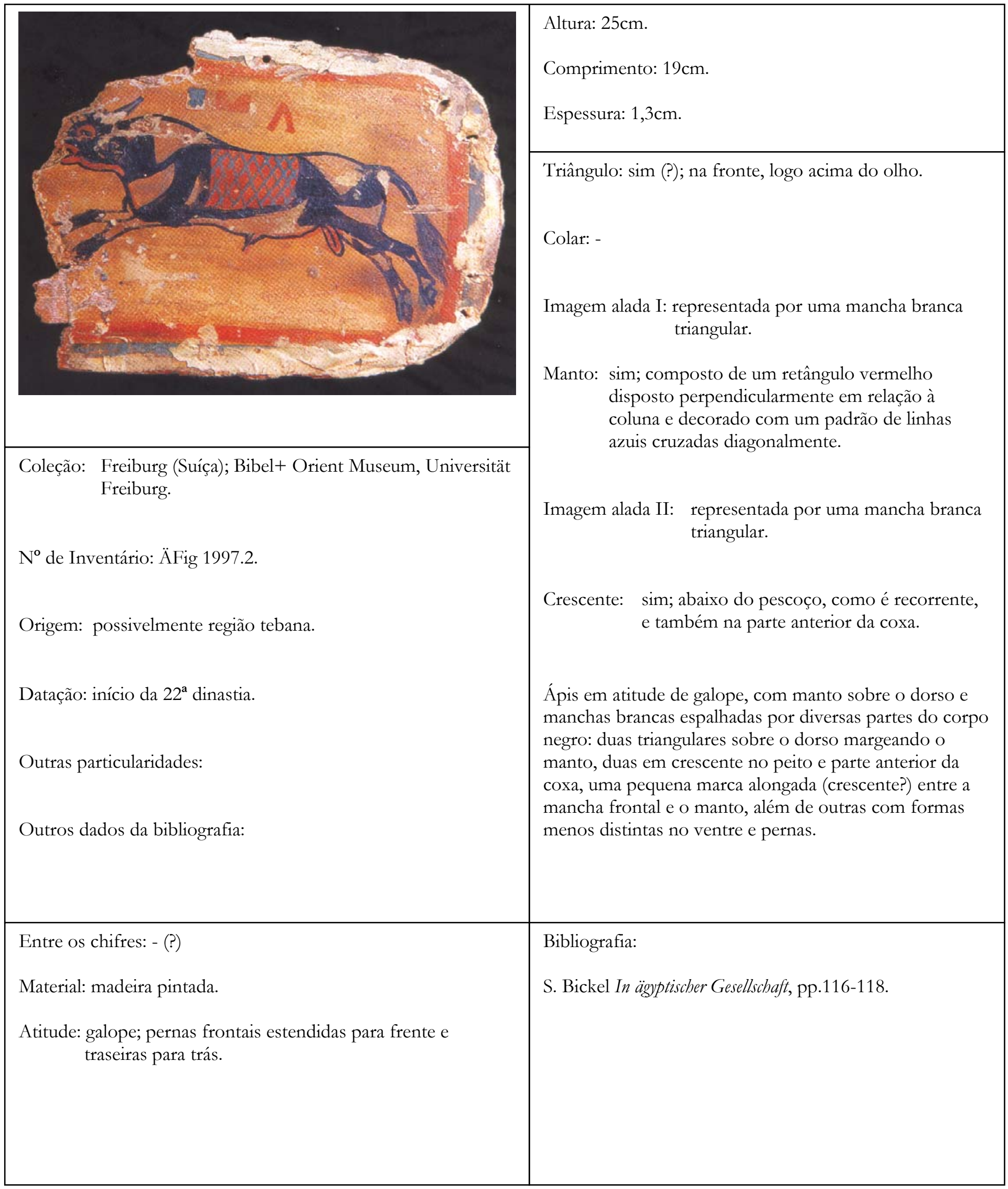


Descrição: touro em atitude de galope voltado para a esquerda, com pernas frontais erguidas e as traseiras supostamente apoiadas no chão - a linha de base não está presente e tudo que se vê são duas faixas, uma vermelha paralela a uma negra, que emolduram a cena. $\mathrm{O}$ animal é descrito com linhas precisas e seu corpo apresenta um porte viril e jovem. Manchas brancas contrastam com a pelagem negra em várias áreas: duas triangulares sobre os ombros e ancas, na posição ocupada pelas imagens solares aladas em determinadas fontes, duas em forma de crescente na parte frontal do peito e detrás das pernas traseiras, uma de irregular sobre o abdômen, e diversas outras sobre as pernas. A linha inferior da papada, o contorno dos olhos e o focinho receberam o mesmo tratamento, que com o verniz, também adquiriu um tom amarelado.

Somente um dos chifres está preservado e ele indica que ambos foram ilustrados à imagem de um "V" aberto. Os membros exibem o movimento de maneira particularmente bem trabalhada, mas a cauda, que apresenta um tufo espesso na extremidade, não acompanha a agitação que o corpo provoca na mesma proporção. Sobre o dorso ilustra um manto vermelho sobreposto de uma tela formada por linhas transversais e que reproduz o efeito daquelas constituídas de tubos de faiança vidrada azul. 


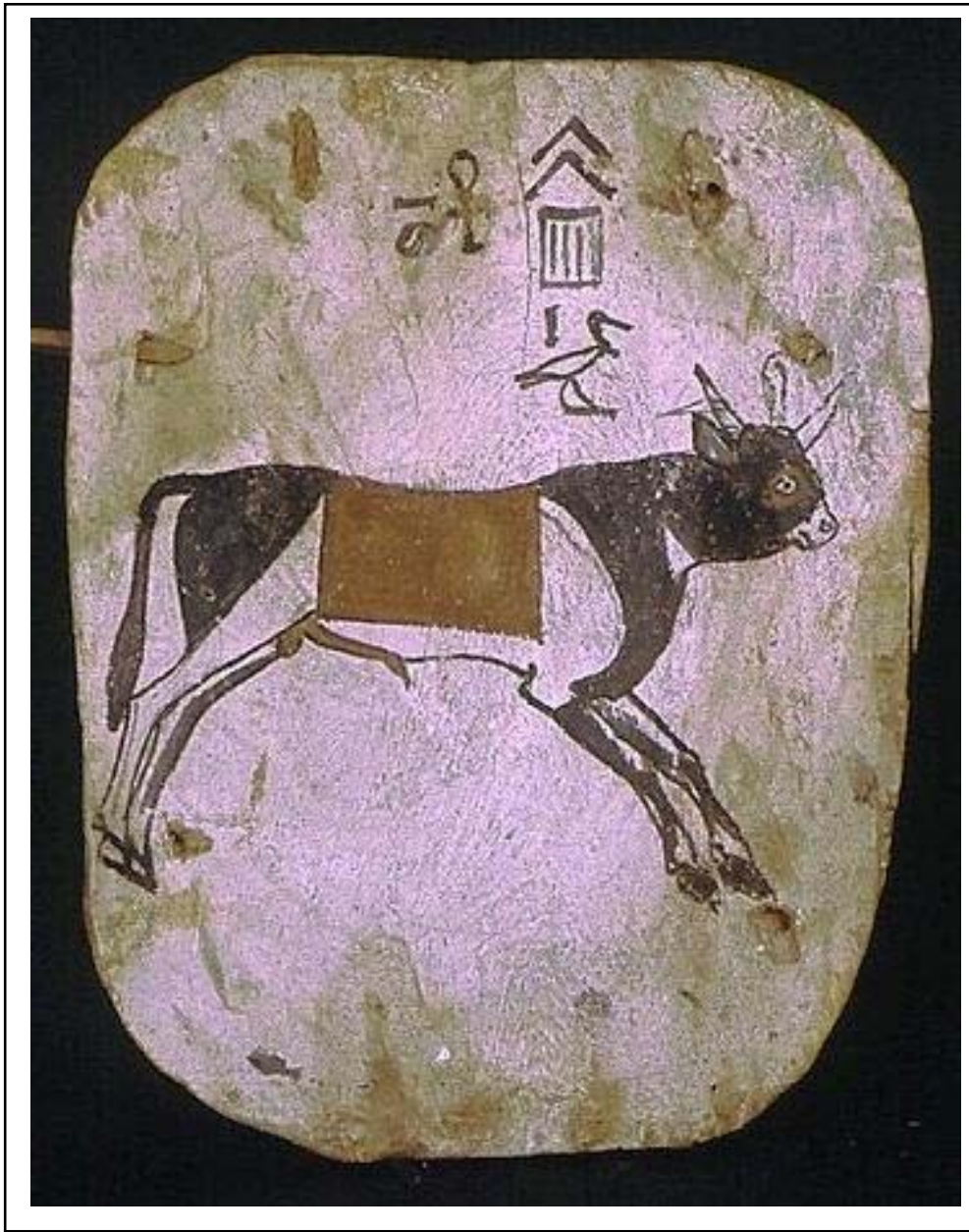

Bibliografia:

S. Bickel In ägyptischer Gesellschaft, p. 117.

http://www.globalegyptianmuseum.org/record.aspx?id=10907
Altura: $26 \mathrm{~cm}$.

Comprimento: $21 \mathrm{~cm}$.

Espessura: 2cm.

Triângulo: $\operatorname{sim}(?)$.

Colar: -

Imagem alada I: -

Manto: sim; constituído de um retângulo vermelho estendido perpendicularmente em relação à coluna.

Imagem alada II: -

Crescente: sim; abaixo do pescoço.

Coleção: Hildesheim, Roemer und Pelizaeus-Museum.

$\mathrm{N}^{0}$ de Inventário: 1902 c /1.

$\mathrm{N}^{0}$ de Inventário no Global Egyptian Museum:

$$
\text { 04/030/10907 }
$$

Origem: Akhmin?

Datação: $22^{\mathrm{a}}$ ou $23^{\mathrm{a}}$ dinastia.

Outras particularidades: pintura sobre madeira estucada.

Outros dados da bibliografia:

Uma funerária de Penju.

Pelizaeus adquiriu o conjunto da urna PM 1902 em nome do Roemer Museum em Hildesheim no Cairo em 1886 através de Gaston Maspero. 
Entre os chifres: uraeus.

Material: madeira estucada e pintada.

Atitude: galope; pernas frontais estendidas para frente e traseiras para trás.

Descrição: Ápis em atitude de galope voltado para a direita, desprovido de linha de base. Seu corpo viril é representado por linhas precisas e nele estão distribuídas manchas negras em locais precisos: na região das ancas, coxa e cauda e uma que, contornando a área dos ombros, engloba este, o pescoço e a cabeça. Na parte central do dorso, onde em outras imagens haveria uma marca negra arredondada, consta um manto retangular vermelho. Outras manchas negras estão dispersas sobre os membros. O focinho foi deixado em branco e a parte inferior do pescoço exibe um crescente da mesma cor. Os chifres em "V" guardam uma uraeus ereta e uma pequena área branca no topo da cabeça pode indicar o triângulo invertido da fronte. A genitália está bem marcada e pintada integralmente de vermelho. As feições do touro estão bem ilustradas, com uma boca pequena, a narina e olho direitos arredondados e a orelha trapezoidal representada atrás da nuca. 


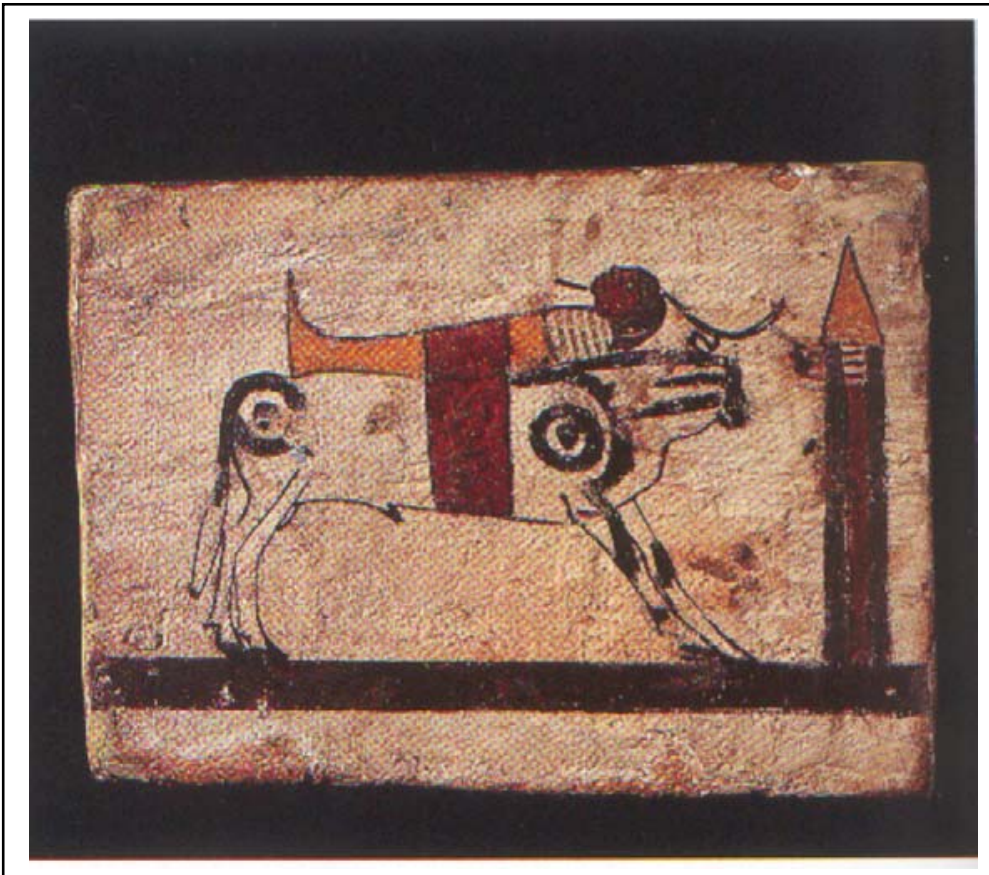

Entre os chifres: -

Material: madeira estucada e pintada.

Atitude: galope; pernas frontais estendidas para frente e as traseiras para trás

Descrição: touro em atitude de galope sobre linha de base constituída de uma faixa preta. Diante do animal está erguido um obelisco com ponteira amarela e decorado em sua extensão por três faixas, duas negras nas laterais e uma vermelha no centro, sobre a qual há um espaço retangular branco decorado com segmentos paralelos. Ao corpo do bovino foram conferidos vigor e vitalidade, bem expressos por suas boas proporções e anatomia. As manchas negras descrevem um padrão sui generis e pouco verossímil pela presença de formas geométricas circulares concêntricas na anca e ombro e linhas paralelas do pescoço à cabeça. A parte frontal da cabeça e focinho são negros mas a região que deveria apresentar um triângulo é completamente branca. Sobre as costas do touro repousa uma múmia com sua cabeça sobre o pescoço do animal, coberta por um manto vermelho estreito que envolve ambos perpendicularmente.
Altura (urna funerária): 1,91m

Largura (urna funerária): $49 \mathrm{~cm}$.

Triângulo: -

Colar: -

Imagem alada I: -

Manto: sim; constituído de um quadrilátero pintado de vermelho que cobre tanto a múmia sobre o dorso do touro quanto as laterais deste até a linha do tórax.

Imagem alada II: -

Coleção: Paris, Musée du Louvre.

No de Inventário: E 3863

Origem: Deir el Bahari.

Datação: fim da $23^{\mathrm{a}}$ dinastia.

Outras particularidades: parte inferior dos pés da tampa do ataúde de Pami. Madeira estucada policromada.

Outros dados da bibliografia:

Ataúde possivelmente encontrado no período de 1857-1858 por $V$. Galli Mannier, o qual escavava por conta de R. Sabatier, consul francês em Alexandria.
Bibliografia:

Perdu in Desti 2004: pp. 242-243. 


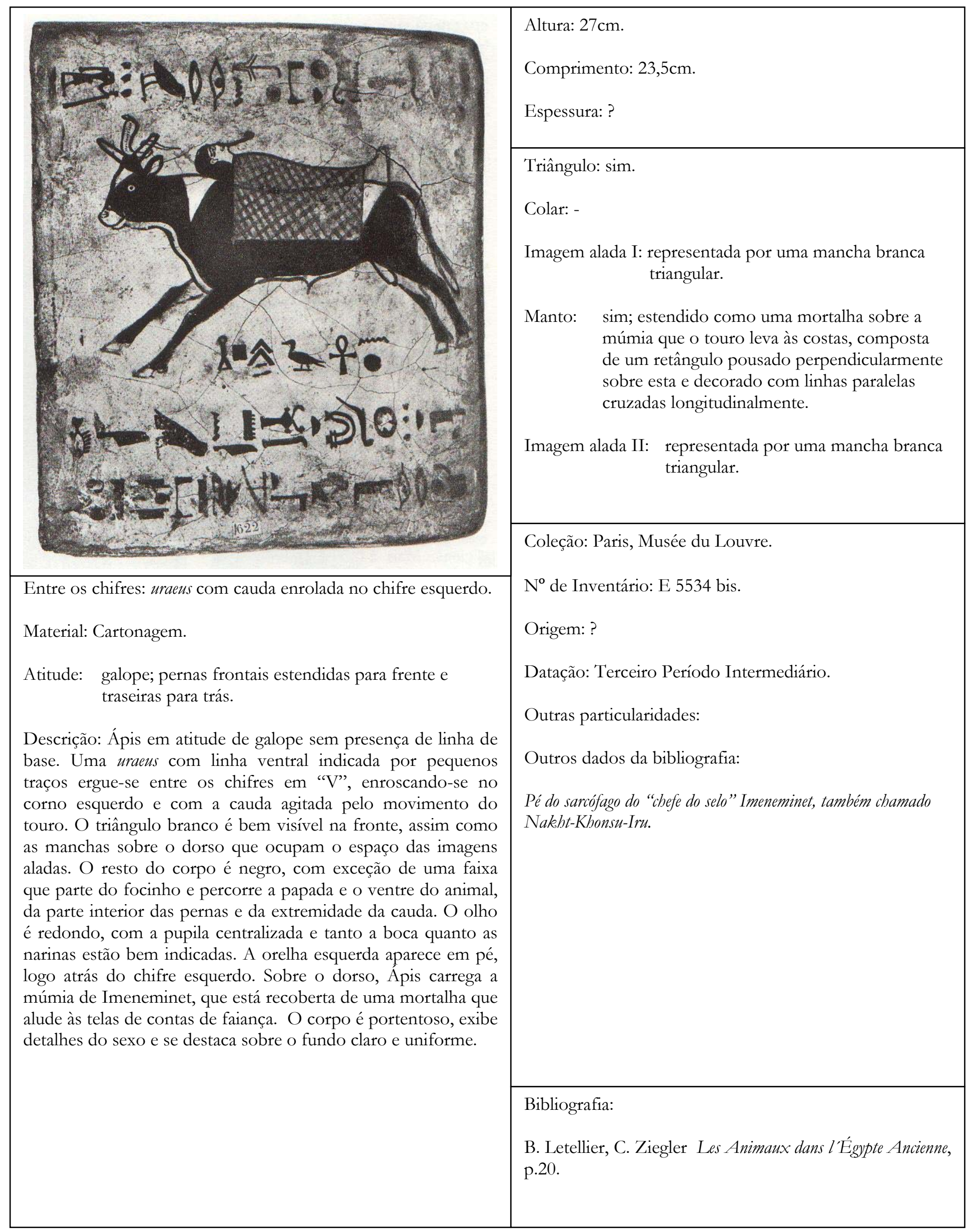




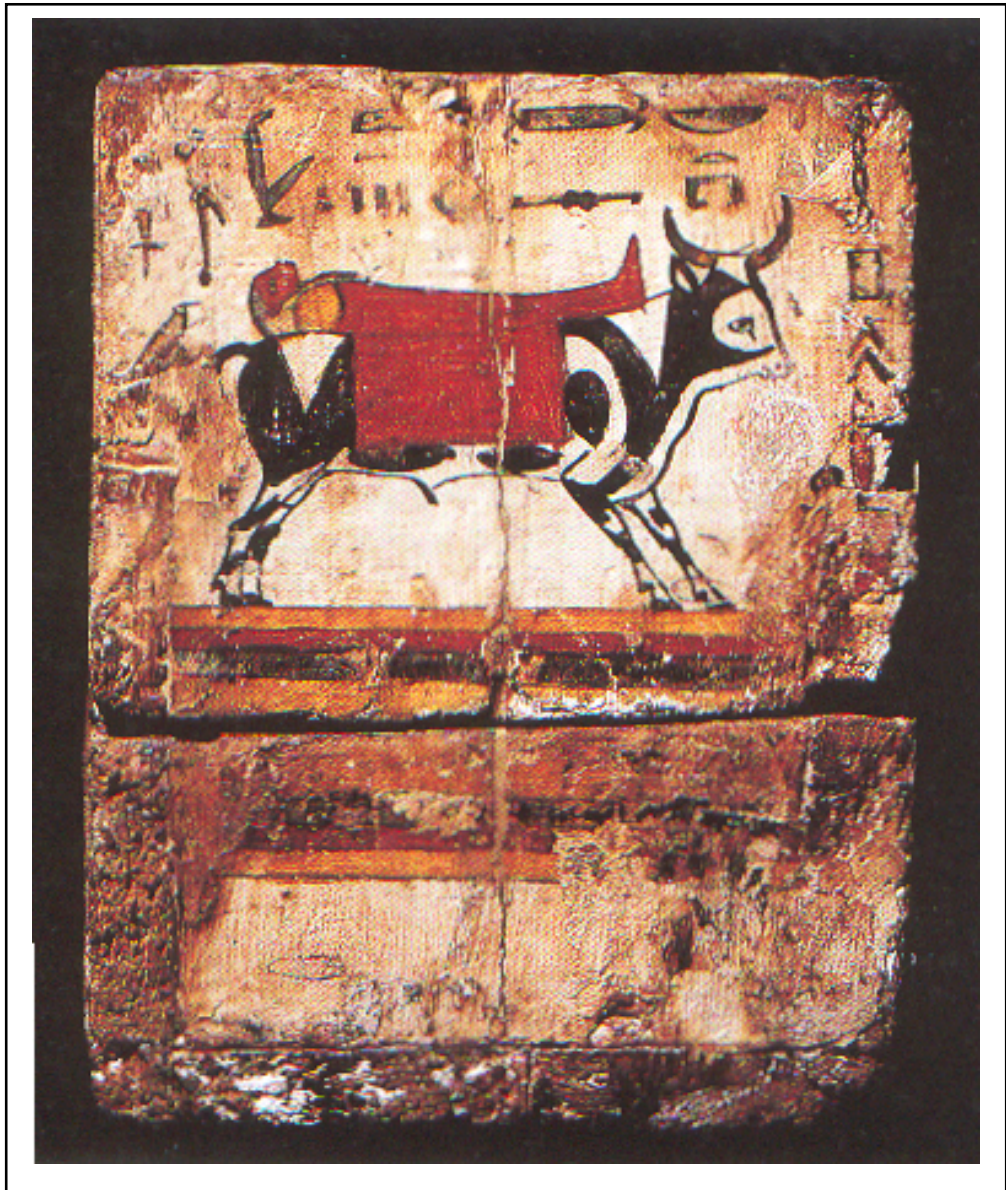

Entre os chifres: -

Material: madeira estucada policromada.

Atitude: galope; pernas frontais estendidas para frente $\mathrm{e}$ traseiras para trás.

Descrição: Ápis em atitude de galope voltado para a direita sobre linha de base formada de várias faixas paralelas de cores diversas. Seu corpo viril é representado por linhas precisas e sua pelagem branca apresenta manchas negras dispostas de maneira pouco comum. No entanto, sobre os ombros, ancas e testa, as partes deixadas em branco sugerem as silhuetas das imagens aladas presentes em outras fontes e o triângulo frontal. Sobre o seu dorso e com a cabeça apoiada sobre as ancas repousa a múmia da dama Gaut-seshen, com uma máscara funerária com colar e mortalha pintada de vermelho. Um manto retangular rubro que se confunde com a cor do corpo da falecida protege as costas do touro, encobrindo parte das laterais do animal. Os chifres alongados assumem a forma de um crescente e a cabeça apresenta feições delicadas, com o olho inserido no centro de uma ampla mancha branca e a narina e boca são especialmente discretas. A cauda está danificada na sua maior parte e os membros ligeiramente flexionados transmitem o ímpeto do movimento e detalhes da anatomia com sutileza.
Altura (da urna funerária): $1,83 \mathrm{~cm}$.

Largura: ?

Espessura:?

Triângulo: sim.

Colar: -

Imagem alada I: sim; sugerida pela marca triangular sobre o pescoço.

Manto: sim; constituído de um retângulo vermelho disposto perpendicularmente em relação ao dorso.

Imagem alada II: sim; sugerida pela marca triangular sobre as ancas.

Ápis em galope, com triângulo na testa e manto cobrindo o dorso sobre o qual repousa a múmia do falecido. Manchas negras espalhadas em diversos locais pouco usuais e presença de marcas nas costas que sugerem as imagens aladas de outras fontes.

Coleção: Copenhagen, Ny Carlsberg Glyptotek.

No de Inventário: AEIN 1522.

Origem: Deir el Bahari, esconderijo dos sacerdotes de Montu.

Datação: final da $25^{a}$-início da $26^{a}$ dinastia.

Outras particularidades: madeira estucada e pintada.

Outros dados da bibliografia:

Urna funerária interna de Gaut-seshen, filha de Hor e neta de Djed-Mut-iu-ef-ankh, ambos sacerdotes de Montu, Amon e Opet.

Bibliografia:

M. Jørgensen Catalogue Egypt III, p. 240. 


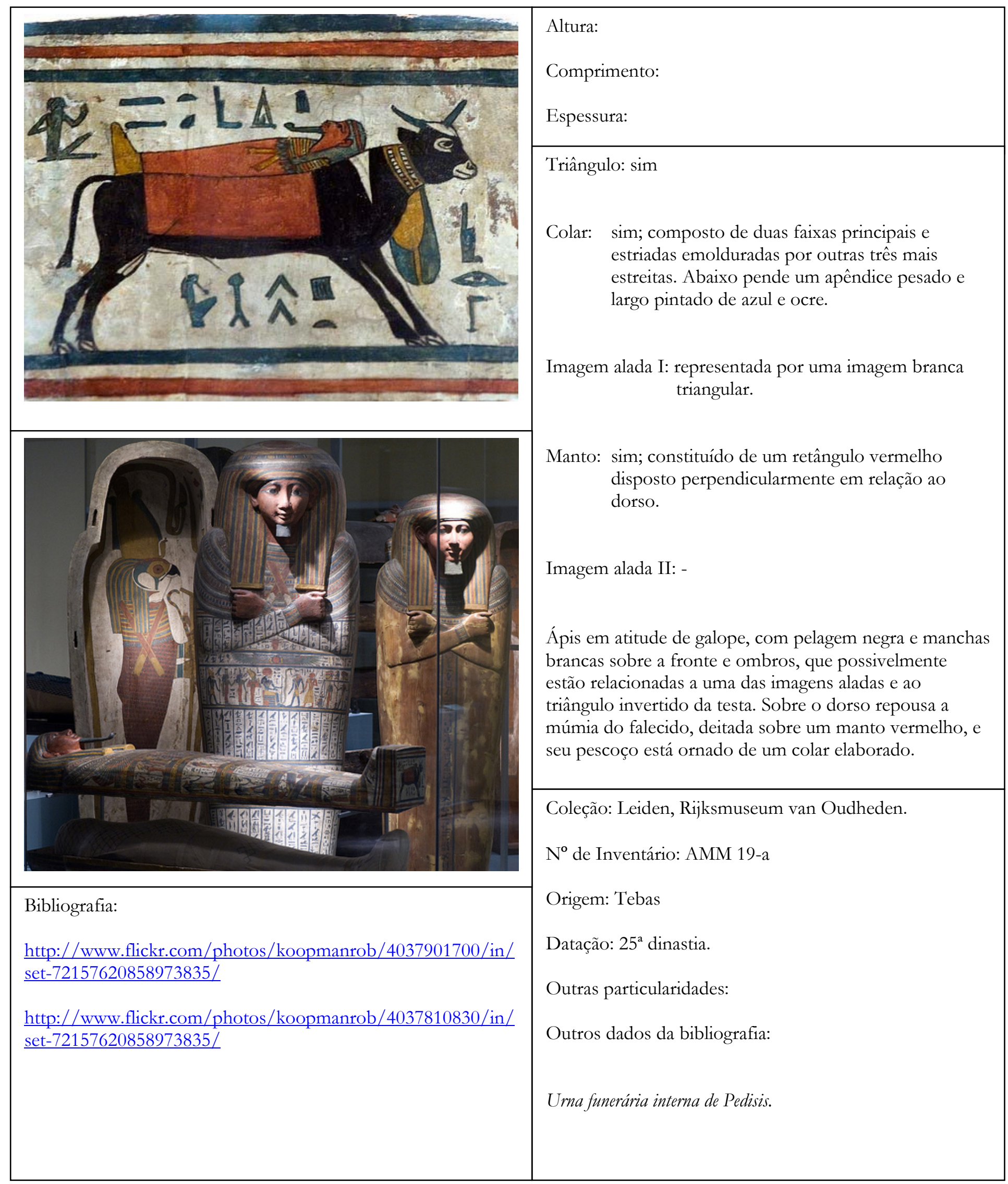


Entre os chifres: -

Material: madeira estucada e policromada

Atitude: galope; pernas frontais estendidas para frente e traseiras para trás.

Descrição: Ápis em atitude de galope voltado para a direita, sobre linha de base que é, ao mesmo tempo, um dos lados de uma moldura que enquadra a cena. Seu corpo expressa vitalidade e vigor é ilustrado por linhas precisas. Sua pelagem negra contrasta com as poucas partes deixadas em branco: uma marca triangular sobre os ombros, que lembra uma imagem alada encontrada em outras fontes, uma mancha no alto da fronte, que por sua localização deve aludir ao triângulo invertido e outras duas que ressaltam o focinho e o olho. Suas feições são delicadas e os membros bem modelados. O sexo é indicado em branco e de maneira discreta, os chifres azuis estão configurados em "V" e a cauda, bastante destacada, procura indicar o a ação do bovino. O pescoço está ornado com um colar elaborado formado de duas faixas estriadas emolduradas por outras três, mais estreitas, e dele pende um ornamento pesado e grande. Sobre o seu dorso e com a cabeça voltada para a sua está a múmia de Petisis, com uma máscara funerária provida de um colar e aparentemente recoberta de uma mortalha vermelha independente do manto sobre a qual está deitada e que cobre o dorso taurino. 


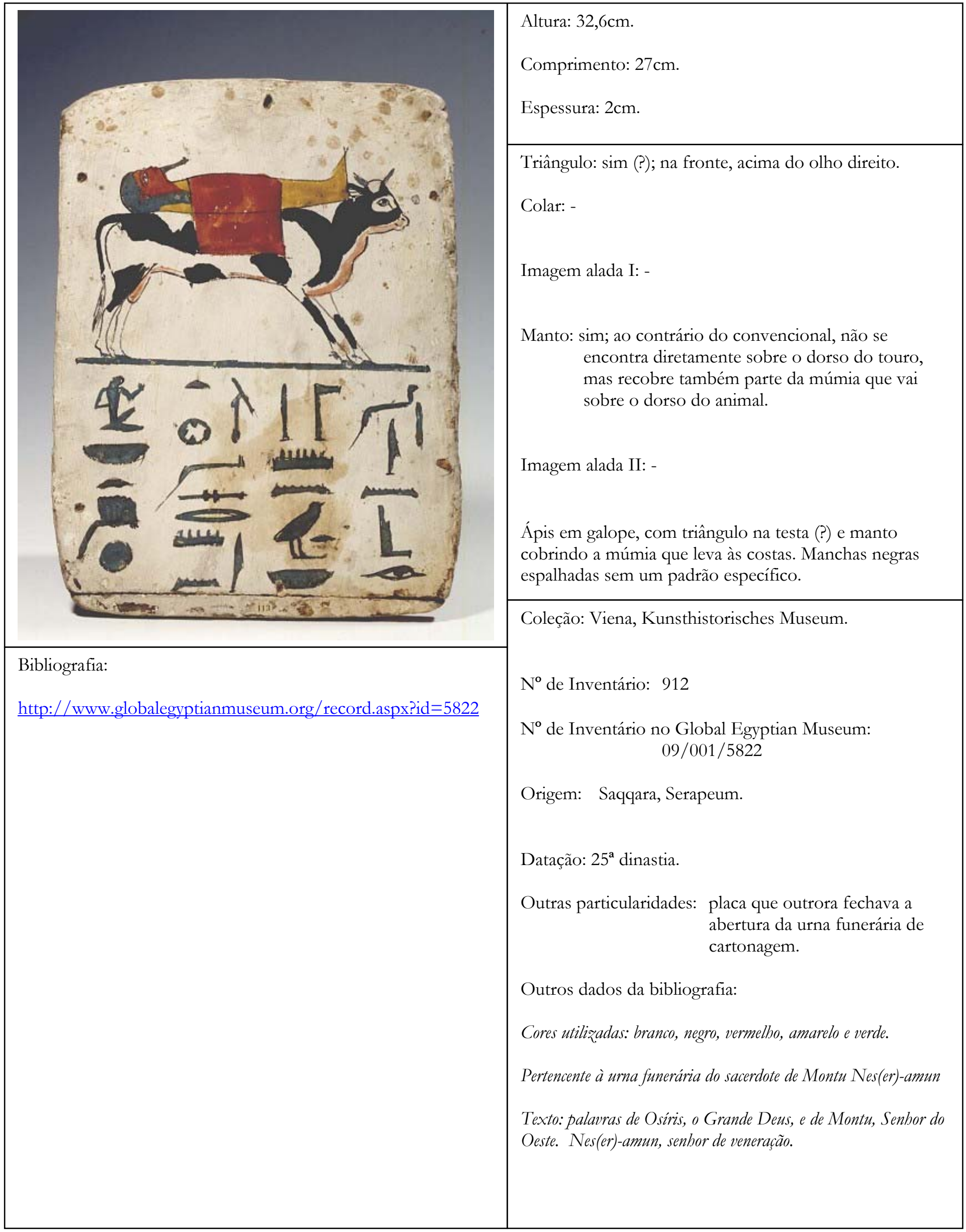


Entre os chifres: -

Material: madeira estucada e pintada.

Atitude: galope; pernas frontais estendidas para frente e traseiras para trás.

Descrição: Ápis em atitude de galope voltado para a direita sobre linha de base. Seu corpo viril é representado por linhas precisas e sua pelagem branca apresenta manchas negras irregulares. No entanto, sobre os ombros e testa, as partes deixadas em branco sugerem uma das imagens aladas, presentes em outras fontes, e o triângulo frontal. Sobre o seu dorso e com a cabeça apoiada sobre as ancas repousa a múmia de Nes(er)-amun, com uma máscara funerária desprovida de colar e mortalha pintada de ocre. Um manto retangular vermelho a cobre parcialmente e desce encobrindo parte das laterais do animal. Os chifres curtos e cinzas assumem a forma de um "V" aberto e a região inferior do corpo que abrange a genitália, o abdômen, o peito e a papada tem coloração rosada. A cabeça apresenta feições delicadas, com o olho inserido no centro de uma mancha branca e a narina e boca são discretas. A cauda, terminada por um tufo, acompanha a curvatura dos membros traseiros, que, como os dianteiros, exibe leveza e detalhes da anatomia com sutileza. 


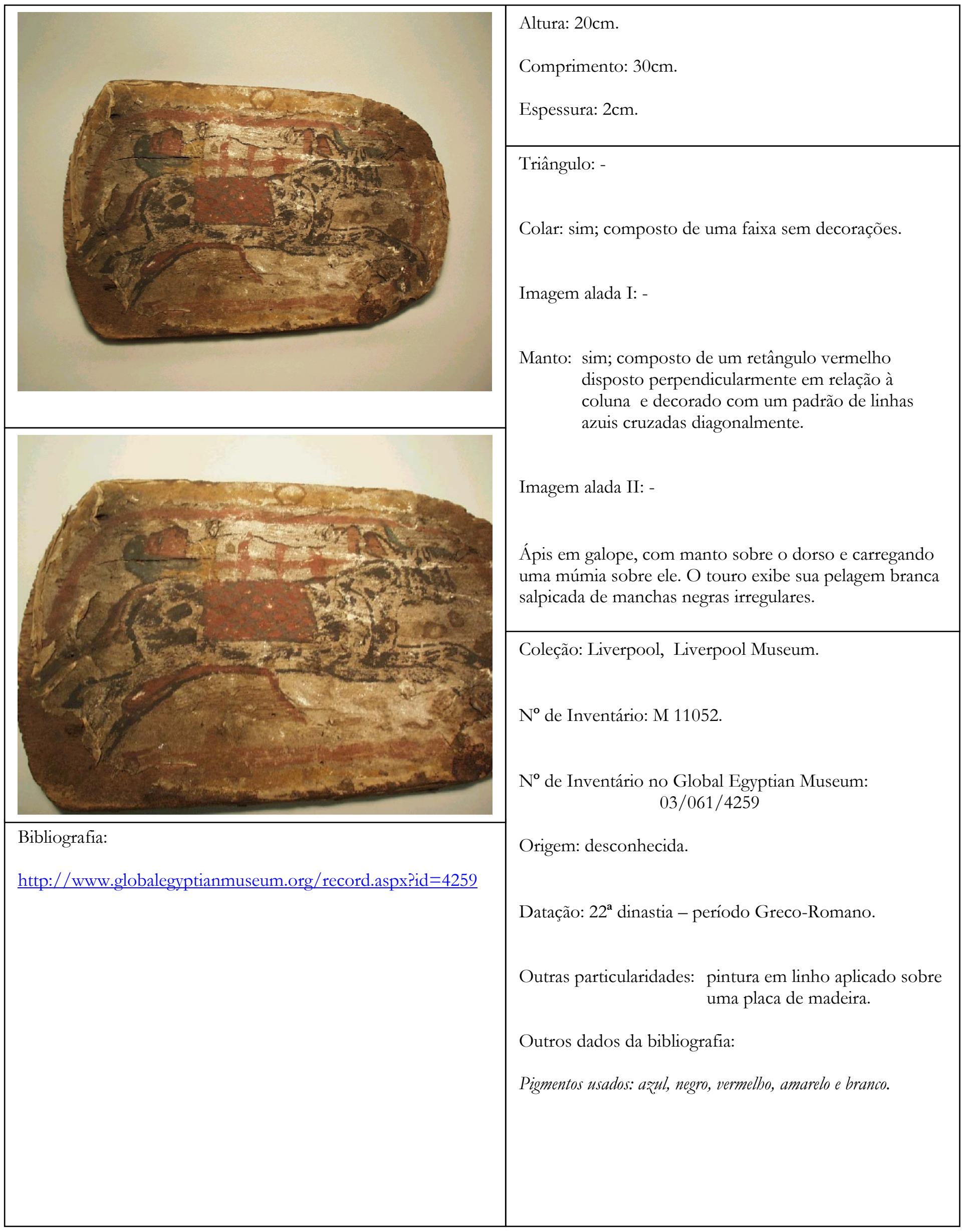


Entre os chifres: -

Material: madeira recoberta de linho e pigmentos.

Atitude: galope; pernas frontais estendidas para frente e traseiras para trás.

Descrição: Ápis em atitude de galope voltado para a direita, desprovido de linha de base. Seu corpo viril é representado por linhas precisas e sua pelagem branca está salpicada de manchas negras irregulares. Na parte central do dorso consta um manto retangular vermelho decorado com uma tela azul, como aquelas constituídas de segmentos tubulares de faiança. Os chifres azuis assumem a forma de um crescente e a genitália, bem distinta, é pintada integralmente de vermelho tal como o pavilhão auditivo. A cabeça do touro exibe feições delicadas e a cauda, já bastante apagada, parece transmitir o movimento do animal. Sobre o seu dorso e com a cabeça apoiada sobre as ancas repousa a múmia do falecido, com uma máscara funerária provida de colar e ataduras vermelhas modelando a mortalha ao corpo mumificado. 


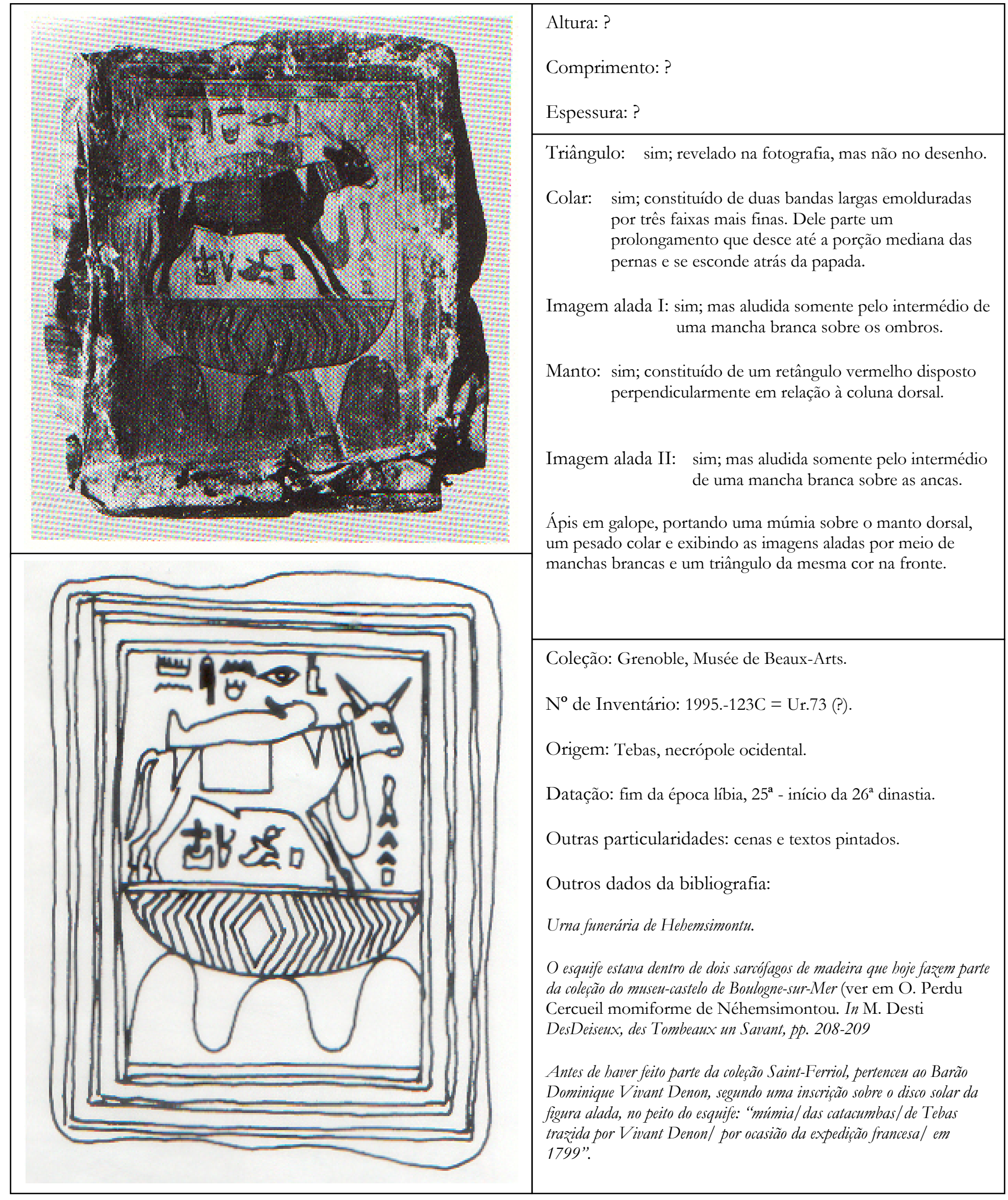


Entre os chifres: -

Material: cartonagem recoberta de pigmentos.

Atitude: galope; pernas frontais estendidas para frente e traseiras para trás.

Descrição: Ápis em atitude de galope sobre o hieróglifo para uma vasilha de alabastro M (W 3) o qual, por sua vez, repousa sobre o símbolo para o deserto e a necrópole $i \quad$ (N 25). O primeiro é usado no sentido de $n b$ A "senhor" e o segundo se refere à necrópole, qualificando Ápis em sua função funerária como "Senhor da Necrópole". O touro tem seu corpo bem definido e descrito de maneira atlética e viril. Sua pelagem é quase que completamente negra, mas destacam-se duas marcas triangulares brancas sobre o dorso no local onde as imagens aladas são ilustradas, e o triângulo invertido na fronte (não apresentado na ilustração em Bickel: 2004: p. 117). Os olhos e focinho são igualmente delineados de branco e os chifres relativamente grandes apontam em "V" sem um disco ou uraeus. Um pesado colar pende do pescoço e, às costas e sobre um manto retangular, descansa a múmia de Nehemsimontu, cuja cabeça está voltada para a do touro.

Bibliografia:

S. Bickel In ägyptischer Gesellschaft, p. 117.

G. Kueny, J. Yoyotte Grenoble, Musée de Beaux-Arts, pp. 100-104. 


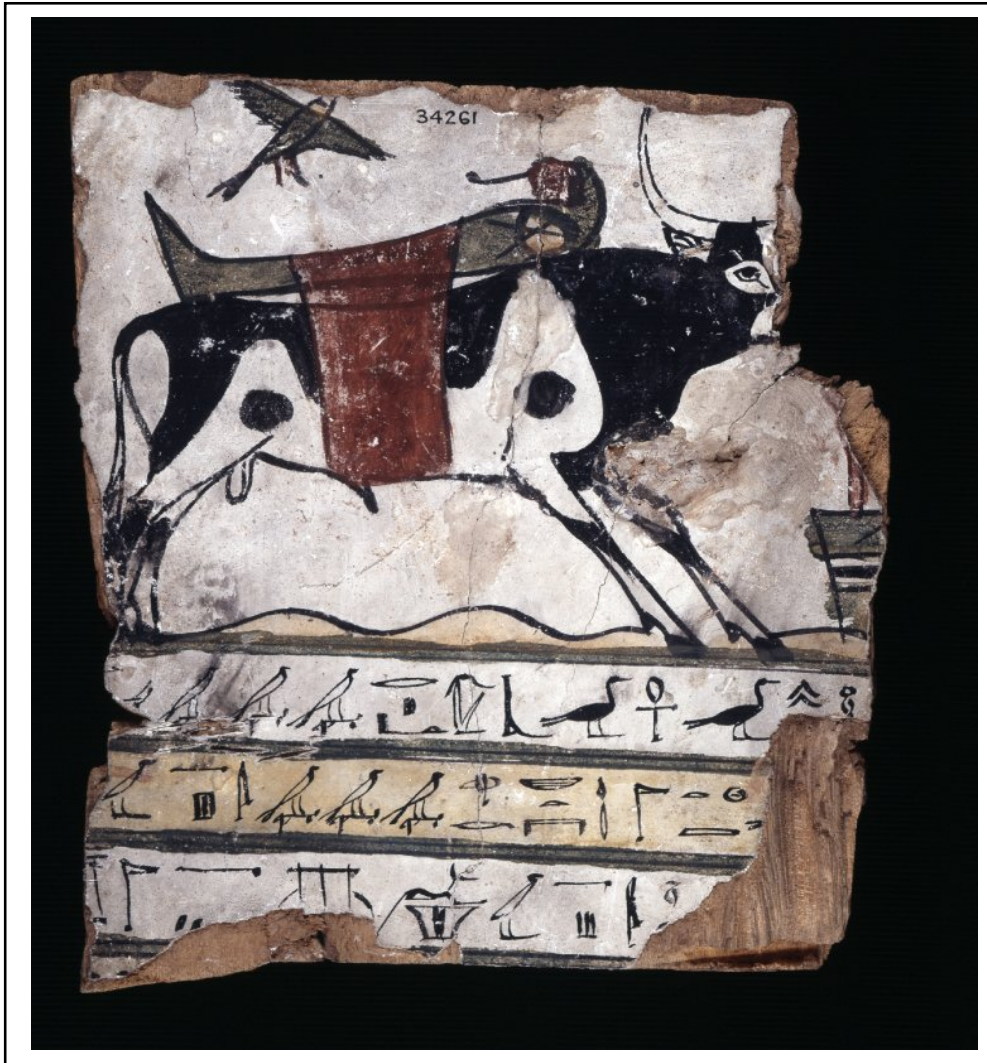

Entre os chifres: -

Material: madeira estucada policromada.

Atitude: galope; pernas frontais estendidas para frente e as traseiras para trás.

Descrição: Ápis em atitude de galope sobre uma linha de base, sobre a qual uma outra, ondulante, possivelmente descreve o cenário desértico. O corpo do touro exibe grande vigor e vitalidade e está descrito com linhas precisas e de maneira proporcional. O padrão de manchas negras comuns nas estelas está indicado com clareza, mas estas se fundem na parte superior do dorso. Em adição à elas, duas manchas circulares negras estão presentes sobre o ombro e parte frontal da coxa e tanto os olhos quanto o focinho estão demarcados de branco. O triângulo frontal, característico em muitas representações de Ápis, não se faz presente e os chifres do animal são grandes e configurados em crescente. As pernas, manchadas em sua região mediana, são esguias e sintetizam as formas presentes na anatomia bovina. Sobre o dorso repousa uma múmia com a cabeça sobre os ombros do touro que representa o proprietário do sarcófago e sobre a qual está pousado um manto vermelho. Logo acima, vê-se a representação do $B a$ do falecido e diante do bovino, sobre o chão, há uma vasilha para incenso da qual sobe uma chama 1 (R 7).
Altura: 22,2cm.

Comprimento: $26,3 \mathrm{~cm}$.

Espessura: 3,8cm.

Triângulo: -

Colar: -

Imagem alada I: -

Manto: sim; constituído de um quadrilátero pintado de vermelho que cobre tanto a múmia sobre o dorso do touro quanto as laterais deste.

Imagem alada II: -

Coleção: Londres, British Museum.

No de Inventário: EA 34261.

Origem: região Tebana

Datação: Período Tardio.

Outras particularidades: Parte dos pés de um ataúde de madeira,.ao qual se fixava por intermédio de pinos.

Outros dados da bibliografia:

Pintado de branco, negro, vermelho, verde e amarelo.

Bibliografia:

http://www.britishmuseum.org/research/search the col lection_database/search_object_details.aspx?objectid=16 $\underline{8071 \& \text { partid }=1 \& \mathrm{IdNum}=34261 \& \text { orig }=\% 2 \text { fresearch } \% 2 \mathrm{fs}}$ earch the collection database $\% 2$ fmuseum no proven ance search.aspx 


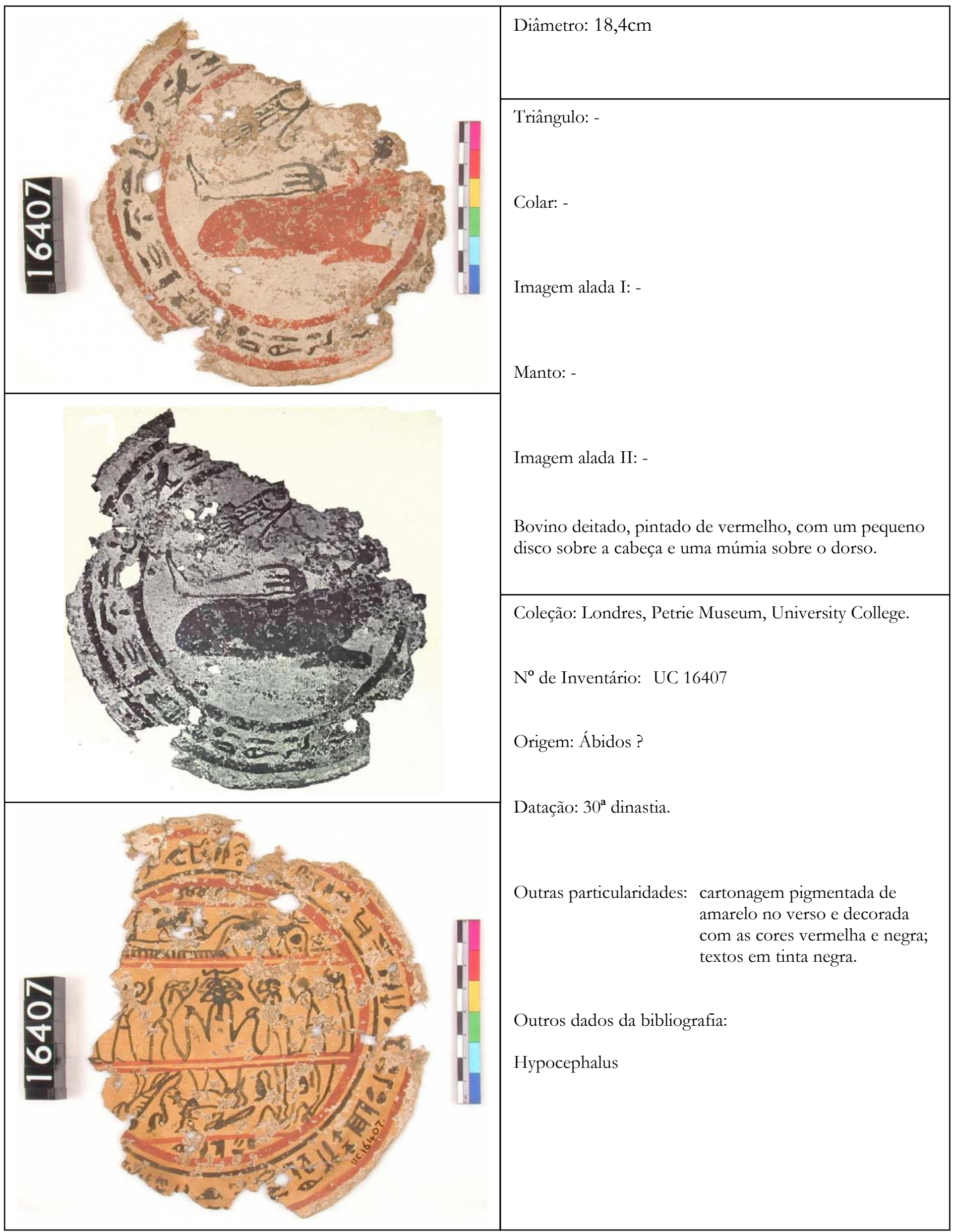


Sobre a cabeça: pequeno disco pintado de negro; um pequeno traço abaixo deste pode ser o vestígio de um dos chifres.

Material: cartonagem policromada

Atitude: repouso; bovino deitado sobre o abdômen com pernas frontais flexionadas.

\section{Descrição:}

Recto: no centro do artefato, representação de um bovino deitado sobre o ventre e com as pernas frontais recolhidas, pintado de vermelho e cujo corpo não é demarcado por contornos ou outros detalhes. Sobre sua cabeça distingue-se um círculo negro que deve representar o disco solar, o qual está unido a um traço da mesma cor que pode ser um dos chifres. Sobre o seu dorso, descrito por linhas negras e com a cabeça pousada em seus ombros, repousa uma múmia provida de uma máscara funerária com colar e dois traços abaixo dele indicando as ataduras. Não se vêem detalhes na face pintada de preto e acima do corpo há a representação parcial de um disco alado com uma uraeus pendente. Emoldurando a cena consta uma fórmula de proteção ao falecido.

Verso: um texto circunda o interior do hypocephalus, o qual está dividido em três registros. No meio do registro central há uma representação criocéfala de Amon, dotado de quatro cabeças e adorado por dois babuínos, dois homens e duas mulheres. Acima, a barca solar puxada por dois chacais. No registro inferior oposto, quando virado cento e oitenta graus, podemos distinguir uma vaca, sobreposta de um disco com uraeus, dois indivíduos em pé em atitude adoração e acompanhados de duas serpentes atrás dela e, à frente, outra naja seguida de uma representação do $B a$ do morto.

Bibliografia:

J. Vandier Le Taureau Apis dans le Papyrus Jumilhac, p. 120, nt. 3

W. M. F. Petrie Amulets, p. 80, n 134, pr. XXa-b. 


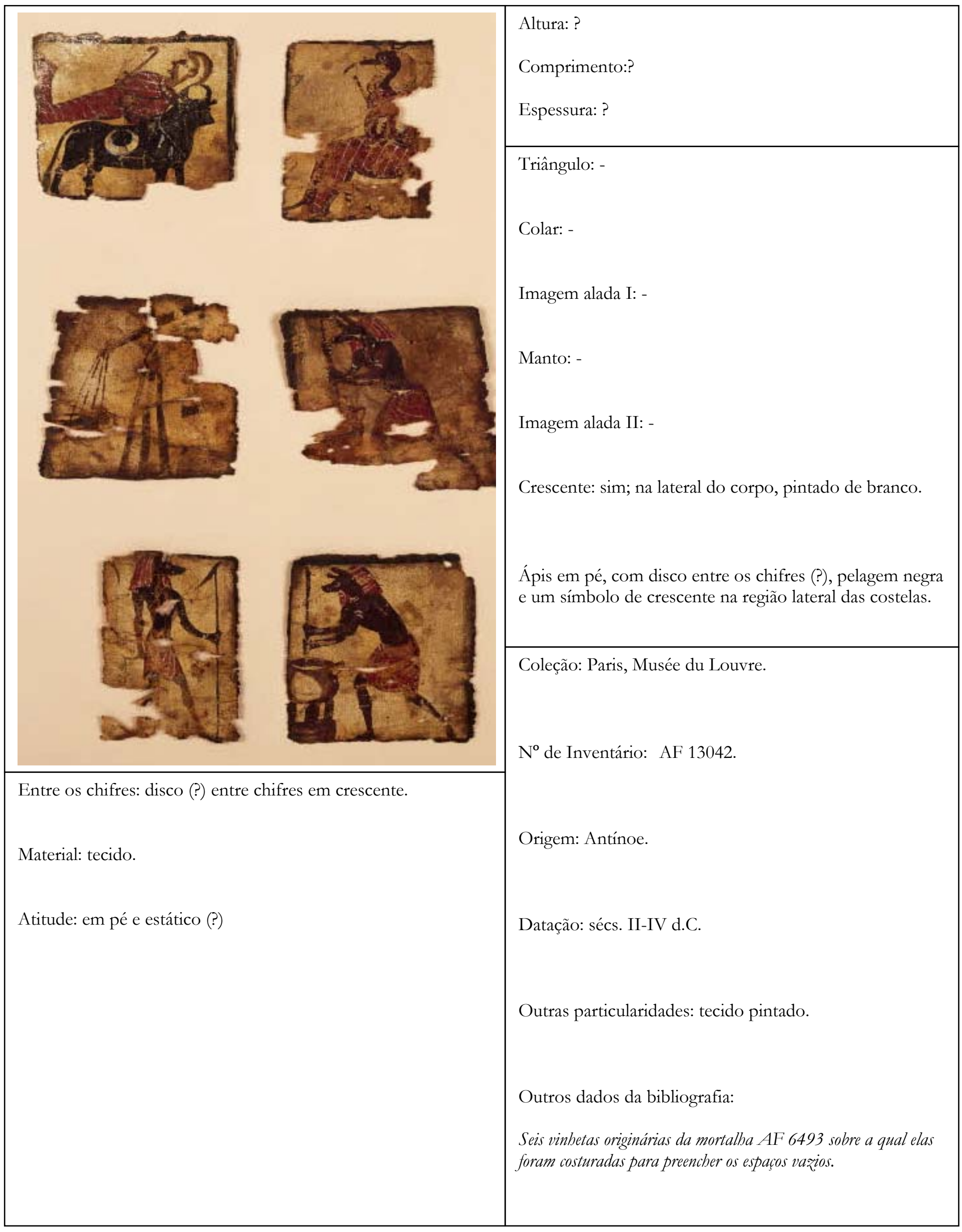


Descrição: da esquerda para a direita:

Primeira vinheta: Ápis em pé, voltado para a direita sobre linha de base. O touro, aqui ilustrado à maneira romana, exibe um porte que salienta a massa corporal do bovino e ilustra as pernas diferentemente da maneira egípcia em galope com as pernas estendidas. Não se percebe detalhamentos na imagem bidimensional do bovino, e de sua cabeça só se observa o contorno do focinho triangular e curto, de ambas orelhas e dos chifres em crescente fechado que possivelmente cercam um disco solar. $\mathrm{Na}$ lateral, sobre as costelas, se nota um grande crescente branco que contrasta com a pelagem completamente negra de Ápis. Sobre o dorso ele carrega uma múmia envolta em faixas de um vermelho vivo e com uma máscara da mesma cor do suporte material com um colar pontilhado de branco. Às mãos a múmia leva um cajado beka.

Segunda vinheta: imagem de Thot sentado, mumificado em bandagens vermelhas e voltado para a esquerda. A cabeça negra é coberta por um toucado ou peruca já muito apagado. As mãos junto ao peito originalmente devem ter ostentado dois cetros, um dos quais presente logo abaixo do bico.

Terceira vinheta: Uma balança com pratos desequilibrados sustentados por três fios e com uma base composta de três traços inclinados.

Quarta vinheta: Anúbis em pé, voltado para a esquerda e curvado diante de um caldeirão no qual prepara os ingredientes para a mumificação com a ajuda de um bastão. Seu corpo é completamente negro, as pernas estão afastadas e flexionadas e tanto seu toucado quanto o saiote são vermelhos - o primeiro com estrias brancas e o segundo com traços que parecem indicar as dobras do tecido.

Quinta vinheta: Anúbis em pé em atitude de marcha, voltado para a direita, portando um cetro was em sua mão esquerda e a outra estendida junto ao corpo. Sua caracterização é semelhante à anterior.

Sexta vinheta: semelhante à quarta cena e melhor preservada. As estrias do toucado são, no entanto, horizontais.

Bibliografia:

http://cartelfr.louvre.fr/cartelfr/visite?srv $=$ car not frame\&idNotice $=27905$ 


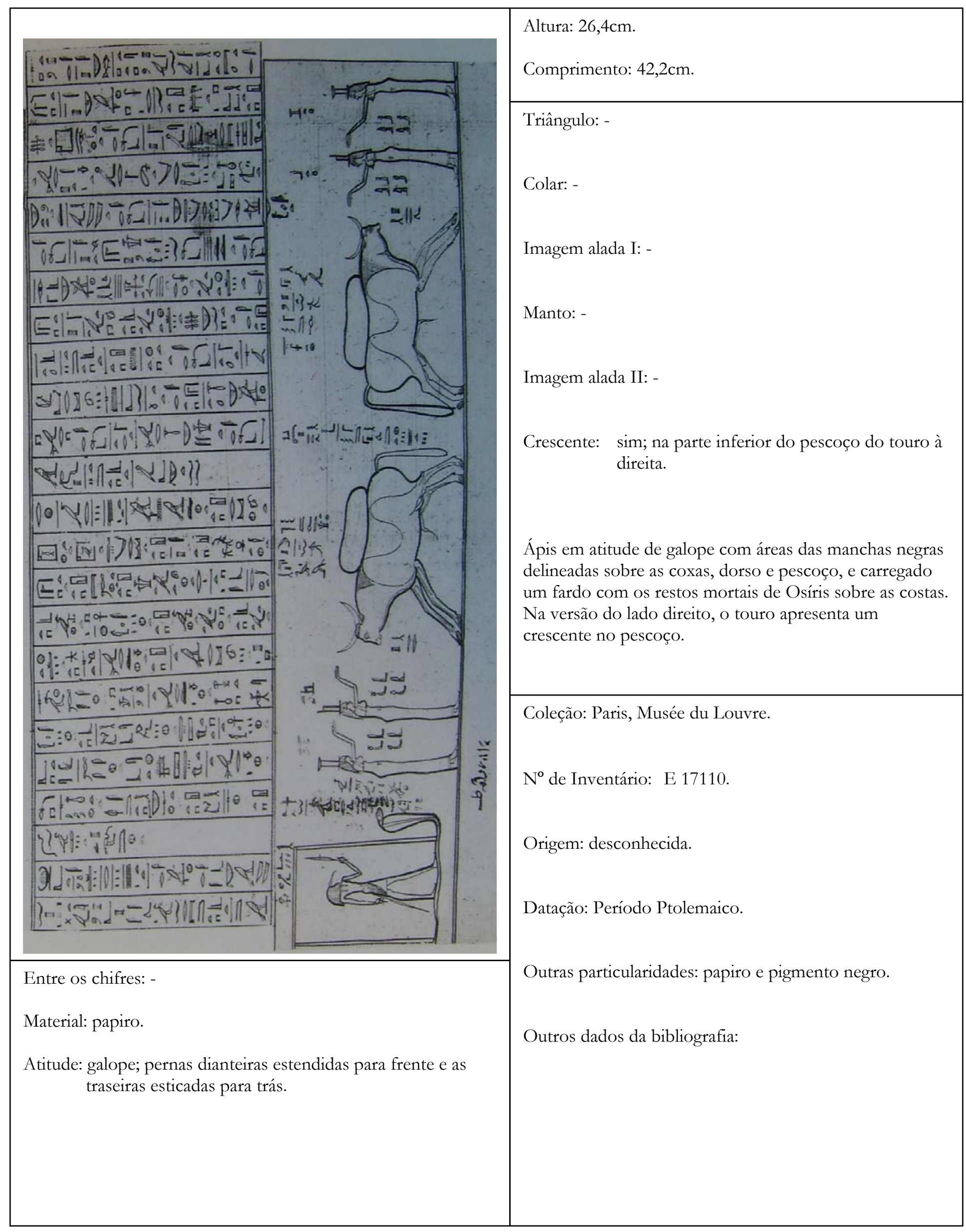


Descrição: A cena duplicada por uma coluna central de texto é descrita na parte inferior do documento, e ilustra Ápis caracterizado pelas linhas demarcatórias das manchas negras de seu corpo, o qual é imponente e descrito por uma mão precisa. O tratamento das pernas procura sintetizar as tensões da musculatura e tanto sobre a cabeça quando sobre os ombros destacam-se linhas que compõem a pelagem. A cabeça, especialmente diminuída no touro à direita, apresenta chifres em crescente e um focinho gentilmente moldado. Os olhos são ilustrados com esmero e as narinas e boca são discretas. Embora as manchas corporais estejam presentes, não notamos em nenhuma das representações o triângulo frontal, e somente o animal do lado direito é ilustrado com um crescente no pescoço. A cauda, que é consideravelmente maior neste touro, apresenta em ambos uma intumescência progressiva até próximo à sua extremidade, e em nenhum dos casos se deixa afetar pela movimentação do galope. Em ambas versões, o sexo do bovino está bem caracterizado tanto pelo falo quanto pelo scrotum. Sobre o dorso, Ápis carrega um fardo que supostamente contém os membros de Osíris, para que estes sejam enfim reunidos e mumificados em Mênfis e o deus encontrasse seu descanso final em Heliópolis. Diante das duas representações de Ápis estão Ísis e Néftis com seus braços erguidos em direção ao animal. Abaixo dos braços das deusas, nos dois lados, aparece escrito duplamente "vem aquele que carrega", enquanto que diante do bovino somente "correr". Sobre ele, do lado direito, a legenda esclarece: "é Apis-Hórus; foi ele que carregon os membros do deus das capelas do (ou, através do) País do Sul". No lado esquerdo, o texto é similar, exceto pela substituição do trecho "País do Sul" por "País do Norte". A coluna que divide os registros especifica um pouco mais o conteúdo dessas legendas: "é o touro que corre e que carrega, por cidades e nomos, os membros desse deus em Hp". Como a palavra "bep", "correr", é homófona do nome do deus taurino e aqui resultaria em um pleonasmo, Vandier conclui, baseado na prática egípcia de utilizar jogos de palavras em seus textos, que a intenção do escritor era que ela significasse "na qualidade de Ápis". Assim, Hórus, na qualidade de Ápis e assumindo a forma deste, estaria recolhendo as partes desmembradas de seu pai Osíris por todo o país para então reuni-las em Mênfis, onde seriam devidamente embalsamadas para o sepultamento no centro de culto solar, Heliópolis.

Bibliografia:

J. Vandier Le Papyrus Jumilhac, pp. 9-10, 138, pr. VII.

J. Vandier Memphis et le Taureau Apis dans le Papyrus Jumillhac, BdE 32, pp. 117-118. 


\section{MONUMENTOS DO SERAPEUM OU ATRIBUÍDOS A ELE}

$(\mathbf{S E})$ 


\section{MONUMENTOS DIVERSOS DO SERAPEUM}

(SEdiv) 


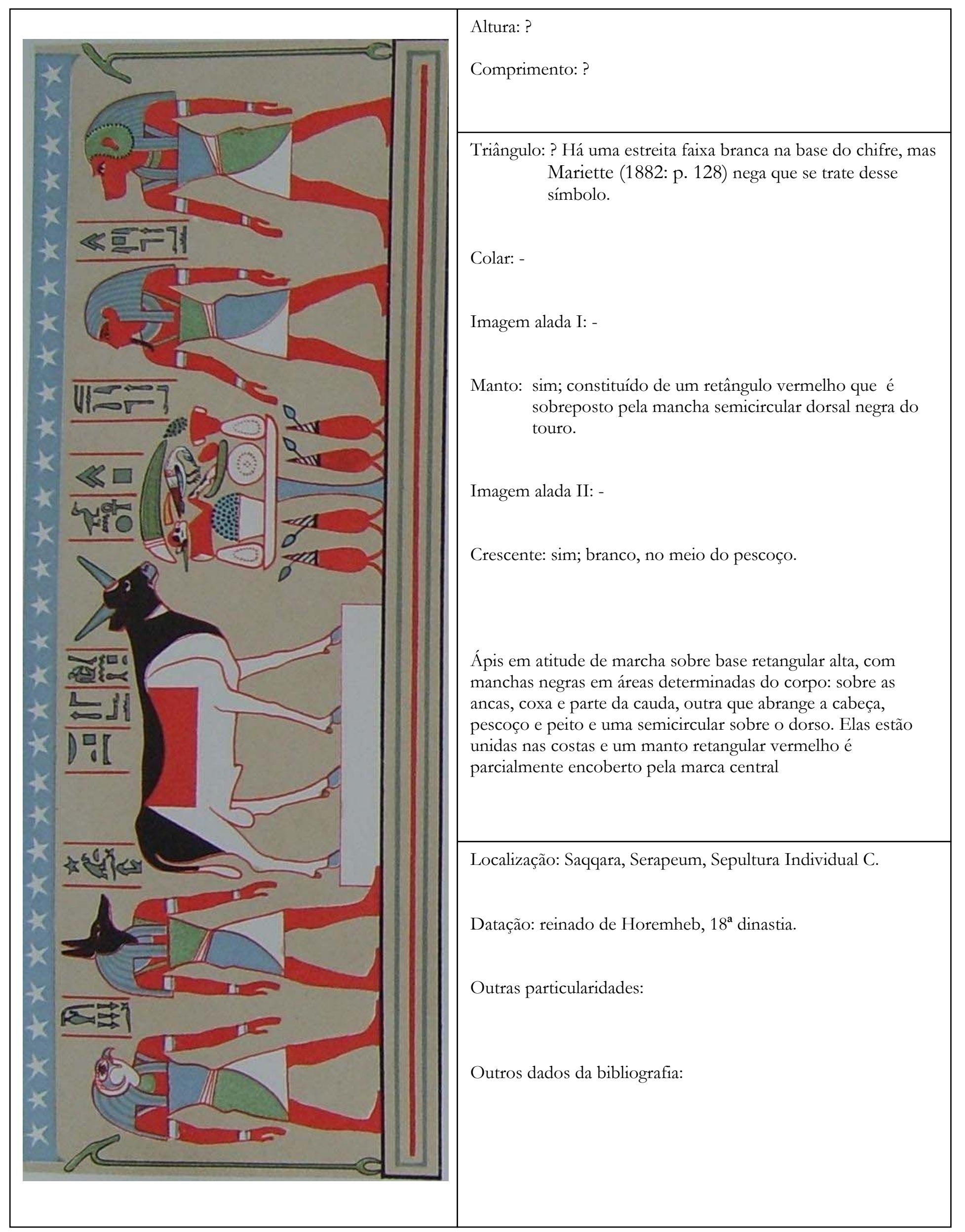


Entre os chifres: -

Material: afresco

Atitude: marcha; pernas do lado esquerdo avançadas em relação às do direito.

Descrição: A cena é enquadrada por dois cetros was nas laterais, um símbolo para o céu (pt) acima e por uma base retangular longa decorada internamente por um quadrilátero semelhante e uma linha. De costas para os cetros que sustentam os céus, voltados para o touro sagrado e em duplas, encontram-se os quatro filhos de Hórus em pé, vestidos de saiotes curtos, coletes com alças e perucas tripartites espessas. Da esquerda para a direita: Qebehsenuf, Duamutef, Imseti e Hapy. Ao centro, sobre uma base retangular branca de altura média e voltado para a direita destaca-se Ápis em sua apresentação teriomórfica, com a parte inferior do corpo branca e a superior coberta de manchas negras em áreas específicas e interligadas: uma que cobre parte das ancas e cauda, uma semicircular sobre o dorso e outra que domina toda a região do pescoço e cabeça. Na parte mediana do pescoço se destaca um crescente branco e uma estreita linha branca pode ser vista na base do corno esquerdo, mas cuja associação ao triângulo encontrado em fontes posteriores é desmentida por Mariette (1882: p. 128). Um manto retangular vermelho cobre o dorso, mas é deixado propositalmente "transparente" próximo à linha dorsal, de forma a exibir uma das manchas que caracterizam a pelagem desse animal. Os chifres são relativamente grandes, pontiagudos e em "V". Diante dele repousa uma mesa de oferendas abundantemente guarnecida.

Bibliografia:

A. Mariette Le Sérapeum de Memphis Découvert et Décrit, pr. 3.

A. Mariette Le Sérapeum de Memphis par Auguste Mariette-Pacha, pp. 126-128 


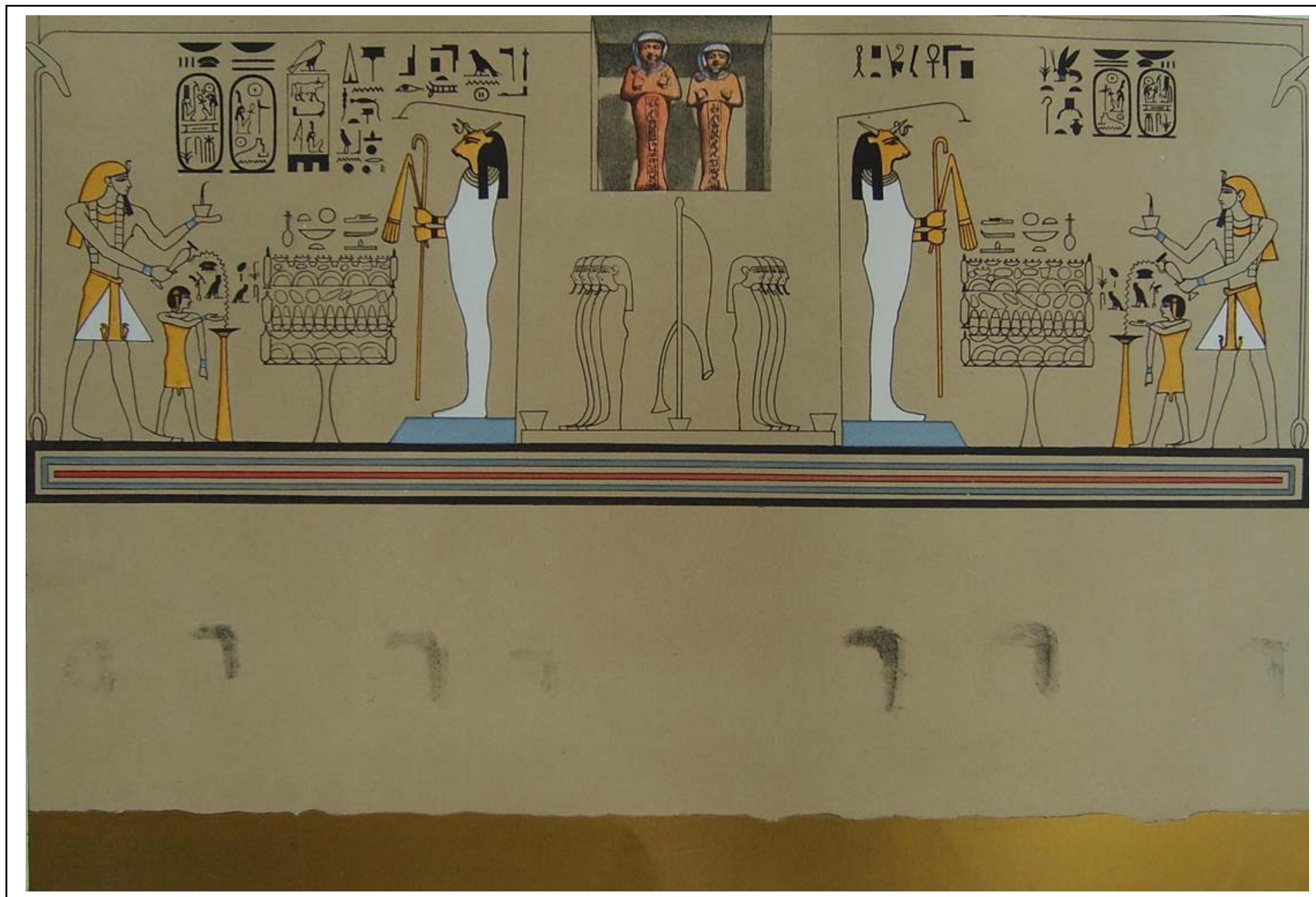

Localização: Saqqara, Serapeum, Sepultura Individual G, parede sul.

Datação: reinado de Ramsés II, $19^{\mathrm{a}}$ dinastia.

Outras particularidades: Ilustração de Mariette do afresco da parede sul da tumba $G$.

Outros dados da bibliografia:

A faixa inferior junto ao chão era composta de folhas de ouro.
Altura: ?

Comprimento: ?

Triângulo: -

Colar: sim; usekh.

Imagem alada I: -

Manto: -

Imagem alada II: -

Ápis antropomórfico e taurocéfalo mumificado, com uraeus entre os chifres e portando um cajado awt e um flagelum. 
Entre os chifres: em ambos registros, uraeus enroscada no chifre frontal.

Material: afresco.

Atitude: repouso; representação antropomórfica em pé e mumificada.

Descrição: O registro é emoldurado por dois cetros was que sustentam o símbolo do céu, pet, e a base é constituída de um retângulo alongado preto decorado internamente por outro da cor azul e, no meio, por uma faixa vermelha. Dividindo a cena repetida há um fetiche imiut, à frente do qual estão os quatro filhos de Hórus e um pequeno vaso, todos acima de uma base retangular. Logo em seguida destaca-se Ápis envolto em uma mortalha branca com parte dos antebraços e punhos à mostra e à sua frente portando um flagelo nekhekh e um cajado de pastor ' $w t$. Braceletes e um colar usekh enriquecem a imagem divina e uma peruca negra desce-lhe por sobre o peito e costas, emoldurando assim sua efígie taurina inconfundível por seus chifres em "V" de onde tomba uma uraeus e pela modelagem cuidadosa do focinho. Ápis, à maneira de Ptah ao qual está claramente identificado na legenda do lado direito, repousa sobre uma base em forma do hieróglifo $\mathrm{H}$ e no interior de uma capela no modelo do Alto Egito 5 . À frente do deus está disposta uma mesa repleta de oferendas, seguida de um altar onde Ramsés II, acompanhado de seu filho Khamewaset, verte libações enquanto queima incenso.

Bibliografia:

A. Mariette Le Sérapeum de Memphis Découvert et Décrit, pr. 8.

A. Mariette Le Sérapeum de Memphis par Auguste Mariette-Pacha, pp. 62, 139 


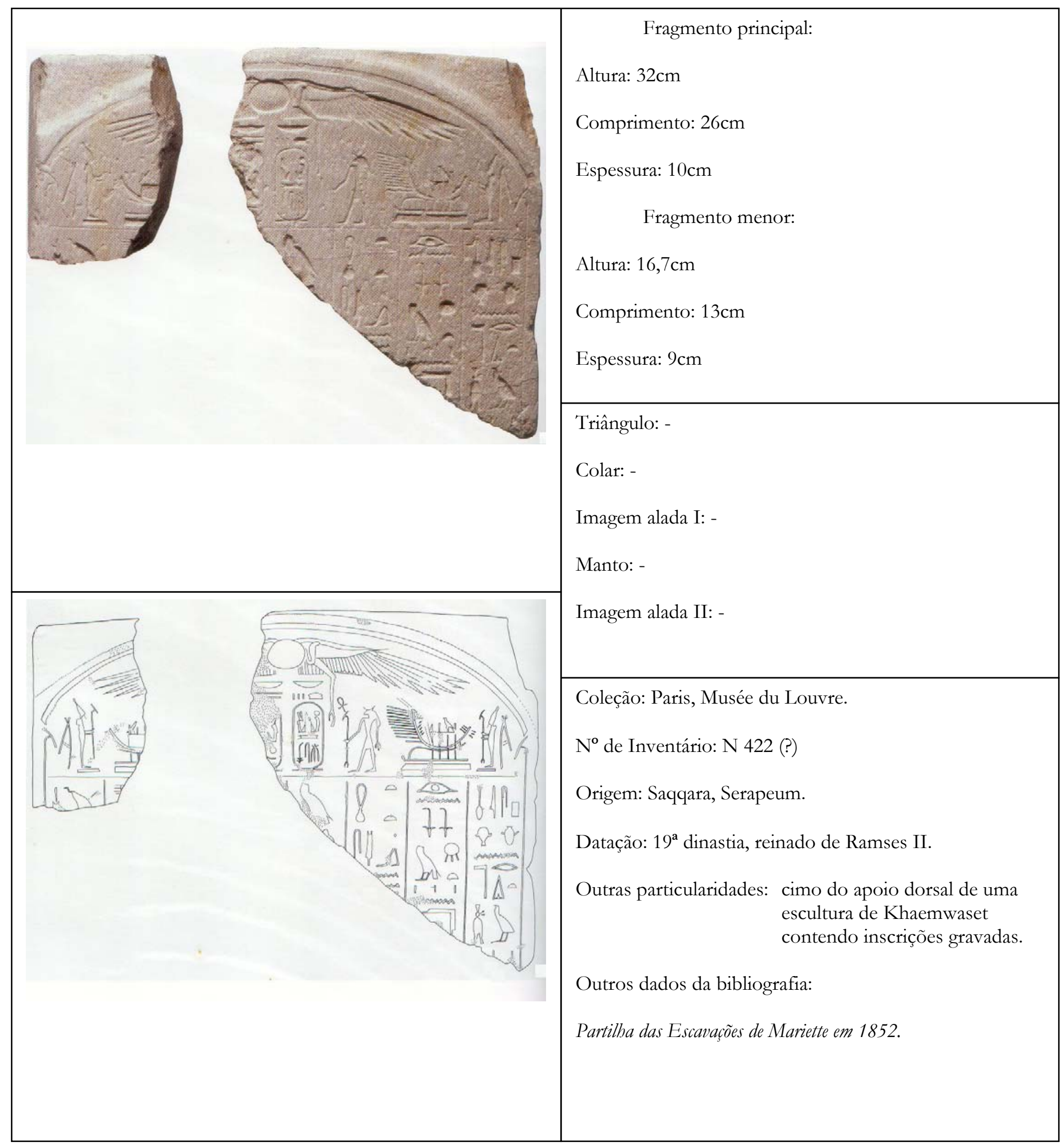


Entre os chifres: -

Material: calcário

Atitude: o deus aparece em pé, voltado para a esquerda e entre os títulos de Ramsés II e a barca de Sokar.

Descrição: Ápis, antropomórfico e taurocéfalo, aparece na linha superior e está voltado para a esquerda, acima da linha da base e abaixo da asa esquerda do disco que, juntamente com o símbolo para o céu $(p t)$ emoldura a parte superior do monumento, esculpido à imagem de uma estela com cimo abobadado. $\mathrm{O}$ deus ostenta diante de si um cetro $w 3 s$ de cuja extremidade superior brota um símbolo da vida ` $h \underline{h}$, ligeiramente tombado para a esquerda. Em sua mão esquerda possivelmente portava um símbolo semelhante e que se encontra atualmente apagado. Não são percebidas neste relevo quaisquer outras particularidades que a própria silhueta da divindade e seus chifres aparecem em "V". À frente de Ápis está o título de filho de Rê de Ramsés II ( $R^{\ulcorner} m s(w) s w$ mry 'Imn) precedido da expressão "senhor das coroas" ( $\left.n b h^{\complement}{ }^{\ulcorner} w\right)$. Seguindo o deus menfita está a barca de Sokar, a silhueta de Osíris em pé sobre o pedestal $m 3^{`} t$ portando o cetro $w 3 s$ e, por fim, o hieróglifo U6 $m r$ (Gardiner 1969: 516). Embora o monumento esteja danificado, é possível perceber que estas últimas imagens estão espelhadas no lado esquerdo e, possivelmente o mesmo ocorria com a representação de Ápis. O outro cartucho de Ramsés II corresponde ao título de rei do Alto e Baixo Egito e embora sua grafia se encontre severamente danificada, há indícios de que esteja escrito wsr M Me.t $r^{r}-\operatorname{stp}(w) n R^{\complement}$ (Poderosa é a ordem/justiça de Rê - Aquele que foi escolhido por Rê). Acima desses registros, como já foi brevemente comentado, há uma imagem alada do disco solar com duas urareus e braços estendidos para baixo abraçando os títulos do rei. Abaixo, uma série de oito colunas verticais contendo uma inscrição hieroglífica incompleta devido ao estado fragmentário da escultura. Da esquerda para a direita: (1) o sacerdote iunmut [ef...] (2) duradouro [...] (3) [...] (4) [...] (5) por meio de [...De] (6) mesmo, en ergui para [ele] (7) Tais são os benefícios que eu realisei para Apis! (8) É doce ao coração do deus de encontrar a contrapartida [...] (Barbotin 2001: 97).

Bibliografia:

C. Barbotin Les Statues Égyptiennes du Nouvel Empire, vol. 1, pp. 96-97; vol. 2, pp. 132-133. 


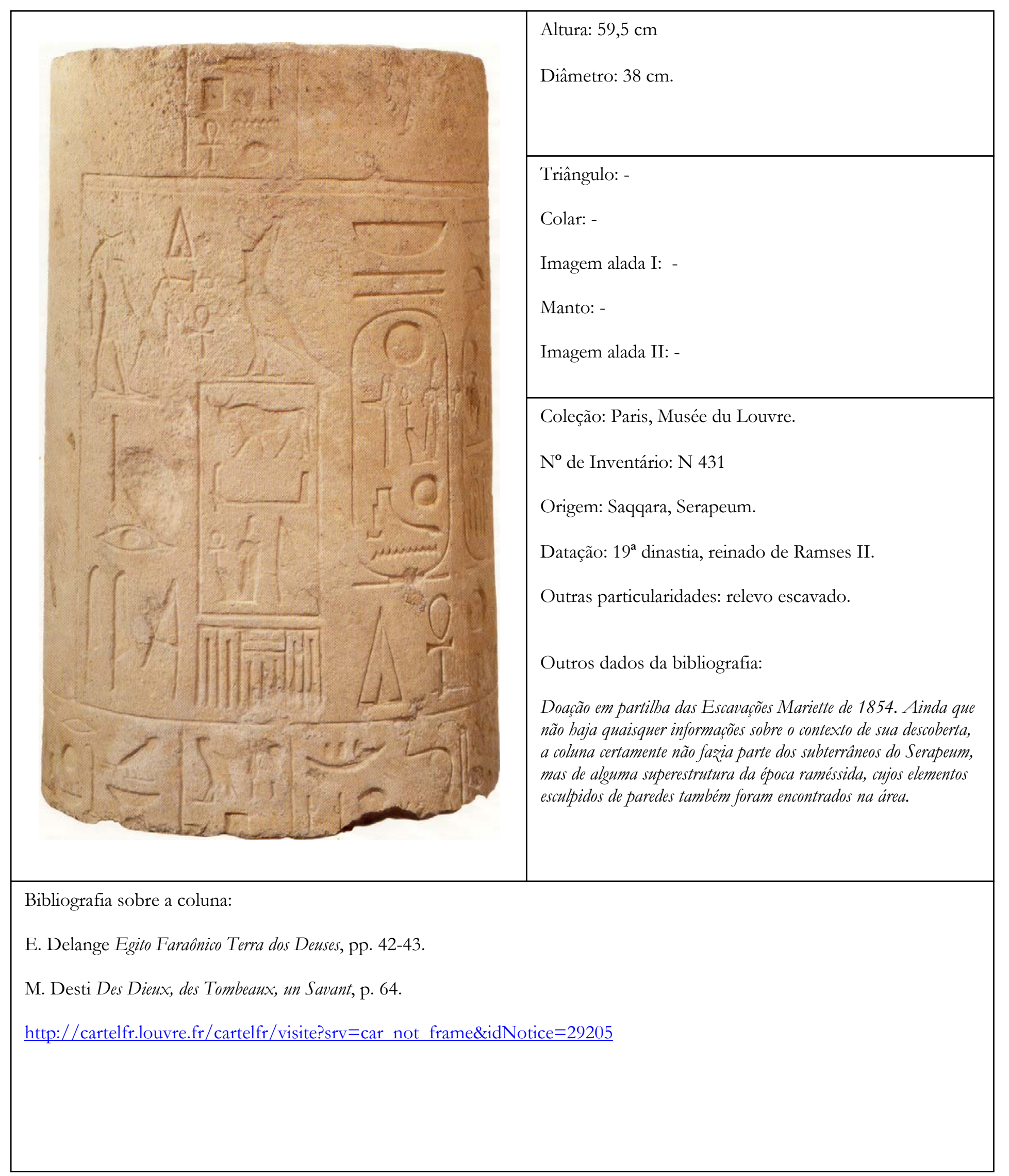


Entre os chifres: -

Material: calcário

Atitude: o deus aparece em pé, voltado para a direita, e está seguido do nome de Osíris e diante do título de Hórus de Ramses II.

Descrição: Ápis é apresentado em pé, antopomórfico e taurocéfalo no canto superior esquerdo. O relevo escavado não apresenta muitos detalhes além de sua silhueta, da peruca e do saiote e os chifres são caracterizados como um "V" aberto. Em sua mão direita porta um ' $n h$ (ou símbolo da vida) e a esquerda, avançada em relação ao corpo, um cetro $w 3 s$ inclinado para a frente de cuja extremidade superior surge outro símbolo da vida inclinado horizontalmente. Sobre ele está a palavra di (dá) e abaixo w3s (poder) e ' $n h$ (vida), resumindo a ação da divindade. Abaixo de Ápis está o nome de Osíris Wsir seguido da palavra "amado (de)" mry. Assim, a representação do deus menfita é para ser lida como ideograma para seu nome seguido de sua associação com Osíris: amado de Ápis-Osíris, que dá poder e vida. O objeto da ação divina é Ramsés II, cuja representação se faz por meio de seus títulos: primeiramente, seu título de Hórus inscrito em um serekh: $k 3$ hht $m r(y) M 3{ }^{\complement} . t$ (touro poderoso, o amado de Maat). Em seguida, seu nome de Rei do Alto e Baixo Egito ( $n b t 3 w y$, Senhor das Duas Terras) inserido em um cartucho e seguido da expressão dá vida $\left(d i{ }^{\top} n h\right): w s r M{ }^{\top}{ }^{\top} . t r^{\top}-\operatorname{stp}(w) n R^{\top}$ (Poderosa é a ordem/justiça de Rê - Aquele que foi escolhido por Rê). Por fim, precedido pela expressão $n b h^{\complement} w$ (senhor das coroas) e também em um cartucho, o título de Filho de Rê: $R^{\complement} m s(w) s w$ mry'Imn (foi Rê que o engendrou, o amado de Amon). Em seguida, mas não visível na fotografia, a frase "como Rê" mi $R^{\Upsilon}$ As inscrições estão contidas em um espaço retangular cuja parte superior parece exibir o símbolo para o céu $p t$. Acima, uma coluna contendo o final de uma inscrição onde se lê $H p$ 'nh "Ápis vivo/vive" (?) e, abaixo, várias colunas que apresentam uma inscrição incompleta e cuja continuação se fazia no tambor inferior. 


\section{SHABTIS DO SERAPEUM}

(SEsh) 


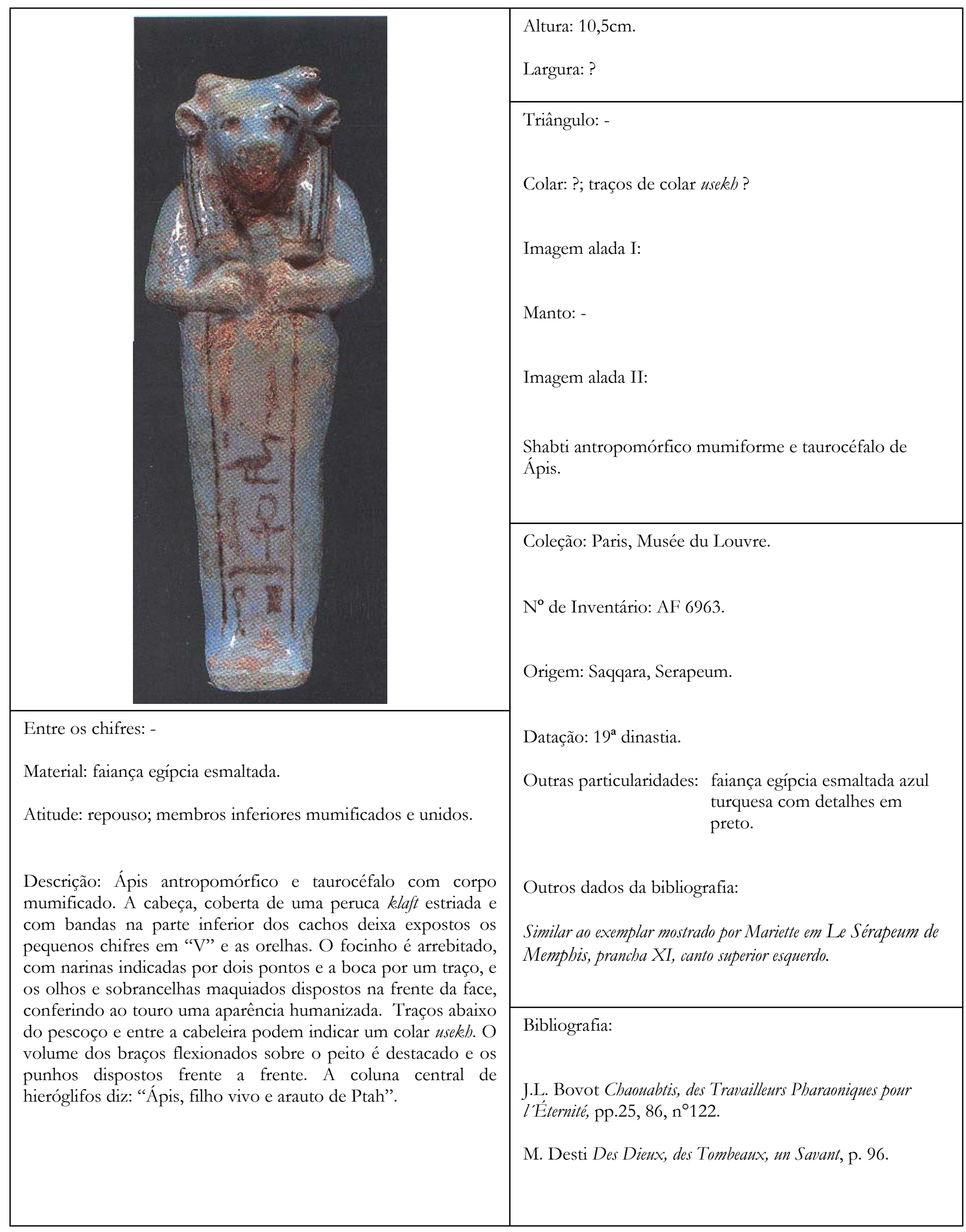




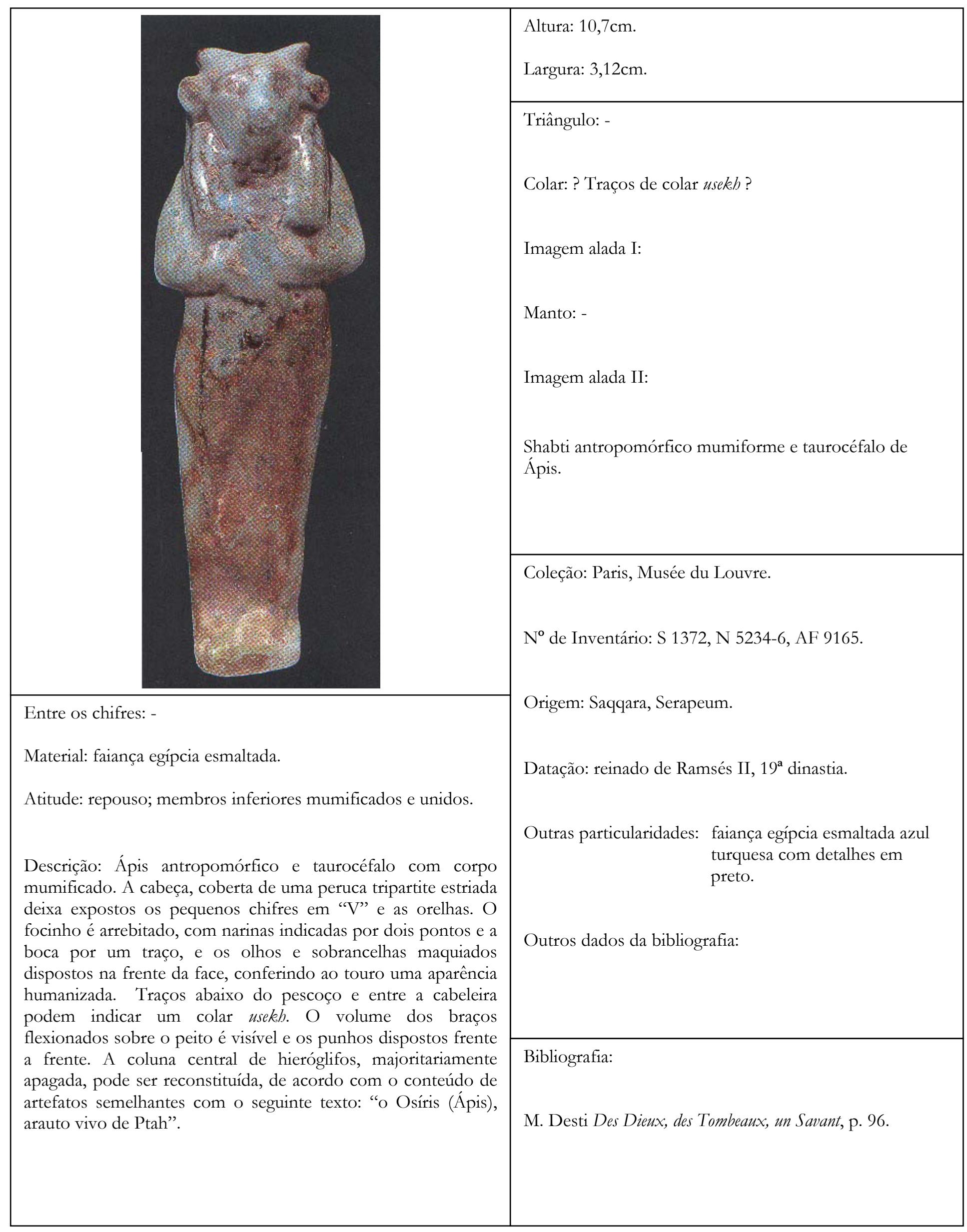




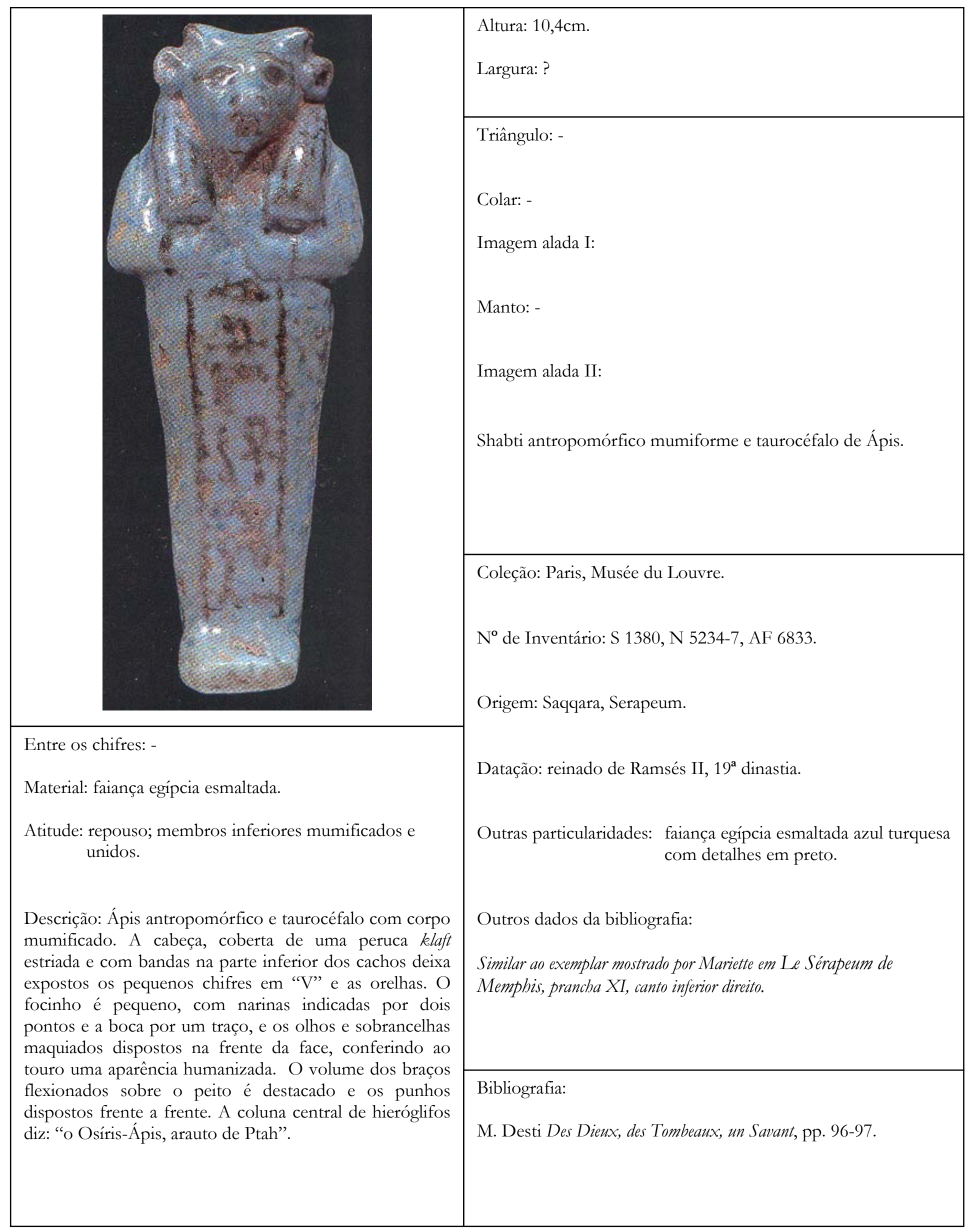




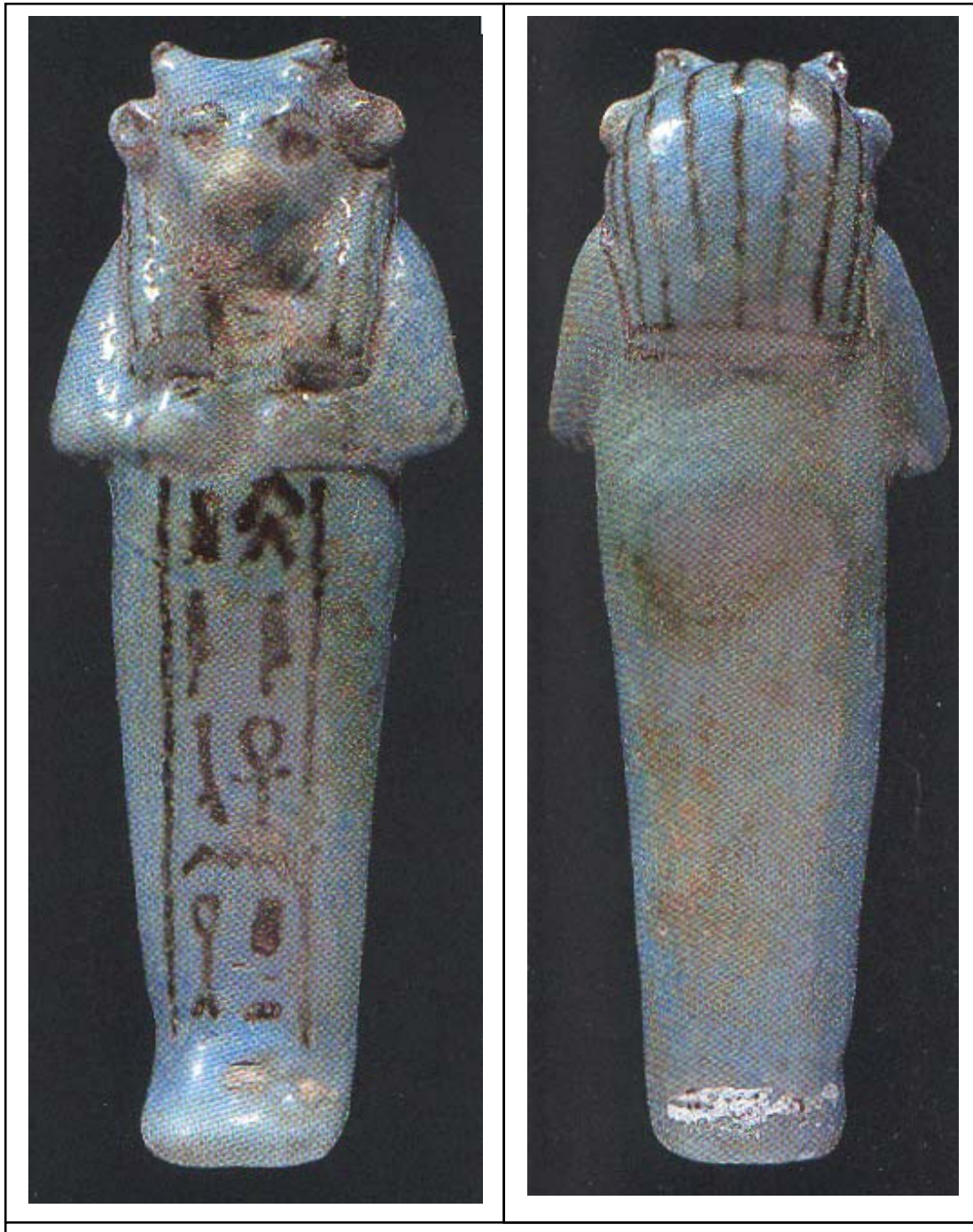

Entre os chifres: -

Material: faiança egípcia esmaltada.

Atitude: repouso; membros inferiores mumificados e unidos.

Descrição: Ápis antropomórfico e taurocéfalo com corpo mumificado. A cabeça, coberta de uma peruca klaft estriada e com bandas na parte inferior dos cachos deixa expostos os pequenos chifres em "V" e as orelhas. O focinho é pequeno, com narinas indicadas por dois pontos e a boca por um traço, e os olhos e sobrancelhas maquiados dispostos na frente da face, conferindo ao touro uma aparência humanizada. Um colar usekh aparentemente composto de quatro carreiras está indicado entre os cachos da cabeleira e abaixo do pescoço. $\mathrm{O}$ volume dos braços flexionados sobre o peito é destacado e os punhos dispostos frente a frente. A coluna central de hieróglifos diz: “Ápis, arauto vivo de Ptah".
Altura: 10,6cm.

Largura: ?

Triângulo: -

Colar: sim; usekh, composto de quatro (?) carreiras.

Imagem alada I:

Manto: -

Imagem alada II:

Shabti antropomórfico mumiforme e taurocéfalo de Ápis.

Coleção: Paris, Musée du Louvre.

No de Inventário: N 5234-74, AF 6832.

Origem: Saqqara, Serapeum.

Datação: reinado de Ramsés II, $19^{\mathrm{a}}$ dinastia.

Outras particularidades: faiança egípcia esmaltada azul turquesa com detalhes em preto.

Outros dados da bibliografia:

Similar ao exemplar mostrado por Mariette em Le Sérapeum de Memphis, prancha XI, canto superior direito.

Bibliografia:

M. Desti Des Dieux, des Tombeaux, un Savant, p. 97. 


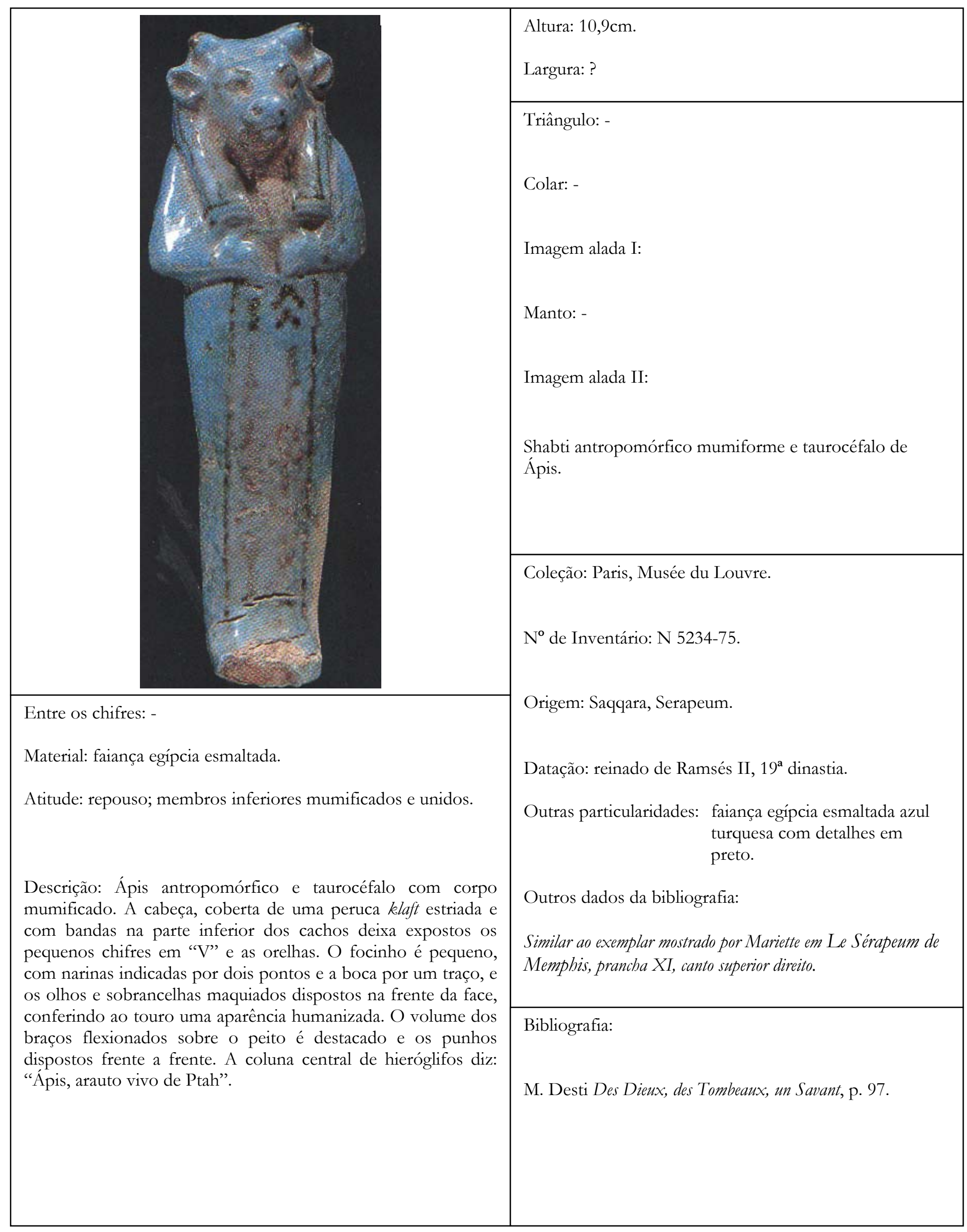




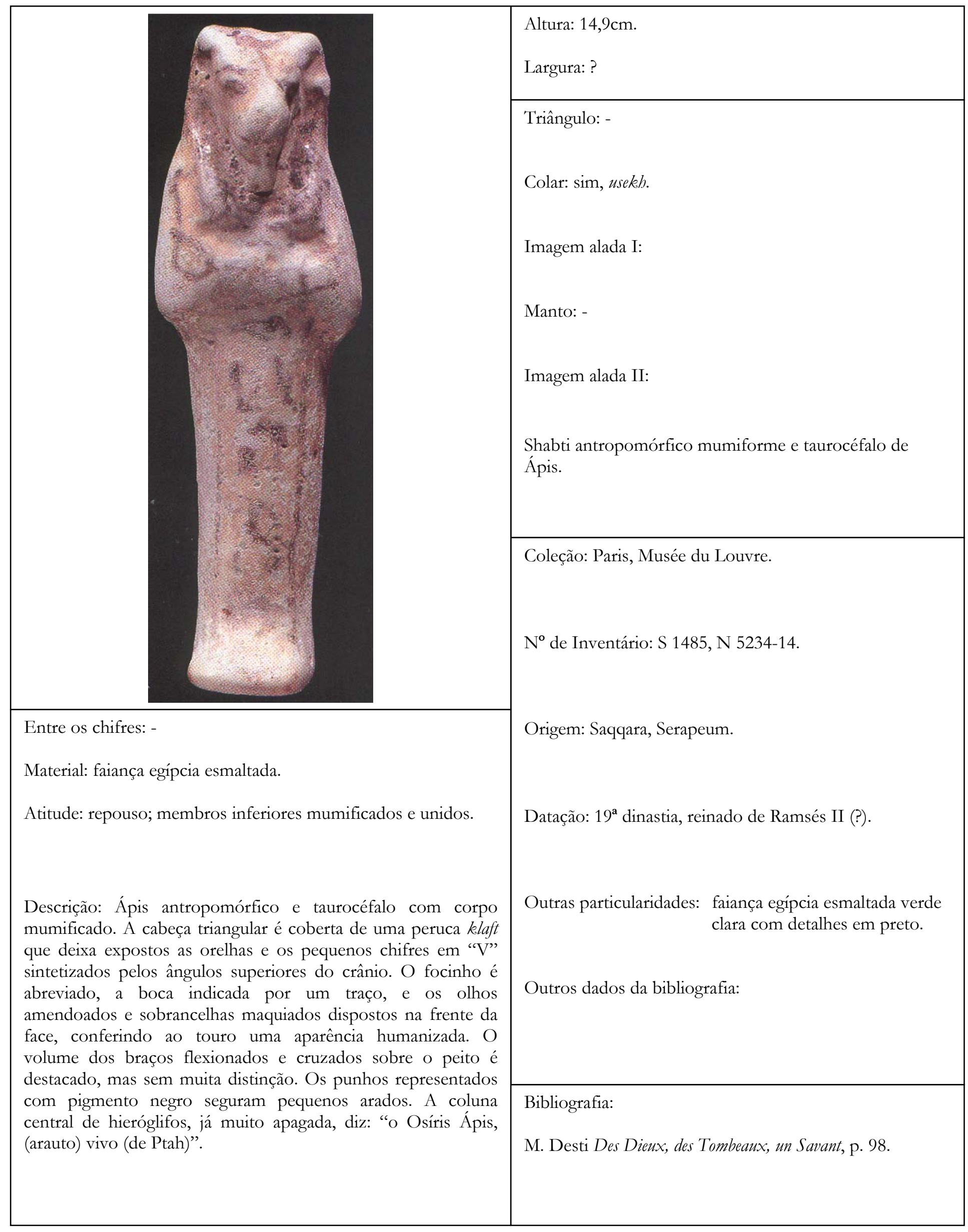




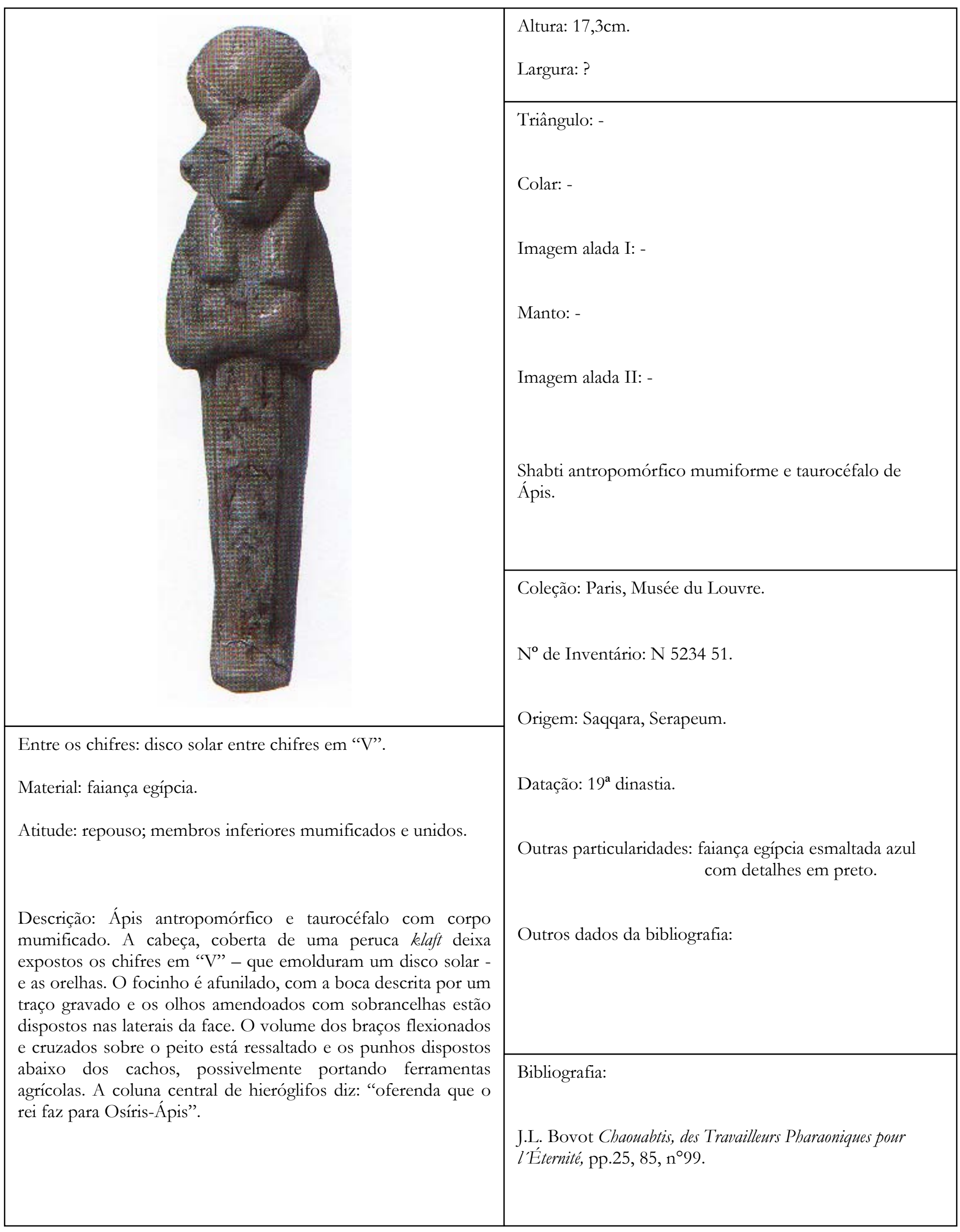




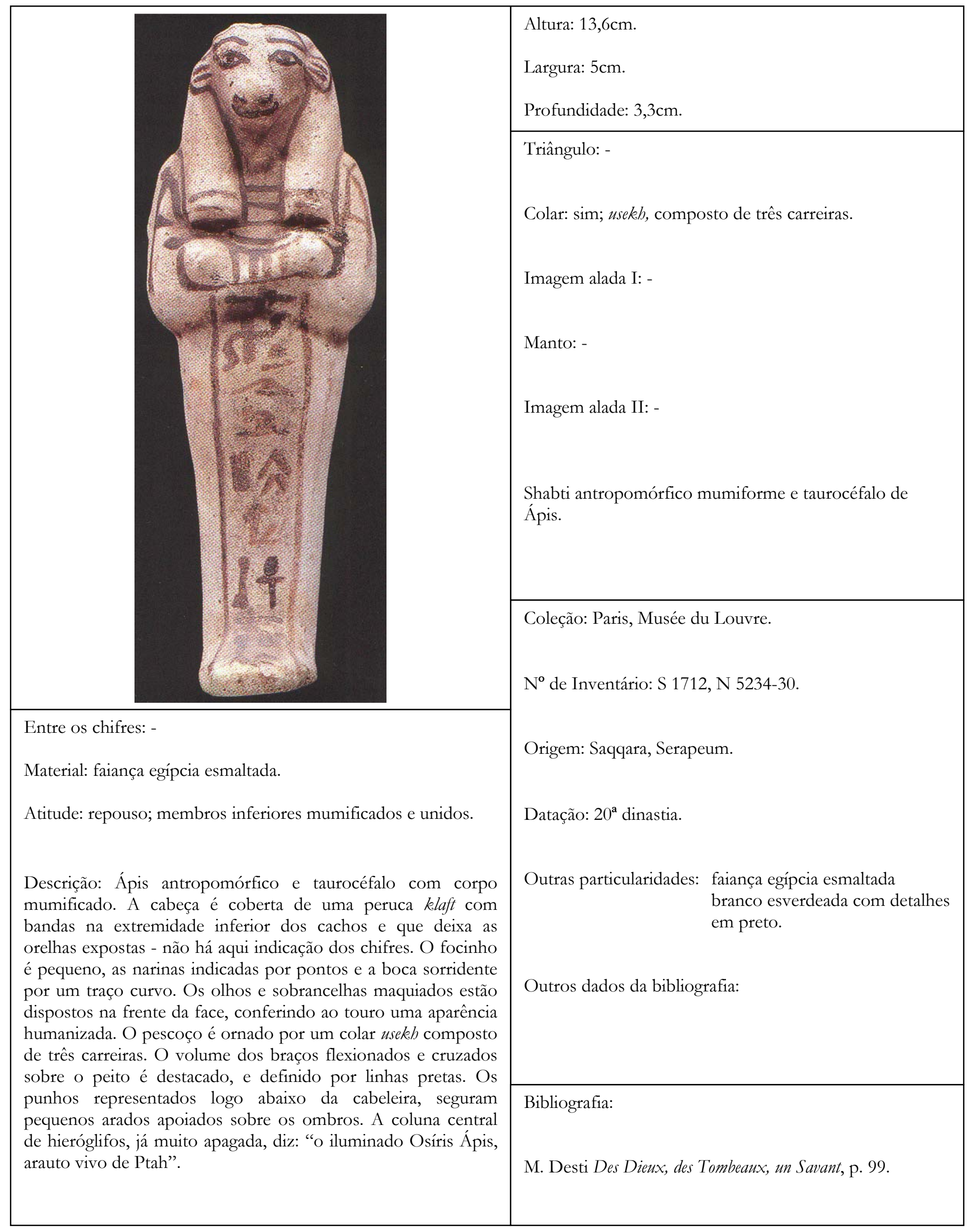




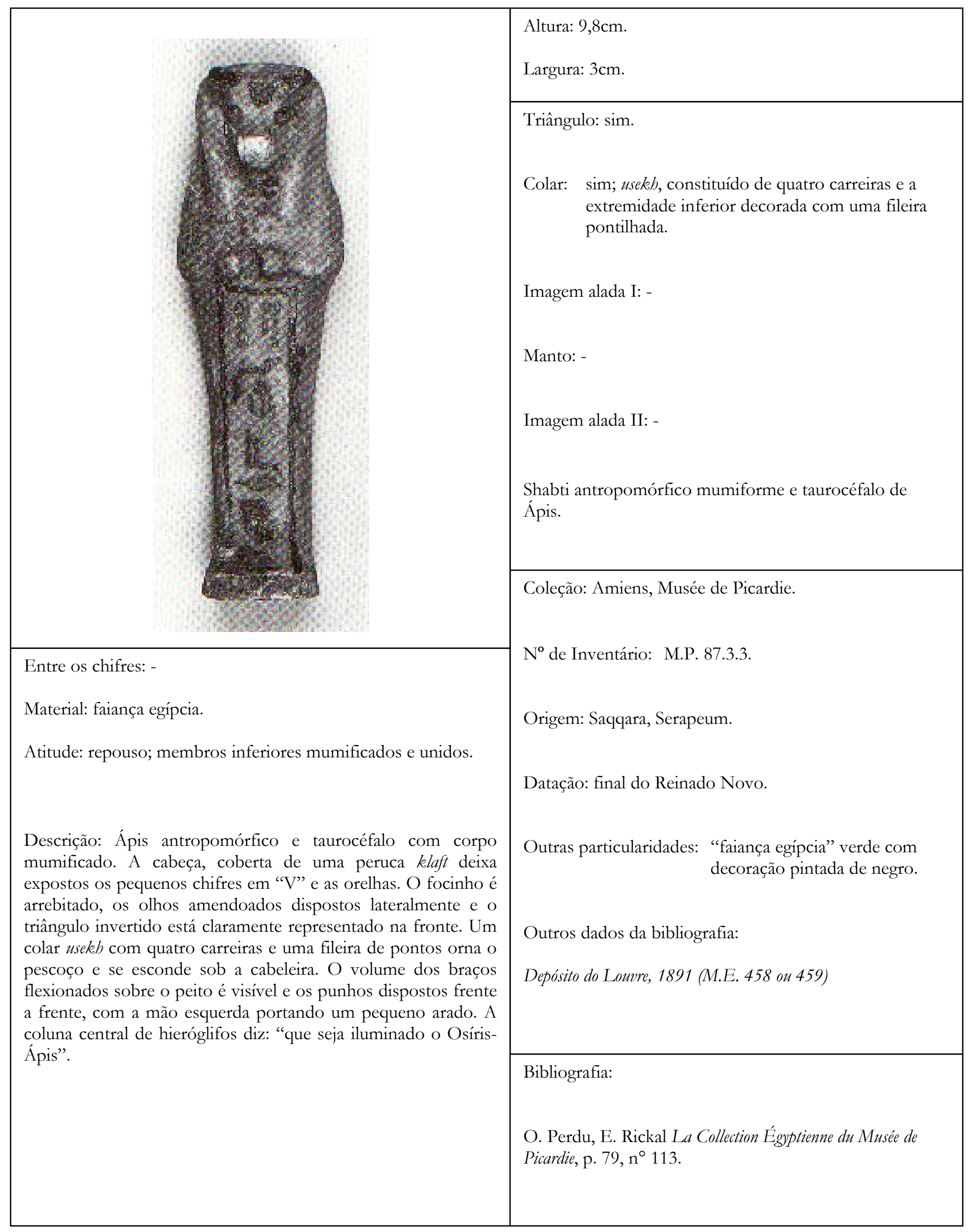




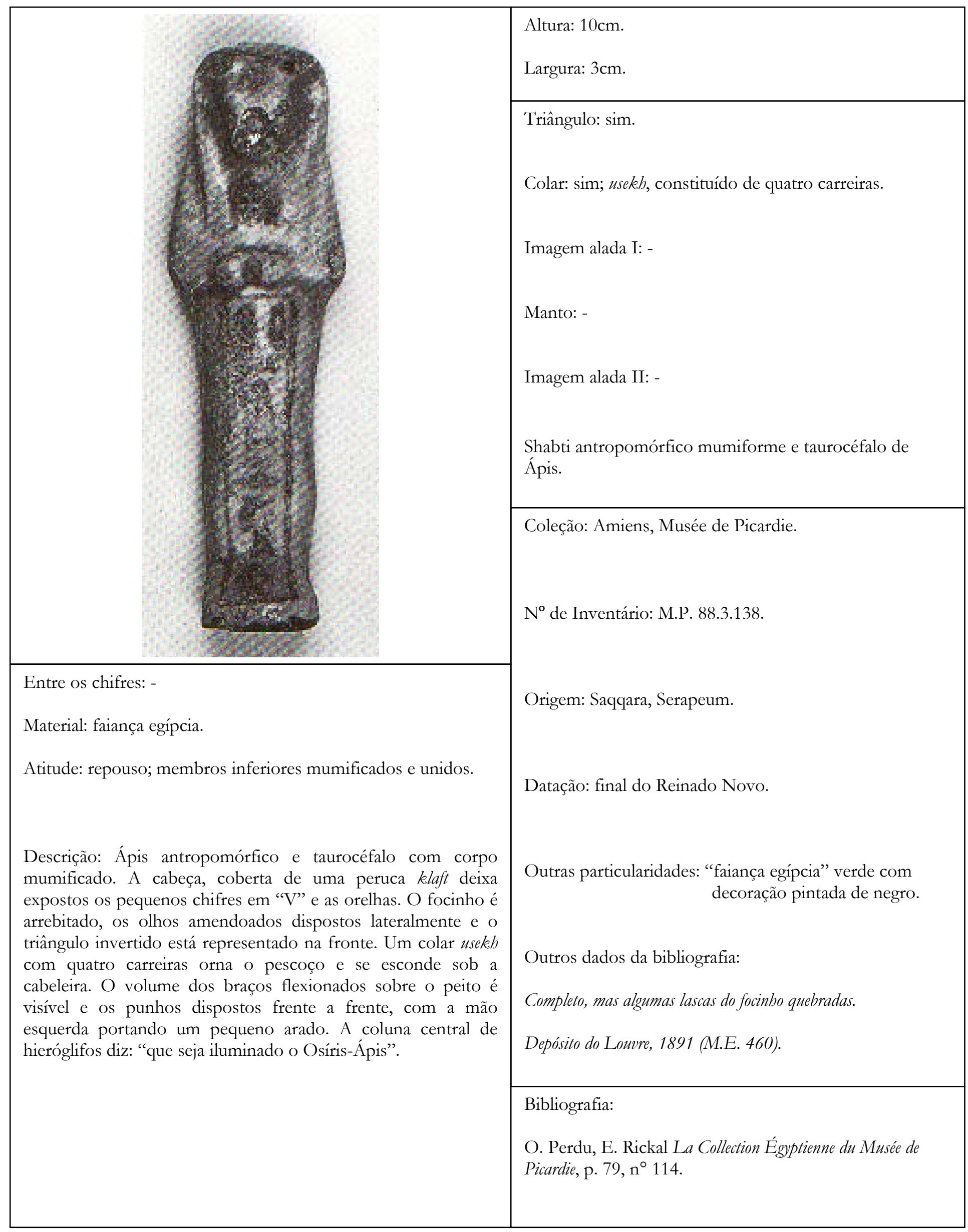




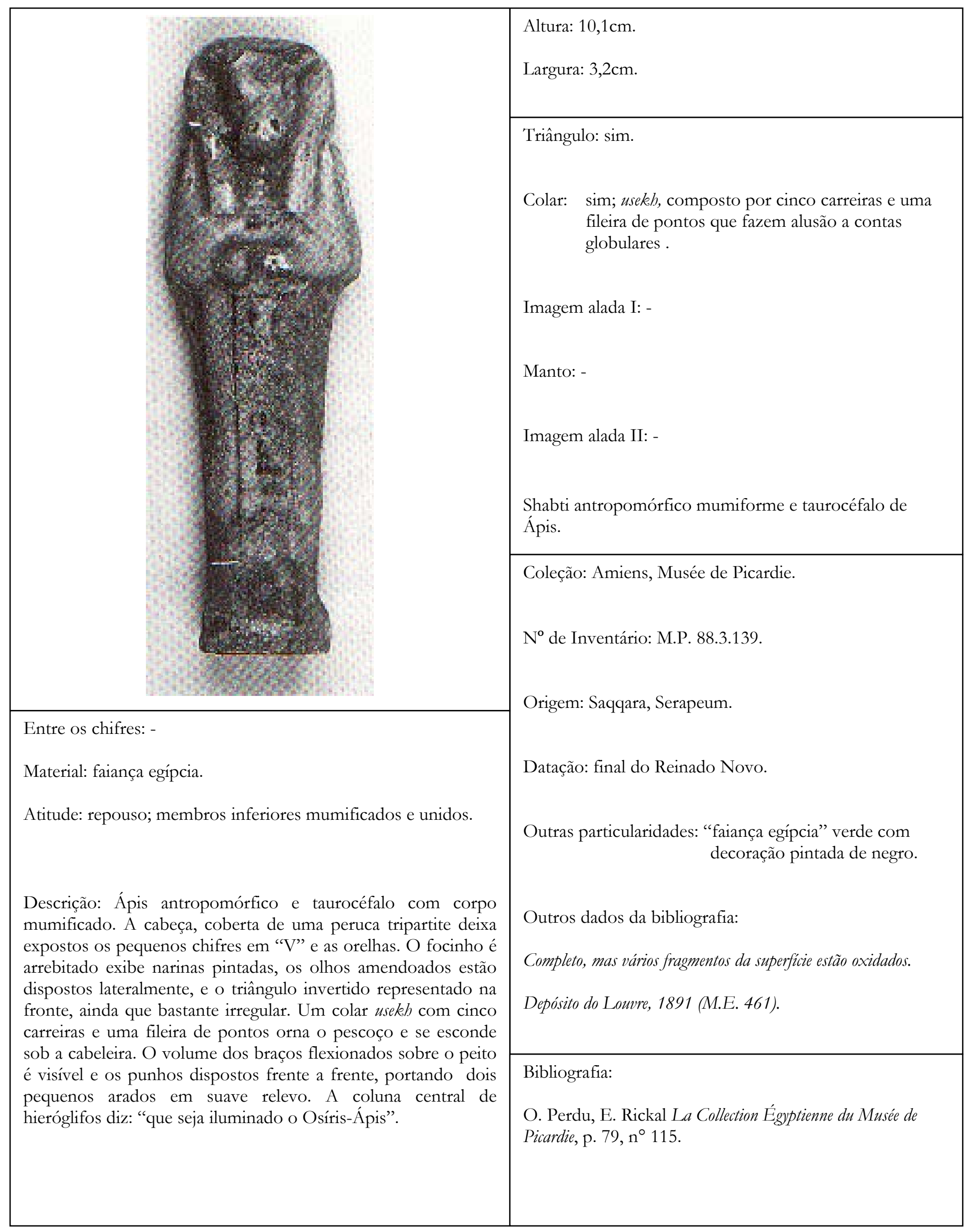




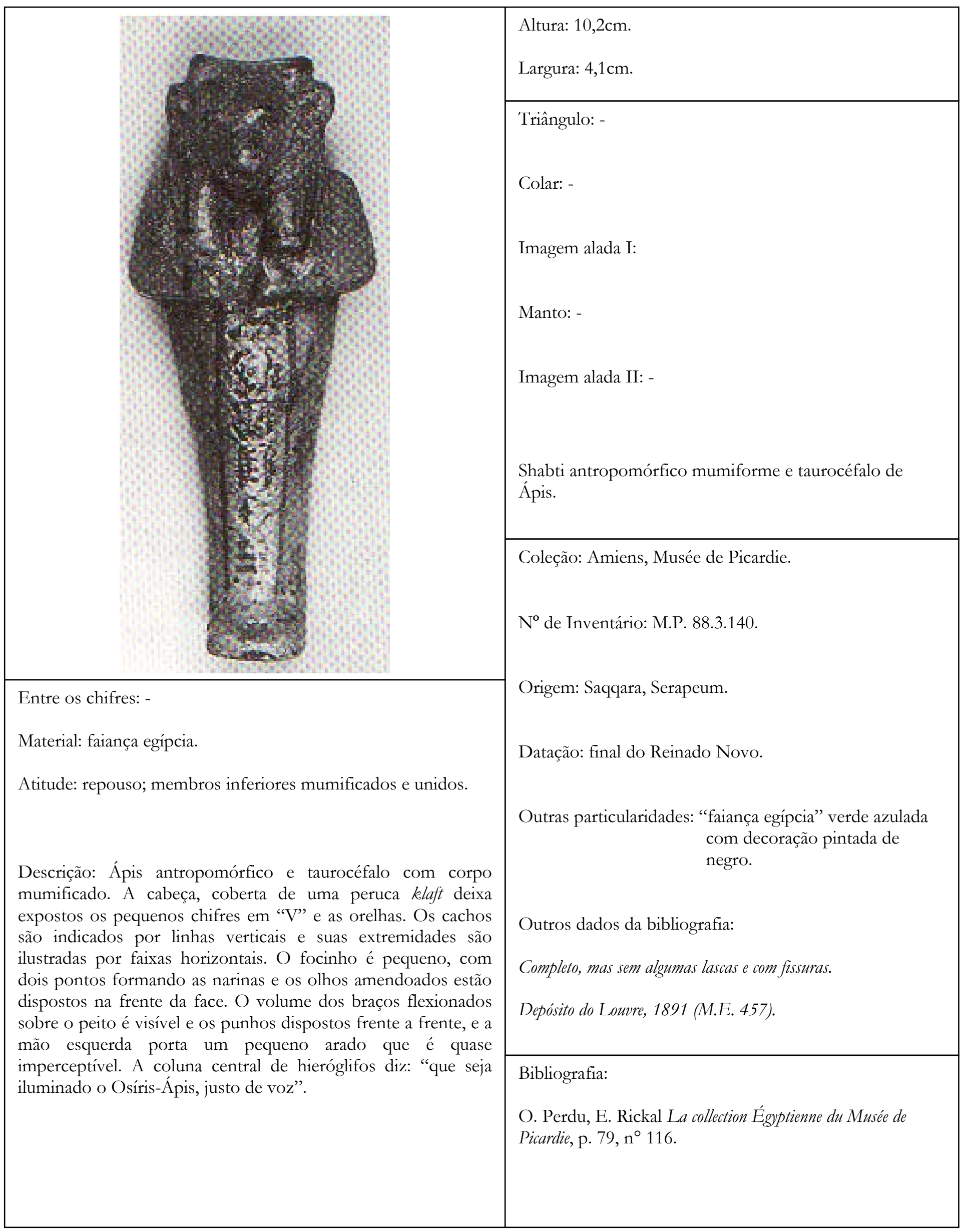




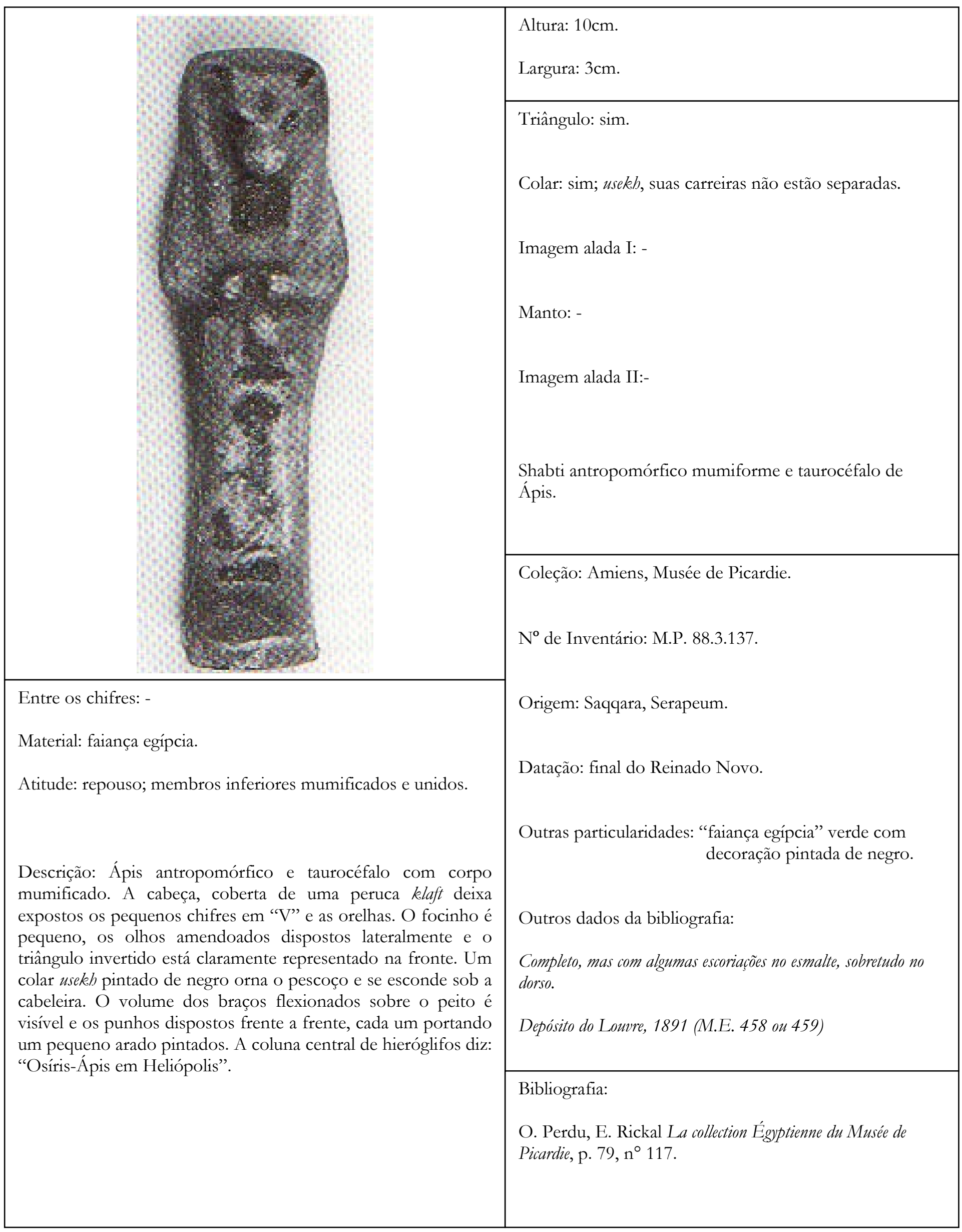




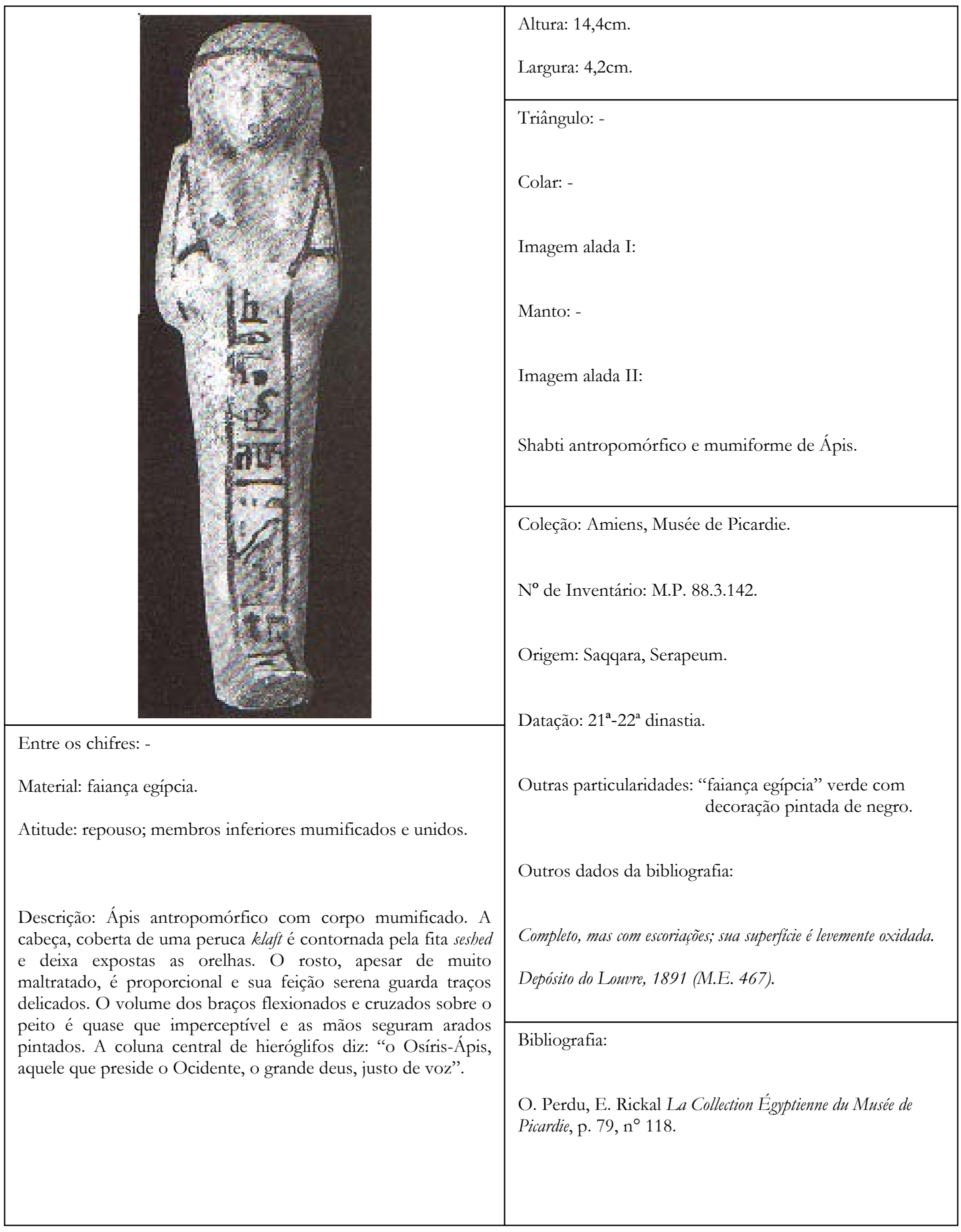




\section{ESCULTURAS DE PEDRA E MARFIM DO SERAPEUM}

(SEesc) 


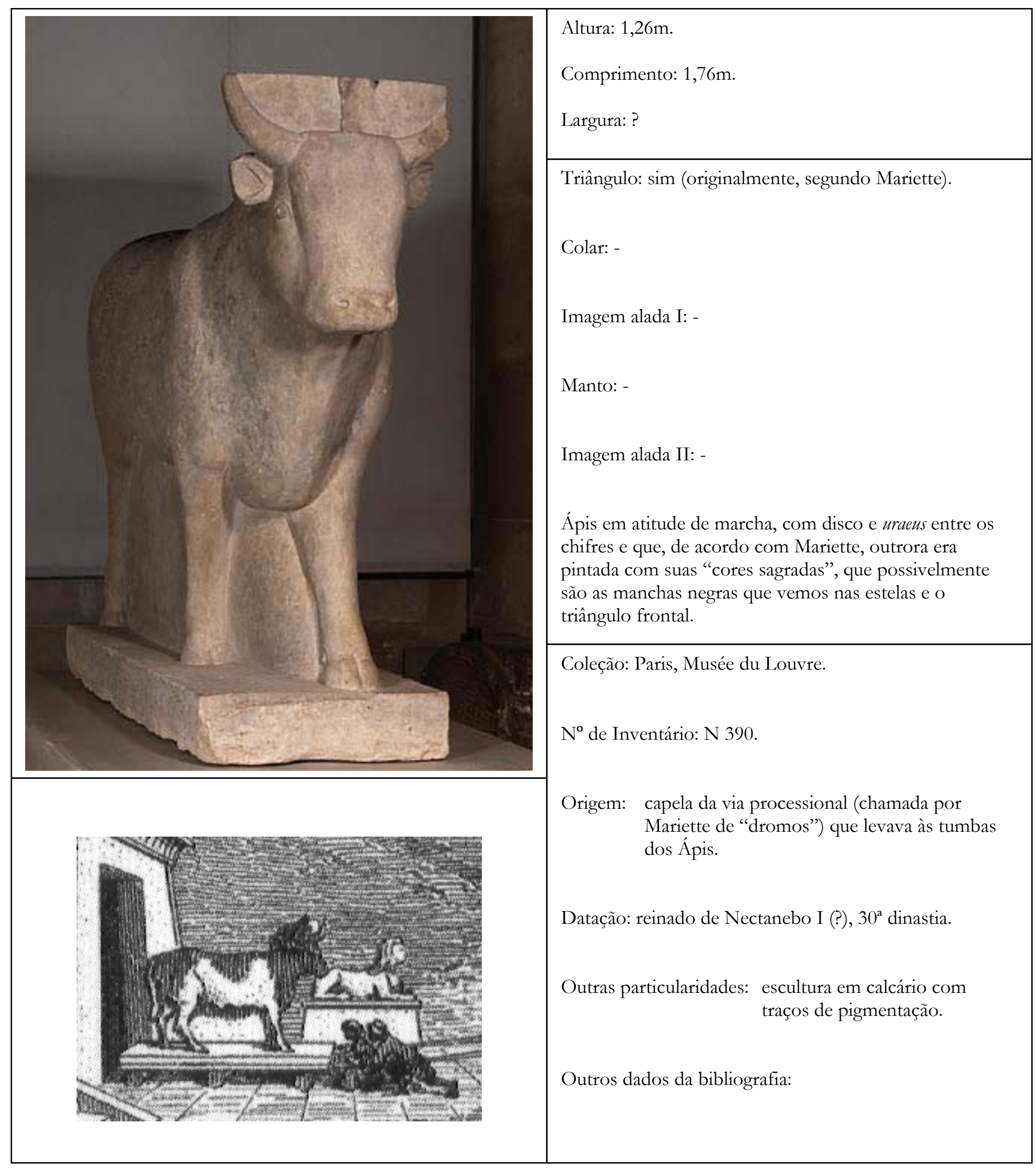


Entre os chifres: disco serrado na parte superior com uraeus entre chifres em crescente.

Material: calcário.

Atitude: marcha; pernas do lado esquerdo avançadas em relação às do direito.

Descrição: Ápis em atitude de marcha sobre base retangular de altura média e com as pernas esquerdas avançadas em relação às do lado direito. Entre os chifres em crescente apresenta um disco solar incompleto com uma uraeus. A escultura confere um porte vigoroso ao animal, sugerindo as tensões de sua musculatura pelos volumes na região superior das pernas. Estas são robustas, trazem determinação à passada e os cascos estão bem definidos. A linha torácico-abdominal descreve um suave aclive até a virilha, enquanto que a dorsal, após um arqueamento no meio das costas, adquire uma inclinação ascendente até a nuca. A cabeça é larga, mas o focinho é bastante abreviado e quadrangular com narinas indicadas por pequenos orifícios. Os olhos amendoados e reduzidos para o tamanho da cabeça são bem definidos assim como as orelhas, dispostas perpendicularmente, voltadas para frente e com os pavilhões auditivos indicados. Segundo Mariette, a escultura originalmente apresentava suas "cores sagradas", termos que ao contrastar com uma gravura contemporânea acreditamos ser relativo ao padrão de manchas negras semelhante ao que encontramos nas estelas. Mariette também confirma a presença do triângulo frontal nessa imagem.

Bibliografia:

G. Andreu (dir.) Objets d'Égypte, pp. 160-161, figs. 1a e 1 b.

A. Mariette Sérapeum (1882), p.29-31.

http://cartelfr.louvre.fr/cartelfr/visite?srv $=$ car not frame\&idNotice $=20284$ 


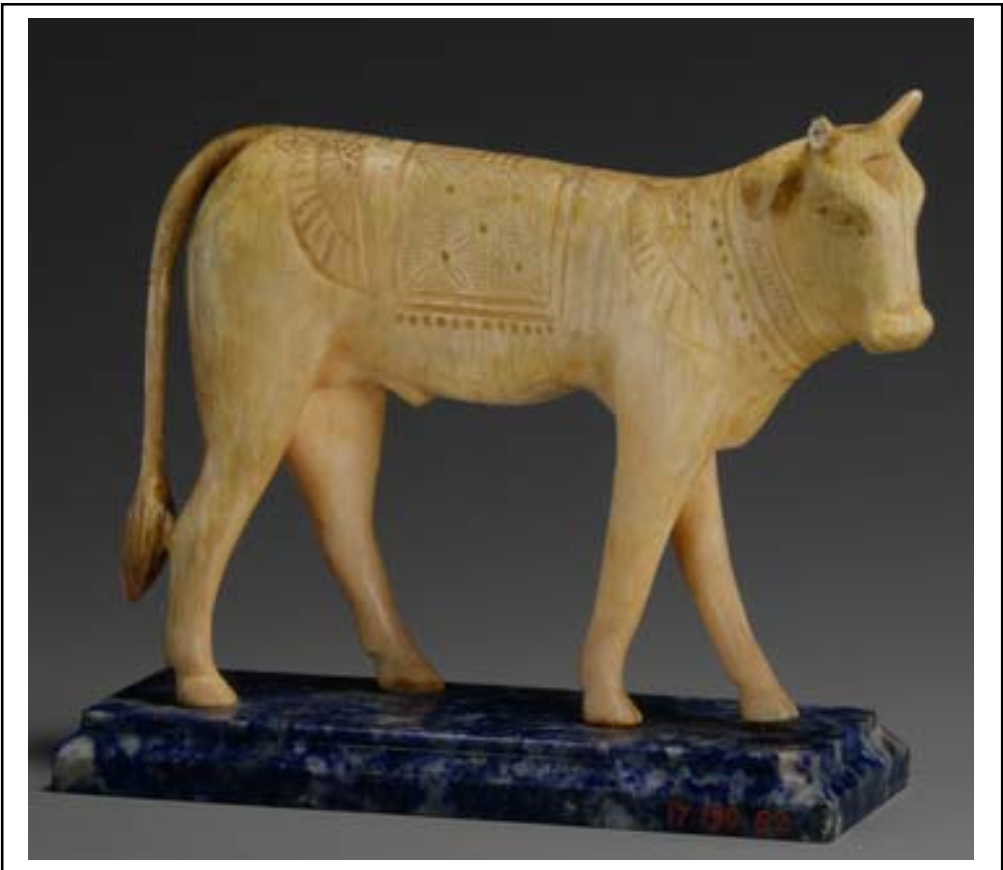

Entre os chifres: possivelmente um disco que hoje está perdido.

Material: marfim.

Atitude: marcha; pernas do lado esquerdo avançadas em relação aos do direito.

Descrição: Ápis em atitude de marcha sobre base moderna. Seu corpo esculpido em marfim foi descrito com esmero e apresenta os detalhes e simbologia apreciados nos bronzes, tais como as imagens solares sobre as costas, o manto, o colar e o triângulo frontal. As pernas da frente, apesar de parecerem rígidas em relação às traseiras, procuram formas que se aproximam daquelas da anatomia bovina, e os cascos estão bem moldados. A papada descreve um suave "S" cuja parte inferior se projeta pouco abaixo do peito. $\mathrm{O}$ abdômen é sensivelmente arqueado e abaixo dele nota-se o sexo. A linha dorsal, por outro lado, descreve um percurso descendente até o início do pescoço, onde muda sua orientação para subir até a cabeça. Os chifres em "V" aparentemente emolduravam um disco solar que era encaixado em um orifício estreito e longo no cimo da cabeça. Os olhos amendoados são expressivos, as orelhas, delicadas, e o focinho bem delineado ilustra a boca $\mathrm{e}$ as narinas. A cauda pende verticalmente e está unida à perna posterior direita somente em sua extremidade.

Trata-se de um artefato ricamente elaborado e que representa, sem quaisquer dúvidas, um Ápis

Bibliografia:

http://www.metmuseum.org/works of art/collection databas e/all/apis bull/objectview_enlarge.aspx?page $=1 \&$ sort $=0 \&$ sort dir $=$ asc\&keyword $=$ Apis\&fp $=1 \& \mathrm{dd} 1=0 \& \mathrm{dd} 2=0 \& v w=1 \&$ collI $\underline{\mathrm{D}=0 \& \mathrm{OID}=100001731 \& \mathrm{v} \mathrm{T}=1}$
Altura: $6,1 \mathrm{~cm}$.

Comprimento: 8,6cm.

Largura: ?

Triângulo: sim.

Colar: sim; constituído de uma faixa central estriada emoldurada por outras duas mais finas e acompanhada na parte inferior de uma linha pontilhada.

Imagem alada I: disco alado; asas estendidas sobre os ombros e compostas por três camadas de plumagem.

Manto: sim; constituído de um retângulo disposto perpendicularmente sobre o dorso dentro do qual há um outro inscrito e com o qual estabelece uma moldura para o padrão de contas tubulares e globulares em "X". Esta tela maior se sobrepõe a uma outra mais fina e formada por linhas horizontais e verticais paralelas. A linha dorsal parece conter uma faixa com estrias na parte central e nas extremidades o manto exibe uma linha pontilhada.

Imagem alada II: abutre; asas estendidas sobre as ancas e compostas por três camadas de plumagem.

Coleção:.Nova York, Metropolitan Museum of Art.

$\mathrm{N}^{0}$ de Inventário: 17.190 .62

Origem: desconhecida.

Datação: Período Tardio.

Outras particularidades:

Outros dados da bibliografia:

Presente de J. Pierpont Morgan, 1917 


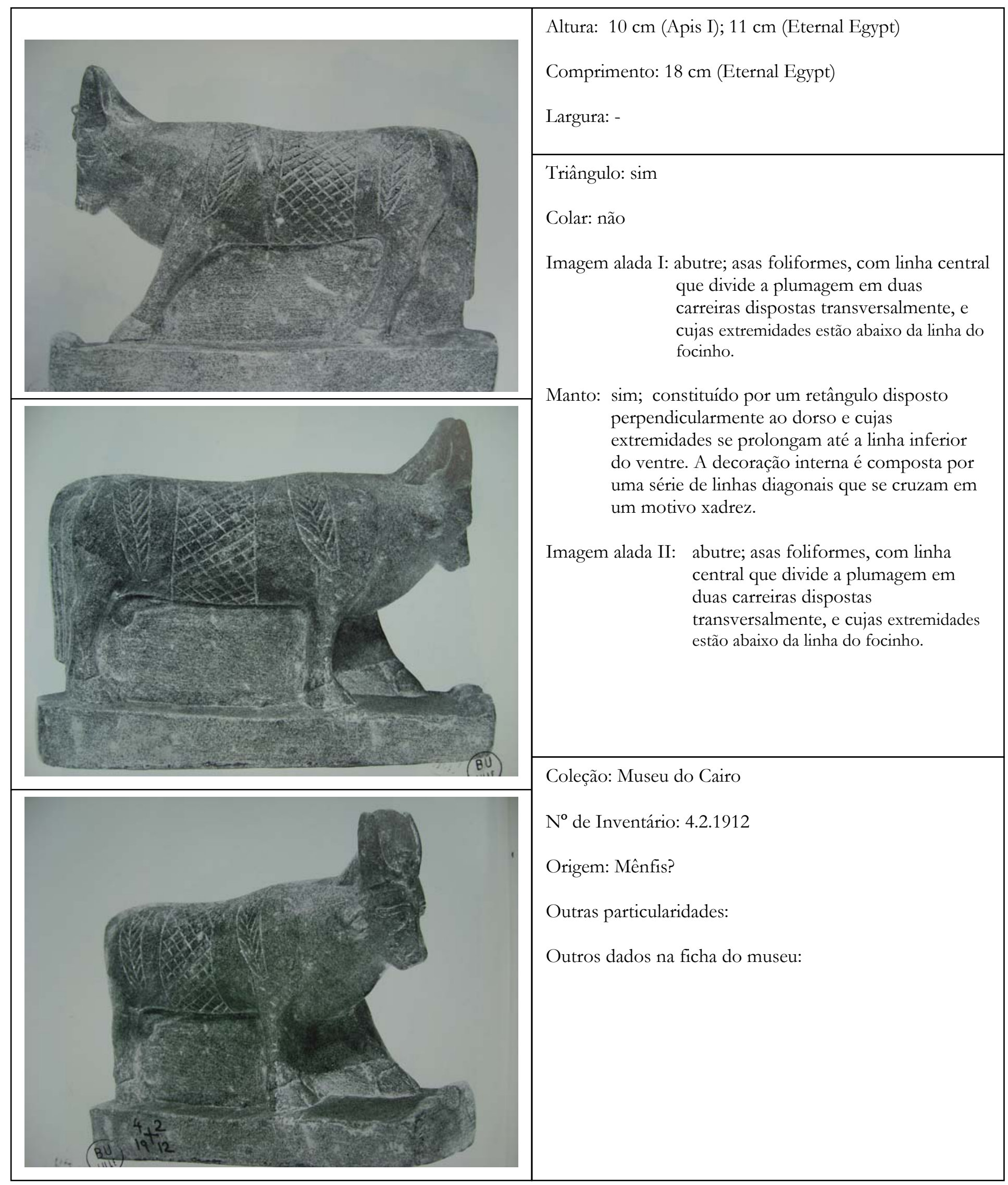




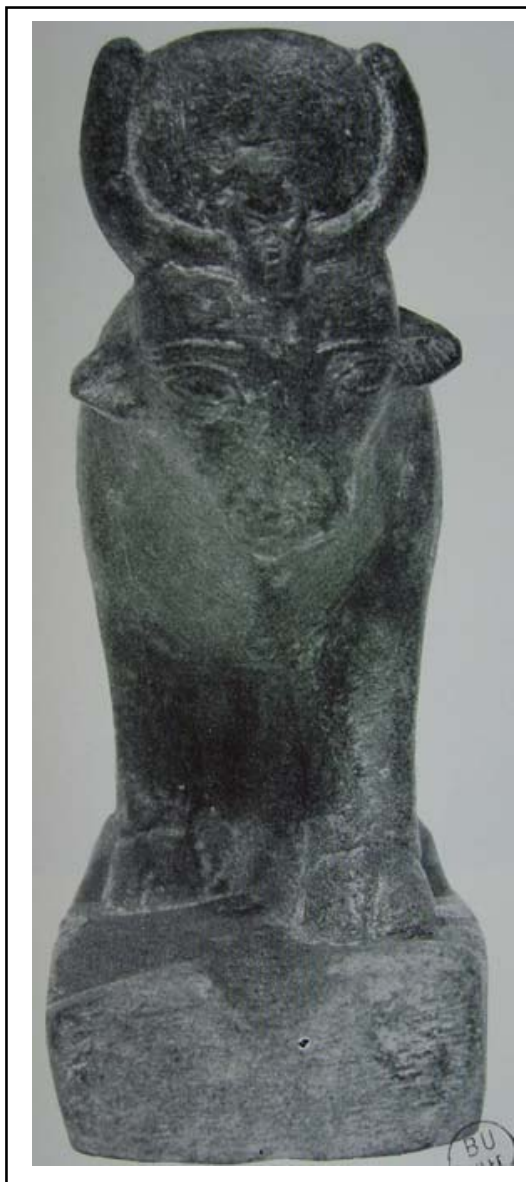

Entre os chifres: disco com uraeus cujo diâmetro é menor do que o comprimento da cabeça.

Material: xisto azul.

Atitude: marcha; pernas da esquerda avançadas em relação às da direita.

Descrição: touro em marcha sobre base alta, cujas extremidades frontais foram esculpidas ao modelo das pás de um trenó e sem inscrições. Disco com uraeus detalhada, com prolongamento na sua parte anterior até o pescoço, diâmetro inferior ao comprimento da cabeça do touro e entre chifres em crescente. Triângulo na fronte logo abaixo da uraeus. Decoração lombar incisa e estilizada por meio de linhas amplas. Olhos amendoados, bem delineados, com pálpebras, sobrancelhas e posicionados na frente da cabeça. As orelhas exibem decoração interna estriada e estão localizadas atrás da cabeça e na altura dos olhos. Focinho pequeno, bem modelado, com narinas discretas e boca indicada por um traço. A papada desenvolve uma curvatura aberta que desce pouco abaixo do peito. O perfil do abdômen é paralelo à base e na sua porção traseira, abaixo da virilha, está representado o sexo. Toda a área entre o tórax, ventre e as pernas está unida ao bloco. Estas, ainda que curtas para as proporções do torso, foram esculpidas de forma a respeitar as particularidades da anatomia bovina e os cascos estão bem indicados. A linha dorsal desenvolve uma ligeira curvatura côncava no meio das costas para ascender na região dos ombros e daí seguir até o cimo da cabeça. A cauda, pendente e espessa, desce perpendicularmente acompanhando o perfil da perna posterior direita, à qual está unida. Os pelos foram indicados através de traços longitudinais.

A estatueta tem porte robusto e ainda que o torso esteja um tanto alongado para as proporções das outras partes, ela exibe linhas convincentes e a simbologia que faz dela a representação de um Ápis.

Bibliografia sobre o referido bronze:

G.J.F. Kater-Sibbes, M. J. Vermaseren Apis I, p. 14, n41, prs. XXVIII n 41, XXIX n 41, XXX n 41, XXXI n 41.

http://www.eternalegypt.org/EternalEgyptWebsiteWeb/HomeServlet?ee website action key=action.display.element\&st ory $\mathrm{id}=\&$ module $\mathrm{id}=\&$ language $\mathrm{id}=1$ \&element $\mathrm{id}=61565 \&$ ee messages=0001.flashrequired.text 


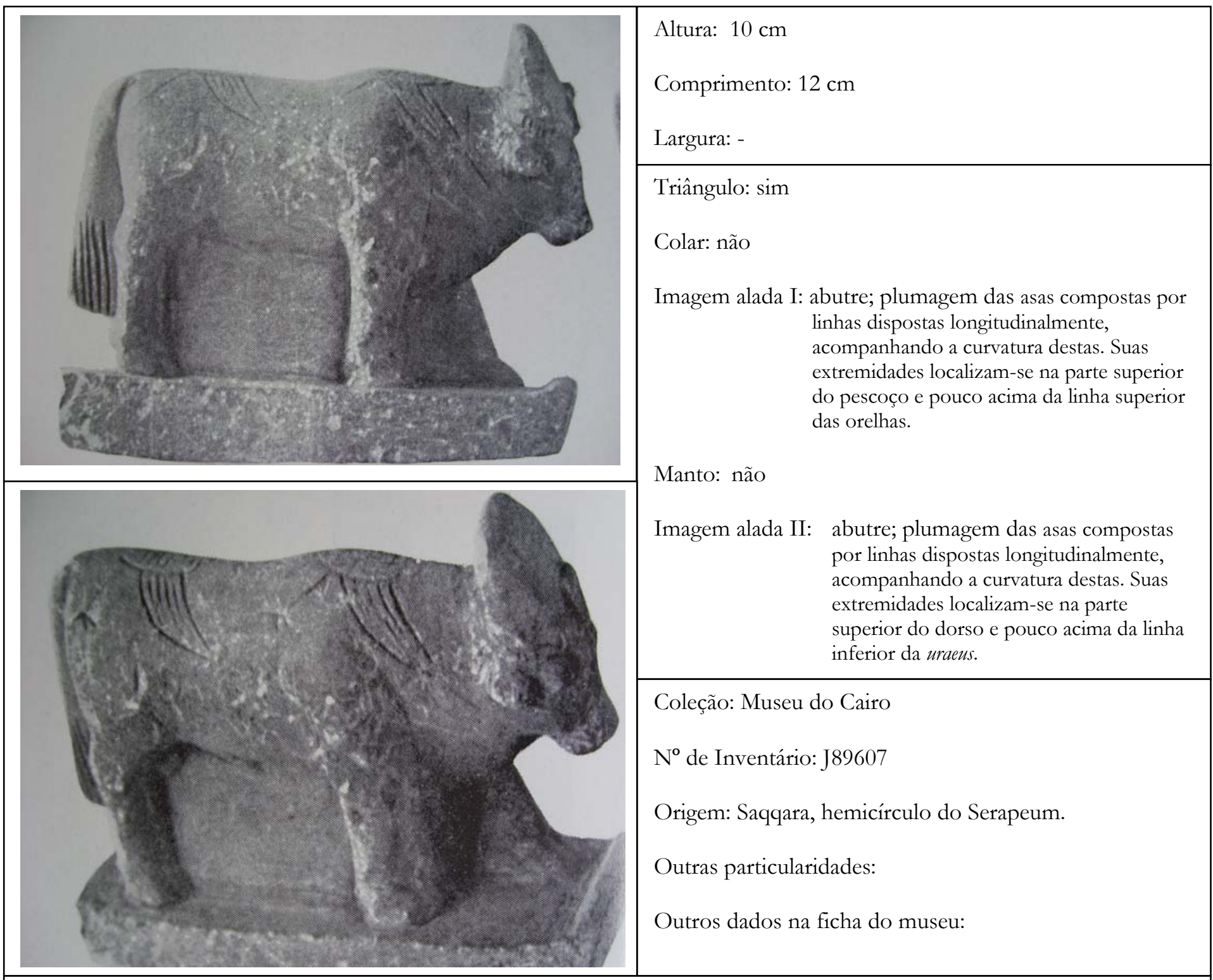

Entre os chifres: disco com uraeus cujo diâmetro é menor do que o comprimento da cabeça.

Material: xisto azul

Atitude: marcha; pernas da esquerda avançadas em relação às da direita.

Descrição: touro em marcha sobre base retangular alta, com acabamento frontal superior recurvado ao modelo de um trenó e sem inscrições. Disco com uraeus com perfil largo na base, diâmetro inferior ao comprimento da cabeça do touro e entre chifres em crescente (?). Triângulo na fronte. Decoração lombar incisa e estilizada por meio de linhas amplas. Olhos salientes sem linhas que os definam posicionados nas laterais superiores da cabeça. As orelhas estão localizadas na intersecção das linhas dos chifres e dos olhos. Focinho bem indicado mas, aparentemente, sem narinas a boca. Abaixo dele se desenvolve uma papada com uma ondulação na parte inferior vindo ao encontro do peito. O perfil do abdômen descreve uma reta ascendente até a virilha sobre a qual o sexo foi acrescido. Toda a área entre o tórax, ventre e as pernas está unida ao bloco. Estas, ainda que volumosas e rígidas, procuram lembrar as particularidades da anatomia bovina. Os cascos estão indicados por saliências mas não parecem estar delineados. A linha dorsal, após um declive que culmina no meio das costas, encontra sua ascensão na região dos ombros para depois descer novamente até o cimo da cabeça.

A cauda, pendente e espessa, desce acompanhando o perfil da perna posterior direita à qual está unida e sua extremidade, que é mais larga, contém incisões verticais que marcam a pelagem.

A estatueta tem porte robusto, não apresenta decoração no pescoço nem um manto sobre dorso e seu acabamento é rústico. Contudo, exibe a simbologia que faz dela a representação de um Ápis. 
Bibliografia sobre o referido bronze:

G.J.F. Kater-Sibbes, M. J. Vermaseren Apis I, p. 11, n 28, pr. XXII, n 28. 


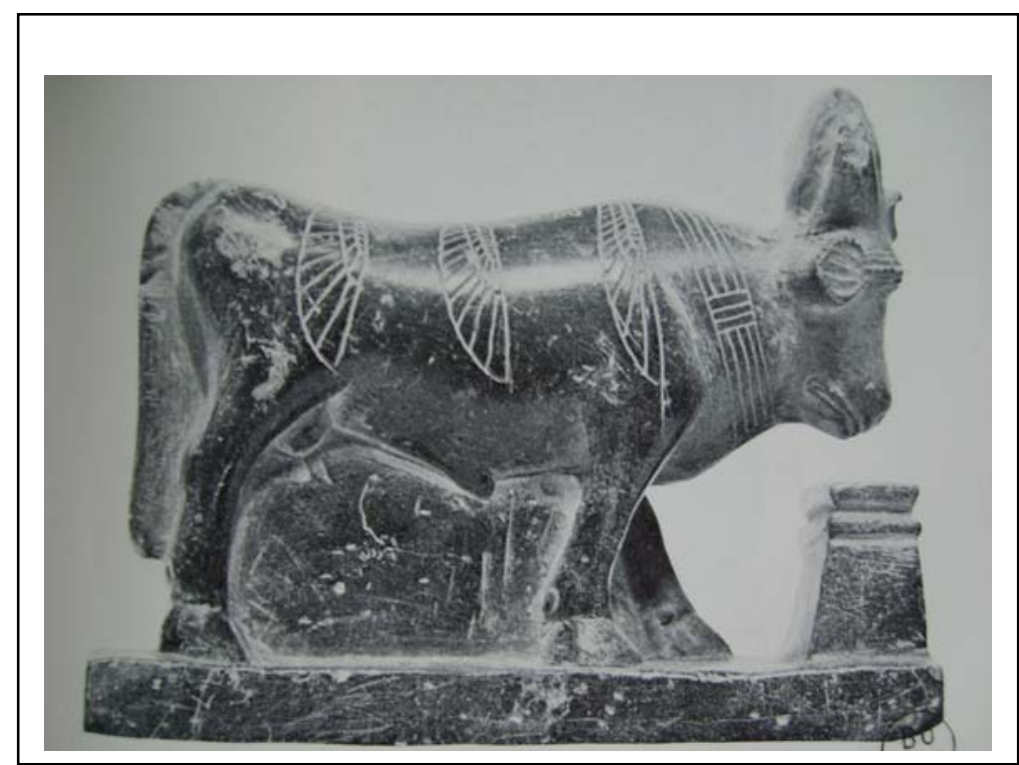

Altura: $13,5 \mathrm{~cm}$

Comprimento: $17,5 \mathrm{~cm}$

Largura: -

Triângulo: sim.

Colar: sim; quatro faixas paralelas e de mesma largura são intercaladas em quatro pontos não eqüidistantes por um número aleatório de bandas dispostas perpendicularmente.

Imagem alada I: falcão; asas compostas por três camadas de plumagem, estendidas sobre os ombros e cujas extremidades estão acima da linha das narinas.

Manto: não;

$>$ substituído por um escaravelho alado; asas compostas por três camadas de plumagem, estendidas sobre o dorso e cujas extremidades estão acima da linha das narinas.

Imagem alada II: asas compostas por três camadas de plumagem, estendidas sobre as ancas e cujas extremidades estão acima da linha das narinas e sobre a parte posterior das coxas.

Coleção: Museu do Cairo

$\mathrm{N}^{0}$ de Inventário: ? (não mencionado no catálogo Apis I)

Origem: Saqqara, Serapeum.

Outras particularidades:

Outros dados da bibliografia: 


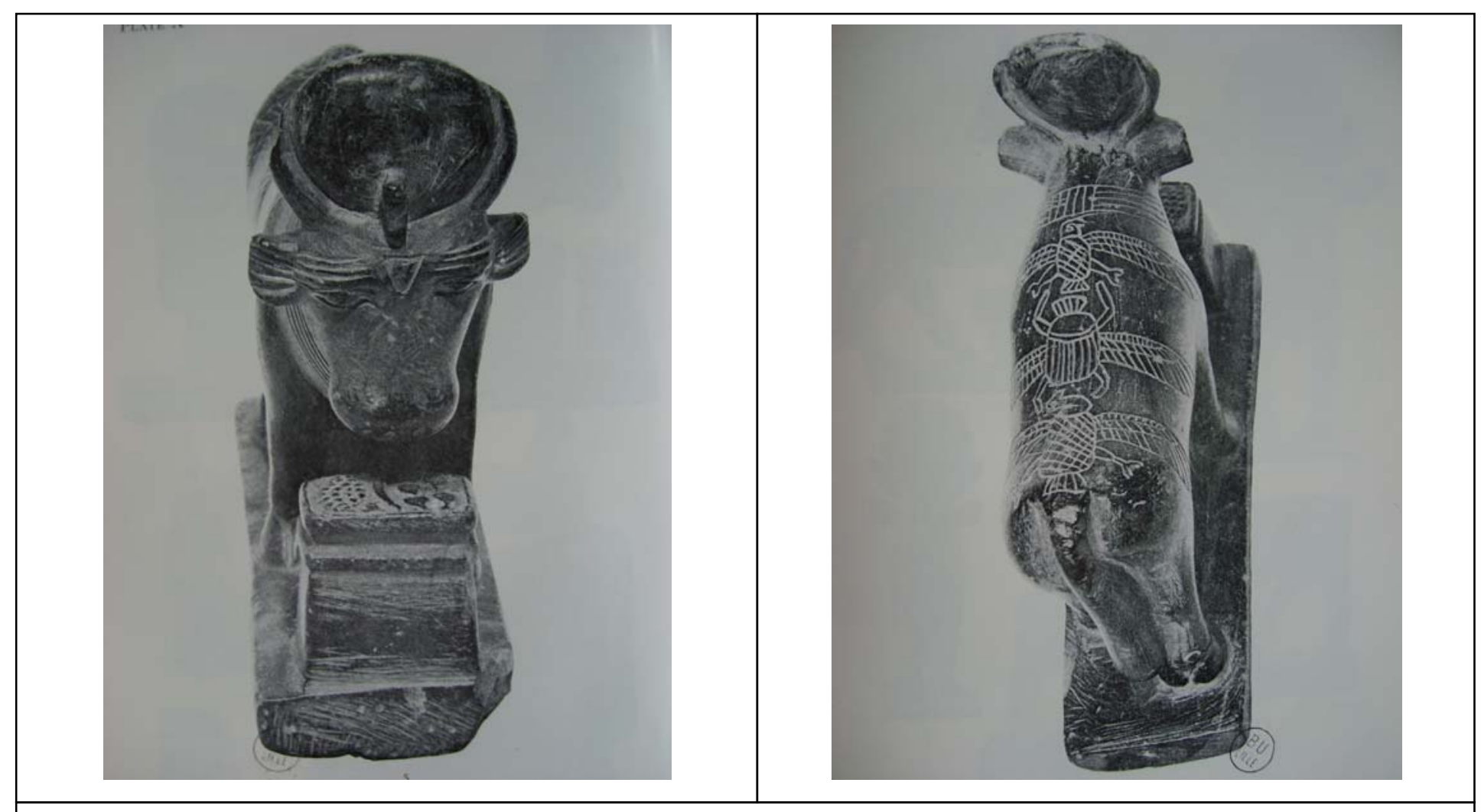

Entre os chifres: disco com uraeus cujo diâmetro é menor do que o comprimento da cabeça.

\section{Material: Serpentinita cinza}

Atitude: marcha; pernas da esquerda avançadas em relação às da direita.

Descrição: touro em marcha sobre base retangular alta sem inscrições e com a representação de uma mesa de oferendas logo à frente dele. Disco com uraeus com perfil lenticular largo e diâmetro inferior ao comprimento da cabeça do touro entre chifres em crescente. Triângulo na fronte. Decoração lombar e do pescoço elaboradas - aqui o manto foi substituído por um escaravelho alado. Olhos amendoados, bem delineados, com pálpebras, sobrancelhas e posicionados na frente da cabeça. As orelhas estão localizadas entre a linha dos chifres e dos olhos e contém decoração estriada horizontalmente. Focinho alargado na extremidade, com narinas discretas mas boca definida. Abaixo dele se desenvolve uma papada com uma ondulação na parte inferior vindo ao encontro do peito. O perfil do abdômen descreve uma curva convexa no meio da qual aponta o sexo. Toda a área entre o tórax, ventre e as pernas está unida ao bloco. Estas foram esculpidas de forma a respeitar as particularidades da anatomia bovina e os cascos estão bem indicados. A linha dorsal, após uma elevação nas ancas, desenvolve uma curvatura côncava no meio das costas para, novamente, ganhar um impulso ascendente na região dos ombros. Daí vai ao encontro do cimo da cabeça por meio de um declive. A cauda, pendente e espessa, desce perpendicularmente acompanhando o perfil da perna anterior direita, à qual está unida.

A estatueta tem porte robusto, e ainda que a cabeça transmita uma certa rusticidade por seus traços, exibe formas elegantes e os motivos decorativos foram particularmente bem elaborados.

Bibliografia sobre o referido artefato:

G.J.F. Kater-Sibbes, M. J. Vermaseren Apis I, p. 6, n 5 , prs. IX n ${ }^{\circ} 5$, X n ${ }^{\circ} 5$ e XI n ${ }^{\circ} 5$. 


\section{BRONZES DO SERAPEUM}

(SEbr) 


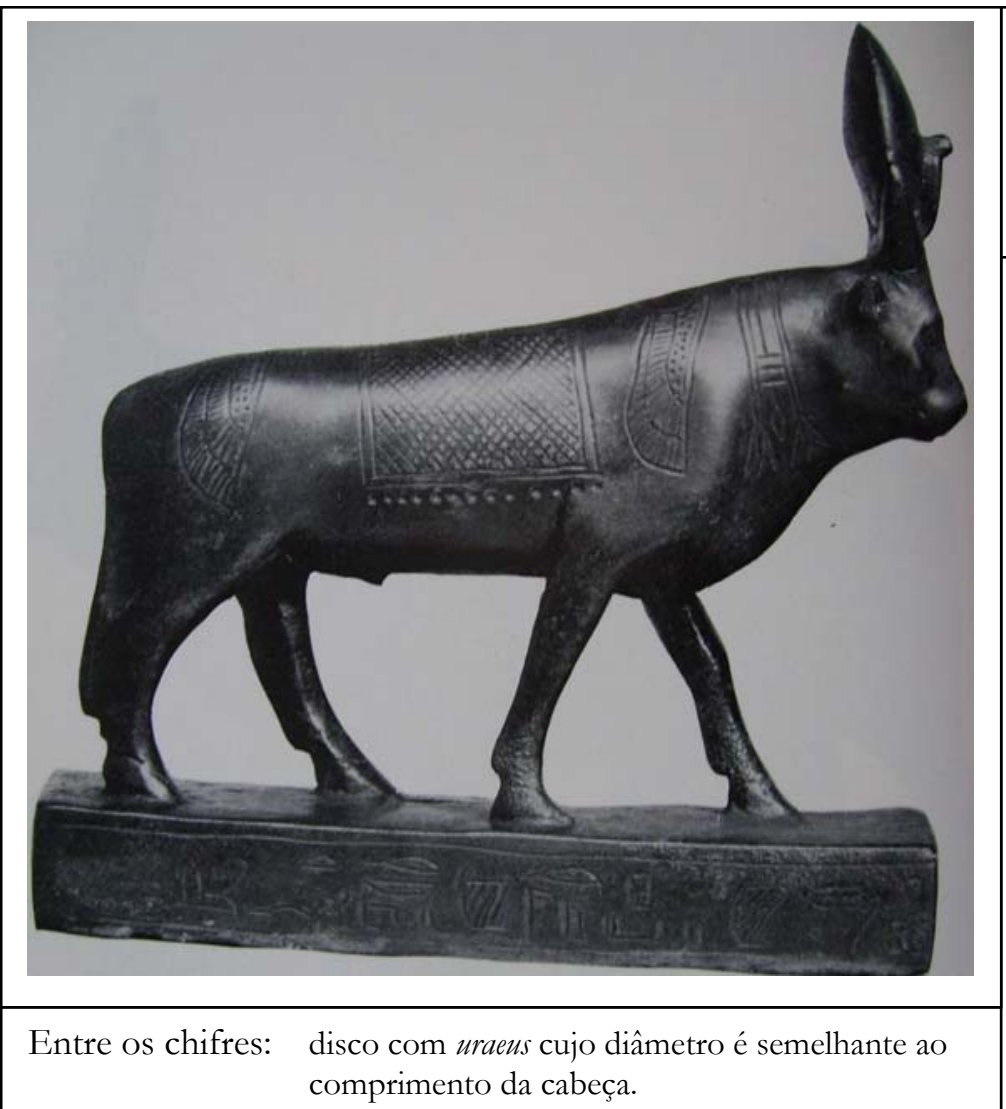

Material: Bronze.

Atitude: marcha; pernas da esquerda avançadas em relação às da direita.

Descrição: atitude de marcha sobre base retangular alta com inscrições margeadas por duas linhas. Disco com uraeus com perfil lenticular, diâmetro semelhante ao comprimento da cabeça e entre chifres em crescente (?). Triângulo originalmente incrustado na fronte. Decoração lombar e do pescoço incisas e elaboradas. Olhos arredondados e bem definidos. Orelhas localizadas na linha detrás da cabeça e acima dos olhos. O focinho é pequeno, bem moldado, e exibe narinas e boca discretas. A papada desce retilínea até a extremidade superior do colar, a partir de onde adquire um perfil curvilíneo descendente que contorna o peito para encontrá-lo pouco além das pernas dianteiras. A linha abdominal se desenvolve paralela à base até a virilha, tendo o sexo indicado de maneira discreta. As pernas traseiras são robustas e tanto estas quanto as dianteiras são bem modeladas e exibem bem os volumes da anatomia bovina. Os cascos são bem esculpidos e delineados. A linha dorsal, grosso modo, descreve um perfil ascendente das ancas até a porção mediana do pescoço. Desse ponto, desce ligeiramente até o cimo da cabeça. A cauda, pendente e espessa, desce acompanhando o perfil da perna posterior direita, à qual está unida.

A estatueta é robusta, bem proporcionada, e apresenta o porte de um jovem touro. Pelo seu alto grau de detalhamento, que inclui a inscrição na base, podemos atribuir a identidade do animal representado a Ápis. Suas superfícies são afeiçoadas e encontra-se entre os melhores exemplares. Seu estado de conservação é muito bom e não apresenta oxidação.
Altura: $12 \mathrm{~cm}$

Comprimento: $11,3 \mathrm{~cm}$

Largura: -

Triângulo: sim; originalmente incrustado.

Colar: sim; duas faixas estreitas e paralelas cujas extremidades estão acima do focinho representam os caules das flores de lótus que figuram em cada extremidade. Unindo-os, logo acima, estão três linhas horizontais e paralelas. Entre esses buquês figura uma linha paralela de comprimento inferior que termina como uma flor de lótus fechada.

Imagem alada I: escaravelho; asas compostas por três camadas de plumagem, posicionadas sobre os ombros e cujas extremidades alcançam a linha do manto.

Manto: sim; dois retângulos, um inscrito dentro do outro, e dispostos perpendicularmente em relação à coluna vertebral estabelecem uma moldura para uma trama de linhas transversais cruzadas. Nas extremidades inferiores exibe uma linha pontilhada paralela.

Imagem alada II: abutre; asas compostas por três camadas de plumagem, posicionadas sobre as ancas e parte superior das coxas cujas extremidades ultrapassam a linha do manto.

Coleção: Baltimore, Walters Art Gallery.

$\mathrm{N}^{0}$ de Inventário: 54.538

Origem: desconhecida.

Datação: $26^{\mathrm{a}}$ dinastia.

Outras particularidades:

Outros dados da bibliografia:

Inscrição: Hep-Horus dá vida (à) Psamético, filho de Pede-nssire (Petosiris) nascido da senhora Tef. G. Steidorff Catalogue of Egyptian Art in the Walters Art Gallery, Baltimore (Maryland), 1946, 146, n 637, Prs. XCVI, CXIX apud Kater-Sibbes, Vermaseren, Apis II: p. 44, nº 375

Bibliografia sobre o referido bronze:

G.J.F. Kater-Sibbes, M. J. Vermaseren Apis II, p. 44 nº 376; Pr. CVII 376.

G. Steindorff Catalogue of the Egyptian Sculpture, p. 146, $\mathrm{n}^{\circ} 637$, pr. XCVI. 


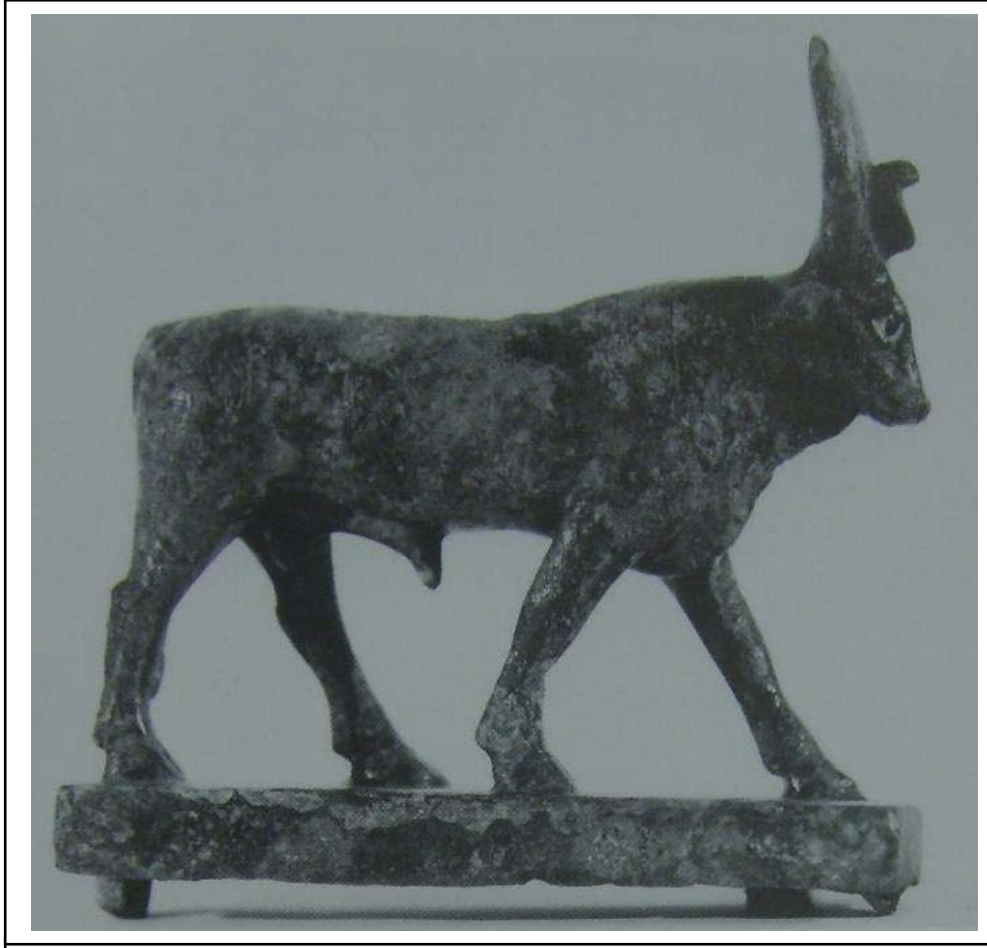

Entre os chifres: disco com uraeus com diâmetro superior ao comprimento da cabeça.

Material: Bronze.

Atitude: marcha; pernas esquerdas avançadas em relação às da direita.

Descrição: touro em atitude de marcha sobre base retangular de altura média com pinos de fixação nas extremidades frontal e traseira. Disco com uraeus entre chifres em "V" e com diâmetro superior ao comprimento da cabeça. Triângulo na fronte inciso, assim como as imagens sobre o resto do corpo. Olhos incrustados de ouro e orelhas acima da altura destes e atrás da linha dos chifres. A cabeça e focinho pequenos dão um ar de docilidade ao animal sagrado. A papada desenvolve duas ondulações, uma suave na parte superior do pescoço e outra mais pronunciada à medida que desce abaixo do peito. A linha torácico-abdominal desenvolve um percurso ascendente sutil até entre as pernas traseiras e sobre ela se destaca o sexo bem desenvolvido. $O$ perfil dorsal desenvolve uma ligeira elevação sobre as ancas e desce de forma ainda mais suave até antes dos ombros, onde ganha uma orientação mais acentuada em um percurso ascendente até o cimo da cabeça. As pernas são volumosas, exibem com elegância as particularidades da anatomia bovina e os cascos estão bem indicados pelos volumes e linhas que os definem. A cauda aparentemente desce colada à perna posterior direita até pouco acima dos cascos.

Apesar do estado de conservação das superfícies indicar uma severa oxidação, percebe-se pela elaboração das formas e detalhes que o artefato estava entre os de melhor qualidade, e sua simbologia confere-lhe sem quaisquer dúvidas a identidade de um Ápis.
Altura: $10,6 \mathrm{~cm}$.

Comprimento: $11,7 \mathrm{~cm}$.

Largura: 3,8cm.

Triângulo: sim.

Colar: sim; apesar dos detalhes não estarem claros na fotografia, parece formado de uma banda com traços perpendiculares com uma "franja" de contas triangulares na parte inferior do pescoço.

Imagem alada I: disco alado; asas com três camadas de plumagem estendidas sobre os ombros e com extremidades acima da linha inferior do manto.

Manto: sim; composto de um retângulo disposto perpendicularmente em relação ao dorso, e decorado em seu interior com um padrão evocativo às redes de contas de faiança.

Imagem alada II: abutre; asas com três camadas de plumagem estendidas sobre as ancas e com extremidades acima da linha inferior do manto.

Coleção: Aix-en-Provence, Musée Granet.

$\mathrm{N}^{\mathrm{o}}$ de Inventário: "Fonds ancien"

Origem: região menfita.

Datação: $26^{\mathrm{a}}-30^{\mathrm{a}}$ dinastia

Outras particularidades:

Outros dados da bibliografia:

Bastante corroída, base quebrada e colada. Restaurada em 1995.

A decoração gravada sobre o dorso do animal classifica a estatueta no grupo F de Roeder (1956: \$411, g, p. 326).

Bibliografia sobre o referido bronze:

C. Barbotin Collection Égyptienne 124-125, nº 59. 


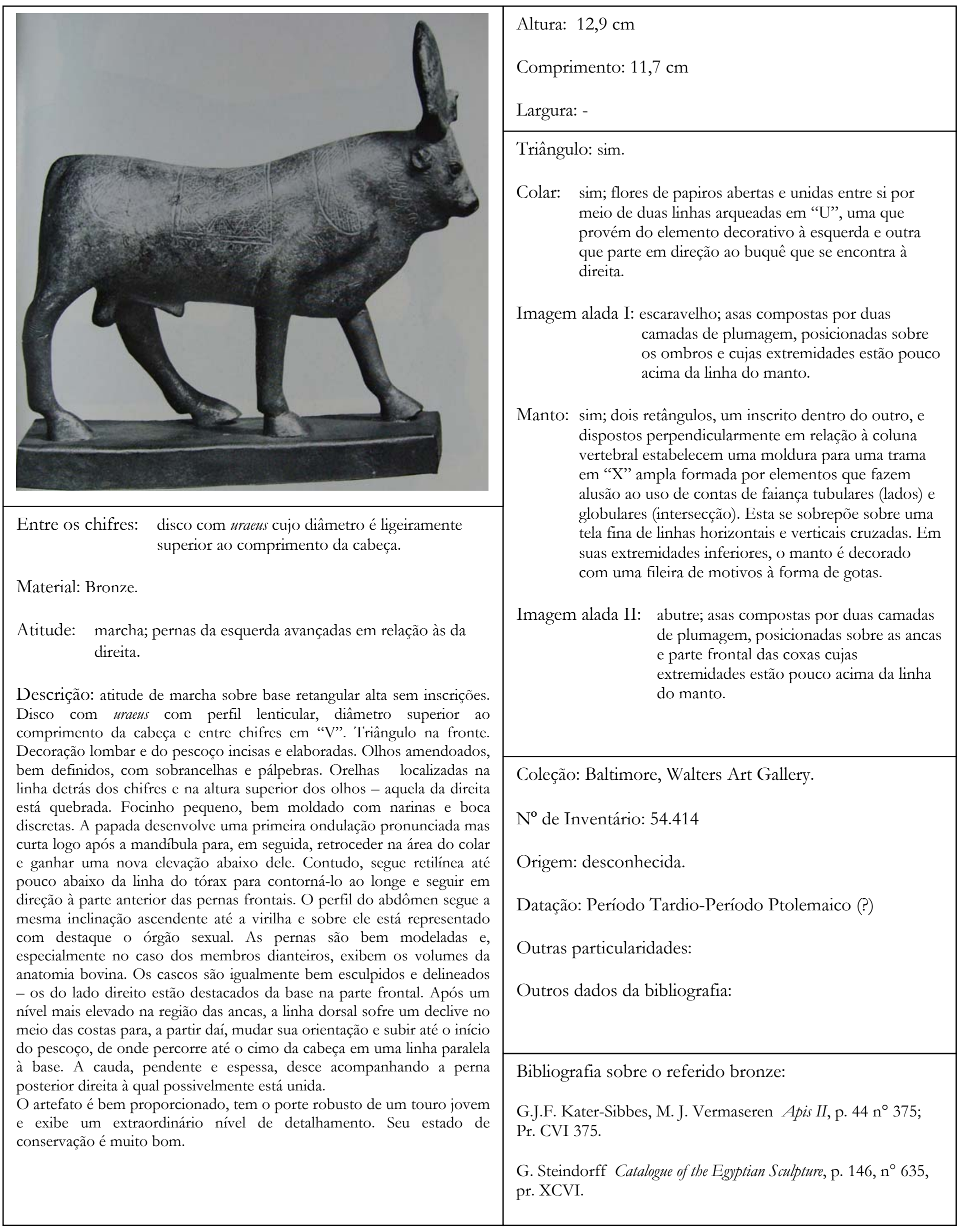




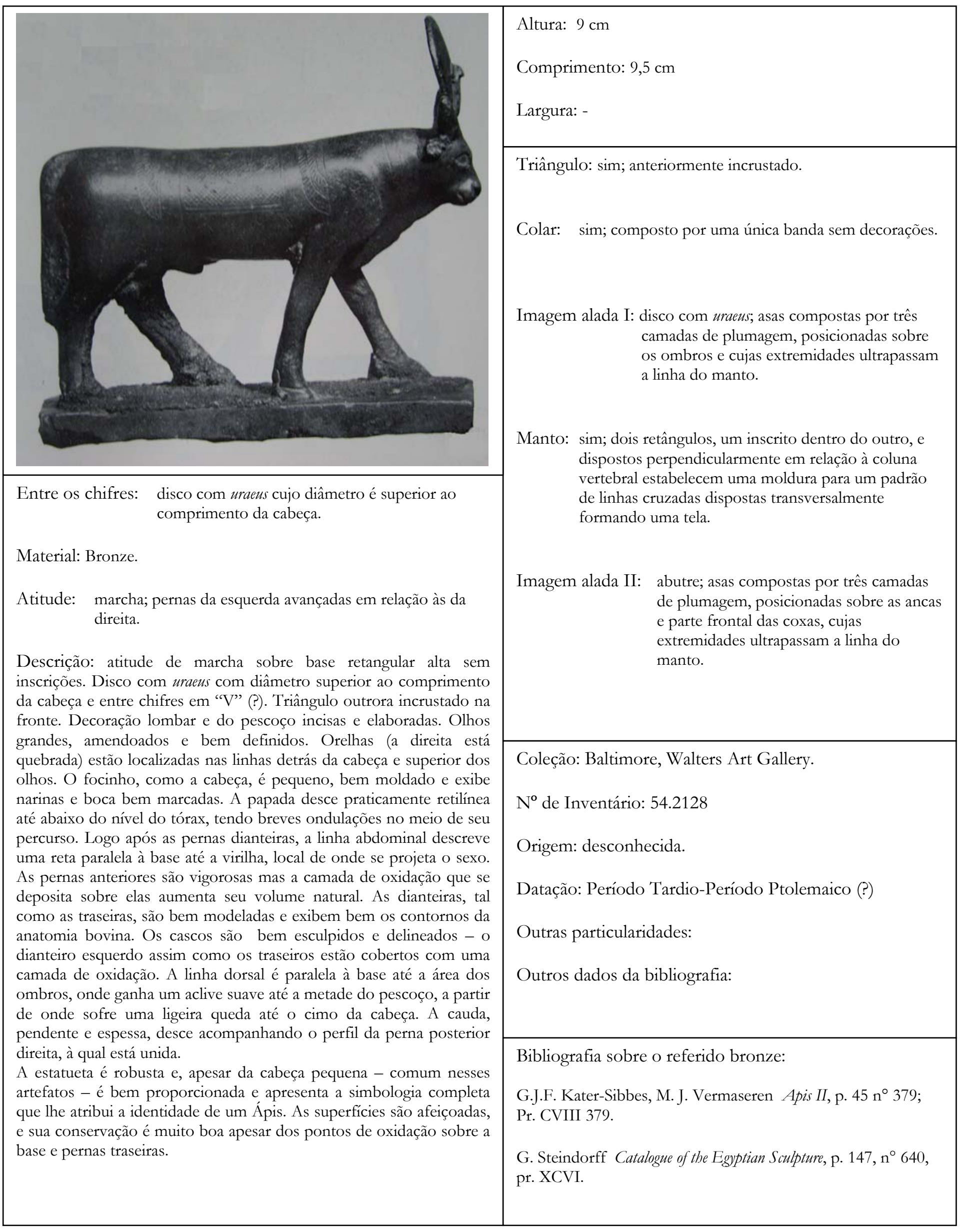




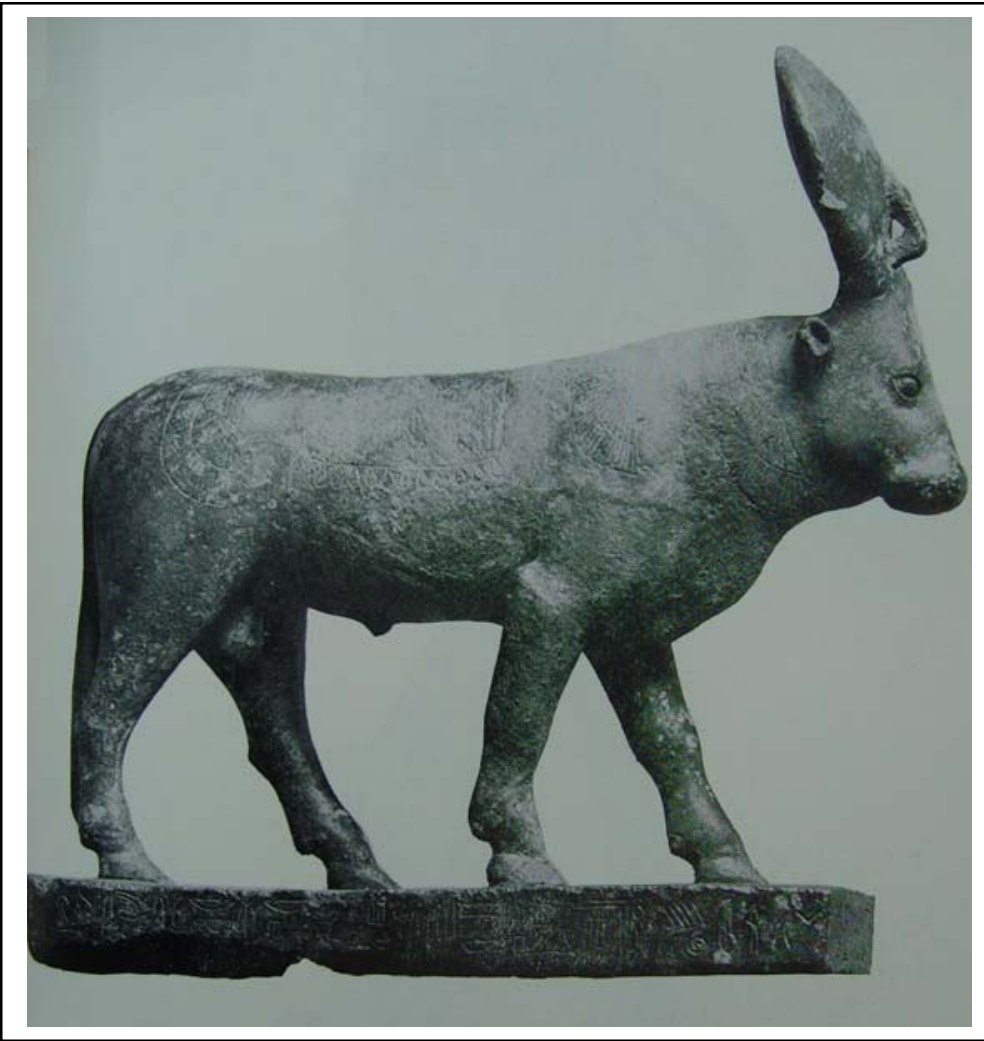

Entre os chifres: disco com uraeus cujo diâmetro é ligeiramente superior ao comprimento da cabeça.

Material: Bronze.

Atitude: marcha; pernas da esquerda avançadas em relação às da direita.

Descrição: atitude de marcha sobre base retangular alta com inscrições. Disco com uraeus com perfil lenticular, diâmetro superior ao comprimento da cabeça e entre chifres em "V" (?). A serpente está destacada do fundo na parte central de seu dorso. Triângulo na fronte. Decoração lombar e do pescoço incisas e elaboradas. Olhos grandes amendoados e bem definidos. Orelhas localizadas na linha detrás da cabeça e bastante acima dos olhos. A cabeça é bem proporcionada e o focinho, bem moldado, exibe narinas e boca discretas. A papada desenvolve dois estágios: no primeiro, desce por meio de uma ondulação suave que se aproxima de uma reta até as extremidades inferiores das asas que substituem o colar. A partir daí, ganha um perfil curvilíneo que margeia ao longe a linha do tórax para vir ao encontro dele entre as pernas frontais. A linha abdominal prossegue igualmente em duas partes: na primeira, ruma paralela à base até a extremidade do falo, a partir de onde o acompanha subindo rumo à virilha. As pernas são robustas, bem modeladas e exibem bem os volumes da anatomia bovina. Os cascos são bem esculpidos e delineados. A linha dorsal desliza paralela à base até a parte frontal do manto, a partir de onde adquire uma orientação ascendente progressiva até a extremidade superior da figura alada do pescoço. Nesse ponto ganha um breve declive até o cimo da cabeça. A cauda, pendente e espessa, desce acompanhando o perfil da perna posterior direita, à qual está unida.

A estatueta é bem proporcionada, apresenta o porte robusto de um jovem touro e qualidades ímpares no seu nível de detalhamento. Seu estado de conservação é muito bom, apesar de alguns traços dispersos de oxidação e da parte inferior direita da base exibir uma fratura.
Altura: $17,8 \mathrm{~cm}$

Comprimento: $15,7 \mathrm{~cm}$

Largura: -

Triângulo: sim.

Colar: > substituído por uma figura alada; asas compostas por três camadas de plumagem e cujas extremidades alcançam a parte inferior do pescoço.

Imagem alada I: escaravelho; asas compostas por três camadas de plumagem, posicionadas sobre os ombros e cujas extremidades ultrapassam a linha do manto.

Manto: sim; um retângulo disposto perpendicularmente em relação à coluna vertebral é decorado por uma série de linhas dispostas longitudinalmente. Entre elas há outras com a mesma orientação mas em zigue-zague. As extremidades do manto possuem uma franja de gotas que possivelmente fazem alusão às contas de faiança ou ouro.

Imagem alada II: abutre; asas compostas por três camadas de plumagem, posicionadas sobre as ancas e parte superior das coxas cujas extremidades ultrapassam a linha do manto.

Coleção: Baltimore, Walters Art Gallery.

$\mathrm{N}^{0}$ de Inventário: 54.418

Origem: a única menção feita no catálogo Apis I para sua proveniência é "Pirâmides", sem mencionar o sítio exato.

Datação: Período Tardio-Paríodo Ptolemaico (?)

Outras particularidades:

Outros dados da bibliografia:

(...) A collar (later on replaced by a wing) ... Contudo, é de se acreditar que haja um par de asas, e não uma só, e que já decoravam a estatueta desde sua elaboração.

\section{Restaurada}

Bibliografia sobre o referido bronze:

G.J.F. Kater-Sibbes, M. J. Vermaseren Apis I, p. 35 n 134; Pr. LXXIX 134.

G. Steindorff Catalogue of the Egyptian Sculpture, p. 146, nº 636 pr. XCVI. 


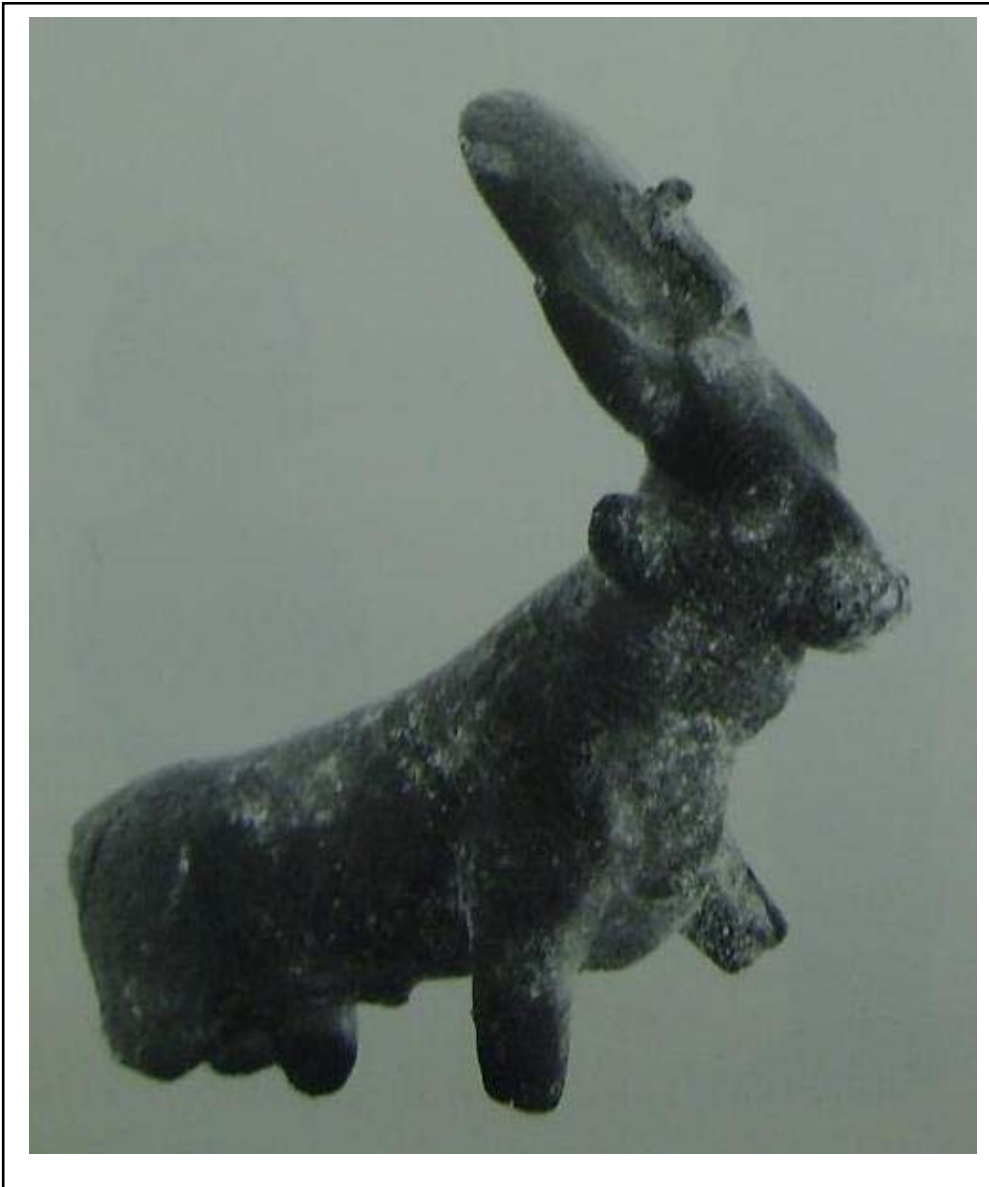

Entre os chifres: disco com uraeus com diâmetro aproximado ao comprimento da cabeça

Material: Bronze.

Atitude: marcha; pernas esquerdas avançadas em relação às da direita.

Descrição: touro em atitude de marcha e partes das pernas e base perdidas. Disco com uraeus entre chifres em crescente e com diâmetro semelhante ao comprimento da cabeça. Triângulo na fronte inciso, assim como as imagens sobre o resto do corpo. Olhos arredondados grandes, com pálpebras e orelhas na altura destes e atrás da linha dos chifres. A cabeça e focinho são proporcionais e bem detalhados. A papada desenvolve duas ondulações, uma menor na parte superior do pescoço e outra mais pronunciada à medida que desce abaixo do peito. A linha torácico-abdominal parece desenvolver um percurso ascendente até entre as pernas traseiras e sobre ela visualiza-se o sexo. O perfil dorsal desenvolve uma ligeira elevação sobre as ancas e desce de forma ainda mais suave até antes dos ombros, onde ganha uma orientação ascendente até o cimo da cabeça. As pernas, embora quebradas, são volumosas, exibem com elegância as particularidades da anatomia bovina. A cauda, igualmente partida, devia acompanhar o perfil da perna posterior direita.

Apesar das fraturas e do estado de conservação das superfícies indicar uma considerável oxidação, percebe-se pela elaboração das formas e detalhes que o artefato estava entre os de melhor qualidade, e sua simbologia confere-lhe sem quaisquer dúvidas a identidade de um Ápis.
Altura: 4,5cm (até a cabeça); 9,3cm (com o disco).

Comprimento: $10,2 \mathrm{~cm}$.

Largura: 2,6cm (cabeça); 4cm (chifres e disco).

Triângulo: sim.

Colar: sim; estriado. Detalhes não visíveis na fotografia.

Imagem alada I: escaravelho alado. Detalhes não visíveis na fotografia.

Manto: sim; decorado com uma tela. Detalhes não visíveis na fotografia.

Imagem alada II: escaravelho alado. Detalhes não visíveis na fotografia.

Coleção: Aix-les-Bains, Musée Archéologique.

$\mathrm{N}^{0}$ de Inventário: 0474.

Origem: Egito.

Datação: Período Tardio, época Saíta, $26^{\mathrm{a}}$ dinastia.

Outras particularidades:

Outros dados da bibliografia:

Técnica excelente.

Bibliografia sobre o referido bronze:

S. Ratié Annency, Musée-Château, Chambéry, Musées d'Art et Histoire, Aix-les-Bains, Musée Archéologique, p.122, nº 258. 


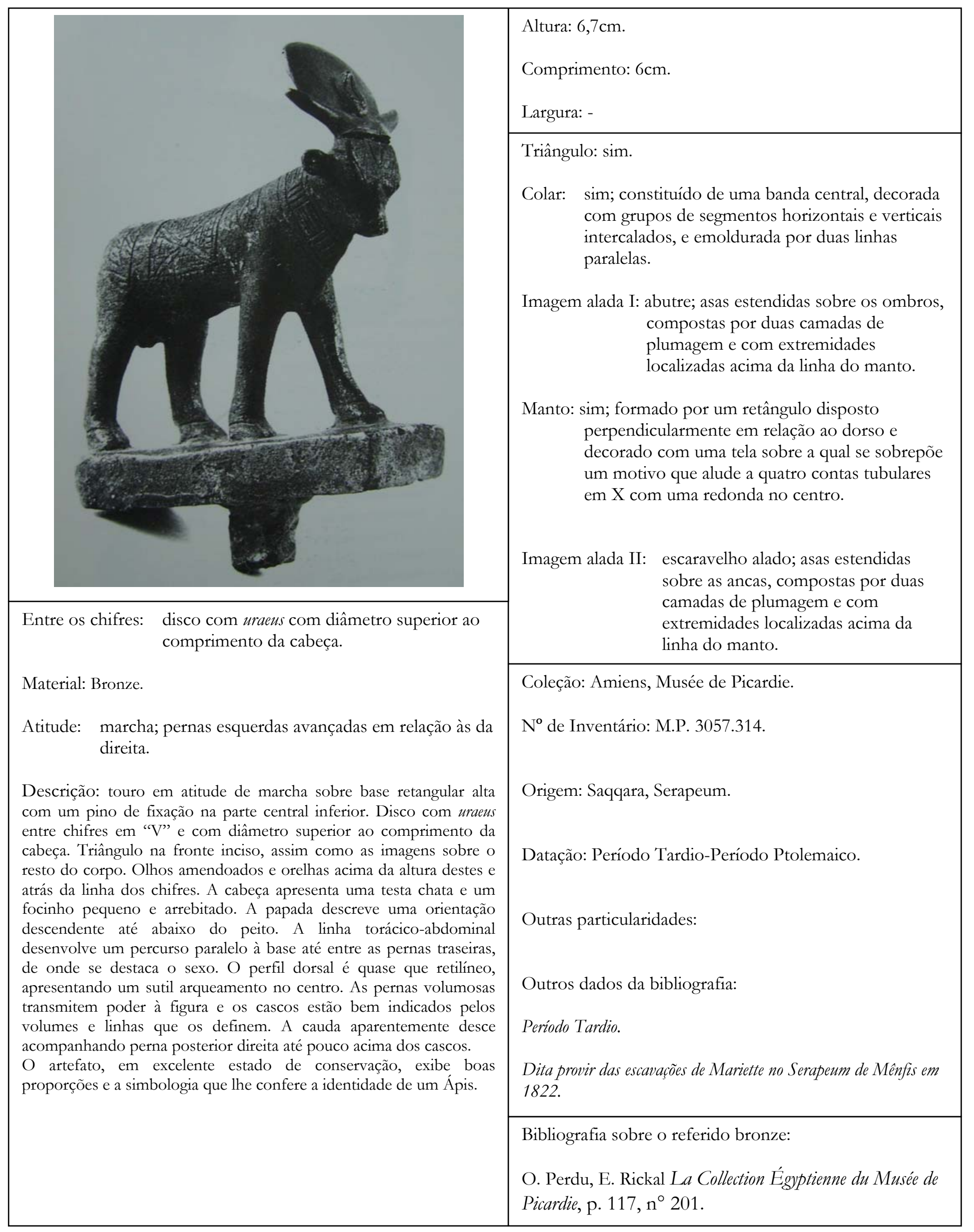




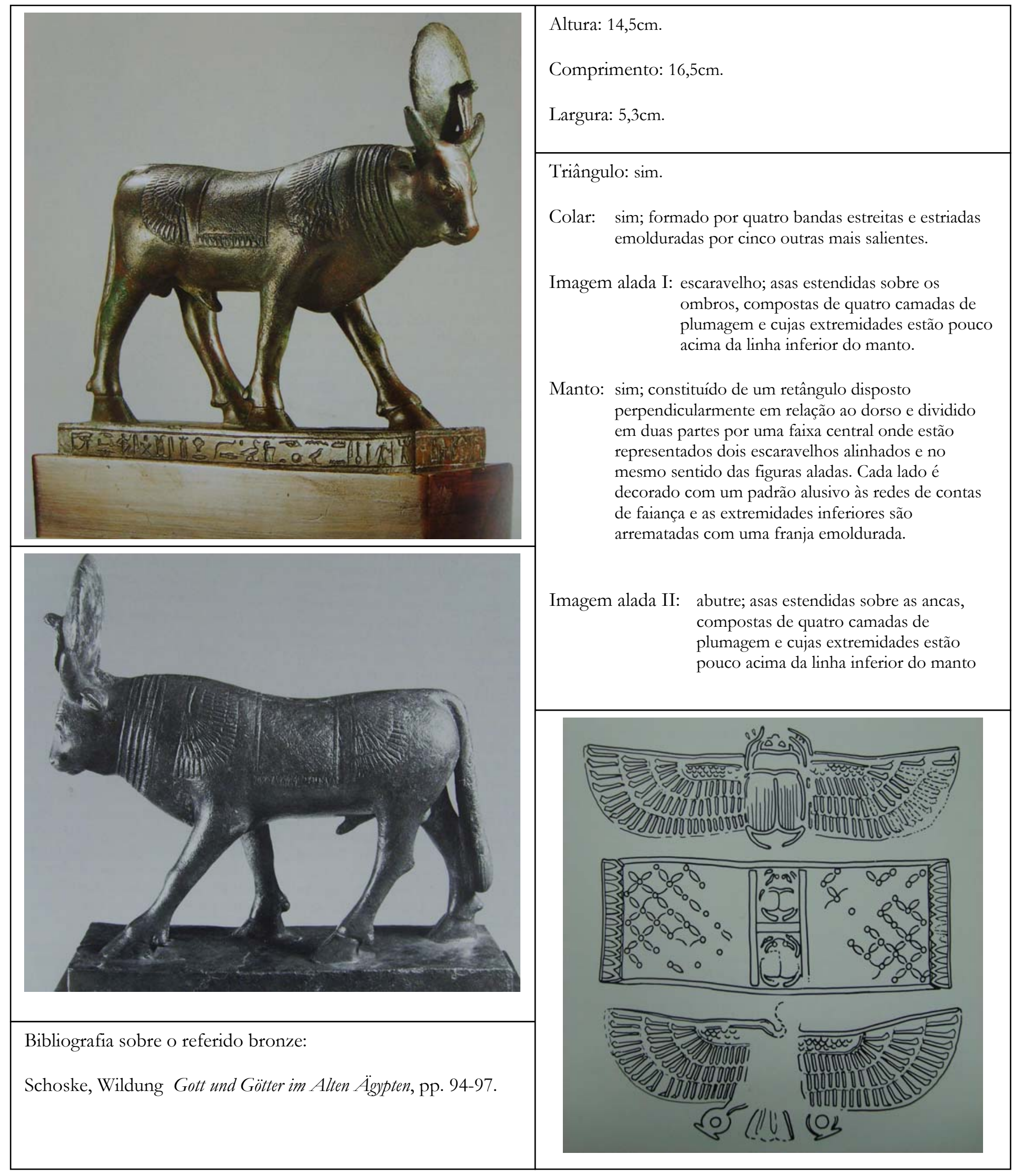


Entre os chifres: disco com uraeus com diâmetro superior ao comprimento da cabeça.

Material: Bronze.

Atitude: marcha; pernas esquerdas avançadas em relação às da direita.

Descrição: touro em atitude de marcha sobre base retangular alta com inscrições. Disco com uraeus com diâmetro superior ao comprimento da cabeça e entre chifres em crescente. Triângulo na fronte e símbolos corporais incisos e ricamente elaborados. Olhos amendoados incrustados de prata e orelhas acima da altura destes e atrás da linha dos chifres. A cabeça é pequena e o focinho pouco prolongado passa uma impressão de docilidade ao touro. A papada descreve uma curta saliência na altura do pescoço e outra mais sutil que desce até abaixo da linha do tórax. A linha torácico-abdominal é quase que paralela à base em toda a sua extensão, e o sexo se destaca sob ela. O perfil dorsal é arqueado na região central das costas e ganha uma inclinação ascendente atrás dos ombros, culminando na área do colar. Daí realiza um declive até o cimo da cabeça.

As pernas são vigorosas, transmitindo um sentido de segurança na marcha, e os cascos estão bem indicados pelos volumes e linhas que os definem. A cauda desce acompanhando a perna posterior direita até pouco acima dos cascos, e está destacada desta na sua média parte. Ela fica mais espessa na extremidade, onde se observa o detalhamento da pelagem.

$O$ artefato exibe qualidades ímpares em sua execução, acabamento e nível de detalhamento dos símbolos que confeririam à imagem - mesmo se não houvesse inscrições na base para prová-lo - a identidade de um Ápis.
Coleção: ?

$\mathrm{N}^{0}$ de Inventário: ?

Origem: desconhecida

Datação: Período Tardio-Período Ptolemaico.

Outras particularidades:

Outros dados da bibliografia:

Olhos incrustados com prata.

Inscrição na base:

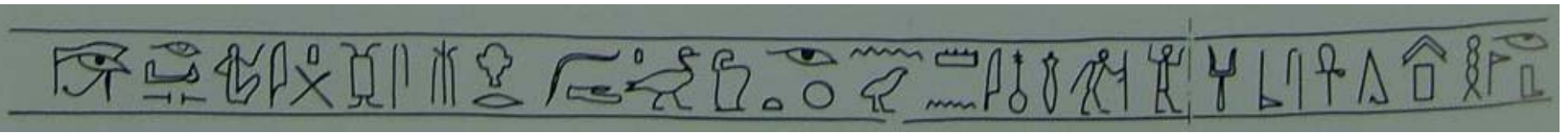




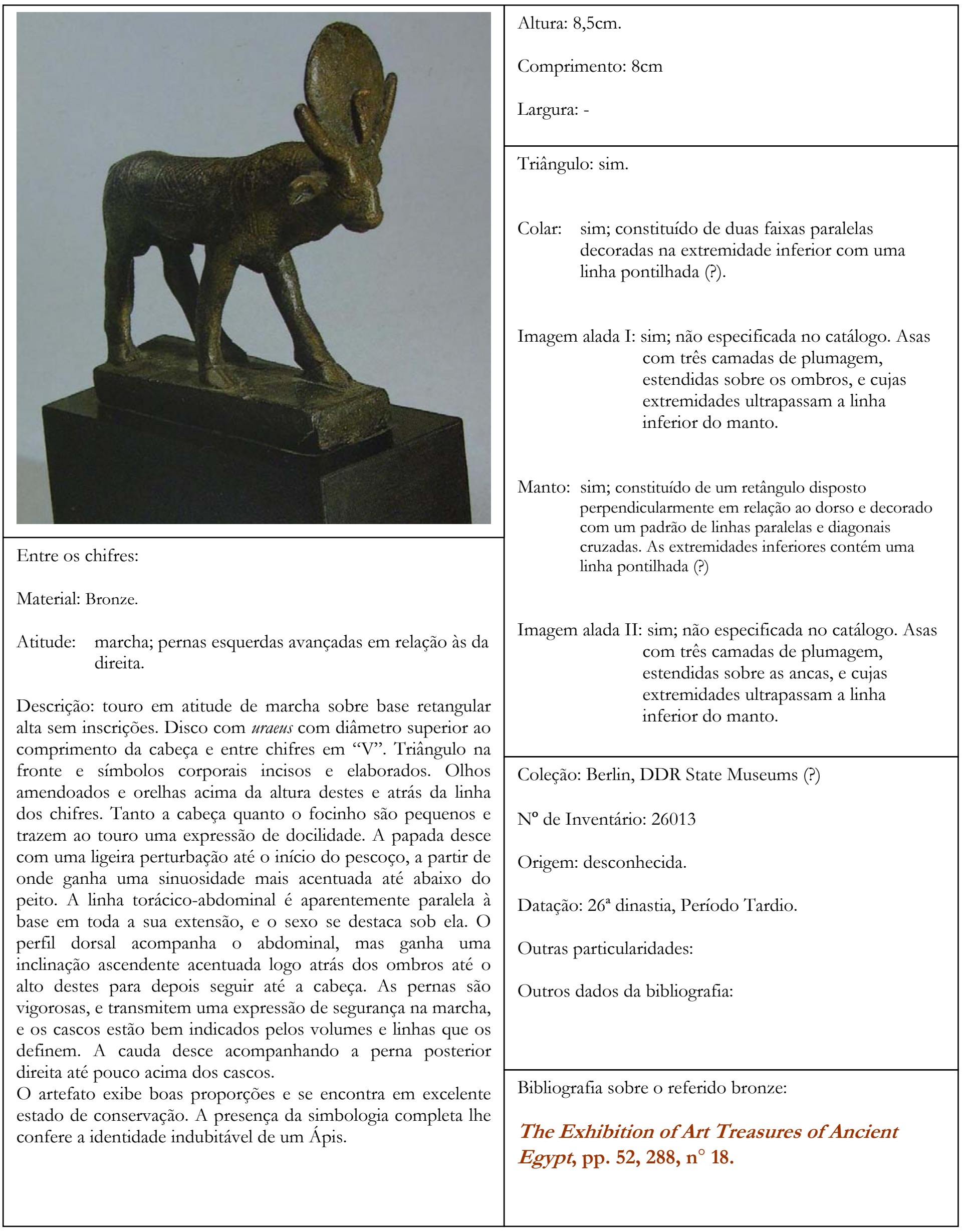




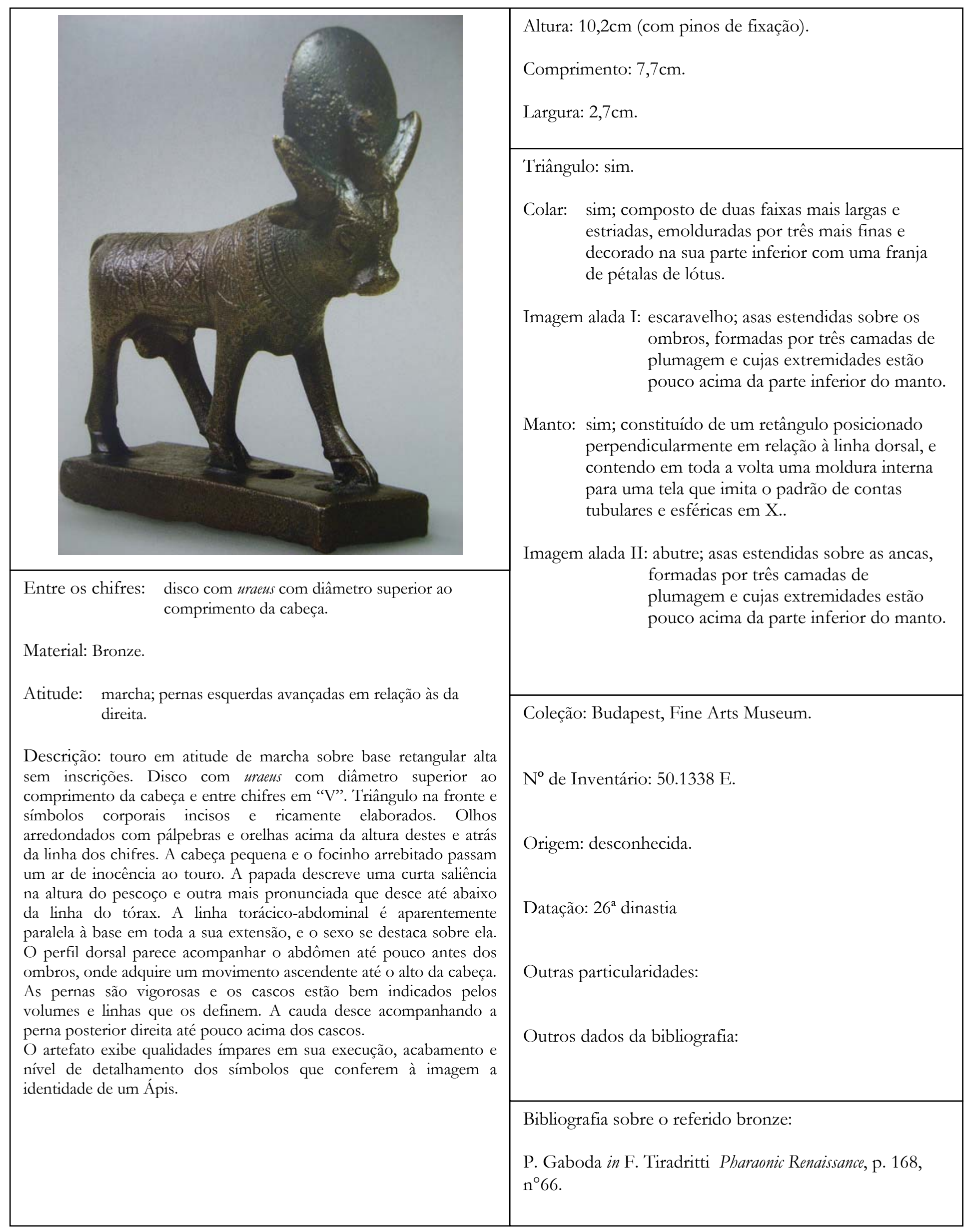




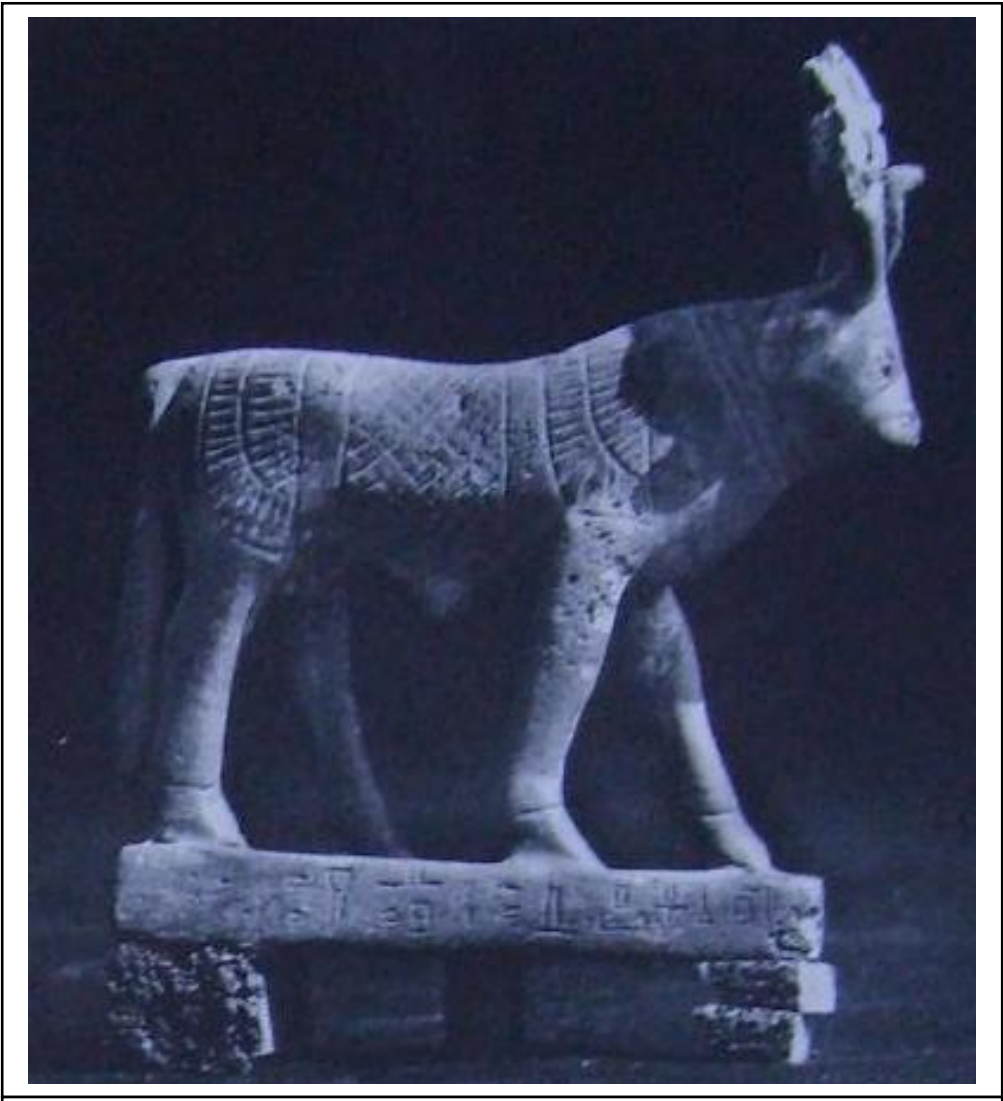

Entre os chifres: disco com uraeus com diâmetro superior ao comprimento da cabeça.

Material: Bronze.

Atitude: marcha; pernas direitas avançadas em relação às da esquerda.
Altura: $12 \mathrm{~cm}$.

Comprimento: $9,30 \mathrm{~cm}$.

Largura: -

Triângulo: sim; incrustado com material esbranquiçado (concha?).

Colar: sim; composto de três faixas paralelas lisas.

Imagem alada I: abutre; asas estendidas sobre os ombros, formadas por duas camadas de plumagem e cujas extremidades estão acima do limite inferior do manto.

Manto: sim; constituído de um retângulo posicionado perpendicularmente em relação à linha dorsal e decorado com um padrão de linhas paralelas e cruzadas formando uma tela.

Imagem alada II: abutre ou escaravelho; asas estendidas sobre as ancas, formadas por duas camadas de plumagem e cujas extremidades ultrapassam o limite inferior do manto.

Coleção: Cairo, Egyptian Museum.

$\mathrm{N}^{0}$ de Inventário: JdE 91957.

Origem: Saqqara, necrópole de animais. Galeria 20 do complexo de catacumbas de falcões.

Datação: Período Tardio-Período Ptolemaico (?)

Outras particularidades:

Outros dados da bibliografia:

H5-2711 [4991]

Inscrição na base:

[-Hp] di `nh (n) P3-di-3st s3 Htp-B3st [t]

"(Possa) [...ÁAis] dar vida a Pediese, filho de Hetepbaste". 


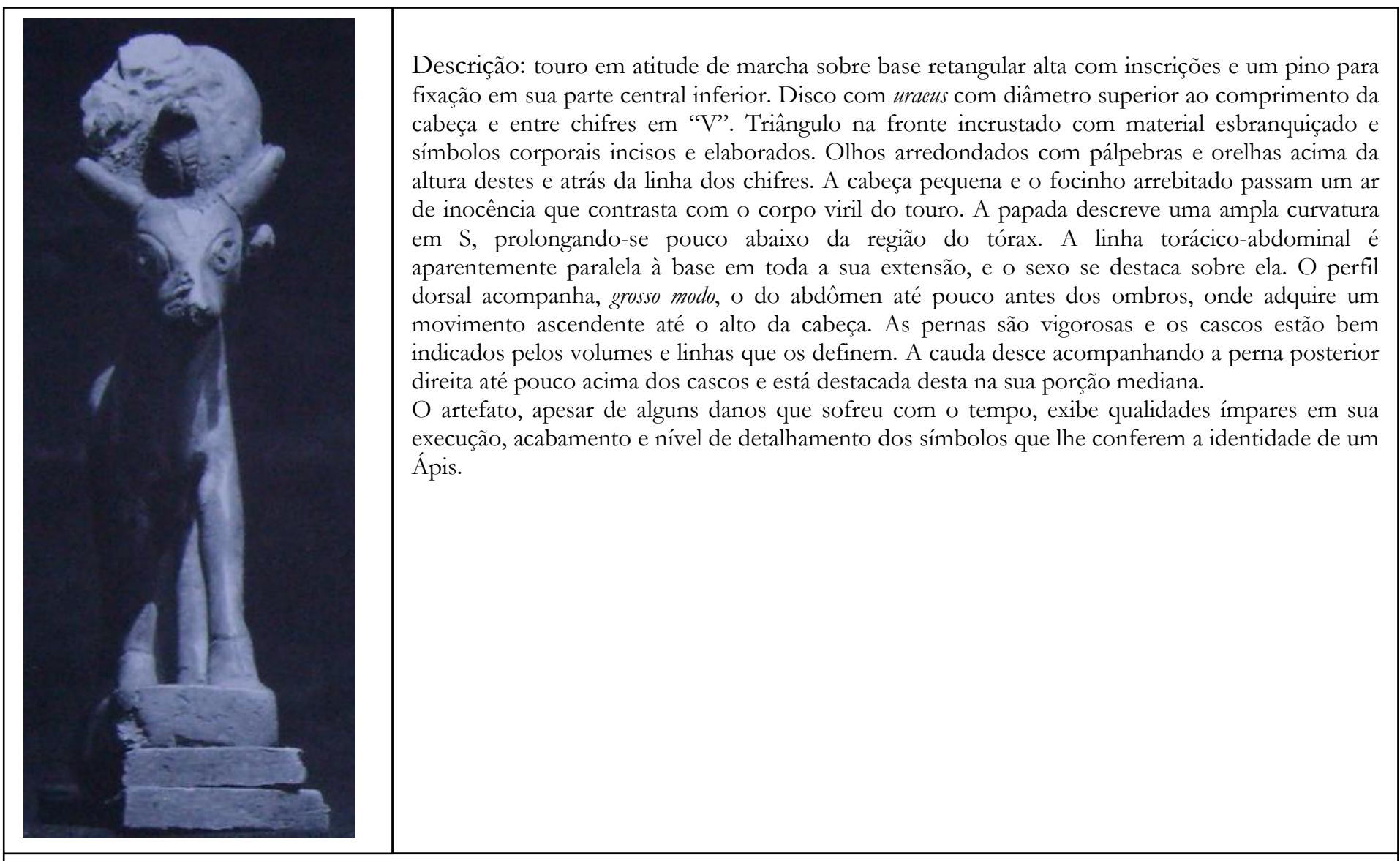

Bibliografia sobre o referido bronze:

S. Davis, H. S. Smith The Sacred Animal Necropolis: The Falcon Complex, pp. 119-120 FCO 443, pr. LX FCO 443. 


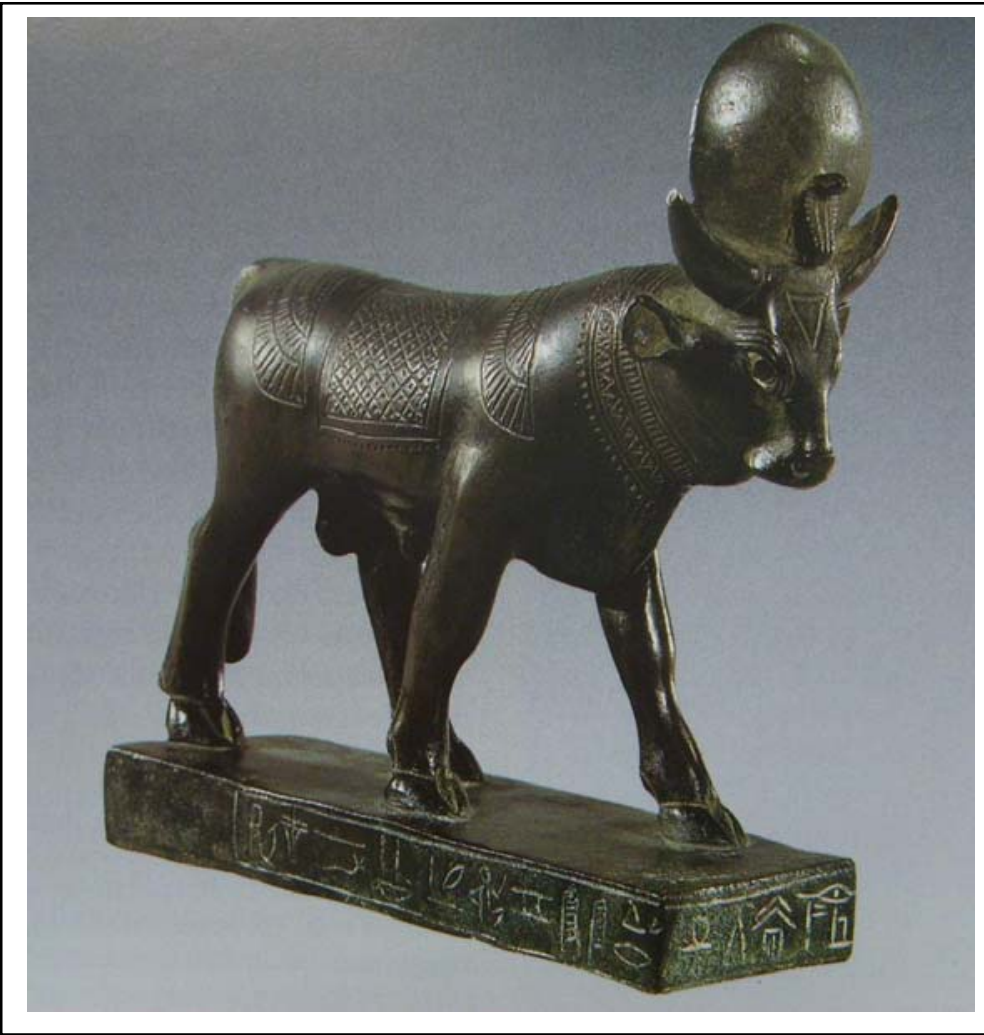

Entre os chifres: disco com uraeus, cujo diâmetro é ligeiramente superior ao comprimento da cabeça.

Material: Bronze.

Atitude: marcha; pernas direitas avançadas em relação às da esquerda.

Descrição: touro em atitude de marcha sobre base retangular alta com inscrições. Disco com uraeus com diâmetro superior ao comprimento da cabeça e entre chifres em crescente. Triângulo na fronte e símbolos corporais incisos e ricamente elaborados. Olhos amendoados com incrustações e pálpebras e orelhas na altura destes e atrás da linha dos chifres. A cabeça pequena e o focinho arrebitado passam uma impressão de docilidade ao touro. A papada descreve duas saliências, uma mais tênue na área do pescoço e outra que daí desce até abaixo do tórax. A linha torácico-abdominal descreve uma leve inclinação rumo à virilha, e o sexo se destaca sobre ela. O perfil dorsal é arqueado na região central das costas e ganha um movimento ascendente atrás dos ombros, culminando no cimo da cabeça. As pernas são vigorosas, procuram espelhar as particularidades da anatomia bovina e transmitem um sentido de segurança na marcha. Os cascos estão bem indicados pelos volumes e linhas que os definem. A cauda volumosa desce acompanhando a perna posterior direita até pouco acima dos cascos.

$\mathrm{O}$ artefato exibe qualidades ímpares em sua execução, acabamento e nível de detalhamento dos símbolos que confeririam à imagem mesmo se não houvesse inscrições na base para prová-lo - a identidade de um Ápis.
Altura: $13,7 \mathrm{~cm}$.

Comprimento: $11,4 \mathrm{~cm}$.

Largura: $4,2 \mathrm{~cm}$.

Triângulo: sim

Colar: sim; formado por duas faixas mais largas, uma decorada com estrias, outra com motivos de flores de lótus abertas e alinhadas, e emolduradas por três bandas mais estreitas. Na parte inferior, o colar está arrematado com uma fileira de pontos que deve aludir ao uso de contas globulares.

Imagem alada I: escaravelho alado; asas estendidas sobre os ombros, compostas por três camadas de plumagem e cujas extremidades estão pouco acima da linha inferior do manto.

Manto: sim; constituído de um retângulo posicionado perpendicularmente em relação à linha dorsal e emoldurado na sua parte interior com uma faixa que percorre todos os lados. Acima o espaço interior é dividido em duas partes por uma banda larga que segue a coluna. Cada lado exibe uma decoração de linhas paralelas transversais e cruzadas com pontos no interior de cada losango formado.

Imagem alada II: abutre; asas estendidas sobre as ancas, compostas por três camadas de plumagem e cujas extremidades estão pouco acima da linha inferior do manto.

Coleção: Suíça, coleção privada.

$\mathrm{N}^{0}$ de Inventário:

Origem: desconhecida.

Datação: $26^{a}$ dinastia.

Outras particularidades:

Outros dados da bibliografia:

Bibliografia sobre o referido bronze:

M. Page-Gasser, A. Wiese Ägypten : Augenblicke der Ewigkeit, pp. 251-252. 


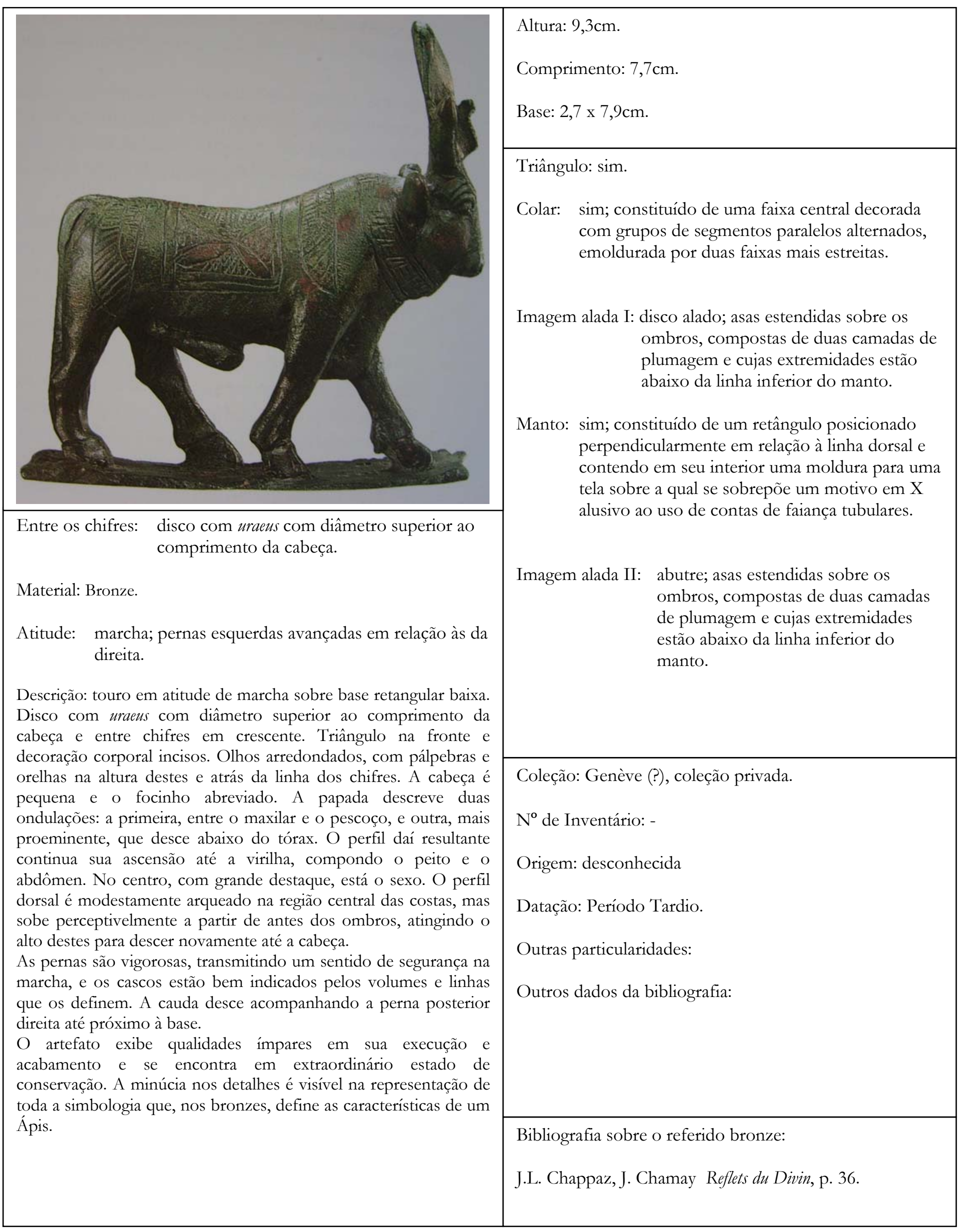




\begin{tabular}{|c|c|}
\hline & $\begin{array}{l}\text { Altura: } 11,6 \mathrm{~cm} . \\
\text { Comprimento: } 12,6 \mathrm{~cm} . \\
\text { Largura: } 4 \mathrm{~cm} .\end{array}$ \\
\hline & $\begin{array}{l}\text { Triângulo: ? } \\
\begin{array}{r}\text { Colar: sim !; formado de três faixas paralelas. A única } \\
\text { decorada com estrias é a central. Na parte } \\
\text { inferior, o adereço é arrematado com uma franja. } \\
\text { Imagem alada I: sim !; símbolo não especificado na } \\
\text { bibliografia. Asas estendidas sobre os } \\
\text { ombros, compostas por duas camadas } \\
\text { de plumagem e cujas extremidades } \\
\text { ultrapassam a linha inferior do manto. }\end{array}\end{array}$ \\
\hline $\begin{array}{l}\text { Entre os chifres: disco com uraeus com diâmetro semelhante } \\
\text { ao comprimento da cabeça. } \\
\text { Material: Bronze. } \\
\text { Atitude: marcha; pernas esquerdas avançadas em relação às da } \\
\quad \text { direita. }\end{array}$ & $\begin{aligned} \text { Imagem alada II: } & \text { sim !; símbolo não especificado na } \\
& \text { bibliografia. Asas estendidas sobre as } \\
& \text { ancas, compostas por duas camadas } \\
& \text { de plumagem e cujas extremidades } \\
& \text { ultrapassam a linha inferior do manto. }\end{aligned}$ \\
\hline $\begin{array}{l}\text { Descrição: touro em atitude de marcha sobre base retangular alta } \\
\text { com inscrições e dois pinos para fixação nas extremidades de sua } \\
\text { parte inferior. Disco com uraeus com diâmetro semelhante ao } \\
\text { comprimento da cabeça e entre chifres em crescente. Dada a presença } \\
\text { dos demais símbolos incisos, é possível que o triângulo esteja gravado } \\
\text { na fronte. Olhos arredondados, pouco definidos na modelagem e } \\
\text { orelhas acima da altura destes e atrás da linha dos chifres. A cabeça } \\
\text { pequena e o focinho abreviado passam um ar de inocência que } \\
\text { contrasta com o corpo viril do touro. A papada, após se confundir } \\
\text { com o pescoço, descreve uma ampla curvatura em S, prolongando-se } \\
\text { pouco abaixo da região do tórax. A linha torácico-abdominal sobe } \\
\text { sutilmente em direção à virilha, e o sexo se destaca sobre ela. O perfil } \\
\text { dorsal adquire um leve arqueamento no meio do manto para em } \\
\text { seguida rumar até o alto da cabeça em uma curva ascendente aberta. } \\
\text { As pernas são vigorosas e os cascos estão bem indicados pelos } \\
\text { volumes e linhas que os definem. A cauda desce acompanhando a } \\
\text { perna posterior direita até pouco acima dos cascos e está destacada } \\
\text { desta na sua porção mediana. } \\
\text { O artefato exibe orandes qualidades em sun concencão execucão e }\end{array}$ & $\begin{array}{l}\text { Coleção: Kaunas, Lituânia. Coleção K. Stankiavitchius. } \\
\text { No de Inventário: Tt - } 4424 \\
\text { Origem: desconhecida. } \\
\text { Datação: } 26^{a} \text { dinastia } \\
\text { Outras particularidades: } \\
\text { Outros dados da bibliografia: } \\
\text { Inscrição: Possa Apis fažer Tjt, filha de T(3)-wgrt, justificada, } \\
\text { viver. }\end{array}$ \\
\hline $\begin{array}{l}\text { acabamento, e o nível de detalhamento dos símbolos, somado à } \\
\text { inscrição hieroglífica, lhe conferem a identidade de um Ápis. }\end{array}$ & $\begin{array}{l}\text { Bibliografia sobre o referido bronze: } \\
\text { O. Berlev, S. Hodjash Catalogue of the Monuments of Ancient } \\
\text { Egypt, p.64, n¹3, pr. 88, VI. } 13 \text {. }\end{array}$ \\
\hline
\end{tabular}




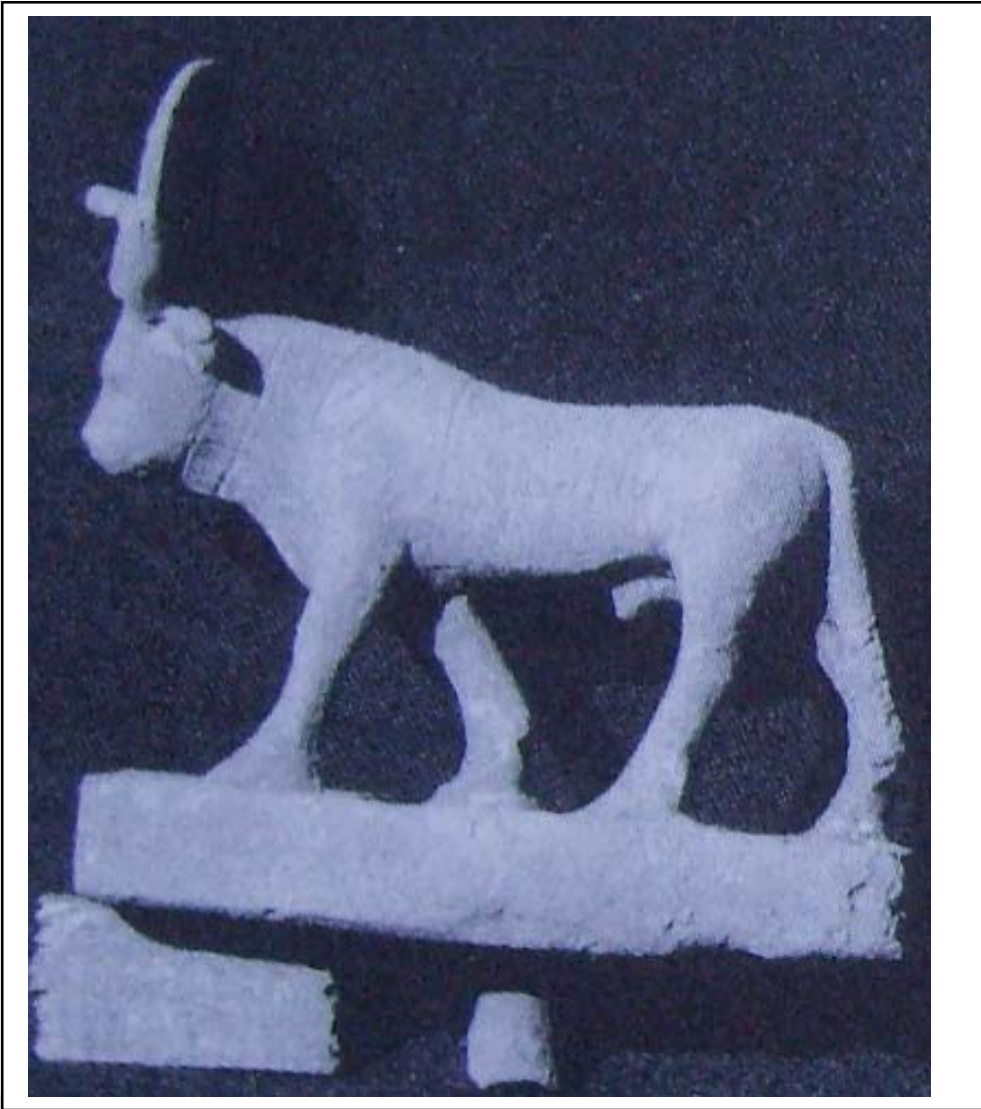

Entre os chifres: disco com uraeus com diâmetro superior ao comprimento da cabeça.

Material: Bronze.

Atitude: marcha; pernas esquerdas avançadas em relação às da direita.

Descrição: touro em atitude de marcha sobre base retangular alta com um pino de fixação na parte central inferior. Disco com uraeus entre chifres em "V" (?) e com diâmetro superior ao comprimento da cabeça. Triângulo na fronte inciso, assim como as imagens sobre o resto do corpo. Olhos arredondados e orelhas acima da altura destes e atrás da linha dos chifres. A cabeça e focinho pequenos dão um ar de docilidade ao animal sagrado. A papada, após acompanhar o pescoço, desenvolve um movimento que desce abaixo do peito. A linha torácico-abdominal desenvolve um percurso ascendente até a virilha, de onde se projeta a genitália. O perfil dorsal sofre um sutil arqueamento na área do manto para, em seguida, ganhar uma orientação ascendente até o meio do pescoço e daí despencar até o cimo da cabeça. As pernas são volumosas, exibem com elegância as particularidades da anatomia bovina e os cascos estão bem indicados pelos volumes e linhas que os definem. A cauda desce acompanhando a perna posterior direita até pouco acima dos cascos.

$\mathrm{O}$ artefato, ainda que castigado pela ação do tempo, exibe formas elegantes e um nível de detalhamento que o classifica entre os melhores exemplares. Mesmo sem apresentar inscrições, é possível identificá-lo como um Ápis tanto pela presença da simbologia recorrente em outros bronzes dessa divindade quanto pela origem comprovada do sítio de Saqqara.
Altura: $8,10 \mathrm{~cm}$ (com pinos para fixação).

Comprimento: $7,10 \mathrm{~cm}$.

Largura: $2,80 \mathrm{~cm}$.

Triângulo: sim.

Colar: sim; constituído de uma faixa decorada com estrias.

Imagem alada I: abutre; asas estendidas sobre os ombros, compostas de duas camadas de plumagem e cujas extremidades estão na linha dos olhos.

Manto: sim; composto de um retângulo disposto perpendicularmente em relação à linha dorsal. Não dá para se ter certeza pela fotografia se havia uma decoração.

Imagem alada II: abutre ou escaravelho alado; asas estendidas sobre as ancas, compostas de duas camadas de plumagem e cujas extremidades estão abaixo da linha dos olhos e pouco acima da do manto.

Coleção: London, British Museum.

$\mathrm{N}^{0}$ de Inventário: BM 67.192

Origem: Saqqara, necrópole de animais. Câmara 4/1 do complexo de catacumbas de falcões.

Datação: Período Tardio-Período Ptolemaico.

Outras particularidades:

Outros dados da bibliografia:

H5-2145 [4215]

Bibliografia sobre o referido bronze:

S. Davis, H. S. Smith The Sacred Animal Necropolis: The Falcon Complex, p.80 FCO 83, pr. XXXc FCO 83. 


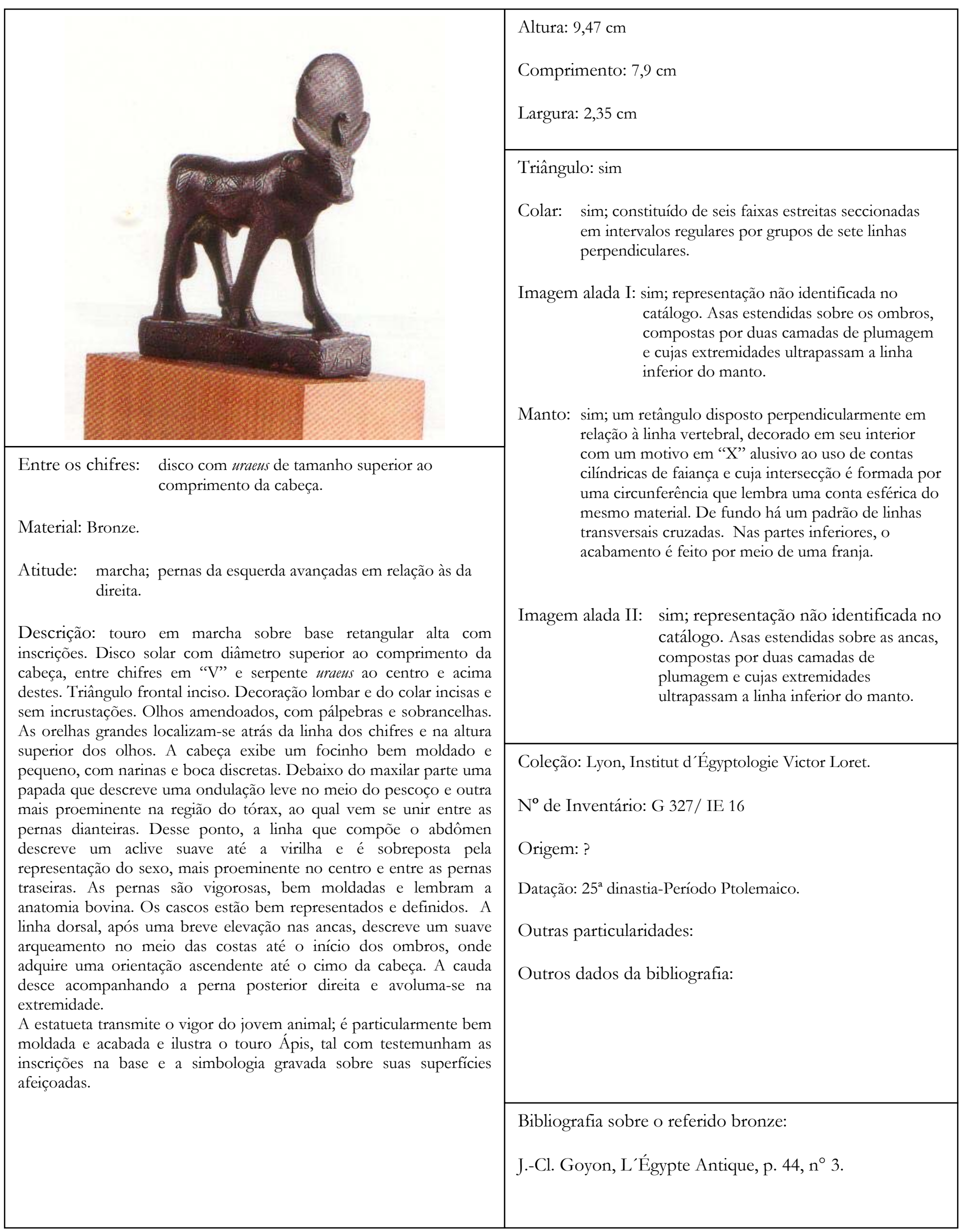




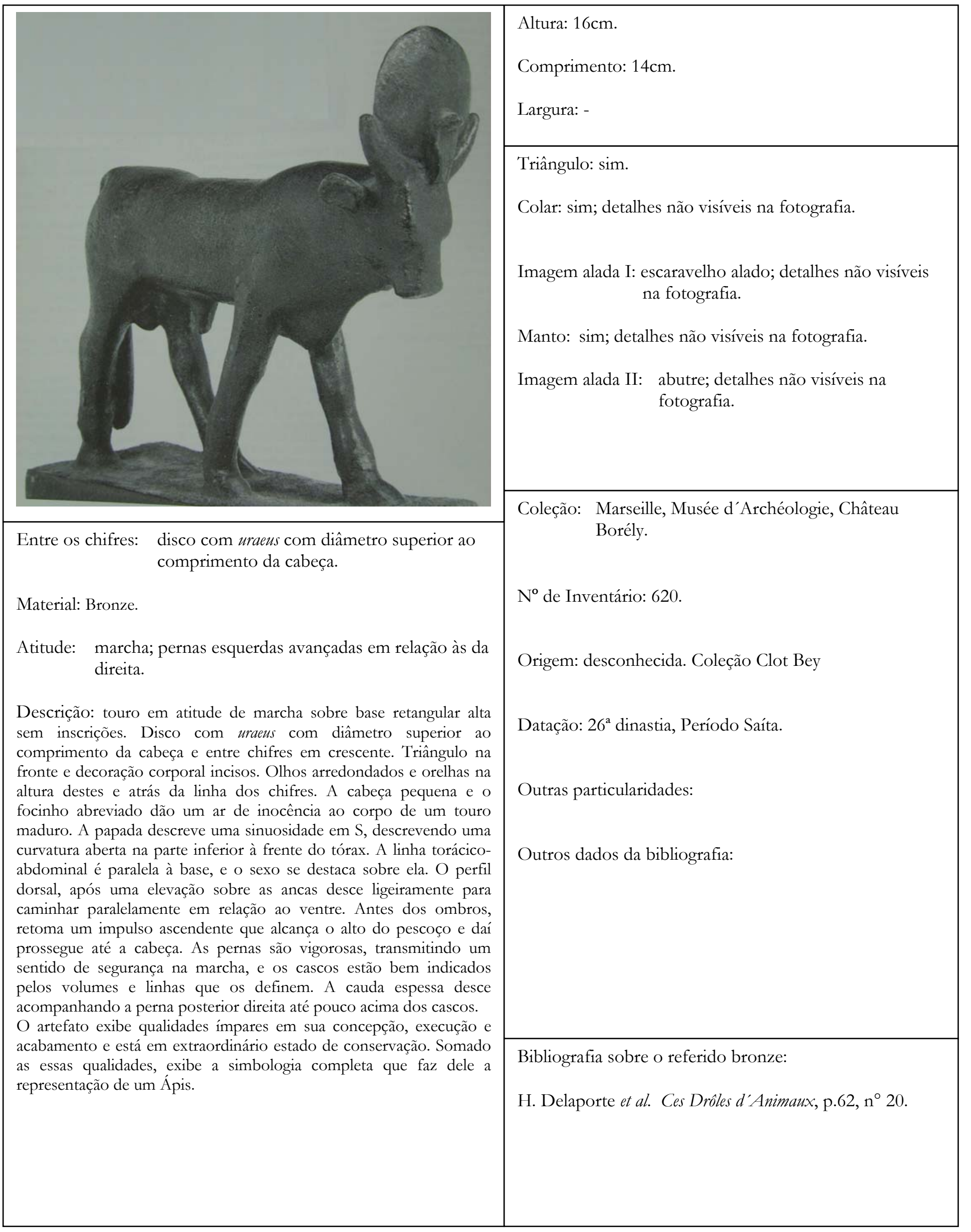




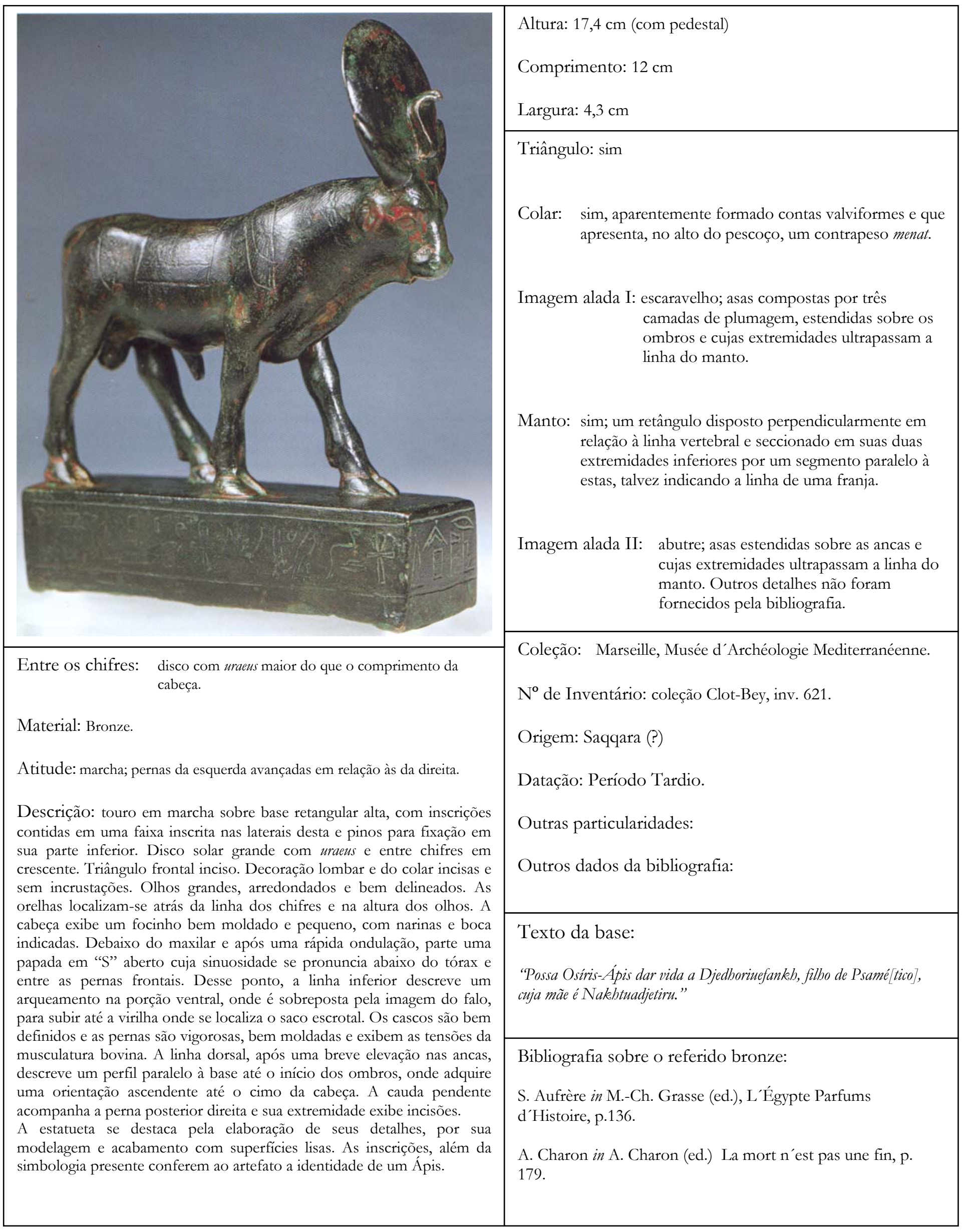




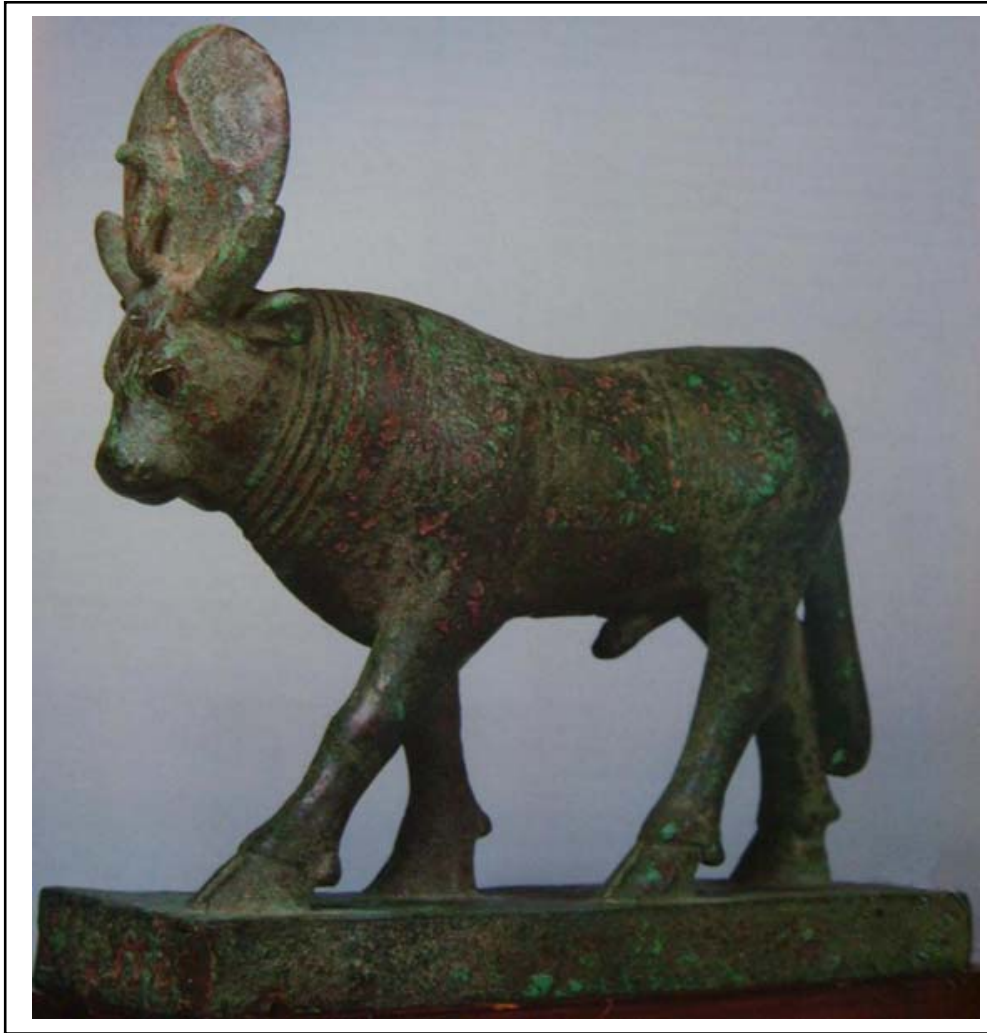

Entre os chifres: disco com uraeus com diâmetro superior ao comprimento da cabeça.

Material: Bronze.

Atitude: marcha; pernas esquerdas avançadas em relação às da direita.

Descrição: touro em atitude de marcha sobre base retangular alta com inscrições deterioradas pela oxidação. Disco com uraeus com diâmetro superior ao comprimento da cabeça e entre chifres em "V". A serpente destaca-se do disco logo abaixo da área mais dilatada o pescoço. Triângulo na fronte incrustado e decoração corporal incisa e particularmente elaborada. Olhos arredondados incrustados de prata e orelhas próximas dos chifres e atrás destes. A cabeça pequena somada ao focinho curto e aos olhos grandes dá um ar de inocência ao corpo de um touro maduro. A papada descreve uma pequena curvatura após o maxilar e outra mais aberta e ampla que se estende até abaixo do peito. A linha torácico-abdominal é paralela à base, e o sexo se destaca sobre ela. O perfil dorsal, após uma elevação sobre as ancas desce ligeiramente sobre o meio das costas para, antes dos ombros, retomar um impulso ascendente que alcança o início do pescoço e daí prossegue até a cabeça. As pernas são vigorosas, procuram reproduzir as particularidades da anatomia bovina e transmitem um sentido de segurança na marcha. Os cascos estão bem indicados pelos volumes e linhas que os definem. A cauda espessa desce acompanhando a perna posterior direita até pouco acima dos cascos e está destacada desta na sua porção mediana.

O artefato exibe qualidades ímpares em sua concepção, execução e acabamento e, apesar dos danos do tempo e da concentração da pátina, está em notável estado de conservação. Somado as essas qualidades, exibe a simbologia completa que faz dele a representação de um Ápis.
Altura: $16,3 \mathrm{~cm}$.

Comprimento: $16,5 \mathrm{~cm}$.

Largura: $5,3 \mathrm{~cm}$.

Triângulo: sim; incrustado.

Colar: sim; composto de quatro faixas paralelas possivelmente decoradas, emolduradas por cinco outras mais finas e lisas.

Imagem alada I: sim, mas símbolo não identificado; asas estendidas sobre os ombros, compostas de duas ou três camadas de plumagem e cujas extremidades ultrapassam a linha inferior do manto.

Manto: sim; constituído de um retângulo disposto perpendicularmente em relação ao dorso que contém uma moldura interna.

Imagem alada II: sim, mas símbolo não identificado; asas estendidas sobre as ancas, compostas de duas ou três camadas de plumagem e cujas extremidades ultrapassam a linha inferior do manto.

Coleção: München, Staatliche Sammlung, Ägyptischer Kunst.

$\mathrm{N}^{\mathrm{o}}$ de Inventário: ?

Origem: desconhecida.

Datação: Período Tardio.

Outras particularidades:

Outros dados da bibliografia:

Olhos incrustados de prata.

Bibliografia sobre o referido bronze:

D. Wildung, S. Schoske et al. Entdeckungen, pp. 127-128, $\mathrm{n}^{\circ} 110$ 


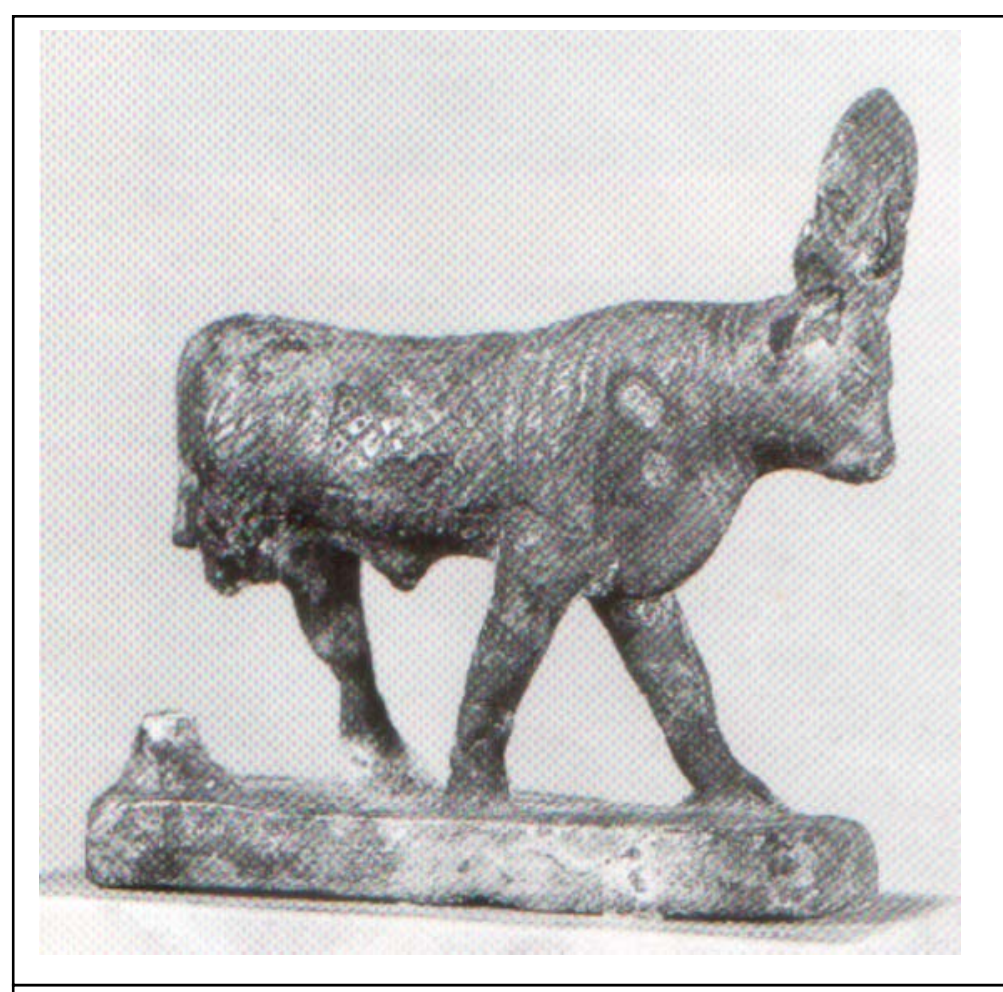

Entre os chifres: disco com uraeus de tamanho semelhante ao comprimento da cabeça.

Material: Bronze.

Atitude: marcha; pernas da esquerda avançadas em relação às da direita.

Descrição: touro em marcha sobre base retangular alta e sem inscrições. Disco solar grande com uraeus e entre chifres em crescente. As dimensões deste, no entanto, não ultrapassam aquelas da cabeça do animal. Triângulo frontal inciso. Decoração lombar e do colar incisas e sem incrustações. Olhos grandes, amendoados e bem delineados. As orelhas localizam-se atrás das linhas dos chifres e superior dos olhos. A cabeça exibe um focinho bem moldado e pequeno, com narinas e boca discretas. Debaixo do maxilar parte uma papada em "S" acentuado e que encontra a região do peito atrás das pernas dianteiras. Desse ponto, a linha que compõe o abdômen descreve um aclive suave até a virilha e é sobreposta pela representação do sexo, mais proeminente no centro e entre as pernas traseiras. As pernas - a posterior direita junto com a cauda está quebrada - são vigorosas e bem moldadas, mas irregularidades na superfície e traços de oxidação impedem uma análise mais apurada. Duas marcas arredondadas e localizadas na parte frontal superior da perna direita indicam falhas na fundição e talvez a modelagem do artefato como um todo tenha sofrido danos nesse processo. A linha dorsal, após uma breve elevação nas ancas, descreve um suave arqueamento no meio das costas até o início dos ombros, onde adquire uma orientação ascendente até o cimo destes. Desse ponto, adquire uma trajetória praticamente retilínea até o cimo da cabeça.

A estatueta, apesar das condições de sua conservação, exibe uma postura viril e suas proporções trazem nobreza ao touro que, pelos detalhes da simbologia que lhe foi conferida, se identifica a Ápis.
Altura: $5,3 \mathrm{~cm}$

Comprimento (touro): $5,1 \mathrm{~cm}$

Comprimento (base): $5,3 \mathrm{~cm}$

Largura: $1,8 \mathrm{~cm}$

Triângulo: sim

Colar: sim; constituído de quatro linhas paralelas.

Imagem alada I: escaravelho; asas estendidas sobre os ombros, compostas por três camadas de plumagem e cujas extremidades estão próximas à linha inferior do manto.

Manto: um retângulo disposto perpendicularmente em relação à linha vertebral, decorado em seu interior com linhas transversais cruzadas formando um motivo de losangos cujo centro é enfeitado com um ponto. As extremidades inferiores apresentam franjas decorativas.

Imagem alada II: disco ?; asas estendidas sobre as ancas e cujas extremidades aparentemente ultrapassam a linha inferior do manto. A fotografia não revela se há mais de duas camadas de plumagem.

Coleção: Strasbourg, Musée Archéologique.

$\mathrm{N}^{0}$ de Inventário: 11.987.0.88; Coleção Schlumberger $n^{\circ}$ 407 (inv. 1929, $\mathrm{n}^{\circ} 207$ ).

Origem: ?

Datação: Período Tardio

Outras particularidades:

Outros dados da bibliografia:

Traços de oxidação que danificaram a perna posterior e orelha direitas e parte da cauda.

Bibliografia sobre o referido bronze:

A. Schweitzer, C. Traunecker, Strasbourg Musée

Arcéologique, p. 37-38, n 42. 


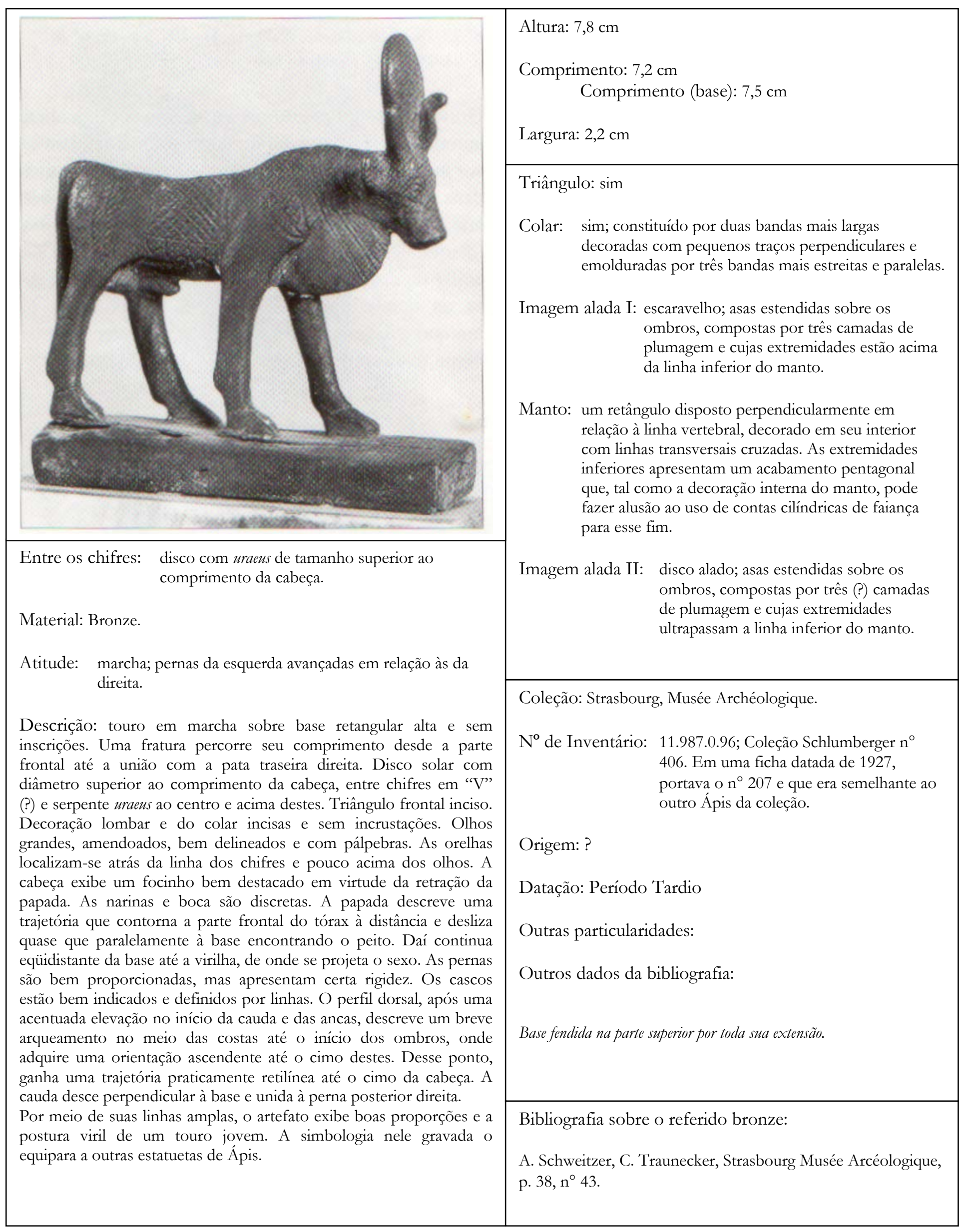




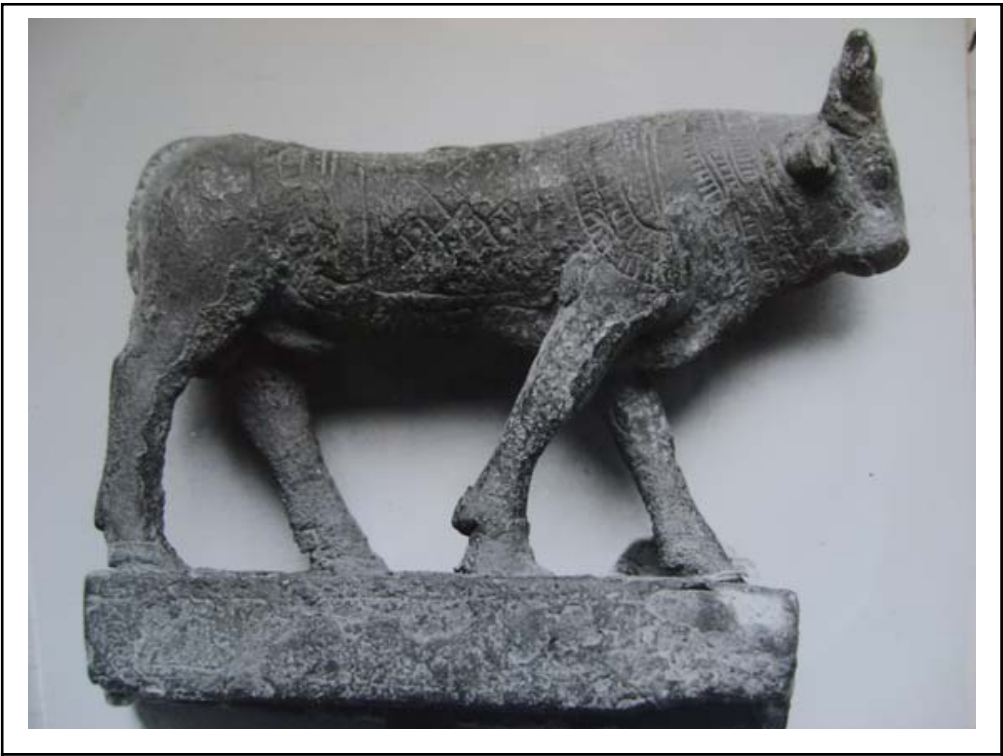

Entre os chifres: vestígios de disco com uraeus.

\section{Material: bronze?}

Atitude: marcha; pernas da esquerda avançadas em relação às da direita.

Descrição: touro em marcha sobre base retangular alta com inscrições e superfícies atacadas pela oxidação. Vestígios do disco com uraeus entre chifres em "V" (?). Decoração lombar e do pescoço elaboradas, incisas, sem incrustações e com acentuada deterioração. Olhos grandes, amendoados e dispostos na diagonal. As orelhas (quebradas ?) localizam-se atrás da linha da cabeça e pouco acima da altura dos olhos. A cabeça é pequena assim como o focinho. Pouco abaixo deste se desenvolve uma papada com duas ondulações: a primeira, menor, segue até a metade do colar dando a vez para a segunda, que daí parte em uma curva mais ampla até abaixo da linha do tórax e termina pouco depois de metade do manto. O nível do abdômen é praticamente retilíneo e paralelo à base, tendo a representação do sexo como apêndice na região da virilha. Apesar da oxidação que se espalhou por elas, as pernas exibem formas robustas e procuram espelhar as particularidades da anatomia bovina e os cascos são bem definidos. A linha dorsal desenvolve uma ligeira curvatura côncava na sua porção média para ascender muito sutilmente a partir dos ombros e, novamente, sofrer uma leve inclinação para atingir o cimo da cabeça. A cauda está quebrada logo acima, o que pode indicar que outrora não estivera ligada à perna posterior direita em toda a sua extensão.

A estatueta tem porte robusto, formas elegantes e, apesar do grau de oxidação e da ausência do disco com uraeus, observa-se que a representação da simbologia é elaborada e o artefato enquadra-se entre os melhores exemplares.

Bibliografia sobre o referido bronze:
Altura: $8,1 \mathrm{~cm}$ (sem pino de fixação)

Altura do pino de fixação: $1,2 \mathrm{~cm}$

Comprimento da base: $9,2 \mathrm{~cm}$

Largura: -

Triângulo: sim

Colar: sim; duas bandas centrais, decoradas com linhas paralelas e perpendiculares, estão emolduradas por três faixas mais estreitas. Contornando o início do pescoço uma franja que pode aludir as contas de faiança tubulares.

Imagem alada I: escaravelho; asas estendidas sobre os ombros, com extremidades alcançando a linha inferior do manto e formadas por três carreiras de plumagem que se sustentam na estrutura estilizada que, nas aves, corresponde os braços e dedos.

Manto: sim; dois retângulos, um inscrito dentro do outro, e dispostos perpendicularmente ao dorso, estabelecem uma moldura para o padrão decorativo em xadrez composto por linhas transversais no quadrilátero interno. $\mathrm{O}$ centro de cada quadrado formado por essa trama é decorado por um ponto. $\mathrm{Na}$ extremidade inferior, uma franja decorativa que possivelmente evoca contas tubulares de faiança ou ouro.

Imagem alada II: escaravelho; asas estendidas sobre as ancas, com extremidades alcançando a linha inferior do manto e formadas por três carreiras de plumagem que se sustentam na estrutura estilizada que, nas aves, corresponde aos braços e dedos

Coleção: Paris, Musée du Louvre.

No de Inventário: E 19911

Origem: ? (não mencionada na ficha do museu)

Datação: Período tardio-Período Ptolemaico.

Outras particularidades:

Outros dados na ficha do museu:

Apis

AE026230

Musée Guimet 2412

Restes de noyean sableux noir sous le socle7983 


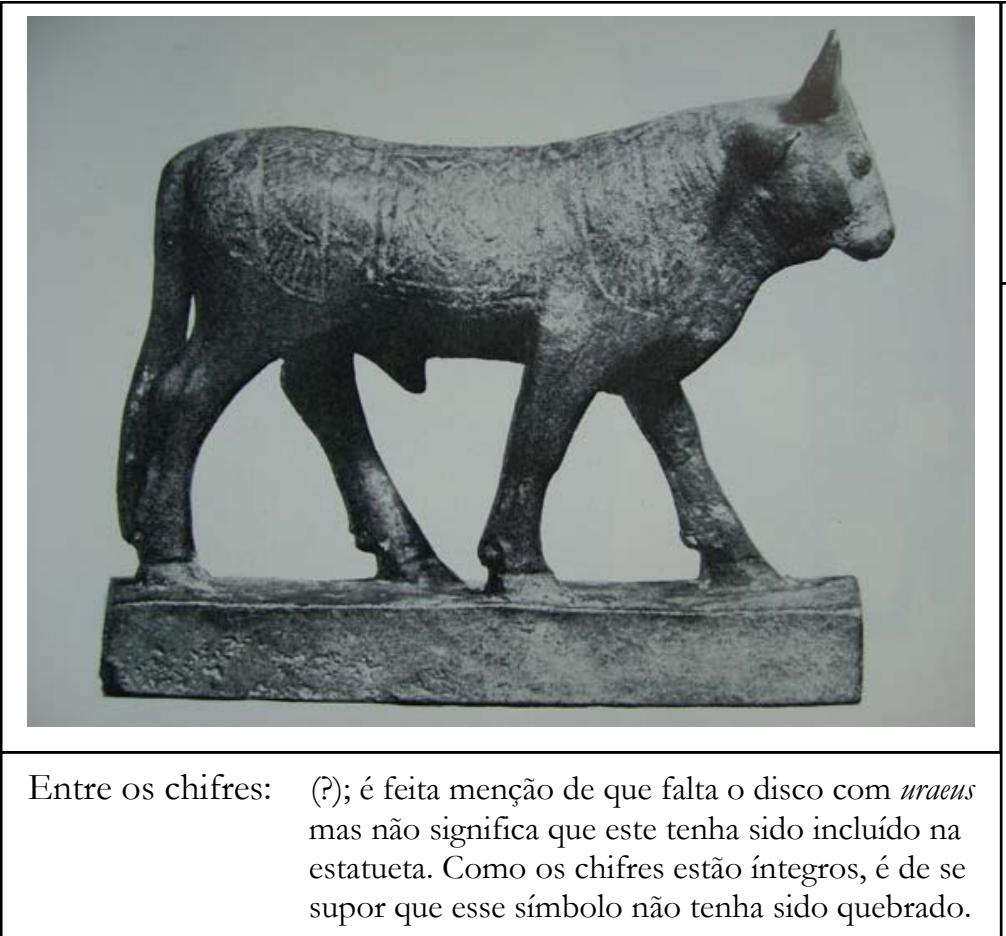

Material: Bronze.

Atitude: marcha; pernas da esquerda avançadas em relação às da direita.

Descrição: atitude de marcha sobre base retangular alta sem inscrições. Chifres em crescente (?) aparentemente sem o disco com uraeus. Triângulo na fronte. Decoração lombar e do pescoço incisas e elaboradas. Olhos amendoados, bem definidos e com pálpebras. Orelhas voltadas para o focinho, localizadas na linha detrás da cabeça e na altura superior dos olhos. Focinho pequeno, bem moldado com narinas e boca discretas. A papada desenvolve dois estágios principais: o primeiro, logo abaixo da mandíbula, inicia-se com uma rápida elevação e depois descreve um perfil retilíneo descendente até a parte inferior do colar. Em seguida, desenvolve um contorno arqueado fechado à frente e abaixo do peito, chegando a altura deste atrás das pernas frontais. A linha abdominal daí continua até a virilha por meio de um segmento paralelo à base e sobre o qual se projeta o sexo. As pernas são robustas, bem modeladas e exibem os volumes da anatomia bovina. Os cascos são igualmente bem esculpidos e delineados. Após uma quase imperceptível elevação na região das ancas, a linha dorsal desce para o nível do manto que é, grosso modo, paralelo à base, para ganhar um perfil ascendente a partir do início dos ombros até o alto da cabeça. A cauda, pendente e espessa, desce acompanhando o perfil da perna posterior direita, à qual está unida exceto no meio.

$\mathrm{O}$ artefato exibe boas proporções, o porte robusto e viril de um jovem touro e qualidades ímpares no seu nível de detalhamento. Seu estado de conservação é muito bom, mas apresenta alguns traços de oxidação dispersos pelo corpo.
Altura: $9 \mathrm{~cm}$

Comprimento: $10 \mathrm{~cm}$

Largura: -

Triângulo: sim;

Colar: sim; composto de cinco (?) bandas paralelas, duas mais largas e decoradas (?) com traços perpendiculares emolduradas por outras três sem decoração. Na parte inferior parece exibir uma franja decorativa.

Imagem alada I: escaravelho; asas compostas por três camadas de plumagem, posicionadas sobre os ombros e cujas extremidades ultrapassam a linha do manto.

Manto: sim; dois retângulos, um inscrito dentro do outro, e dispostos perpendicularmente em relação à coluna vertebral estabelecem uma moldura para uma faixa decorativa que divide o quadrilátero interno em duas metades. Em cada lado exibe uma trama em "X" ampla formada por elementos que fazem alusão ao uso de contas de faiança tubulares (lados) e globulares (intersecção).

Imagem alada II: abutre; asas compostas por três camadas de plumagem, posicionadas sobre as ancas e parte frontal das coxas cujas extremidades ultrapassam a linha do manto.

Coleção: Baltimore, Walters Art Gallery.

$\mathrm{N}^{0}$ de Inventário: 54.2126

Origem: Mit Rahineh ?

Datação: Período Tardio-Período Ptolemaico.

Outras particularidades:

Outros dados da bibliografia:

Sun-disc with uraeus missing

Bibliografia sobre o referido bronze:

G.J.F. Kater-Sibbes, M. J. Vermaseren Apis I, p. 19 n 64; Pr. XLVI 64.

G. Steindorff Catalogue of the Egyptian Sculpture, pp. 146-147, $\mathrm{n}^{\circ}$ 638 , pr. XCVI. 


\begin{tabular}{|c|c|}
\hline & $\begin{array}{l}\text { Altura: } 5,6 \mathrm{~cm} \\
\text { Comprimento: } 8 \mathrm{~cm} \\
\text { Largura: - }\end{array}$ \\
\hline $\begin{array}{l}\text { Entre os chifres: - } \\
\text { Material: bronze? } \\
\text { Atitude: marcha; pernas da esquerda avançadas em relação às } \\
\text { da direita } \\
\text { Descrição: touro em marcha sobre base retangular fina sem } \\
\text { inscriçôes. Disco e uraeus, se existiram, estão perdidos juntamente } \\
\text { como os chifres, que estão quebrados na altura da base. } \\
\text { Triângulo frontal. Decoração lombar incisa, sem incrustações e } \\
\text { que pode ser um manto com arestas arredondadas, uma } \\
\text { reprodução de uma das manchas do touro ou mesmo um } \\
\text { manto à forma da dita mancha. Olhos arredondados, bem } \\
\text { delineados e com carúncula lacrimal estendida na diagonal. As } \\
\text { orelhas localizam-se atrás da linha dos chifres e na altura dos } \\
\text { olhos. A cabeça apresenta traços delicados, o focinho é } \\
\text { sugerido por um traço curvo que vem de baixo e as narinas } \\
\text { foram sugeridas por pequenos traços. Do início do focinho e } \\
\text { abaixo, parte uma papada com duas ondulações; a primeira até } \\
\text { o início do pescoço e a outra, bem maior, desenvolve uma } \\
\text { ampla curva até pouco abaixo da linha do abdômen, o qual só } \\
\text { ganha uma linha paralela com a base na região do sexo. Os } \\
\text { cascos estão relativamente bem definidos e as pernas procuram } \\
\text { indicar particularidades da anatomia bovina, especialmente a } \\
\text { musculatura no alto dos membros dianteiros. A linha dorsal } \\
\text { desenha um declive em curva aberta a partir das ancas e só } \\
\text { recobra a altura a partir da metade do dorso, alcançando a linha } \\
\text { destas nos ombros de onde se estende até o alto da cabeça. } \\
\text { Cauda pendente, que desce em uma curva secante ao perfil da } \\
\text { perna posterior direita à qual pode estar unida. A imagem exibe } \\
\text { formas elegantes e, apesar de seu estado de conservação ou } \\
\text { ausência das imagens aladas, parece ter sido originalmente } \\
\text { elaborada. O artefato encontra-se fixado em uma base } \\
\text { moderna. }\end{array}$ & 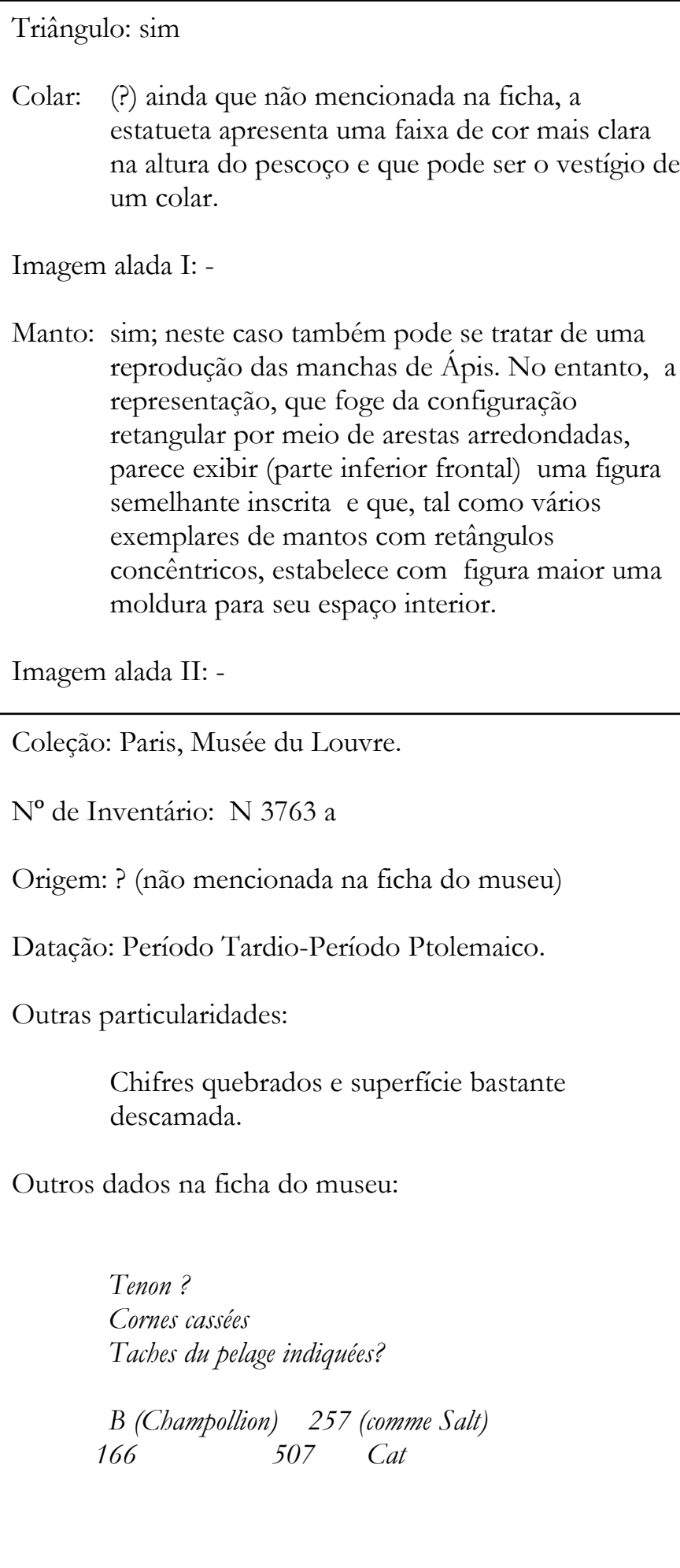 \\
\hline Bibliografia sobre o referido bronze: & \\
\hline
\end{tabular}




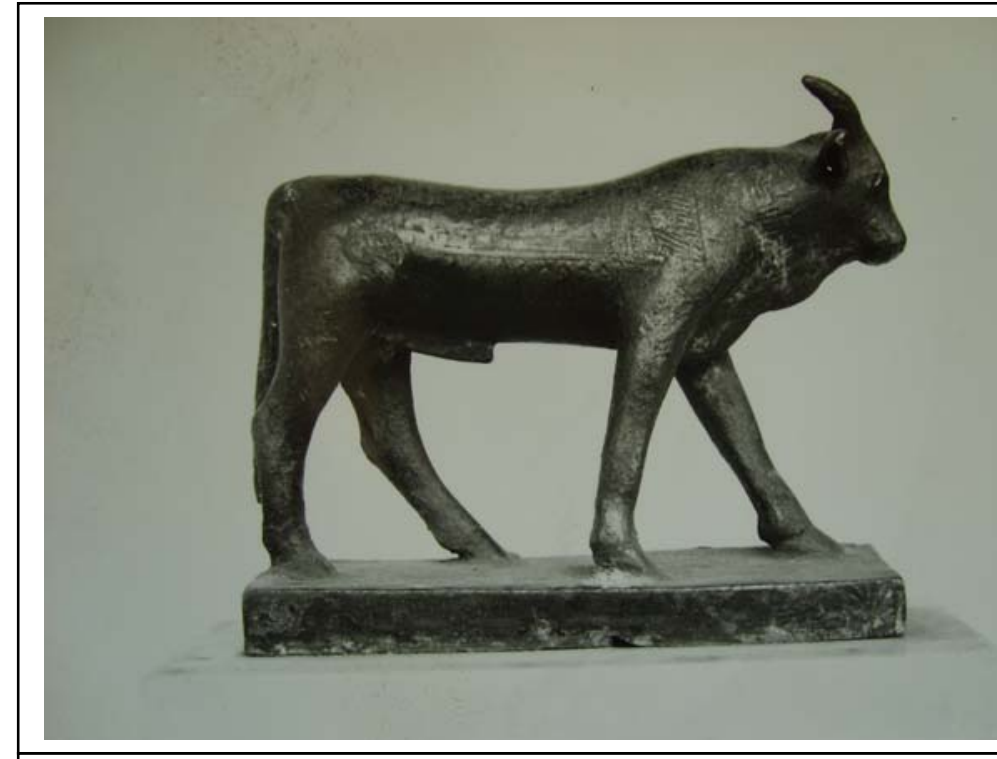

Entre os chifres: -(?)

Material: Bronze?

Atitude: marcha; pernas da esquerda avançadas em relação às da direita.

Descrição: touro em marcha sobre base retangular alta com inscrições. Chifre esquerdo quebrado e o direito entortado para trás. Triângulo frontal. Decoração lombar e do pescoço incisas, sem incrustações e bastante apagadas. Olhos grandes, arredondados, dispostos na diagonal e com pálpebras (?). As orelhas estão direcionadas para frente e localizam-se atrás da linha da cabeça e abaixo do canto superior dos olhos. Focinho pequeno com narinas sugeridas por pequenos pontos. A papada desenvolve duas ondulações: a primeira do meio do pescoço ao seu início, e a segunda daí se encaminha para pouco abaixo da linha do peito. A linha que segue em direção ao abdômen é aparentemente uma reta paralela à base, e que sobe ligeiramente em direção à virilha acompanhando o sexo bem desenvolvido. As pernas procuram aludir as particularidades da anatomia bovina e os cascos estão indicados. A linha dorsal desenvolve uma curvatura côncava relativamente pronunciada até o início dos ombros, a partir de onde ganha um ímpeto ascendente que termina em uma reta que leva ao alto da cabeça. Nesta região aparece uma elevação que pode ser a base do chifre esquerdo ou vestígios do disco solar. A cauda, pendente e espessa, desce verticalmente em uma reta secante ao perfil da perna posterior direita, à qual parece estar unida. $\mathrm{O}$ tronco aparenta estar ligeiramente afinado em relação aos ombros para uma boa proporção. Contudo, a estatueta exibe formas elegantes e mesmo com a simbologia muito apagada e a ausência do disco solar observa-se um alto nível na elaboração do artefato
Altura com base: $8,3 \mathrm{~cm}$

Altura da base: $1 \mathrm{~cm}$

Comprimento: $10 \mathrm{~cm}$

Largura: -

Triângulo: sim

Colar: sim; constituído de uma única banda decorada com traços (?).

Imagem alada I: disco (?); asas estendidas sobre os ombros, cujo comprimento atinge a linha inferior do manto. A plumagem apresenta-se como traços diagonais cortados na metade por uma linha que liga a extremidade das asas ao símbolo.

Manto: sim, dois retângulos, um inscrito dentro do outro, constituem uma moldura para um motivo decorativo que se encontra muito apagado. $\mathrm{Na}$ extremidade inferior o manto parece ter uma decoração em zigue zague, que possivelmente alude à disposição de contas de faiança tubulares.

Imagem alada II: disco (?); não visível na fotografia

Coleção: Paris, Musée du Louvre.

$\mathrm{N}^{\text {o }}$ de Inventário: E 4206

Origem: ? (não mencionada na ficha do museu)

Datação: Período Tardio-Período Ptolemaico (?)

Outras particularidades:

Outros dados na ficha do museu:

AE008278

Corne g cassée.

Ni disque ni uraeus (traces?)

$B E$

Tenon?

1864. achat Coll. Delapor (?)

Reserve des colonnes

502 Cat

D 3267

Bibliografia sobre o referido bronze:

G. J. F. Kater-Sibbes, M. J. Vermaseren, Apis II, p.69 n 510, Pr. CLXXVI 510. 


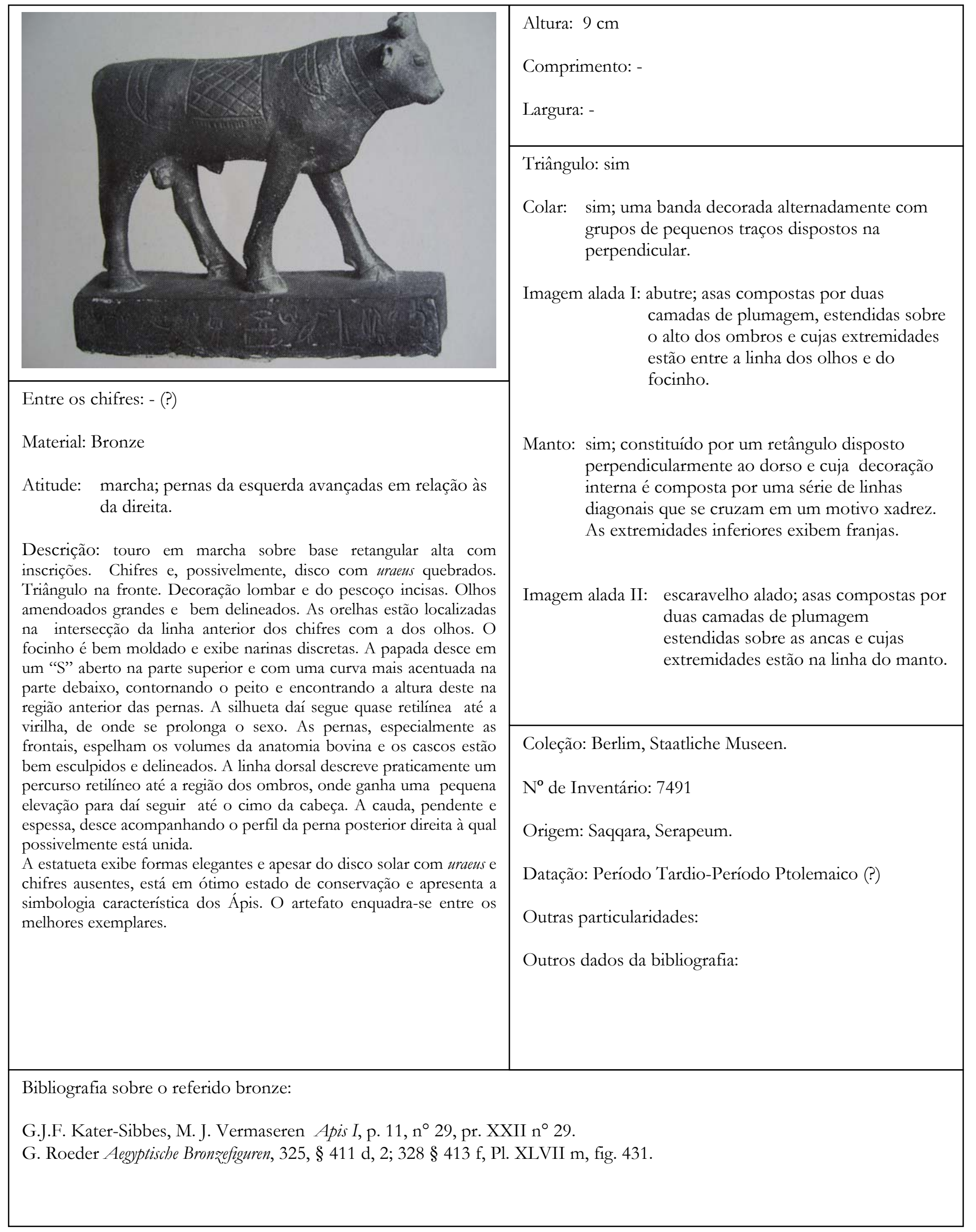




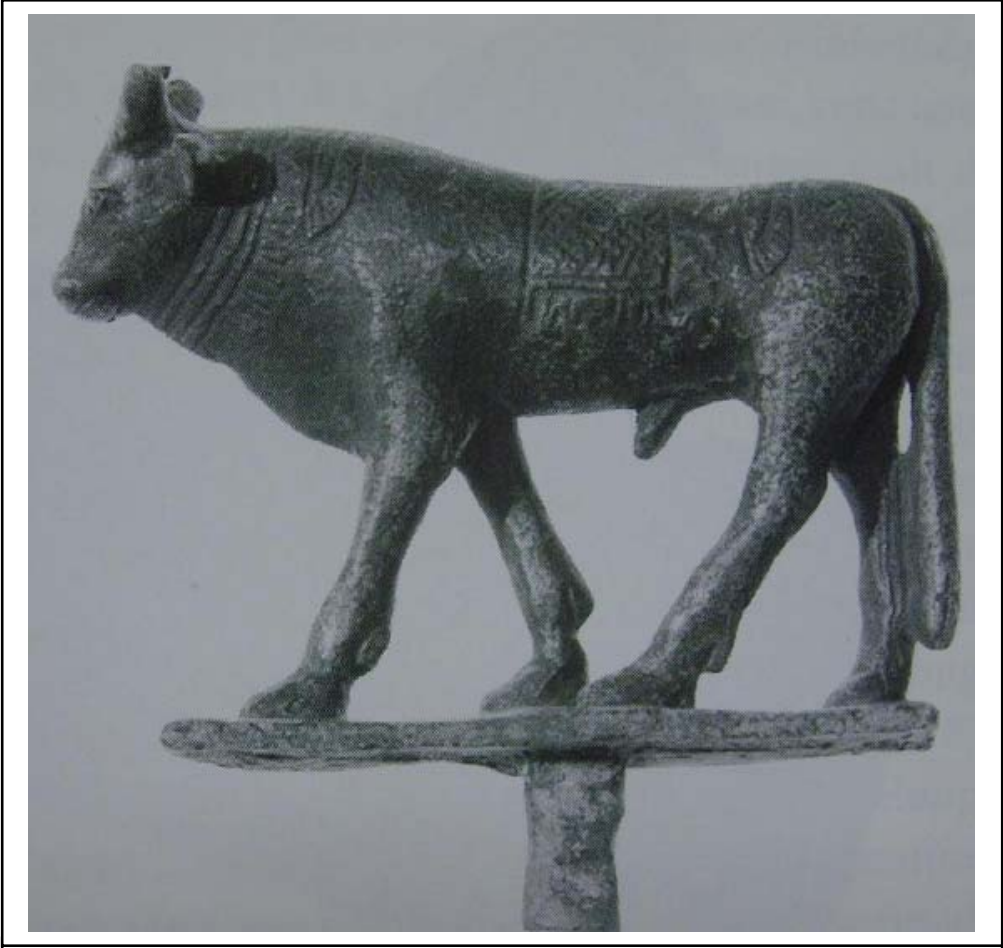

Entre os chifres: -

Material: Bronze.

Atitude: marcha; pernas esquerdas avançadas em relação às da direita.

Descrição: touro em atitude de marcha sobre base retangular baixa, sem inscrições e um pino para fixação em sua parte central inferior. Disco com uraeus ausentes - possivelmente quebrados - e chifres quebrados. Triângulo na fronte $\mathrm{e}$ símbolos corporais incisos. Olhos amendoados e orelhas logo acima da altura destes e atrás da linha dos chifres. A cabeça pequena e o focinho arrebitado passam um ar de inocência que contrasta com a massa do corpo viril do touro. A papada desce até abaixo do peito com uma leve perturbação na sua parte mediana. A linha torácico-abdominal sobe em direção à virilha, e o sexo se destaca sobre ela. O perfil dorsal acompanha, grosso modo, o plano da base até pouco antes dos ombros, onde adquire um movimento ascendente até o alto da cabeça. As pernas são vigorosas, exibem particularidades da anatomia bovina e os cascos estão bem indicados pelos volumes e linhas que os definem. A cauda desce acompanhando a perna posterior direita até pouco acima dos cascos e está destacada desta na sua porção mediana.

$\mathrm{O}$ artefato, apesar de um estreitamento na região abdominal que lhe tira uma boa proporcionalidade, e dos danos na região dos chifres, exibe um bom acabamento e os símbolos que lhe conferem a identidade de um Ápis.
Altura: $6,3 \mathrm{~cm}$.

Comprimento: $6,5 \mathrm{~cm}$.

Largura: -

Triângulo: sim.

Colar: sim; formado de três faixas paralelas e decorado na parte inferior com uma franja.

Imagem alada I: escaravelho; asas estendidas sobre os ombros, compostas de duas camadas de plumagem e cujas extremidades estão pouco abaixo da linha dos olhos.

Manto: sim; constituído de um retângulo posicionado perpendicularmente em relação à linha dorsal e decorado internamente com um padrão de linhas paralelas e cruzadas transversalmente. Na parte inferior há uma estreita faixa que antecede uma franja.

Imagem alada II: abutre; asas estendidas sobre as ancas, compostas de duas camadas de plumagem e cujas extremidades estão entre a linha inferior do manto e a dos olhos.

Coleção: particular B

$\mathrm{N}^{0}$ de Inventário: -

Origem: desconhecida.

Datação: Período Tardio-Período Ptolemaico (?).

Outras particularidades:

Outros dados da bibliografia:

Periodo Tardio-periodo Helenístico,

Bibliografia sobre o referido bronze:

E. Warmenbol Ombres d'Egypte, pp. 27, 133, nº 184. 


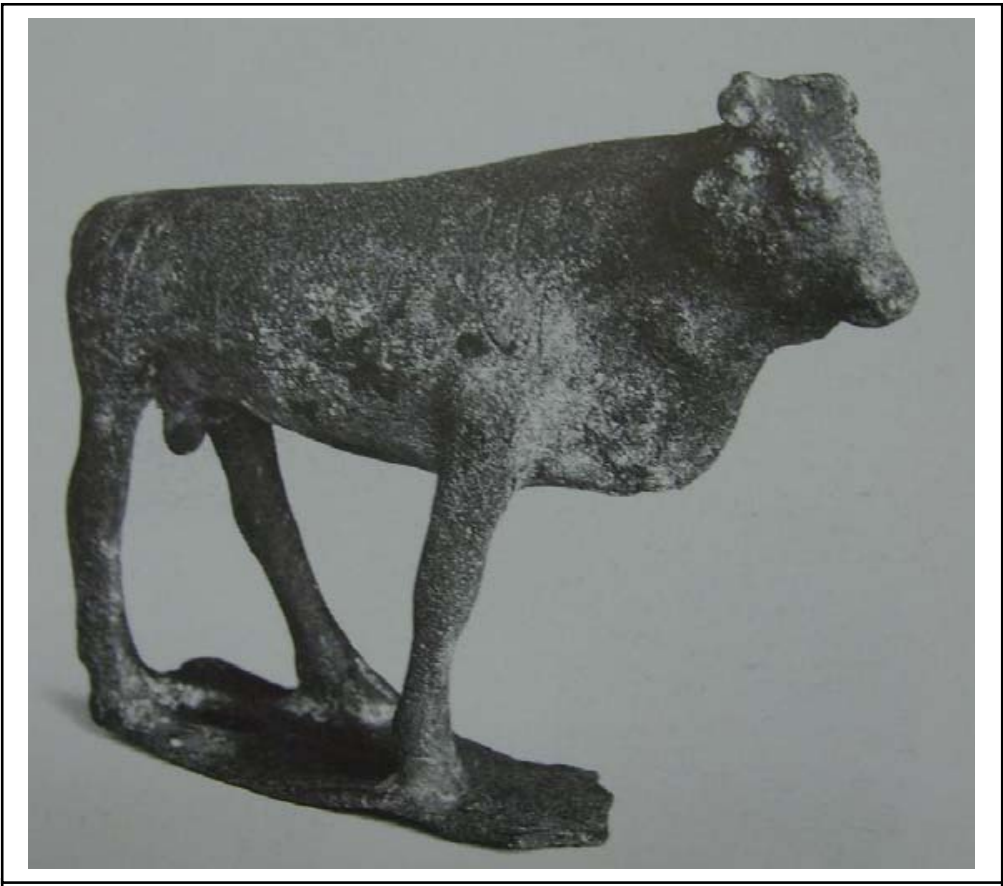

Entre os chifres: -

Material: Bronze.

Atitude: marcha; pernas esquerdas avançadas em relação às da direita.

Descrição: touro em atitude de marcha sobre base retangular baixa. Disco com uraeus possivelmente perdidos e chifres quebrados. Triângulo na fronte inciso, assim como as imagens sobre o resto do corpo. Olhos arredondados grandes e orelhas na altura destes e atrás da linha dos chifres. A cabeça e focinho são pequenos para o tamanho do corpo, mas apresentam uma modelagem cuidadosa. A papada desenvolve duas ondulações, uma menor na parte superior do pescoço e outra mais pronunciada logo abaixo do peito. A linha torácico-abdominal desenvolve um percurso ascendente até entre as pernas traseiras e sobre ela visualiza-se o sexo. O perfil dorsal parece descrever um percurso retilíneo até os ombros, a partir de onde ganha uma orientação ascendente suave até o cimo da cabeça. As pernas exibem com elegância as particularidades da anatomia bovina - o membro anterior esquerdo está quebrado juntamente com parte da base - e os cascos estão indicados pelos volumes e linhas que os definem. A cauda aparentemente acompanha o perfil da perna posterior direita até pouco acima do casco.

Apesar das fraturas e do considerável grau de oxidação, percebe-se pela elaboração das formas e detalhes que o artefato estava entre os de melhor qualidade, e sua simbologia conferelhe sem quaisquer dúvidas a identidade de um Ápis.
Altura: $7,2 \mathrm{~cm}$.

Comprimento: $9,1 \mathrm{~cm}$.

Largura: -

Triângulo: sim.

Colar: sim; detalhes não observáveis na fotografia.

Imagem alada I: abutre; localizado sobre os ombros, tem suas asas compostas por duas camadas de plumagem e suas extremidades estão acima da linha inferior do manto.

Manto: sim; formado por um retângulo posicionado perpendicularmente em relação à linha dorsal e decorado com um padrão de linhas paralelas e cruzadas formando uma rede (?).

Imagem alada II: escaravelho alado; localizado sobre as ancas, tem suas asas compostas por duas camadas de plumagem e suas extremidades estão acima da linha inferior do manto.

Coleção: Amiens. Musée de Picardie.

$\mathrm{N}^{\mathrm{o}}$ de Inventário: M.P. 94.3.120.

Origem: desconhecida.

Datação: Período Tardio.

Outras particularidades:

Outros dados da bibliografia:

Bibliografia sobre o referido bronze:

O. Perdu, E. Rickal La Collection Égyptienne du Musée de Picardie, p. 118, n 202. 


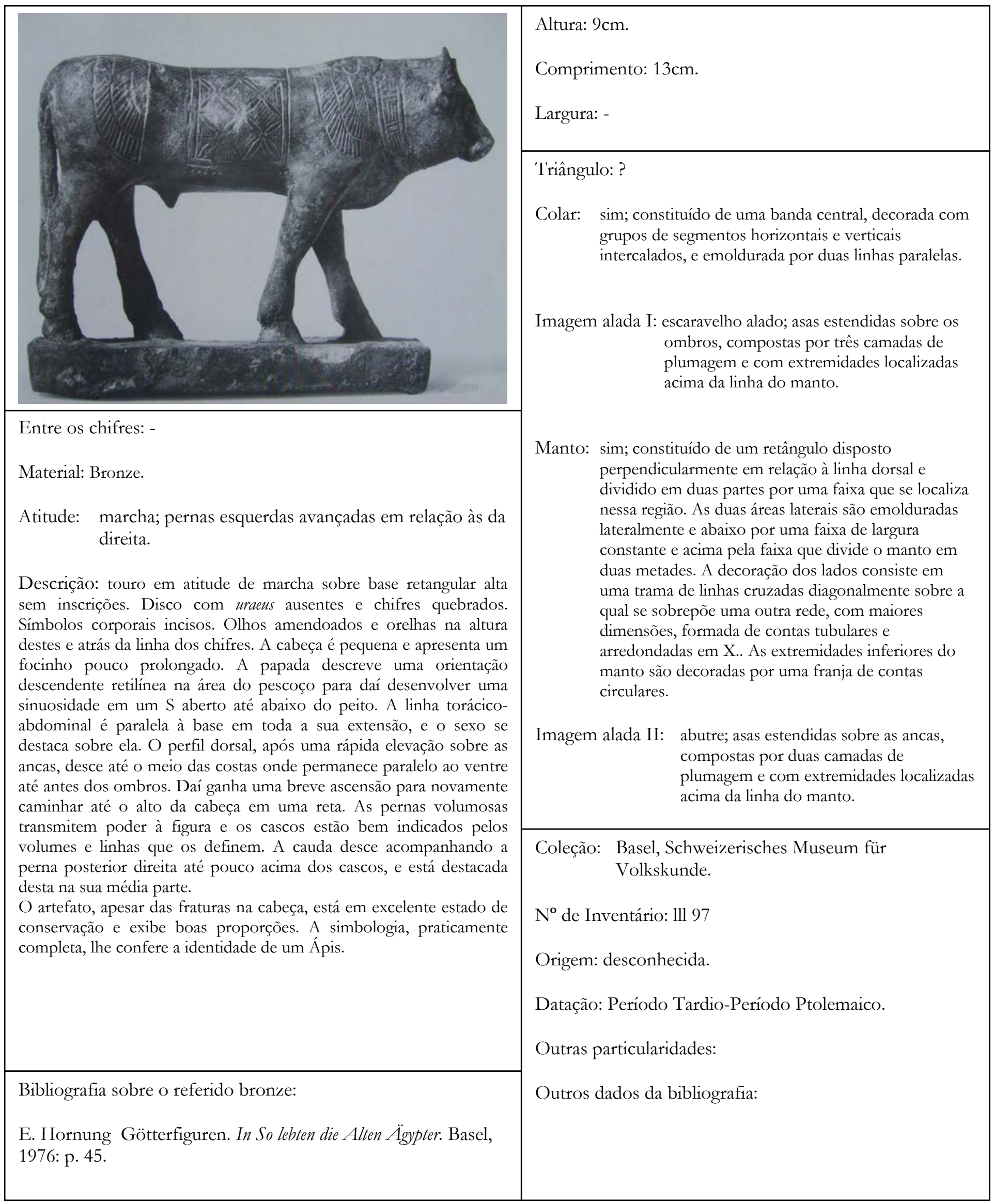




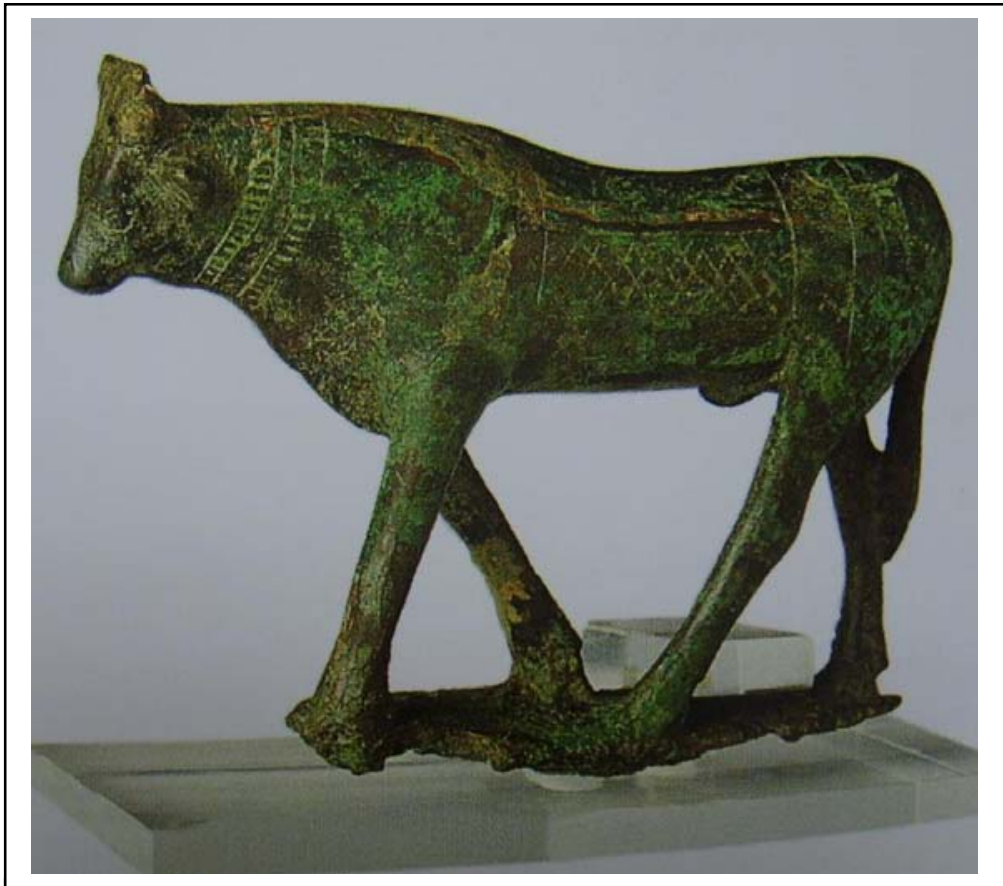

Entre os chifres: -

Material: Bronze.

Atitude: marcha; pernas esquerdas avançadas em relação às da direita.

Descrição: touro em atitude de marcha sobre base baixa bastante corroída. Disco com uraeus ausentes - possivelmente quebrados - e chifres perdidos. A presença de certos elementos incisos, como o manto e o colar, e os indícios da existência de uma imagem alada sobre as ancas levanta a suspeita da presença de outros símbolos, como o triângulo e a outra imagem alada sobre os ombros. Contudo, nada é mencionado na bibliografia. Os símbolos presentes também parecem apresentar seus contornos ressaltados com incrustação de ouro. A cabeça e focinho pequenos passam um ar de inocência que contrasta com a massa do corpo viril do touro. Os olhos são amendoados, possuem pálpebras e as orelhas localizam-se acima deles, atrás da linha dos chifres. A papada segue o pescoço até o colar para depois ganhar peso e se projetar para baixo, contornando o peito ao longe. A linha torácico-abdominal segue paralela à base até a virilha, e o sexo se sobrepõe a ela. O perfil dorsal é arqueado na região do manto e adquire um impulso ascendente atrás dos ombros, culminando no início do pescoço e daí seguindo até a cabeça paralelamente à base. Uma rachadura se estende por uma boa parte do lombo, na face direita.

As pernas exibem particularidades da anatomia bovina e os cascos estão visíveis pelos volumes, apesar do alto grau de oxidação. A cauda desce acompanhando a perna posterior direita até pouco abaixo da dobra desta e está destacada dela na sua porção mediana.

$\mathrm{O}$ artefato, apesar da severa oxidação que sofreu e da falta de certas partes, parece ter sido bem elaborado em sua confecção e há uma possibilidade de ter retratado um Ápis, caso se confirme a existência do resto da simbologia aparentemente ausente.
Altura: $8,3 \mathrm{~cm}$.

Comprimento: $12 \mathrm{~cm}$.

Largura: 2,2cm.

Triângulo: ?

Colar: sim; composto de três faixas paralelas e estriadas.

Imagem alada I: - ?

Manto: sim; constituído de um retângulo disposto perpendicularmente em relação ao dorso e decorado com um padrão de linhas paralelas transversais e cruzadas.

Imagem alada II: ?; a fotografia parece indicar os contornos de asas e de um corpo.

Coleção: Guéret, Musée de Guéret.

$\mathrm{N}^{0}$ de Inventário: 84.9.18.

Origem: Saqqara?

Datação: Período Tardio-Período Ptolemaico.

Outras particularidades:

Outros dados da bibliografia:

Período Tardio.

Bibliografia sobre o referido bronze:

G. Andreu et al. Egyptologie, le Rêve et la Science p. 86, $\mathrm{n}^{\circ}$ 72. 


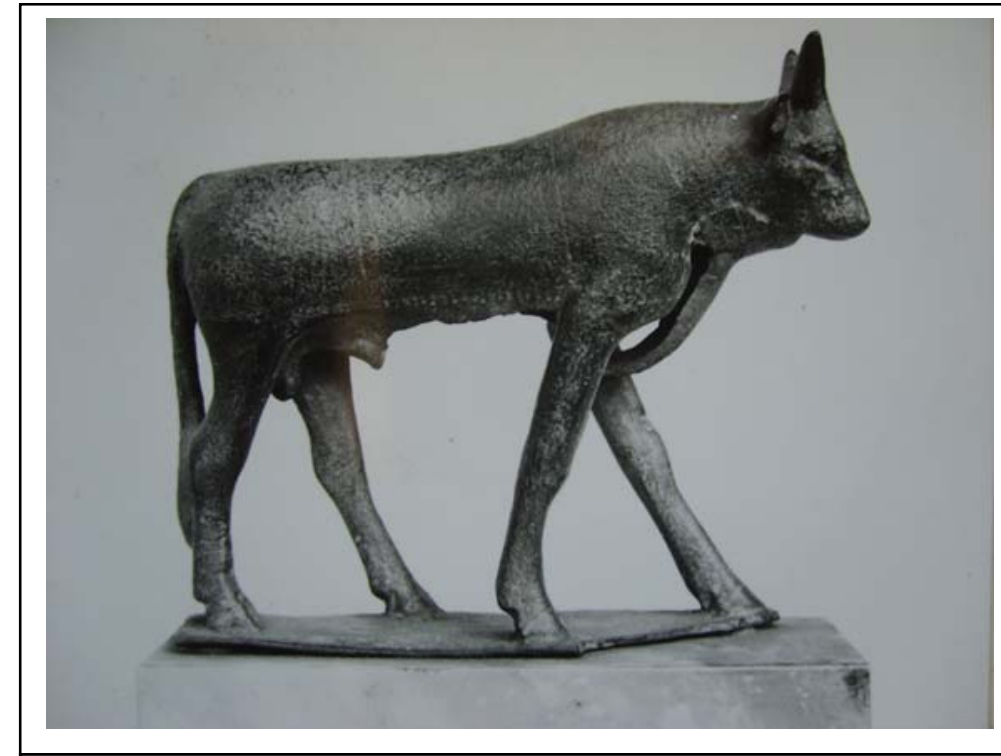

Entre os chifres: -

Material: Bronze

Atitude: marcha; pernas da esquerda avançadas em relação às da direita

Descrição: touro em marcha sobre base retangular fina, sem inscrições e com sua extremidade anterior direita quebrada diagonalmente logo depois do casco direito do animal. Disco com uraeus ausentes e chifres em crescente. Triângulo frontal inciso. Decoração lombar e do colar incisas, sem incrustações, e bastante apagadas. Olhos em relevo e particularmente bem delineados. A cabeça apresenta traços delicados e dela parte uma papada com duas ondulações, uma após o queixo e outra (que apresenta uma grave fratura) que desce a partir do início do pescoço. Os cascos estão tão bem definidos e o tronco do animal apresenta um perfil esbelto e bem proporcionado. Cauda pendente e unida (?) à perna posterior direita na sua parte inferior. $\mathrm{O}$ sexo está bem indicado. Orelhas presentes na parte anterior da cabeça e pouco acima da linha dos olhos. A estatueta encontra-se fixada em uma base moderna.
Altura: 9,3 cm (com pino)

Comprimento: $10,7 \mathrm{~cm}$

Largura: -

Triângulo: sim

Colar: sim; aparentemente formado por seis linhas paralelas. Outros detalhes são difíceis de se reconhecer.

Imagem alada I: - (?)

Manto: sim; formado por dois retângulos, um dentro do outro, e formando uma moldura. Nas extremidades parecem estar representadas pequenas contas em forma de gota.

Imagem alada II: - (?)

Coleção: Paris, Musée du Louvre.

No de Inventário: N 5164 d

Origem: Serapeum.

Datação: Período Tardio-Período Ptolemaico.

Outras particularidades:

Outros dados na ficha do museu:

SERAPEUM (style patine) ex. no 5164

Bibliografia sobre o referido bronze: 


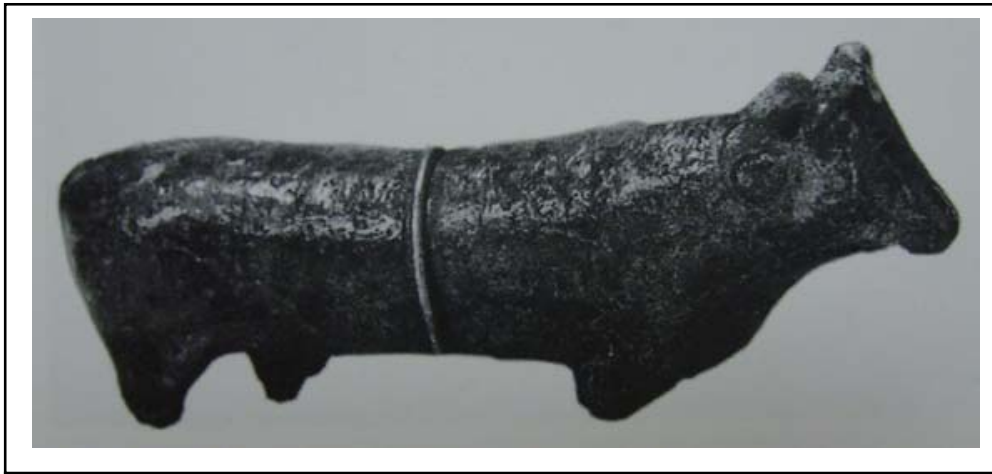

Entre os chifres: -

Material: Bronze.

Atitude: marcha; pernas esquerdas avançadas em relação às da direita.

Descrição: touro em atitude de marcha - pernas quebradas próximo ao corpo e, tal como a base, perdidas. Disco com uraeus ausentes assim como os chifres. Não há indícios de simbologia gravada sobre o corpo. A cabeça é pequena e o focinho bem moldado. As orelhas estão próximas aos chifres e atrás da linha destes. A papada realiza uma sinuosidade em $\mathrm{S}$ bastante aberto, e se junta ao peito à frente deste. O perfil torácico-abdominal é retilíneo e a representação do sexo é sutil. A linha dorsal descreve um arco quase que imperceptível, que segue até o alto da cabeça. Pouco antes existe uma calosidade que pode ter sido originada com a oxidação ou pode ter sido um reforço para o disco solar que constava entre os chifres. A cauda, como as pernas, está perdida.

$\mathrm{O}$ artefato, ainda que muito danificado, exibe certa elegância nas proporções do torso e uma cabeça bem moldada. Infelizmente, por não terem sobrevivido quaisquer elementos que pudessem lhe dar uma identificação indubitável - se existiram - e por ignorarmos sua origem, é impossível afirmar que a estatueta tenha retratado um Ápis.
Altura: $1,2 \mathrm{~cm}$.

Comprimento: $6,1 \mathrm{~cm}$.

Largura: 3,1 cm.

Triângulo: -

Colar: -

Imagem alada I: -

Manto: -

Imagem alada II: -

Coleção: Perm, Russia.

$\mathrm{N}^{0}$ de Inventário: 3221.

Origem: desconhecida.

Datação: Período Tardio-Período Ptolemaico (?)

Outras particularidades:

Outros dados da bibliografia:

Adquirida da sra. Matveyeva, São Petersburgo, cujo irmão havia adquirido a estatueta no Egito.

Bibliografia sobre o referido bronze:

O. Berlev, S. Hodjash Catalogue of the Monuments of Ancient Egypt, p.64, nº15, pr. 89, VI. 15. 


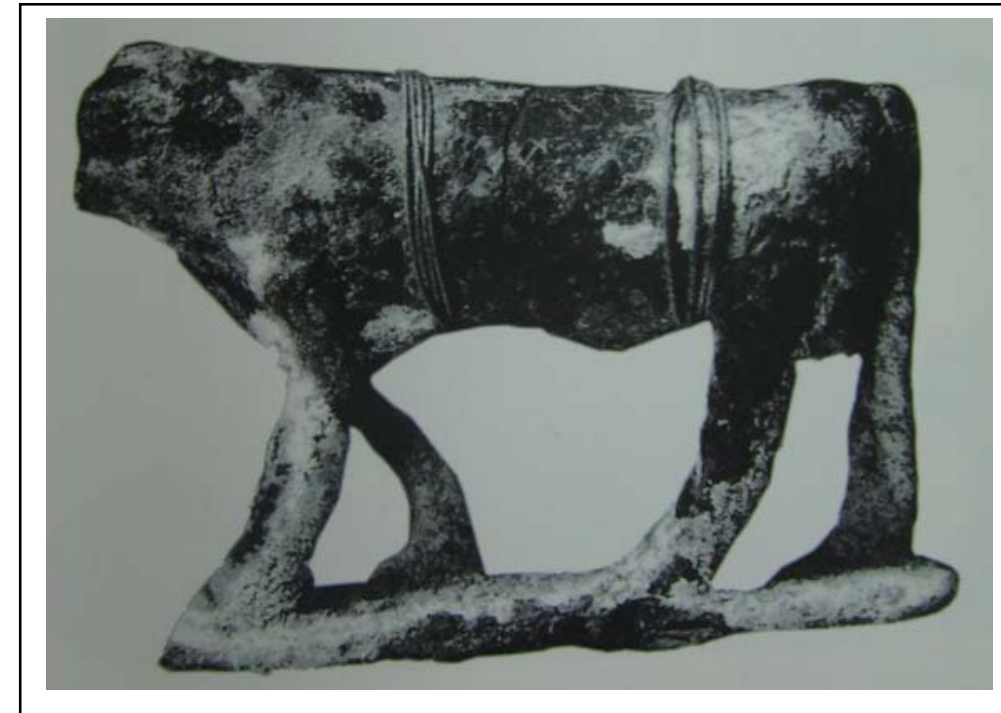

Entre os chifres: -

Material: Bronze.

Atitude: marcha; pernas esquerdas avançadas em relação às da direita.

Descrição: touro em atitude de marcha sobre base retangular baixa. Disco com uraeus ausentes assim como os chifres. Não há indícios de simbologia gravada sobre o corpo. A cabeça está muito danificada e mal se percebem seus detalhes. A papada só fica visível depois que se destaca do pescoço, descendo de forma constante e contornando o tórax. A linha torácicoabdominal procura seguir paralela à base, sendo perturbada pela elevação que representa a genitália. $O$ perfil dorsal descreve uma reta que liga as ancas até o alto da cabeça. As pernas são volumosas - apesar do membro frontal direito estar afinado na parte superior, talvez pela oxidação - e exibem os contornos dos cascos. A cauda desce unida à perna posterior direita até próximo à base. Uma fratura no meio da estatueta exigiu que esta fosse reagrupada por meio de uma estrutura de arame, visível na fotografia.

$\mathrm{O}$ artefato exibe sem dificuldades as formas de um touro, mas seu estado de conservação compromete uma análise mais meticulosa. A ausência da simbologia e de textos e o desconhecimento de sua origem impedem sua identificação como um Ápis.
Altura: $4 \mathrm{~cm}$.

Comprimento: $5,4 \mathrm{~cm}$.

Largura: $1 \mathrm{~cm}$.

Triângulo:-

Colar: -

Imagem alada I: -

Manto: -

Imagem alada II: -

Coleção: Perm, Russia, coleção A. A Palnikov.

$\mathrm{N}^{0}$ de Inventário: 3221.

Origem: desconhecida.

Datação: Período Tardio-Período Ptolemaico.

Outras particularidades:

Outros dados da bibliografia:

Adquirida da sra. Matveyeva, São Petersburgo, cujo irmão havia adquirido a estatueta no Egito.

Bibliografia sobre o referido bronze:

O. Berlev, S. Hodjash Catalogue of the Monuments of Ancient

Egypt, p.64, n¹4, pr. 89, VI. 14. 


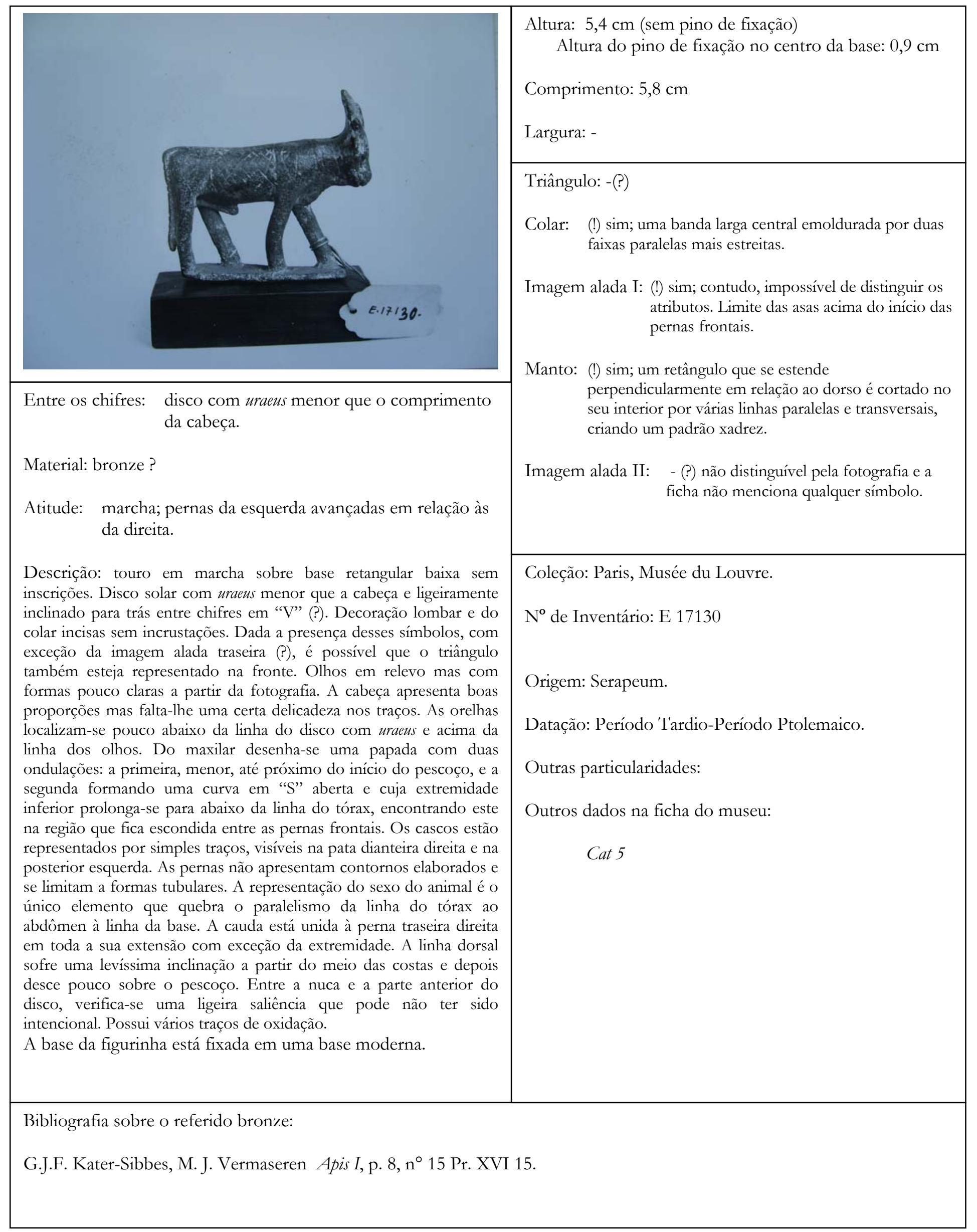




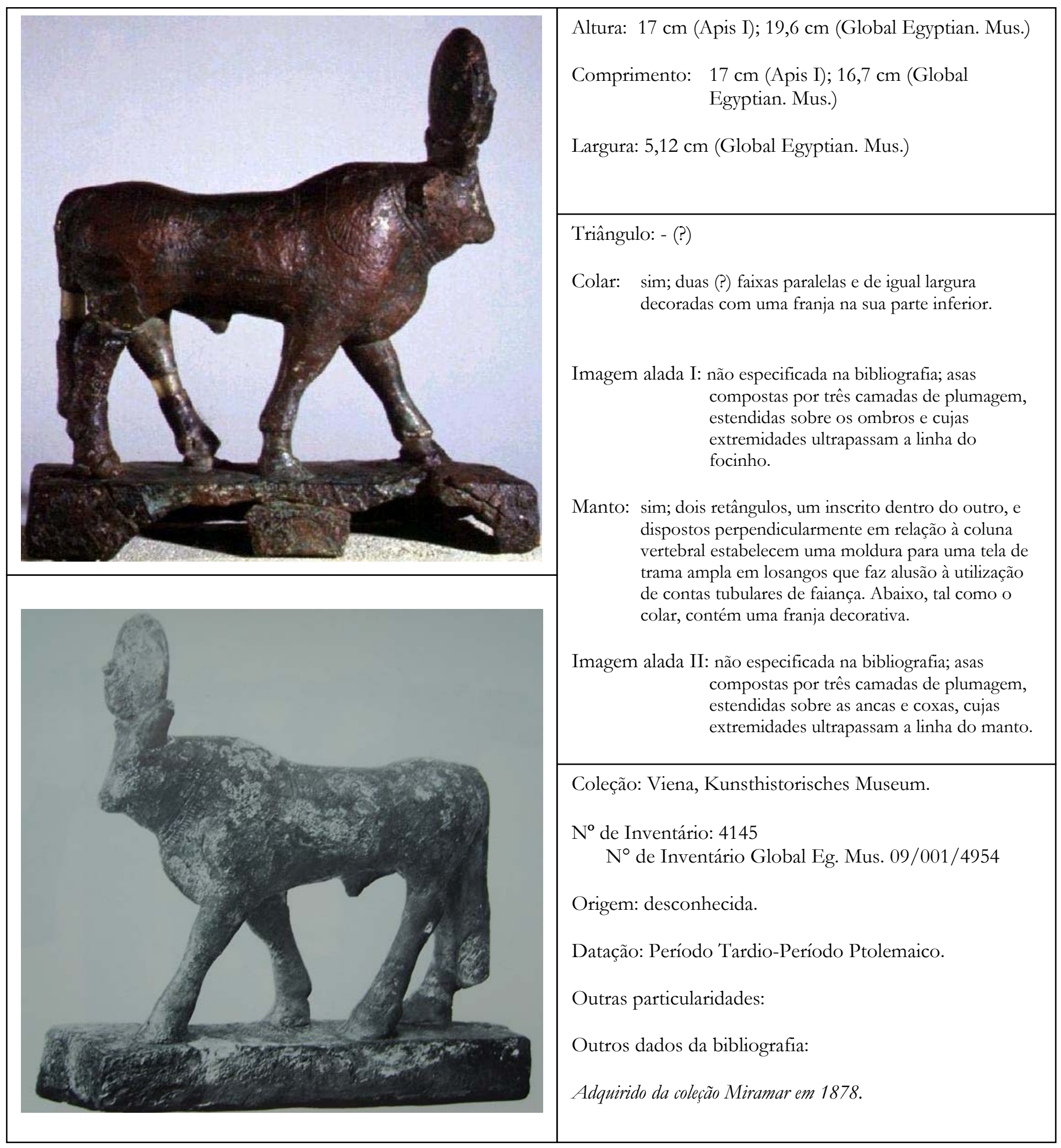




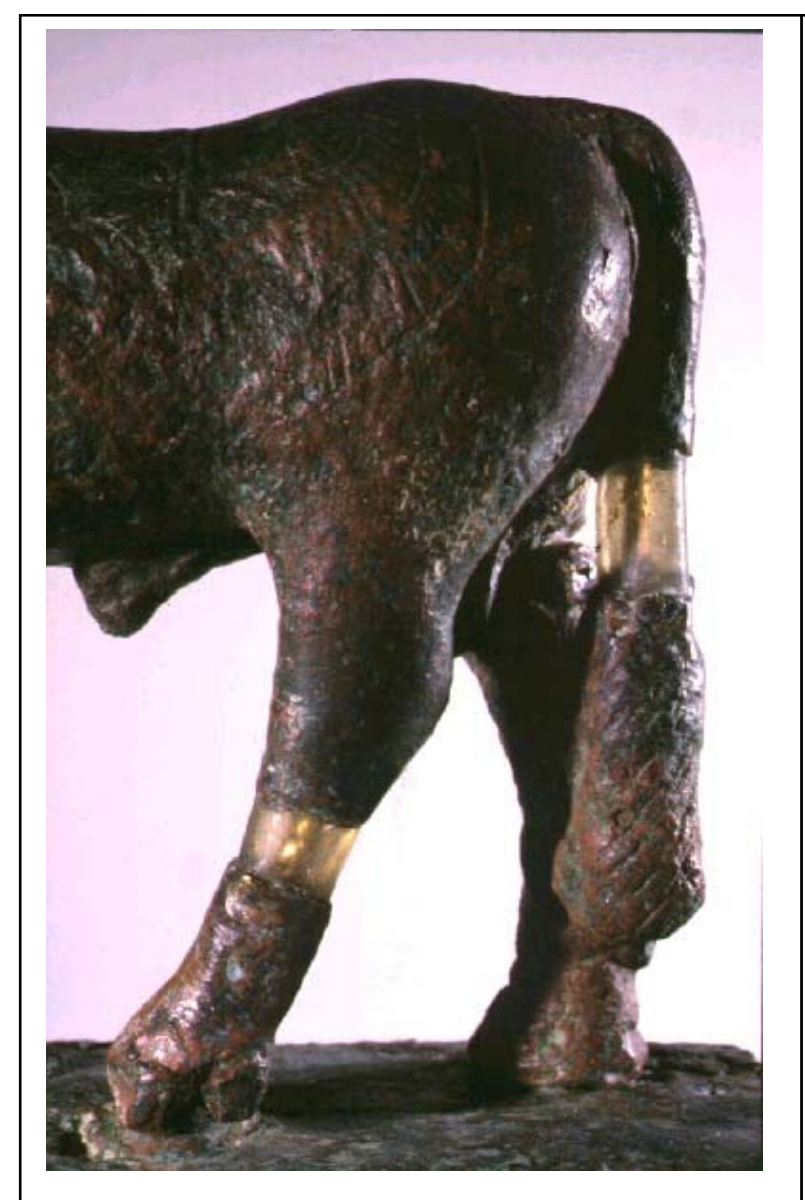

Bibliografia sobre o referido bronze:

Kater-Sibbes, G. J. F., M. J. Vermaseren, Apis I, p. 51, n . 214; Pr. CXXVI 51.

http://www.globalegyptianmuseum.org/record.a spx?id $=4954$
Entre os chifres: disco com uraeus cujo diâmetro é superior ao comprimento da cabeça.

Material: Bronze.

Atitude: marcha; pernas da esquerda avançadas em relação às da direita.

Descrição: atitude de marcha sobre base retangular alta, sem inscrições e quebrada na lateral direita. Disco com uraeus espesso, com diâmetro superior ao comprimento da cabeça e entre chifres em "V". Decoração lombar e do pescoço incisas, elaboradas mas muito deterioradas. Em virtude do grau de sofisticação dos detalhes da simbologia, e devido aos efeitos nocivos da oxidação, é possível que o triângulo originalmente constasse na fronte. Olhos aparentemente amendoados. Orelhas localizadas na linha detrás da cabeça e acima da altura dos olhos. Focinho pequeno, bem moldado com extremidade arredondada. Narinas e boca não observáveis nas imagens e possivelmente deterioradas demais para serem notadas. A papada desenvolve duas ondulações principais: a primeira, mais tênue, se prolonga até o final do colar. A segunda adquire uma curvatura pronunciada e projetada para frente, contornando o peito a uma certa distância para encontrar a linha deste somente atrás das pernas dianteiras. Daí o perfil continua sua trajetória inclinada até a virilha, de onde surge o órgão sexual. As pernas são robustas, bem modeladas e exibem os volumes da anatomia bovina - os membros traseiros exibem, proporcionalmente falando, menos volume que os dianteiros. Os cascos são igualmente bem esculpidos e delineados. Após uma considerável elevação na região das ancas, a linha dorsal desce para seguir paralela à base até o limite do manto. A partir desse ponto, ganha um impulso ascendente pronunciado até o alto do pescoço e daí desliza em outro segmento paralelo até a cabeça. A cauda, pendente e espessa, desce acompanhando o perfil da perna posterior direita, à qual está unida em suas porções superior e inferior. Sua extremidade exibe traços paralelos espiralados que ilustram a pelagem.

$\mathrm{O}$ artefato exibe o porte robusto e viril de um touro jovem e qualidades ímpares tanto no seu nível estético quanto ao seu detalhamento. No entanto, suas superfícies foram severamente atacadas pela oxidação e certas partes, como a cauda e pernas posteriores, estão quebradas. Exibe uma forte coloração bordeaux. 


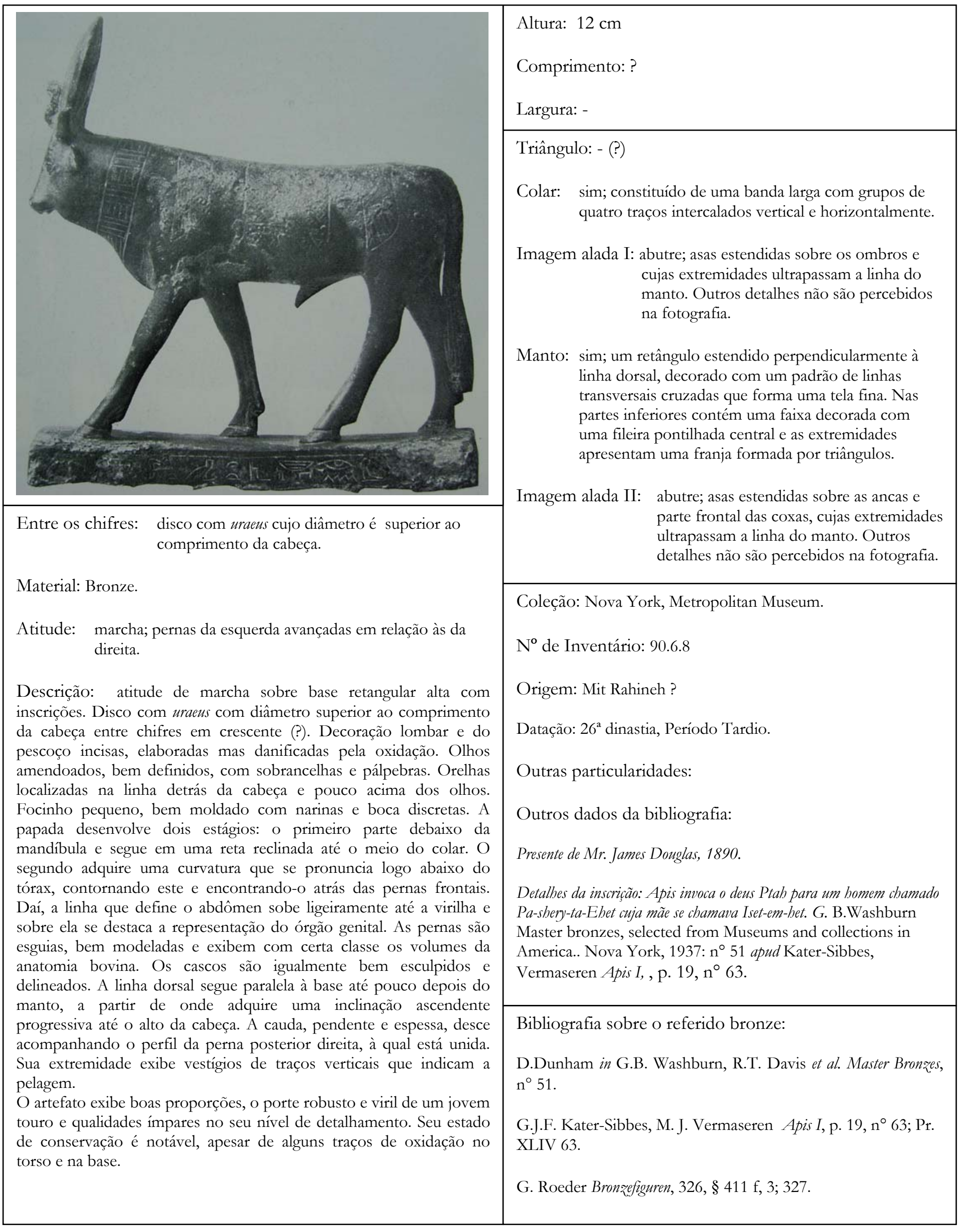




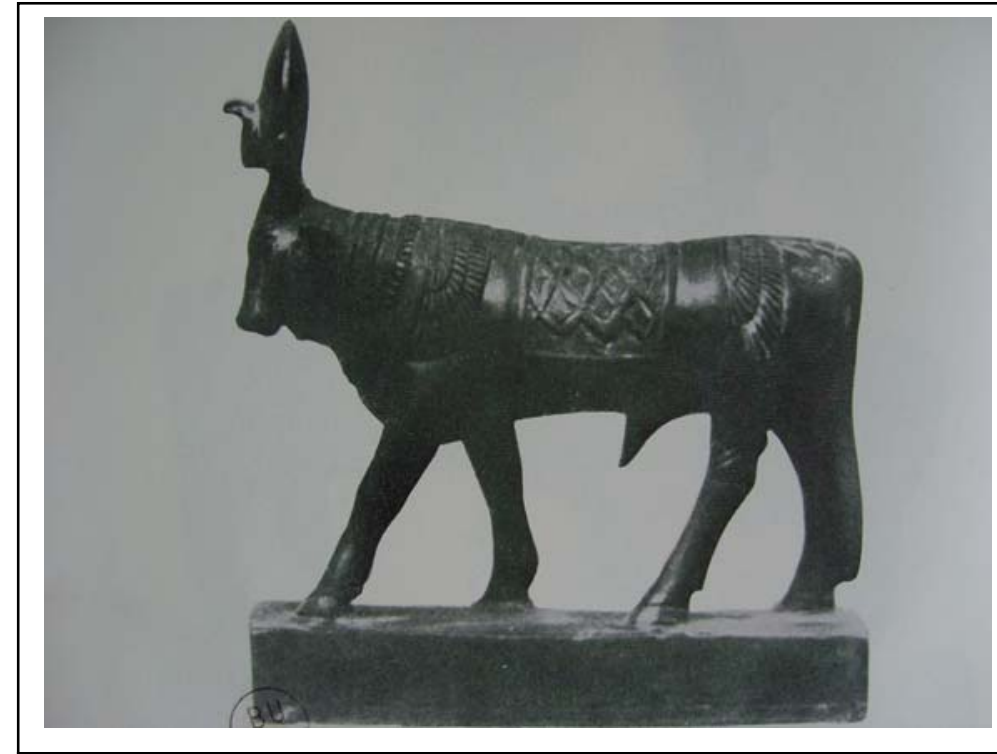

Entre os chifres: disco com uraeus cujo diâmetro é semelhante ao comprimento da cabeça.

Material: Bronze

Atitude: marcha; pernas da esquerda avançadas em relação às da direita.

Descrição: touro em marcha sobre base retangular alta sem inscrições. Disco com uraeus com perfil lenticular e diâmetro semelhante ao comprimento da cabeça do touro e entre chifres em "V" (?). Decoração lombar e do pescoço elaboradas e em relevo. Devido a isso, é possível que o triângulo tenha sido adicionado na fronte. Olhos grandes e amendoados, dispostos na diagonal e com pálpebras. As orelhas localizam-se atrás da linha da cabeça e na altura dos olhos. Focinho bem modelado abaixo do qual se desenvolve uma papada com três ondulações: a primeira, angulosa se prolonga até a metade do colar; a segunda é muito suave e termina pouco antes do início do colar. Por fim, a terceira ganha uma ampla curvatura abaixo do peito e só encontra a linha deste depois das pernas dianteiras. Daí a linha prossegue até a virilha tendo em seu caminho o sexo bem definido. As pernas procuram respeitar as particularidades da anatomia bovina e os cascos estão bem esculpidos e delineados. A linha dorsal desenvolve uma suave curvatura côncava no meio das costas e ganha um impulso ascendente na região dos ombros, seguindo dessa região até o alto da cabeça. A cauda, pendente e espessa, desce acompanhando o perfil da perna posterior direita, à qual está unida.

A estatueta tem porte robusto, exibe formas elegantes e está em ótimo estado de conservação. Os motivos decorativos foram particularmente bem elaborados por meio da exploração dos relevos. $\mathrm{O}$ artefato enquadra-se entre os melhores exemplares.
Altura: 17,5 cm (Apis I) - contudo, como é dito abaixo, a atribuição das informações a esse bronze estão equivocadas

Comprimento: -

Largura: -

Triângulo: - (?)

Colar: sim; composto por várias faixas paralelas e de largura variáveis, e decorado na extremidade inferior com uma franja de contas (?).

Imagem alada I: disco; asas compostas por três camadas de plumagem, estendidas sobre os ombros e cujas extremidades ultrapassam a linha do manto.

Manto: sim; dois retângulos dispostos um dentro do outro e perpendicularmente ao dorso estabelecem uma moldura para um padrão decorativo ao modelo de uma tela larga de contas tubulares e globulares dispostas em "X". Os espaços quadriláteros formados pela rede estão rebaixados deixando a trama em relevo.

Imagem alada II: abutre; asas compostas por três camadas de plumagem, estendidas sobre as coxas e cujas extremidades ultrapassam a linha do manto.

Coleção: Museu do Cairo

No de Inventário: 49061 (Apis I) - na verdade, a atribuição desse registro é incorreta, uma vez que o artefato com esse número é diferente e contém inscrição cariana em sua base (Masson, Yoyotte 1956: pp. 40-49, Pr. Va.). Estas particularidades foram mencionadas no próprio catálogo Apis I mas a foto correspondente (ver acima) não revela tal característica. Cf. artefato de número E 49061.

Origem: Saqqara, Serapeum.

Datação: Período Tardio.

Outras particularidades:

Outros dados da bibliografia :

土571-528 a.C. (de acordo com Mariette)

Bibliografia sobre o referido bronze:

G.J.F. Kater-Sibbes, M. J. Vermaseren Apis I, p. 5-6, n 4, pr. VIII, n 4. 


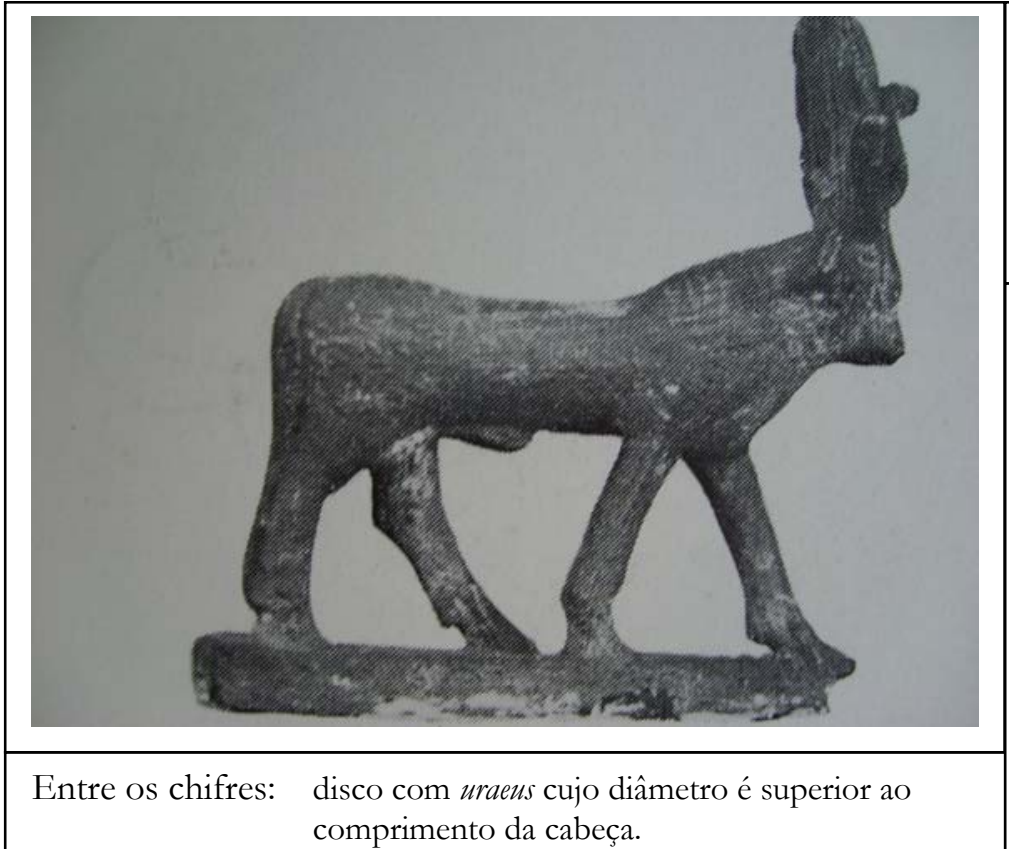

Material: Bronze.

Atitude: marcha; pernas da esquerda avançadas em relação às da direita.

Descrição: touro em marcha sobre base retangular alta sem inscrições e quebrada na sua parte frontal inferior. Disco com uraeus com diâmetro superior ao comprimento da cabeça do touro e entre chifres em "V" (?). Decoração lombar e do pescoço presentes, muito apagadas e realizadas com traços secos - possivelmente acrescidas depois da elaboração da estatueta. Ainda que não tenha sido mencionado, é possível que o triângulo tenha sido adicionado na fronte juntamente com o restante da decoração. Olhos grandes dispostos na diagonal (?), orelhas localizadas atrás da linha da cabeça e acima da altura dos olhos. O focinho, tal como a cabeça, exibe pequenas proporções, um perfil trapezoidal, e a mandíbula abreviada. A papada desce retilínea até sua extremidade inferior onde realiza uma curvatura para alcançar o peito na área entre as pernas. Daí segue uma reta paralela à base até a virilha, a partir de onde se sobrepõe a genitália até a porção mediana do abdômen. As pernas procuram lembrar as formas da anatomia bovina, mas a perna frontal direita é mais rígida. Os cascos foram bem esculpidos. A linha dorsal ganha a partir das ancas uma orientação descendente que se estabiliza na região do manto para, no início dos ombros, adquirir um impulso ascendente e seguir rumo ao cimo da cabeça. A cauda, pendente e espessa, desce acompanhando o perfil da perna posterior direita, à qual está unida. $\mathrm{O}$ torso é alongado sobretudo em virtude da linha dorsal ter sido posicionada mais abaixo do que o convencional.

Entretanto, a estatueta tem porte elegante, e procura se equiparar aos melhores exemplares. Seu estado de conservação é razoável, apesar das superfícies não tão afeiçoadas e dos traços de oxidação.
Altura: $6,5 \mathrm{~cm}$

Comprimento: $5,5 \mathrm{~cm}$

Largura: -

Triângulo: - (?)

Colar: sim; detalhes não perceptíveis na fotografia.

Imagem alada I: escaravelho; detalhes não perceptíveis na fotografia.

Manto: sim; detalhes não perceptíveis na fotografia.

Imagem alada II: abutre; detalhes não perceptíveis na fotografia.

Coleção: Berlim, Staatliche Museen.

No de Inventário: 219

Origem: Saqqara.

Datação: Período Tardio-Período Ptolemaico.

Outras particularidades:

Outros dados da bibliografia:

Anteriormente coleção Bartholdy e, em seguida, do Städtisches Museum de Celle para Berlim (1903)

Bibliografia sobre o referido bronze:

G.J.F. Kater-Sibbes, M. J. Vermaseren Apis I, p. 13, n 35; Pr. XXVI 35.

G. Roeder Aegyptische Bronzefiguren, 325, § 411 b, 4; 329, § 413, m; Pr. XLVIII i. 


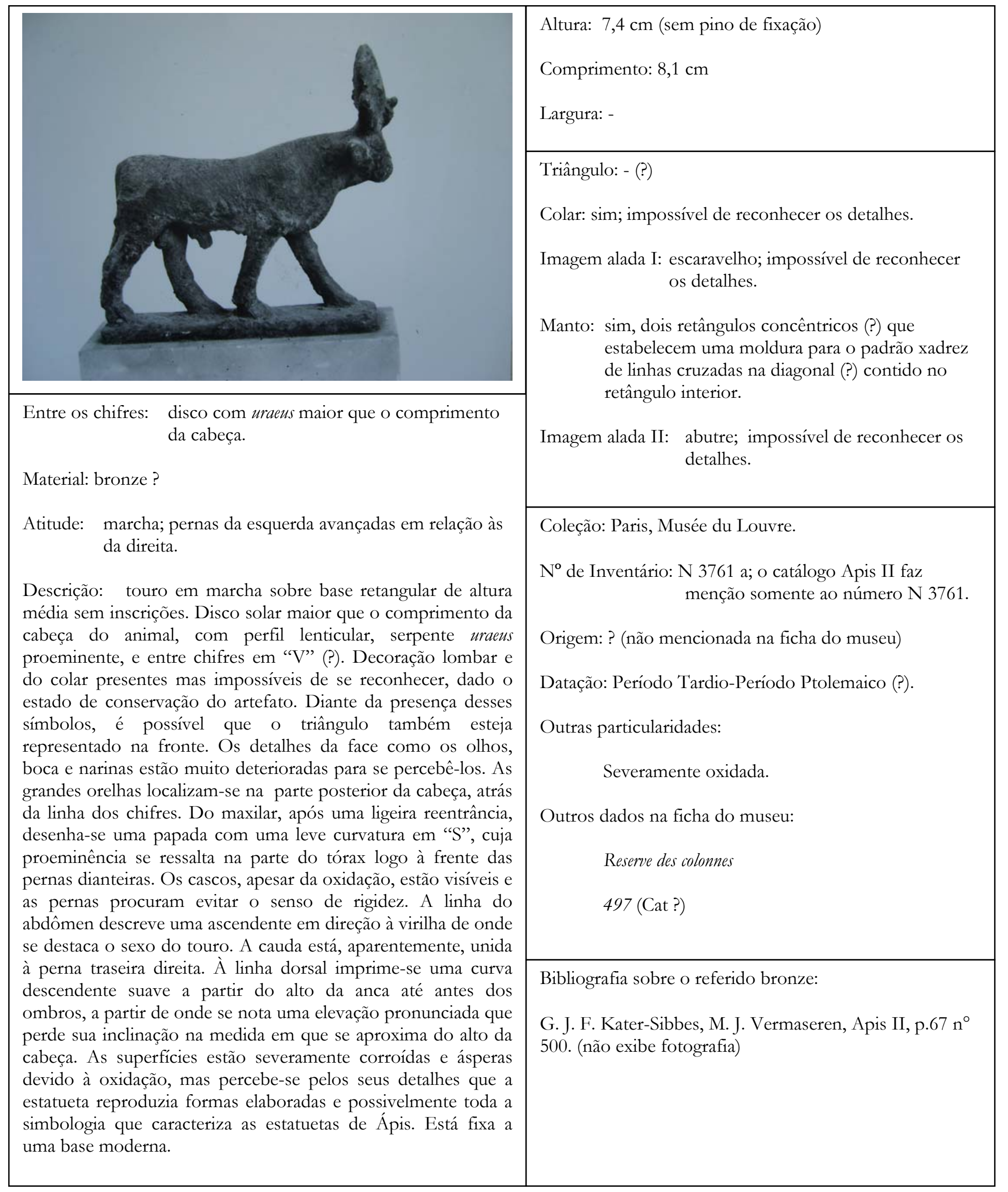




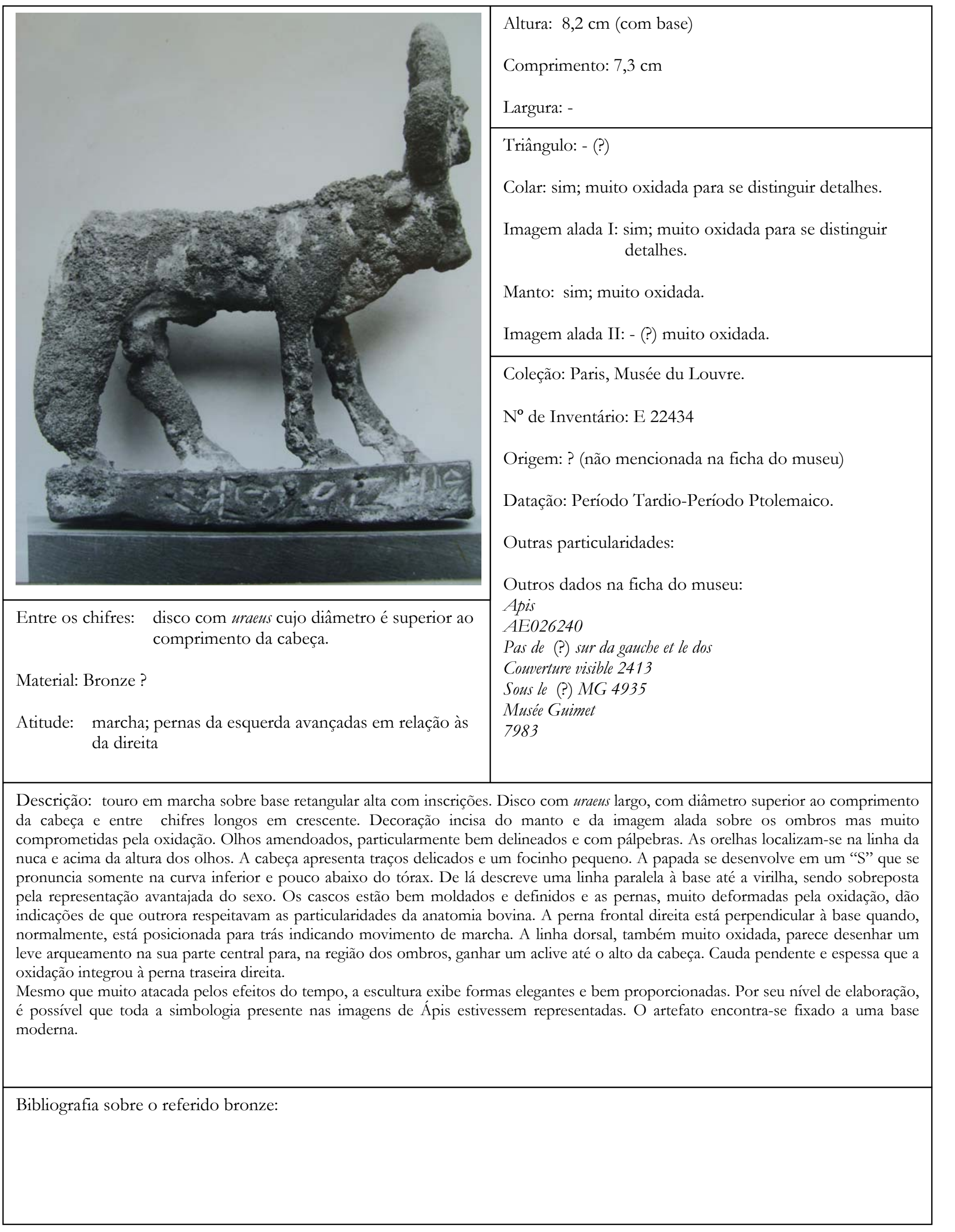




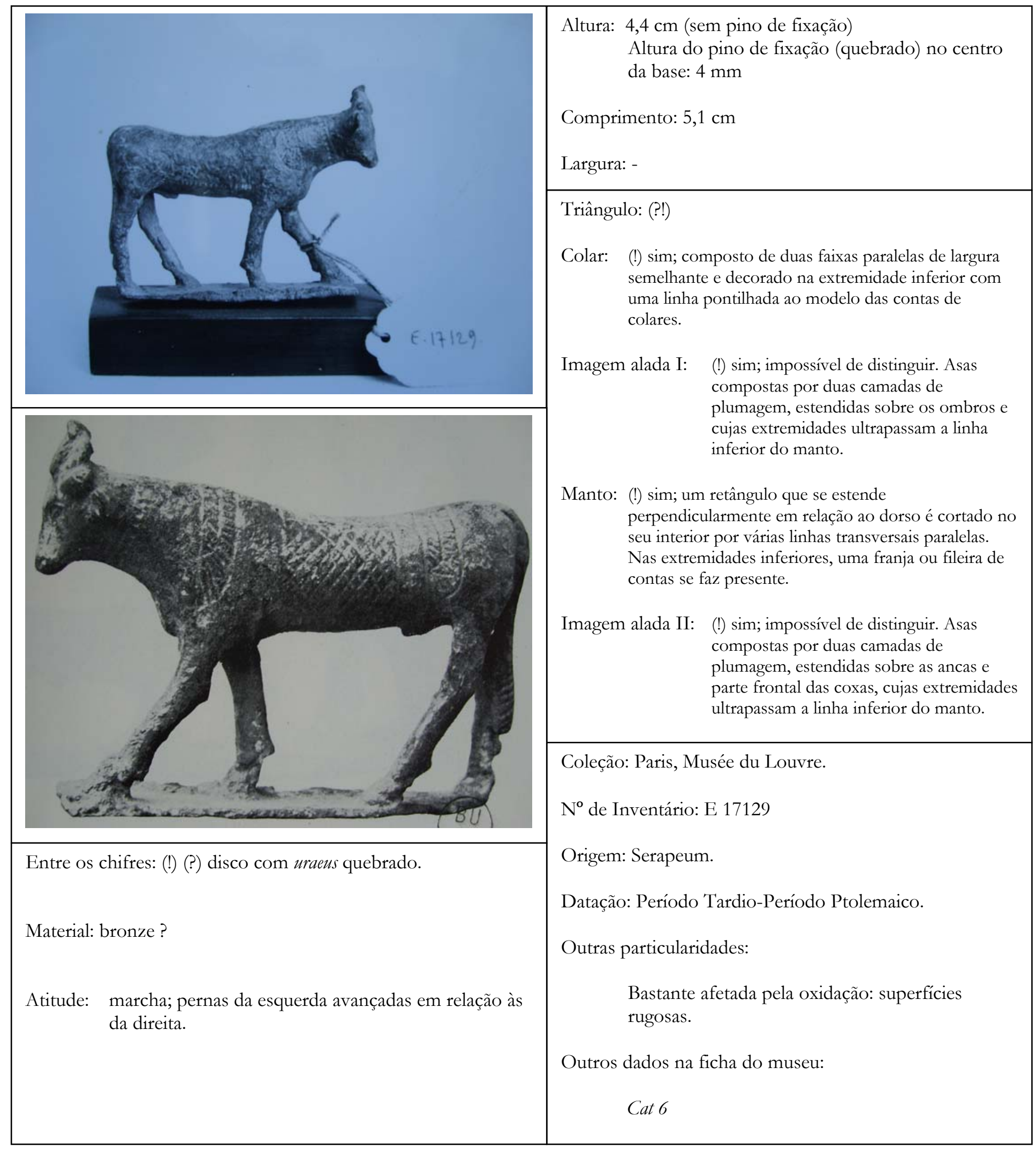


Descrição: touro em marcha sobre base retangular baixa sem inscrições e entortada. Disco solar quebrado pouco acima da cabeça do touro mas percebe-se uma suave silhueta em "S" do corpo da serpente uraeus no alto da fronte. Chifres quebrados. Decoração lombar e do colar incisas, sem incrustações e bastante comprometidas pela oxidação. Dada a presença desses símbolos, é possível que o triângulo também esteja representado na fronte. Olhos incisos de maneira discreta. A cabeça apresenta boas proporções, a boca é visível e as orelhas localizam-se pouco antes do início da cabeça, acima e próximos à linha dos olhos. Da cabeça parte uma papada que descreve uma linha suave em forma de foice. Os cascos estão representados, ainda que a linha que os defina não seja visível, e as pernas são altas e finas - especialmente as traseiras. A linha do tórax sobe levemente em direção à virilha, onde o sexo do animal está presente. A cauda aparentemente está unida à perna posterior direita praticamente em toda a sua extensão e sua extremidade é decorada com linhas espiraladas que sugerem a pelagem.. A linha dorsal sofre um declive na região do manto para depois retomar uma curva ascendente em direção ao alto da cabeça do touro, fundindo-se assim, ao início do disco. Superfícies rugosas e maltratadas pela oxidação.

A base da figurinha está fixada em uma base moderna.

Bibliografia sobre o referido bronze:

G.J.F. Kater-Sibbes, M. J. Vermaseren Apis I, p. 8, nº 14 Pr. XV 14. 


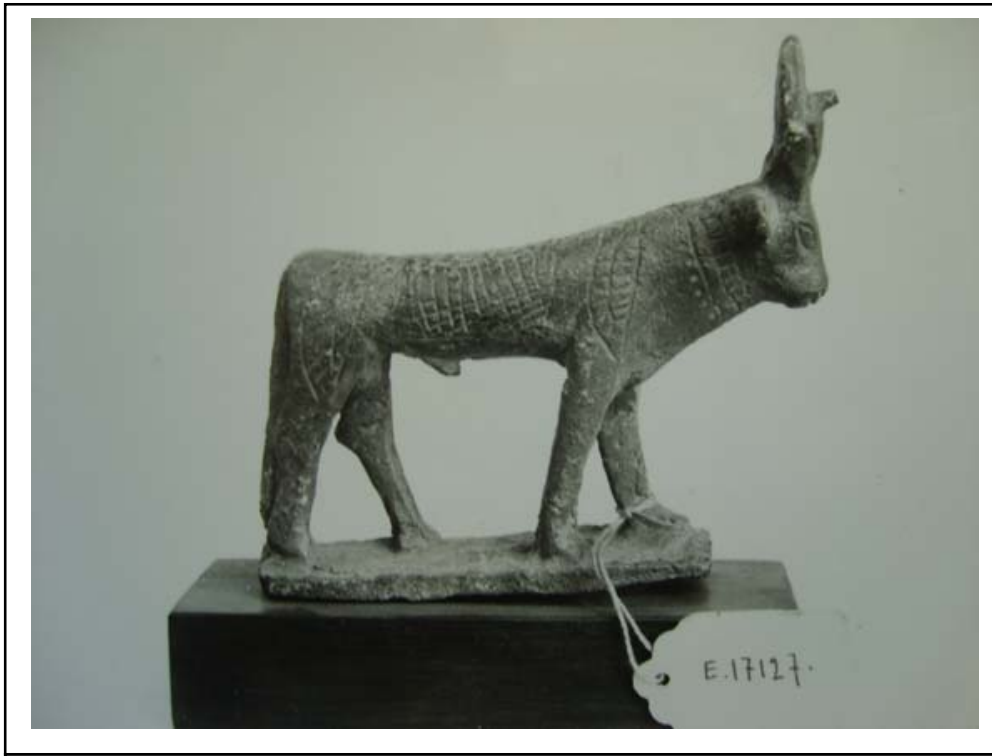

Entre os chifres: (!) disco com uraeus aproximadamente do comprimento da cabeça

Material: bronze?

Atitude: marcha; pernas da esquerda avançadas em relação às da direita.

Descrição: touro em marcha sobre base retangular baixa sem inscrições e que se encontra ligeiramente recurvada para cima a partir de sua parte média até a frente. Destaque ao disco com uraeus, aparentemente entre chifres em "V". Decoração lombar e do colar incisas com traços amplos e por vezes rústicos sem incrustações. Dada a presença desses símbolos, é possível que o triângulo também esteja representado na fronte. Olhos incisos e amendoados. A cabeça apresenta boas proporções e as orelhas localizam-se no início da cabeça e na altura da extremidade superior dos olhos. Da cabeça parte uma papada quase retilínea e se interpõe entre o início das pernas dianteiras. Os cascos estão fundidos à modelagem das pernas e o ventre está subido em relação ao início das pernas, trazendo à estatueta uma aparência quase cilíndrica no centro. Esta impressão é mudada quando se observa a linha ascendente suave que parte do meio do dorso e encontra seu fim no alto da cabeça. Cauda longa pendente e unida (?) à perna posterior direita. O sexo está bem indicado. A base da figurinha está fixada em uma base moderna.
Altura: $7,3 \mathrm{~cm}$ (sem o pino de fixação da base) Altura do pino de fixação no centro da base: $1,6 \mathrm{~cm}$

Comprimento: $7,6 \mathrm{~cm}$

Triângulo: (?!)

Colar: (!) sim; composto por duas fileiras: a mais próxima à cabeça com pequenas divisões (como tubos de faiança), a segunda está vazia e contém em sua extremidade exterior uma fileira paralela de pontos que fazem alusão às contas de faiança ou ouro dos colares.

Imagem alada I: (!) sim; mas impossível de distinguir. Asas estendidas sobre os ombros, compostas por duas camadas de plumagem cujas extremidades ultrapassam a linha do manto e alcançam o início das pernas.

Manto: (!) sim; um retângulo que se estende perpendicularmente em relação ao dorso é cortado no seu interior por várias linhas paralelas e transversais, criando um padrão xadrez.

Imagem alada II: (!) sim; mas impossível de distinguir. Asas estendidas sobre as ancas e a totalidade das coxas, compostas por duas camadas de plumagem e cujas extremidades ultrapassam a linha do manto.

Coleção: Paris, Musée du Louvre.

No de Inventário: E 17127

Origem: Serapeum.

Datação: Período Tardio-Período Ptolemaico (?).

Outras particularidades:

A ficha do museu não menciona as particularidades dos símbolos gravados nem sequer se a estatueta apresenta o triângulo na fronte

Outros dados na ficha do museu:

Cat

Bibliografia sobre o referido bronze:

G.J.F. Kater-Sibbes, M. J. Vermaseren Apis I, p. 7, n 12 Pr. XIV 12. 


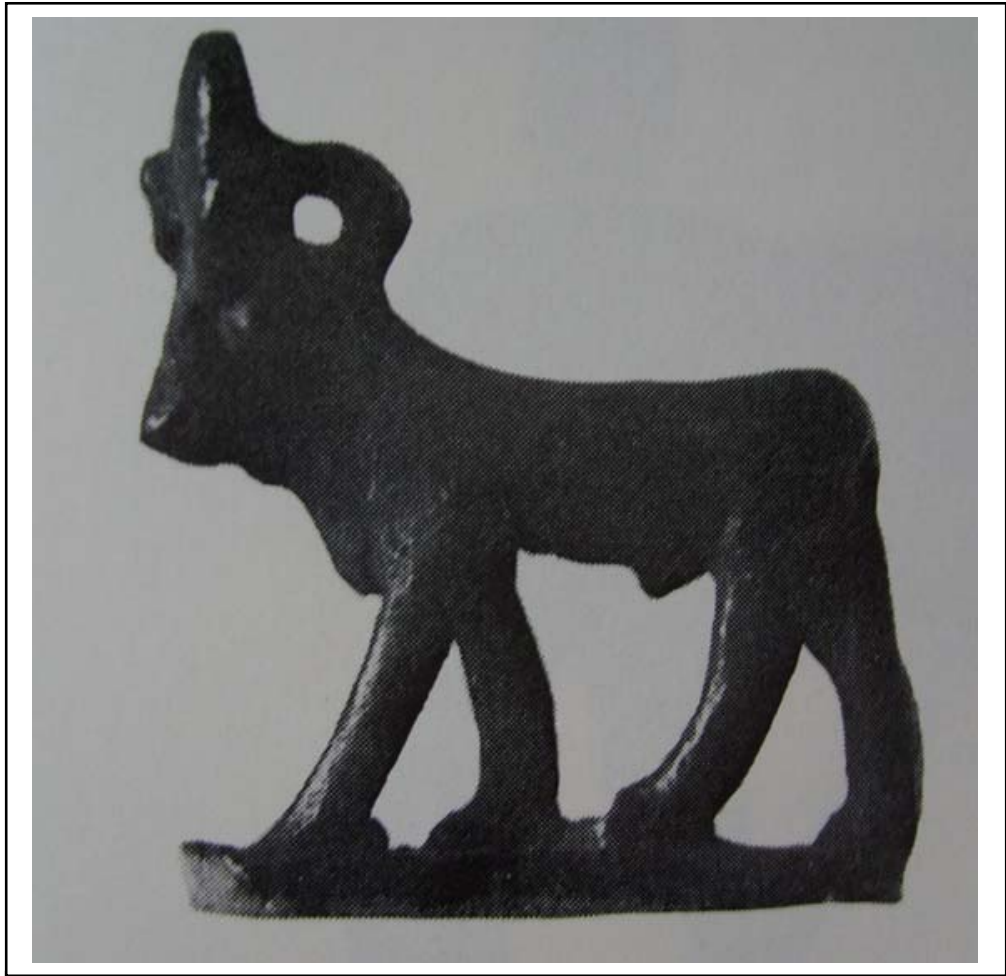

Entre os chifres: disco com uraeus cujo diâmetro é superior ao comprimento da cabeça.

Material: Bronze.

Atitude: marcha; pernas da esquerda avançadas em relação às da direita.

Descrição: atitude de marcha sobre base retangular fina e sem inscrições. Disco com uraeus com diâmetro superior ao comprimento da cabeça e entre chifres. Logo atrás e fundido à superfície anterior do disco e ao pescoço está um anel de suspensão. Não exibe decorações incisas. Cabeça estilizada cujas únicas características apontadas são as orelhas, localizadas na linha anterior dos chifres. O focinho é abreviado e está ligeiramente destacado do pescoço. A papada desenvolve duas ondulações principais: a primeira, que se prolonga do maxilar até aproximadamente a metade do pescoço e a segunda, que se pronuncia abaixo da região do tórax, ao qual se junta entre as pernas frontais. A linha abdominal surge bem acima do tórax e desce levemente arqueada em direção à virilha, tendo o sexo representado antes de chegar ao seu destino. As pernas são volumosas, descritas por linhas simplificadas mas não de todo rígidas. Os cascos são figurados como prolongamentos achatados da parte inferior das pernas. Após uma breve elevação na região das ancas, a linha dorsal ganha a feição de um arco aberto, com sua porção mediana paralela à base e dirigindo-se para cima logo após. Como o anel de suspensão está unido à figurinha, a linha que deveria seguir até $\mathrm{o}$ alto da cabeça contorna este e depois se dirige à parte anterior do disco. A cauda está imperceptível na imagem mas é de se acreditar que esteja unida à perna posterior direita.

A figurinha, que deve ter sido usada como amuleto, exibe certa rusticidade na representação do touro mas este está relativamente bem proporcionado e exibe vigor em seus membros. Contudo, sua identidade não pode ser assegurada como um Ápis tanto pela ausência de inscrições ou da simbologia que lhe é própria quanto pelo desconhecimento de sua real origem. Encontra-se em bom estado de conservação.
Altura: $4 \mathrm{~cm}$

Comprimento: $3,8 \mathrm{~cm}$

Largura: -

Triângulo: -

Colar: -

Imagem alada I: -

Manto: -

Imagem alada II: -

Coleção: Londres, British Museum.

No de Inventário: EA (?) 61619

Origem: desconhecida.

Datação: Período Tardio-Período Ptolemaico (?).

Outras particularidades:

Outros dados da bibliografia:

On the left side of the Bull an inlaid letter $K$.

Bibliografia sobre o referido bronze:

G.J.F. Kater-Sibbes, M. J. Vermaseren Apis I, pp. 59-60, $n^{\circ}$ 458; Pr. CXLVIII 458. 


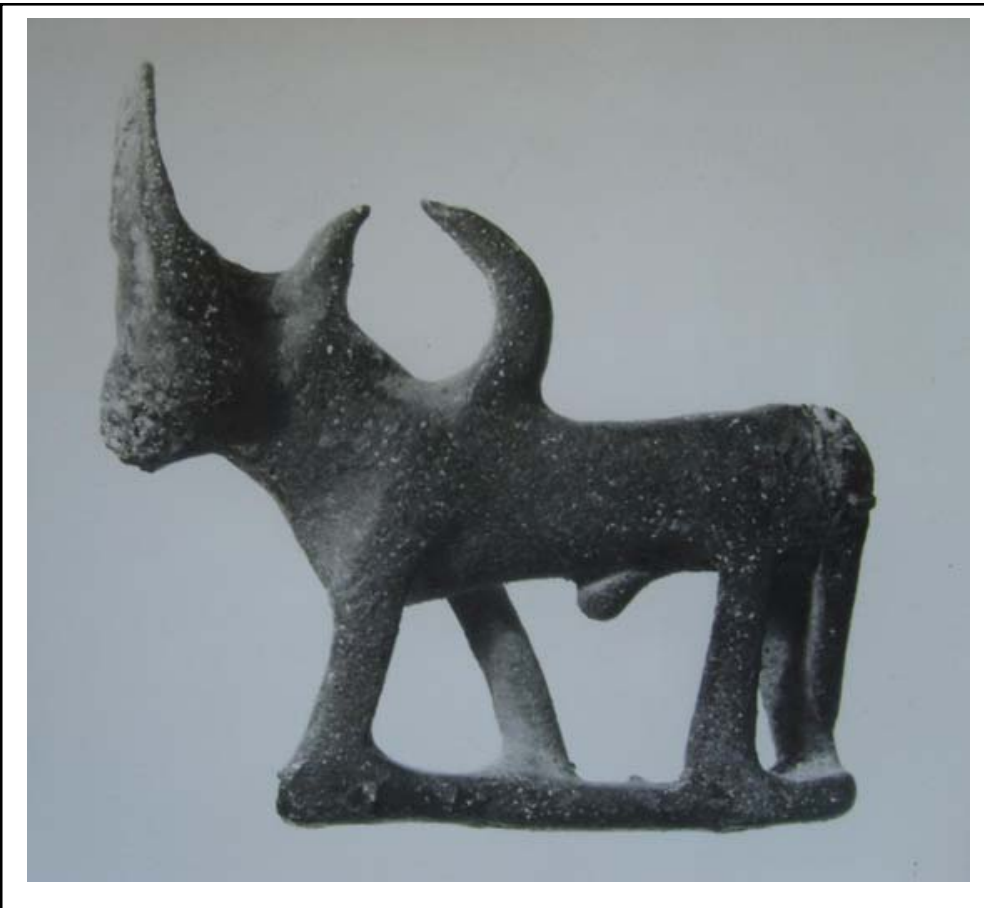

Entre os chifres: disco com uraeus cujo diâmetro é superior ao comprimento da cabeça.

Material: Bronze

Atitude: marcha; pernas da esquerda avançadas em relação às da direita.

Descrição: touro em marcha sobre base retangular baixa sem inscrições e quebrada na parte frontal. Disco com uraeus com diâmetro superior ao comprimento da cabeça entre os chifres em crescente (?). Sobre o pescoço e ombros há um anel para suspensão quebrado na extremidade superior. A cabeça é estilizada, pequena, apresenta um focinho abreviado e encontra-se quebrada no lado direito. O pescoço a mantém bem ereta e o contorno da papada se confunde com o dele, desenhando uma breve curvatura côncava na sua porção mediana e terminando pouco abaixo do peito. A linha que daí progride é ascendente até a virilha. Na metade do abdômen projeta-se o sexo. As pernas são estilizadas por barras alongadas aglutinadas à base que mal lembram a configuração de cascos. A linha dorsal desenha um percurso descendente até o ponto de onde emerge o anel de suspensão. Cauda pendente que desce verticalmente em uma reta secante ao perfil da perna posterior direita, à qual está unida em toda a sua extensão. Sua parte superior contém traços de oxidação.

Ainda que rústico, este amuleto procura uma certa elegância na representação do touro sagrado, cuja identidade não é reconhecida dada à ausência de uma simbologia mais precisa.
Altura: $3,2 \mathrm{~cm}$ (com base)

Comprimento: $3,3 \mathrm{~cm}$

Largura: $0,9 \mathrm{~cm}$

Triângulo: -

Colar: -

Imagem alada I: -

Manto: -

Imagem alada II: -

Coleção: Paris, Musée du Louvre.

$\mathrm{N}^{0}$ de Inventário: AF 969

Origem: ? (não mencionada na ficha do museu)

Datação: Período Tardio-Período Ptolemaico.

Outras particularidades:

Outros dados na ficha do museu:

Partie droite de la tête cassée.

Avant du socle cassé.

Produit de corrosion sur l'arrière (au-dessus de la queue). AE027740

Rés. Bronzes

8246

Bibliografia sobre o referido bronze: 


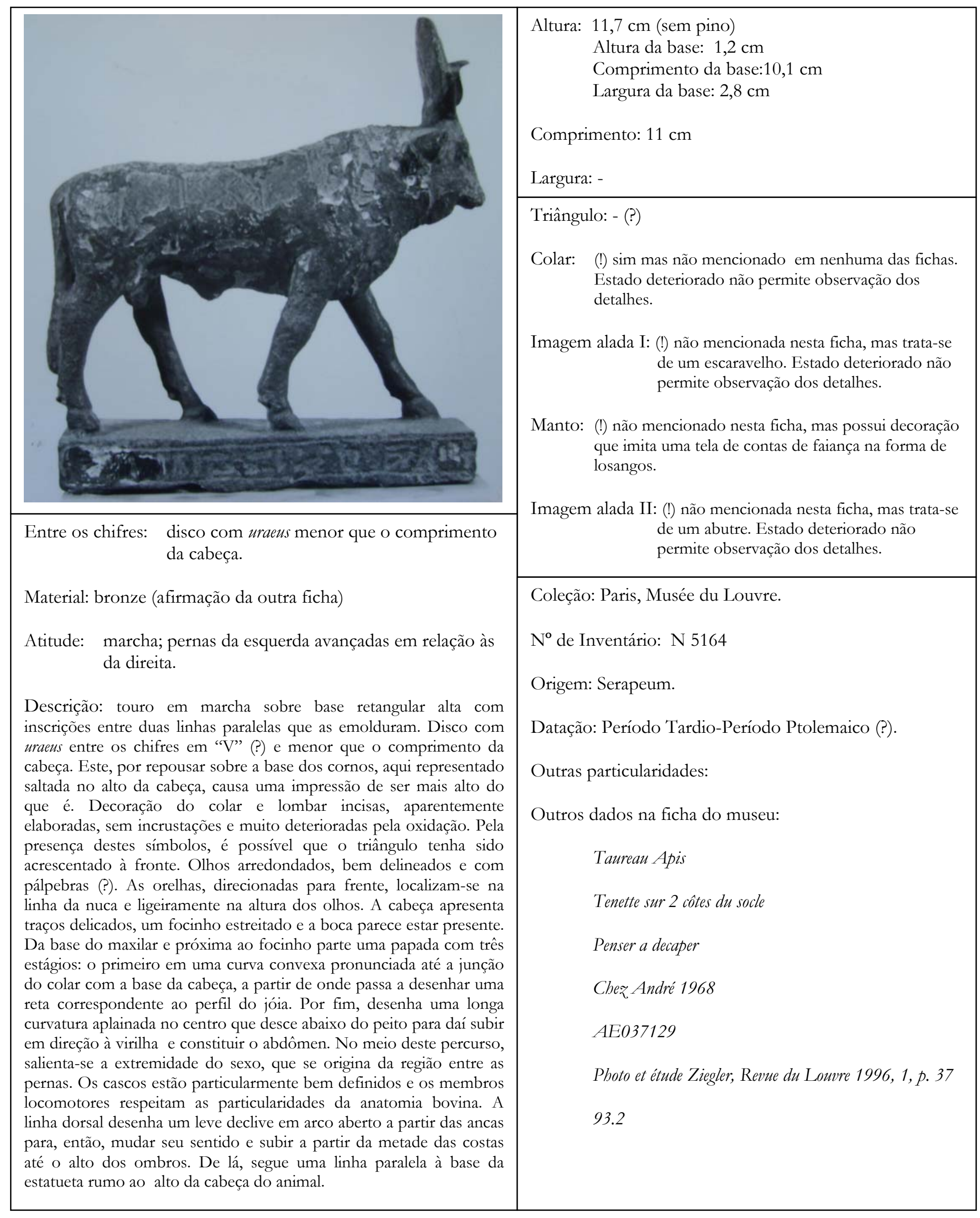


Cauda pendente e espessa, que desce em uma curva que se aproxima do perfil da perna anterior direita, à qual parece estar unida. Sua extremidade se encontra longe da base. A escultura está muito ressentida pela oxidação mais ainda revela a elaborada simbologia que lhe é própria e formas elegantes.

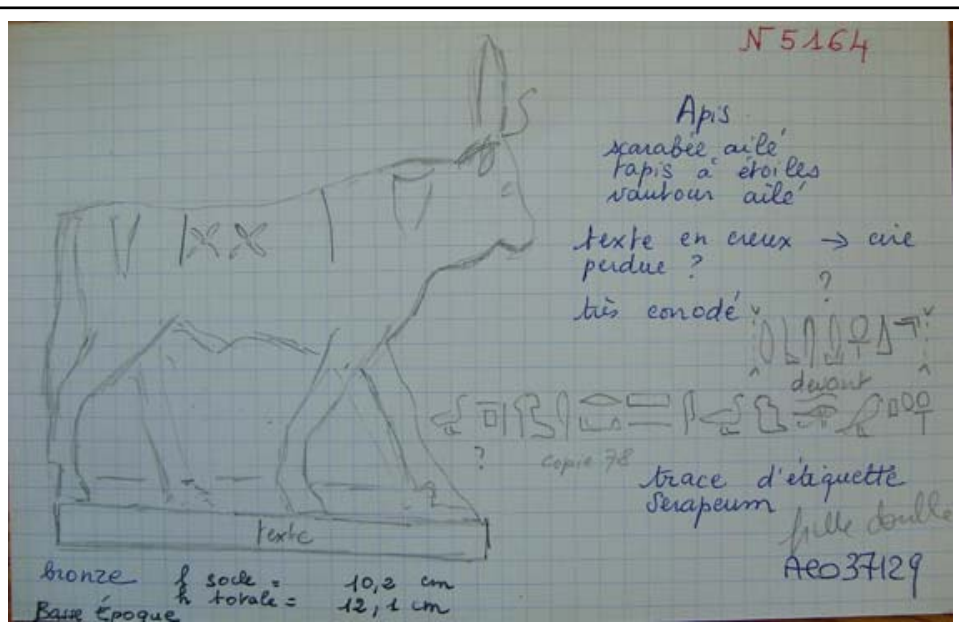

Entre os chifres: disco com uraeus menor que o comprimento da cabeça (?)

Material: bronze

Atitude: marcha; pernas da esquerda avançadas em relação às da direita.

Descrição: ver detalhes da ficha anterior.
Altura: $12,1 \mathrm{~cm}$ (com base)

Comprimento: $10,2 \mathrm{~cm}$

Largura: -

Triângulo: -

Colar: -

Imagem alada I: escaravelho

Manto: sim; com decoração que imita uma tela de contas de faiança na forma de losangos.

Imagem alada II: abutre

Coleção: Louvre

No de Inventário: N5164

Origem: Serapeum

Outras particularidades:

Outros dados na ficha do museu:

Trace d'étiquette Serapeum

Basse Époque

Texte en creux $\rightarrow$ cire perdue?

Très corrodé 


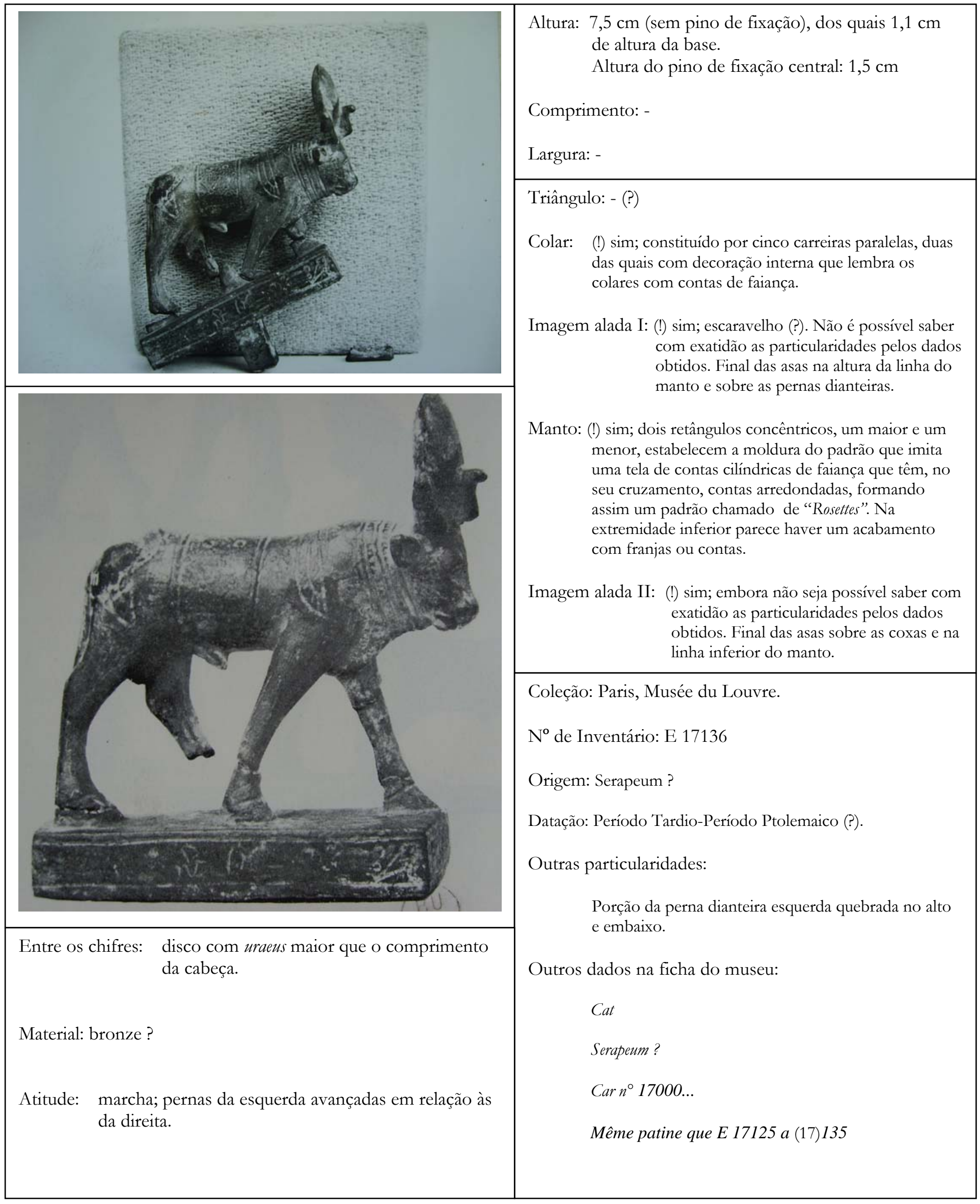


Descrição: touro em marcha sobre base retangular alta com inscrições e pino de fixação central. Disco solar com perfil lenticular, com serpente uraeus proeminente, e maior que o comprimento da cabeça entre chifres em "V" (?). Decoração lombar e do colar elaboradas e incisas sem incrustações. Dada a presença desses símbolos, é possível que o triângulo também esteja representado na fronte. Olhos grandes e direcionados para frente que, somados às proporções pequenas da cabeça, conferem ao animal um ar de docilidade. As orelhas localizam-se na linha anterior dos chifres e acima daquela dos olhos. Do maxilar, após uma ligeira reentrância, desenha-se uma papada com uma leve curvatura em "S", cuja proeminência se ressalta na parte do tórax entre as pernas dianteiras. Os cascos estão parcialmente representados (pata dianteira esquerda) e devido à qualidade da liga, são, juntamente com as pernas, os pontos frágeis da estatueta, onde diversas fraturas são observáveis. Apesar dessa contingência, nota-se que as pernas procuram reproduzir os contornos da musculatura e que a estatueta é elaborada nos seus detalhes. A linha do abdômen descreve uma ligeira curvatura que sobe em direção à virilha e ao sexo do touro. A cauda está, aparentemente, unida à perna traseira direita. À linha dorsal imprimese uma curva descendente suave a partir do alto da anca até antes dos ombros, a partir de onde se nota uma nova elevação que termina num declive até o alto da cabeça. Possui vários traços de oxidação e a porção superior direita da anca, onde há a representação de uma figura alada, encontra-se danificada. No entanto, é visível a qualidade estética do objeto na reprodução de suas particularidades.

Bibliografia sobre o referido bronze:

G.J.F. Kater-Sibbes, M. J. Vermaseren Apis I, p. 9, n² 21, Pr. XVIII 21. 


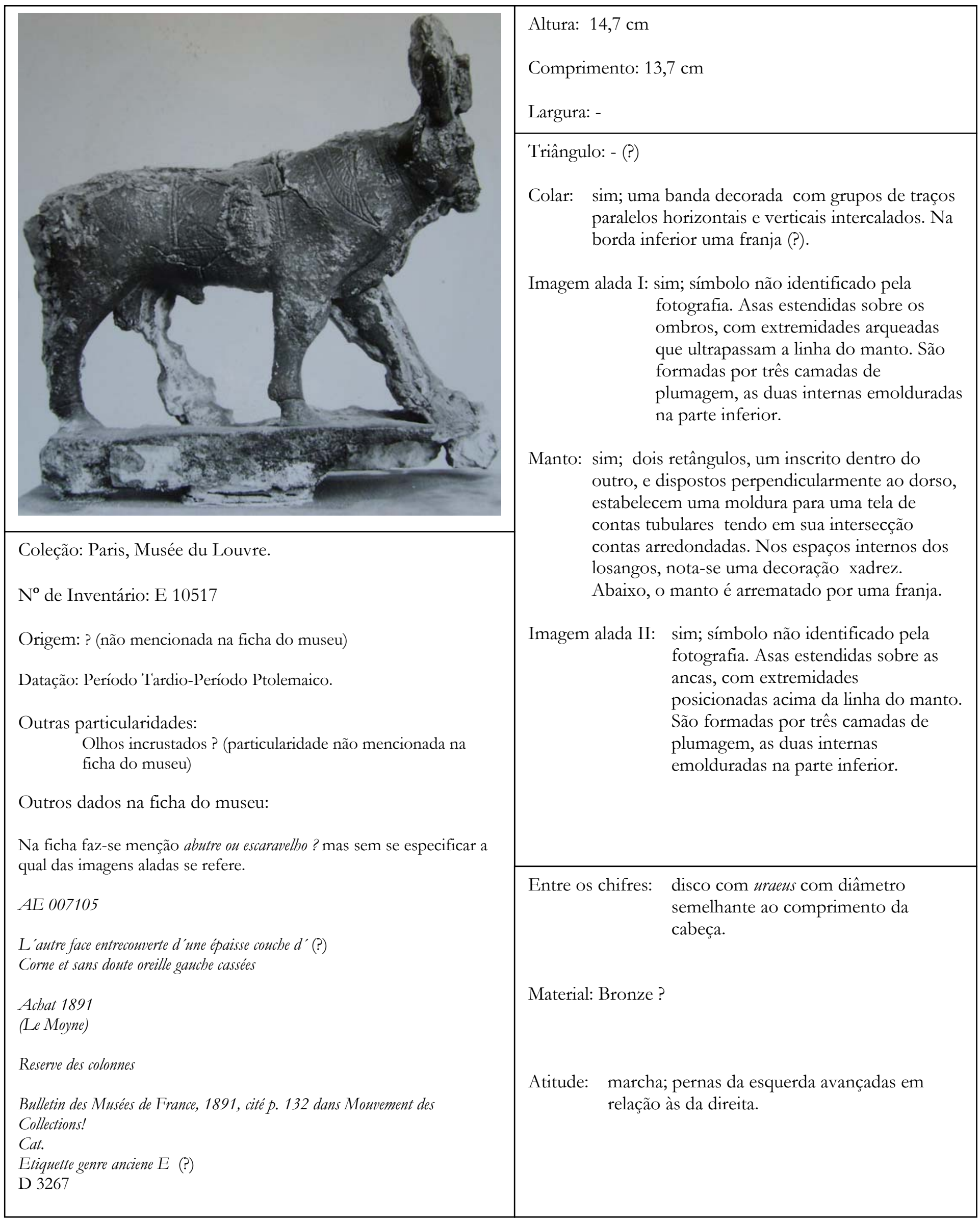


Descrição: touro em marcha sobre base retangular alta sem inscrições e bastante deteriorada. Disco com perfil lenticular, uraeus bem desenvolvida, e diâmetro semelhante ao comprimento da cabeça do touro entre chifres em "V" (?). Decoração lombar e do pescoço elaboradas, incisas, sem incrustações e muito deterioradas. Olhos grandes, amendoados e dispostos na diagonal. As orelhas estão ligeiramente voltadas para frente e localizam-se atrás da linha da cabeça e pouco acima da altura dos olhos. O focinho é pequeno e bem definido. Pouco abaixo deste se desenvolve uma papada em "S" aberto e quebrada em alguns pontos: a primeira parte é formada por uma linha reta que surge após uma leve ondulação abaixo do focinho e segue até a região do colar. Daí projeta-se em uma curvatura acentuada para frente para depois se dirigir para abaixo do tórax, onde gradativamente encontra a linha do abdômen. Esta, por seu lado, desempenha uma reta ascendente até a virilha, onde o sexo está bem representado. As pernas robustas procuram espelhar as particularidades da anatomia bovina, apesar do alto nível de oxidação que se concentrou sobre elas e as desfigurou - especialmente a perna traseira esquerda. Os cascos que estão conservados exibem boa definição e são delineados. A linha dorsal desenvolve quase que uma reta paralela à base até o início dos ombros para ascender muito sutilmente e atingir o cimo da cabeça. A cauda, pendente e espessa, desce em uma quase reta secante ao perfil da perna posterior direita, à qual aparentemente está unida. A estatueta tem porte robusto, exibe formas elegantes e, apesar do severo grau de deterioração causada pela oxidação, observa-se que a representação da simbologia é elaborada e o artefato enquadra-se entre os melhores exemplares.

Bibliografia sobre o referido bronze:

G.J.F. Kater-Sibbes, M. J. Vermaseren Apis I, pp. 50-51, n² 210, Pr. CXXV 210. 


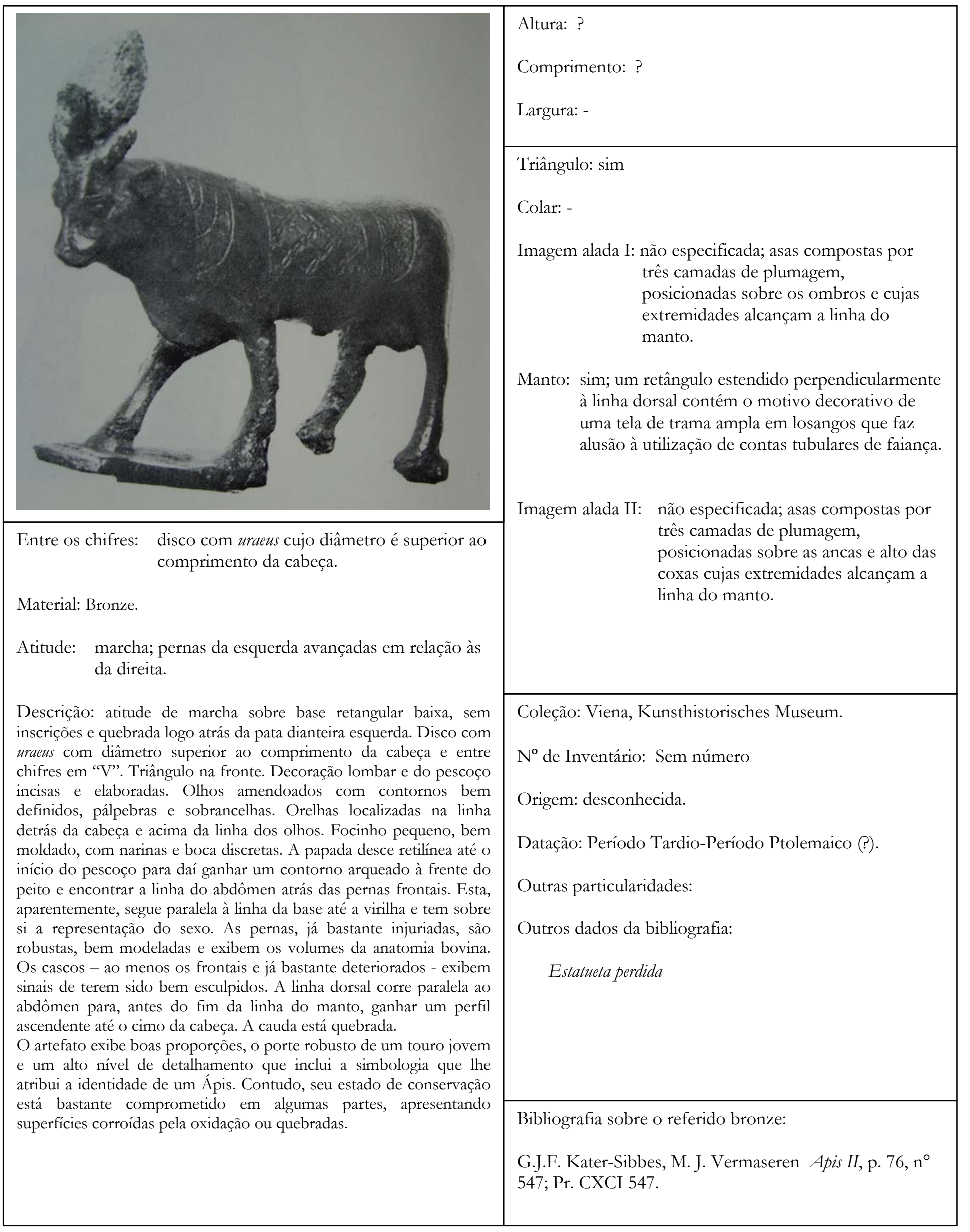




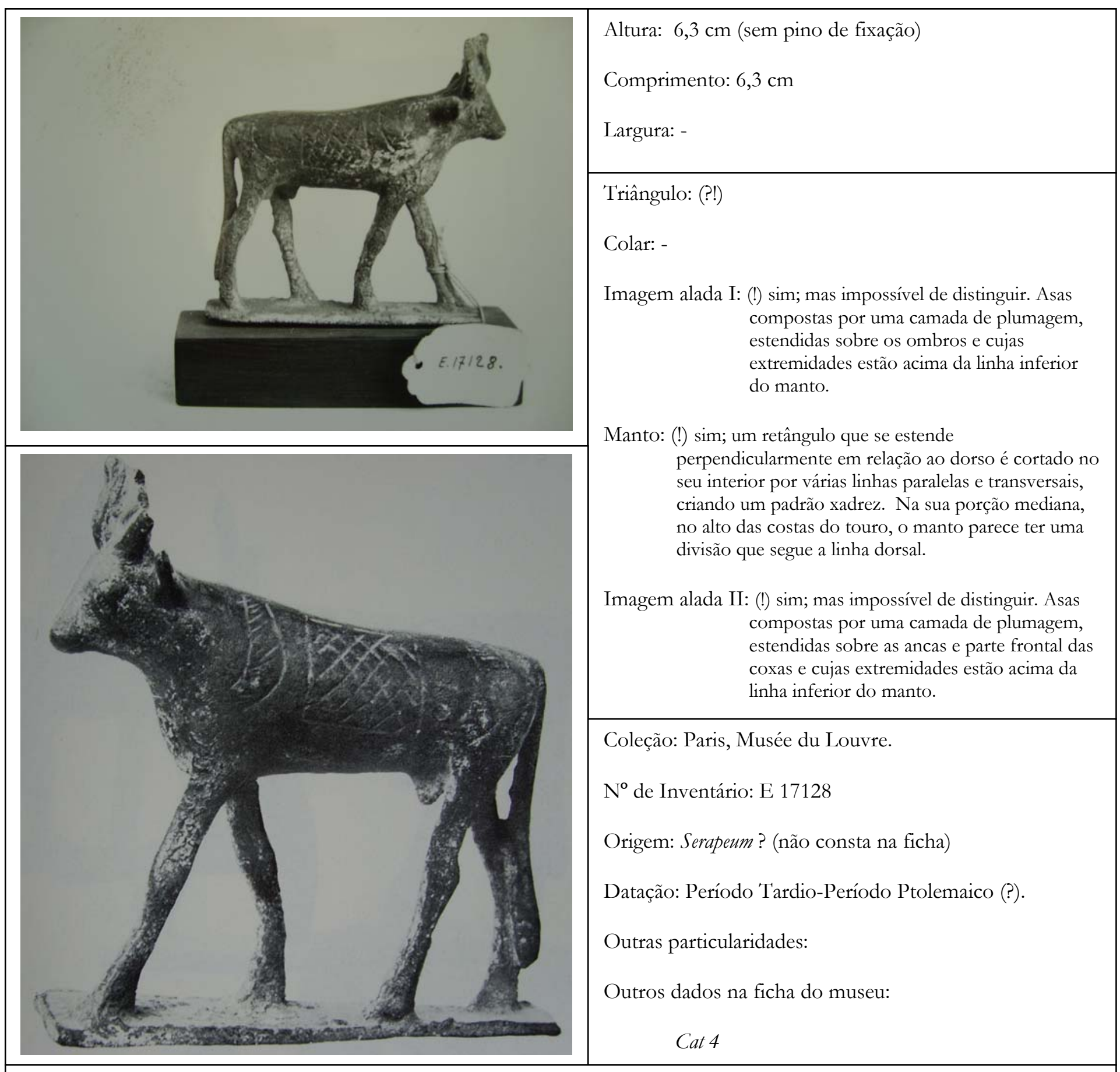

Entre os chifres: disco solar quebrado acima da uraeus.

Material: bronze?

Atitude: marcha; pernas da esquerda avançadas em relação às da direita. 
Entre os chifres: disco solar quebrado acima da uraeus.

Material: bronze?

Atitude: marcha; pernas da esquerda avançadas em relação às da direita.

Descrição: touro em marcha sobre base retangular baixa sem inscrições. Disco solar quebrado logo acima da cabeça da uraeus, representada aqui particularmente avantajada, entre chifres em crescente (?). Decoração lombar incisa sem incrustações. Dada a presença desses símbolos, é possível que o triângulo também esteja representado na fronte. Olhos em relevo mas com formas pouco claras a partir da fotografia. A cabeça apresenta boas proporções e as orelhas localizam-se no centro do pescoço e ligeiramente mais acima da linha dos olhos. Da cabeça parte uma papada em forma de um "S" suave. Os cascos estão representados, ainda que a oxidação da peça dificulte sua observação, e as pernas são altas e finas. A linha do tórax sobe em direção à virilha, onde o sexo do animal está presente. A cauda está destacada na sua porção média e se une à perna posterior direita na sua metade inferior. A linha dorsal sofre uma inclinação em direção ao alto da cabeça do touro a partir da metade do manto, dando, juntamente com a linha inferior do tórax, uma configuração trapezoidal à secção lateral do torso. Vários traços de oxidação. A base da figurinha está fixada em uma base moderna.

Bibliografia sobre o referido bronze:

G.J.F. Kater-Sibbes, M. J. Vermaseren Apis I, p. 7, n 13 Pr. XV 13. 


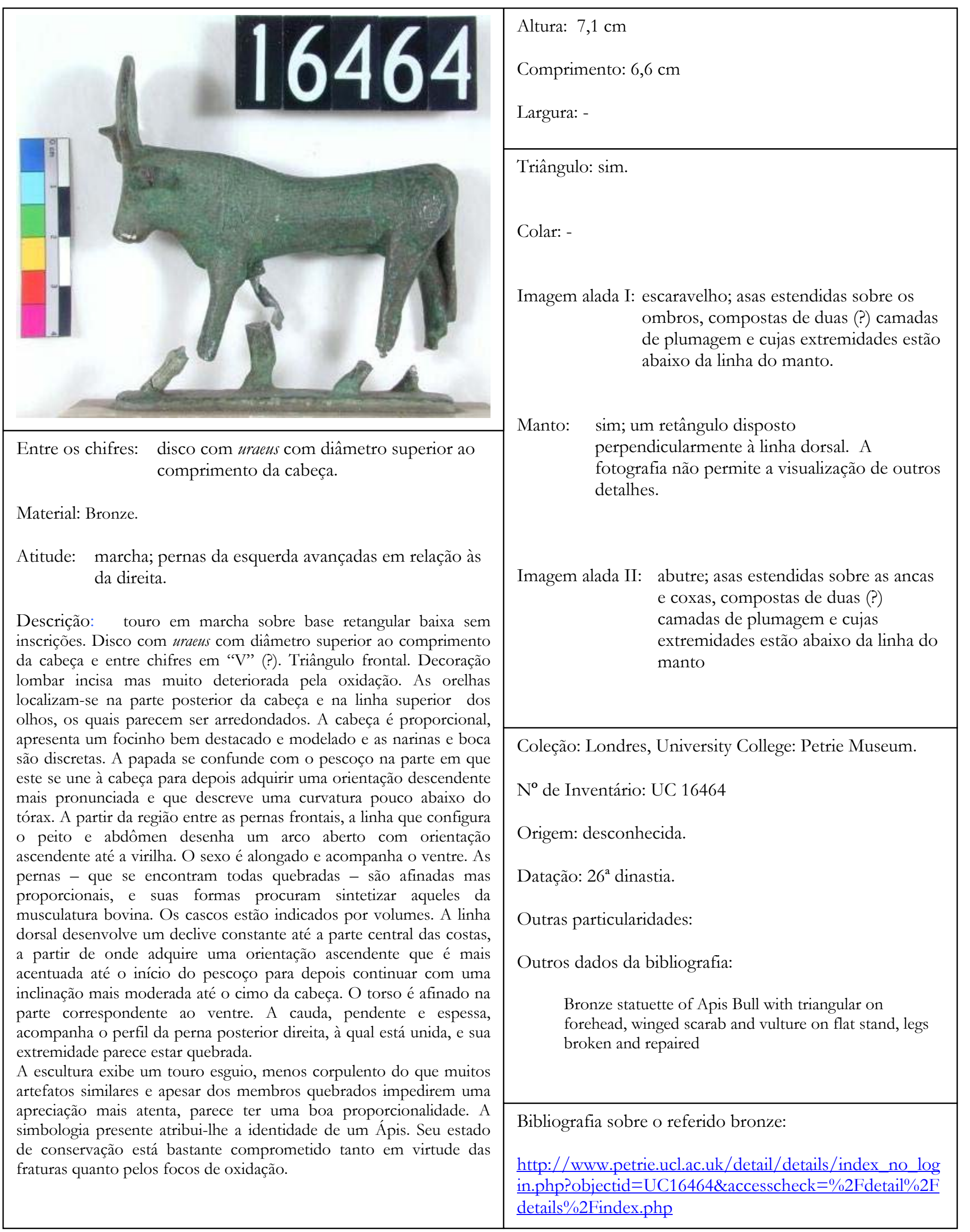




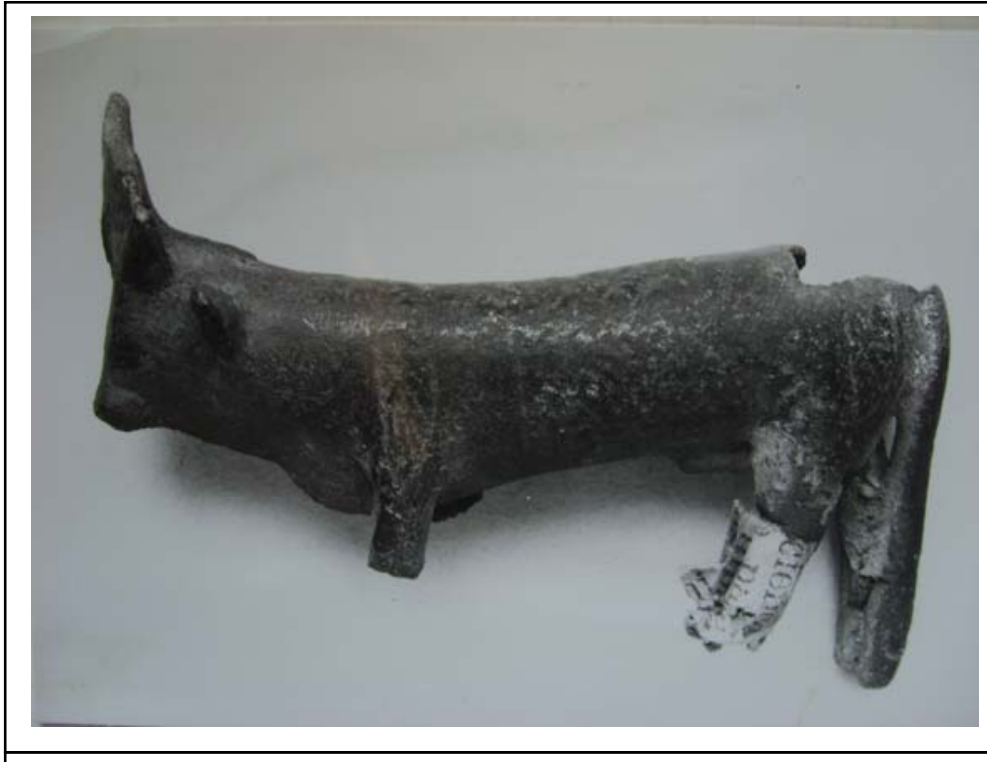

Entre os chifres: disco quebrado transversalmente, do canto superior direito para a altura do chifre esquerdo.

Material: Bronze?

Atitude: marcha; pernas da esquerda avançadas em relação às da direita.

Descrição: touro em marcha, pernas dianteiras quebradas acima de sua metade e traseiras pouco acima dos cascos. Base perdida. Disco (com uraeus ?) quebrado transversalmente entre o canto superior direito e chifre esquerdo e entre os chifres em "V". Triângulo frontal muito apagado. Decoração lombar gravada, sem incrustações e muito desgastada. Olhos grandes e salientes mas pouco definidos. As orelhas localizam-se na linha da nuca e acima da altura dos olhos. A cabeça apresenta traços delicados e um focinho pequeno. Da base do maxilar e próxima ao focinho se desenvolve uma papada primeiramente retilínea até próximo do início do pescoço que depois ganha uma curvatura pronunciada que se estende para abaixo do tórax. A linha que daí sai ganha um aspecto retilíneo até a área da virilha, de onde se projeta o sexo. Ainda que quebradas, observa-se que as pernas exibem contornos elegantes, embora não se apresentem volumosas. A região das ancas está quebrada na parte superior e revela um interior oco. A linha dorsal, desenha um perfil retilíneo e paralelo à linha do abdômen até o início dos ombros, onde ganha um leve impulso ascendente que culmina no cimo da cabeça. Cauda pendente e espessa, que desce em uma reta secante ao perfil da perna posterior direita, à qual está unida nas partes superior e inferior deixando um espaço livre pouco acima do centro. O tronco é mais alongado do que o usual e contrasta com as proporções da cabeça.

Ainda que fuja das boas proporções e sua simbologia esteja muito apagada - falha no molde ? - a escultura procura conferir nobreza ao porte do touro e os símbolos que nela se apresentam condizem com as representações canônicas dos Ápis.
Altura: $3,2 \mathrm{~cm}$

Comprimento: $5,9 \mathrm{~cm}$

Largura: -

Triângulo: sim

Colar: -

Imagem alada I: disco ou escaravelho;

Manto: (!) sim; um retângulo disposto na perpendicular em relação ao dorso e cuja decoração consiste em um padrão de linhas diagonais em xadrez (?).

Imagem alada II: sim; impossível de reconhecer porque a parte superior das ancas está quebrada.

Coleção: Paris, Musée du Louvre.

No de Inventário: E 19920

Origem: ? (não mencionada na ficha)

Datação: Período Tardio-Período Ptolemaico (?).

Outras particularidades:

Outros dados na ficha do museu:

AE026239

Noyau ...(?) à l'interieur

Musée Guimet 2421

80-6

Bibliografia sobre o referido bronze: 


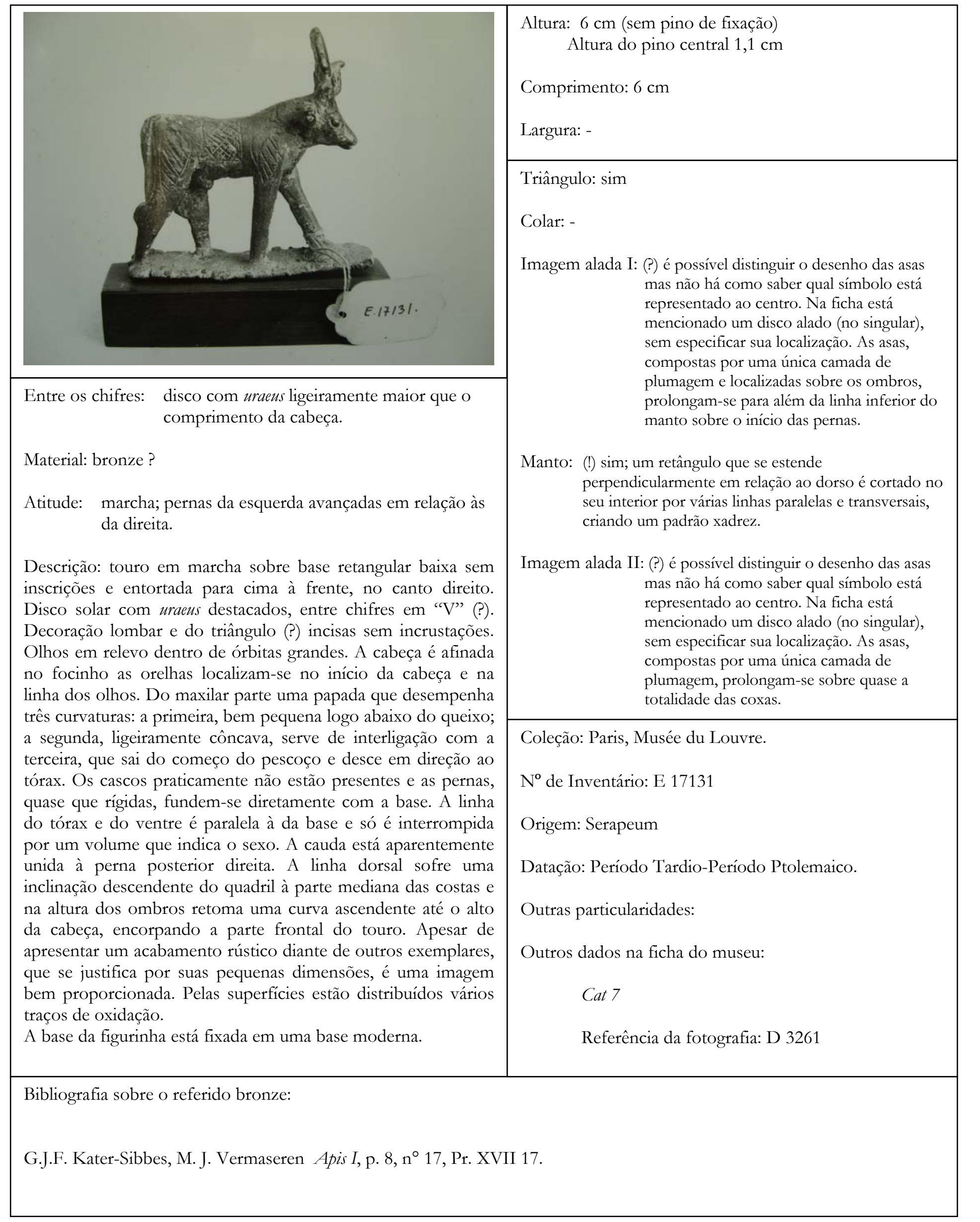




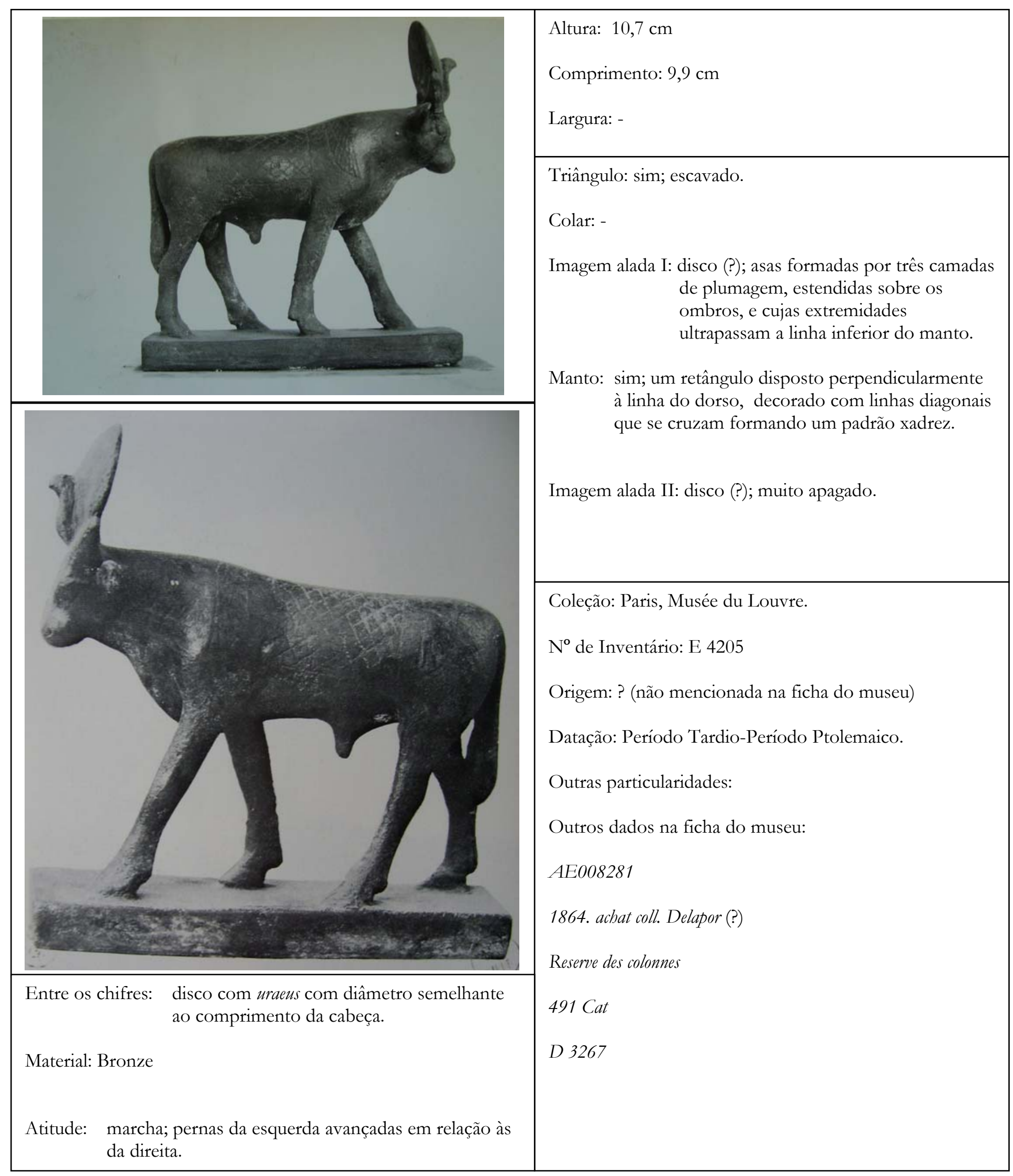


Descrição: touro em marcha sobre base retangular alta sem inscrições. Disco com uraeus com diâmetro semelhante ao comprimento da cabeça do touro e entre chifres em "V" (?). Triângulo frontal escavado onde possivelmente se encaixava uma incrustação de prata ou ouro. Decoração lombar e do pescoço incisas, sem incrustações e apagadas sobre as ancas. Olhos grandes e amendoados, dispostos na diagonal e com pálpebras. As orelhas estão ligeiramente inclinadas para a direção do focinho e localizam-se atrás da linha da cabeça e na altura do canto superior dos olhos. Focinho pequeno, com narinas sugeridas por pequenos pontos e boca discreta. A papada desce quase que reta no pescoço e só ganha uma curvatura pronunciada a partir do início deste, estendendo-se à região do tórax. Daí, a linha que segue em direção ao abdômen e a virilha é aparentemente uma reta paralela à base, sobre a qual sobrepõe-se o sexo que lhe tira a uniformidade. As pernas procuram respeitar as particularidades da anatomia bovina e os cascos estão bem definidos. A linha dorsal desenvolve uma suave curvatura côncava até o início dos ombros, a partir de onde ganha um leve contorno ascendente que culmina no alto da cabeça. A cauda, pendente e espessa, desce verticalmente em uma reta secante ao perfil da perna posterior direita, à qual está unida acima e na sua extremidade inferior.

A estatueta tem porte robusto, exibe formas elegantes e, apesar da deterioração causada pela oxidação, observa-se que a representação da simbologia é elaborada e o artefato enquadra-se entre os melhores exemplares.

Bibliografia sobre o referido bronze:

G. J. F. Kater-Sibbes, M. J. Vermaseren, Apis II, p.69 n 509, Pr. CLXXV 509. 


\begin{tabular}{|c|c|}
\hline & $\begin{array}{l}\text { Altura: } 5,7 \mathrm{~cm} \text { (com o pino) } \\
\text { Comprimento: } 6,2 \mathrm{~cm} \\
\text { Largura: ? }\end{array}$ \\
\hline & $\begin{array}{l}\text { Triângulo: sim } \\
\text { Colar: - } \\
\text { Imagem alada I: escaravelho; asas projetadas para frente, } \\
\text { em direção à papada } \\
\text { Manto: sim, nas laterais imitando rede de contas de } \\
\text { faiança; sobre o dorso uma faixa decorativa não } \\
\text { reconhecível pela fotografia }\end{array}$ \\
\hline $\begin{array}{l}\text { Entre os chifres: disco com uraeus maior que comprimento da } \\
\text { cabeça. }\end{array}$ & $\begin{array}{ll}\text { Imagem alada II: } & \text { abutre; extremidade das asas } \\
& \text { ultrapassa início das coxas. }\end{array}$ \\
\hline $\begin{array}{l}\text { Inscrição na base: - } \\
\text { Atitude: marcha; pernas da esquerda avançadas em relação às } \\
\text { da direita. }\end{array}$ & $\begin{array}{l}\text { Coleção: Paris, Musée du Louvre. } \\
\text { No de Inventário: N5164 C }\end{array}$ \\
\hline $\begin{array}{l}\text { Descrição: touro em marcha sobre base retangular fina sem } \\
\text { inscriçoses. Destaque ao disco com uraeus, sugerida por uma } \\
\text { proeminência sobre o alto da cabeça, e aparentemente entre } \\
\text { chifres em "V". Triângulo frontal inciso. Decoração lombar } \\
\text { incisa e sem incrustações. Olhos em relevo e bem delineados. A } \\
\text { cabeça apresenta traços delicados e dela parte uma papada com } \\
\text { três ondulações, duas mais proeminentes e outra mais suave. Os } \\
\text { cascos, por outro lado, não estão tão bem definidos e o tronco } \\
\text { do animal está ligeiramente afinado entre as pernas dianteiras e } \\
\text { traseiras. Cauda pendente e unida (?) à perna posterior direita. } \\
\text { O sexo está bem indicado. Orelhas presentes mas não } \\
\text { distinguíveis. A figurinha encontra-se fixada em uma base } \\
\text { moderna. }\end{array}$ & $\begin{array}{l}\text { Origem: Serapeum (inscrito sobre a base) } \\
\text { Datação: Período Tardio-Período Ptolemaico. } \\
\text { Outras particularidades: } \\
\qquad \text { Possui pino de fixação central. } \\
\text { Outros dados na ficha do museu: } \\
n^{\circ} 504 \text { sob a base e referente a um catálogo } \\
\text { (qual?). }\end{array}$ \\
\hline \multicolumn{2}{|l|}{ Bibliografia sobre o referido bronze: } \\
\hline
\end{tabular}




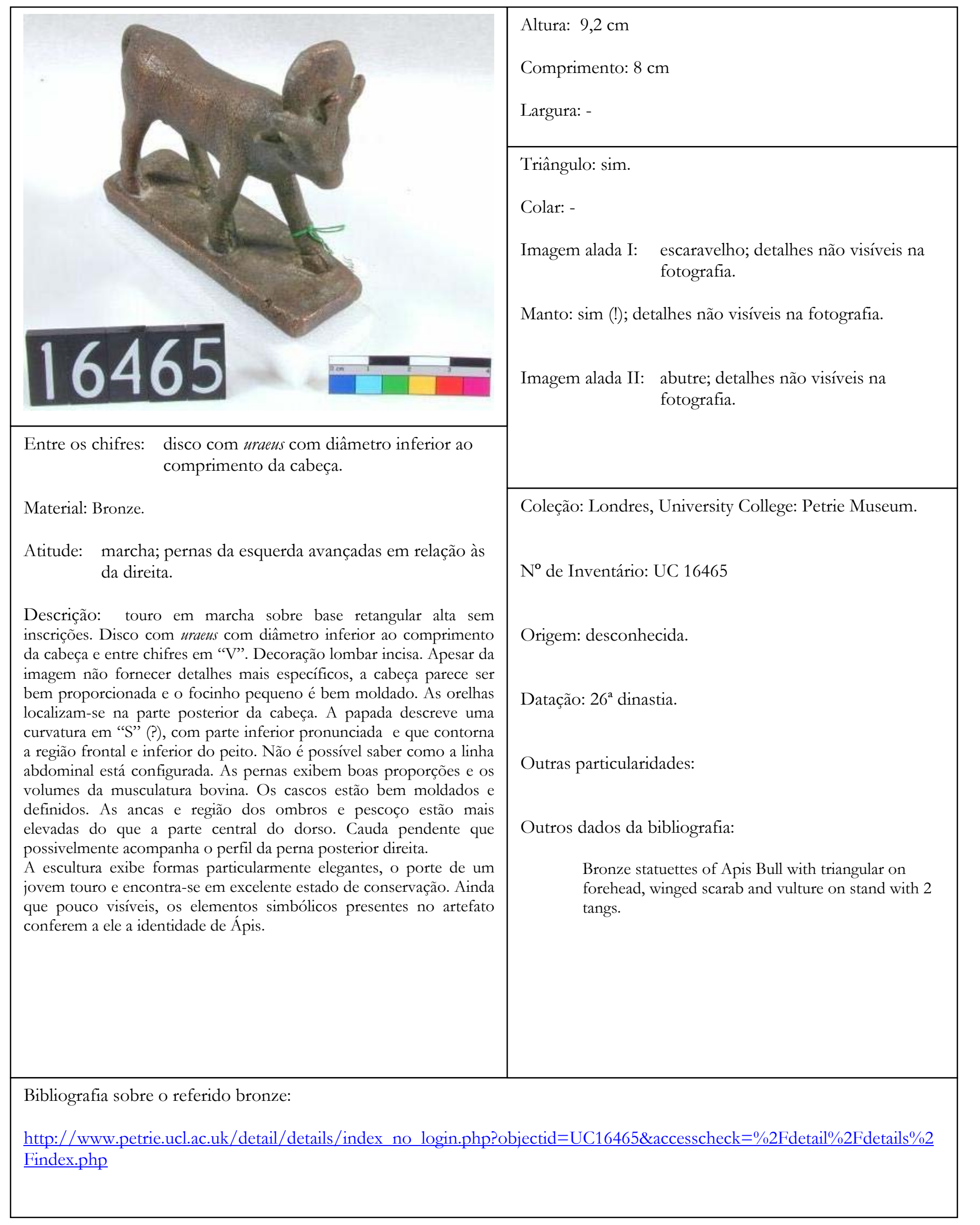




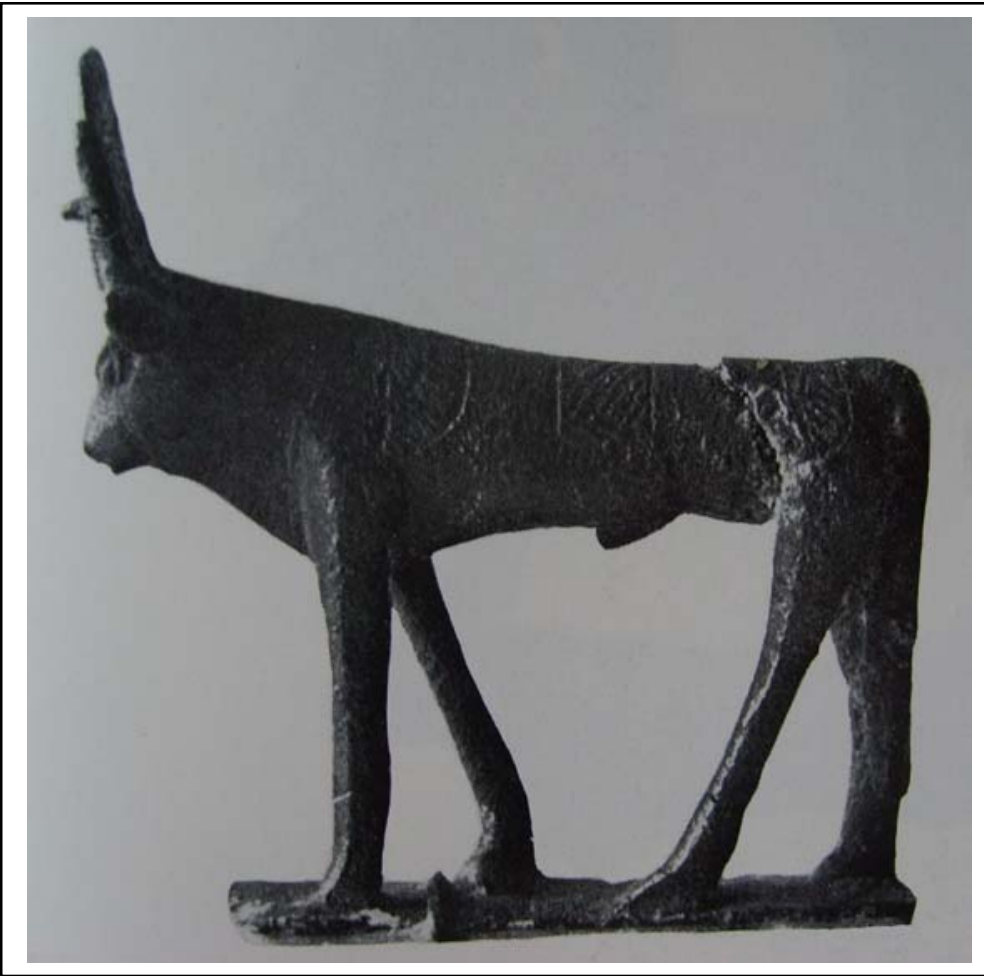

Entre os chifres: disco com uraeus cujo diâmetro é superior ao comprimento da cabeça.

Material: Bronze

Atitude: marcha; pernas da esquerda avançadas em relação às da direita.

Descrição: touro em atitude de marcha sobre base retangular baixa sem inscrições. Disco com uraeus com diâmetro superior ao comprimento da cabeça do touro e entre chifres longos em "V" (?). Triângulo na fronte. Decoração lombar e do pescoço incisas. Olhos amendoados dispostos na diagonal. As orelhas localizam-se na linha anterior dos chifres e logo acima dos olhos. Focinho pequeno, abreviado, e com boca indicada por uma retração na parte frontal deste. A papada, antes de desenvolver um percurso quase que retilíneo até logo abaixo do peito, apresenta uma leve saliência após o maxilar. Da parte inferior do tórax até a extremidade do sexo, o perfil é arqueado e ascendente. Logo em seguida, ele continua com seu perfil arqueado até a virilha, porém, com orientação descendente. A linha dorsal desenha uma reta paralela à base até a metade do manto para então subir até $\mathrm{o}$ alto da cabeça. As pernas são alongadas e trazem linhas rústicas e rígidas. Os cascos consistem em um alargamento das pernas junto à base. O perfil resultante é o de um torso magro, alongado e posicionado muito acima da base. A cauda desce verticalmente acompanhando o perfil da perna posterior direita á qual está unida.

$\mathrm{O}$ artefato traz linhas rústicas e suas proporções fogem à harmonia dos melhores exemplares. Contudo, a simbologia que o associa a Ápis está completa e seu estado de conservação está satisfatório, apesar da fratura na parte anterior, logo após as pernas dianteiras.
Altura: $7,2 \mathrm{~cm}$

Comprimento: $7 \mathrm{~cm}$

Largura: -

Triângulo: sim.

Colar: -

Imagem alada I: disco ?; asas constituídas de duas camadas de plumagem, estendidas sobre os ombros cujas extremidades alcançam a linha do focinho.

Manto: sim; um retângulo disposto perpendicularmente em relação à linha dorsal decorado em seu interior com linhas diagonais cruzadas. Em suas extremidades é arrematado por franjas.

Imagem alada II: abutre; asas constituídas de duas camadas de plumagem, estendidas sobre as ancas e parte superior das coxas cujas extremidades alcançam a linha do focinho.

Coleção: Londres, British Museum.

No de Inventário: EA (?) 61614

Origem: desconhecida.

Datação: Período Tardio-Período Ptolemaico (?).

Outras particularidades:

Outros dados da bibliografia:

Bronze (with copper-gloss)

Bibliografia sobre o referido bronze:

G.J.F. Kater-Sibbes, M. J. Vermaseren Apis I, p. 59, n ${ }^{\circ}$ 453; Pr. CXLVI 453. 


\begin{tabular}{|c|c|}
\hline & $\begin{array}{l}\text { Altura: } 5,5 \mathrm{~cm} \text { (sem pino de fixação) } \\
\text { Comprimento: } 5,7 \mathrm{~cm} \\
\text { Largura: - }\end{array}$ \\
\hline & $\begin{array}{l}\text { Triângulo: sim } \\
\text { Colar: - } \\
\begin{array}{l}\text { Imagem alada I: escaravelho (?) com asas estendidas } \\
\text { formadas por duas camadas de plumagem } \\
\text { cujas extremidades ultrapassam a linha } \\
\text { inferior do manto e alcançam o peito do } \\
\text { touro. }\end{array}\end{array}$ \\
\hline $\begin{array}{ll}\text { Entre os chifres: } & \text { disco com uraeus maior que o comprimento } \\
& \text { da cabeça e entortado para trás. }\end{array}$ & $\begin{array}{l}\text { Manto: sim; retângulo disposto diagonalmente em relação ao } \\
\text { dorso decorado por um padrão de linhas transversais } \\
\text { cruzadas. }\end{array}$ \\
\hline $\begin{array}{l}\text { Material: bronze? } \\
\text { Atitude: marcha; pernas da esquerda avançadas em relação às } \\
\text { da direita. }\end{array}$ & $\begin{aligned} & \text { Imagem alada II: } \text { (?) traços visíveis sobre o lombo, mas } \\
& \text { pouco precisos. Característica não } \\
& \text { mencionada na ficha do museu. }\end{aligned}$ \\
\hline $\begin{array}{l}\text { Descrição: touro em marcha sobre base retangular baixa sem } \\
\text { inscrições. Disco solar entortado para trás, porém maior que o } \\
\text { comprimento da cabeça, com serpente uraeus destacada, e entre } \\
\text { chifres em "V" (?). Decoração lombar incisa, sem incrustações } \\
\text { e muito apagada. Triângulo na fronte. Olhos arredondados } \\
\text { incisos, com pálpebras e direcionados para frente. As orelhas } \\
\text { localizam-se na região da nuca e acima da linha dos olhos. Do } \\
\text { pescoço junto à cabeça desenha-se uma papada curva cuja } \\
\text { proeminência se ressalta na parte do tórax entre as pernas } \\
\text { dianteiras e abaixo da linha do abdômen. Os cascos estão } \\
\text { parcialmente visíveis e as pernas traseiras exibem contornos } \\
\text { mais próximos aos da anatomia bovina que as dianteiras. O } \\
\text { abdômen é quase que paralelo à base, e da virilha se projeta o } \\
\text { sexo. A cauda está, aparentemente, unida à perna traseira direita } \\
\text { e desce perpendicular até próximo à base. O dorso é desenhado } \\
\text { por uma linha arqueada aberta, que encontra um aclive no início } \\
\text { dos ombros e daí se dirige ao alto da cabeça. O tronco é bem } \\
\text { modelado e seu volume na região dos ombros evoca virilidade. }\end{array}$ & $\begin{array}{l}\text { Coleção: Paris, Musée du Louvre. } \\
\text { No de Inventário: N } 3761 \text { e; o catálogo Apis II faz } \\
\text { menção somente ao número N } 3761 . \\
\text { Origem: ? (não mencionada na ficha do museu) } \\
\text { Datação: Período Tardio-Período Ptolemaico (?). } \\
\text { Outras particularidades: } \\
\text { Outros dados na ficha do museu: } \\
\qquad 506 \text { Cat } 405 \text { (genre Serap (?.)) } \\
\text { D } 3262\end{array}$ \\
\hline $\begin{array}{l}\text { incisões já bastante apagadas. Observam-se traços de oxidação, } \\
\text { principalmente no alto da base. Ainda assim, é um artefato que } \\
\text { moldado com respeito às proporções e exibe certa elegância nas } \\
\text { formas. Está fixa a uma base moderna. }\end{array}$ & $\begin{array}{l}\text { Bibliografia sobre o referido bronze: } \\
\text { G. J. F. Kater-Sibbes, M. J. Vermaseren, Apis II, p. } 67 \text { nº } \\
\text { 499. (não exibe fotografia) }\end{array}$ \\
\hline
\end{tabular}




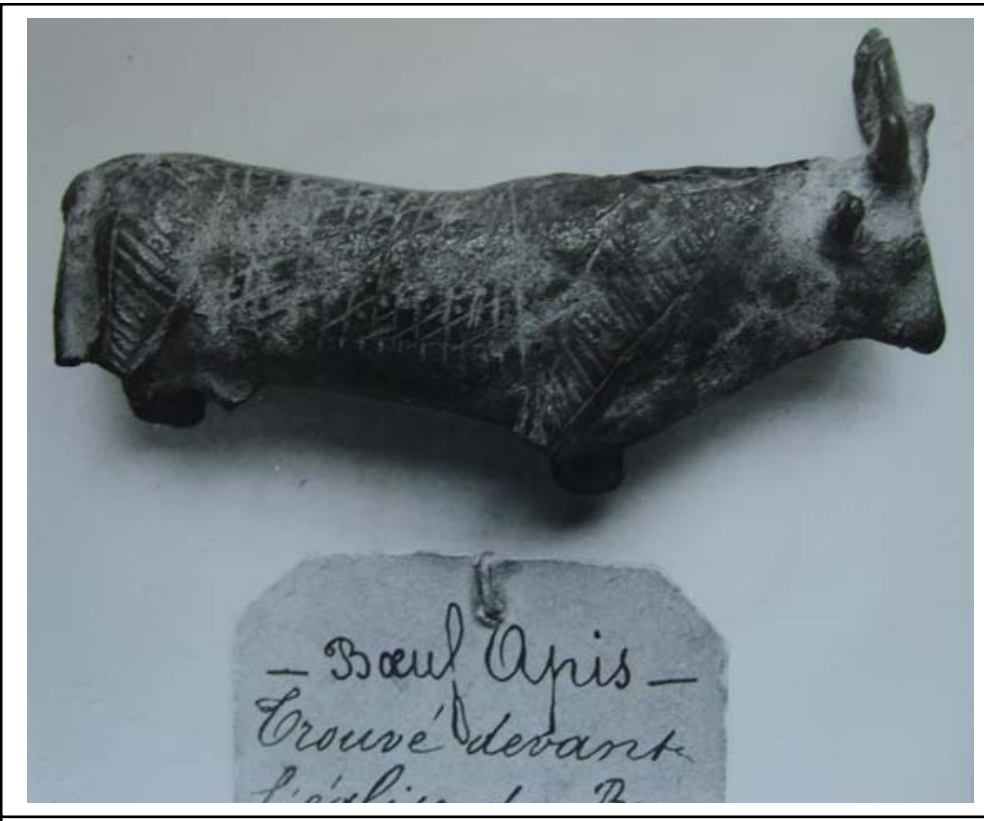

Entre os chifres: disco com uraeus cujo diâmetro é inferior ao comprimento da cabeça.

Material: Bronze?

Atitude: marcha; pernas da esquerda avançadas em relação às da direita.

Descrição: touro em marcha, pernas dianteiras quebradas logo abaixo do tronco. Base perdida. Disco com uraeus com diâmetro menor do que o comprimento da cabeça e entre os chifres em crescente. Triângulo frontal inciso. Decoração lombar gravada com linhas amplas e sem incrustações que parece ter sido feita em duas etapas: a primeira, através do molde e que trouxe sulcos mais afeiçoados, e a segunda, com incisões sobre a estatueta já pronta e que revelam traços secos e menos precisos. Olhos grandes, arredondados e com pálpebras. As orelhas localizam-se na linha da nuca e acima da altura dos olhos. A cabeça apresenta um perfil triangular com traços delicados e um focinho pequeno onde parece estar presente uma boca. A papada se confunde com o perfil do pescoço, que desce da base do maxilar até pouco abaixo do nível do tórax. Desse ponto, descreve uma reta até a virilha onde o sexo, quebrado, está presente. Mesmo quebradas, percebe-se que as pernas traseiras são estreitas, não exibindo coxas muito grandes, e as frontais procuram espelhar a musculatura bovina. A linha dorsal, desenha um perfil retilíneo e paralelo à linha do abdômen até o início dos ombros, onde ganha um leve impulso ascendente que culmina no cimo da cabeça. Em toda essa área que se propaga até a fronte e a parte inferior do pescoço o artefato apresenta uma falha que revela seu núcleo. Cauda pendente quebrada logo no seu início. O tronco é mais alongado do que o usual e contrasta com as proporções da cabeça e das coxas.

Apesar de ter sido encontrado em território francês - circunstâncias e contexto não conhecidos - o artefato revela um parentesco com as imagens egípcias de Ápis, ainda que certas particularidades de suas proporções, como comprimento do corpo, e figuração rústica da simbologia deixem a desejar diante dos melhores exemplares. Contudo, observa-se nesta estatueta um esforço de se equiparar à estas.
Altura: $4,5 \mathrm{~cm}$

Comprimento: $7,65 \mathrm{~cm}$

Largura: -

Triângulo: sim

Colar: -

Imagem alada I: sim; símbolo não identificado na ficha do museu. As asas se estendem do alto dos ombros até a altura do peito, acompanhando, no caso do lado direito, a perna frontal. A plumagem está representada estilizada por meio de traços inclinados e paralelos.

Manto: sim; um retângulo disposto perpendicularmente à linha dorsal é decorado por linhas transversais paralelas que se cruzam em um motivo xadrez. No interior de cada um dos losangos formados por essa trama há um ponto. A borda inferior é decorada com uma franja.

Imagem alada II: disco ?; as asas se estendem do alto das ancas até a linha da virilha, mas posicionada na região posterior das coxas. A plumagem está representada estilizada por meio de traços inclinados e paralelos.

Coleção: Paris, Musée du Louvre.

$\mathrm{N}^{0}$ de Inventário: E 22263

Origem: ? A etiqueta do artefato diz ter sido encontrado diante da igreja de Brou, em Bourg-em-Bresse (Ain)

Datação: Período Tardio-Período Ptolemaico (?).

Outras particularidades:

Outros dados na ficha do museu:

AE026241

Noyau visible par une large gente dans le cou.

Musée Guimet 476

7983

Bibliografia sobre o referido bronze: 


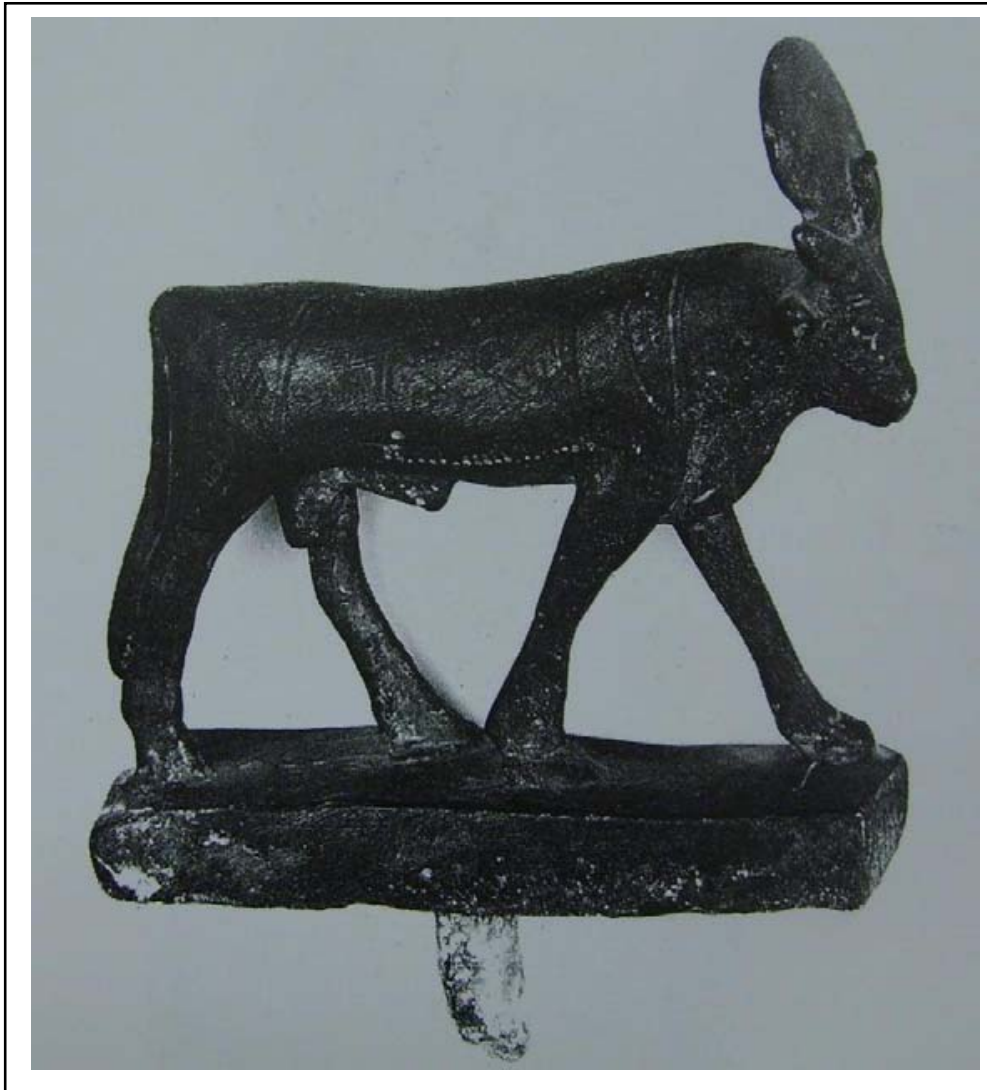

Entre os chifres: disco com uraeus com diâmetro semelhante ao comprimento da cabeça.

Material: Bronze.

Atitude: marcha; pernas esquerdas avançadas em relação às da direita.

Descrição: touro em atitude de marcha sobre base retangular alta com um pino de fixação na parte central inferior. Disco com uraeus entre chifres em "V" e com diâmetro semelhante ao comprimento da cabeça. Triângulo na fronte inciso, assim como as imagens sobre o resto do corpo. Olhos amendoados com pálpebras e sobrancelhas (?) e orelhas acima da altura destes e atrás da linha dos chifres. A cabeça e focinho pequenos dão um ar de docilidade ao animal sagrado. A papada desenvolve uma ondulação que desce abaixo do peito. A linha torácico-abdominal desenvolve um percurso paralelo à base até entre as pernas traseiras, de onde se destaca o sexo. O perfil dorsal desenvolve uma ligeira elevação sobre as ancas e desce de forma ainda mais suave até sobre o manto, onde ganha uma orientação ascendente até o início do pescoço, para daí despencar até o cimo da cabeça. As pernas são volumosas, exibem com elegância as particularidades da anatomia bovina e os cascos estão bem indicados pelos volumes e linhas que os definem. A cauda aparentemente desce acompanhando a perna posterior direita até pouco acima dos cascos.

O artefato, em notável estado de conservação, exibe formas elegantes e um nível de detalhamento que o classifica entre os melhores exemplares. Ainda que sem inscrições, dá para identificá-lo como um Ápis pela presença da simbologia recorrente em outros bronzes dessa divindade.
Altura: $7,8 \mathrm{~cm}$.

Comprimento: $7,5 \mathrm{~cm}$.

Largura: -

Triângulo: sim.

Colar: -

Imagem alada I: abutre; asas estendidas sobre os ombros, compostas por três (?) camadas de plumagem e com extremidades localizadas acima da linha do manto.

Manto: sim; formado por um retângulo posicionado perpendicularmente em relação à linha dorsal e decorado com um padrão de linhas paralelas e cruzadas formando uma rede (?). Nas extremidades inferiores apresenta uma franja de contas fusiformes.

Imagem alada II: escaravelho alado; asas estendidas sobre as ancas, compostas por três (?) camadas de plumagem e com extremidades localizadas acima da linha do manto.

Coleção: Amiens, Musée de Picardie.

$\mathrm{N}^{0}$ de Inventário: M.P. 3057.313

Origem: Saqqara, Serapeum.

Datação: Período Tardio

Outras particularidades:

Outros dados da bibliografia:

Dita proveniente das escavações de Mariette no Serapeum de Mênfis em 1822.

Bibliografia sobre o referido bronze:

O. Perdu, E. Rickal La Collection Égyptienne du Musée de Picardie, p. 117, $\mathrm{n}^{\circ} 200$. 


\begin{tabular}{|c|c|}
\hline & $\begin{array}{l}\text { Altura: } 6,8 \mathrm{~cm} \\
\text { Comprimento: } 7,6 \mathrm{~cm} \\
\text { Largura: } 1,9 \mathrm{~cm}\end{array}$ \\
\hline & 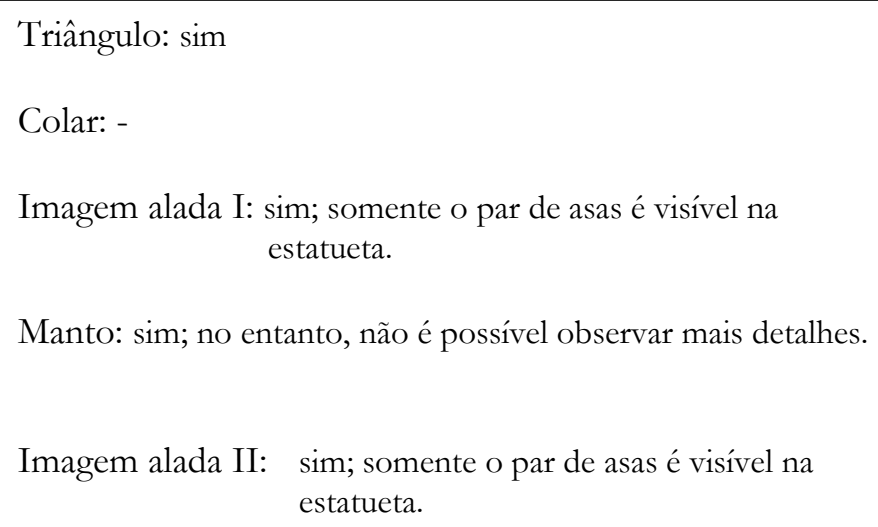 \\
\hline $\begin{array}{ll}\text { Entre os chifres: } & \text { disco com uraeus de tamanho superior ao } \\
& \text { comprimento da cabeça. }\end{array}$ & \\
\hline $\begin{array}{l}\text { Material: metal cuproso. } \\
\text { Atitude: marcha; pernas da esquerda avançadas em relação às da } \\
\text { direita. }\end{array}$ & $\begin{array}{l}\text { Coleção: Angers, Musée Pincé. } \\
\text { No de Inventário: MTC } 694\end{array}$ \\
\hline $\begin{array}{l}\text { Descrição: touro em marcha sobre base retangular baixa e sem } \\
\text { inscriçôes. Disco solar com diâmetro superior ao comprimento da } \\
\text { cabeça, entre chifres em "V" (?) e serpente uraeus ao centro e acima } \\
\text { destes. Triângulo frontal inciso. Decoração lombar e do colar incisas, } \\
\text { sem incrustações e tal como o triângulo, muito apagadas devido ao } \\
\text { estado de conservação da imagem. Os detalhes da face estão } \\
\text { apagados, mas percebem-se as feições delicadas do focinho e da } \\
\text { cabeça. As orelhas aparentemente localizam-se na linha anterior dos } \\
\text { chifres e na altura dos olhos. O pescoço é retilíneo e ligeiramente } \\
\text { inclinado para baixo até o ponto onde se desenvolve uma papada que } \\
\text { ganha uma forte sinuosidade abaixo do peito, ao qual vem se unir } \\
\text { somente atrás das pernas frontais. A linha que compõe o abdômen é } \\
\text { praticamente paralela à base e a única perturbação à sua harmonia se } \\
\text { faz pela representação do sexo, projetado a partir da virilha. As pernas } \\
\text { são esbeltas e proporcionais e os cascos são indicados pelos volumes } \\
\text { próximo à base. A linha dorsal é paralela à do abdômen com exceção } \\
\text { da região das ancas - onde apresenta um defeito de fabricação que } \\
\text { expõe o núcleo arenoso da peça - e a partir dos ombros, onde ganha } \\
\text { um aclive sensível até o início do pescoço. Daí, em outro ângulo } \\
\text { ascendente, caminha até o alto da cabeça. Sobre o pescoço se fixa um } \\
\text { apêndice que se liga à parte anterior do disco. Sua função não é muito } \\
\text { clara dada à conservação do artefato, mas pode ter sido simplesmente }\end{array}$ & $\begin{array}{l}\text { Origem: desconhecida. } \\
\text { Datação: Período Tardio-Período Ptolemaico. } \\
\text { Outras particularidades: } \\
\text { Outros dados da bibliografia: } \\
\text { Estado de conservação medíocre, bastante erodido, corrosão de } \\
\text { metal: a peça apresenta sobre o flanco esquerdo um buraco que } \\
\text { deixa aparecer um núcleo arenoso que teria servido à fabricação do } \\
\text { objeto. A má conservação se deve provavelmente a esse núcleo onde a } \\
\text { umidade teria feito rachar o envelope. }\end{array}$ \\
\hline $\begin{array}{l}\text { um suporte para o simbolo solar, a representaçao de uma menat ou } \\
\text { ambos. A cauda desce perpendicularmente acompanhando o perfil da } \\
\text { perna posterior direita. } \\
\text { Apesar de seu estado de conservação bastante deteriorado, é possível } \\
\text { observar o esmero na busca pelos volumes do touro e a intenção de } \\
\text { dar-lhe certa graça por meio de membros pouco musculosos e um } \\
\text { focinho pequeno. Embora os sinais estejam muito apagados, é } \\
\text { possível concluir por seu conjunto de que o animal representado é um } \\
\text { Ápis. }\end{array}$ & $\begin{array}{l}\text { Bibliografia sobre o referido bronze: } \\
\text { B. Affholder-Gérard, M.-J. Cornic, Angers, Musée Pincé, p.52, } \\
\mathrm{n}^{\circ} 17 .\end{array}$ \\
\hline
\end{tabular}




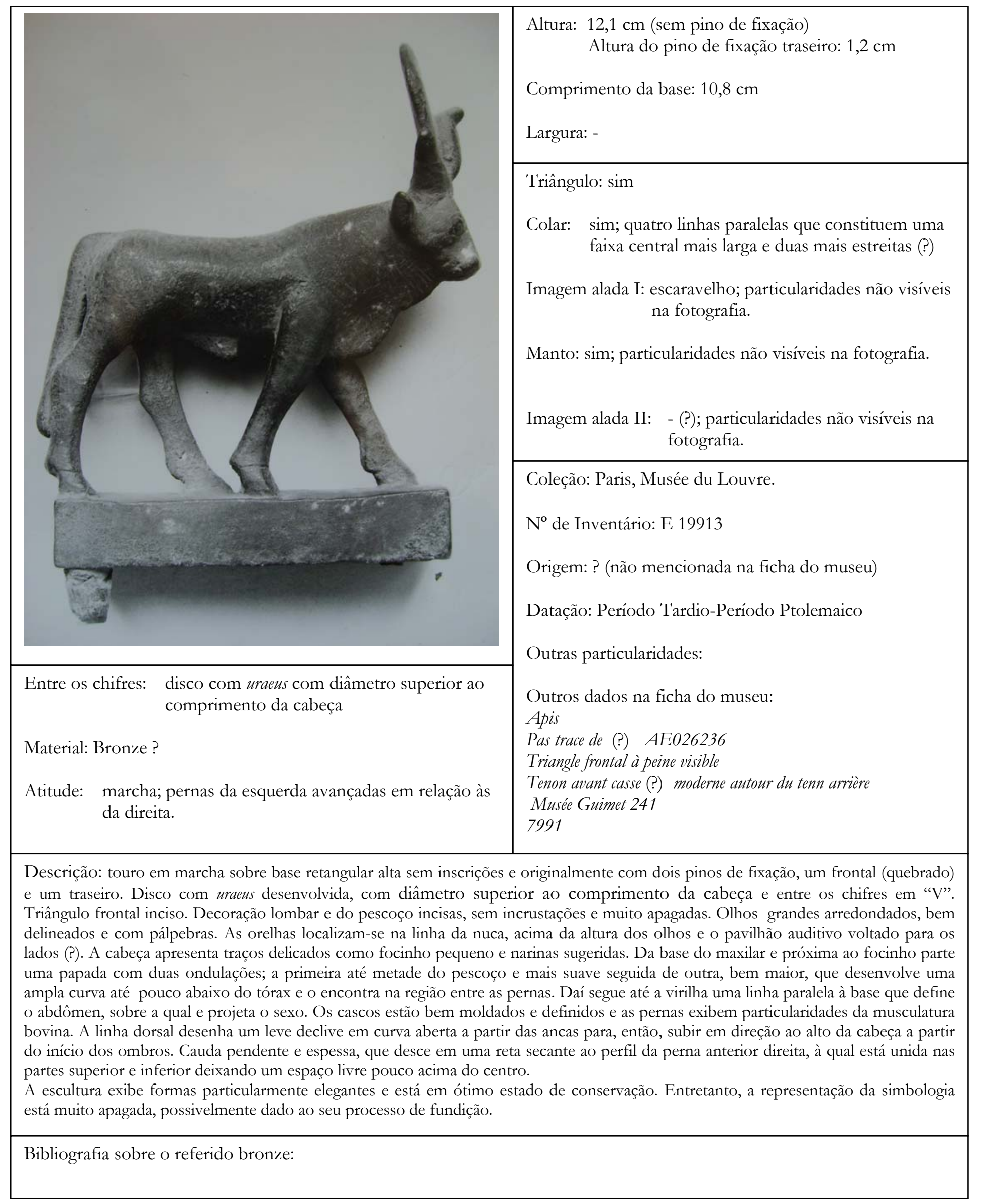




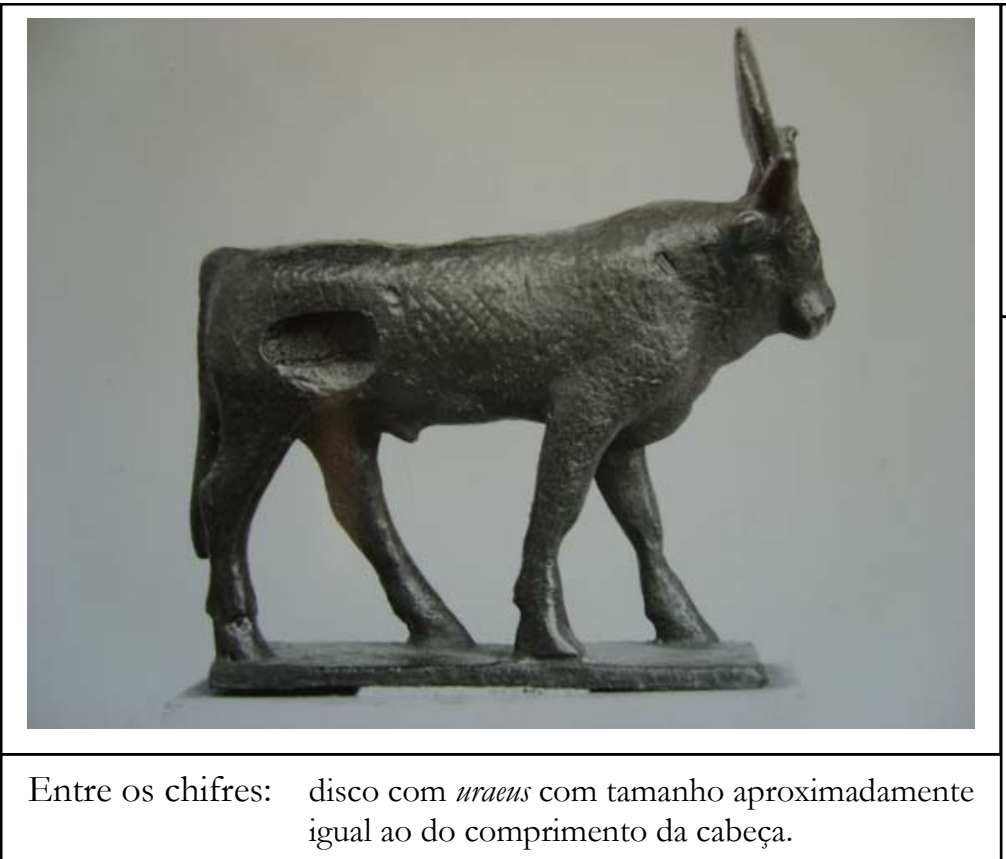

Material: bronze?

Atitude: marcha; pernas da esquerda avançadas em relação às da direita.

Descrição: touro em marcha sobre base retangular baixa sem inscrições. Disco com uraeus com diâmetro aproximadamente igual à medida do comprimento da cabeça e entre os chifres em "V" (?). Decoração do colar e lombar incisa, sem incrustações e muito deteriorada. Triângulo na fronte. Olhos grandes amendoados e bem delineados. As orelhas, inclinadas para baixo, localizam-se nas linhas da nuca e do canto superior dos olhos. A cabeça apresenta traços delicados, com o focinho bem modelado, e da base do maxilar parte uma papada com três estágios: tanto o primeiro quanto o segundo desenham curvaturas suaves, sendo a primeiro mais aberto e se estende até para além da metade do pescoço. O segundo daí parte e se encaminha até o início do tórax onde, após uma leve reentrância, se desenvolve a terceira parte da papada, que desce da linha do peito para encontrar a altura do abdômen somente depois das pernas dianteiras. Este último descreve um perfil quase paralelo à base cujo percurso só é afetado pela representação do falo que, neste caso, não é tão volumoso. Os cascos estão relativamente bem definidos e os membros locomotores respeitam as particularidades da anatomia bovina, especialmente a musculatura superior das pernas frontais. Contudo, o artefato contém defeitos de fundição que se revelam tanto na coxa da perna posterior direita até quase o início do manto quanto acima da perna anterior da mesma face. A linha dorsal, tal como a do abdômen, é quase paralela à base até o início dos ombros, onde ganha uma proeminência que culmina no alto da cabeça. Cauda pendente e espessa, que desce perpendicularmente numa reta secante ao contorno da perna posterior direita, à qual pode estar unida. Sua extremidade se encontra longe da base.

A estatueta encontra-se em um estado bastante deteriorado e é possível que já apresentasse muitos desses problemas na antiguidade, tais como as superfícies irregulares mas não propriamente ásperas e os orifícios presentes no lado direito. Ainda assim, o artefato revela um porte elegante e apresenta a simbologia que é própria aos Ápis.
Altura: $9,2 \mathrm{~cm}$ (sem pino de fixação)

Altura do pino de fixação sob centro da base: $2 \mathrm{~cm}$

Comprimento: $9 \mathrm{~cm}$

Largura: -

Triângulo: sim

Colar: sim; particularidades não visíveis.

Imagem alada I: escaravelho; a extremidade das asas parece se projetar para além da linha do focinho, alcançando a parte frontal do alto das pernas dianteiras.

Manto: sim; aparentemente um retângulo disposto perpendicularmente ao dorso é decorado por um padrão de linhas na diagonal, formando um xadrez

Imagem alada II: -(?)

Coleção: Paris, Musée du Louvre.

$\mathrm{N}^{\mathrm{o}}$ de Inventário: N 5164e

Origem: ? (Não mencionada na ficha do museu)

Datação: Período Tardio-Período Ptolemaico (?).

Outras particularidades:

Outros dados na ficha do museu:

AE008330

Bronze creux

Pas de patine verte.

No. 496 sous socle

Reserve des colonnes

496 Cat.

D3267

Bibliografia sobre o referido bronze:

G. J. F. Kater-Sibbes, M. J. Vermaseren, Apis II, p. $70 \mathrm{n}^{\circ}$ 514. (não apresenta fotografia). 


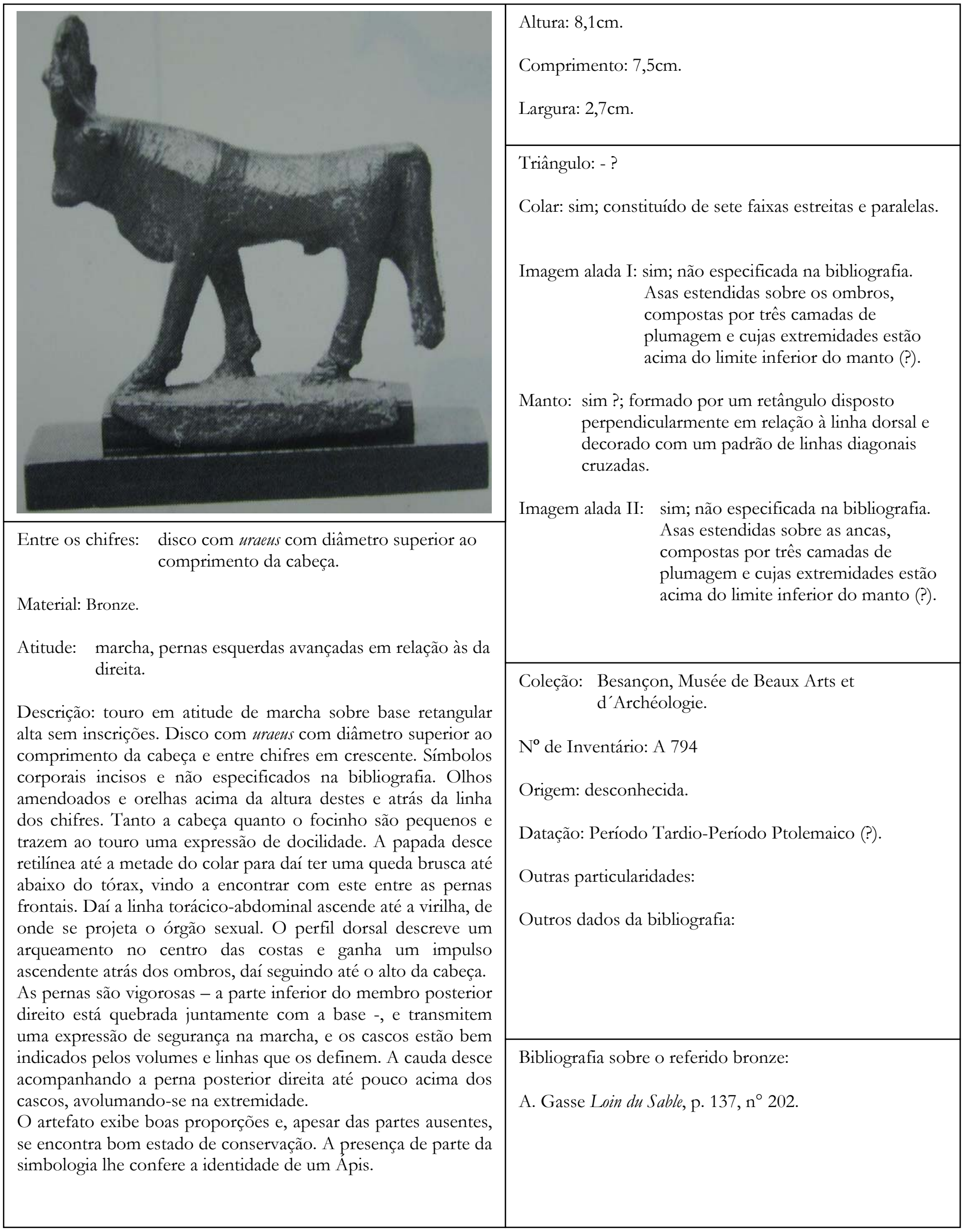




\begin{tabular}{|c|c|}
\hline & $\begin{array}{l}\text { Altura: } 5 \mathrm{~cm} . \\
\text { Comprimento: } 6,3 \mathrm{~cm} \text {. } \\
\text { Largura: } 2,5 \mathrm{~cm} .\end{array}$ \\
\hline 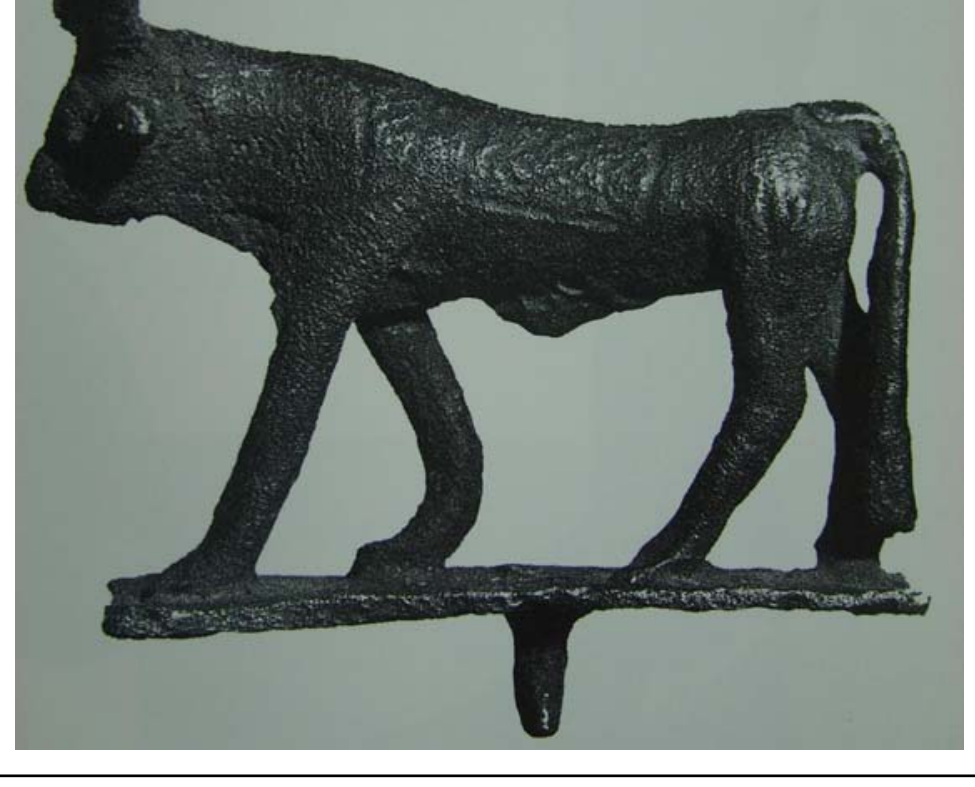 & $\begin{array}{l}\text { Triângulo: } \\
\text { Colar: - } \\
\text { Imagem alada I: sim !; asas estendidas sobre os ombros, } \\
\text { compostas de uma camada de } \\
\text { plumagem e cujas extremidades } \\
\text { ultrapassam a linha inferior do manto. }\end{array}$ \\
\hline $\begin{array}{ll}\text { Entre os chifres: } & \text { disco com uraeus com diâmetro superior ao } \\
& \text { comprimento da cabeça. }\end{array}$ & \\
\hline $\begin{array}{l}\text { Material: Bronze. } \\
\text { Atitude: marcha; pernas esquerdas avançadas em relação às da } \\
\text { direita. }\end{array}$ & $\begin{array}{l}\text { Coleção: St. Petersburg, Russia. } \\
\text { No de Inventário: A-1054 II }\end{array}$ \\
\hline $\begin{array}{l}\text { Descrição: touro em atitude de marcha sobre base retangular baixa } \\
\text { com um pino para fixação em sua parte central inferior. Disco com } \\
\text { uraeus com diâmetro superior ao comprimento da cabeça e entre } \\
\text { chifres em "V" (?). Dada a presença dos demais símbolos incisos } \\
\text { (igualmente não mencionados na bibliografia), é possível que o } \\
\text { triângulo esteja gravado na fronte. Olhos arredondados, pouco } \\
\text { definidos na modelagem e orelhas na altura destes e abaixo da linha } \\
\text { dos chifres. A cabeça pequena e o focinho abreviado passam um ar de } \\
\text { docilidade que contrasta com o corpo viril do touro. A papada se } \\
\text { confunde com o pescoço e desce em direção ao peito. A linha } \\
\text { torácico-abdominal sobe sensivelmente em direção à virilha, e o sexo } \\
\text { se destaca sobre ela por meio de uma elevação. O perfil dorsal, após } \\
\text { uma suave descida muda sua orientação a partir da região anterior do } \\
\text { manto e continua sua ascensão progressiva até o alto da cabeça. As } \\
\text { pernas são finas e os cascos estão visíveis pelos volumes. A cauda } \\
\text { acompanha a perna posterior direita somente a partir de sua metade, }\end{array}$ & $\begin{array}{l}\text { Origem: desconhecida. } \\
\text { Datação: Período Tardio-Período Ptolemaico (?). } \\
\text { Outras particularidades: } \\
\text { Outros dados da bibliografia: }\end{array}$ \\
\hline $\begin{array}{l}\text { A estatueta, apesar da impressão inicial de rusticidade, apresenta } \\
\text { detalhes notáveis como a cauda destacada e a forma da serpente no } \\
\text { disco, o que mostra que seu criador procurou estar atento aos } \\
\text { detalhes. Esta suspeita se materializa quando observamos a presença } \\
\text { dos símbolos sobre o dorso e, possivelmente, o triângulo na testa, que } \\
\text { caracterizam a iconografia de um Ápis. }\end{array}$ & $\begin{array}{l}\text { Bibliografia sobre o referido bronze: } \\
\text { O. Berlev, S. Hodjash Catalogue of the Monuments of Ancient } \\
\text { Egypt, p.64, n¹8, pr. 89, VI. } 18 \text {. }\end{array}$ \\
\hline
\end{tabular}




\begin{tabular}{|c|c|}
\hline & $\begin{array}{l}\text { Altura: } 5,4 \mathrm{~cm} \text { (sem pino de fixação) } \\
\quad \text { Altura do pino de fixação sob centro da base: } 1,5 \mathrm{~cm} \\
\text { Comprimento: } 5,4 \mathrm{~cm} \\
\text { Largura: - }\end{array}$ \\
\hline & 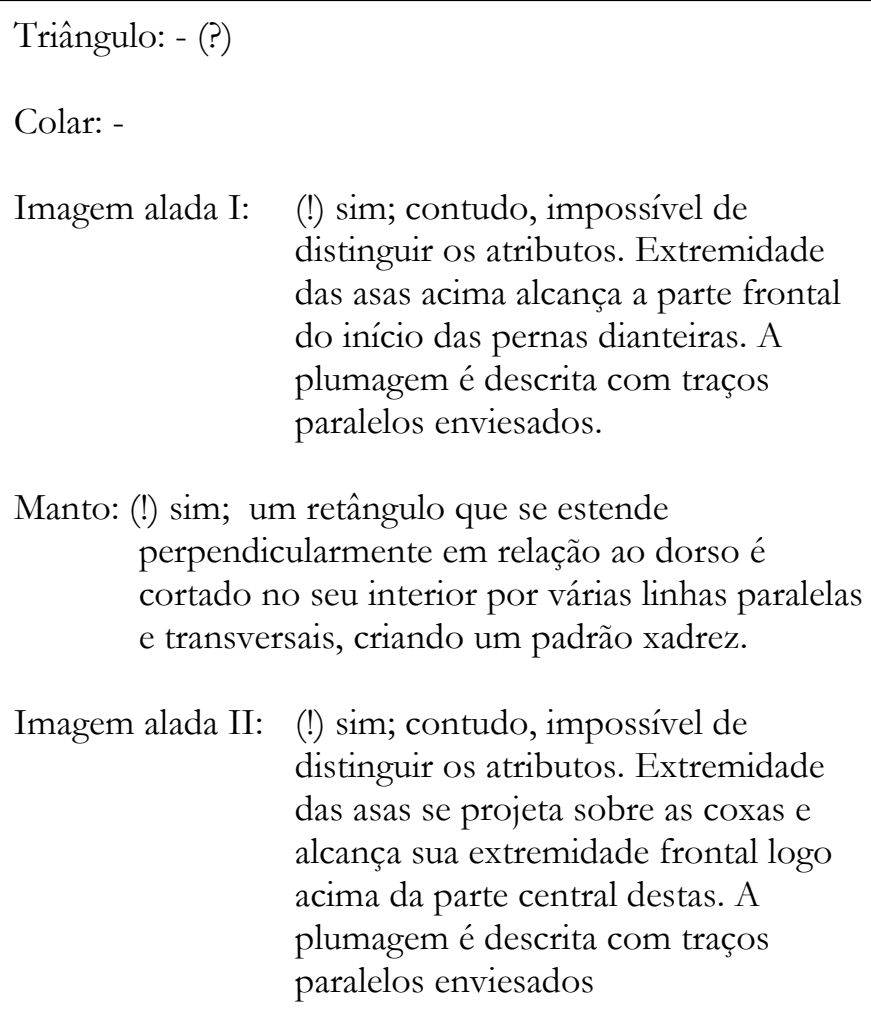 \\
\hline 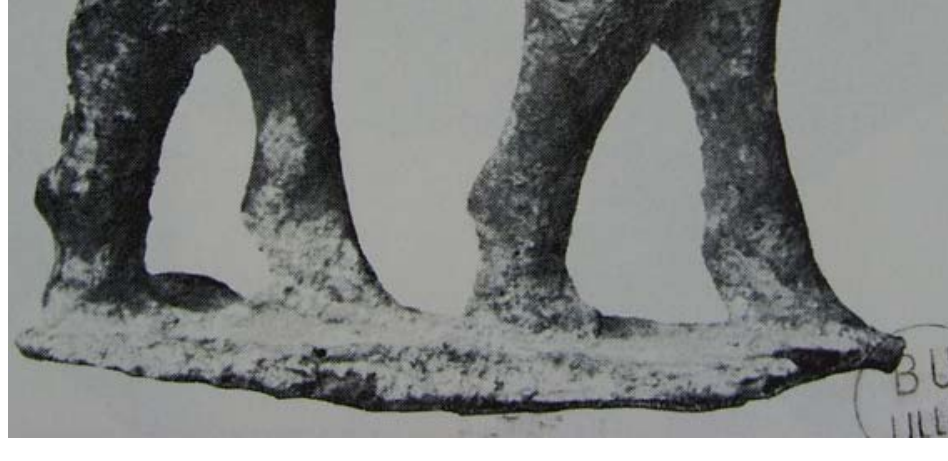 & $\begin{array}{l}\text { Coleção: Paris, Musée du Louvre. } \\
\text { No de Inventário: E } 17133 \\
\text { Origem: Serapeum. } \\
\text { Datação: Período Tardio-Período Ptolemaico (?). } \\
\text { Outras particularidades: }\end{array}$ \\
\hline $\begin{array}{ll}\text { Entre os chifres: } & \text { disco com uraeus maior que comprimento da } \\
\text { cabeça. }\end{array}$ & restauration Serapeum \\
\hline Material: bronze? & oreille $d r$. (droite) cassée \\
\hline $\begin{array}{l}\text { Atitude: marcha; pernas da esquerda avançadas em relação às } \\
\text { da direita. }\end{array}$ & Cat9 \\
\hline
\end{tabular}


Descrição: touro em marcha sobre base retangular baixa sem inscrições. Disco solar com uraeus maior que a cabeça e com acentuada inclinação para trás entre chifres em crescente (?). Decoração lombar rústica e incisa sem incrustações. Dada a presença desses símbolos, é possível que o triângulo também esteja representado na fronte. Olhos salientados mas com formas pouco claras a partir da fotografia. A cabeça apresenta boas proporções e as orelhas localizam-se no cruzamento das linhas do disco com uraeaus e dos olhos. Do maxilar desenha-se uma papada em um "S" pronunciado que termina entre as pernas dianteiras. Os cascos estão representados de maneira rústica mas as pernas procuram reproduzir contornos adequados. Sobre o alto da perna direita e prolongando-se sobre o ombro, visualiza-se uma série de quatro (?) pequenas cavidades que podem ser defeitos de fundição. A linha do abdômen descreve uma ligeira curvatura para baixo e o sexo do animal não está presente. A cauda está unida à perna traseira direita em toda a sua extensão e parece ter uma junção com a base. À linha dorsal imprime-se uma inclinação suave até antes dos ombros. Lá o aclive se acentua até o início do pescoço, onde há outra alteração no ângulo de subida até o alto da cabeça. Possui vários traços de oxidação e as superfícies são irregulares, tanto pela fundição quanto pela oxidação.

A base da figurinha está fixada em uma base moderna.

Bibliografia sobre o referido bronze:

G.J.F. Kater-Sibbes, M. J. Vermaseren Apis I, p. 8, nº 16, Pr. XVI 16. 


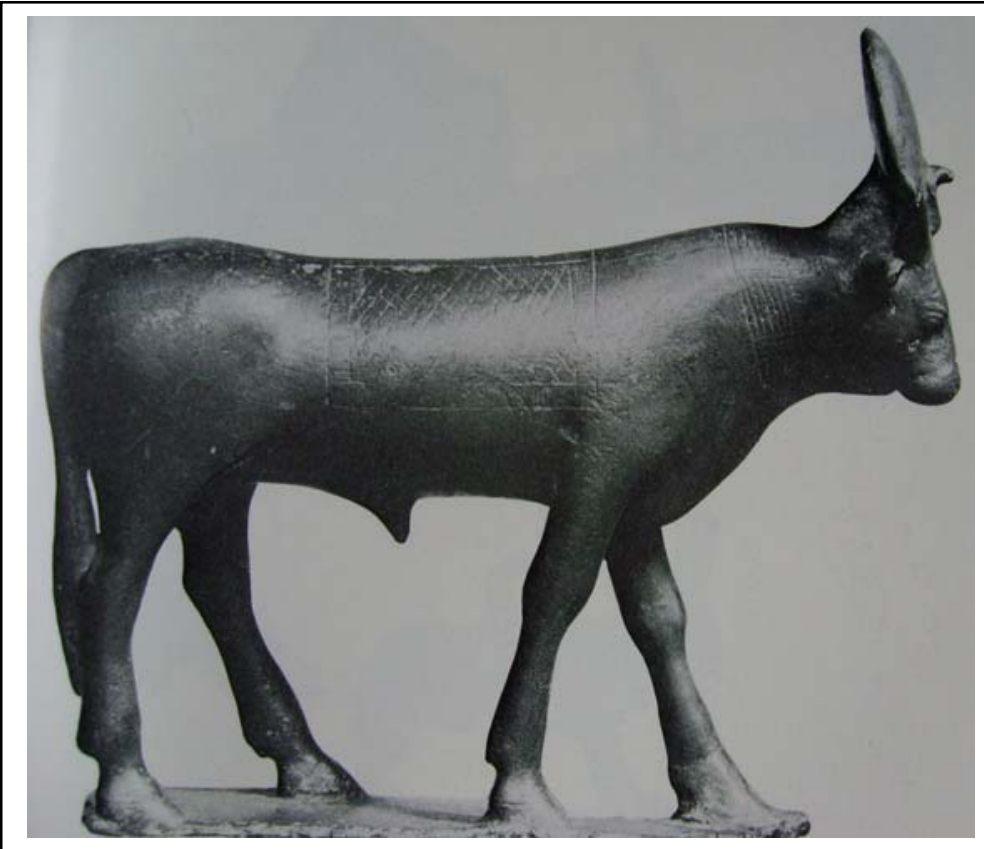

Entre os chifres: disco com uraeus cujo diâmetro é superior ao comprimento da cabeça.

Material: Bronze.

Atitude: marcha; pernas da esquerda avançadas em relação às da direita.

Descrição: atitude de marcha sobre base retangular baixa sem inscrições. Disco com uraeus com perfil lenticular, diâmetro superior ao comprimento da cabeça e entre chifres em "V" (?). Na parte traseira e anterior do disco há um prolongamento que se estende ao pescoço e que serve como reforço para que o atributo não se quebre. Triângulo na fronte. Decoração lombar e do pescoço incisas e elaboradas. Olhos amendoados, bem definidos e com pálpebras. Orelhas localizadas na linha detrás da cabeça e acima dos olhos. O focinho, como a cabeça, é pequeno, bem moldado e exibe narinas e boca discretas. O primeiro segmento da papada, logo depois da mandíbula, é paralelo à base até a extremidade superior do colar. A partir daí adquire uma curvatura descendente que ganha, em seguida, um perfil retilíneo igualmente reclinado e, por fim, contorna o peito para encontrar a linha abdominal atrás das pernas dianteiras. Esta é, grosso modo, retilínea e muito ligeiramente inclinada em direção à virilha, localizada um pouco mais acima. A representação do sexo se destaca no centro quebrando a monotonia da reta. As pernas não estão entre as mais volumosas, mas são bem modeladas e exibem bem os contornos da anatomia bovina. Os cascos são bem esculpidos e delineados. A linha dorsal, após uma elevação nas ancas, desce para a região do manto para percorrer a parte central das costas quase paralela à base. $\mathrm{Na}$ medida em que se aproxima dos ombros, ganha uma orientação ascendente para encontrar seu ápice no início do pescoço. Contudo, para alcançar o cimo da cabeça, a linha é obrigada a realizar uma descida que passa por debaixo do reforço do disco solar, conferindo a este um perfil triangular. A cauda, pendente e espessa, desce acompanhando o perfil da perna posterior direita, à qual está unida nas suas porções superior e inferior.

A estatueta é robusta e, apesar da cabeça pequena - comum nesses artefatos - é bem proporcionada e apresenta a simbologia que lhe atribui a identidade de um Ápis. As superfícies são afeiçoadas, sua conservação é muito boa e encontra-se entre os melhores exemplares.
Altura: $12,5 \mathrm{~cm}$

Comprimento (base): 10,7 cm

Largura: -

Triângulo: sim.

Colar: sim; sete bandas paralelas e de mesma largura seccionadas perpendicularmente e em intervalos regulares por três faixas.

Imagem alada I: -

Manto: sim; dois retângulos, um inscrito dentro do outro, e dispostos perpendicularmente em relação à coluna vertebral estabelecem uma moldura para uma faixa decorativa que divide o quadrilátero interno em duas metades. Em cada uma delas há um padrão de linhas cruzadas dispostas transversalmente formando uma tela.

Imagem alada II: -

Coleção: Baltimore, Walters Art Gallery.

$\mathrm{N}^{0}$ de Inventário: 54.2127

Origem: desconhecida

Datação: Período Tardio-Período Ptolemaico (?)

Outras particularidades:

Outros dados da bibliografia:

Bibliografia sobre o referido bronze:

G.J.F. Kater-Sibbes, M. J. Vermaseren Apis II, p. 44 n 378; Pr. CVIII 378.

G. Steindorff Catalogue of the Egyptian Sculpture, p. 147, $\mathrm{n}^{\circ}$ 639, pr. XCVI. 


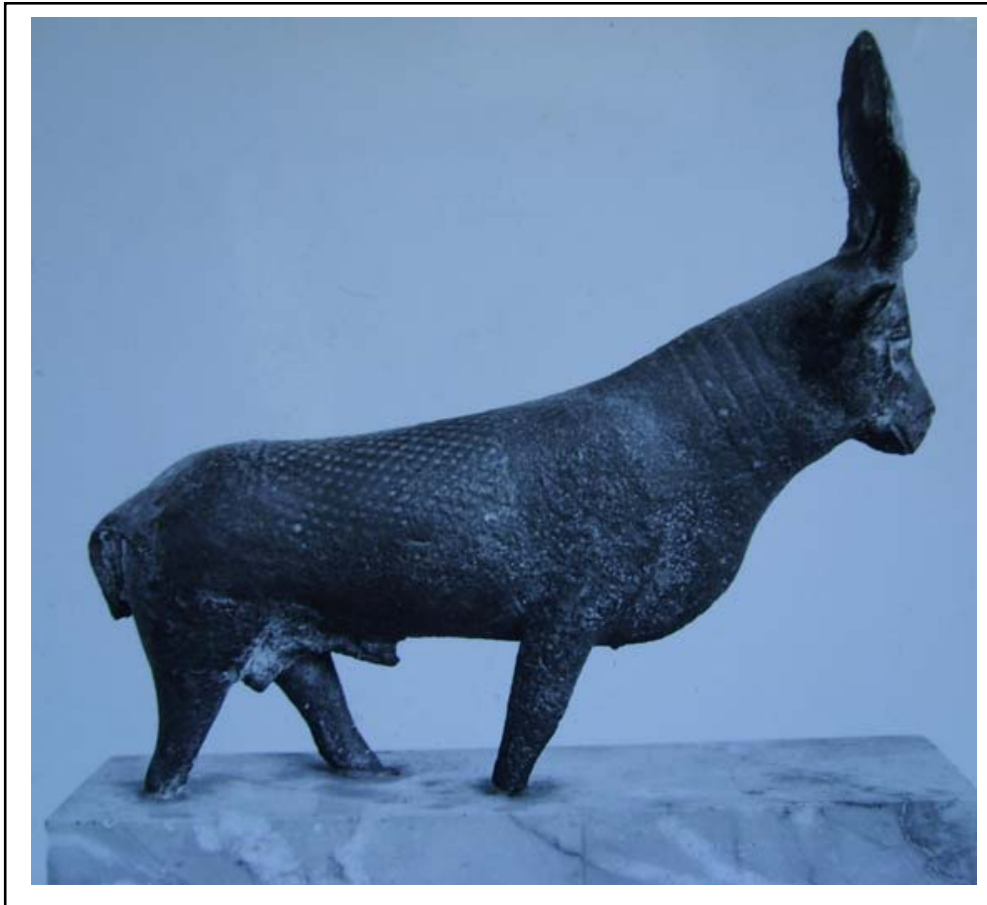

Entre os chifres: disco com uraeus maior que o comprimento da cabeça.

Material: bronze?

Atitude: marcha; pernas da esquerda avançadas em relação às da direita.

Descrição: touro em atitude de marcha; base e porção inferior das pernas traseiras e dianteira direita quebradas na altura da rótula. A perna dianteira esquerda está perdida. Disco solar com perfil lenticular e serpente uraeus maior que o comprimento da cabeça entre chifres em crescente (?). Decoração do manto e do colar incisas sem incrustações. Triângulo representado na fronte. Olhos particularmente grandes e direcionados para frente. $\mathrm{O}$ focinho e a boca estão bem indicados. As orelhas, que se encontram direcionadas para o plano dos olhos, localizam-se na linha acima destes e atrás daquela dos chifres. Do maxilar, após uma leve reentrância, desenha-se uma papada com uma leve curvatura em "S", cuja proeminência vem ao encontro do tórax. Apesar dos danos às pernas, observa-se pelas partes sobreviventes que estas foram bem moldadas e que as formas da musculatura estão indicadas, tal como pode ser notado na junção da perna dianteira direita ao tronco. A linha do abdômen descreve um levíssimo aclive em direção à virilha, de onde avança o sexo do touro. A cauda está quebrada no alto, o que indica que, ao menos, uma boa porção dela estava destacada da perna traseira direita. A linha dorsal desenvolve desde o seu começo na altura da anca uma linha ascendente que se pronuncia no início do pescoço e segue até o alto da cabeça. Além das fraturas, a estatueta possui uma superfície marcada por vários traços de oxidação. No entanto, é visível a qualidade estética do objeto nas suas proporções, elegância postural e na reprodução de suas particularidades.
Altura: $11,6 \mathrm{~cm}$

Comprimento: $13,4 \mathrm{~cm}$

Largura: -

Triângulo: sim

Colar: sim; constituído por três bandas paralelas formadas por quatro linhas.

Imagem alada I: -

Manto: sim; constituído por um retângulo (?) que se estende perpendicularmente em relação ao dorso da estatueta e cujo interior é decorado por um padrão pontilhado disposto no cruzamento de linhas diagonais.

Imagem alada II: -

Coleção: Paris, Musée du Louvre.

No de Inventário: N 3761

Origem: ? (não mencionada na ficha do museu)

Datação: Período Tardio-Período Ptolemaico (?).

Outras particularidades:

Outros dados na ficha do museu:

Reserve des colonnes

489 (comme les $n^{\circ} \mathrm{N}$ de Benedite)

D 3271

Bibliografia sobre o referido bronze: 


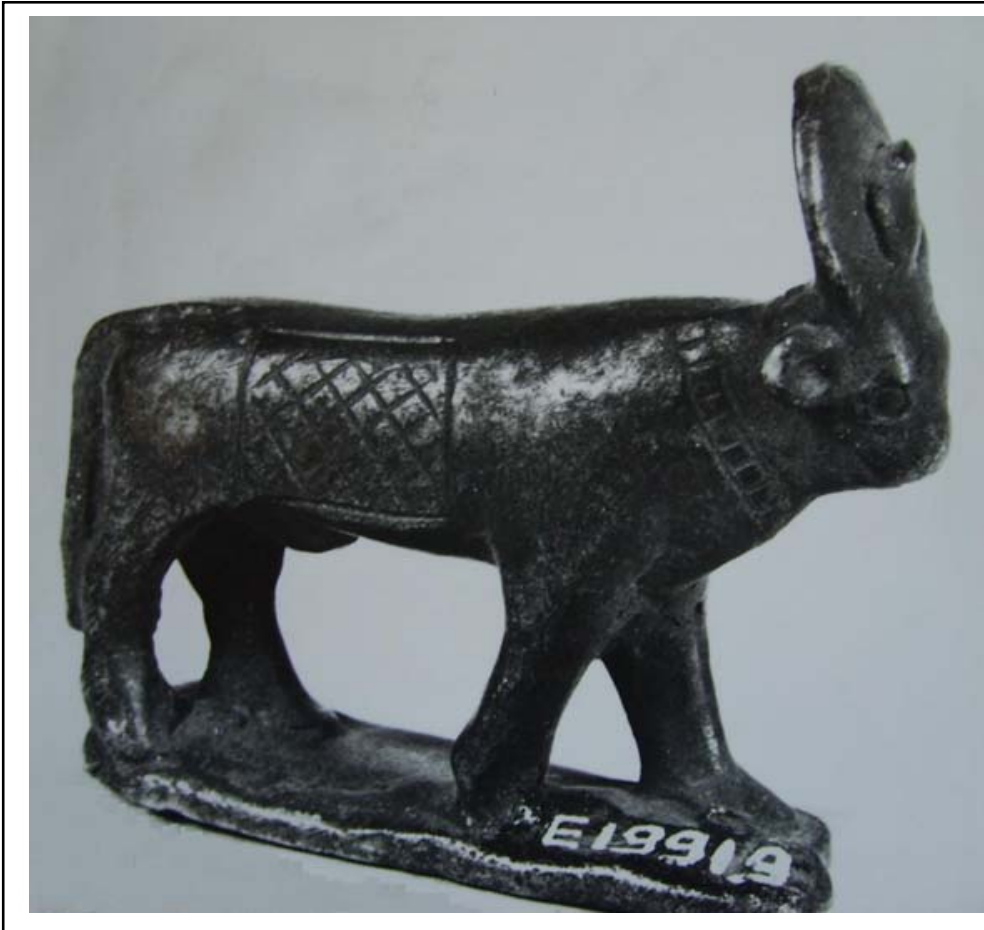

Entre os chifres: disco com uraeus com diâmetro superior ao comprimento da cabeça.

Material: Bronze

Atitude: marcha; pernas da esquerda avançadas em relação às da direita.

Descrição: touro em marcha sobre base aproximadamente retangular baixa e sem inscrições. Disco com uraeus com diâmetro maior do que o comprimento da cabeça, entre os chifres pequenos em crescente. Decoração do manto e do colar com linhas profundas, sem incrustações e com desenhos estilizados. Olhos arredondados e simplificados. As orelhas localizam-se na linha da nuca e ligeiramente acima da altura dos olhos. A cabeça é pequena e apresenta um focinho abreviado. O pescoço desenha uma linha reta descendente até pouco acima do colar a partir de onde a papada ganha certo destaque com uma leve curvatura até a altura do peito. Daí parece desenvolver uma paralela à base até a virilha, onde ganha a representação do sexo. Os cascos estão indicados pelos volumes junto à base e as pernas são compactas. A linha dorsal desenha um percurso quase que retilíneo até o início dos ombros onde ganha um leve aclive que só se pronuncia pouco depois do colar para atingir o cimo da cabeça. Cauda pendente e espessa, que desce em uma reta (?) secante ao perfil da perna posterior direita, à qual está unida.

Mesmo que rústica quanto à apresentação de seus detalhes, o que se explica por suas dimensões diminutas, a escultura exibe boas proporções, superfícies lisas e procura inspiração em artefatos mais elaborados.
Altura: $5,5 \mathrm{~cm}$ (com pino de fixação)

Comprimento da base: $3,8 \mathrm{~cm}$

Largura: -

Triângulo: - (?); não dá para se afirmar pela fotografia.

Colar: (!) sim; composta por uma banda decorada perpendicularmente por pequenos traços.

Imagem alada I: -

Manto: (!) sim; um retângulo disposto perpendicularmente à linha dorsal que contém, nessa região, uma faixa no mesmo sentido que divide seu interior em duas partes. Estas exibem padrões laterais em xadrez compostos por linhas transversais.

Imagem alada II: -

Coleção: Paris, Musée du Louvre.

No de Inventário: E 19919

Origem: desconhecida.

Datação: Período Tardio-Período Ptolemaico.

Outras particularidades:

Outros dados na ficha do museu:

Taureau - Apis

Musée Guimet

Bronze (três jaune cuivre)

AE034152

$88-43$

Bibliografia sobre o referido bronze: 


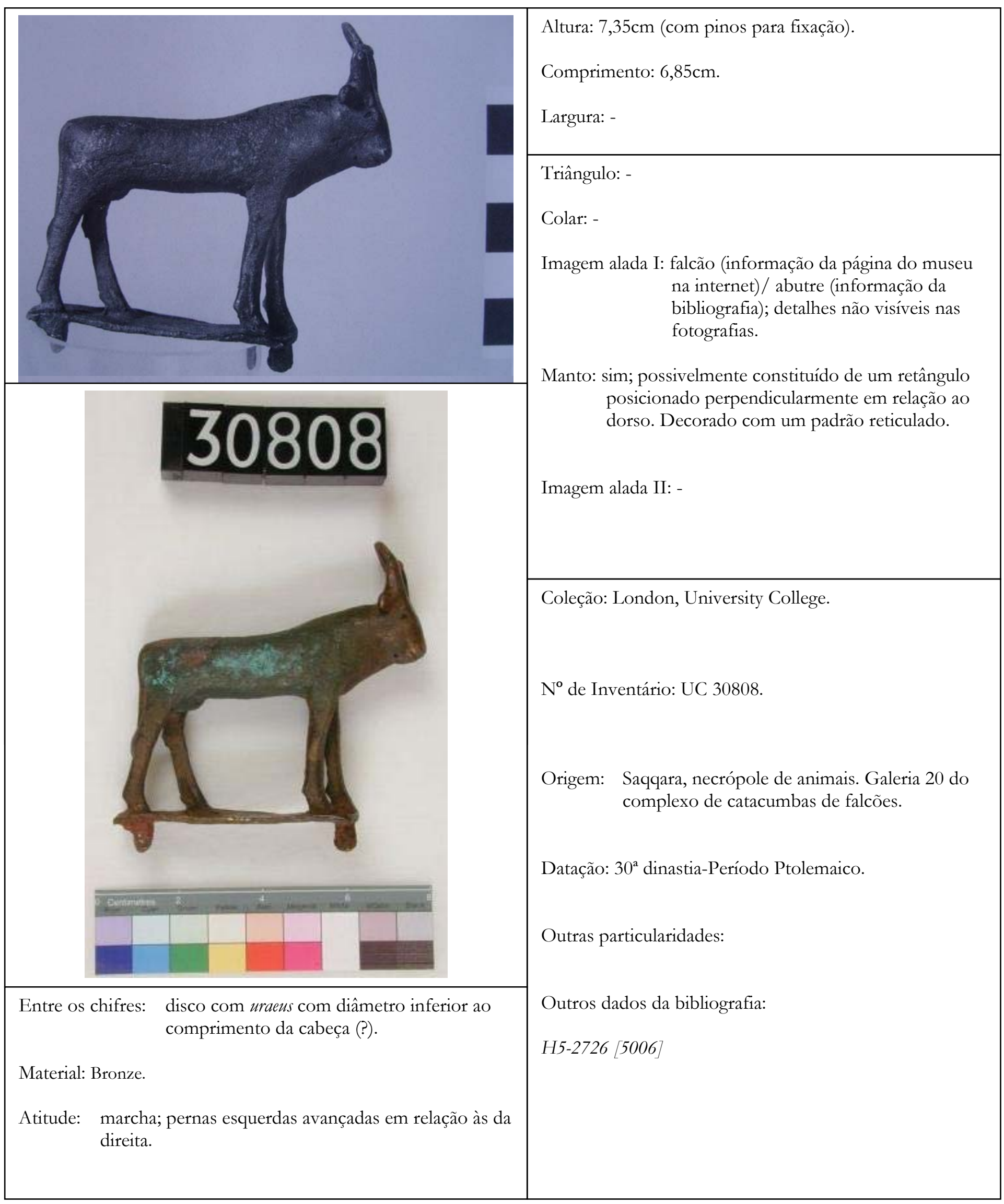


Descrição: $\quad$ touro em atitude de marcha sobre base baixa com dois pinos para fixação em sua parte inferior frontal e traseira. Disco com uraeus com diâmetro aparentemente inferior ao comprimento da cabeça e entre chifres em "V". Alguns símbolos incisos estão visíveis, como o falcão sobre os ombros e o manto. A cabeça é pequena e o focinho praticamente não existe, sendo uma ligeira curvatura para além da linha do pescoço. A boca e as narinas estão indicadas por traços. Os olhos são descritos com pontos e as orelhas encontram-se no alto da cabeça e abaixo da região anterior do chifres. A papada se confunde com o pescoço e desce sem interrupções até a área do peito. Daí a linha torácico-abdominal continua até a virilha em um percurso paralelo à base e sobreposta pelo sexo. O perfil dorsal acompanha o abdominal até antes dos ombros, quando realiza um arqueamento ascendente até o cimo da cabeça. As pernas são finas como as de um animal jovem e as posteriores transmitem mais senso de movimento que as frontais. Os cascos estão bem indicados pelos volumes e a cauda acompanha a perna posterior direita até pouco depois de sua parte mediana.

$\mathrm{O}$ artefato exibe um corpo alongado no centro, um acabamento rústico e superfícies bastante oxidadas. No entanto, procura em suas formas as proporções de um touro jovem e, pela presença de parte da simbologia de um Ápis, é possível que originalmente a tivesse completa e atualmente, devido à ação do tempo, não seja possível observá-la.

Bibliografia sobre o referido bronze:

S. Davis, H. S. Smith The Sacred Animal Necropolis: The Falcon Complex, p.122 FCO 458, pr. LXIc FCO 458.

http://www.petrie.ucl.ac.uk/detail/details/index no login.php?objectid=UC30808\&accesscheck $=\% 2 \mathrm{Fdetail} \% 2 \mathrm{Fdetails} \% 2$ Findex.php 


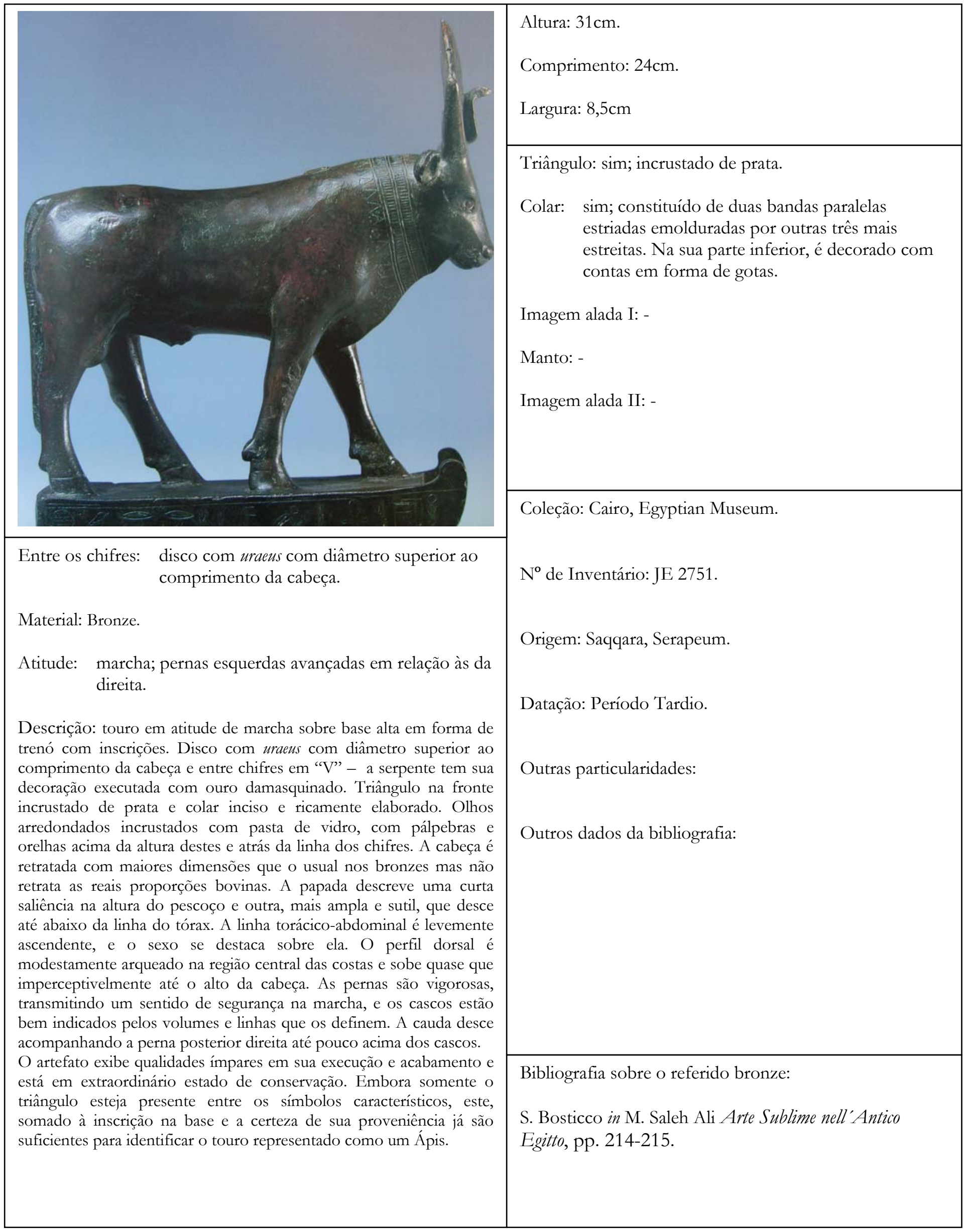




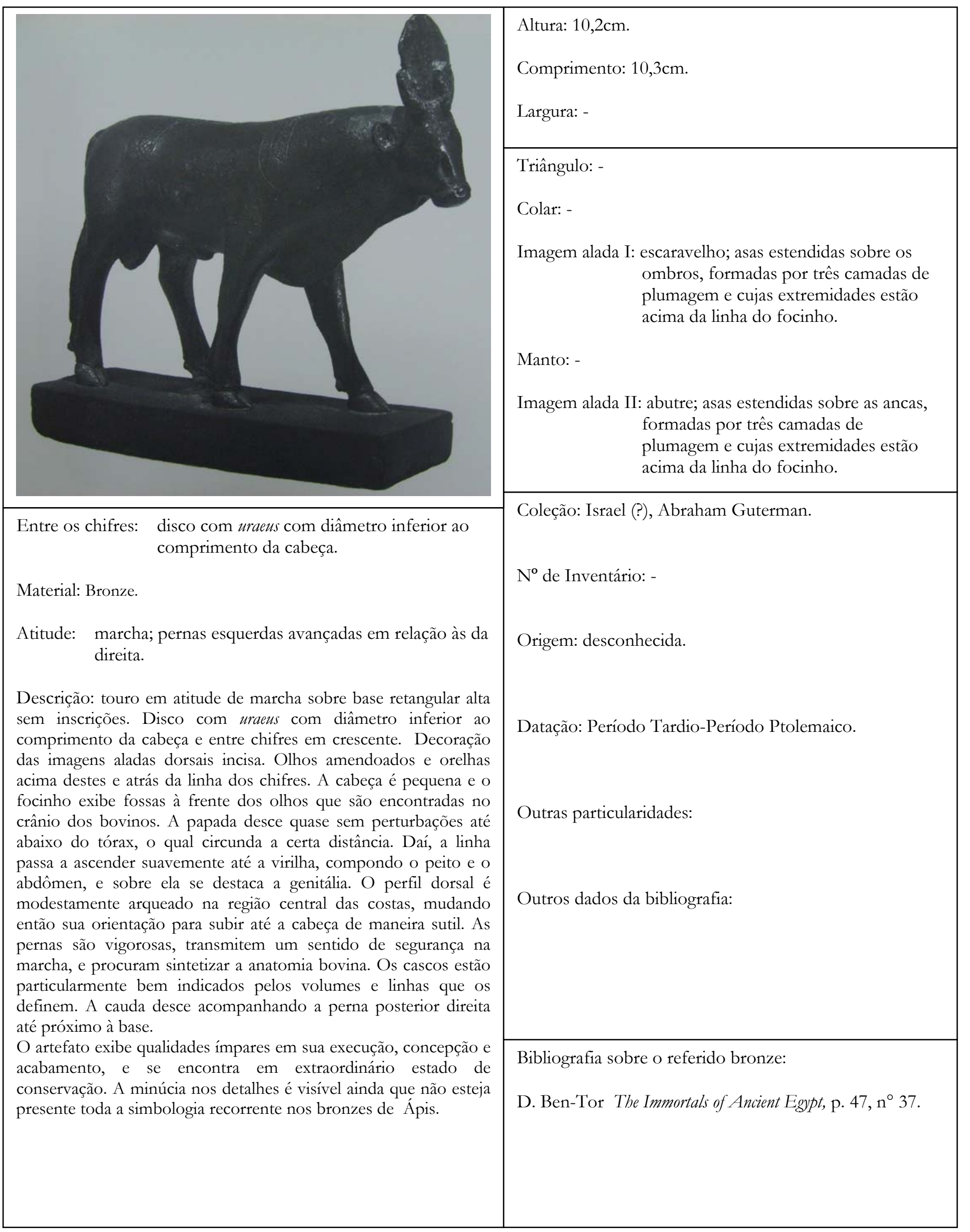




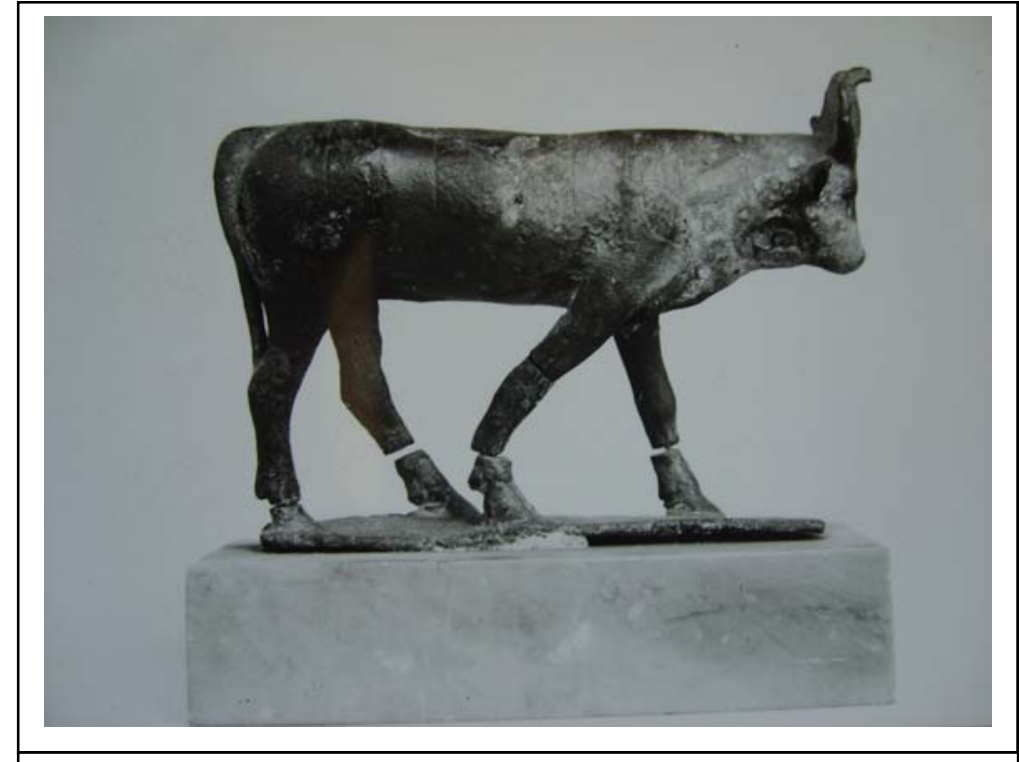

Entre os chifres: disco pequeno com uraeus.

Material: Bronze?

Atitude: marcha; pernas da esquerda avançadas em relação às da direita

Descrição: touro em marcha sobre base retangular fina sem inscrições. Disco em pequenas proporções de onde se destaca a serpente uraeus aparentemente entre chifres em crescente. Triângulo frontal inciso. Decoração lombar incisa, sem incrustações e muito deteriorada. Os olhos estão bem delineados e a cabeça apresenta traços delicados, de onde parte uma papada com duas leves ondulações, uma a partir da queixada e outra do início do pescoço. Os cascos estão bem definidos, mas as pernas estão quebradas pouco acima deles - a perna anterior direita apresenta outra fratura na sua porção mediana. O pescoço apresenta uma grande corrosão ou defeito de fundição circular na sua parte inferior do lado direito. Cauda pendente, afinada, e unida (?) à perna posterior direita. O sexo não está presente. As orelhas estão presentes, na parte posterior da cabeça e à altura dos olhos.

Apesar de seu estado de conservação, estatueta é encorpada e exibe proporções elegantes.

A estatueta encontra-se fixada em uma base moderna.
Altura: $7,7 \mathrm{~cm}$ (com pino ?)

Comprimento: $10,5 \mathrm{~cm}$

Largura: -

Triângulo: sim

Colar: ? o início do pescoço parece apresentar uma faixa, mas seus detalhes são irreconhecíveis.

Imagem alada I: disco alado (?)

Manto: sim (detalhes difíceis de serem reconhecidos)

Imagem alada II: ? - sobre a anca é possível reconhecer o traço característico da parte superior de uma asa, mas é impossível reconhecer a particularidade da imagem.

Coleção: Paris, Musée du Louvre.

$\mathrm{N}^{0}$ de Inventário: N 5164 i

Origem: Serapeum (etiqueta)

Datação: Período Tardio-Período Ptolemaico (?).

Outras particularidades:

Outros dados na ficha do museu:

Pés quebrados

Serapeum Cat. 492

Referência da fotografia: 03271

Bibliografia sobre o referido bronze:

G.J.F. Kater-Sibbes, M. J. Vermaseren Apis I, p. 7, n 9. (Não apresenta fotografia) 


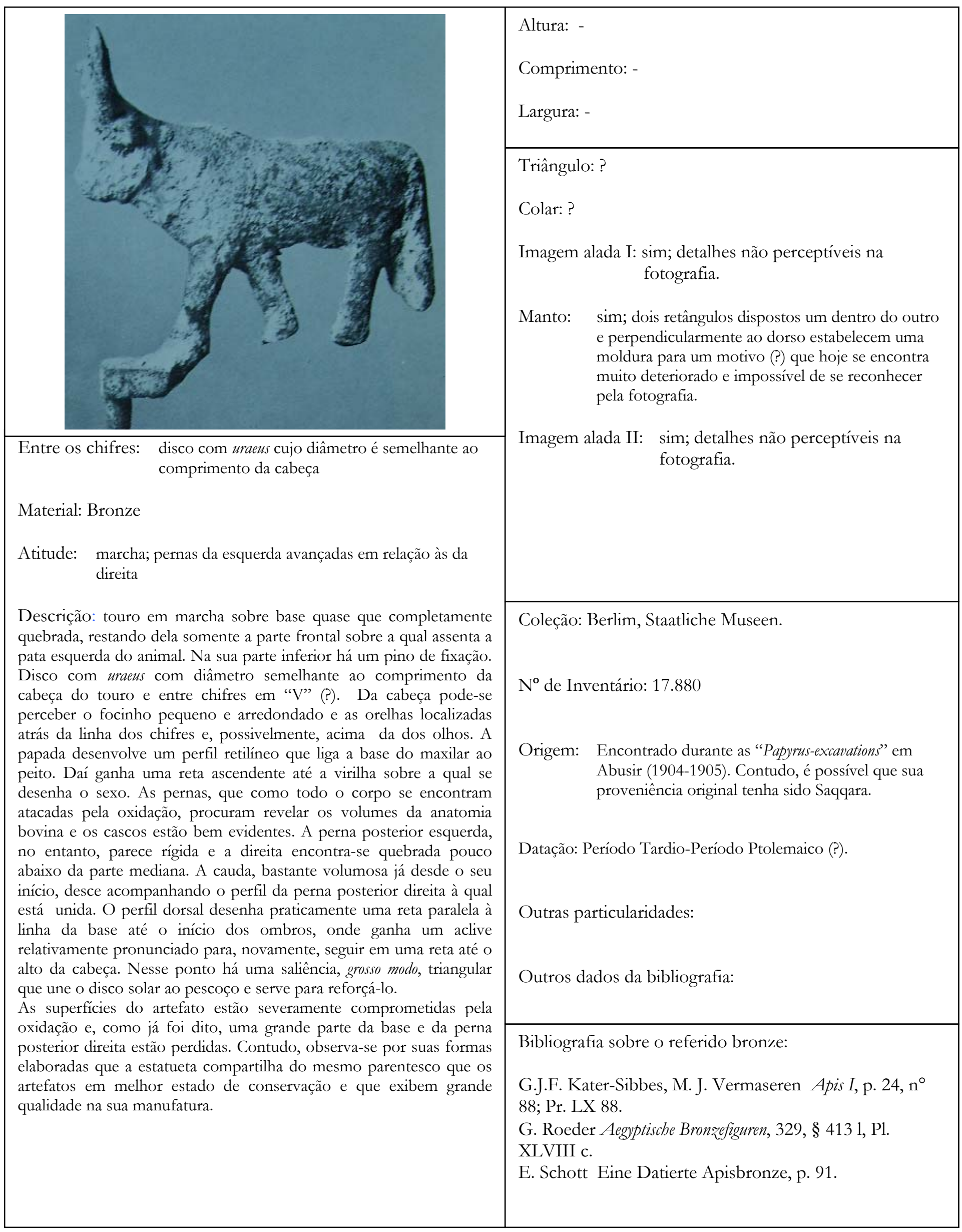




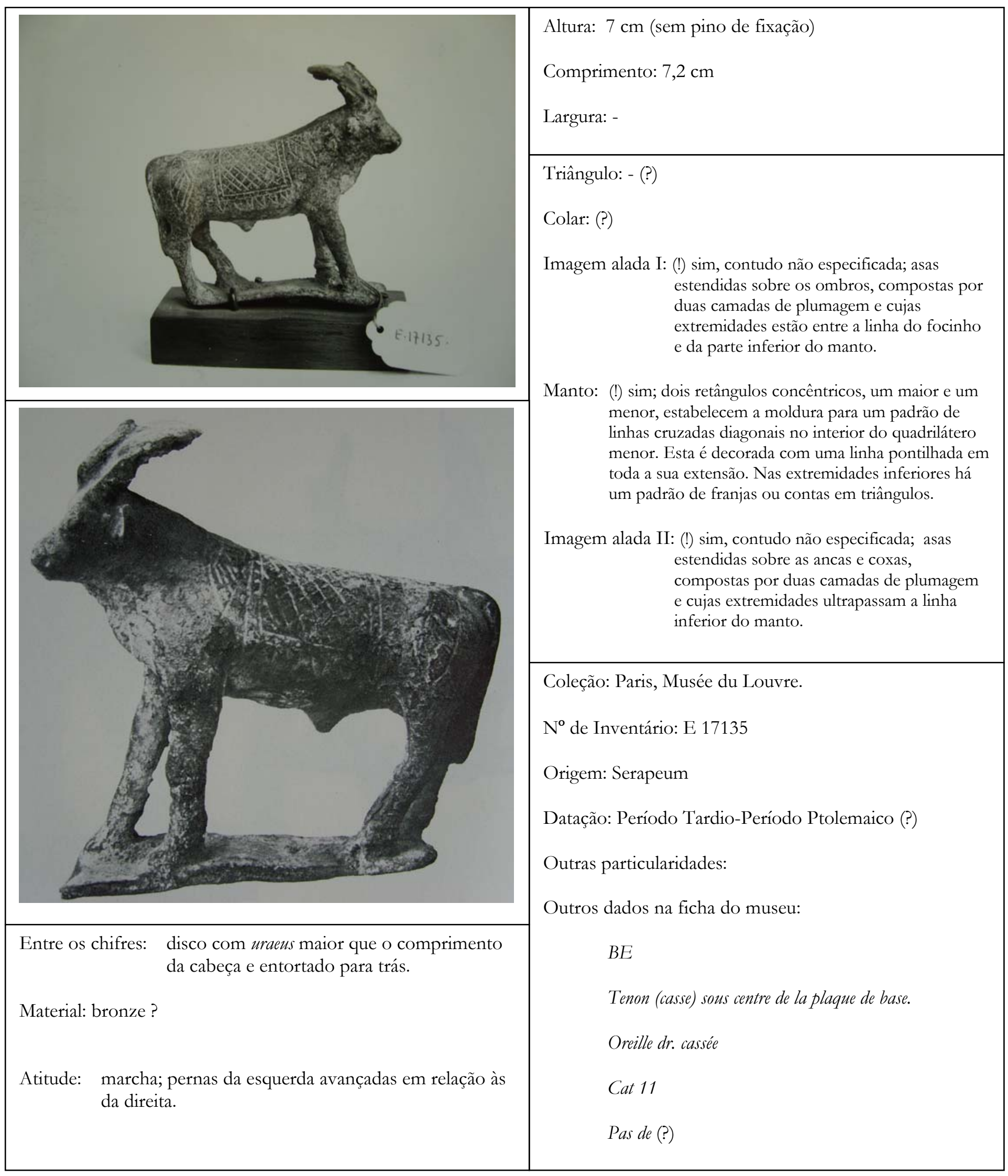


Descrição: touro em marcha sobre base retangular baixa sem inscrições e entortada para cima na sua porção mediana. Disco solar com uraeus maior que a cabeça, entortado para trás, e posicionado entre chifres em "V" (?). Decoração lombar e do colar (?) incisas sem incrustações. Dada a presença desses símbolos, é possível que o triângulo também esteja representado na fronte. Olhos saltados das órbitas circulares. A cabeça apresenta boas proporções e as orelhas localizam-se no cruzamento das linhas do disco com uraeaus e dos olhos. Do maxilar desenha-se uma papada em um "S" suave que termina entre as pernas dianteiras. Os cascos estão representados, embora bastante oxidados, e as pernas procuram reproduzir os contornos da anatomia bovina. A linha do tórax à virilha descreve uma ligeira curvatura para baixo e ao centro, onde se destaca o sexo do animal. A cauda está unida à perna traseira direita e sua extensão vai até a metade desta. À linha dorsal imprime-se uma inclinação suave até antes dos ombros, onde o aclive se acentua até o alto da cabeça. As superfícies estão sensivelmente ásperas devido à oxidação que se espalha por todas as partes do bronze.

A imagem está fixada em uma base moderna.

Bibliografia sobre o referido bronze:

G.J.F. Kater-Sibbes, M. J. Vermaseren Apis I, p. 9, n 20, Pr. XVIII 20. 


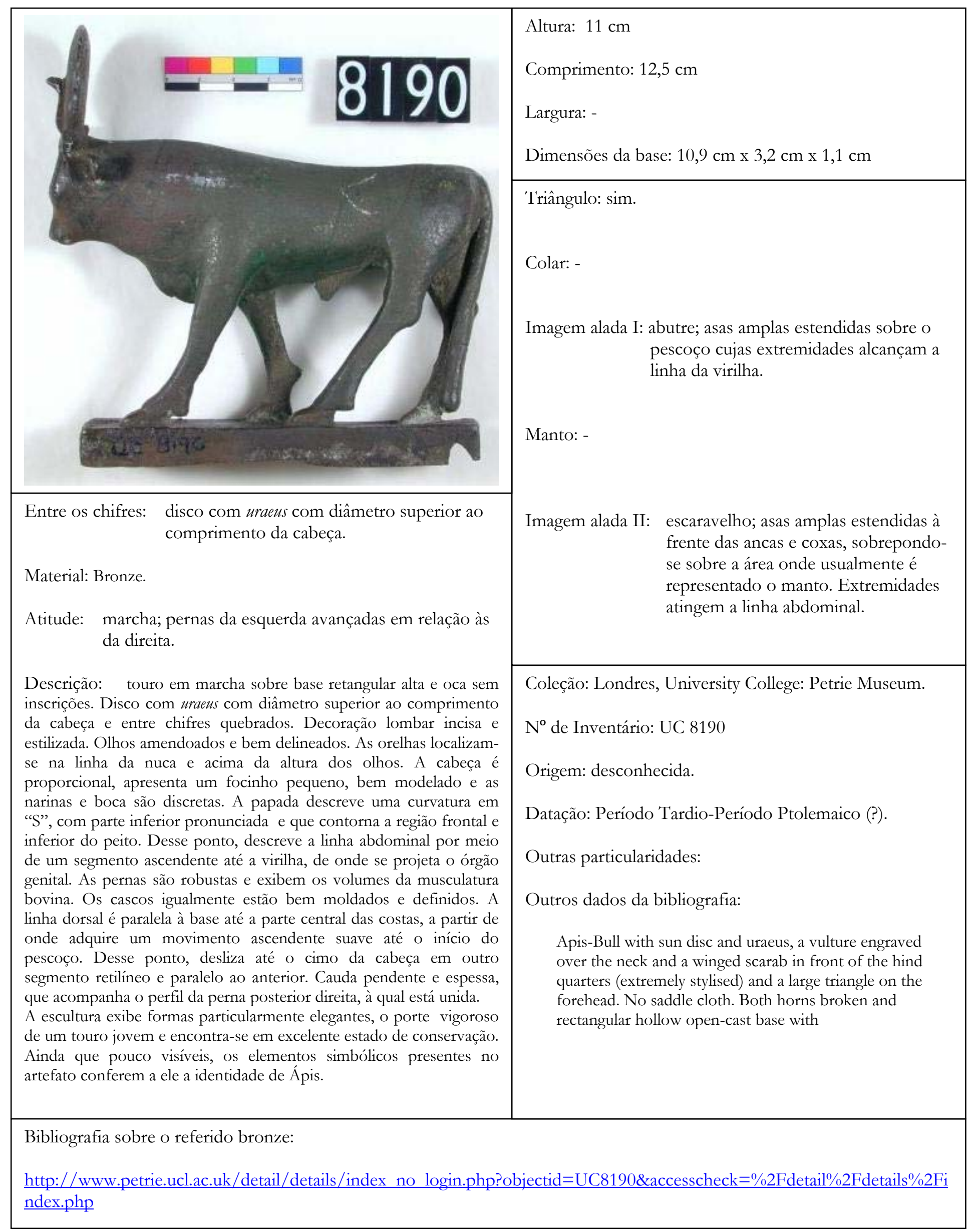




\begin{tabular}{|c|c|}
\hline & $\begin{array}{l}\text { Altura: } 6,4 \mathrm{~cm} \text { (com base) } \\
\text { Comprimento: } 5,1 \mathrm{~cm} \\
\text { Largura: - }\end{array}$ \\
\hline 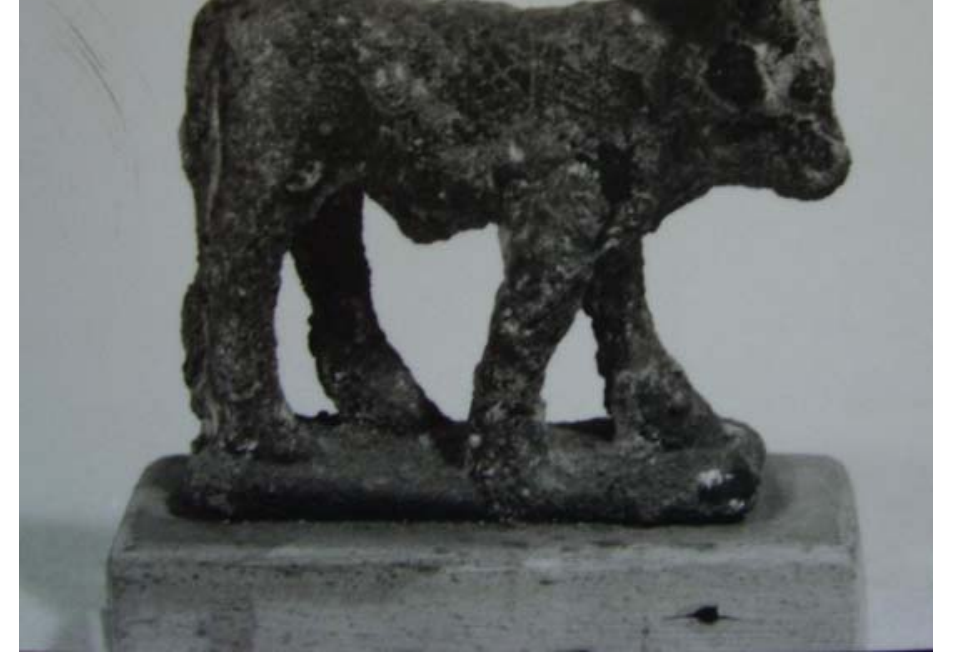 & $\begin{array}{l}\text { Triângulo: - (?) } \\
\text { Colar: - (?) } \\
\text { Imagem alada I: sim; muito oxidada para se distinguir } \\
\text { suas particularidades. Aparentemente a } \\
\text { plumagem é constituída de traços } \\
\text { paralelos dispostos longitudinalmente. }\end{array}$ \\
\hline $\begin{array}{l}\text { Entre os chifres: disco com uraeus cujo diâmetro é superior ao } \\
\text { comprimento da cabeça. }\end{array}$ & $\begin{array}{l}\text { Coleção: Paris, Musée du Louvre. } \\
\text { No de Inventário: E } 24223 \\
\text { Origem: ? (não mencionada na ficha do museu) } \\
\text { Datação: Período Tardio-Período Ptolemaico (?) } \\
\text { Outras particularidades: } \\
\text { Outros dados na ficha do museu: } \\
\text { Taureau } \\
\text { Disque solaire et uraeus } \\
\text { Quelques traces de décor incise sur le dos } \\
\text { Très oxydé } \\
\text { Legs R. Weill } 1950 \text { - } 1992 \\
\text { AE038452 } \\
\text { Réserve } \\
\text { Tardif } \\
92 \text { weill } 25\end{array}$ \\
\hline \multicolumn{2}{|l|}{ Bibliografia sobre o referido bronze: } \\
\hline
\end{tabular}




\begin{tabular}{|c|c|}
\hline & $\begin{array}{l}\text { Altura: } 5,2 \mathrm{~cm} \\
\text { Comprimento: } 5,4 \mathrm{~cm} \text {. } \\
\text { Largura: - }\end{array}$ \\
\hline & $\begin{array}{l}\text { Triângulo: sim } \\
\text { Colar: - } \\
\text { Imagem alada I: - } \\
\text { Manto: sim; um retângulo disposto perpendicularmente em } \\
\text { relação à coluna vertebral é decorado por um motivo } \\
\text { de linhas transversais cruzadas. O lado voltado para a } \\
\text { frente parece estar decorado com uma banda paralela } \\
\text { a ele. }\end{array}$ \\
\hline $\begin{array}{ll}\text { Entre os chifres: } & \text { disco com uraeus cujo diâmetro é superior ao } \\
& \text { comprimento da cabeça. }\end{array}$ & Coleção: Londres, British Museum. \\
\hline $\begin{array}{l}\text { Material: Bronze. } \\
\text { Atitude: marcha; pernas da esquerda avançadas em relação às da } \\
\text { direita. }\end{array}$ & No de Inventário: 64511 \\
\hline $\begin{array}{l}\text { Descrição: atitude de marcha sobre base retangular baixa sem } \\
\text { inscrições. Disco com uraeus com diâmetro superior ao comprimento } \\
\text { da cabeça entre chifres em "V" (?). Triângulo na fronte. O manto é o } \\
\text { único elemento decorativo inciso na região lombar. Olhos grandes e } \\
\text { amendoados. Orelhas localizadas na linha detrás dos chifres e logo } \\
\text { acima dos olhos. O focinho é bem moldado, e apresenta narinas e } \\
\text { boca discretas. A papada desenvolve duas ondulações principais: a } \\
\text { primeira se prolonga até o início do pescoço e a segunda se estende } \\
\text { até abaixo da altura do tórax, ao qual vem se juntar após uma } \\
\text { curvatura aberta atrás das pernas frontais. A linha que daí prossegue } \\
\text { até a virilha é praticamente paralela à base, sendo perturbada pela } \\
\text { representação do órgão genital. As pernas são magras e alongadas mas } \\
\text { exibem contornos que sugerem os volumes da anatomia bovina, } \\
\text { especialmente na união com o torso. Os cascos são indicados por } \\
\text { prolongamentos fundidos à base. Após uma ligeira elevação na região } \\
\text { das ancas, a linha dorsal desce para o nível do manto que é, grosso modo, } \\
\text { paralelo à base, para ganhar um perfil ascendente após o manto e } \\
\text { alcançar o seu ápice no alto dos ombros, a partir de onde ruma } \\
\text { paralelo à base até o cimo da cabeça. Vestígios da cauda são visíveis } \\
\text { sobre a perna posterior direita e é possível que ela estivesse destacada }\end{array}$ & $\begin{array}{l}\text { Datação: Período Tardio-Período Ptolemaico (?). } \\
\text { Outras particularidades: } \\
\text { Outros dados da bibliografia: } \\
\text { Anteriormente coleção Acworth. }\end{array}$ \\
\hline $\begin{array}{l}\text { do membro na sua parte central. } \\
\text { A estatueta exibe superfícies não muito afeiçoadas e parte da } \\
\text { simbologia recorrente nos artefatos que se atribui a identidade de } \\
\text { Ápis. Contudo, dada a representação do triângulo na fronte, julga-se } \\
\text { que esta seja igualmente uma imagem desse touro sagrado. Suas } \\
\text { proporções se aproximam dos melhores exemplares, apesar da } \\
\text { modelagem uma pouco mais alongada dos membros. Seu estado de } \\
\text { conservação é satisfatório. }\end{array}$ & $\begin{array}{l}\text { Bibliografia sobre o referido bronze: } \\
\text { G.J.F. Kater-Sibbes, M. J. Vermaseren Apis I, p. 61, nº } \\
\text { 464; Pr. CL } 464 .\end{array}$ \\
\hline
\end{tabular}




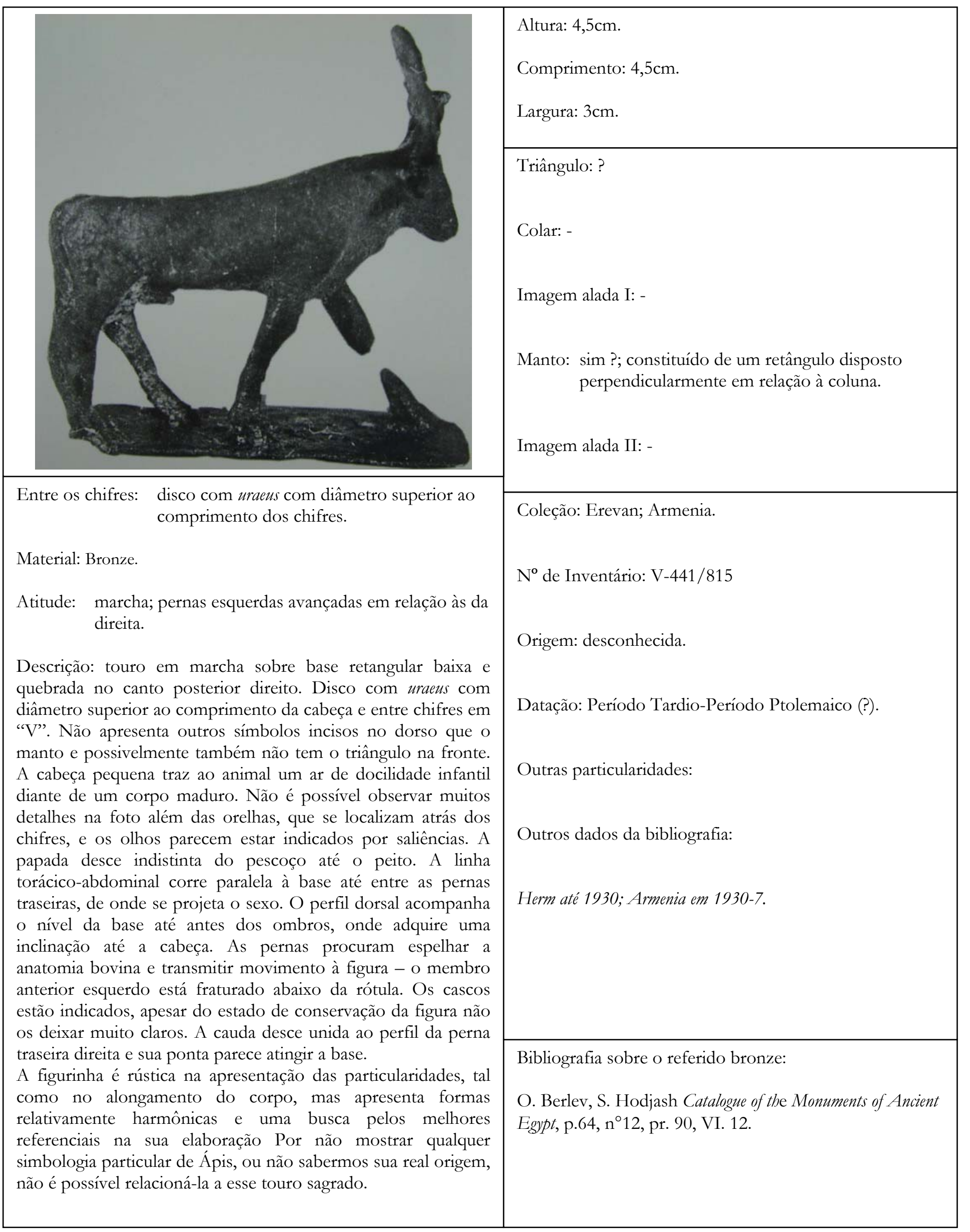




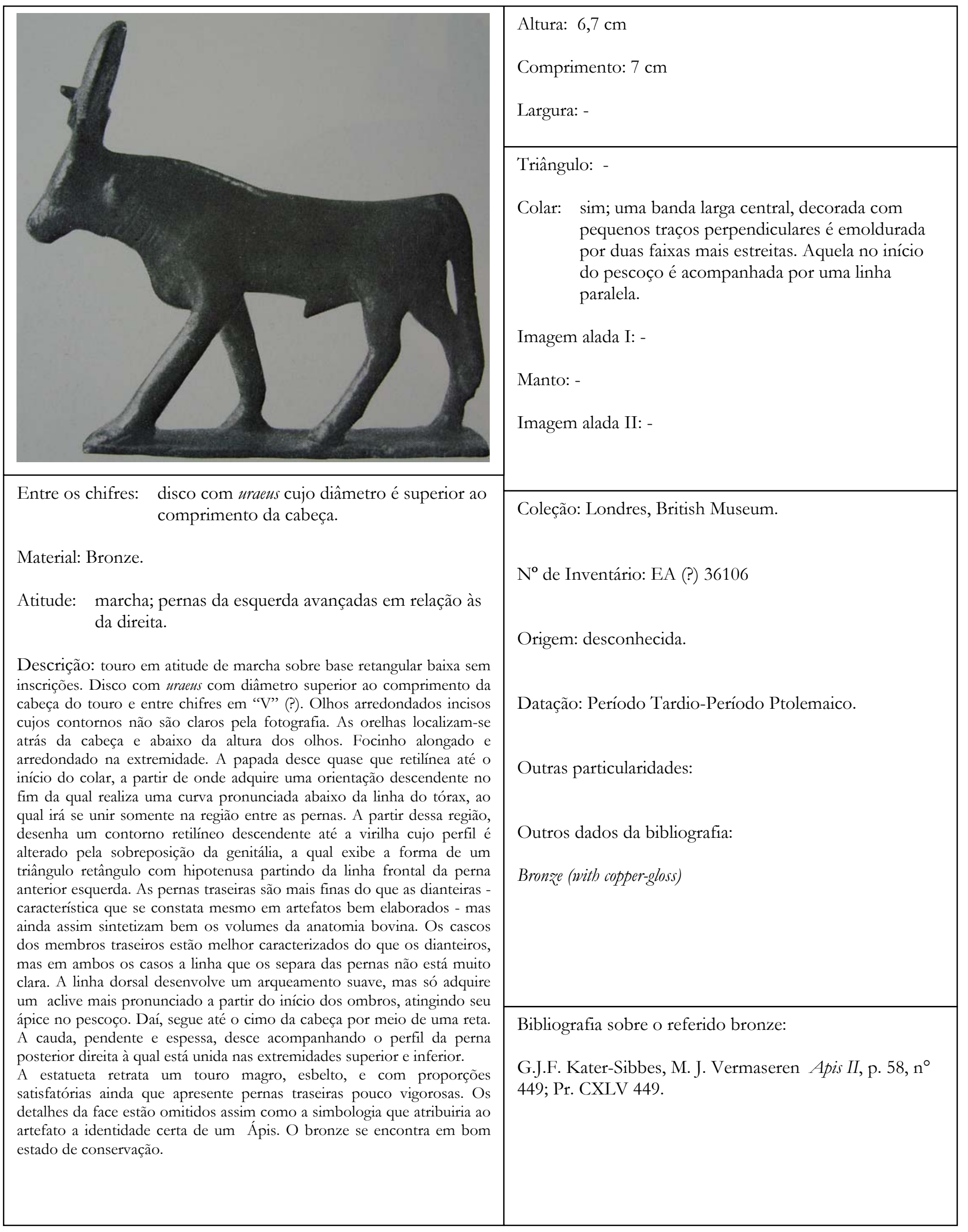




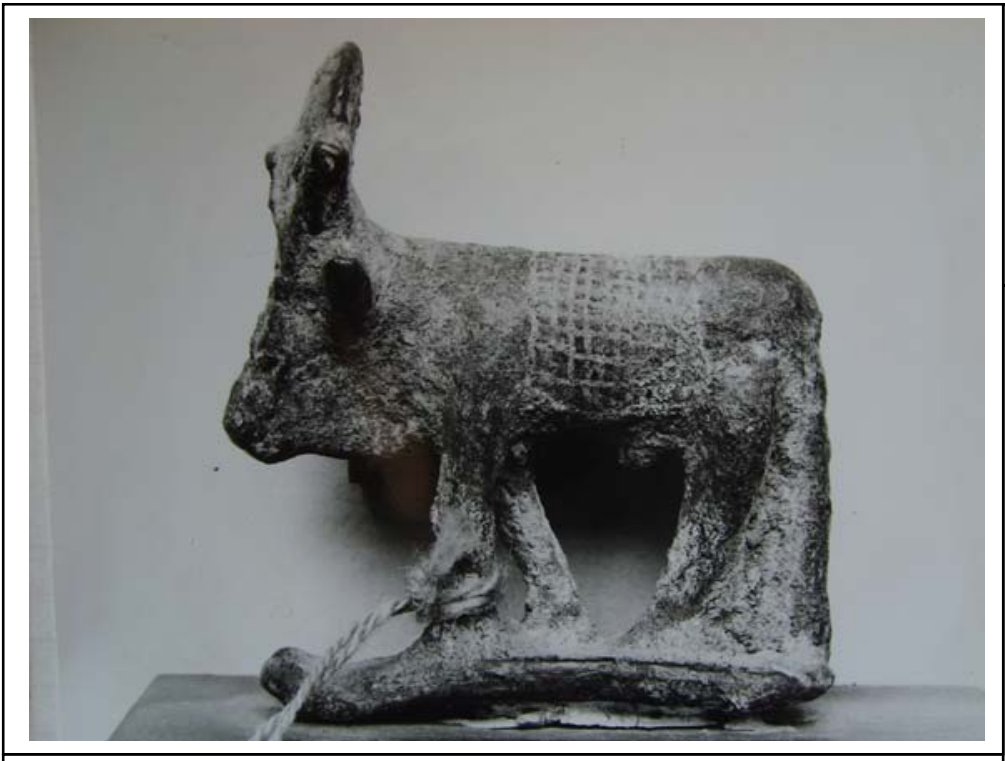

Entre os chifres: disco com uraeus cujo diâmetro é inferior ao comprimento da cabeça.

Material: Bronze?

Atitude: marcha; pernas da esquerda avançadas em relação às da direita.

Descrição: touro em marcha sobre base retangular baixa, sem inscrições e entortada em suas partes frontal e inferior central. Disco com uraeus com diâmetro inferior ao comprimento da cabeça e entre chifres pequenos em crescente (?). Decoração do manto gravada e sem incrustações. Olhos amendoados gravados e dispostos na diagonal. As feições são pequenas e se integram de maneira não muito harmônica ao tamanho da cabeça e ao pescoço largo. Focinho com indicação das narinas. As orelhas estão estranhamente posicionadas em virtude das próprias proporções da cabeça e se encontram na linha da nuca mas muito acima dos olhos. A papada desenvolve um perfil convexo que termina logo abaixo do tórax que, neste artefato, está localizado no nível do maxilar. A configuração do abdômen descreve leve inclinação em direção à virilha onde o sexo está bem presente. Os cascos estão sugeridos pelos volumes junto à base e as pernas são rijas e cilíndricas. A linha dorsal desenha um percurso retilíneo até o cimo da cabeça, trazendo ao torso um perfil semelhante a um retângulo. Cauda pendente e espessa, que desce em uma reta unida à perna posterior direita até a base.

$\mathrm{O}$ artefato tem suas superfícies ásperas devido à oxidação, que é visível nas ranhuras, e sua elaboração é rústica.
Altura: $4,95 \mathrm{~cm}$ (sem pino de fixação)

Comprimento: $4,4 \mathrm{~cm}$

Largura: -

Triângulo: - (?)

Colar: -

Imagem alada I: -

Manto: sim; um retângulo disposto perpendicularmente à linha dorsal é decorado por linhas horizontais e verticais paralelas que se cruzam em um motivo xadrez.

Imagem alada II: -

Coleção: Paris, Musée du Louvre.

No de Inventário: E 19921

Origem: ? (não mencionada na ficha do museu)

Datação: Período Tardio-Período Ptolemaico.

Outras particularidades:

Outros dados na ficha do museu:

AE026238

Sur le dos seulement cowverture

Le triangle frontal n'est pas visible

Musée Guimet

2422

5185 (peint em rouge)

7991

Bibliografia sobre o referido bronze: 


\begin{tabular}{|c|c|}
\hline $\begin{array}{l}\text { Descrição: Ápis em atitude de marcha sobre base retangular baixa } \\
\text { ligeiramente entortada e sem inscrições. Disco com uraeus com } \\
\text { diâmetro inferior ao comprimento da cabeça do touro e entre chifres } \\
\text { em crescente. Triângulo na fronte. Decoração do manto incisa e } \\
\text { manchada (?) - não visível na fotografia. Olhos grandes amendoados, } \\
\text { bem delineados, com pálpebras (?) e dispostos transversalmente. As } \\
\text { amplas orelhas estão localizadas na linha posterior da cabeça e da } \\
\text { parte superior dos olhos. A cabeça é pequena e o focinho bem } \\
\text { modelado - maiores detalhes não perceptíveis na imagem. A papada } \\
\text { desenvolve uma curvatura em "S" aberto, cuja extremidade inferior } \\
\text { desce pouco abaixo da linha do tórax para, em seguida, prosseguir em } \\
\text { uma linha ascendente até a extremidade do sexo - que se prolonga } \\
\text { desde a virilha. A partir daí, o contorno ganha uma nova inclinação } \\
\text { mais pronunciada para alcançar a região inferior do ventre. As pernas } \\
\text { mostram o vigor da anatomia bovina e os cascos estão bem esculpidos } \\
\text { e delineados. A linha dorsal desenha um declive que termina logo } \\
\text { atrás dos ombros, onde adquire uma orientação ascendente suave que } \\
\text { encontra repouso sobre estes e daí se encaminha para o cimo da } \\
\text { cabeça. A cauda desce em uma reta secante ao perfil da perna } \\
\text { posterior direita à qual está unida na parte superior e inferior. } \\
\text { A estatueta se encontra em ótimo estado de conservação e exibe o } \\
\text { vigor de um touro no auge da maturidade. Seu perfil é robusto e } \\
\text { proporcional - com exceção da cabeça que, como em muito artefatos, } \\
\text { é em escala menor. Contudo, não se pode afirmar sua identificação } \\
\text { com Ápis na falta de toda a simbologia, legenda ou proveniência } \\
\text { exata. }\end{array}$ & $\begin{array}{l}\text { Coleção: Berlim, Staatliche Museen. } \\
\text { No de Inventário: } 8301 \\
\text { Origem: ? } \\
\text { Datação: Período Tardio-Período Ptolemaico (?). } \\
\text { Outras particularidades: } \\
\text { Outros dados da bibliografia: } \\
\text { The engraved cover is stained. } \\
\text { Adquirido da coleção de Mr. Theremin em } 1883 .\end{array}$ \\
\hline
\end{tabular}

Bibliografia sobre o referido bronze:

G.J.F. Kater-Sibbes, M. J. Vermaseren Apis I, p.40-1, n 154; Pr. LXXXVII 154.

G. Roeder Aegyptische Bronzefiguren, 329, § 413 q, pr. XLVIII n. 


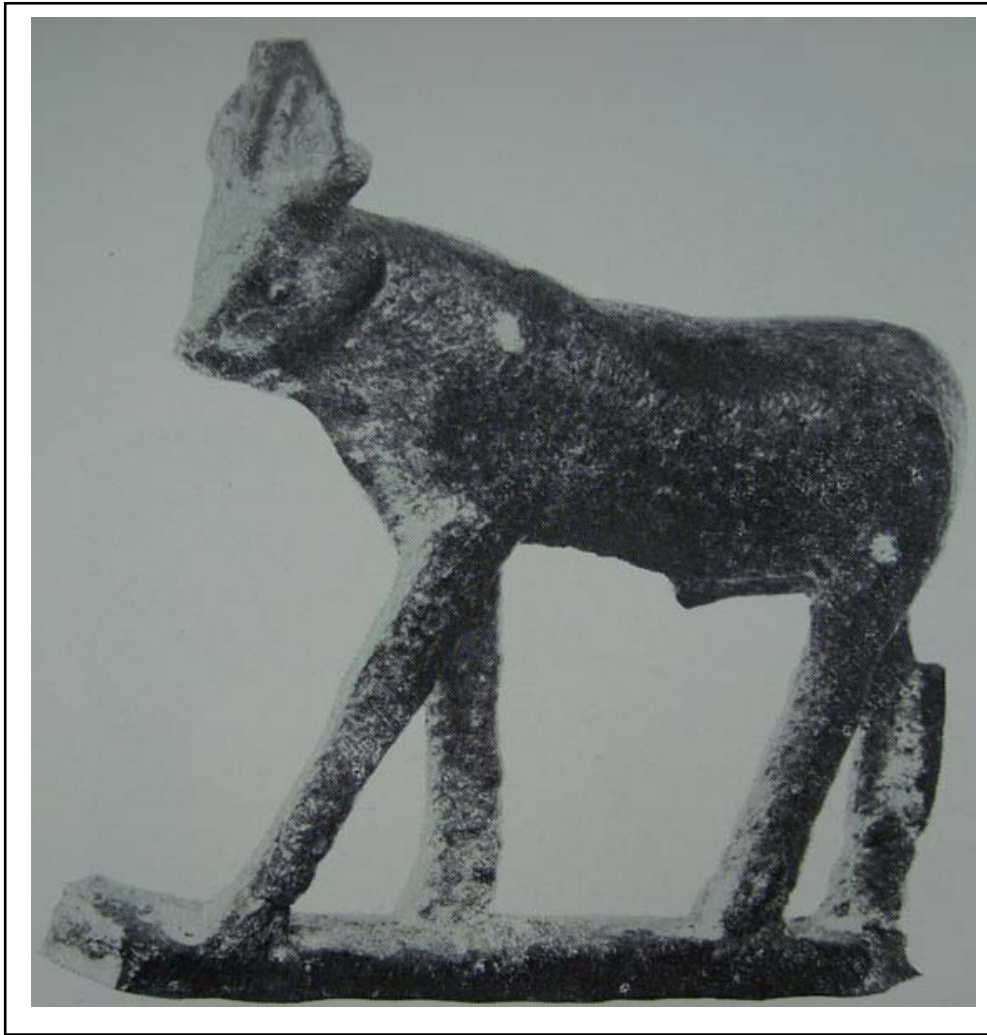

Entre os chifres: disco com uraeus quebrado.

Material: Bronze.

Atitude: marcha; pernas da esquerda avançadas em relação às da direita.

Descrição: atitude de marcha sobre base retangular baixa e sem inscrições. Disco com uraeus quebrado entre chifres em "V". Triângulo inciso na fronte. Decoração lombar e do pescoço ausentes. Olhos indicados por orifícios arredondados. Fronte plana, triangular e focinho abreviado, sem narinas ou boca, com o maxilar emendado à papada. As orelhas são indicadas por saliências na parte anterior da cabeça na altura dos olhos. A papada se confunde com o pescoço na sua primeira parte para, logo em seguida, descer quase que retilínea até pouco abaixo da região do tórax. A linha abdominal, a princípio desenvolve uma trajetória reclinada até a extremidade do falo para depois subir acompanhada deste até a virilha. As pernas são constituídas de bastões longos e rígidos e os cascos não estão indicados. Após um percurso estável sobre as ancas, a linha dorsal sofre duas alterações em seu ângulo de inclinação antes de chegar ao alto da cabeça do touro. Parte da cauda sobrevive unida à perna posterior direita e é possível que sua porção superior estivesse destacada - daí o motivo de ter se quebrado com facilidade.

A estatueta é rústica quanto à modelagem do torso e das pernas e a cabeça é proporcionalmente muito reduzida. As superfícies são irregulares e apresentam vários traços de oxidação e partes quebradas. Mesmo com a simbologia incompleta, a presença do triângulo é suficiente para associar a imagem ao touro sagrado de Mênfis.
Altura: $7,1 \mathrm{~cm}$

Comprimento: ?

Largura: -

Triângulo: sim

Colar: -

Imagem alada I: -

Manto: -

Imagem alada II: -

Coleção: Viena, Kunsthistorisches Museum.

$\mathrm{N}^{0}$ de Inventário: 5518

Origem: Saqqara?

Datação: Período Tardio-Período Ptolemaico (?).

Outras particularidades:

Outros dados da bibliografia:

Adquirido da coleção Miramar, 1878.

Bibliografia sobre o referido bronze:

Kater-Sibbes, G. J. F., M. J. Vermaseren, Apis I, p. 18, $n^{\circ}$. 59; Pr. XLIV 59.

Roeder, G., Ägyptische Bronzefiguren, § 412, § 327. 


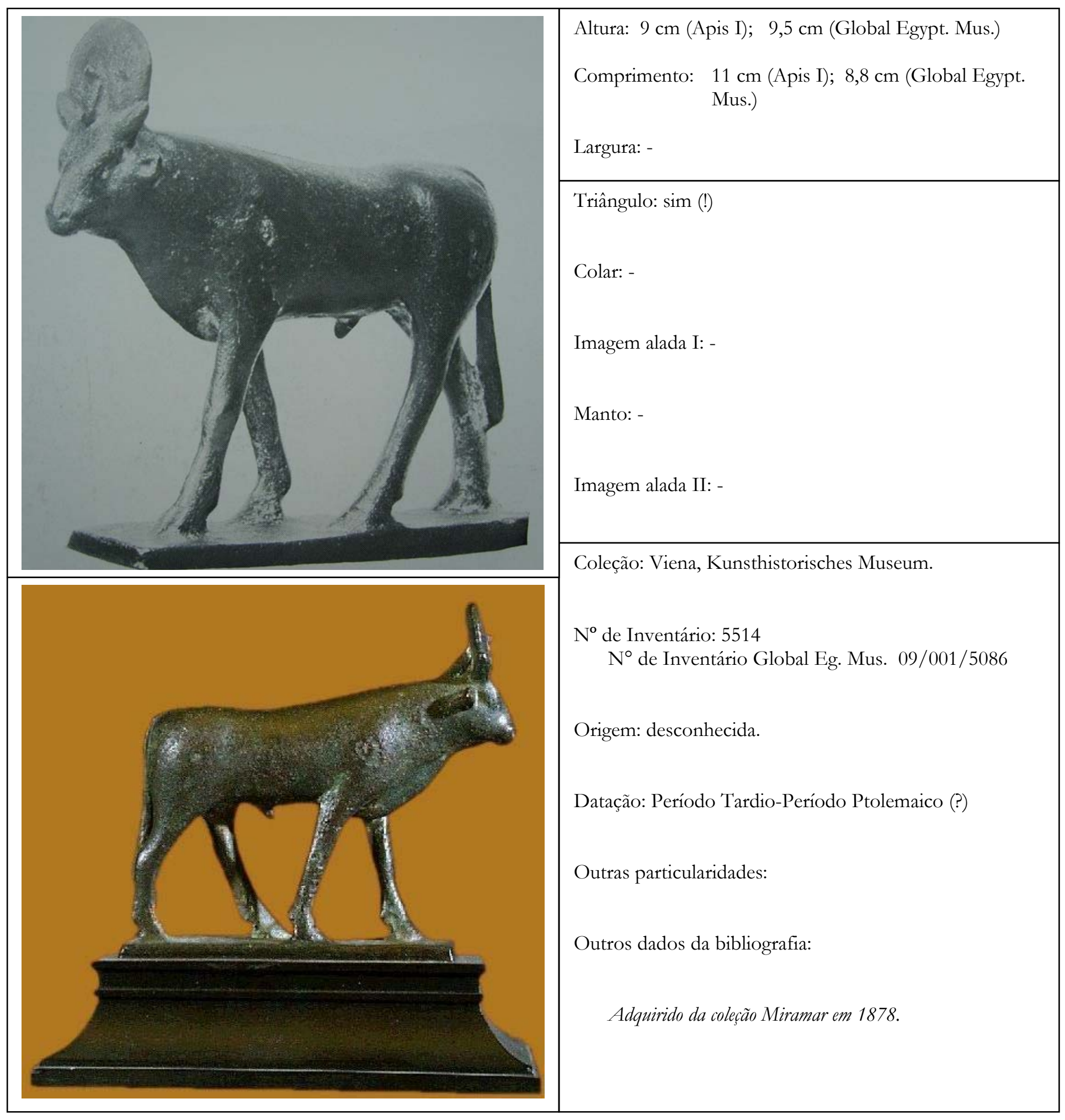




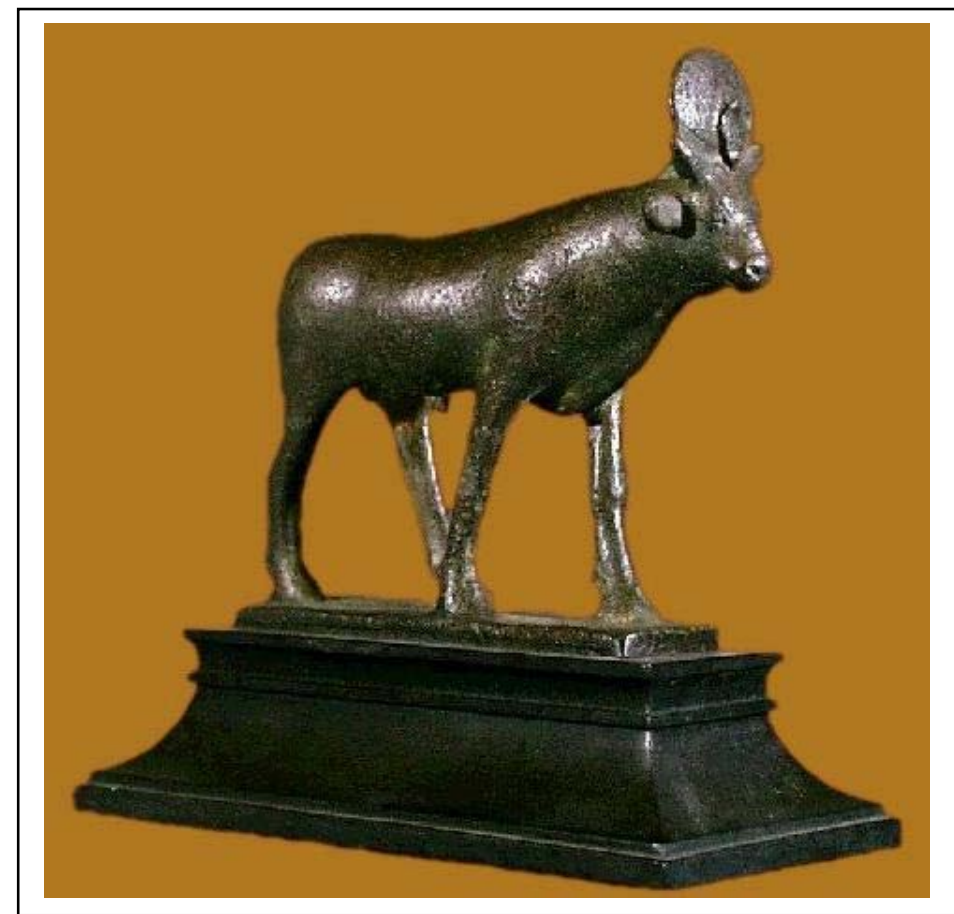

Bibliografia sobre o referido bronze:

G.J.F. Kater-Sibbes, M. J. Vermaseren Apis I, p. 52, n 217; Pr. CXXVIII 217.

http://www.globalegyptianmuseum.org/record.aspx?id $=50$ $\underline{86}$
Entre os chifres: disco com uraeus cujo diâmetro é inferior ao comprimento da cabeça.

Material: Bronze.

Atitude: marcha; pernas da esquerda avançadas em relação às da direita.

Descrição: atitude de marcha sobre base retangular baixa sem inscrições. Disco com uraeus com diâmetro inferior ao comprimento da cabeça, entre chifres em "V" e reforçado por um prolongamento que se estende ao pescoço. $\mathrm{O}$ triângulo na fronte é o único elemento inciso. Olhos pequenos e amendoados. Orelhas localizadas na linha detrás dos chifres e pouco acima dos olhos. O focinho é bem moldado, e apresenta narinas e boca discretas. A papada desenvolve duas ondulações principais: a primeira, bastante tênue, se prolonga até o início do pescoço. A segunda desenvolve uma ampla curvatura até abaixo do tórax, ao qual vem se juntar atrás das pernas frontais. A linha que desenha o abdômen é paralela à base e na sua porção central está indicado o órgão genital. As pernas são esbeltas e exibem contornos que sugerem os volumes da anatomia bovina. Os cascos estão bem indicados e delineados. Após uma quase imperceptível elevação na região das ancas, a linha dorsal ganha uma ligeira queda para depois desenvolver uma trajetória ascendente constante até o alto da cabeça. Cauda pendente e espessa unida à perna posterior direita em suas porções inferior e superior.

Ainda que traga alguns pontos de oxidação, a estatueta encontra-se em ótimo estado de conservação, exibe superfícies lisas e bem modeladas. $\mathrm{O}$ touro é apresentado com boas proporções e com o triângulo que o associa a Ápis. 


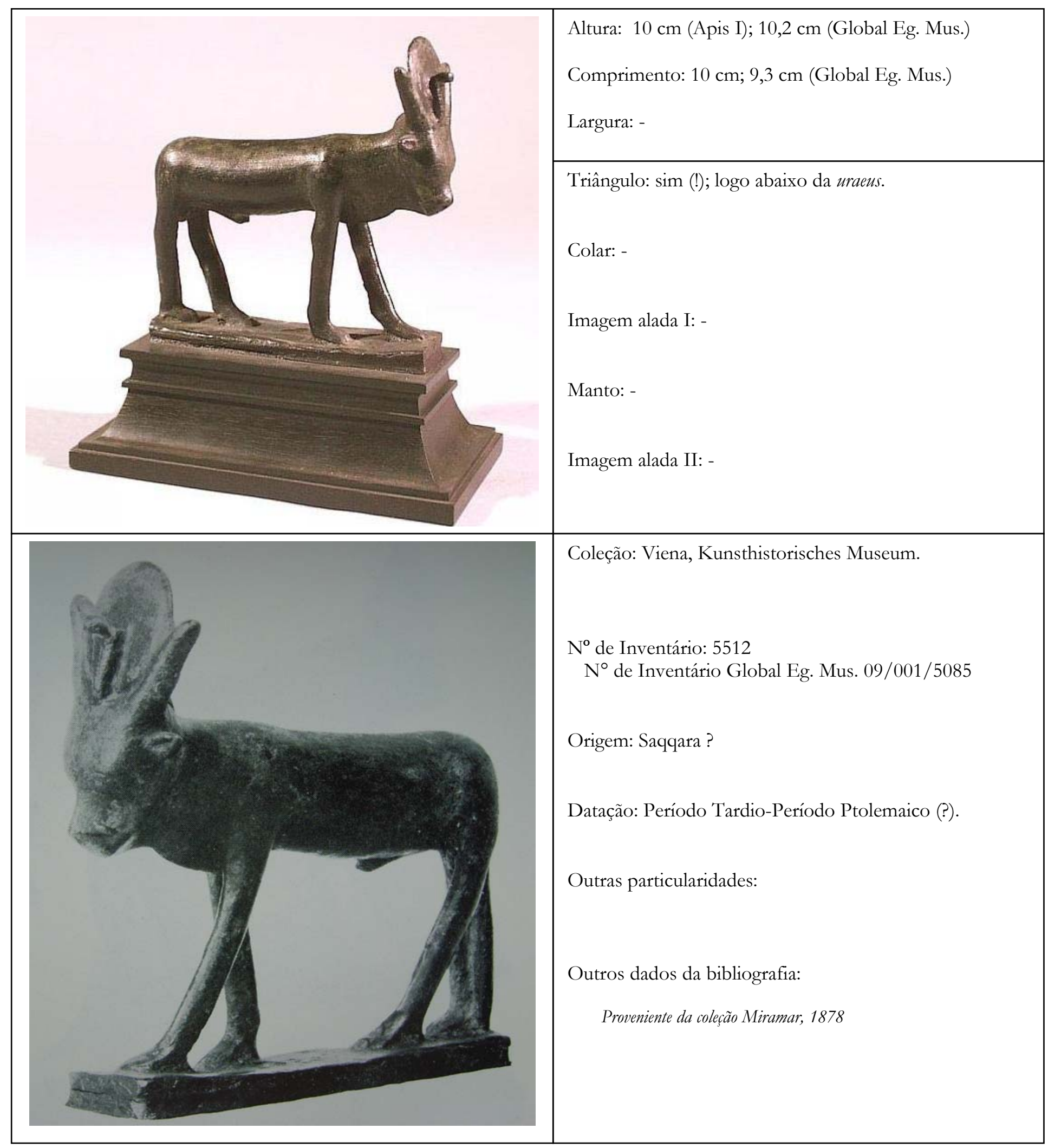


Entre os chifres: disco com uraeus cujo diâmetro é inferior ao comprimento da cabeça.

Material: Bronze.

Atitude: marcha; pernas da esquerda avançadas em relação às da direita.

Descrição: atitude de marcha sobre base retangular baixa e sem inscrições. Disco com uraeus com diâmetro inferior ao comprimento da cabeça e entre chifres em "V". Triângulo inciso na fronte. Decoração lombar e do pescoço ausentes. Olhos amendoados e sobrancelhas descritos por meio de incisões fracas. Orelhas localizadas abaixo dos chifres e muito acima da altura dos olhos. Focinho pequeno, sem boca ou narinas, com o maxilar emendado à papada. Esta se confunde com o pescoço na sua primeira parte para, na metade deste, ganhar um contorno curvilíneo que desce pouco abaixo da linha do tórax e a encontra atrás das pernas dianteiras. O torso, grosso modo, é moldado à forma de um cilindro - o perfil abdominal é levemente arqueado e da virilha se projeta o sexo. As pernas, constituídas de bastões longos e rígidos, são fundidas ao torso de maneira pouco natural e os cascos são representados por um prolongamento da extremidade inferior delas sobre a base. A linha dorsal que se estende das ancas à cabeça é paralela à base, com uma ligeira elevação na região dos ombros. A cauda pendente desce acompanhando o perfil da perna posterior direita, à qual está unida até a base.

A estatueta é rústica quanto à modelagem do torso e das pernas. Todavia procura evocar, ainda que por linhas estilizadas, os contornos da fronte e do focinho com certo sucesso e suas superfícies são afeiçoadas. Mesmo com a simbologia incompleta, a presença do triângulo é suficiente para associar a imagem ao touro sagrado de Mênfis. Seu estado de conservação é satisfatório.

Bibliografia sobre o referido bronze:

Kater-Sibbes, G. J. F., M. J. Vermaseren, Apis I, p. 17, nº 57; Pr. XLIII 57.

Roeder, G., Ägyptische Bronzefiguren, p. 327, § 411e, § 412a.

http://www.globalegyptianmuseum.org/record.aspx?id $=5085$ 


\begin{tabular}{|c|c|}
\hline & $\begin{array}{l}\text { Altura: } 5,7 \mathrm{~cm} \text { (sem pino de fixação) } \\
\quad \text { Altura do pino de fixação ao centro: } 1 \mathrm{~cm} \\
\text { Comprimento: } 6 \mathrm{~cm} \\
\text { Largura: - }\end{array}$ \\
\hline$E .17132$. & $\begin{array}{l}\text { Triângulo: sim } \\
\text { Colar: - (?) } \\
\text { Imagem alada I: -(?) } \\
\text { Manto: -(?) } \\
\text { Imagem alada II: -(?) }\end{array}$ \\
\hline $\begin{array}{l}\text { Entre os chifres: disco com uraeus com tamanho semelhante } \\
\text { ao comprimento da cabeça. } \\
\text { Material: bronze? }\end{array}$ & \\
\hline $\begin{array}{l}\text { Atitude: marcha; pernas da esquerda avançadas em relação às da } \\
\text { direita. }\end{array}$ & Coleção: Paris, Musée du Louvre. \\
\hline $\begin{array}{l}\text { Descrição: touro em marcha sobre base baixa irregular, cujos pontos } \\
\text { de fixação às pernas do animal parecem descrever uma linha } \\
\text { serpenteada (devido à oxidação a uma base originalmente retangular?), } \\
\text { sem inscrições. Disco solar com uraeus de tamanho semelhante ao da } \\
\text { cabeça e entre chifres em "V" (?). Dada a presença do triângulo na } \\
\text { fronte, é possível que outros símbolos tenham sido representados } \\
\text { sobre o corpo do animal, que se encontra totalmente ressentido pelos } \\
\text { efeitos da oxidação. Olhos amendoados em relevo, bem delineados e } \\
\text { com pálpebras. A cabeça apresenta boas proporções mas sua parte } \\
\text { inferior é relativamente expandida. As orelhas localizam-se entre a } \\
\text { linha do disco com uraeaus e a nuca, acima da linha dos olhos. Do } \\
\text { maxilar desenha-se uma papada que desce quase retilínea até entre o } \\
\text { alto das pernas frontais. Os cascos, apesar da oxidação, estão bem } \\
\text { representados e as pernas parecem ter sido trabalhadas quanto à } \\
\text { disposição de seus volumes. A representação do sexo do animal é bem } \\
\text { presente no centro do abdômen, o qual descreve uma linha } \\
\text { descendente da região entre as pernas traseiras ao tórax. A cauda } \\
\text { aparentemente está unida à perna traseira direita. A linha dorsal, após } \\
\text { uma elevação sobre a bacia, sofre uma levíssima inclinação até o meio } \\
\text { das costas de onde retoma um plano ascendente até os ombros do } \\
\text { touro. A partir daí descreve outra inclinação que muda seu curso no } \\
\text { início do pescoço para então subir até a junção traseira do disco solar, } \\
\text { no alto da cabeça. Oxidação generalizada e superfícies rugosas. } \\
\text { A base da figurinha está fixada em uma base moderna. }\end{array}$ & $\begin{array}{l}\text { No de Inventário: E } 17132 \\
\text { Origem: Serapeum } \\
\text { Datação: Período Tardio-Período Ptolemaico (?). } \\
\text { Outras particularidades: } \\
\text { Outros dados na ficha do museu: } \\
\text { Reste illisible } \\
\text { Cat } 8\end{array}$ \\
\hline \multicolumn{2}{|l|}{ Bibliografia sobre o referido bronze: } \\
\hline
\end{tabular}




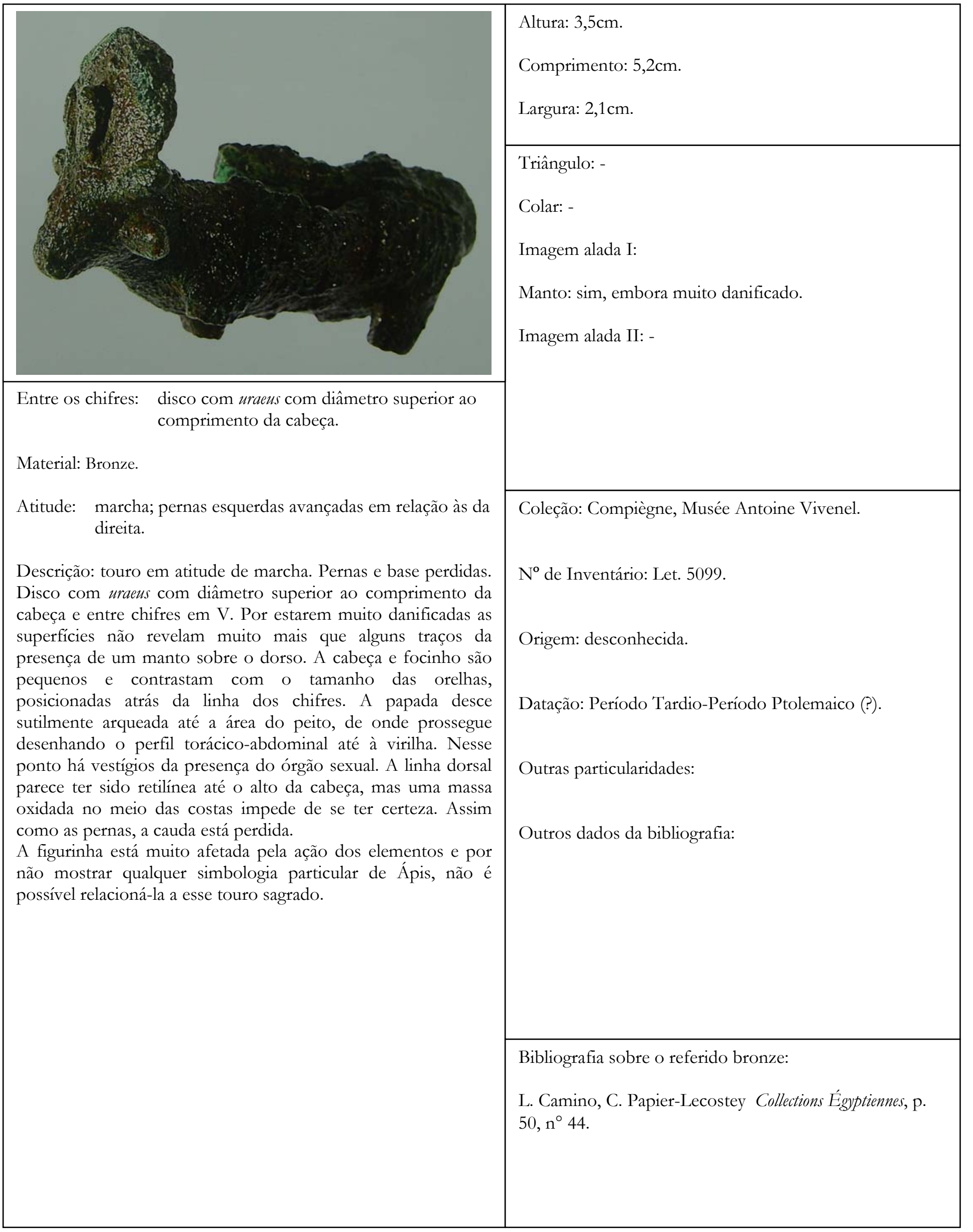




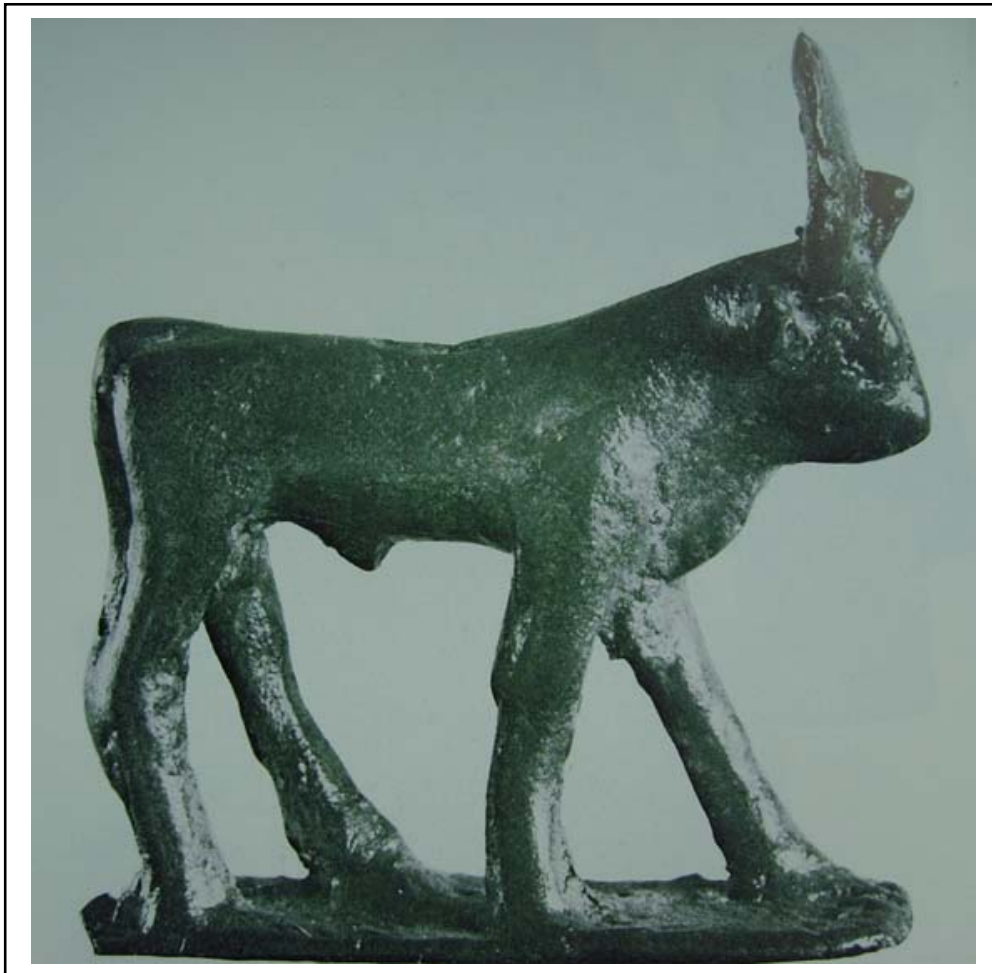

Entre os chifres: disco com uraeus cujo diâmetro é semelhante ao comprimento da cabeça.

Material: Bronze

Atitude: marcha; pernas da esquerda avançadas em relação às da direita.

Descrição: touro em atitude de marcha sobre base retangular baixa sem inscrições. Disco com uraeus com diâmetro semelhante ao comprimento da cabeça do bovino e entre chifres em "V" (?). Olhos incisos dispostos na diagonal. As orelhas localizam-se na linha anterior dos chifres e na altura dos olhos. Focinho pequeno e abreviado, cuja linha inferior se confunde com parte do pescoço. A papada desce a partir da metade deste em uma curva que contorna a parte frontal do tórax para encontrá-lo na área entre as pernas frontais. $\mathrm{O}$ abdômen é descrito por uma linha ascendente em direção à virilha, a partir de onde emerge a genitália. As pernas são alongadas e trazem linhas rústicas - especialmente as traseiras - que procuram sintetizar os volumes da anatomia bovina. Os cascos consistem em um alargamento das pernas junto à base. A linha dorsal, após a saliência da cauda, desenha uma reta em declive até o meio das costas para mudar sua orientação e subir até o alto da cabeça. A cauda desce acompanhando o perfil da perna posterior direita à qual está aparentemente unida.

A estatueta é esbelta mas rústica em sua elaboração. As pernas fogem às proporções do tronco e o restante da simbologia de Ápis está ausente. $\mathrm{O}$ artefato se encontra em bom estado de conservação.
Altura: $4,5 \mathrm{~cm}$

Comprimento: -?

Largura: -

Triângulo: -

Colar: -

Imagem alada I: -

Manto: -

Imagem alada II: -

Coleção: Antuérpia, Vleeshuis Museum.

$\mathrm{N}^{0}$ de Inventário: 79.1 .75

Origem: Athribis.

Datação: Período Tardio-Período Ptolemaico (?).

Outras particularidades:

Outros dados da bibliografia:

Traces of an attachment of a ring are visible on the back.

Bibliografia sobre o referido bronze:

G.J.F. Kater-Sibbes, M. J. Vermaseren Apis I, p. 30, n 108; Pr. LXX 108. 


\begin{tabular}{|c|c|}
\hline $\begin{array}{l}\text { Entre os chifres: - (?) } \\
\text { Material: Bronze ? } \\
\text { Atitude: marcha; pernas da esquerda avançadas em relação às } \\
\qquad \text { da direita. } \\
\text { Descrição: touro em marcha sobre base retangular baixa, sem } \\
\text { inscrições e com pino de fixação central. Chifres quebrados e, com } \\
\text { eles, possivelmente o disco com uraeus. Por estar muito atacada pela } \\
\text { oxidação, não é possível saber se a estatueta exibia alguma decoração } \\
\text { gravada. A cabeça, ainda que muito erodida, exibe traços delicados e é } \\
\text { pequena. Os olhos são percebidos por uma leve saliência. Acima } \\
\text { deles, na linha da nuca, notam-se as orelhas bem presentes. A papada } \\
\text { desenha um "S" aberto, cuja protuberância inferior ultrapassa o nível } \\
\text { do peito e só vem a encontrá-lo atrás da perna dianteira direita. A } \\
\text { partir daí desenha o abdômen através de uma linha paralela à base, } \\
\text { sendo sobreposta pelo sexo na altura da virilha. A linha dorsal } \\
\text { desenvolve uma pronunciada sinuosidade, começando por um perfil } \\
\text { côncavo no meio das costas para ganhar elevação nos ombros. Daí } \\
\text { dirige-se para o alto da cabeça em uma reta. Apesar de ter o membro } \\
\text { traseiro direito quebrado - e com ele a cauda que possivelmente a ele } \\
\text { estava unida-, as pernas foram bem moldadas e refletem as formas da } \\
\text { anatomia bovina com bastante vigor. Os cascos estão bem indicados e } \\
\text { definidos. } \\
\text { A estatueta está bastante castigada pela oxidação e não é possível } \\
\text { saber se exibia um disco solar com uraeus e a simbologia de Ápis. } \\
\text { Contudo, observa-se através de suas formas que o artefato recebeu } \\
\text { uma atenção especial quanto à sua modelagem apesar de suas } \\
\text { dimensões reduzidas. }\end{array}$ & $\begin{array}{l}\text { Coleção: Paris, Musée du Louvre. } \\
\text { No de Inventário: ? } \\
\text { Origem: ? (não mencionada na ficha do museu) } \\
\text { Datação: Período Tardio-Período Ptolemaico (?). } \\
\text { Outras particularidades: } \\
\text { Outros dados na ficha do museu: } \\
\text { Haut de la tête brisé } \\
\text { AE018032 }\end{array}$ \\
\hline
\end{tabular}




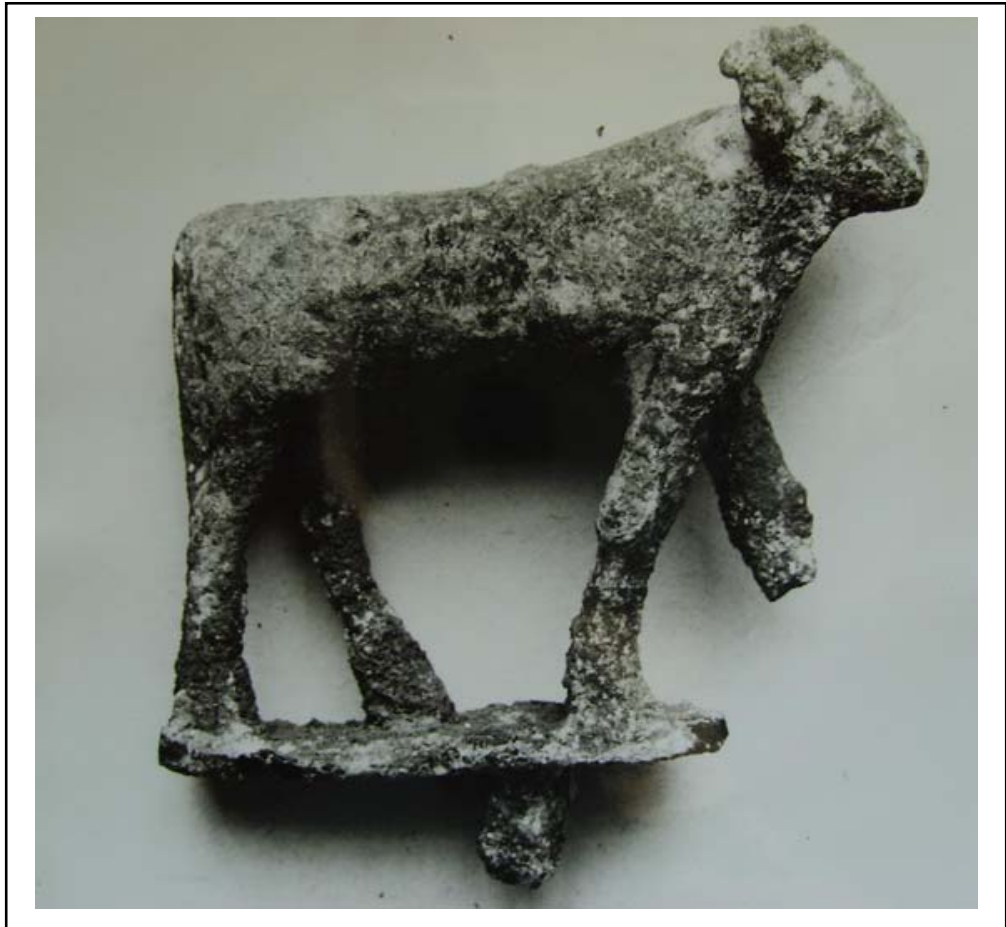

Entre os chifres: - (?)

Material: Bronze?

Atitude: marcha; pernas da esquerda avançadas em relação às da direita.

Descrição: touro em marcha sobre base retangular (?) baixa e quebrada na frente, sem inscrições e com pino de fixação central. Chifres quebrados e, com eles, possivelmente o disco com uraeus. Por estar muito atacada pela oxidação, não é possível saber se a estatueta exibia alguma decoração gravada. A cabeça, ainda que muito erodida, exibe traços delicados e é pequena. Os olhos são percebidos por uma saliência e acima deles, na linha da nuca, notam-se traços das orelhas. A papada desce reta até o tórax e a linha daí se prolonga em uma paralela à base até a virilha. Não é possível perceber o sexo pela fotografia. A linha dorsal desenvolve uma reta até a metade das costas para então iniciar uma ascensão até o alto da cabeça. Apesar de serem alongadas e de ter o membro dianteiro esquerdo quebrado, as pernas parecem ter sido bem moldadas e refletem as formas da anatomia bovina. Os cascos estão indicados por volumes. A cauda desce perpendicular à base e unida (?) à perna posterior direita.

A estatueta está bastante castigada pela oxidação e não é possível saber se exibia um disco solar com uraeus e a simbologia de Ápis. Contudo, observa-se através de suas formas que o artefato recebeu uma atenção especial quanto à sua modelagem.
Altura: $6,5 \mathrm{~cm}$ (com pino de fixação)

Comprimento: $6,0 \mathrm{~cm}$

Largura: -

Triângulo: -(?)

Colar: -(?)

Imagem alada I: -(?)

Manto: -(?)

Imagem alada II: -(?)

Coleção: Paris, Musée du Louvre.

$\mathrm{N}^{0}$ de Inventário: ?

Origem: ? (não mencionada na ficha do museu)

Datação: Período Tardio-Período Ptolemaico (?).

Outras particularidades:

Outros dados na ficha do museu:

Taurean?

AE026231

Musée Guimet? bout

Convert d'oxyde.

Patte cassée et base casée oxydées à coeur 7991

Bibliografia sobre o referido bronze: 


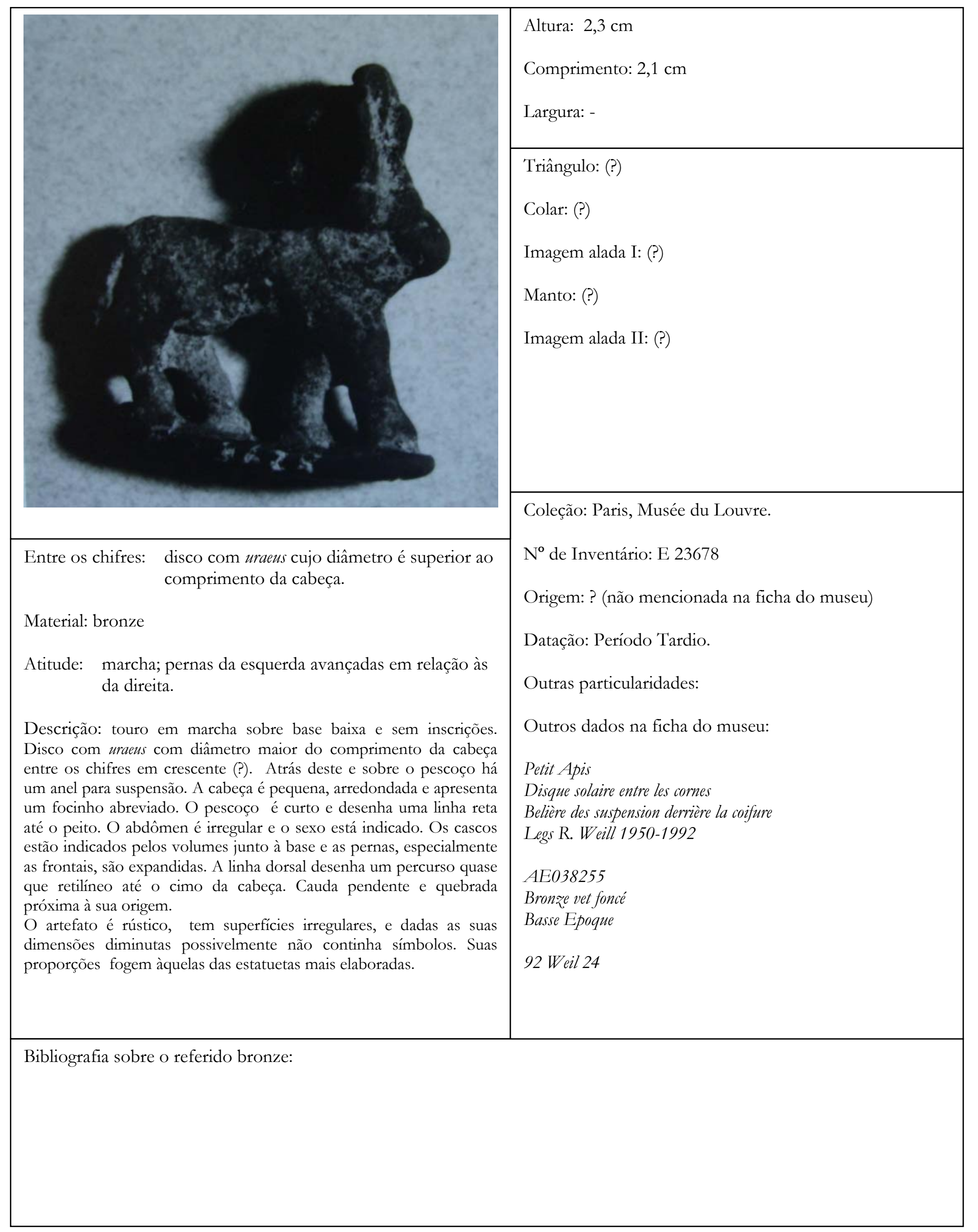




\begin{tabular}{|c|c|}
\hline & $\begin{array}{l}\text { Altura: } 4,3 \mathrm{~cm} \\
\text { Comprimento da base: } 5,7 \mathrm{~cm} \\
\text { Largura: - }\end{array}$ \\
\hline$\left\{\begin{array}{c}216 b 1 \exists \\
z \\
1132-94\end{array}\right.$ & $\begin{array}{l}\text { Triângulo: -(?) } \\
\text { Colar: -(?) } \\
\text { Imagem alada I: -(?) } \\
\text { Manto: -(?) } \\
\text { Imagem alada II: -(?) }\end{array}$ \\
\hline 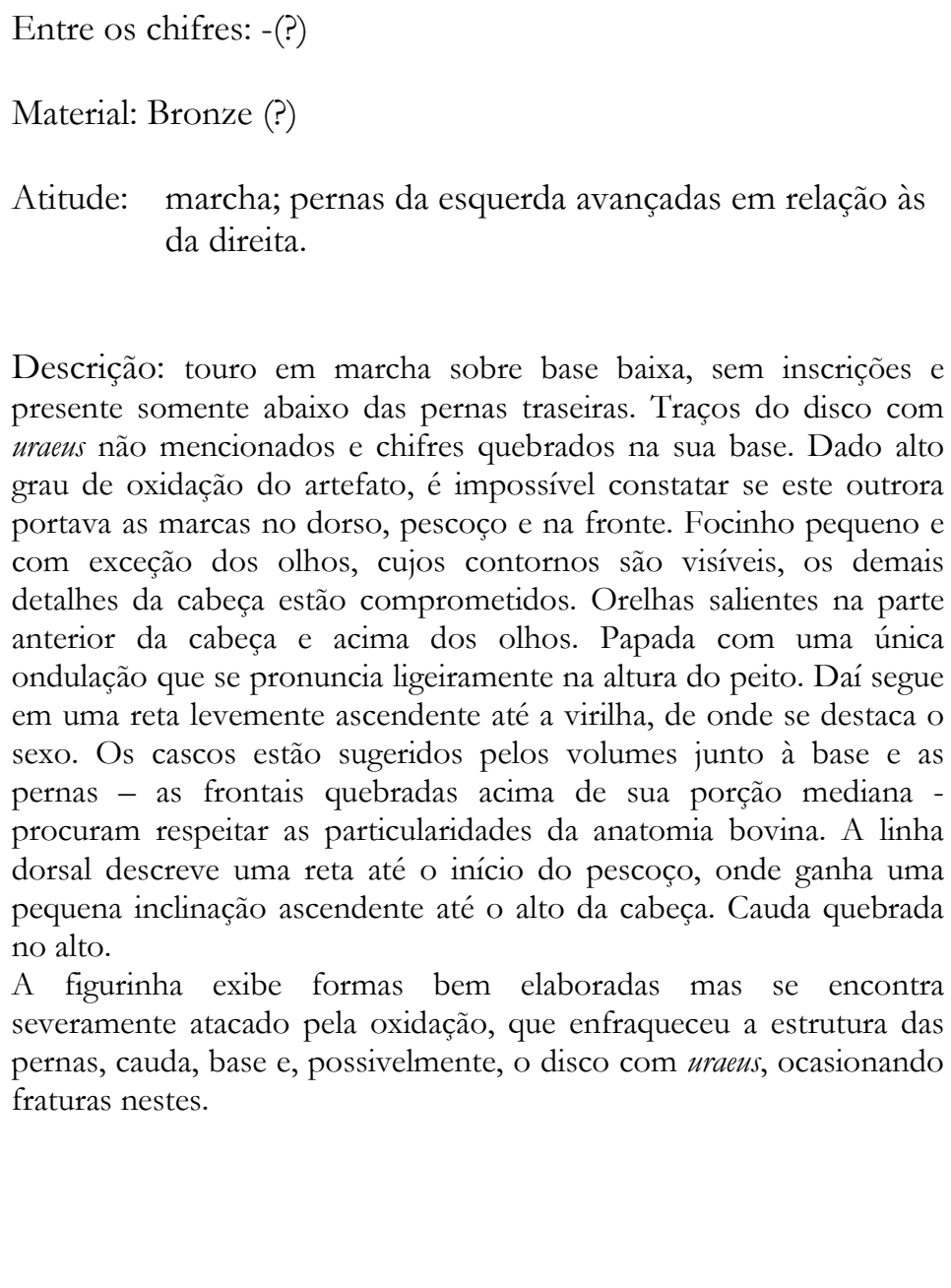 & $\begin{array}{l}\text { Coleção: Paris, Musée du Louvre. } \\
\mathrm{N}^{\mathrm{o}} \text { de Inventário: E } 19912 \\
\text { Origem: ? (não mencionada na ficha do museu) } \\
\text { Datação: Período Tardio-Período Ptolemaico (?). } \\
\text { Outras particularidades: } \\
\text { Outros dados na ficha do museu: } \\
\text { Apis? } \\
\text { AE001548 } \\
\text { Musée Guimet } 2413 \\
\text { Deserve des colonnes }\end{array}$ \\
\hline \multicolumn{2}{|l|}{ Bibliografia sobre o referido bronze: } \\
\hline
\end{tabular}




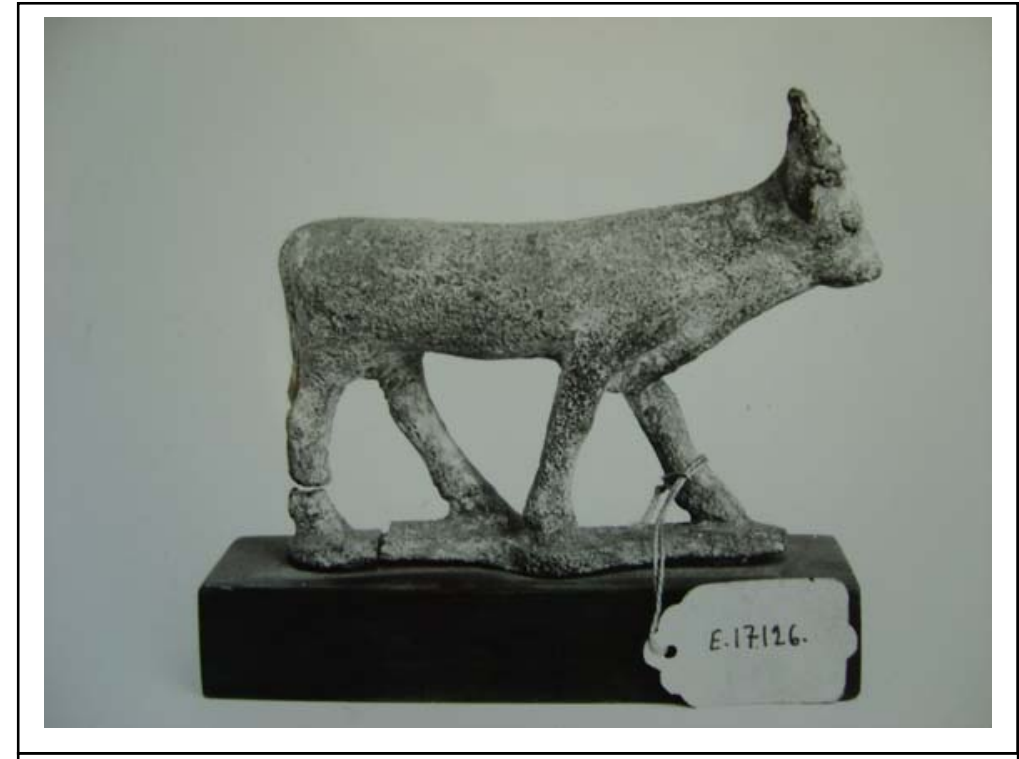

Entre os chifres: disco solar quebrado. Uraeus: - (?)

Material: bronze?

Atitude: marcha; pernas da esquerda avançadas em relação às da direita.

Descrição: touro em marcha sobre base outrora retangular (?) baixa sem inscrições. Disco quebrado (com uraeus ?) aparentemente entre chifres (difícil de se perceber seu formato). Olhos grandes, em relevo e ligeiramente amendoados. A cabeça apresenta boas proporções e as feições parecem ter sido mais elaboradas que o estado de conservação do artefato deixa perceber. Da cabeça parte uma papada com três ondulações muito sutis, dando a impressão de uma única linha descendente até abaixo da altura do tórax, onde retoma a direção ascendente na região superior e anterior da perna dianteira. Os cascos estão bem definidos apesar das rachaduras nas pernas traseiras e da severa oxidação que se vê na totalidade da imagem. A cauda desempenha uma linha curva que acompanha o perfil da perna traseira direita, à qual possivelmente está unida em algum ponto. Observa-se uma linha ascendente dos ombros do touro até a união da cabeça ao pescoço, onde a curvatura se acentua mais abruptamente. Do sexo é possível observar o volume do saco escrotal. Orelhas aparentemente quebradas.

Apesar do estado degradado, nota-se pelas formas que a escultura exibia formas elaboradas e que talvez possuísse uma simbologia gravada que hoje é impossível de se perceber com a oxidação.

O bronze encontra-se fixado em uma base moderna.
Altura: $6,8 \mathrm{~cm}$ sem pino de fixação da base. Altura do pino no centro da estatueta: $1,4 \mathrm{~cm}$

Comprimento: $8,5 \mathrm{~cm}$

Largura: -

Triângulo: - (?)

Colar: - (?)

Imagem alada I: - (?)

Manto: - (?)

Imagem alada II: - (?)

Coleção: Paris, Musée du Louvre.

No de Inventário: E 17126

Origem: Serapeum

Datação: Período Tardio-Período Ptolemaico (?).

Outras particularidades:

Base quebrada (?) em dois pontos, ambos do lado direito: da pata posterior até onde repousa a anterior direita, e desta até a pata anterior esquerda. Entre as patas posteriores esquerda e direita há uma rachadura longitudinal.

Outros dados na ficha do museu:

Cat 2 (?) Inscrição rasurada, e corrigida com a palavra non abaixo.

03271

Bibliografia sobre o referido bronze:

G.J.F. Kater-Sibbes, M. J. Vermaseren Apis I, p. 7, n 11 Pr. XIV 11. 


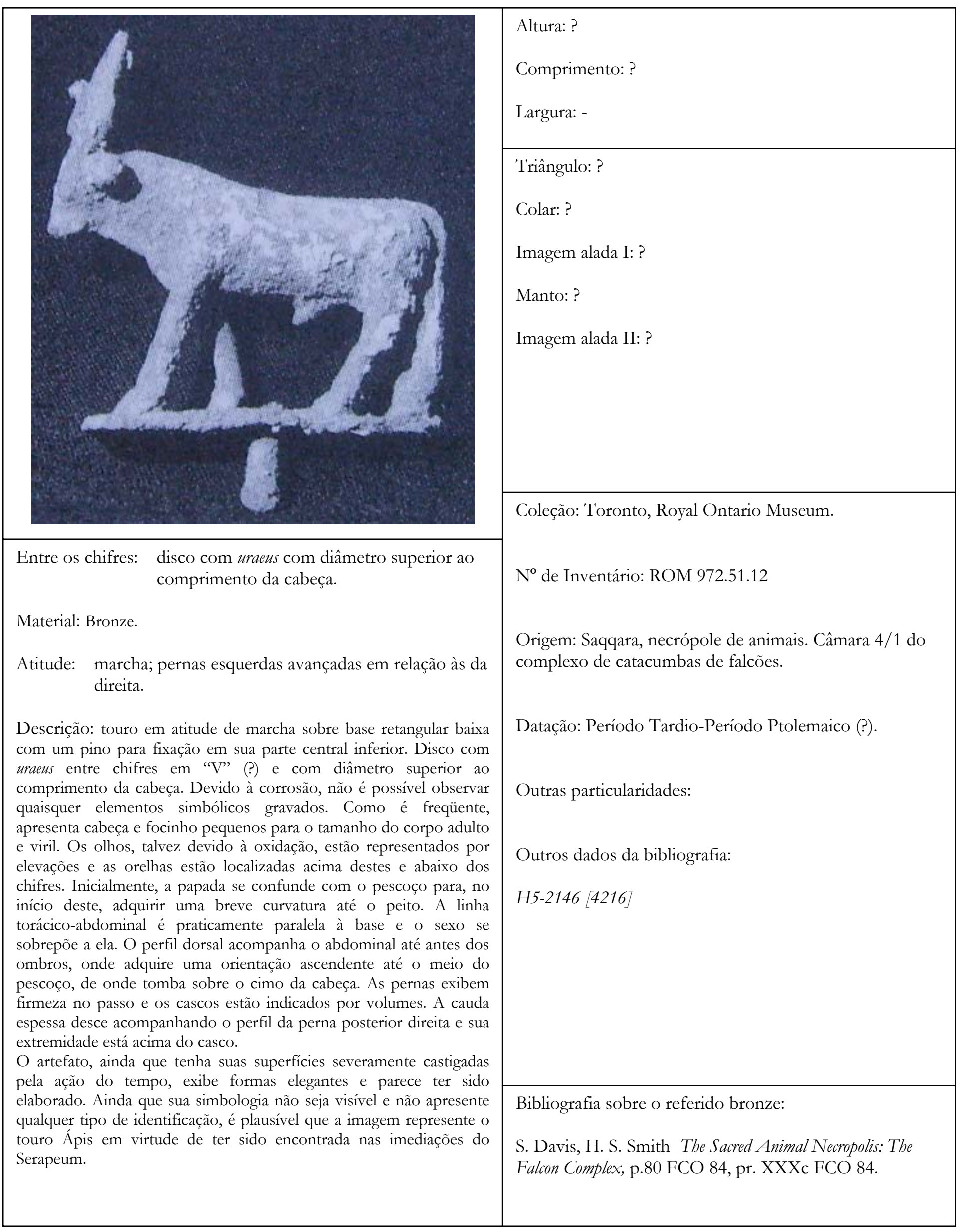




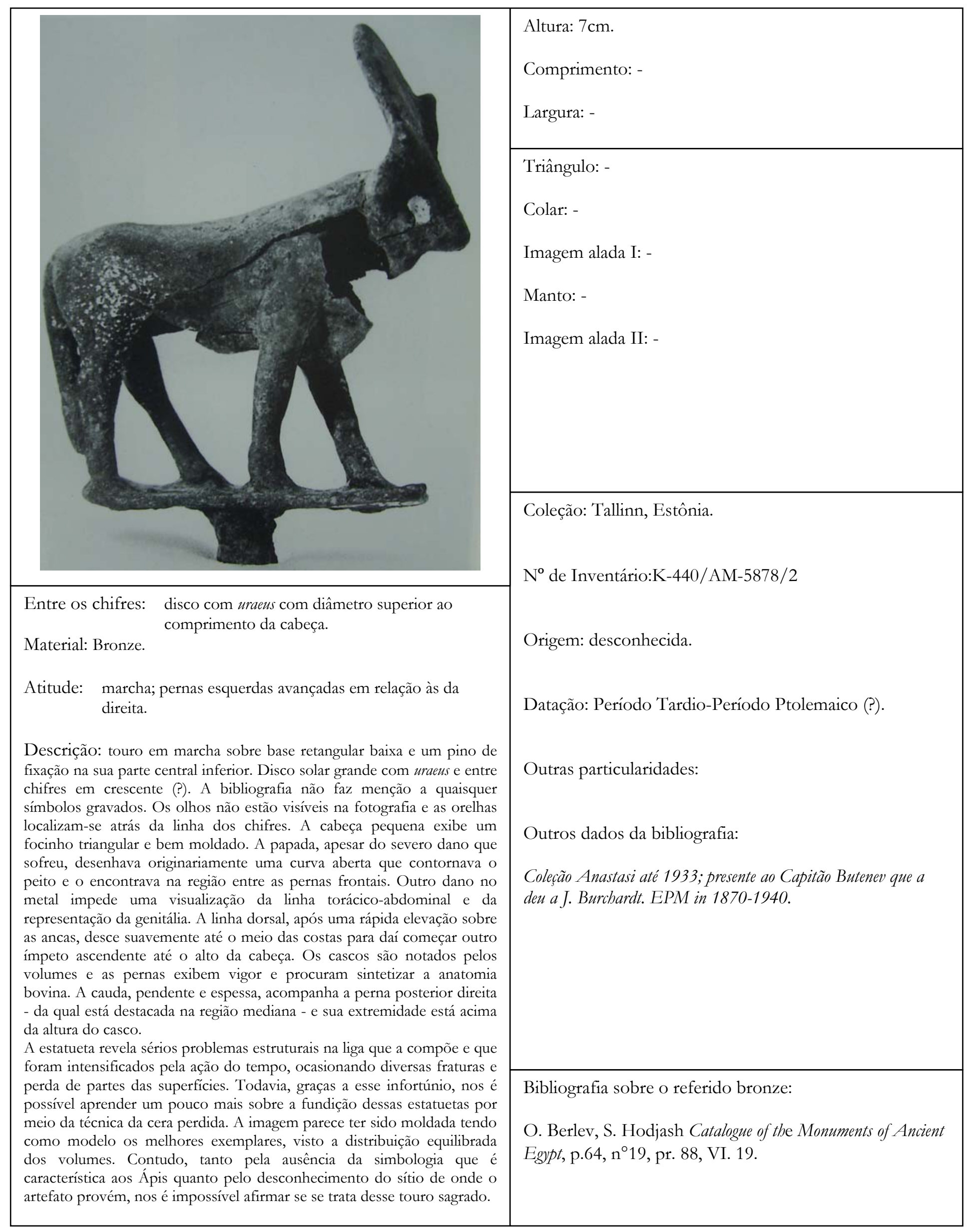




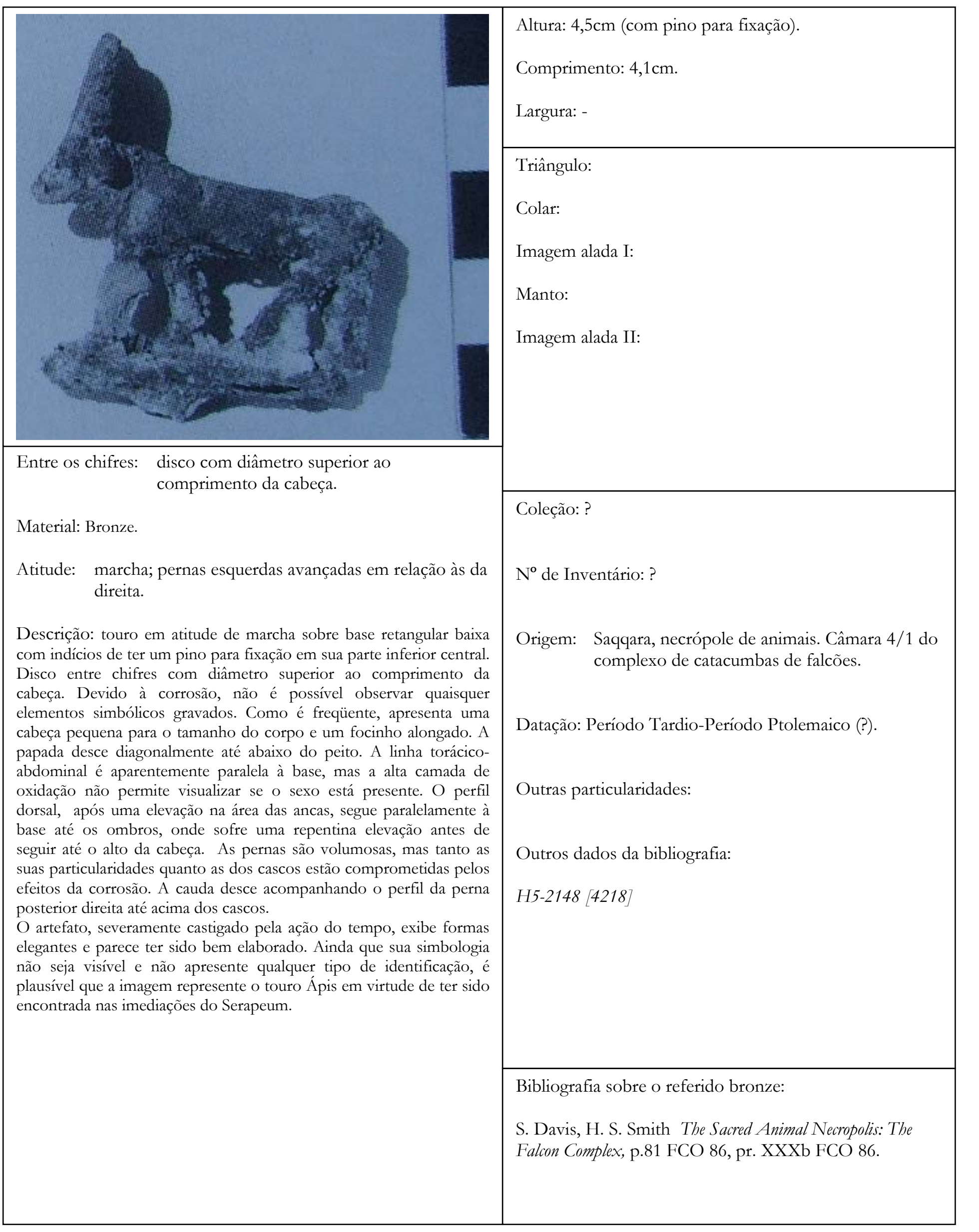




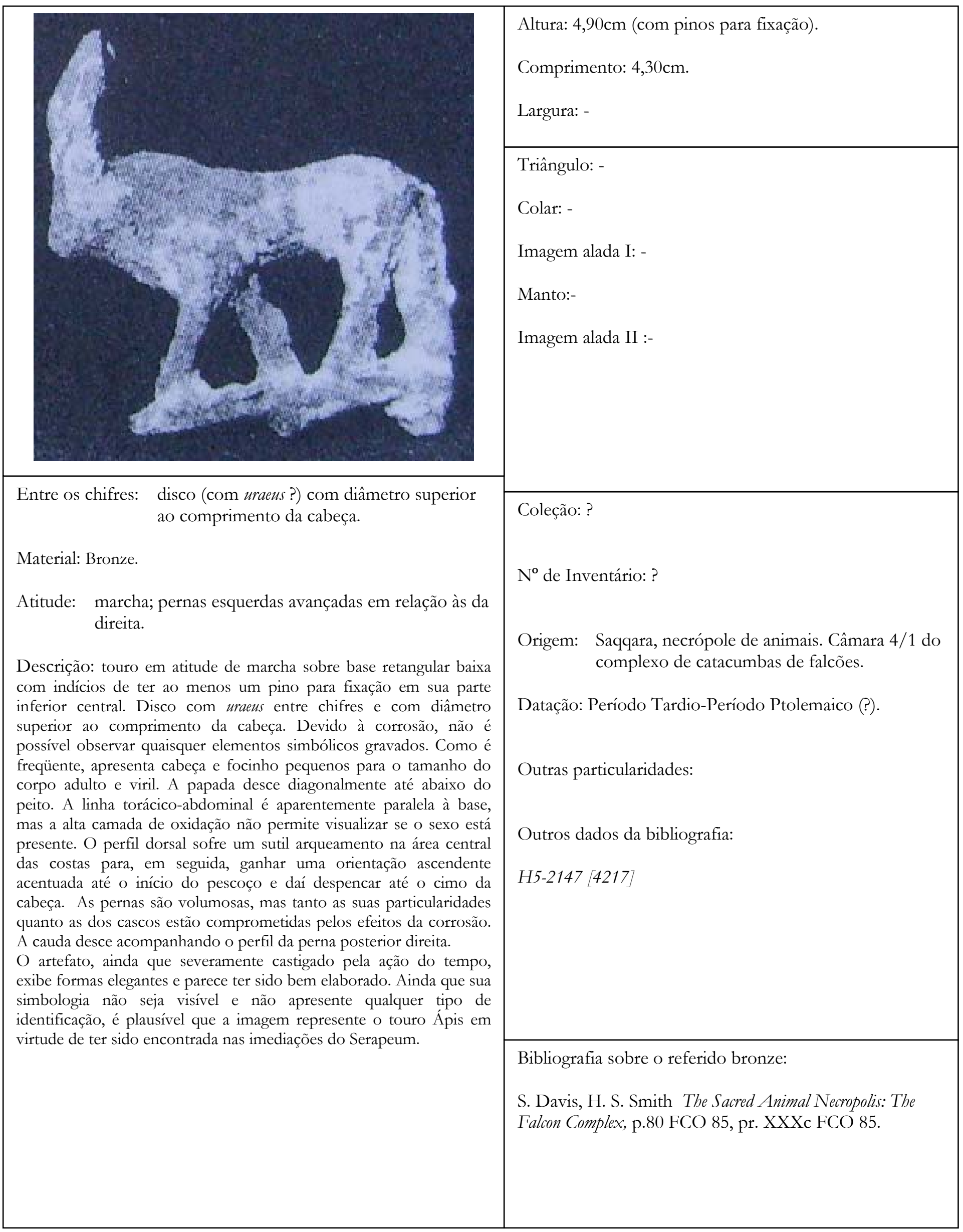




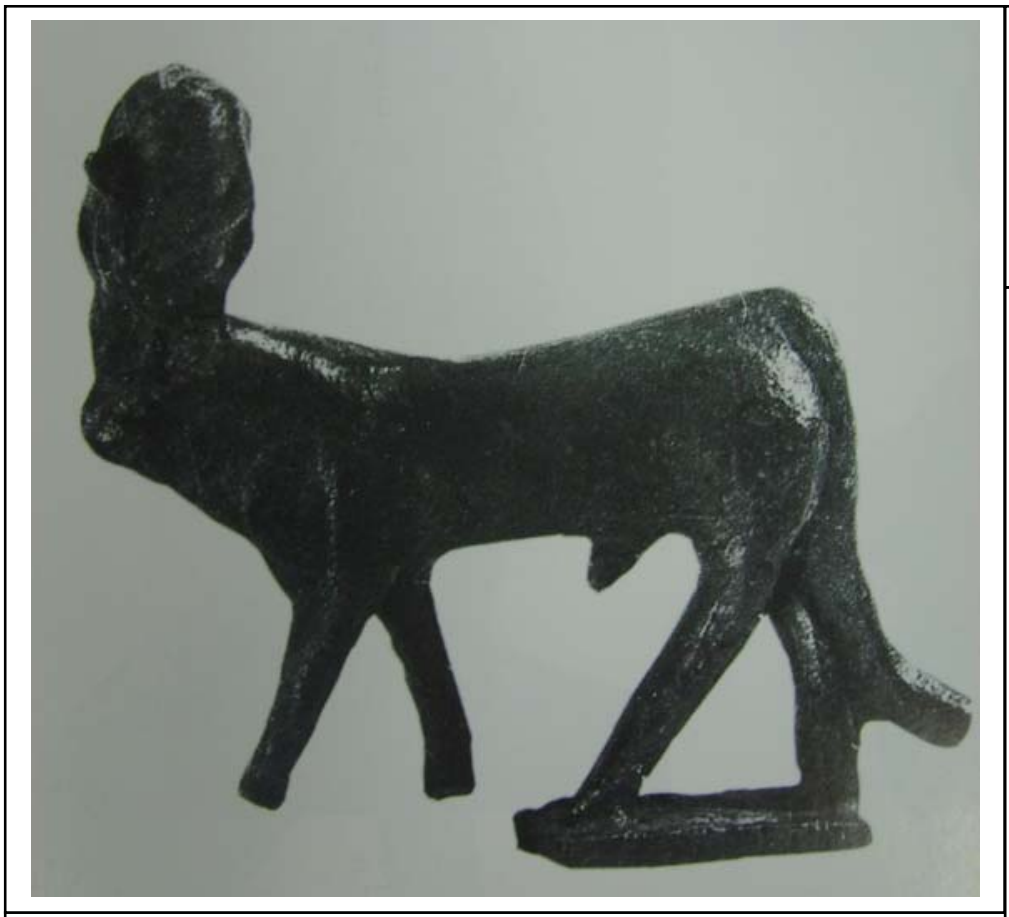

Entre os chifres: disco com uraeus, com diâmetro superior ao comprimento dos chifres.

Material: Bronze.

Atitude: marcha; pernas esquerdas avançadas em relação às da direita.

Descrição: touro em marcha sobre base retangular baixa e quebrada na sua parte mediana, assim como as patas frontais da imagem. Disco com uraeus com diâmetro superior ao comprimento da cabeça e entre chifres em "V". Não apresenta símbolos incisos no dorso e pescoço e possivelmente também não o triângulo na fronte. Cabeça pequena e focinho abreviado que parecem nada mais do que um prolongamento do pescoço. Não é possível observar muitos detalhes na foto além das orelhas, que se localizam abaixo dos chifres. A papada desce indistinta do pescoço desde o início deste, a partir de onde adquire um movimento curvilíneo que contorna o peito. A linha torácico-abdominal corre paralela à base até entre as pernas traseiras, tendo sua harmonia perturbada pela representação do sexo. A linha dorsal desce em um pronunciado declive até antes dos ombros, onde muda a inclinação para subir até a cabeça. As pernas são finas e rígidas, mas procuram aludir ao movimento do animal. Os cascos não estão indicados e a parte correspondente nas pernas frontais está quebrada juntamente com a base. A cauda desce acompanhando o perfil da perna traseira direita, mas ao contrário dos demais exemplares, curva sua extremidade para trás.

A figurinha é rústica na apresentação das particularidades, mas apresenta superfícies afeiçoadas, talvez por obra de uma restauração. Por não mostrar qualquer simbologia particular de Ápis, ou não sabermos sua real origem, não é possível relacioná-la a esse touro sagrado.
Altura: $6 \mathrm{~cm}$.

Comprimento: $6,3 \mathrm{~cm}$.

Largura: 2,3cm.

Triângulo: ?

Colar: -

Imagem alada I: -

Manto: -

Imagem alada II: -

Coleção: Dnepropetrovsk, Ukrania.

$\mathrm{N}^{0}$ de Inventário: E-3064.

Origem: desconhecida.

Datação: Período Tardio-Período Ptolemaico.

Outras particularidades:

Outros dados da bibliografia:

Bibliografia sobre o referido bronze:

O. Berlev, S. Hodjash Catalogue of the Monuments of Ancient Egrpt, p.63, n¹1, pr. 89, VI. 11. 


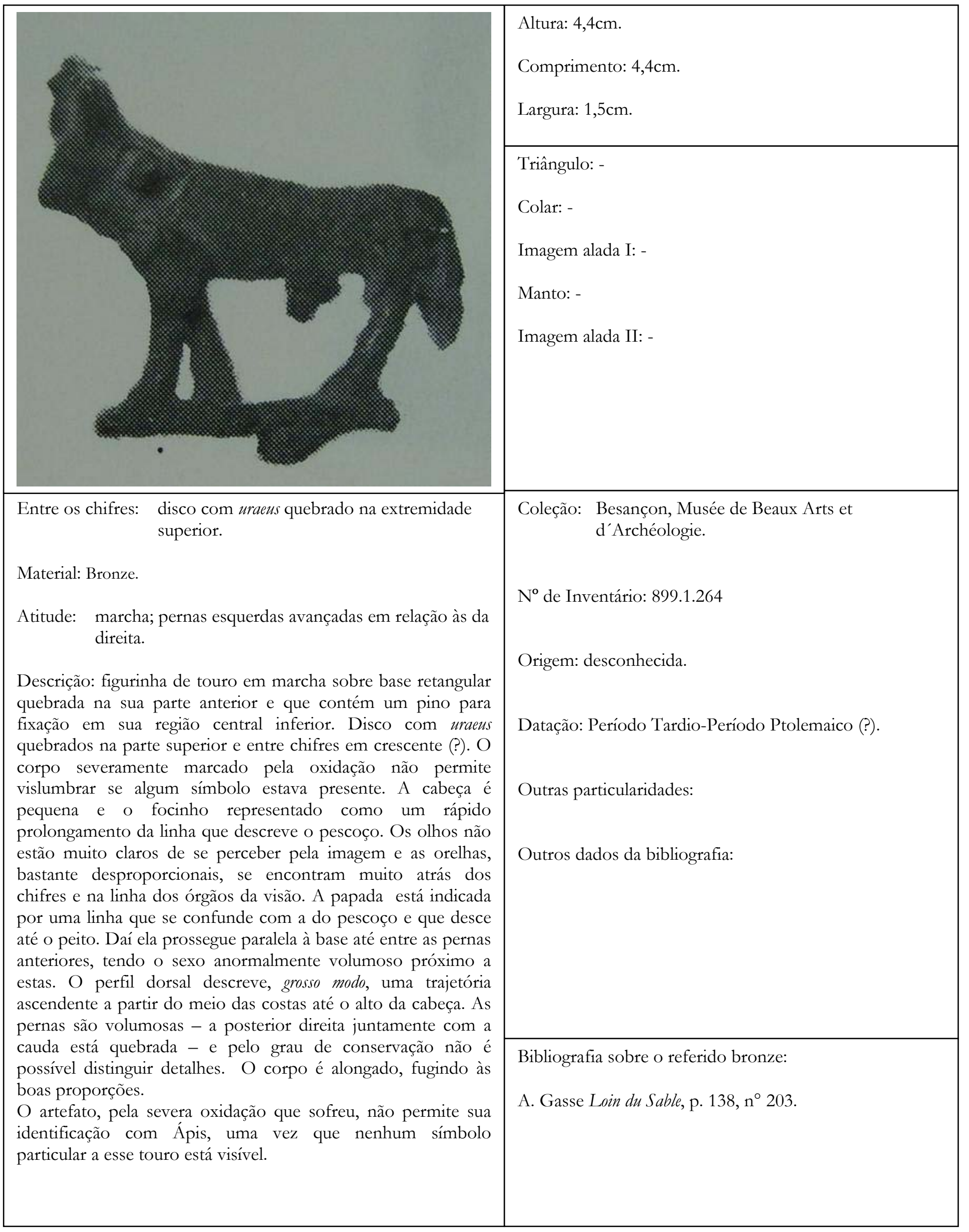




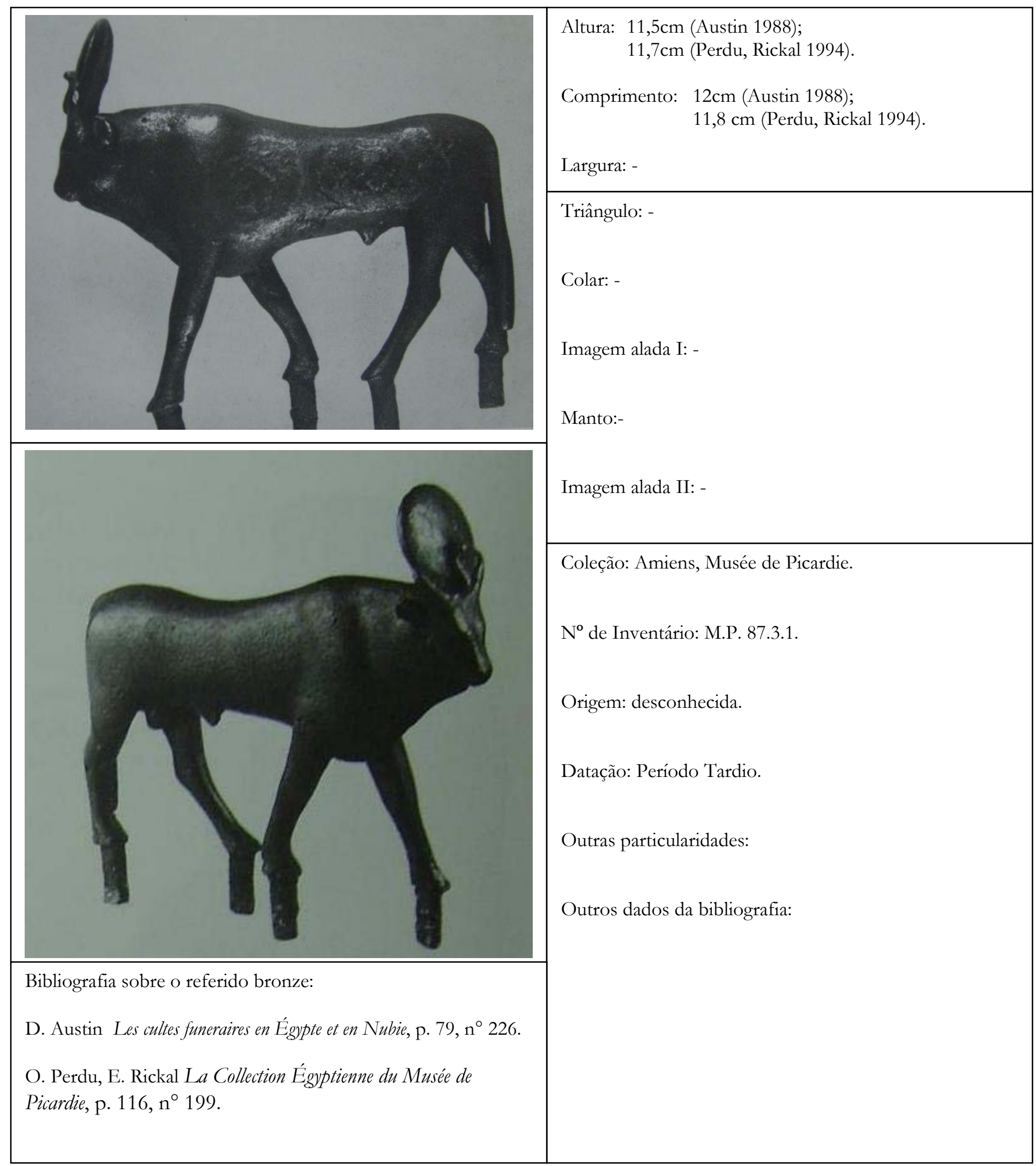


Entre os chifres: disco com uraeus com diâmetro superior ao comprimento da cabeça.

Material: Bronze.

Atitude: marcha; pernas esquerdas avançadas em relação às da direita.

Descrição: touro em atitude de marcha com pinos de fixação forjados diretamente abaixo dos cascos como um prolongamento destes. Disco com uraeus entre chifres em "V" e com diâmetro superior ao comprimento da cabeça. Não apresenta quaisquer símbolos incisos sobre o corpo. Olhos amendoados e orelhas acima da altura destes e atrás da linha dos chifres. A cabeça e focinho, com sua acentuada pequenez, dão um ar menos ameaçador às proporções do corpo viril do animal sagrado. A papada descreve uma única inclinação descendente até abaixo do peito, onde se nota uma grande acentuação que destaca o tórax. A linha torácico-abdominal segue um percurso ascendente pronunciado até entre as pernas traseiras e sobre ela se destaca o sexo. O perfil dorsal desenvolve uma ligeira elevação sobre as ancas e desce até o meio das costas. De lá, ganha uma orientação ascendente suave até o alto dos ombros para daí caminhar até o alto da cabeça. As pernas exibem por meio de volumes elegantes as particularidades da anatomia bovina e os cascos estão bem indicados pelos volumes e linhas que os definem. A cauda acompanha o perfil da perna posterior direita até pouco acima dos cascos e está destacada em sua parte mediana.

O corpo apresenta um afunilamento que lhe tira uma boa proporcionalidade. No entanto sua confecção é superior e deve ter sido um artefato de acesso restrito. Como não apresenta inscrições ou qualquer simbologia, e tampouco sua proveniência é conhecida, não é possível saber se o animal representado é um Ápis. 


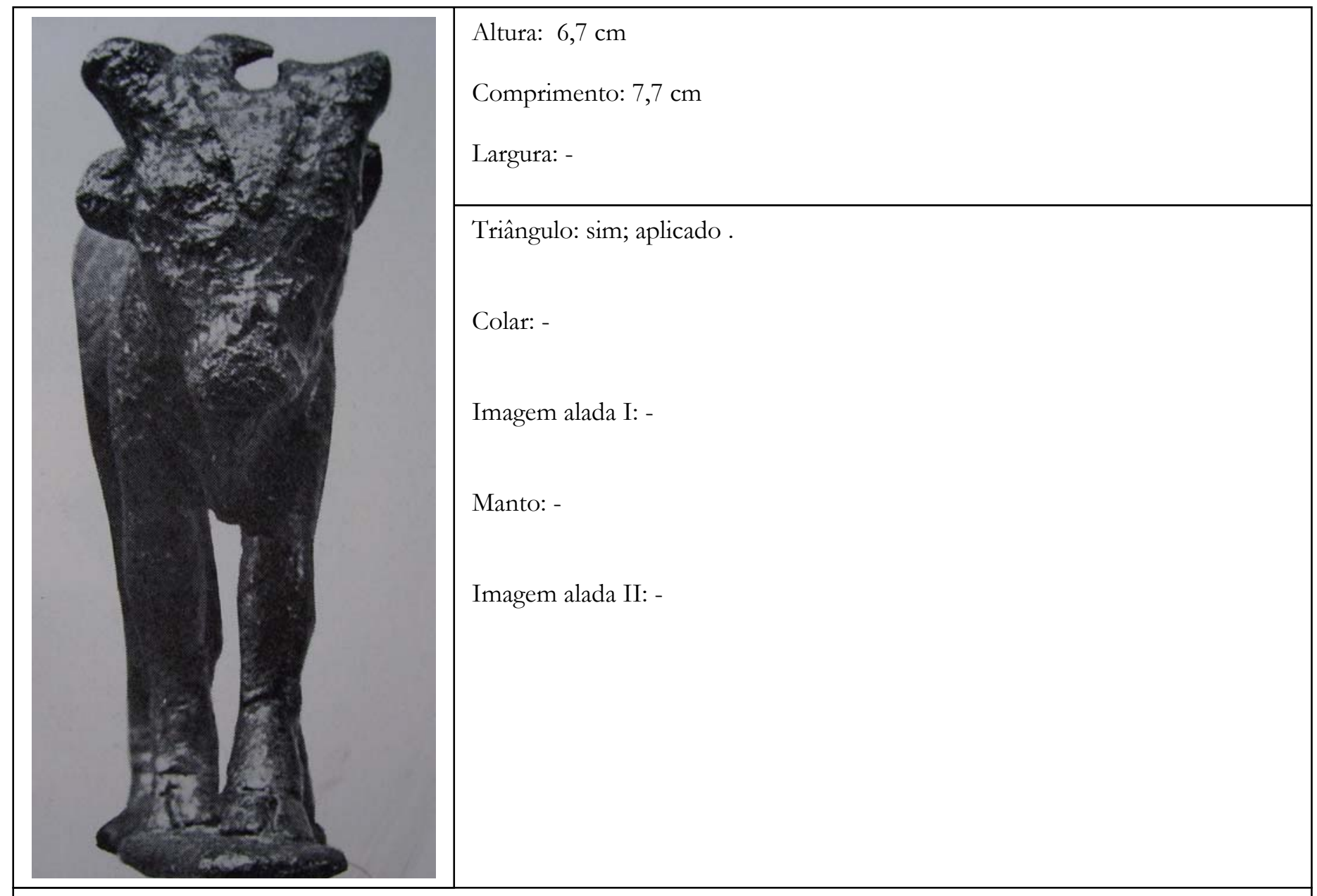

Coleção: Budapeste, Szépművészeti Múzeum.

$\mathrm{N}^{\mathrm{o}}$ de Inventário: $56.51 \mathrm{~A}$

Origem: desconhecida

Datação: Período Tardio

Outras particularidades:

Imagens sobre o dorso espelham manchas na pelagem, tal como nas representações das estelas.

Outros dados da bibliografia:

Datado do segundo terço do $6^{\circ}$ século a.C. 


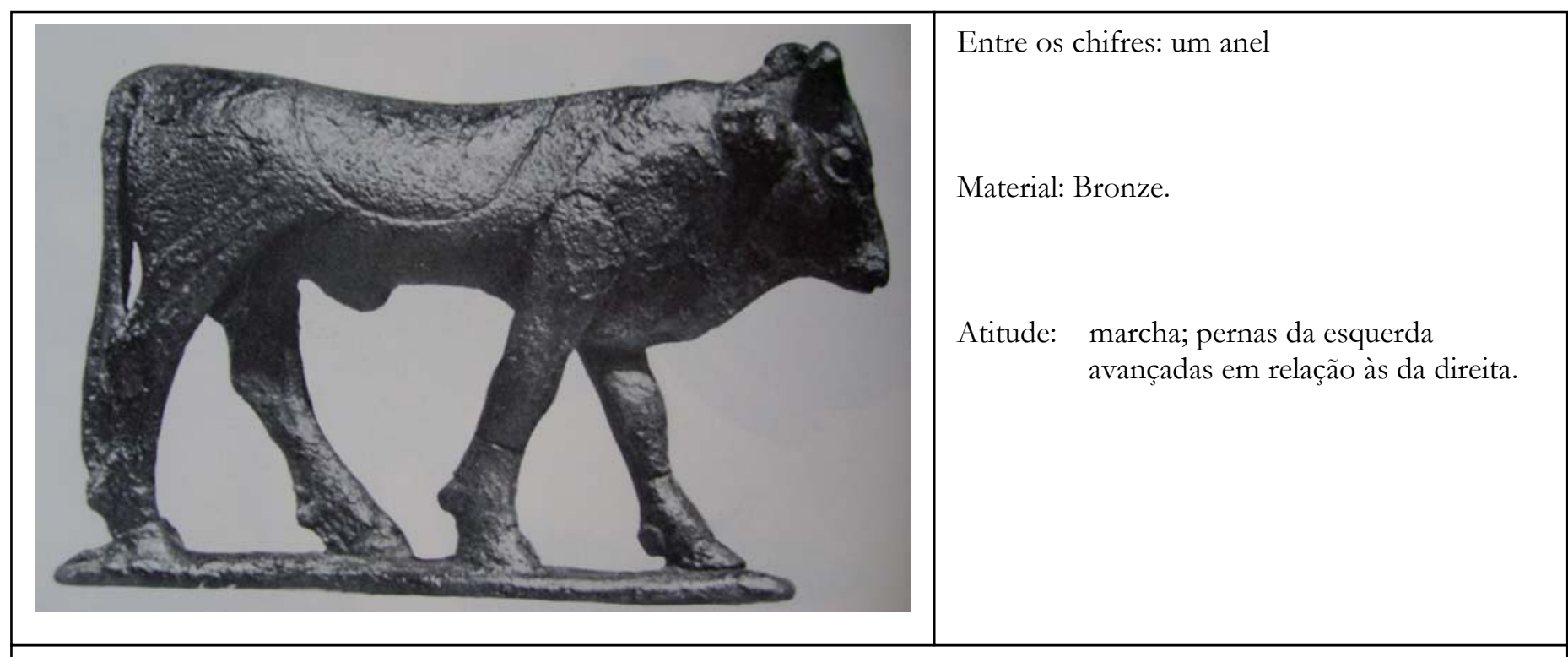

Entre os chifres: um anel

Material: Bronze.

Atitude: marcha; pernas da esquerda avançadas em relação às da direita.

Descrição: atitude de marcha sobre base baixa, sem inscrições na forma de um "S" invertido. Entre os chifres curtos em "V", ao invés do disco com uraeus, apresenta um anel cuja forma não é regular e que está quebrado no seu canto superior esquerdo. Triângulo aplicado na fronte. Decoração lombar incisa e que reproduz os limites das manchas visíveis nas estelas do Serapeum. Olhos arredondados e bem definidos. Orelhas localizadas na linha detrás da cabeça e acima dos olhos. O focinho exibe um perfil triangular e, aparentemente narinas e boca discretas - dada a superfície irregular da cabeça, é difícil se perceber as sutilezas da face. A papada desce em um único impulso descendente que contorna o peito à certa distância para encontrar a linha abdominal atrás das pernas frontais. $\mathrm{O}$ abdômen é constituído de um segmento que corre paralelo à base até a virilha, tendo sobreposto o órgão genital. As pernas são bem modeladas e mostram os contornos da anatomia bovina - os membros dianteiros apresentam rachaduras logo acima dos cascos e na junção com o torso. Os cascos são bem esculpidos e delineados. A linha dorsal desempenha uma curvatura côncava, com sua parte central no meio das costas, e retoma seu segundo ponto mais alto depois da região das ancas no início do pescoço. Daî desempenha um movimento semelhante porém mais curto para atingir o cimo da cabeça. A cauda pendente desce acompanhando o perfil da perna posterior direita, à qual está unida nas suas porções superior e inferior.

A estatueta, ainda que apresente a cabeça um pouco maior do que o convencional, ilustra bem as proporções do touro. Uma particularidade interessante deste objeto, é que de todos os símbolos recorrentes nos bronzes de Ápis, só exibe o triângulo na fronte. No lugar dos outros, exibe as mesmas linhas que contornam as manchas negras vistas nas estelas dedicadas a esse animal sagrado no Serapeum. A base também foge do modelo retangular convencional. Suas superfícies apresentam-se rugosas e observam-se, como já foi dito, pontos de fratura nos membros dianteiros. Apesar disso, seu estado de conservação é satisfatório.

Bibliografia sobre o referido bronze:

L. Castiglione, Un Taureau Apis Gréco-Égyptien du VIe. Siècle avant N.E., pp. 21-29.

G.J.F. Kater-Sibbes, M. J. Vermaseren Apis II, p. 48 n 396; Pr. CXV 396. 


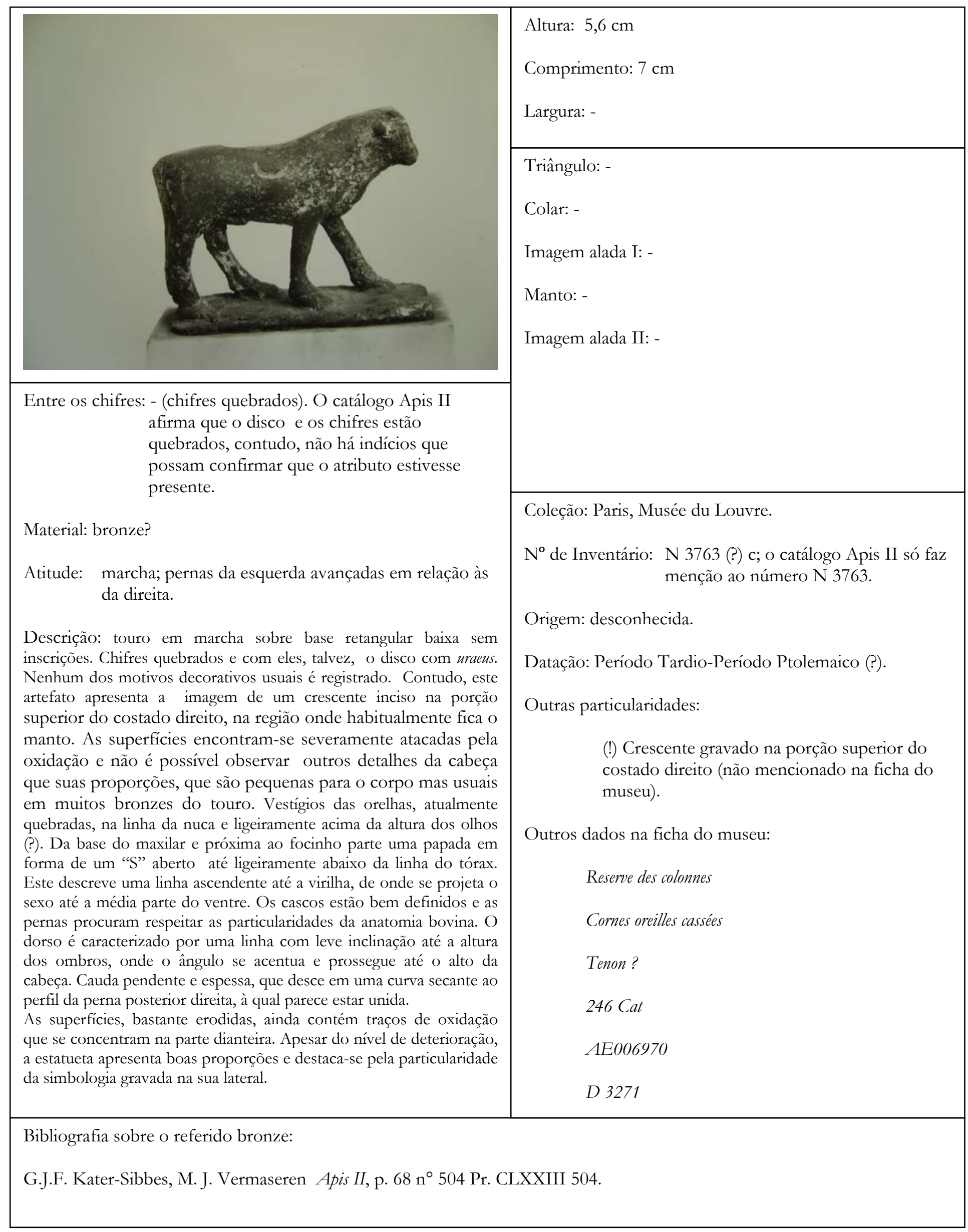




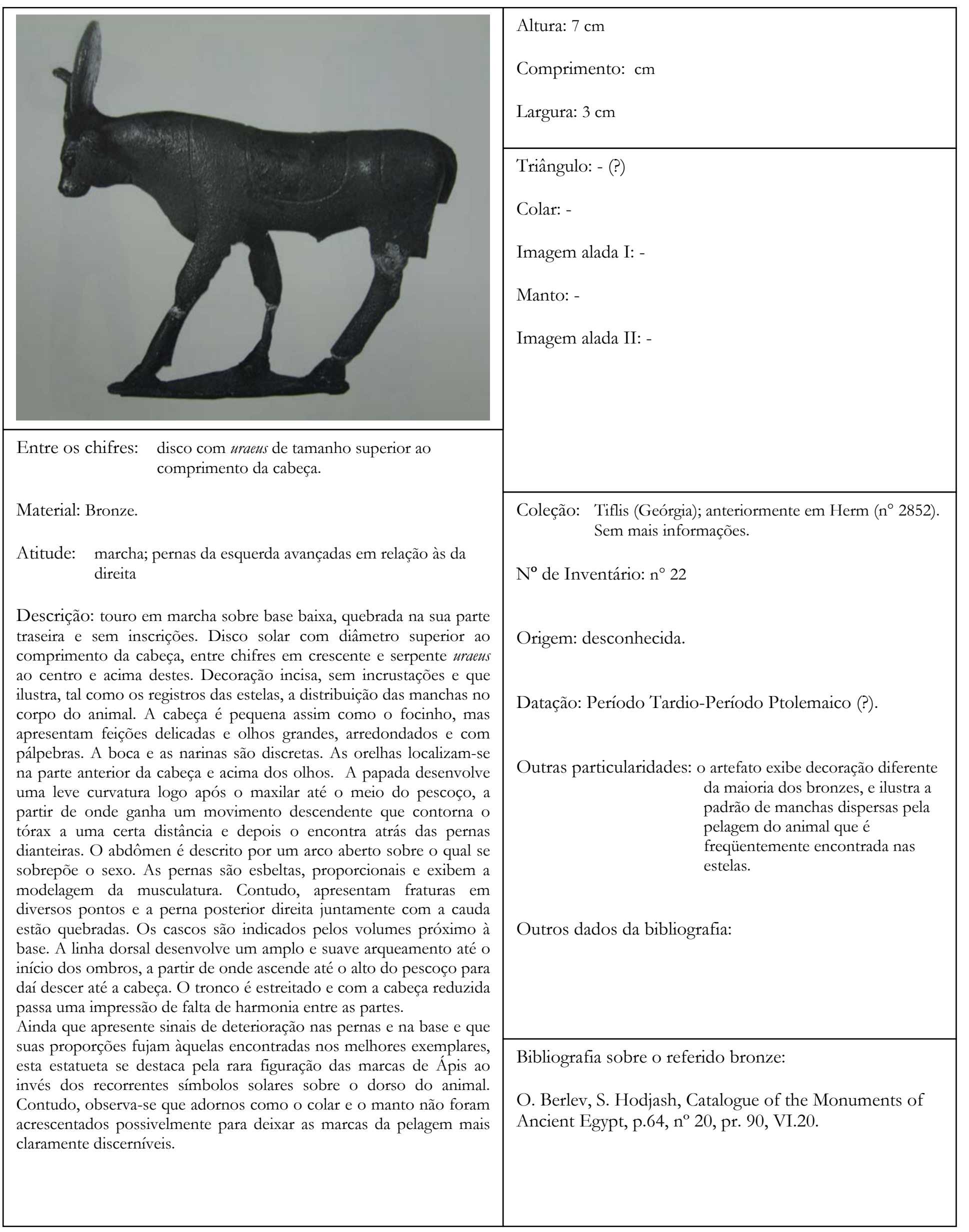




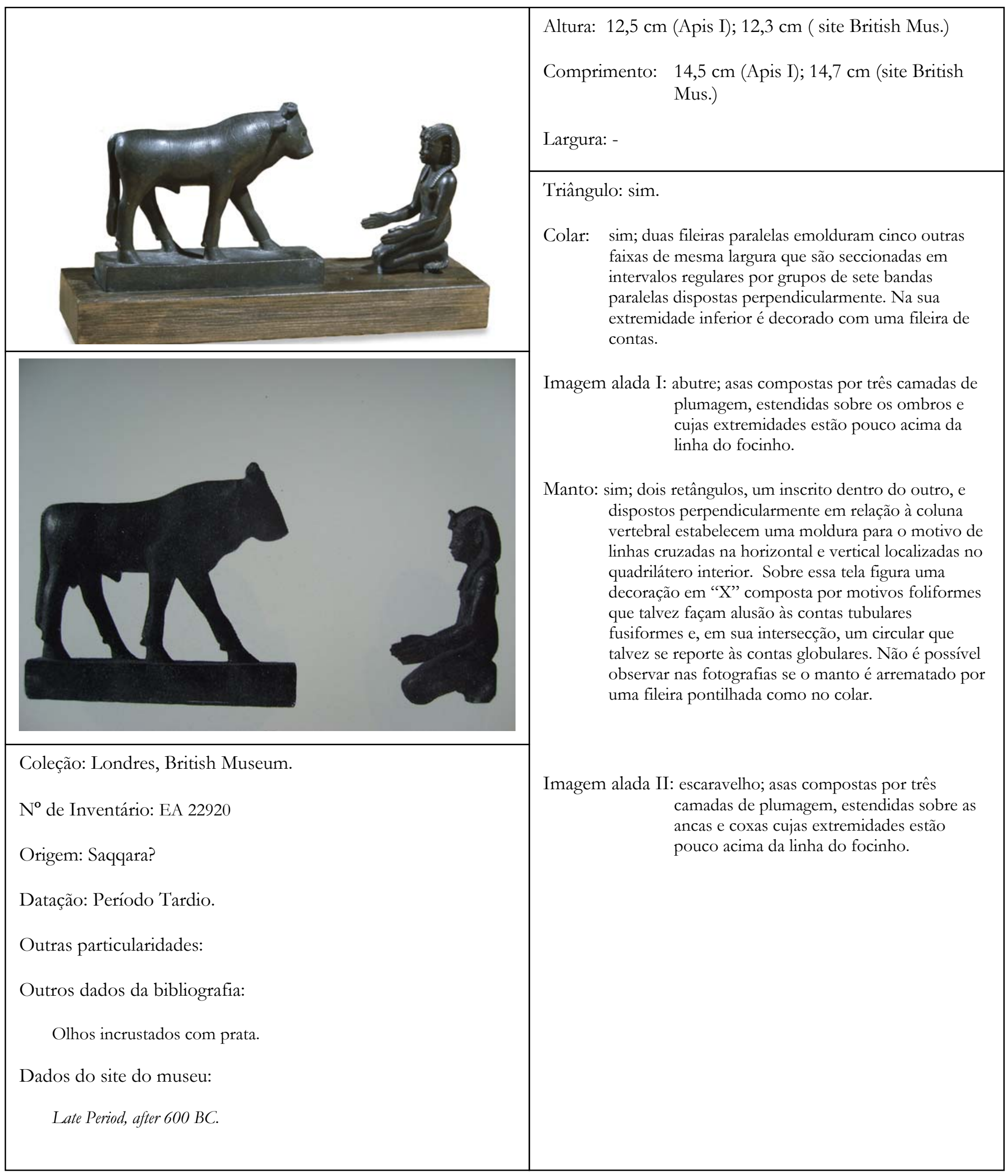


Entre os chifres: (?) quebrado.

Material: Bronze.

Atitude: marcha; pernas da esquerda avançadas em relação às da direita.

Descrição do touro: atitude de marcha sobre base retangular alta com inscrições. O artefato está acompanhado, à frente, da representação de um rei ajoelhado prestando-lhe oferendas e que outrora se fixava a uma base comum possivelmente de madeira. Chifres e, possivelmente, disco com uraeus quebrados. Triângulo gravado na fronte. Decoração lombar e do pescoço incisas e elaboradas. Olhos grandes, arredondados e com incrustação de prata. Orelhas localizadas na linha detrás da cabeça e acima da altura dos olhos. O focinho é largo e bem moldado com extremidades afeiçoadas. Exibe narinas e boca discretas. A papada desenvolve duas ondulações: a primeira se prolonga até o início do colar e a segunda se estende até a altura do tórax, ao qual vem se juntar após uma curvatura aberta. A linha que daí prossegue até a virilha é paralela à base e só é perturbada pela representação do órgão genital. As pernas são robustas, bem modeladas e exibem os volumes da anatomia bovina. Os cascos são igualmente bem esculpidos e delineados. A linha dorsal descreve um percurso paralelo ao abdômen até o início dos ombros, onde ganha uma orientação ascendente cujo ápice se encontra no início do pescoço. A partir dessa área, retoma o curso paralelo à base e ao abdômen para encontrar o cimo da cabeça. A cauda, pendente e espessa, desce acompanhando o perfil da perna posterior direita, à qual está unida na parte inferior e superior. Esta é decorada na sua extremidade por linhas espiraladas que denotam a pelagem.

O artefato exibe qualidades ímpares tanto em suas formas quanto na representação da simbologia que o associa a Ápis. Seu estado de conservação é excelente.

Descrição do ofertante: rei cuja identidade não nos é conhecida, com toucado nemes listrado e representação da serpente uraeus na fronte, ajoelhado e apresentando uma oferenda hoje perdida. É fixado a uma base moderna, sobre a qual também está Ápis, por meio de pinos localizados na parte inferior dos joelhos e pés, os quais estão unidos entre si. Estes últimos encontram-se flexionados e os dedos estão indicados com detalhe. O personagem veste um saiote plissado com cinturão e no pescoço porta um colar usekh. Seus braços estão ligeiramente projetados para frente e os antebraços virados para dentro e acima das pernas. As mãos espalmadas, com os dedos bem definidos, estão voltadas uma para a outra na atitude de portar uma oferenda. Sua linha dorsal exibe as sinuosidades próprias e sobre sua parte superior desce o arremate do toucado. O rosto exibe minuciosamente suas feições, com olhos, sobrancelhas e boca bem delineados e nariz e orelhas cuidadosamente moldados. O tórax sugere os volumes da musculatura e o umbigo está logo acima do cinturão. A linha da cabeça está na altura dos olhos de Ápis.

Como a estatueta do touro, este artefato exibe um acabamento superior e encontra-se em excelente estado de conservação.

Bibliografia sobre o referido bronze:

G.J.F. Kater-Sibbes, M. J. Vermaseren Apis I, p. 16, n 51; Pr. XXXIX 51.

http://www.britishmuseum.org/explore/highlights/highlight objects/aes/b/bronze of the king before bull.aspx 


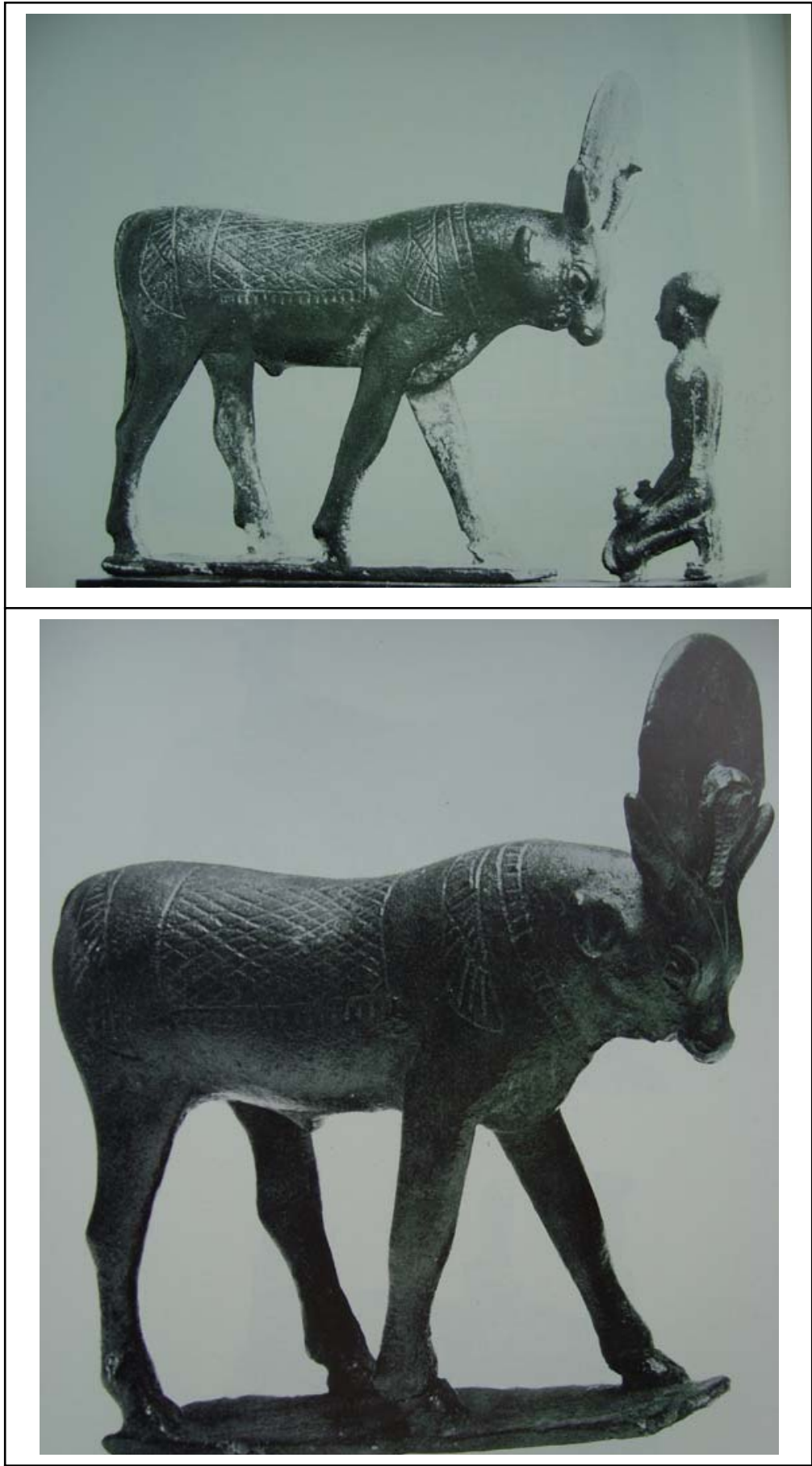

Foto do mesmo touro e que foi classificado equivocadamente como sendo de número 2574 da coleção de Berlim.
Altura: $6,6 \mathrm{~cm}$ ?

Comprimento: $6,7 \mathrm{~cm}$ ?

Largura: -

Triângulo: sim.

Colar: sim; uma faixa decorada com traços espaçados dispostos perpendicularmente.

Imagem alada I: abutre; asas estendidas sobre os ombros e ultrapassando a linha do manto. Plumagem indicada por traços que se iniciam na parte superior das asas e se dirigem para o lado oposto. Para definir as três camadas desta, traços transversais e horizontais (na parte superior das asas, na linha do dorso) foram adicionados sobre a representação das plumas emparelhadas.

Manto: sim; um retângulo disposto perpendicularmente à linha dorsal é decorado em seu interior com um padrão de linhas diagonais que formam uma tela de losangos e nas suas extremidades inferiores por franjas.

Imagem alada II: escaravelho; asas estendidas sobre as ancas e coxas cujas extremidades ultrapassam a linha do manto. Plumagem indicada por traços que se iniciam na parte superior das asas e se dirigem para o lado oposto. Para definir as três camadas desta, traços transversais e horizontais (na parte superior das asas, na linha do dorso) foram adicionados sobre a representação das plumas.

Coleção: Berlim, Staatliche Museen.

$\mathrm{N}^{0}$ de Inventário: 2571 (?)

O mesmo artefato foi mencionado com outro número de registro (2574) e medidas diferentes (11,2 cm !): G.J.F. Kater-Sibbes, M. J. Vermaseren Apis I, p. 21, nº 74; Pr. LIII 74

Origem: Saqqara?

Datação: Período Tardio-Período Ptolemaico (?).

Outras particularidades:

Outros dados da bibliografia: 
Entre os chifres: disco com uraeus cujo diâmetro é superior ao comprimento da cabeça

Material: Bronze

Atitude: marcha; pernas da esquerda avançadas em relação às da direita

Descrição do touro: Ápis em atitude de marcha sobre base retangular baixa sem inscrições. Diante dele, e igualmente fixo a uma base moderna, está um ofertante. Disco com uraeus com diâmetro superior ao comprimento da cabeça do touro e entre chifres em "V". Triângulo na fronte. Decoração lombar incisa estilizada. Olhos grandes amendoados, bem delineados, com pálpebras e dispostos transversalmente. As amplas orelhas estão localizadas na linha anterior da cabeça e acima dos olhos. O focinho, pequeno e arrebitado, exibe as narinas mas a boca está invisível. Após uma união do pescoço com a cabeça não muito harmônica abaixo do focinho, parte uma papada em "S" cuja curvatura inferior é ampla e se projeta para baixo da altura do tórax. A linha que constitui seu perfil só irá encontrar o peito na região entre as patas dianteiras e daí prossegue paralelamente à base até a virilha. Aproximadamente na metade do ventre se destaca a imagem do sexo. As pernas são esguias mas espelham bem os volumes da anatomia bovina e os cascos estão bem esculpidos e delineados. A linha dorsal desenha um arqueamento pronunciado logo após as ancas para ganhar um impulso ascendente constante até o alto dos ombros, onde adquire uma inclinação para alcançar a cabeça. A cauda desce acompanhando o perfil da perna posterior direita à qual está possivelmente unida.

A estatueta se encontra em ótimo estado de conservação e exibe o vigor de um touro no auge da maturidade. Ainda que haja particularidades não tão harmônicas na junção da cabeça com o focinho, o artefato exibe formas elegantes, boas proporções e a simbologia completa de um Ápis.

Descrição do $2^{\circ}$ personagem: indivíduo ajoelhado, com pinos de fixação sob os joelhos e pés (?) encaixados em uma base moderna. Suas pernas e pés estão emparelhados e ele veste um saiote com linhas não muito definidas. Seus braços acompanham o torso, ao qual possivelmente está unido, e se prolongam sobre as pernas porta em cada uma das mãos espalmadas um vaso $n w$. Suas costas eretas desenham as curvaturas da coluna e da união do pescoço com a cabeça. Esta é proporcional ao corpo e apresenta o nariz, as orelhas e os traços da face bem moldados - outras particularidades não são visíveis na fotografia. A linha que define a altura do ofertante encontra-se pouco abaixo da extremidade superior dos olhos de Ápis.

Bibliografia sobre o referido bronze:

G.J.F. Kater-Sibbes, M. J. Vermaseren Apis I, p. 21, n 73; Pr. LII 73.

G. Roeder Aegyptische Bronzefiguren, 325, § 411 d, 4; 329, § 413, n, fig. 436.

E. Schott Eine Datierte Apisbronze, p.91. 


\begin{tabular}{|c|c|}
\hline & $\begin{array}{l}\text { Altura do touro: } 7 \mathrm{~cm} \text { (com pino de fixação) } \\
\text { Altura do ofertante: } 4,3 \mathrm{~cm} \\
\text { Comprimento do touro: } 6,7 \mathrm{~cm} \\
\text { Comprimento da base: } 10,9 \mathrm{~cm} \\
\text { Largura: - }\end{array}$ \\
\hline 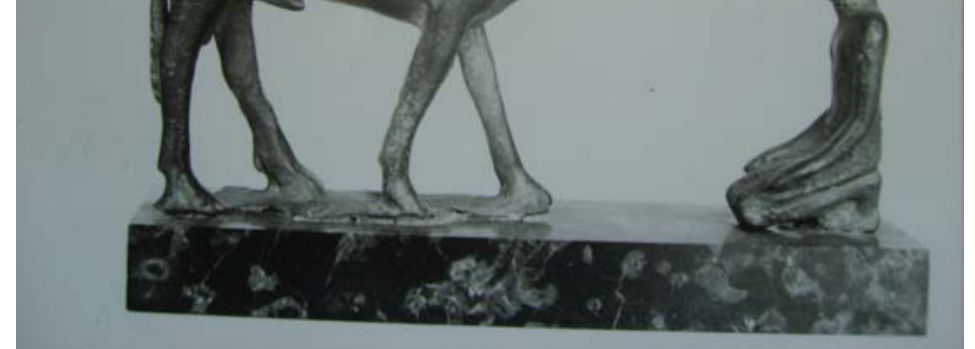 & $\begin{array}{l}\text { Triângulo: sim } \\
\text { Colar: -(?) } \\
\text { Imagem alada I: disco; com asas estendidas sobre os ombros } \\
\begin{array}{l}\text { cujas extremidades ultrapassam a linha } \\
\text { inferior do manto e compostas por três } \\
\text { camadas de plumagem. }\end{array}\end{array}$ \\
\hline $\begin{array}{l}\text { Entre os chifres: disco com uraeus com tamanho aproximadamente } \\
\text { igual ao do comprimento da cabeça. } \\
\text { Material: bronze? } \\
\text { Atitude: marcha; pernas da esquerda avançadas em relação às } \\
\text { da direita. } \\
\text { Descrição (touro): atitude de marcha sobre base baixa, } \\
\text { deteriorada e sem inscrições. Disco com uraeus com diâmetro } \\
\text { aproximadamente igual à medida do comprimento da cabeça e } \\
\text { entre os chifres em crescente (?). Decoração lombar incisa, sem } \\
\text { incrustações e bastante apagada. Olhos grandes e em relevo. As } \\
\text { orelhas, projetadas para frente, localizam-se nas linhas da nuca e } \\
\text { do canto superior dos olhos. A cabeça apresenta traços } \\
\text { delicados e da base do maxilar parte uma papada que, após uma } \\
\text { reentrância no seu início, desenvolve um percurso quase } \\
\text { retilíneo até pouco abaixo da região frontal do tórax. Daí, a } \\
\text { silhueta segue uma linha ascendente até a virilha de onde se } \\
\text { projeta o sexo. Os cascos estão relativamente bem definidos e } \\
\text { os membros locomotores dão a impressão de serem mais } \\
\text { longos do que o convencional pelo fato de apresentarem o } \\
\text { touro mais magro. A linha dorsal descreve quase uma linha } \\
\text { paralela à base, ganhando um leve aclive na região dos ombros } \\
\text { e, por fim, um novo declive para depois alcançar o alto da } \\
\text { cabeça. Cauda pendente e perpendicular à base, destacada da } \\
\text { perna posterior direita na sua porção mediana e cuja } \\
\text { extremidade se encontra bastante acima da linha dos cascos. } \\
\text { Apesar de ter seu simbolismo um tanto apagado, a estatueta } \\
\text { encontra-se em excelente estado de conservação, com alguns } \\
\text { traços de oxidação localizados nas áreas mais rugosas. } \\
\text { O artefato está fixo a uma base moderna juntamente com a } \\
\text { representação do personagem que lhe presta adoração. }\end{array}$ & $\begin{array}{l}\text { Coleção: Paris, Musée du Louvre. } \\
\begin{array}{l}\mathrm{N}^{\mathrm{o}} \text { de Inventário: } \mathrm{N} 5166 \text { b; no catálogo Apis II consta } \\
\text { simplesmente } 5166 \text { (vitrine 14). }\end{array} \\
\text { Origem: ? (Não mencionada na ficha do museu) } \\
\text { Datação: Período Tardio-Período Ptolemaico (?). } \\
\text { Outras particularidades: } \\
\text { Outros dados na ficha do museu: } \\
\text { AE007102 } \\
\text { Taureau et donateur ont de (?) differentes mais toutes (?) } \\
\text { genre Serapeum. } \\
\text { Salle F vit } 14 \\
\text { D5490 }\end{array}$ \\
\hline
\end{tabular}


Descrição do personagem: homem ajoelhado, com braços estendidos sobre as pernas. Entre seus pés observa-se um pino de fixação à base (moderna) e possivelmente conta com outro, de diâmetro menor, abaixo dos joelhos. Sua cabeça está raspada e suas orelhas estão representadas sem muito detalhamento, mas seu nariz e boca estão particularmente distinguíveis. Os olhos estão bem indicados nas órbitas. Ele veste um saiote com cinturão que se prolonga até pouco acima da altura dos joelhos. As costas descrevem uma ligeira curvatura na região lombar e estão dispostas perpendicularmente à base. A linha do tórax ao ventre é plana, o umbigo está presente e o pescoço é largo. Nota-se o esforço do escultor em dar à figurinha uma expressão de vida através de seu detalhamento e proporções.

Bibliografia sobre o referido grupo:

G. J. F. Kater-Sibbes, M. J. Vermaseren, Apis II, p.71 n 518, Pr. CLXXIX 518. 


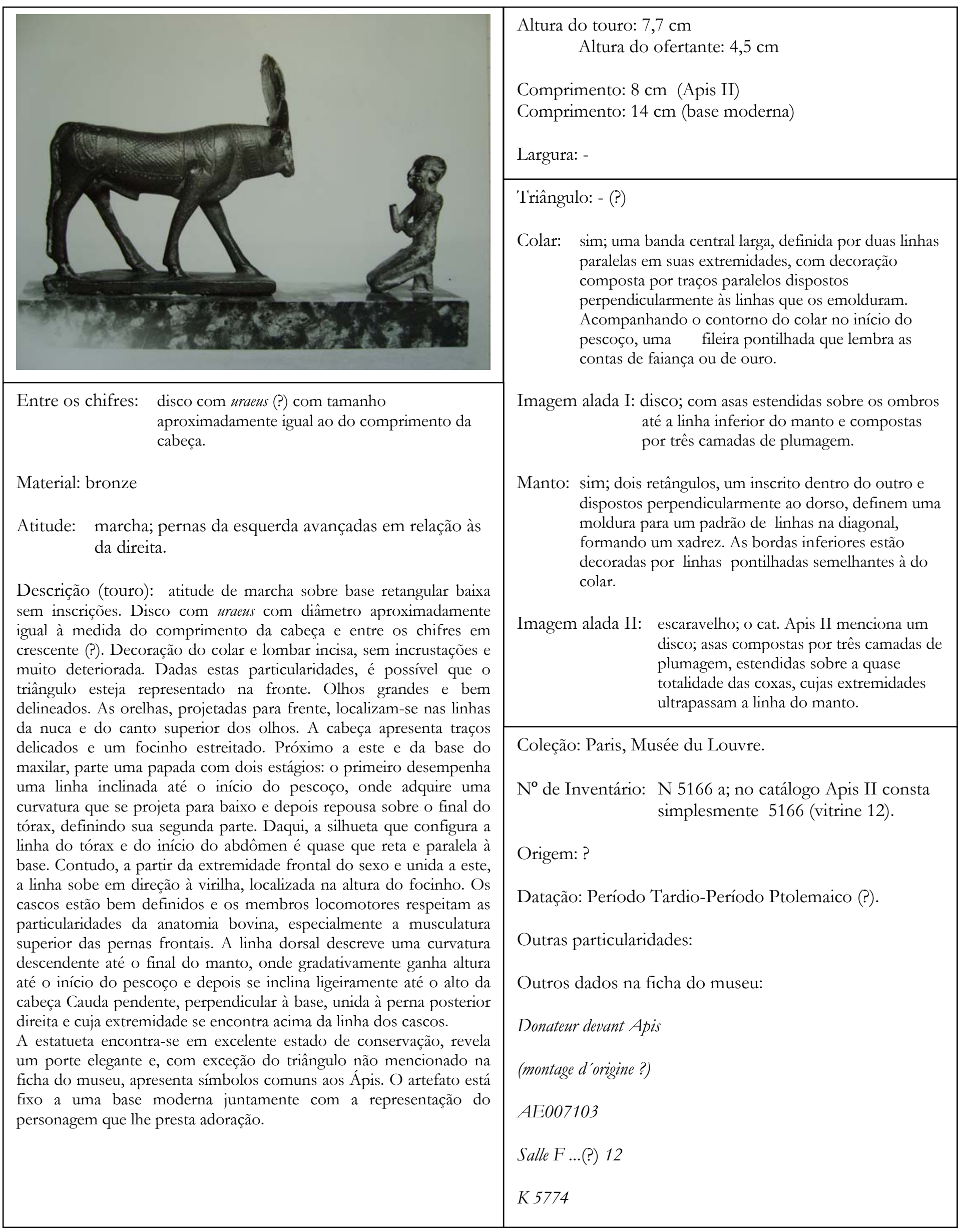


Descrição do personagem: homem ajoelhado, com braços erguidos e quebrados em atitude de adoração. Entre seus pés observa-se um pino de fixação à base (moderna) e possivelmente conta com outro, de diâmetro menor, abaixo dos joelhos. Sua cabeça está raspada e suas orelhas estão representadas sem muito detalhamento, mas o nariz e boca estão particularmente distinguíveis. Os olhos estão indicados nas órbitas. À cintura parece ter um saiote que se prolonga até pouco acima da altura dos joelhos. As costas descrevem uma ligeira curvatura na região lombar e estão dispostas perpendicularmente à base. A linha do tórax ao ventre é plana e o pescoço é largo. A imagem está bastante atacada pela corrosão e parte de seus braços estão perdidos, mas nota-se a intenção do escultor em dar-lhe formas e proporções apropriadas, ainda que a imagem do touro à sua frente esteja mais elaborada.

Bibliografia sobre o referido grupo:

G. J. F. Kater-Sibbes, M. J. Vermaseren, Apis II, p.70 n 517, Pr. CLXXIX 517. 


\begin{tabular}{|c|c|}
\hline & $\begin{array}{l}\text { Altura: } 16 \mathrm{~cm} \text { (contando com atributo na cabeça da } \\
\text { divindade) } \\
\text { Comprimento da base: } 16 \mathrm{~cm} \\
\text { Largura: - }\end{array}$ \\
\hline & $\begin{array}{l}\text { Triângulo: -(?) } \\
\text { Colar: (!) sim; duas bandas decoradas com pequenos traços } \\
\text { na perpendicular são intercaladas por três faixas mais } \\
\text { estreitas e paralelas. Na extremidade junto ao início } \\
\text { do pescoço uma fileira pontilhada que possivelmente } \\
\text { alude as contas globulares de faiança. }\end{array}$ \\
\hline $\begin{array}{l}\text { Entre os chifres: disco com uraeus com diâmetro superior ao } \\
\text { comprimento da cabeça. }\end{array}$ & $\begin{array}{l}\text { Manto: (!) sim; dois retângulos, um inscrito dentro do outro, e } \\
\text { dispostos perpendicularmente ao dorso, estabelecem } \\
\text { uma moldura para o padrão decorativo em xadrez } \\
\text { composto por linhas transversais no quadrilátero } \\
\text { interno. Abaixo desde e acima da moldura citada, há } \\
\text { uma estreita faixa paralela e não decorada. Na } \\
\text { extremidade inferior, há uma seqüência de pontos que } \\
\text { possivelmente evoca contas esféricas de faiança ou } \\
\text { ouro. } \\
\text { Imagem alada II: (!) sim; asas estendidas sobre as coxas, e } \\
\text { cujas extremidades ultrapassam a linha } \\
\text { inferior do manto. São formadas por três } \\
\text { camadas de plumagem, as duas internas } \\
\text { emolduradas nas extremidades. }\end{array}$ \\
\hline $\begin{array}{l}\text { detalhes, é possivel que apresente um triângulo na tronte. Olhos } \\
\text { grandes, arredondados, dispostos na diagonal e com pálpebras. As } \\
\text { orelhas estão ligeiramente inclinadas para a direção do focinho e } \\
\text { localizam-se atrás da linha da cabeça e acima da altura dos olhos. O } \\
\text { focinho é pequeno, bem modelado, com narinas e boca discretas. } \\
\text { Logo abaixo se desenvolve uma papada em dois estágios: o primeiro, } \\
\text { formado por uma leve ondulação até o meio do colar, e o segundo } \\
\text { que segue a partir do início do colar e desce contornando ao longe a } \\
\text { região frontal e inferior do peito. A linha que se prolonga daí até o } \\
\text { meio do abdômen é paralela à base e depois ganha um aclive que } \\
\text { acompanha o desenvolvimento do sexo. As pernas procuram } \\
\text { respeitar as particularidades da anatomia bovina e os cascos estão bem } \\
\text { definidos e delineados. A perna frontal esquerda apresenta uma } \\
\text { curvatura antinatural logo atrás da papada. A linha dorsal percorre um } \\
\text { caminho quase retilíneo até o início dos ombros, onde desenvolve } \\
\text { uma pronunciada ascensão até o alto destes e daí prossegue numa } \\
\text { segunda reta até o cimo da cabeça. A cauda, pendente e espessa, desce } \\
\text { acompanhando o perfil da perna posterior direita, à qual está } \\
\text { provavelmente unida. }\end{array}$ & $\begin{array}{l}\text { Coleção: Paris, Musée du Louvre. } \\
\text { No de Inventário: E } 5888 \\
\text { Origem: ? (Não mencionada na ficha do museu) } \\
\text { Datação: Período Tardio-Período Ptolemaico (?). } \\
\text { Outras particularidades: } \\
\text { Outros dados na ficha do museu: } \\
\text { AE007828 } \\
\text { Fils "du Saris" } \\
\text { Inscrive (?) } 1 \text { bras eut sur (?)(?) } 123 c\end{array}$ \\
\hline
\end{tabular}




\begin{abstract}
Descrição (ofertante): ajoelhado sobre a extremidade superior da base retangular alta e com inscrições à qual parece estar unido. Assim, tudo indica que no momento da fundição o personagem já estava incluído na peça juntamente com a flor de lótus que ele apresenta ao touro - este sim encaixado separadamente como a imagem da deusa logo atrás. Suas pernas apresentam-se comprometidas na sua parte inferior, possivelmente devido à técnica de fundição empregada, e é possível observar fraturas acima do tornozelo esquerdo e abaixo do joelho do mesmo lado. Os pés são grandes e estão posicionados um pouco além de sua localização ideal. $O$ personagem usa um saiote estriado longitudinalmente com cinturão e braceletes acima dos punhos. Colar não visível através da fotografia. $\mathrm{O}$ torso está nu e sua cabeça exibe a linha do cabelo raspado. A coluna está levemente arqueada mas o eixo do corpo está perpendicular à base. As orelhas, nariz, e olhos estão admiravelmente bem modelados e há indícios de que a boca também esteja presente. Os braços estão projetados para frente, com os antebraços quase que paralelos à base. As mãos, com dedos indicados, estão fundidas ao caule do lótus logo abaixo da flor, cujas pétalas estão abertas em cálice e dispostas alternadamente umas dentro das outras.

A figurinha e a flor que ela porta, apesar do estado deteriorado de suas pernas, estão em ótimo estado de conservação e exibem detalhes que atestam sua classificação entre os melhores exemplares.
\end{abstract}

Xerxès Ier?

Rousset bey en 1868

Salle F vit 12

E Schott RdE 19196787

(sur vereve (?) et dave)-

Tel encyclopédie photographique de l'Art I pl 123 c-

K 5774

Descrição (deusa pterófora): encontra-se em pé sobre uma base quadrangular (?) com uma plataforma de mesma configuração mas que se sobressai em relação à sua parte inferior. Esta está, aparentemente, fixada à base do ofertante por meio de um pino. Suas pernas estão emparelhadas e pouco acima dos tornozelos nota-se o prolongamento de seu vestido que desenha as linhas do corpo. Seus braços, que se encontram quebrados, têm abaixo de si e unidos a eles asas que partem da lateral do corpo. Estas estão igualmente quebradas mas observase sua decoração composta por três camadas de plumagem, as duas internas emolduradas nas extremidades - característica que se observa nas figuras aladas sobre o dorso do touro. A deusa usa uma peruca tripartite à frente da qual está uma uraeus. Acima dela há um modius do qual partem dois chifres de vaca - o esquerdo quebrado na ponta - com um disco solar entre eles, relacionando a imagem divina à deusa Ísis. As orelhas estão indicadas mas com menos detalhamento que as do personagem ajoelhado. O nariz está bem modelado mas tanto a boca quanto os olhos aparecem muito sutilmente. A linha que desce da região superior das costas aos calcanhares revela o cuidado com as formas femininas.

A estatueta, mesmo com partes faltando devido às fraturas, exibe um corpo bem moldado e um alto grau de elaboração quanto aos seus detalhes.

Bibliografia sobre o referido bronze:

G.J.F. Kater-Sibbes, M. J. Vermaseren Apis I, p. 50, n² 209, Pr. CXXIV 209. 


\begin{tabular}{|c|c|}
\hline & $\begin{array}{l}\text { Altura: } 8,2 \mathrm{~cm} \\
\text { Comprimento: } 10 \mathrm{~cm} \\
\text { Largura: - }\end{array}$ \\
\hline colne & 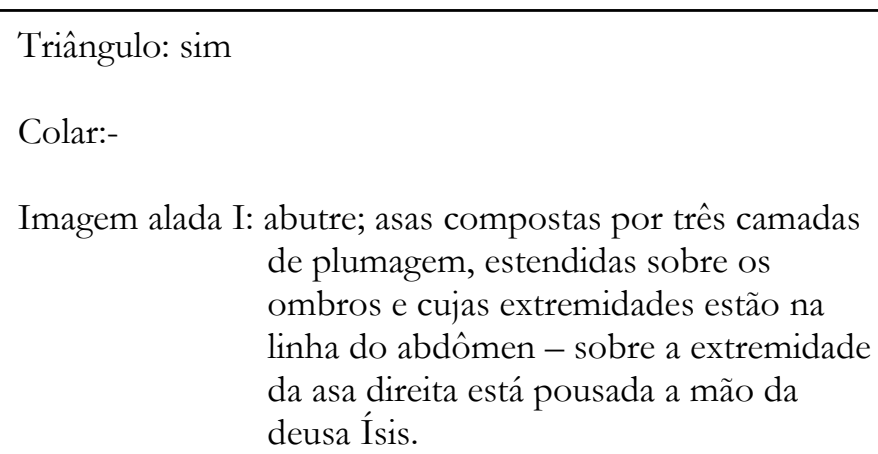 \\
\hline $\begin{array}{l}\text { Entre os chifres: disco com uraeus cujo diâmetro é menor do } \\
\text { que o comprimento da cabeça. } \\
\text { Material: Bronze } \\
\text { Atitude: marcha; pernas da esquerda avançadas em relação às } \\
\text { da direita. }\end{array}$ & $\begin{array}{l}\text { Manto: - } \\
\begin{array}{ll}\text { Imagem alada II: } & \text { abutre; asas compostas por três } \\
& \text { camadas de plumagem, estendidas } \\
& \text { sobre as ancas e cujas extremidades } \\
& \text { estão na linha do abdômen. Sobre a } \\
& \text { parte mediana das asas estão pousadas } \\
& \text { as mãos da deusa Néftis. }\end{array}\end{array}$ \\
\hline $\begin{array}{l}\text { Descrição do animal: touro em marcha sobre base baixa, sem } \\
\text { inscriçôes e modelada na forma de um trenó. Sobre ela, estão } \\
\text { posicionadas duas deusas: Ísis à direita e Néftis na parte traseira. }\end{array}$ & \\
\hline $\begin{array}{l}\text { Disco com uraeus com diâmetro inferior ao comprimento da cabeça } \\
\text { do touro e entre chifres em crescente. Triângulo frontal na fronte. } \\
\text { Decoração lombar incisa e detalhada. Olhos arredondados } \\
\text { ligeiramente amendoados e bem definidos. As orelhas são grandes, } \\
\text { estão apontadas para cima e localizam-se na da linha dos chifres e } \\
\text { acima dos olhos. A cabeça é muito pequena para as proporções do } \\
\text { corpo mas está modelada com traços suaves e exibe um focinho bem } \\
\text { torneado com narinas e boca discretas. A papada desce reta até } \\
\text { aproximadamente a metade do pescoço para aí adquirir uma certa } \\
\text { curvatura que ganha expressão abaixo do peito e o encontra na região } \\
\text { entre as pernas. O abdômen desenvolve, aparentemente, um perfil } \\
\text { paralelo à base e na região da virilha ganha os volumes do sexo. Sua } \\
\text { união ao tórax está um tanto conflituosa, uma vez que se encontra } \\
\text { muito acima deste e não há uma transição suave para intermediá-los. } \\
\text { Às pernas foi dada uma atenção especial e estas exibem, bem como os } \\
\text { cascos definidos, as particularidades da anatomia bovina. A linha } \\
\text { dorsal possivelmente desenvolve uma suave curvatura côncava no } \\
\text { meio das costas e ganha um impulso ascendente na região dos } \\
\text { ombros, de onde parte em uma leve descida até o alto da cabeça. A } \\
\text { cauda, pendente e espessa, desce acompanhando o perfil da perna } \\
\text { posterior direita, à qual está unida (?). } \\
\text { A estatueta tem porte robusto, e apesar da cabeça desproporcional, } \\
\text { exibe formas elegantes e está em ótimo estado de conservação. Além } \\
\text { disso, porta um simbolismo que não deixa dúvidas quanto sua } \\
\text { associação à Apis, que é reforçado pela presença das duas deusas. O } \\
\text { artefato enquadra-se entre os melhores exemplares tanto por sua } \\
\text { apresentação quanto por sua elaboração técnica.. }\end{array}$ & $\begin{array}{l}\text { No de Inventário: } 39380 \\
\text { Origem: Saqqara? }\end{array}$ \\
\hline
\end{tabular}


Descrição da personagem na lateral direita:

deusa Ísis, reconhecida pelo atributo sobre sua cabeça: um modius do qual partem dois chifres de vaca que emolduram um disco solar. Este repousa sobre uma peruca tripartite à frente da qual está figurada uma uraeus. As feições do rosto estão indicadas com detalhe assim como as orelhas. O braço esquerdo acompanha o dorso do touro e o direito está estendido em direção a ele, com a mão bem definida sobre o alto da perna frontal direita. Seu corpo está bem modelado, é esguio e está coberto por um vestido colante que desce até acima dos tornozelos. Os pés estão dispostos juntos, pouco atrás da pata frontal esquerda de Ápis e seus detalhes não são reconhecíveis pela fotografia.

Descrição da personagem na parte traseira: deusa Néftis, reconhecida pelo hieróglifo $N b t$ - $h w t$ sobre sua cabeça que constitui o seu nome: $\checkmark n b(. t)$ "senhor(a)" (do) f $h w t$ "recinto". Este repousa sobre uma peruca tripartite à frente da qual está figurada uma uraeus. As feições do rosto estão indicadas mas com menos detalhamento que as de Ísis. As orelhas, contudo, apresentam o mesmo grau de minúcia. Os braços envolvem a porção anterior do touro num ato protetor e as mãos repousam sobre a porção superior das coxas. Seu corpo curvilíneo está bem modelado, é esguio e está coberto por um vestido colante que desce até acima dos tornozelos. Os pés estão dispostos paralelamente, atrás da linha posterior da pata traseira esquerda de Ápis. Suas particularidades não são reconhecíveis pela fotografia.

Bibliografia sobre o referido bronze:

G.J.F. Kater-Sibbes, M. J. Vermaseren Apis I, p. 22, n 78 , pr. LIV n 78.

G. Roeder Aegyptische Bronzefiguren, 324, § 410 c; § 411 f, 1; § 669 e.

G. Roeder Aegyptische Bronzewerke, 41, § 175, d; 


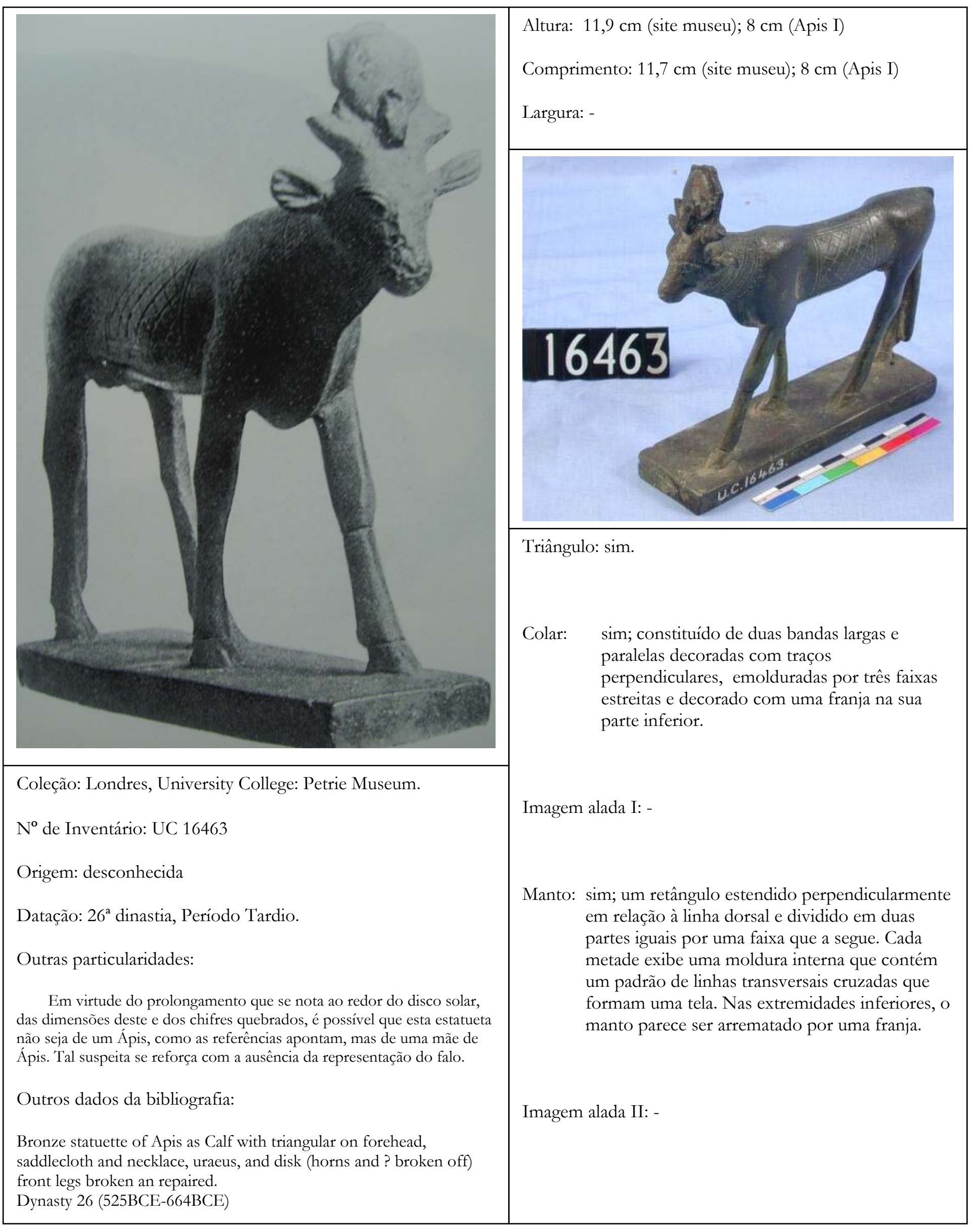


Entre os chifres: disco com uraeus com diâmetro inferior ao comprimento da cabeça.

Material: Bronze.

Atitude: marcha; pernas da esquerda avançadas em relação às da direita.

Descrição: bovino em marcha sobre base retangular alta com inscrições. Disco com uraeus com diâmetro muito inferior ao comprimento da cabeça e entre os chifres quebrados. Triângulo frontal. Decoração do colar e do manto elaboradas e incisas, sem incrustações. Olhos amendoados bem delineados, com pálpebras e sobrancelhas (?). As orelhas destacam-se na cabeça pequena e localizam-se na linha da nuca, ligeiramente acima da altura dos olhos. O focinho é bem modelado mas não é possível perceber seus detalhes pelas imagens disponíveis. A papada desce retilínea até o início do pescoço para, em seguida, desenvolver uma curvatura que acompanha o perfil do tórax para encontrá-lo na área entre as pernas. A linha abdominal aparentemente realiza uma leve ascensão até a virilha. As pernas, ainda que procurem as formas da anatomia bovina, são afinadas e demasiadamente alongadas para as dimensões do torso - o membro dianteiro esquerdo apresenta uma fratura na sua porção mediana. Os cascos estão bem indicados e delineados. A linha dorsal desenha uma concavidade sensível na região central das costas para, logo atrás dos ombros, ganhar um aclive até o alto da cabeça (?). Cauda pendente e espessa, que acompanha o perfil da perna posterior direita, à qual está possivelmente unida.

Pelas dimensões do atributo solar e os prolongamentos quebrados ao redor deste, é possível que os chifres estivessem unidos a esse núcleo para além da altura do disco, acompanhando a representação de duas plumas sobrepostas a este. Neste caso, o artefato possivelmente ilustrava não ao touro Ápis, mas a sua mãe (apesar de mencionar a possível representação das plumas, o catálogo Apis I se refere à imagem como sendo do touro de Mênfis). Esta suspeita se reforça quando se observa a ausência do órgão genital e a semelhança com estatuetas de outras coleções com as mesmas características e em melhor estado de conservação. Nota-se também que, apesar de em uma primeira vista a escultura aparente ser desproporcional quanto à modelagem dos seus membros - que pode levar a uma conclusão falaciosa sobre inabilidade de quem a elaborou -, ela exibe particularidades bem definidas e moldadas como, por exemplo, os detalhes da cabeça e os elementos incisos. Assim, é possível que certas características tenham sido reforçadas justamente para estabelecer uma diferenciação entre a modelagem de uma vaca daquela de um touro, que, via de regra, aparece muito mais corpulento. Suas formas são elegantes e, apesar das fraturas na perna e cabeça, encontra-se em um estado de conservação satisfatório.

Bibliografia sobre o referido bronze:

J. Capart Recueil de Monuments Egyptiens, v.2, pr. XCV.

G. J. F. Kater-Sibbes, M. J. Vermaseren, Apis I, p.48 nº 198, Pr. CXVII 198.

http://www.petrie.ucl.ac.uk/detail/details/index no login.php?objectid=UC16463\&accesscheck $=\% 2 \mathrm{Fdetail} \% 2 \mathrm{Fdetails} \% 2$ Findex.php 


\begin{tabular}{|c|c|}
\hline & $\begin{array}{l}\text { Altura: } 14,5 \mathrm{~cm} \text { (com base moderna ?) } \\
\text { Comprimento da base: } 13,5 \mathrm{~cm} \text { (com base moderna ?) } \\
\text { Largura: - }\end{array}$ \\
\hline $\begin{array}{ll}\text { Entre os chifres: } & \begin{array}{l}\text { disco com uraeus com diâmetro semelhante } \\
\text { ao comprimento da cabeça. }\end{array}\end{array}$ & $\begin{array}{l}\text { Triângulo: - } \\
\text { Colar: - } \\
\text { Imagem alada I: - } \\
\text { Manto: (!) sim; dois retângulos, um inscrito dentro do outro, } \\
\quad \text { e dispostos perpendicularmente ao dorso, } \\
\quad \begin{array}{l}\text { estabelecem uma moldura para o padrão decorativo } \\
\text { em xadrez composto por linhas transversais no } \\
\text { quadrilátero interno. }\end{array} \\
\text { Imagem alada II: - }\end{array}$ \\
\hline Material: Bronze & \\
\hline $\begin{array}{l}\text { Atitude: marcha; pernas da esquerda avançadas em relação às } \\
\text { da direita. }\end{array}$ & Coleção: Paris, Musée du Louvre. \\
\hline $\begin{array}{l}\text { Descrição: touro em marcha sobre base retangular alta com } \\
\text { inscrições. Disco com uraeus com diâmetro superior ao comprimento } \\
\text { da cabeça do touro e entre chifres em crescente. Decoração minuciosa } \\
\text { do manto incisa e sem incrustações. Olhos não muito grandes, } \\
\text { arredondados, dispostos na diagonal e com pálpebras. As orelhas } \\
\text { estão ligeiramente inclinadas para frente e localizam-se atrás da linha } \\
\text { da cabeça e acima da altura dos olhos. O focinho é pequeno, bem } \\
\text { modelado, com narinas e boca discretas. Logo abaixo se desenvolve } \\
\text { uma papada em dois estágios: o primeiro, formado por uma leve } \\
\text { ondulação até o meio do pescoço, e o segundo que daí segue } \\
\text { descendo e contornando ao longe a região frontal e inferior do peito } \\
\text { para encontrá-la atrás das pernas dianteiras. A linha se prolonga até a } \\
\text { virilha em aclive e sobre ela se desenvolve o sexo. As pernas } \\
\text { procuram moldar as particularidades da anatomia bovina, } \\
\text { especialmente nas pernas frontais, e os cascos estão bem definidos e } \\
\text { delineados. A linha dorsal contém uma fratura próximo à anca no lado } \\
\text { superior esquerdo, e percorre um caminho quase retilíneo até o início } \\
\text { dos ombros, onde desenvolve uma pronunciada ascensão até o alto } \\
\text { destes e daí prossegue numa segunda reta até o cimo da cabeça. A } \\
\text { cauda, pendente e espessa, desce acompanhando o perfil da perna } \\
\text { posterior direita, à qual está provavelmente unida. } \\
\text { A estatueta tem porte robusto, formas elegantes e simbologia } \\
\text { elaborada. O artefato enquadra-se entre os melhores exemplares e está } \\
\text { assentado sobre uma base moderna. }\end{array}$ & $\begin{array}{l}\begin{array}{l}\text { No de Inventário: AF } 349 \text { E } 6857 \text { (este último é o } \\
\text { número que consta na base Atlas) }\end{array} \\
\text { Origem: ? (não mencionada na ficha do museu) } \\
\text { Datação: Período Tardio-Período Ptolemaico } \\
\text { Outras particularidades: } \\
\text { Outros dados na ficha do museu: } \\
\text { Mnèvis } \\
\text { AE0083 } \\
\text { Eclaté le long du dos et sur la fesse g. } \\
\text { Pas de triangle frontal } \\
\text { Salle G -3 } \\
\text { /// } 462 \\
\text { D } 2654\end{array}$ \\
\hline
\end{tabular}




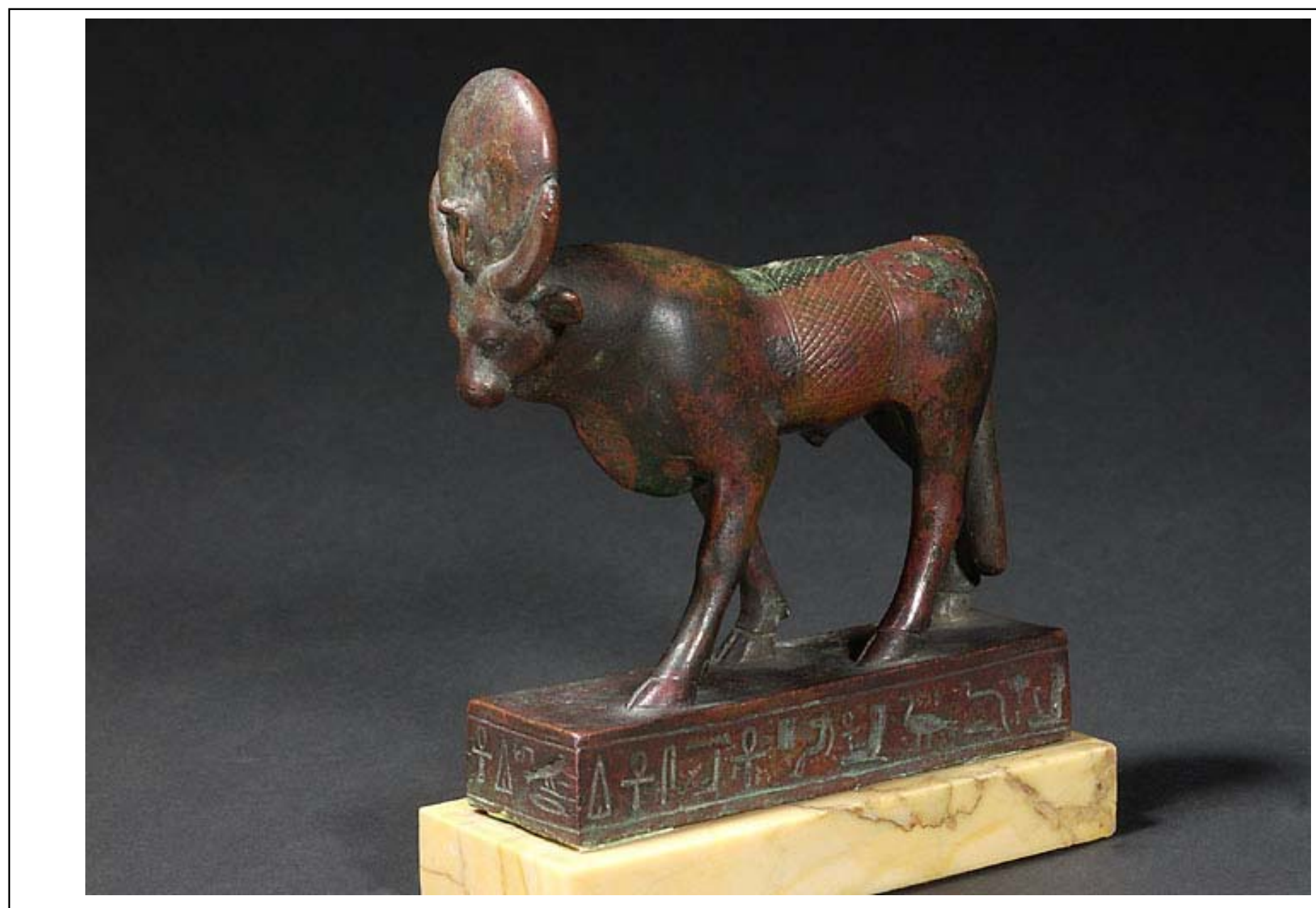

Bibliografia sobre o referido bronze:

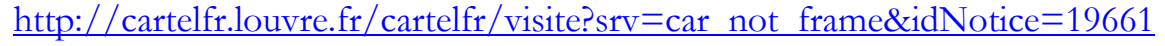




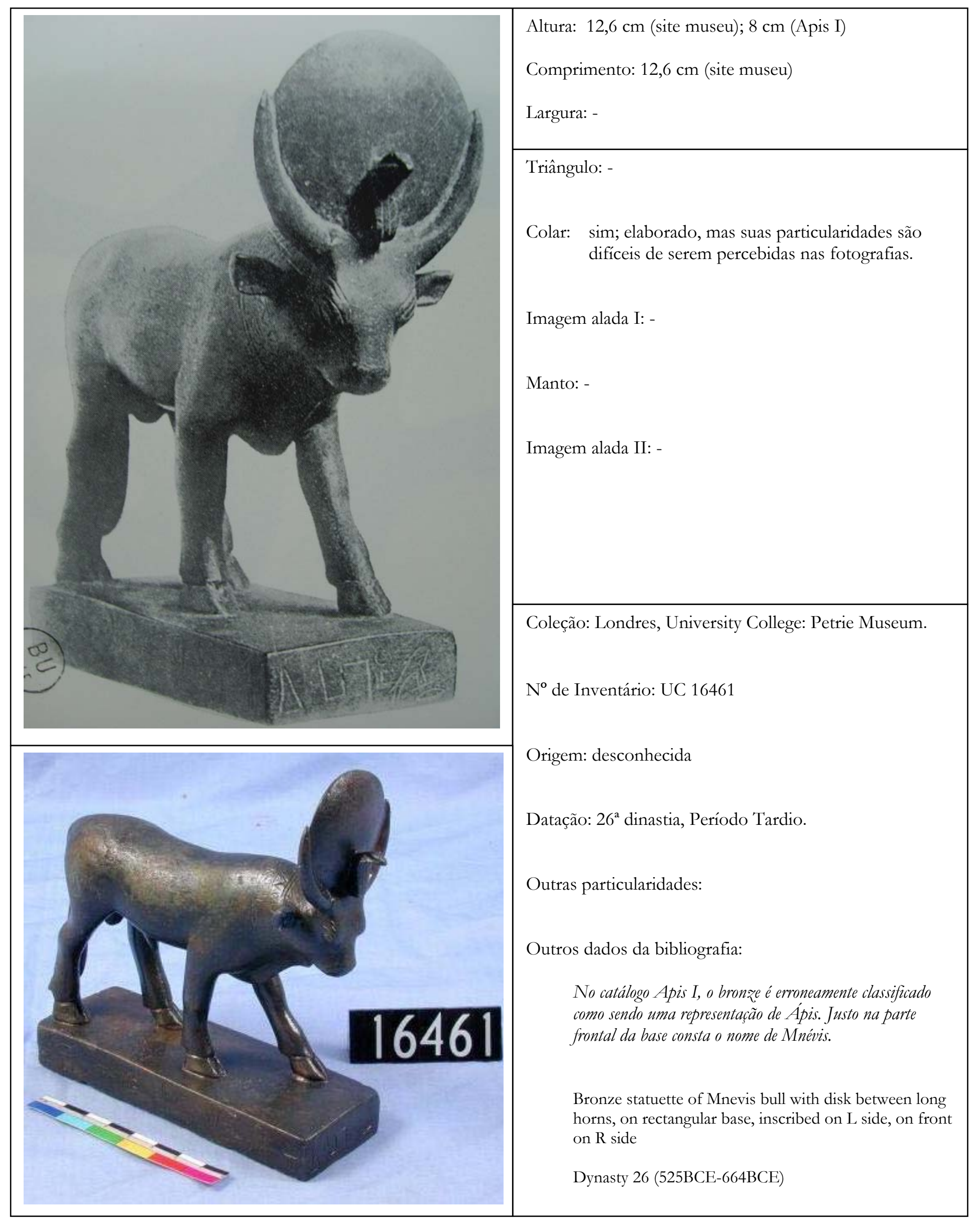


Entre os chifres: disco com uraeus com diâmetro superior ao comprimento da cabeça.

Material: Bronze.

Atitude: marcha; pernas da esquerda avançadas em relação às da direita.

Descrição: touro em marcha sobre base retangular alta com inscrições. Disco com uraeus com diâmetro superior ao comprimento da cabeça e entre os chifres grandes em crescente. A cabeça da serpente está bastante evidenciada e a parte frontal de seu corpo apresenta uma faixa estreita centralizada e traços (?) simétricos nas laterais dela e que subdividem as duas metades. Decoração do colar elaborada e incisa, sem incrustações. Olhos amendoados bem delineados, com pálpebras e sobrancelhas. As orelhas localizam-se na linha da nuca e ligeiramente acima da altura dos olhos. A cabeça é proporcional, apresenta um focinho bem modelado e as narinas foram sugeridas por pequenos traços. Da base do maxilar e próxima ao focinho parte uma papada com duas ondulações; a primeira até metade do pescoço e a outra, bem maior, desenvolve uma ampla curva até abaixo do tórax. Não é possível saber detalhadamente, pelas imagens, como a linha abdominal foi representada. Contudo, nota-se que a genitália está bem evidenciada. As pernas são robustas e exibem os volumes da musculatura bovina. Os cascos igualmente estão bem moldados e definidos. A linha dorsal, aparentemente, desenha uma concavidade pronunciada na região central das costas para , logo atrás dos ombros, ganhar um aclive cujo ápice está no início do pescoço. Daí, para alcançar a cabeça, desliza em um breve declive. Cauda pendente e espessa, que acompanha o perfil da perna posterior direita, à qual está possivelmente unida.

A escultura exibe formas particularmente elegantes, o porte vigoroso de um touro jovem e encontra-se em excelente estado de conservação. A inscrição na base atribui ao artefato a identidade do touro Mnévis.

Bibliografia sobre o referido bronze:

J. Capart Recueil de Monuments Egyptiens, v.2, pr. XCV.

G. J. F. Kater-Sibbes, M. J. Vermaseren, Apis I, p.48 n 197, Pr. CXVII 197.

G. Roeder, Ägyptische Bronzefiguren, p. 331, § 419 a.

http://www.petrie.ucl.ac.uk/detail/details/index no login.php?objectid=UC16461\&accesscheck=\% $\% 2 \mathrm{Fdetail} \% 2 \mathrm{Fdetails} \% 2$ Findex.php 


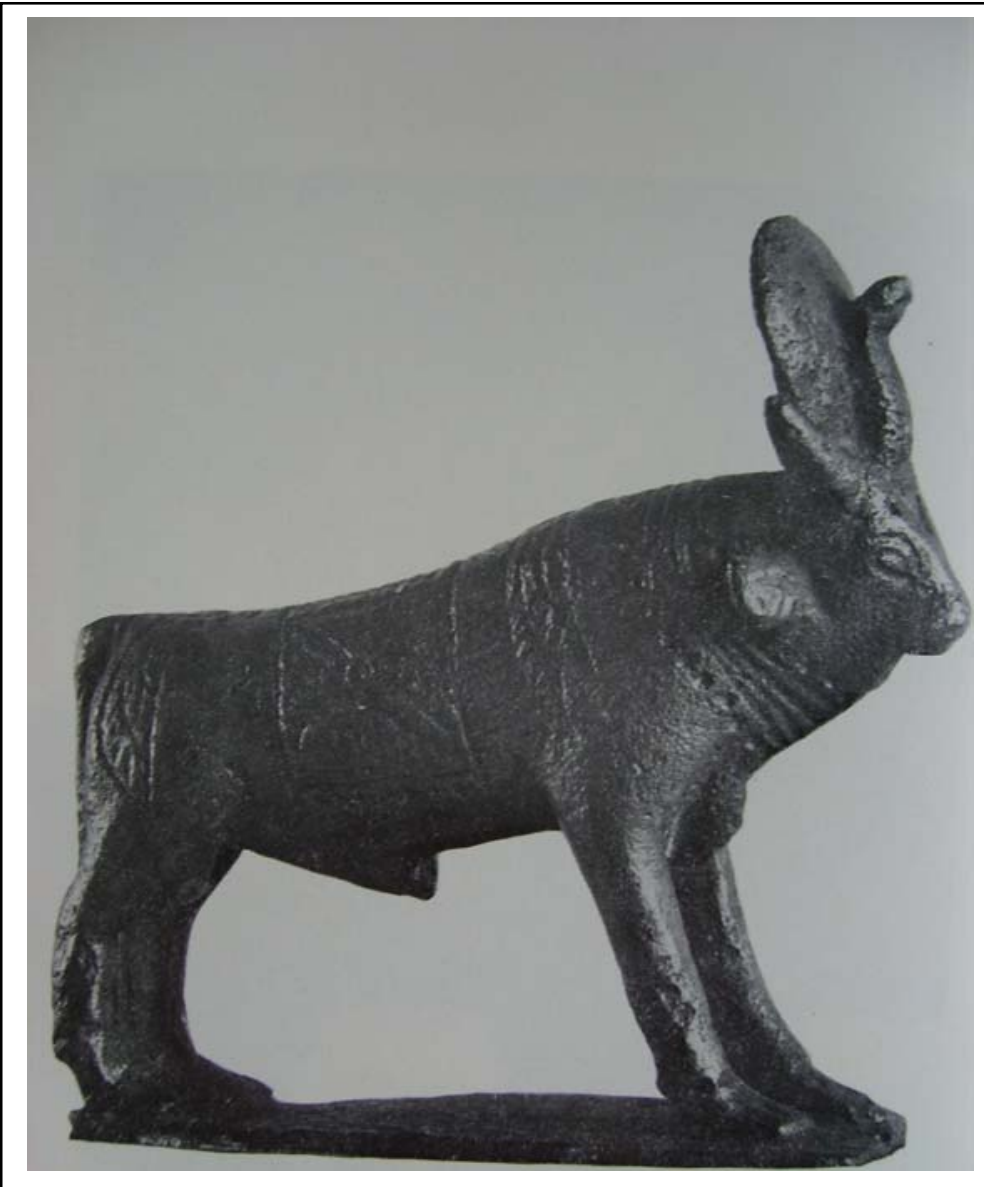

Entre os chifres: disco com uraens cujo diâmetro é superior ao comprimento da cabeça.

Material: Bronze.

Atitude: Galope (?); pernas frontais e dianteiras estendidas e emparelhadas.

Descrição: touro em atitude de galope (?) sobre base retangular baixa sem inscrições. Disco com uraeus com diâmetro superior ao comprimento da cabeça do touro e entre chifres em "V". Triângulo frontal. Decoração lombar e do pescoço elaboradas e incisas. Olhos amendoados, dispostos na diagonal e com pálpebras ou sobrancelhas. As orelhas localizam-se no final do pescoço e pouco abaixo da altura dos olhos. Focinho pequeno e quase que imperceptível se não fosse uma retração abaixo da mandíbula para dar início à papada. Esta desenvolve um percurso retilíneo descendente até o início do pescoço, onde ganha abruptamente uma sinuosidade que se desenvolve abaixo da linha do tórax para encontrá-lo na região entre as pernas frontais. $\mathrm{O}$ abdômen é constituído de um perfil inclinado até a extremidade do sexo, a partir de onde a linha fica menos clara e se confunde com o perfil ascendente da genitália. As pernas estão esculpidas com linhas definidas que procuram sintetizar os volumes da anatomia bovina e os cascos se resumem a prolongamentos achatados unidos à base. A linha dorsal desenha uma curvatura em um "S" alongado e suave, cuja acentuação se nota a partir da metade do manto. A extremidade, que é o ponto mais alto, coincide com o cimo da cabeça. A cauda, pendente e perpendicular à base (?), desce acompanhando o perfil da perna anterior direita, à qual está unida.

A estatueta tem porte robusto, é elaborada mesmo que as linhas que a compõem sejam estilizadas. Está em ótimo estado de conservação e exibe a simbologia observável em outras estatuetas de Ápis.
Altura: $5,5 \mathrm{~cm}$

Comprimento: ?

Largura: -

Triângulo: sim.

Colar: sim; composto por três bandas paralelas de largura semelhante e decorado nas extremidades superior e inferior com uma fileira pontilhada que possivelmente alude às contas globulares de faiança ou ouro.

Imagem alada I: escaravelho; asas compostas por três (?) camadas de plumagem, estendidas sobre os ombros e cujas extremidades alcançam a linha do manto.

Manto: sim; um retângulo disposto perpendicularmente à linha dorsal é dividido em duas partes por uma faixa decorativa que segue essa mesma orientação. Cada lado contém um padrão xadrez sobre o qual está uma decoração em " $X$ " composta por motivos foliformes que talvez façam alusão às contas tubulares fusiformes e, em sua intersecção, um circular que talvez se reporte às contas globulares. Logo abaixo, há uma faixa horizontal que antecede uma fileira pontilhada paralela.

Imagem alada II: abutre; asas compostas por três camadas de plumagem, estendidas sobre as ancas e coxas e cujas extremidades alcançam a linha do manto.

Coleção: Antuérpia, Vleeshuis Museum.

$\mathrm{N}^{0}$ de Inventário: 79.1.76

Origem: Saqqara

Datação: Período Tardio-Período Ptolemaico (?).

Outras particularidades:

Outros dados da bibliografia:

Bibliografia sobre o referido bronze:

G.J.F. Kater-Sibbes, M. J. Vermaseren Apis I, p. 12, n ${ }^{\circ}$ 34; Pr. XXVI 34. 


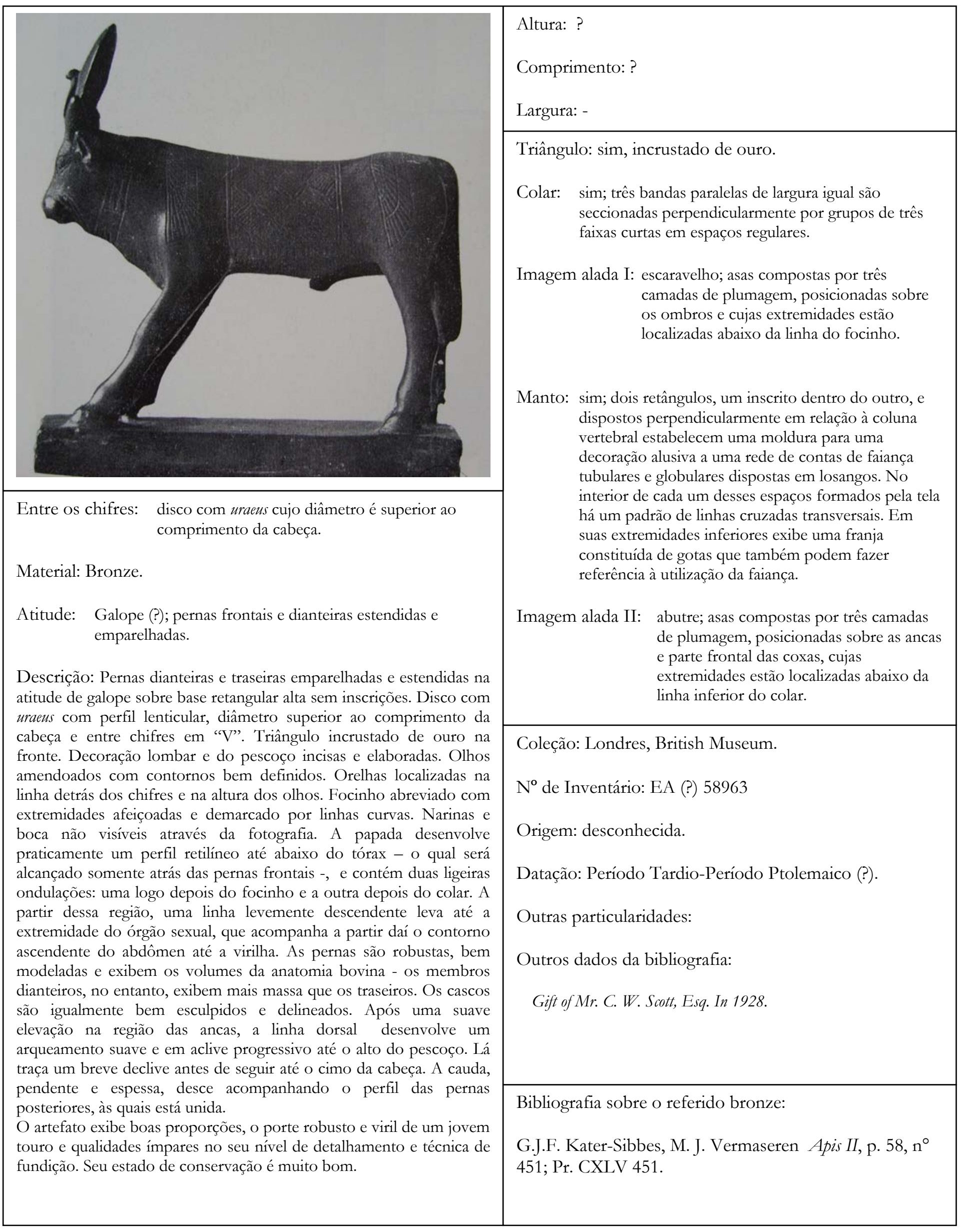




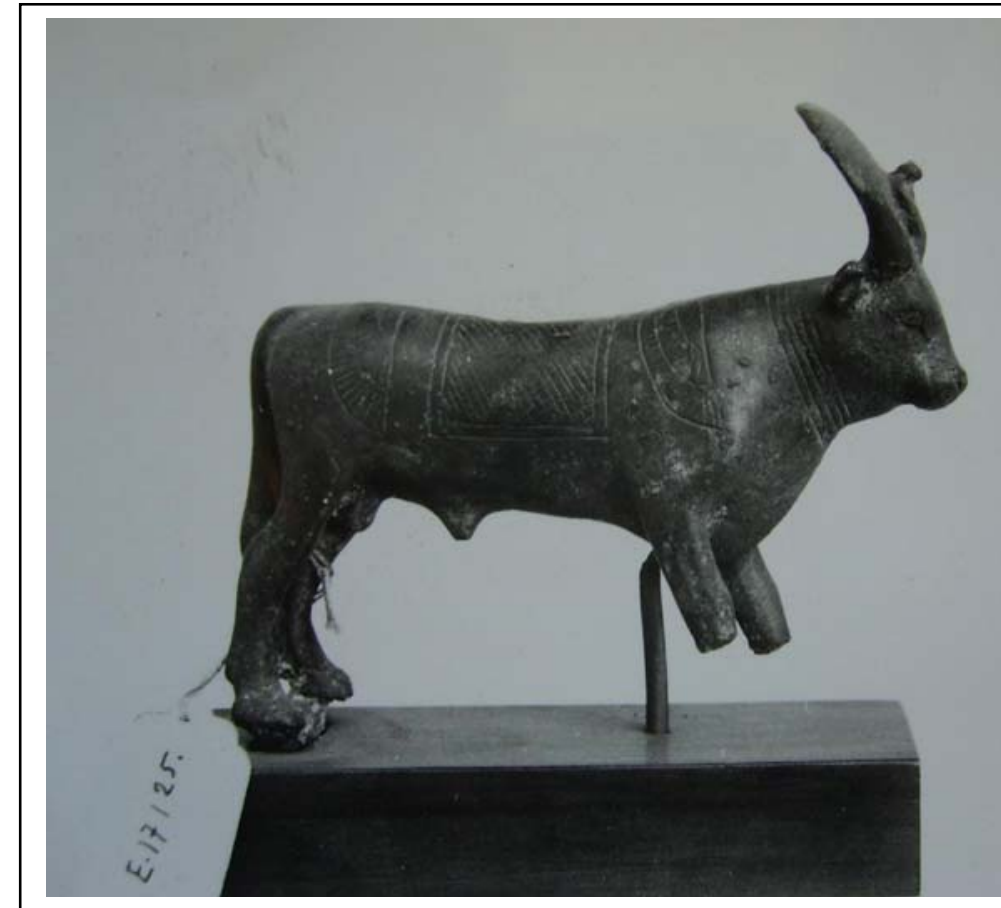

Entre os chifres: disco com uraeus ligeiramente maior que o comprimento da cabeça

Material: bronze?

Atitude: galope; pernas traseiras emparelhadas e estendidas para trás e as dianteiras igualmente emparelhadas projetadas para frente.

Descrição: touro em atitude de galope (pernas dianteiras quebradas na altura do joelho) e fixo unicamente a uma base moderna. Disco em grandes proporções de onde se destaca a serpente uraeus aparentemente entre chifres em "V". Triângulo frontal inciso. Decoração lombar incisa, sem incrustações e em excelente estado de conservação. Os olhos são bem delineados e a cabeça apresenta traços delicados, de onde parte uma papada com duas leves ondulações, uma menor a partir do maxilar até a metade do colar e outra que daí parte e projeta-se abaixo da linha do ventre para encontrá-lo na linha da extremidade frontal do manto. Os cascos estão bem definidos, mas as pernas dianteiras estão quebradas na sua porção mediana. A cauda, já espessa no alto, ganha certo volume na extremidade, que se localiza na média parte das pernas traseiras às quais se acha unida. O sexo está bem indicado e as orelhas, ligeiramente inclinadas para baixo, estão localizadas na parte posterior da cabeça e acima da altura dos olhos.

A estatueta é encorpada e exibe proporções elegantes.
Altura: $7,2 \mathrm{~cm}$

Comprimento: $9 \mathrm{~cm}$

Largura: -

Triângulo: sim

Colar: sim; formado por cinco linhas paralelas incisas; sem contrapeso

Imagem alada I: disco solar; asas compostas por três camadas de plumagem, localizadas sobre os ombros e cujas extremidades alcançam a linha do manto.

Manto: sim: dois retângulos concêntricos formam margens estreitas à decoração contida no centro, i.e., dentro do retângulo menor. Esta é constituída de um padrão de linhas diagonais que forma um xadrez ao modelo daqueles de contas de faiança.

Imagem alada II: disco solar; asas compostas por três camadas de plumagem, localizadas sobre as ancas e parte frontal das coxas e cujas extremidades alcançam a linha do manto.

Coleção: Paris, Musée du Louvre.

$\mathrm{N}^{0}$ de Inventário: E 17125

Origem: Serapeum

Datação: Período Tardio-Período Ptolemaico (?).

Outras particularidades:

Outros dados na ficha do museu:

Cat (referência ao catálogo do Serapeum?)

Referência da fotografia: D3261

Bibliografia sobre o referido bronze:

G.J.F. Kater-Sibbes, M. J. Vermaseren Apis I, p. 7, n 10 Pr. XIII 10. 


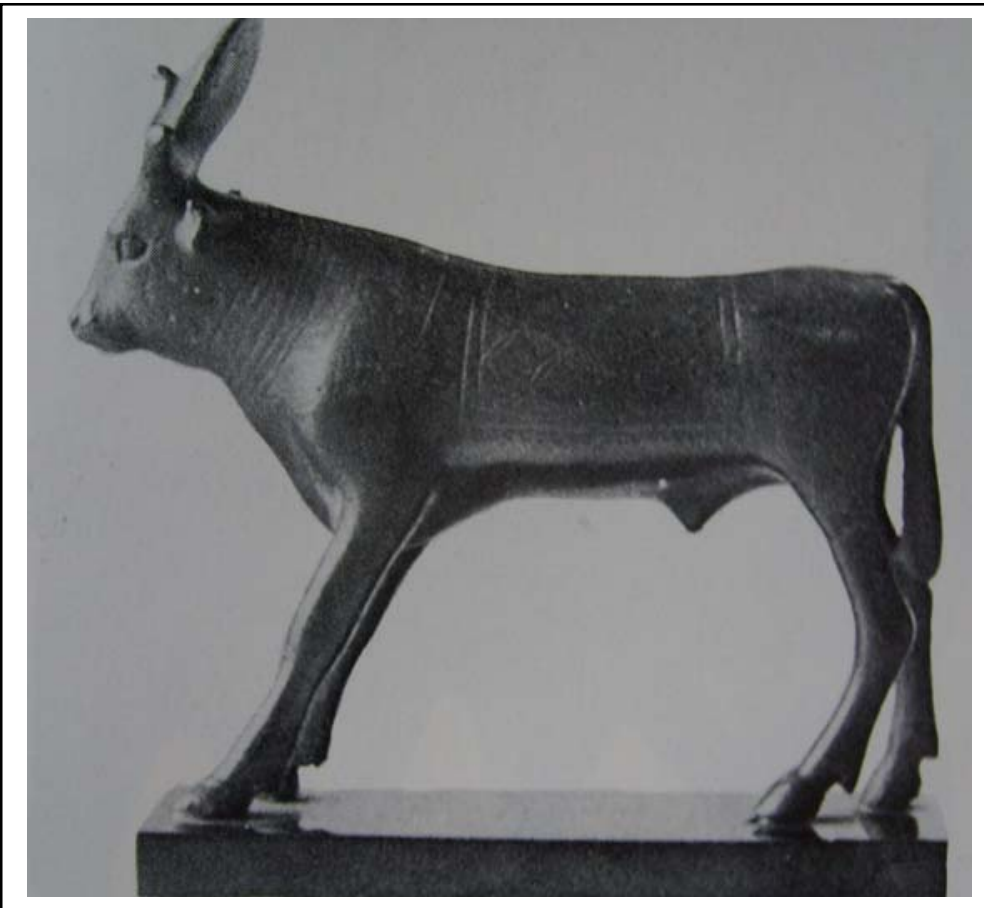

Entre os chifres: disco com uraeus cujo diâmetro é semelhante ao comprimento da cabeça.

Material: Bronze.

Atitude: Galope (?); pernas frontais e dianteiras estendidas e emparelhadas.

Descrição: touro em atitude de galope sobre base moderna. Disco com uraeus, perfil lenticular, diâmetro semelhante ao comprimento da cabeça e entre chifres em "V". Triângulo na fronte. Decoração lombar e do pescoço incisas e elaboradas. Olhos arredondados grandes com contornos bem definidos. Orelhas localizadas na linha detrás da cabeça e acima dos olhos. Focinho abreviado, bem moldado com extremidades afeiçoadas e narinas discretas. A papada quase não se distingue do pescoço entre o maxilar e o final do colar, ganhando um perfil próprio somente a partir da metade deste e prolongando-se até abaixo do tórax, onde desempenha uma ampla curvatura. A linha assim constituída só encontrará o nível do peito atrás das pernas dianteiras e abaixo do manto. Daí ela se prolonga em um segmento paralelo à base até a virilha, a partir de onde se projeta o sexo. As pernas são robustas, bem modeladas e exibem os volumes da anatomia bovina - os membros traseiros, no entanto, são um pouco menos volumosos. Os cascos são bem moldados e delineados. Após uma suave elevação na região das ancas, a linha dorsal segue paralela ao abdômen até o final do manto para então adquirir um impulso ascendente até o alto da cabeça. A cauda, curta e espessa, desce acompanhando o perfil das pernas traseiras, às quais está unida em suas porções superior e inferior.

$\mathrm{O}$ artefato exibe boas proporções, o porte robusto e viril de um touro jovem e qualidades ímpares no seu nível de detalhamento e técnica de fundição. Seu estado de conservação é muito bom.
Altura: $11,9 \mathrm{~cm}$

Comprimento: $12 \mathrm{~cm}$

Largura: -

Triângulo: sim.

Colar: sim; constituído de seis faixas paralelas de largura semelhante.

Imagem alada I: disco; asas estendidas sobre os ombros cujas extremidades estão abaixo da linha do focinho. Demais detalhes não estão visíveis na fotografia.

Manto: sim; dois retângulos, um inscrito dentro do outro, e dispostos perpendicularmente em relação à coluna vertebral estabelecem uma moldura para decoração alusiva a uma rede de contas de faiança tubulares e globulares dispostas em losangos.

Imagem alada II: abutre; demais detalhes não estão visíveis na fotografia.

Coleção: Londres, British Museum.

No de Inventário: EA (?) 64507

Origem: desconhecida.

Datação: Período Tardio-Período Ptolemaico (?).

Outras particularidades:

Outros dados da bibliografia:

Bronze (with cooper-gloss)

Base moderna

Anteriormente coleção Acworth.

Bibliografia sobre o referido bronze:

G.J.F. Kater-Sibbes, M. J. Vermaseren Apis I, p. 60, n ${ }^{\circ}$ 460; Pr. CXLVIII 460. 


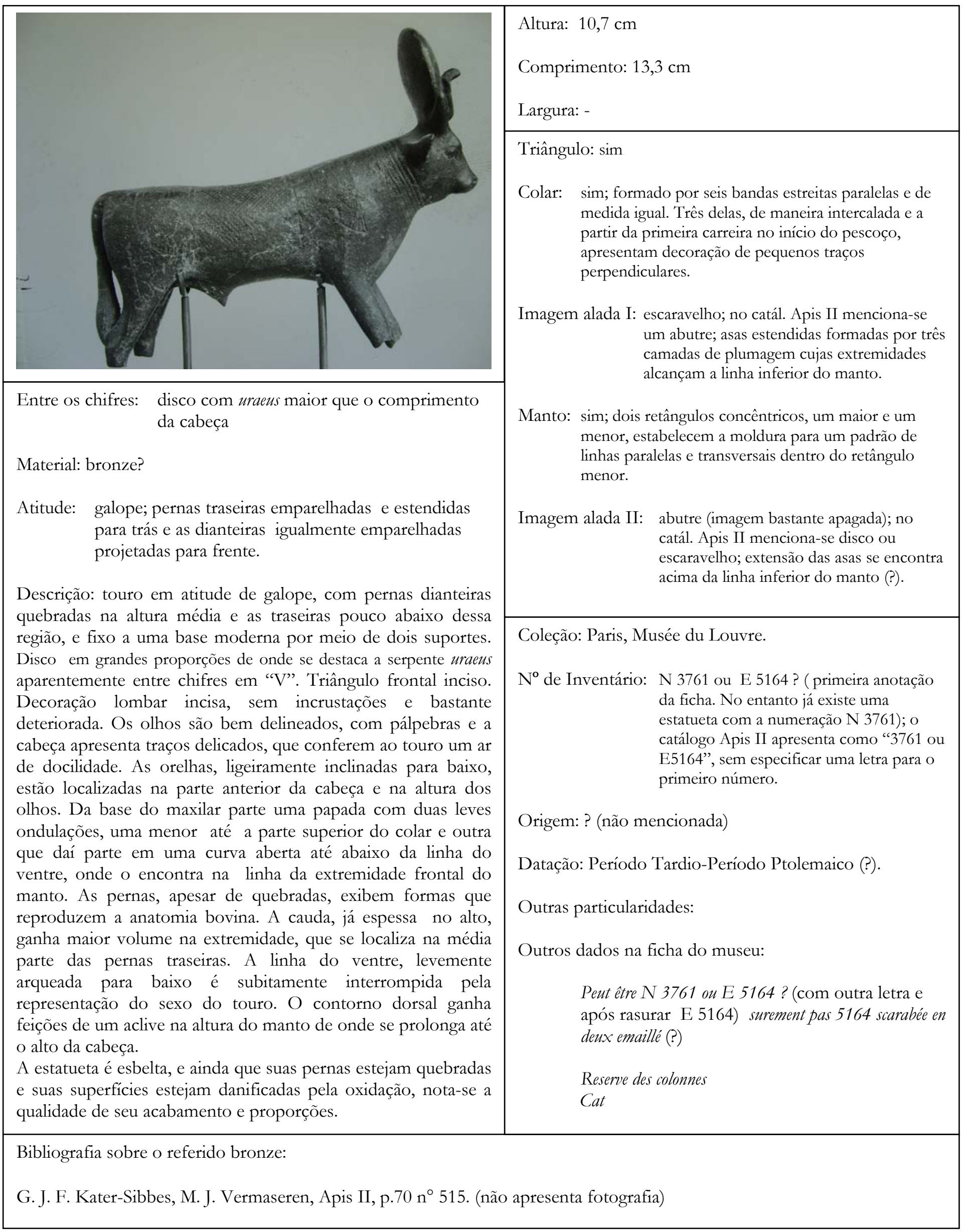




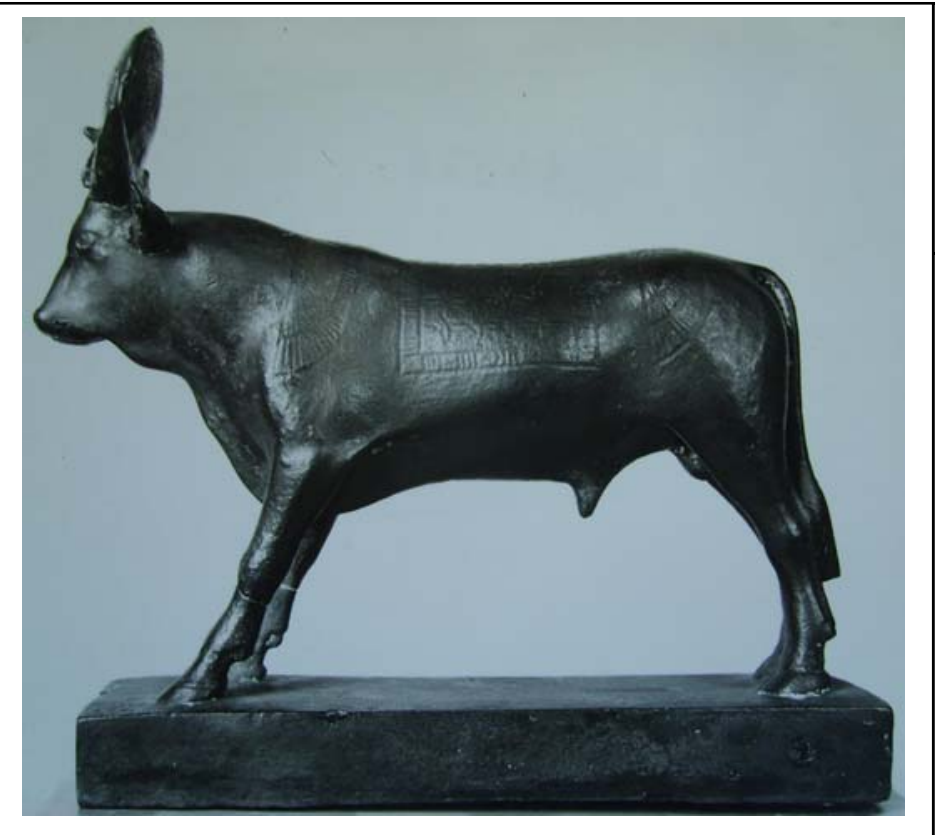

Altura: $20 \mathrm{~cm}$

Comprimento: $20,2 \mathrm{~cm}$ (base)

Largura: -

Triângulo: sim

Colar: -

Imagem alada I: disco com uraeus com asas estendidas sobre os ombros e formadas por quatro carreiras de plumagem cujas extremidades ultrapassam a linha inferior do manto.

Manto: (!) sim; dois retângulos concêntricos, um maior e um menor, estabelecem a moldura para um motivo em forma de grade, cujos lados aludem a contas tubulares e, sua intersecção, a contas arredondadas.

$\mathrm{Na}$ linha dorsal e também inscrita no retângulo central, nota-se uma faixa decorada por traços perpendiculares que é margeada por duas outras mais estreitas e lisas. A moldura descrita pelos dois retângulos principais que constituem o manto possui um motivo intercalado de quatro traços paralelos, posicionados perpendicularmente em relação à moldura, e que dão a volta à coberta.

Imagem alada II: escaravelho com asas estendidas sobre as ancas e formadas por quatro carreiras de plumagem cujas extremidades ultrapassam a linha inferior do manto e se projetam sobre o início das coxas.

Coleção: Paris, Musée du Louvre.

No de Inventário: AF 2894 N.5073 (na base de dados eletrônica, o número de tombo registrado é o último)

Origem: Serapeum

Datação: Período Tardio-Período Ptolemaico (?).

Outras particularidades:

Pernas dianteiras fraturadas abaixo de sua dobra.

Estátua de touro dedicada por Pekhemenu

Base quebrada na lateral direita.

Outros dados na ficha do museu:

Triangle frontal autre fois plaqué?

Base creuse mais plaine

Texte verifié

Blanc des yeux plaqué d'or

Serapeum etiquette

AE002852

K5319 


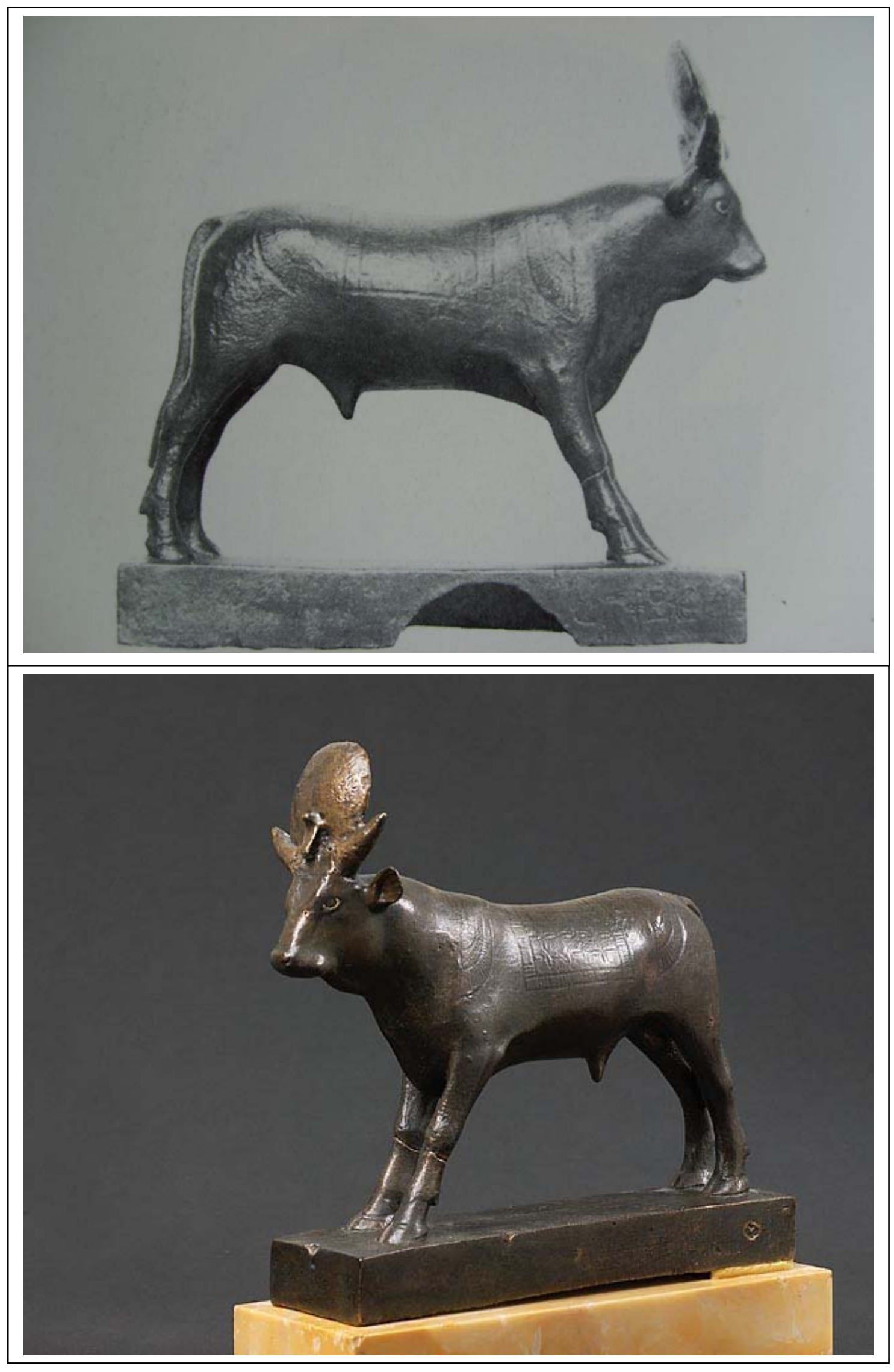


Entre os chifres: disco com uraeus menor que o comprimento da cabeça.

Material: bronze?

Atitude: galope; pernas traseiras emparelhadas e estendidas para trás e as dianteiras igualmente emparelhadas projetadas para frente.

Descrição: touro em atitude de galope, com pernas dianteiras fraturadas na altura mediana, sobre base alta, oca, com inscrições e quebrada no lado direito. Diâmetro do disco menor que o comprimento da cabeça, com perfil lenticular, serpente uraeus e entre chifres em "V". Triângulo frontal rebaixado possivelmente para conter incrustação. Decoração lombar incisa, sem incrustações e levemente apagada. Os olhos arredondados são bem delineados, com esclerótica incrustada de ouro, e inclinados. A cabeça apresenta traços delicados, focinho arrebitado com narinas e boca posicionada bem abaixo deste. As amplas orelhas, estão localizadas atrás da linha dos chifres, na altura dos olhos e posicionadas suavemente inclinadas em relação à base. Da metade do maxilar parte uma papada com três ondulações: uma menor mas bem marcada até metade do pescoço, seguida de uma levíssima curvatura até o início das pernas frontais e finalmente uma outra, que daí parte em uma curva pronunciada até abaixo da linha do tórax. Desse ponto, a linha do peito desliza paralelamente à base para encontrar a extremidade do falo, onde adquire uma linha descendente em $90^{\circ}$ para depois subir repentinamente até a virilha onde se posiciona o saco escrotal. Os cascos estão definidos com certa elegância e as pernas exibem a tensão da musculatura bovina na atitude do galope. A cauda desce acompanhando o contorno das pernas traseiras mas está unida (?) a elas somente na sua extremidade, onde ganha maior volume. O contorno dorsal ganha um arqueamento côncavo suave na região dorsal para, na região do início dos ombros, ascender em dois arcos ligeiramente convexos cujo fim se localiza no alto da cabeça.

A estatueta, além de grande, é esbelta, minuciosamente elaborada e, apesar das pernas fraturadas, está em excelente estado de conservação. O metal encontra-se amarelado na região dos chifres e do disco.

Bibliografia sobre o referido bronze:

G.J.F. Kater-Sibbes, M. J. Vermaseren Apis I, p. 6, nº 6 Pr. XII 6.

http:/ / cartelfr.louvre.fr/cartelfr/visite?srv $=$ car_not_frame\&idNotice $=23155$ 


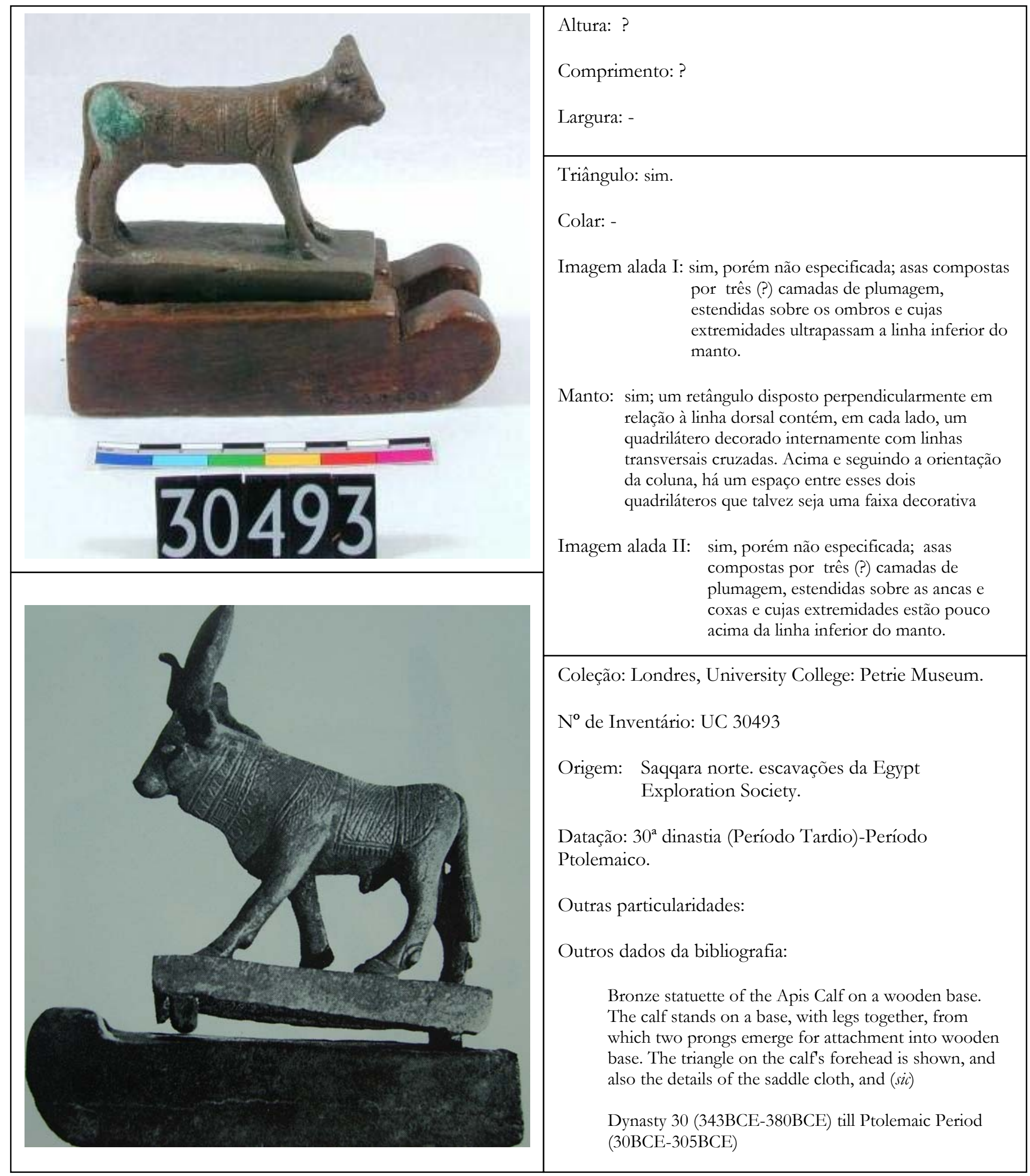


Entre os chifres: esta parte encontra-se quebrada.

Material: Bronze.

Atitude: galope; pernas traseiras e dianteiras estendidas, respectivamente para trás e para frente, e alinhadas.

Descrição: touro em atitude de galope sobre base retangular alta e sem inscrições. Esta está fixa a uma outra base, de madeira, em forma de trenó e por meio de dois pinos. Chifres quebrados e, com eles possivelmente o disco com uraeus. Triângulo gravado na fronte. Decoração lombar e do pescoço incisas, elaboradas e sem incrustações. Olhos amendoados e bem delineados. As orelhas localizam-se na parte anterior da cabeça, na linha superior dos olhos. A cabeça é proporcional, apresenta um focinho pequeno, bem modelado com narinas e boca discretas. A papada descreve uma ondulação em "S" sutil, sem um grande pronunciamento na curvatura inferior e cujo perfil se confunde com aquele do peito. A linha continua até a virilha em um segmento paralelo à base formando assim o abdômen. O sexo está indicado pouco depois da virilha. As pernas são robustas e exibem os volumes da musculatura bovina. Os cascos igualmente estão bem moldados e definidos. A linha dorsal desenvolve um declive a partir das ancas para alcançar a região do manto, a partir de onde se dirige até o início dos ombros em um segmento paralelo ao abdômen. Dessa região a linha ganha uma orientação ascendente até a nuca. A cauda, pendente e espessa, acompanha o perfil das pernas posteriores, às quais está aparentemente unida.

$\mathrm{O}$ artefato contém traços de oxidação, bem visíveis sobre a perna anterior direita e fraturas no alto da cabeça. No entanto, seu estado de conservação é suficientemente bom para se perceber seu alto nível de elaboração e a simbologia que lhe confere a identidade de um Ápis.

Bibliografia sobre o referido bronze:

G.J.F. Kater-Sibbes, M. J. Vermaseren Apis I, p. 23, nº 83, Pr. LVI 83.

W. B. Emery Preliminary report on the excavations at North Saqqâra, JEA 55, 33, Pr. VIII, 6.

http://www.petrie.ucl.ac.uk/detail/details/index no login.php?objectid=UC30493\&accesscheck= $\% 2 F$ detail $\% 2 F d e t a i l s \%$ 2Findex.php 


\begin{tabular}{|c|c|}
\hline & $\begin{array}{l}\text { Altura: } 5 \mathrm{~cm} \text { (sem pino de fixação) } \\
\quad \text { Altura do pino de fixação no centro da base: } 1 \mathrm{~cm} \\
\text { Comprimento: } 5,6 \mathrm{~cm} \\
\text { Largura: - }\end{array}$ \\
\hline $\begin{array}{ll}\text { Entre os chifres: } & \text { disco com uraeus maior que comprimento da } \\
& \text { cabeça. }\end{array}$ & $\begin{array}{l}\text { Triângulo: sim } \\
\text { Colar: - } \\
\text { Imagem alada I: - } \\
\text { Manto: sim: um retângulo que se estende } \\
\quad \text { perpendicularmente em relação ao dorso é } \\
\text { cortado no seu interior por várias linhas que se } \\
\text { cruzam criando um padrão xadrez. }\end{array}$ \\
\hline $\begin{array}{l}\text { Atitude: galope; pernas traseiras emparelhadas e estendidas } \\
\text { para trás e as dianteiras igualmente emparelhadas } \\
\text { projetadas para frente. } \\
\text { Descrição: touro em atitude de galope sobre base retangular baixa e } \\
\text { sem inscrições. Disco em grandes proporções de onde se destaca a } \\
\text { serpente uraeus aparentemente entre chifres em "V". Triângulo frontal } \\
\text { e manto incisos sem incrustações. Os olhos amendoados são bem } \\
\text { delineados, a boca parece transmitir um sorriso amigável e a cabeça } \\
\text { apresenta traços delicados, de onde parte uma papada retilínea até o } \\
\text { início do tórax. As orelhas estão localizadas no início da cabeça, na } \\
\text { linha do disco com uraeus e acima da linha dos olhos. Os cascos são } \\
\text { sugeridos pelos volumes e as pernas procuram encontrar um } \\
\text { equilíbrio nas suas formas. A cauda, já espessa no alto, ganha certo } \\
\text { volume na extremidade na medida em que se reclina para trás. Sobre } \\
\text { ela parecem estar gravados pares de linhas perpendiculares com } \\
\text { função decorativa. O sexo está bem indicado e a linha de contorno } \\
\text { que dele sai em direção às patas desempenha uma curva pronunciada. } \\
\text { A linha dorsal possui uma elevação entre a bacia e o meio das costas e } \\
\text { um contorno ascendente a partir daí até o alto da cabeça. Nessa região } \\
\text { aglutina-se uma união do pescoço ao disco com a função de dar } \\
\text { estabilidade à imagem solar. Este também pode ter sido concebido } \\
\text { como um prolongamento da serpente uraeus presente acima da fronte } \\
\text { do touro. Ainda que pequena, observa-se o empenho do artesão em } \\
\text { trazer à figurinha boas proporções e alguns atributos das imagens de } \\
\text { Ápis. } \\
\text { Possui vários traços de oxidação. }\end{array}$ & $\begin{array}{l}\text { Coleção: Paris, Musée du Louvre. } \\
\text { No de Inventário: E } 17134 \\
\text { Origem: Serapeum } \\
\text { Datação: Período Tardio-Período Ptolemaico (?). } \\
\text { Outras particularidades: } \\
\quad \text { Prolongamento que sai do pescoço do touro e } \\
\quad \text { vai ao encontro da parte traseira do disco solar } \\
\quad \text { entre seus chifres. } \\
\text { Outros dados na ficha do museu: } \\
\text { Cat } 10 \\
\text { Referência da fotografia: D } 3261\end{array}$ \\
\hline \multicolumn{2}{|l|}{ Bibliografia sobre o referido bronze: } \\
\hline
\end{tabular}




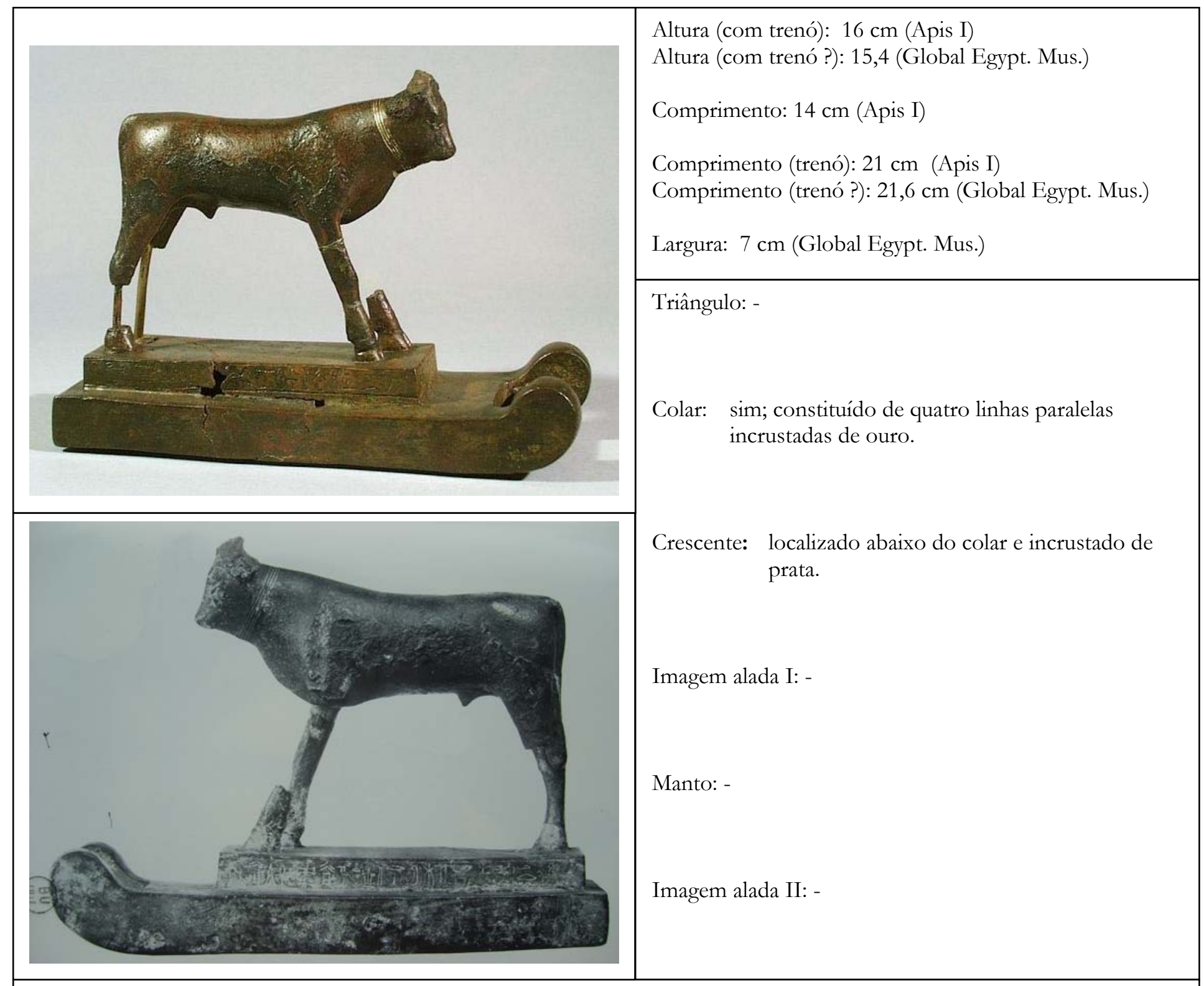

Coleção: Viena, Kunsthistorisches Museum.

$\mathrm{N}^{\mathrm{o}}$ de Inventário: 4151

$\mathrm{N}^{\circ}$ de Inventário Global Eg. Mus. 09/001/4955

Origem: desconhecida.

Datação: Período Tardio-Período Ptolemaico.

Outras particularidades:

Outros dados da bibliografia:

Adquirido da coleção Miramar em 1878. 
Entre os chifres: (?) quebrado

Material: Bronze.

Atitude: galope (?); pernas dianteiras e traseiras estendidas e emparelhadas.

Descrição: touro em atitude de galope (?) sobre base retangular alta com inscrições. Esta, por sua vez, está integrada a uma outra base em forma de trenó igualmente oca e com fraturas na parte superior do lado direito. Chifres e, possivelmente, disco com uraeus quebrados. Em torno do pescoço exibe um colar incrustado de ouro, formado por quatro linhas paralelas, e abaixo dele um crescente de prata. Apesar de muito afetada pela oxidação, a região lombar não parece ter contido quaisquer incisões. A papada desce quase retilínea até depois do colar para então desenvolver uma curvatura aberta até a altura do peito. Daí prossegue em uma linha ascendente arqueada até a virilha, tendo o sexo sobreposto na sua última parte. As pernas são bem modeladas, exibem as formas da anatomia bovina mas estão quebradas - a única que consta inteira mas com fraturas é a perna frontal direita. A linha dorsal é praticamente paralela à base até antes dos ombros, a partir de onde adquire uma orientação ascendente até o cimo da cabeça. A cauda, pendente e espessa, desce paralela às pernas traseiras, às quais deve estar unida em algum ponto - sua extremidade, contudo, parece estar livre.

O artefato apresenta uma grande sofisticação tanto em sua elaboração quanto em sua apresentação. Infelizmente foi vítima de uma severa oxidação que deteriorou suas superfícies e enfraqueceu a estrutura do metal em diversos pontos que levaram à sua ruptura. O único símbolo presente, e que não é muito comum nos bronzes, é o crescente na parte inferior do pescoço, cujo paralelo pode ser feito com as imagens de Ápis em diversas estelas. A estatueta apresenta uma coloração caramelo-avermelhada que está coberta em algumas partes por uma pátina esverdeada.

Bibliografia sobre o referido bronze:

G.J.F. Kater-Sibbes, M. J. Vermaseren Apis I, pp. 51-52, n 215; Pr. CXXVII 215.

G. Roeder Aegyptische Bron₹efiguren, 332, § 420 c, fig. 441 (inscrição). 


\begin{tabular}{|c|c|}
\hline & $\begin{array}{l}\text { Altura: } 10 \mathrm{~cm} \\
\text { Comprimento: } 12 \mathrm{~cm} \\
\text { Largura: - }\end{array}$ \\
\hline $8=$ & $\begin{array}{l}\text { Triângulo: sim; incrustado (material ?) } \\
\text { Colar: - } \\
\text { Imagem alada I: - } \\
\text { Manto: - } \\
\text { Imagem alada II: - }\end{array}$ \\
\hline Entre os chifres: disco com uraeus com tamanho & \\
\hline $\begin{array}{l}\text { aproximadamente igual ao comprimento da } \\
\text { cabeça. }\end{array}$ & $\begin{array}{l}\text { Coleção: Paris, Musée du Louvre. } \\
\text { No de Inventário: E } 3810\end{array}$ \\
\hline Material: bronze & \\
\hline $\begin{array}{l}\text { Atitude: galope; pernas traseiras emparelhadas e estendidas } \\
\text { para trás e as dianteiras igualmente } \\
\text { emparelhadas projetadas para frente. }\end{array}$ & $\begin{array}{l}\text { Origem: ? (não mencionada na ficha do museu) } \\
\text { Datação: Período Tardio-Período Ptolemaico (?). }\end{array}$ \\
\hline $\begin{array}{l}\text { Descrição: touro em atitude de galope sobre base moderna. Pinos } \\
\text { de fixação abaixo das patas dianteiras e traseiras que ligavam a } \\
\text { estatueta diretamente a uma base possivelmente de madeira. Disco } \\
\text { com uraeus menor que o comprimento da cabeça e entre chifres em } \\
\text { "V" (?). Triângulo frontal com incrustação (não especificada, mas } \\
\text { provavelmente com prata ou ouro), contudo o artefato não apresenta } \\
\text { qualquer decoração lombar ou no pescoço. Os olhos arredondados } \\
\text { ligeiramente amendoados, com pálpebras e bem delineados. A cabeça } \\
\text { apresenta traços delicados, focinho com narinas e boca bem } \\
\text { modeladas. As amplas orelhas, estão localizadas atrás da linha dos } \\
\text { chifres, acima da altura das pálpebras e posicionadas inclinadas para } \\
\text { baixo. Da metade do maxilar parte uma papada com duas ondulações: } \\
\text { uma menor mas bem marcada até metade do pescoço, seguida por } \\
\text { uma linha descendente que ganha uma curvatura pronunciada à } \\
\text { frente das pernas frontais e segue até aproximadamente o final do } \\
\text { tórax. Desse ponto, a linha do peito desliza quase que paralelamente à } \\
\text { base sendo interrompida no meio pela extremidade do falo e }\end{array}$ & $\begin{array}{l}\text { Outras particularidades: } \\
\text { Outros dados na ficha do museu: } \\
\text { AE008341 } \\
\text { Pas de trace de décor grave } \\
\text { "donnépar le comte Tyazkiewicz" em } 1862 \\
\text { Reserve des colonnes } \\
\text { Renil (?), Essays... Lipinska (?), 1997, p. } 219 \\
490 \text { ? } \\
460 \text { (genre anastasi). Cat } \\
\text { D } 3267\end{array}$ \\
\hline $\begin{array}{l}\text { terminando no saco escrotal. Os cascos estão definidos com esmero e } \\
\text { as pernas, especialmente as frontais, exibem a tensão da musculatura } \\
\text { bovina na atitude do galope. A cauda desce acompanhando o } \\
\text { contorno das pernas traseiras e aparenta estar unida a estas. Sua } \\
\text { extremidade está localizada na média parte dos membros traseiros. O } \\
\text { contorno dorsal desempenha uma leve curvatura côncava até a região } \\
\text { dos ombros, sendo interrompido por uma pequena elevação nas } \\
\text { ancas. Dos ombros o contorno segue um aclive suave até o alto da } \\
\text { cabeça. O tronco foi moldado um pouco mais alongado em relação às } \\
\text { proporções encontradas em outras imagens. } \\
\text { Apesar disso, o porte da estatueta é esbelto, é minuciosamente } \\
\text { elaborada na distribuição das massas musculares e encontra-se em } \\
\text { satisfatório estado de conservação, com algumas marcas de oxidação } \\
\text { nas pernas traseiras e na cauda. }\end{array}$ & $\begin{array}{l}\text { Bibliografia sobre o referido bronze: } \\
\text { G. J. F. Kater-Sibbes, M. J. Vermaseren, Apis II, p.68 n } \\
\text { 506, Pr. CLXXIV } 506 . \\
\text { G. Roeder, Aegyptische Bronzefiguren, } 332 \S 420 \text { c. } \\
\text { E. Schott, Eine datierte Apisbronze; RdE 19, 90, n } 4 .\end{array}$ \\
\hline
\end{tabular}




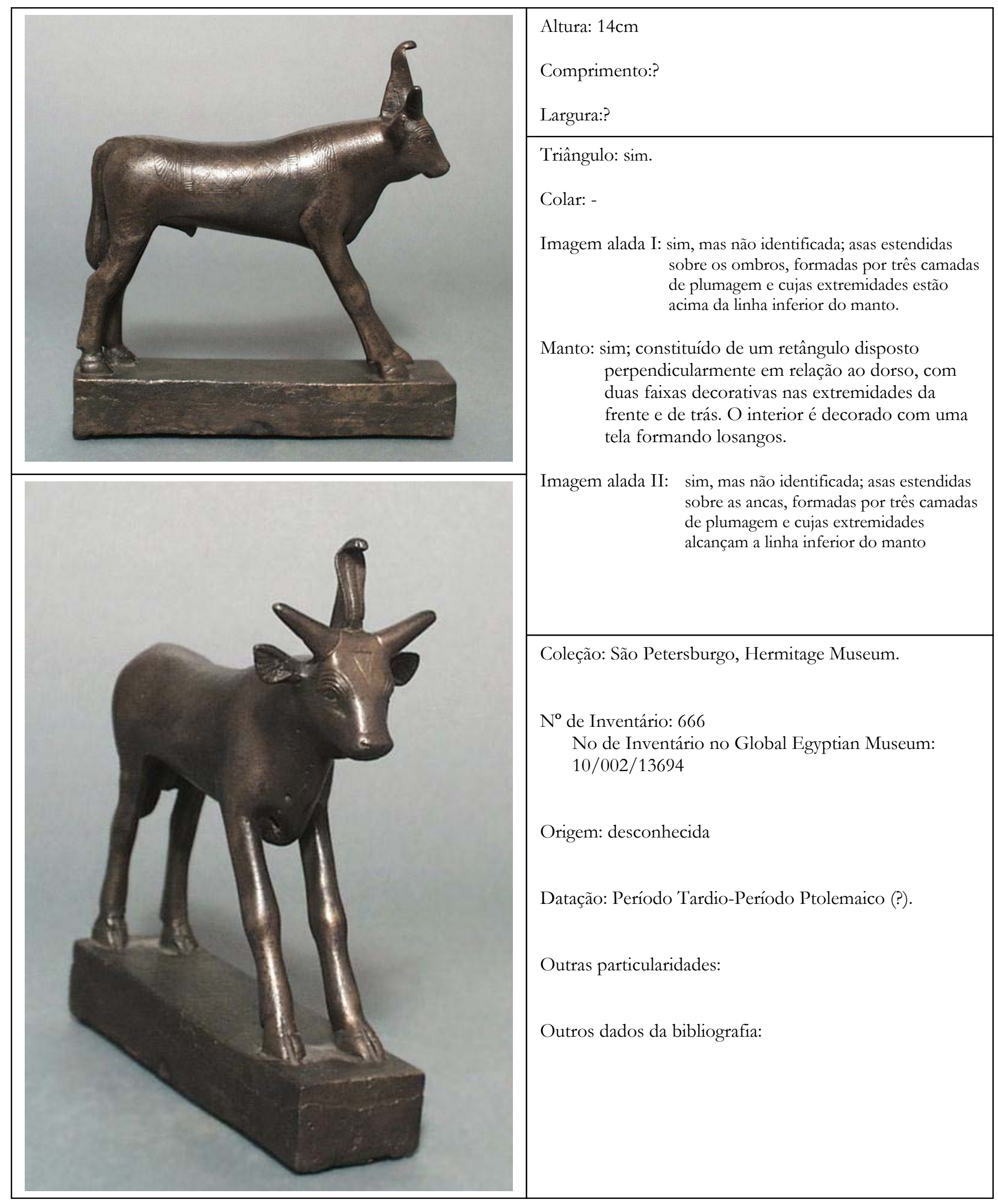


Entre os chifres: uraeus entre chifres em "V"

Material: bronze.

Atitude: galope; pernas traseiras emparelhadas e estendidas para trás e as dianteiras igualmente emparelhadas projetadas para frente.

Descrição: touro em atitude de galope sobre base retangular alta. Serpente uraeus com reforço na parte posterior e entre chifres em "V". Triângulo gravado na fronte. Decoração lombar e do pescoço incisas e elaboradas. Olhos amendoados grandes com contornos bem definidos, pálpebras e órbitas. Orelhas localizadas na linha de trás da cabeça e acima dos olhos. Focinho bem moldado com extremidades afeiçoadas e narinas e boca discretas. A papada descreve um ligeiro arqueamento na região do pescoço para então descer com uma ligeira perturbação no centro até a linha do tórax. Daí ela se prolonga em um segmento ascendente até a virilha, a partir de onde se projeta o sexo. As pernas são robustas, bem modeladas e exibem os volumes da anatomia bovina. Os cascos são bem moldados e delineados. Após uma suave elevação na região das ancas, a linha dorsal desce sutilmente até o meio das costas a partir de onde adquire um impulso ascendente até o alto da cabeça. A cauda, curta e espessa, desce acompanhando o perfil das pernas traseiras, às quais está unida.

$\mathrm{O}$ artefato exibe boas proporções, o porte robusto e viril de um touro jovem e qualidades ímpares no seu nível de detalhamento e técnica de fundição. Seu estado de conservação é muito bom.

Bibliografia sobre o referido bronze:

http://www.globalegyptianmuseum.org/record.aspx?id=13694 


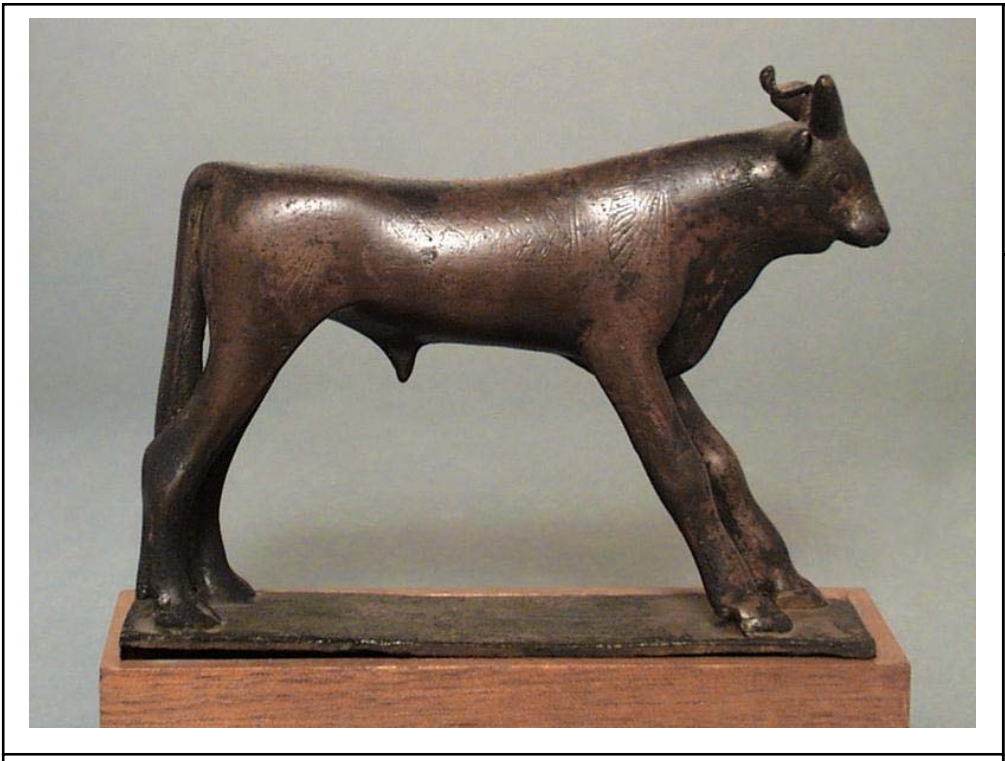

Entre os chifres: uraeus entre chifres em " $\mathrm{V}$ "

Material: bronze

Atitude: galope; pernas traseiras emparelhadas e estendidas para trás e as dianteiras igualmente emparelhadas projetadas para frente.

Descrição: touro em atitude de galope sobre base retangular baixa. Serpente uraeus reclinada com reforço na parte posterior e entre chifres em "V". Decorações frontal, lombar e do pescoço incisas e elaboradas. Pela apresentação dos símbolos solares e outros detalhes, é possível que o triângulo esteja presente na fronte. Olhos arredondados grandes com contornos bem definidos. Orelhas localizadas na linha de trás da cabeça e acima dos olhos. Focinho pequeno bem moldado com extremidades afeiçoadas e narinas e boca discretas. A papada descreve uma acentuada e breve curva na região do pescoço para então descer com uma ligeira perturbação no centro até abaixo da linha do tórax, o qual encontra atrás das pernas da frente. Daí ela se prolonga em um segmento ascendente até a virilha, a partir de onde se projeta o sexo. As pernas são robustas, bem modeladas e exibem os volumes da anatomia bovina. Os cascos são bem moldados e delineados. A linha dorsal descreve um arqueamento muito discreto na região central das costas e a partir desse ponto adquire um impulso ascendente até o alto da cabeça. A cauda espessa desce acompanhando o perfil das pernas traseiras, às quais está unida em suas partes superior e inferior.

O artefato exibe boas proporções, o porte robusto e viril de um touro jovem e qualidades ímpares no seu nível de detalhamento e técnica de fundição. Seu estado de conservação é excelente.
Altura: $9,7 \mathrm{~cm}$.

Comprimento: ?

Largura: ?

Triângulo: ?

Colar: sim; constituído de uma faixa decorada por grupos de segmentos perpendiculares.

Imagem alada I: sim, mas não identificada; asas estendidas sobre os ombros, formadas por três camadas de plumagem e cujas extremidades ultrapassam a linha inferior do manto.

Manto: sim; constituído de um retângulo disposto perpendicularmente em relação ao dorso decorado no interior com uma tela formando losangos.

Imagem alada II: sim, mas não identificada; asas estendidas sobre as ancas, formadas por três camadas de plumagem e cujas extremidades ultrapassam a linha inferior do manto.

Coleção: São Petersburgo, Hermitage Museum.

$\mathrm{N}^{0}$ de Inventário: 668.

No de Inventário no Global Egyptian Museum: 10/002/13694

Origem: desconhecida.

Datação: Período Tardio-Período Ptolemaico (?).

Outras particularidades:

Outros dados da bibliografia:

Bibliografia sobre o referido bronze:

http://www.globalegyptianmuseum.org/record.aspx?id= $\underline{13696}$ 


\begin{tabular}{|c|c|}
\hline & $\begin{array}{l}\text { Altura: } 4,8 \mathrm{~cm} \text { (sem pinos de fixação modernos) } \\
\text { Comprimento: } 4,75 \mathrm{~cm} \\
\text { Largura: - }\end{array}$ \\
\hline & $\begin{array}{l}\text { Triângulo: - } \\
\text { Colar: - } \\
\text { Imagem alada I: - } \\
\text { Manto: - } \\
\text { Imagem alada II: - }\end{array}$ \\
\hline Entre os chifres: disco com diâmetro inferior ao & \\
\hline $\begin{array}{l}\text { comprimento da cabeça. } \\
\text { Material: Bronze ? }\end{array}$ & Coleção: Paris, Musée du Louvre. \\
\hline Atitude: em pé, com pernas emparelhadas - galope?. & No de Inventário: E $1941 ?$ \\
\hline $\begin{array}{l}\text { Descrição: touro em pé, com pernas emparelhadas e sem base. Pinos } \\
\text { de fixaça modernos. Disco com diâmetro menor que o comprimento } \\
\text { da cabeça e com formas indistintas dos chifres que normalmente o } \\
\text { emolduram. A cabeça está estilizada e embora pareça rústica, sua } \\
\text { superfície assim como de todo o corpo é polida. Os olhos são } \\
\text { indicados por incisões circulares amplas e o focinho apresenta as } \\
\text { narinas e a boca. A papada desenvolve uma curvatura convexa que } \\
\text { termina pouco abaixo do peito. Daí progride como uma linha reta e } \\
\text { paralela ao eixo da base até a virilha. O sexo não está indicado. Os } \\
\text { cascos estão indicados embora não delineados, e as pernas frontais } \\
\text { exibem mais massa muscular do que as traseiras. O dorso descreve um } \\
\text { perfil retilíneo em leve aclive que ganha ímpeto no início dos ombros } \\
\text { para encaminhar até o cimo da cabeça, criando assim um volume } \\
\text { elevado que antecede esta. Cauda pendente vertical que acompanha o } \\
\text { perfil das pernas traseiras às quais está unida. } \\
\text { O artefato traz uma representação não usual do touro na estética } \\
\text { egípcia, com linhas amplas mas bem definidas. Sua identidade não é } \\
\text { sugerida nem por sua origem - que não foi comentada na ficha do } \\
\text { museu - nem pela simbologia, que está representada somente pelo } \\
\text { disco solar. Ainda que pareça rústico na sua concepção e apresentação } \\
\text { dos detalhes, apresenta superfícies lisas e seu porte lembra o dos } \\
\text { bronzes de Ápis do período Romano. }\end{array}$ & $\begin{array}{l}\text { Origem: ? (não mencionada na ficha do museu) } \\
\text { Datação: Período Tardio-Período Ptolemaico (?). } \\
\text { Outras particularidades: } \\
\text { Outros dados na ficha do museu: } \\
\text { ? } \\
\text { Pas de detail perceptible } \\
\text { Pas d'uraeus, triangle frontal pas (?) } \\
\text { AE026566 } \\
\text { Petits tenons modernes } \\
\text { Musée Guimet }\end{array}$ \\
\hline \multicolumn{2}{|l|}{ Bibliografia sobre o referido bronze: } \\
\hline
\end{tabular}




\begin{tabular}{|c|c|}
\hline & $\begin{array}{l}\text { Altura: } 2,1 \mathrm{~cm} \text { (com base) } \\
\text { Comprimento da base: }(2,1 \mathrm{~cm}) \\
\text { Largura: - }\end{array}$ \\
\hline & $\begin{array}{l}\text { Triângulo: - } \\
\text { Colar: - } \\
\text { Imagem alada I: - } \\
\text { Manto: - } \\
\text { Imagem alada II: - }\end{array}$ \\
\hline $\begin{array}{l}\text { Entre os chifres: disco com altura inferior ao comprimento da } \\
\text { cabeça. } \\
\text { Material: bronze? } \\
\text { Atitude: galope/ em pé (?); pernas dianteiras e traseiras } \\
\text { emparelhadas. } \\
\text { Descrição: bovino com pernas emparelhadas sobre base baixa. } \\
\text { Calosidade ou vestígio de pino de fixação na parte central e inferior da } \\
\text { base. Disco entre os chifres, cujas formas não são facilmente } \\
\text { reconhecidas pela fotografia. Cabeça simplificada, sem feições ou } \\
\text { orelhas (?) e perfil curvo. Papada e linha do pescoço unificadas. O } \\
\text { abdômen descreve uma reentrância na sua parte central e desce em } \\
\text { uma reta inclinada abaixo da virilha - indicação simplificada do sexo? } \\
\text { As pernas são rijas, praticamente retilíneas e sem detalhamentos } \\
\text { como, por exemplo, os cascos. O contorno dorsal descreve uma reta } \\
\text { paralela à base até pouco antes da região dos ombros onde } \\
\text { abruptamente desenvolve uma elevação que continua como uma reta } \\
\text { ascendente até o alto da cabeça. A cauda é modelada como uma } \\
\text { curva que se projeta para trás e termina abaixo da metade das pernas } \\
\text { traseiras. O pescoço e o tronco são demasiadamente alongados para } \\
\text { uma adequação às proporções dos artefatos mais elaborados. } \\
\text { A figurinha possui superfícies rugosas e acabamento rústico. }\end{array}$ & $\begin{array}{l}\text { Coleção: Paris, Musée du Louvre. } \\
\text { No de Inventário: E } 13546 \\
\text { Origem: ? (não mencionada da ficha do museu). } \\
\text { Datação: Período Tardio-Período Ptolemaico (?). } \\
\text { Outras particularidades: } \\
\text { Outros dados na ficha do museu: } \\
\text { Taureau disque? } \\
\text { Disque a uraeus? } \\
\text { Rondebosse aplatie } \\
\text { AE032075 } \\
\text { don Daressy } 1929 \\
8725\end{array}$ \\
\hline \multicolumn{2}{|l|}{ Bibliografia sobre o referido bronze: } \\
\hline
\end{tabular}




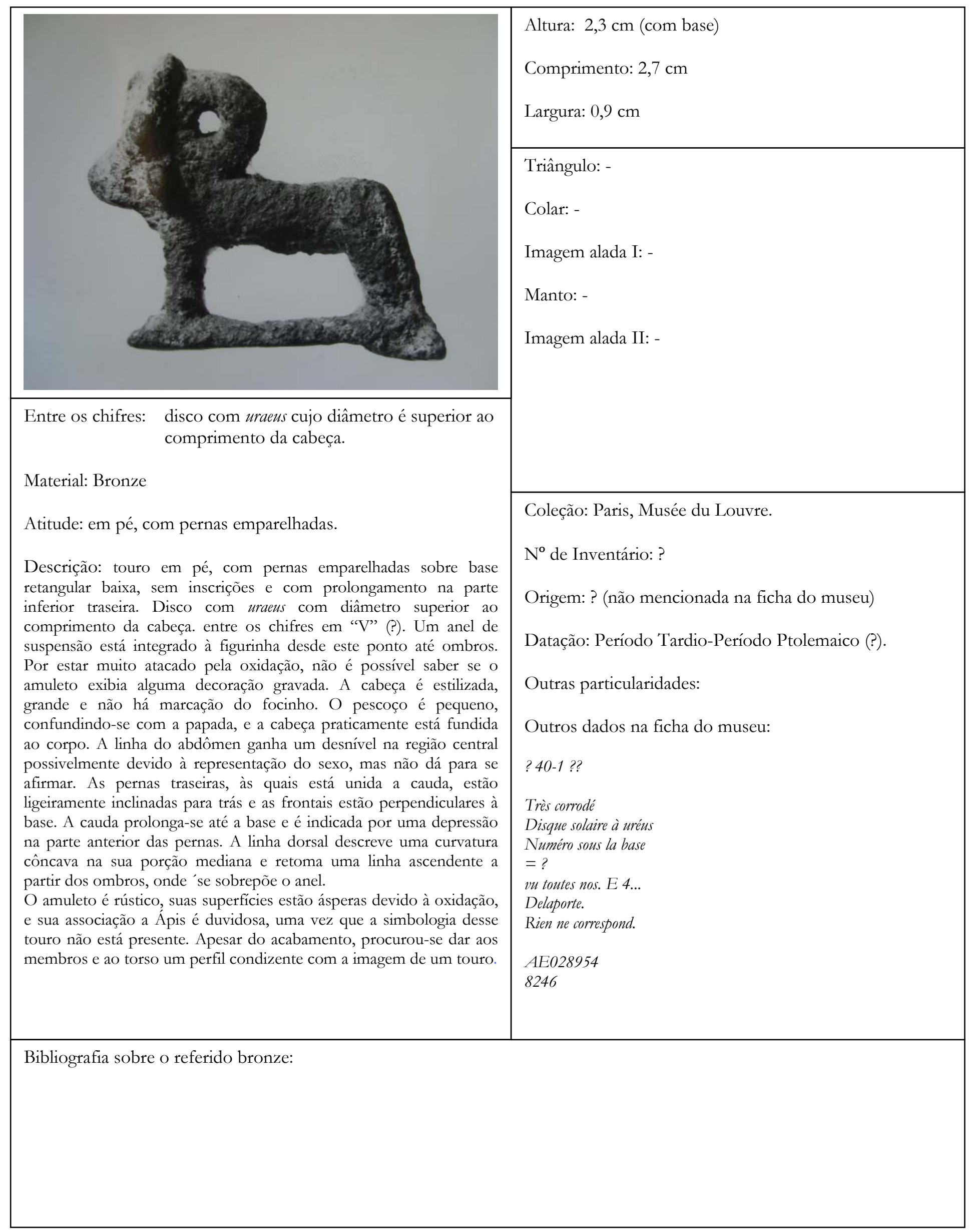




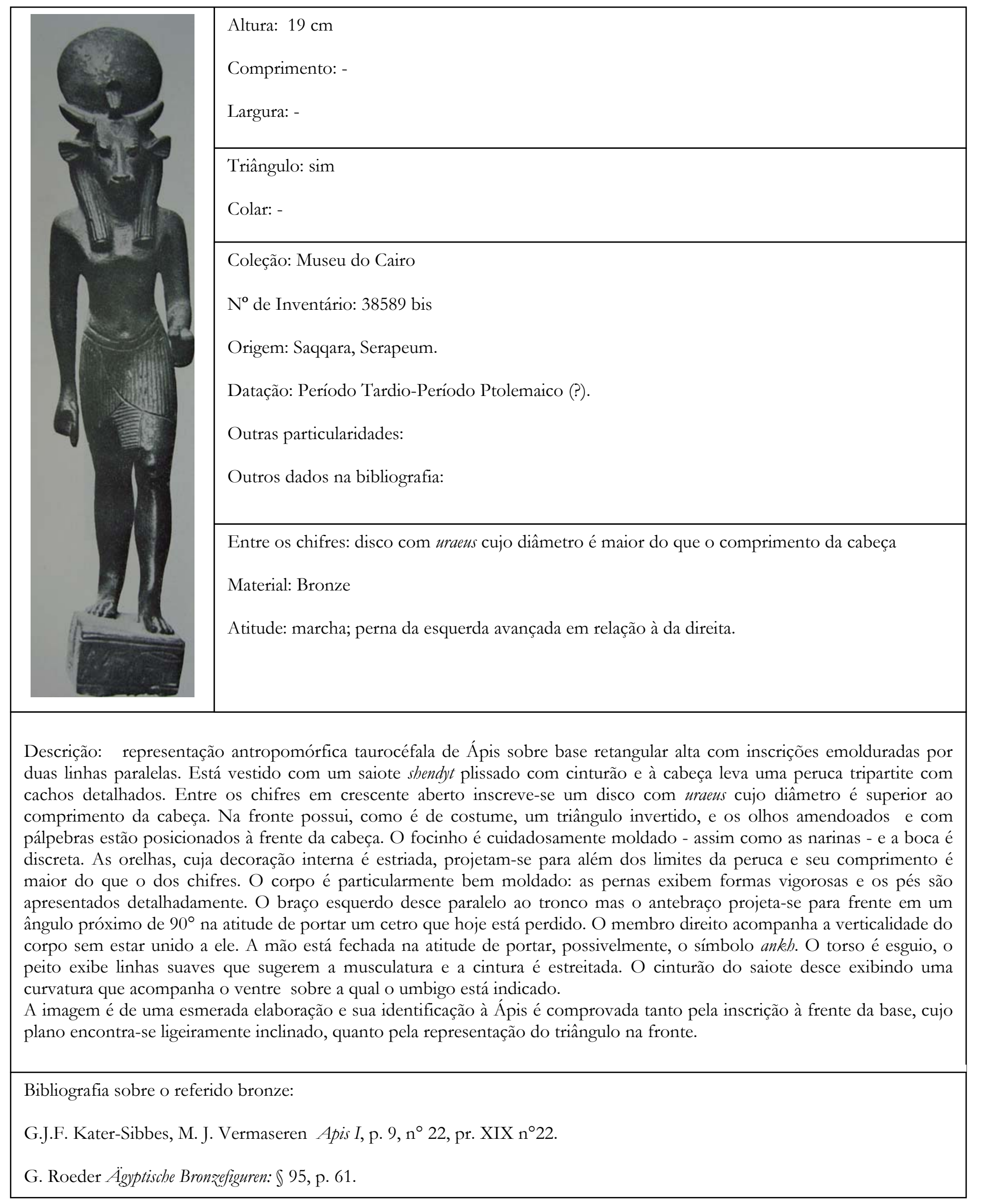




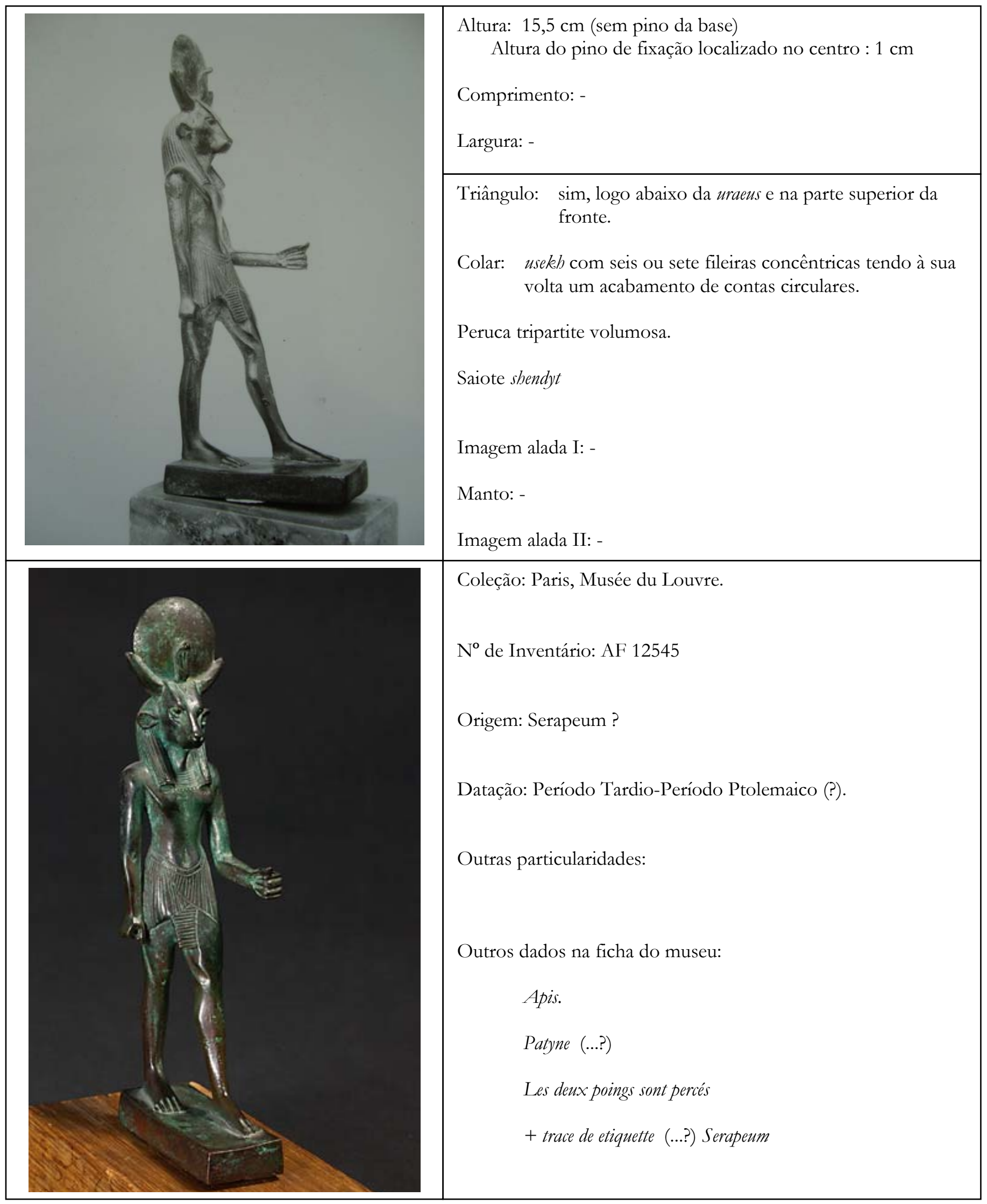


Entre os chifres: disco com uraeus maior que o comprimento da cabeça.

Material: bronze?

Atitude: marcha, com a perna esquerda avançada em relação a direita.

Descrição: representação antropomórfica taurocéfala de Ápis em atitude de marcha sobre base retangular alta sem inscrições. Disco com uraeus, maior que o comprimento da cabeça, entre chifres em crescente aberto. Colar usekh com seis ou sete fileiras, emoldurado por uma carreira exterior de contas arredondadas. Sobre ele repousam os cachos de uma peruca tripartite volumosa que passa por detrás das orelhas e da cabeça. O triângulo aparece claramente inciso abaixo da uraeus e no alto da fronte. O focinho é alongado, com dois pontos que representam as narinas, e os olhos amendoados inseridos acima dos arcos zigomáticos salientes dão uma expressão severa para o touro aqui divinizado. As orelhas são amplas, sua forma lembra aquela da cauda de certos peixes e está posicionada verticalmente no cruzamento das linhas dos chifres e da parte inferior dos olhos. O corpo da estatueta é esbelto e em alguns pontos como no peito, no braço e nas coxas nota-se os volumes da musculatura. No entanto, o antebraço esquerdo, que se encontra avançado para portar um cetro, hoje desaparecido, está demasiadamente alongado para as proporções do corpo. O braço direito desce paralelo ao torso e está destacado deste ao menos até metade do antebraço. A mão direita também contém uma perfuração que talvez servisse para a inserção de outro atributo, como o símbolo da vida ankh. Os pés estão bem modelados e as medidas estão de acordo com as outras partes. Saiote shendyt plissado com cinturão. A estatueta exibe uma modelagem bastante elaborada, com diversos elementos incisos, incluindo na representação da serpente uraeus, e a cor bordeaux do metal contrasta harmonicamente com a pátina esverdeada que se distribui principalmente pelo torso, cabeça e braços.

Bibliografia sobre o referido bronze:

http://cartelfr.louvre.fr/cartelfr/visite?srv $=$ car not frame\&idNotice $=19639$ 


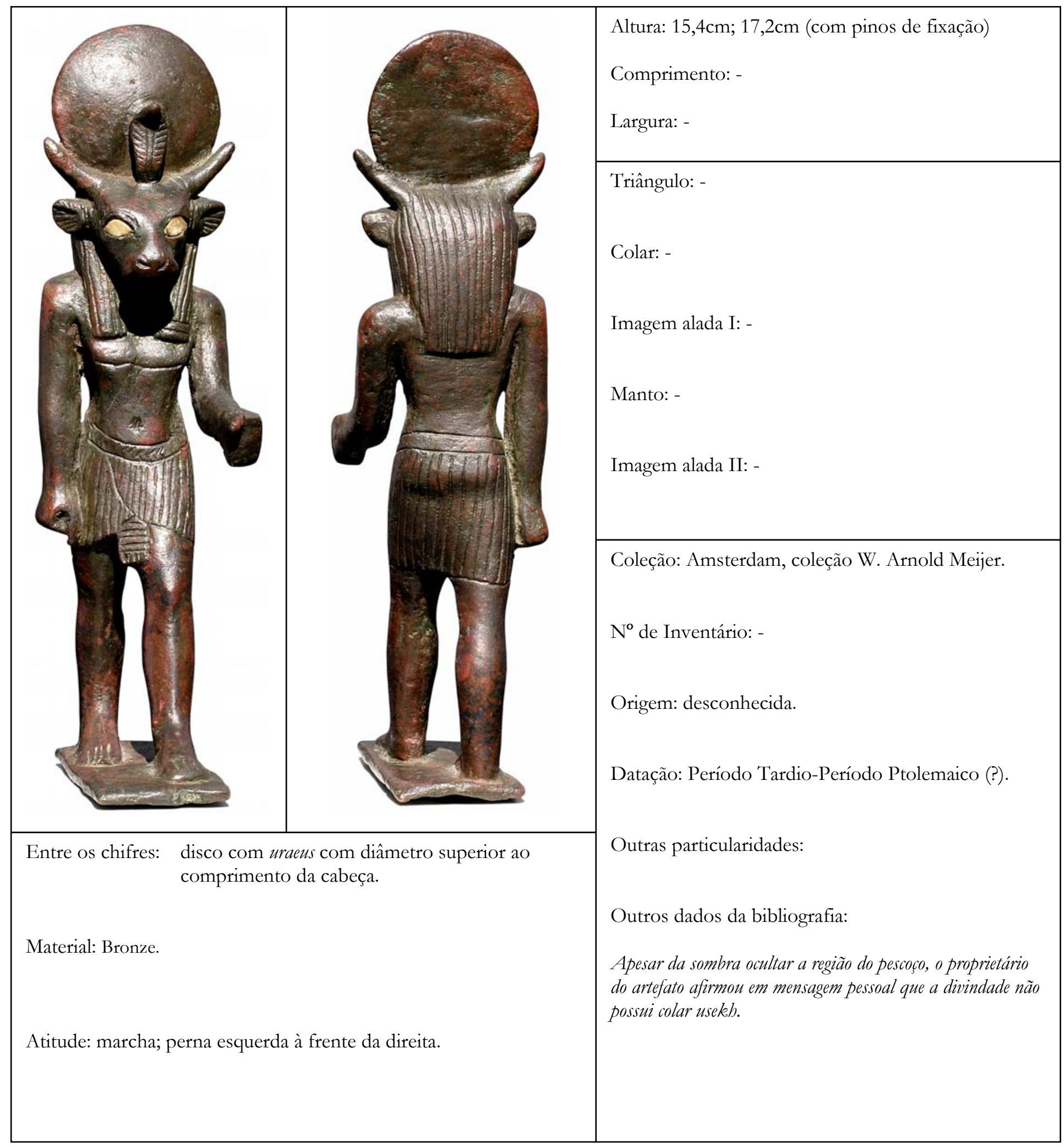




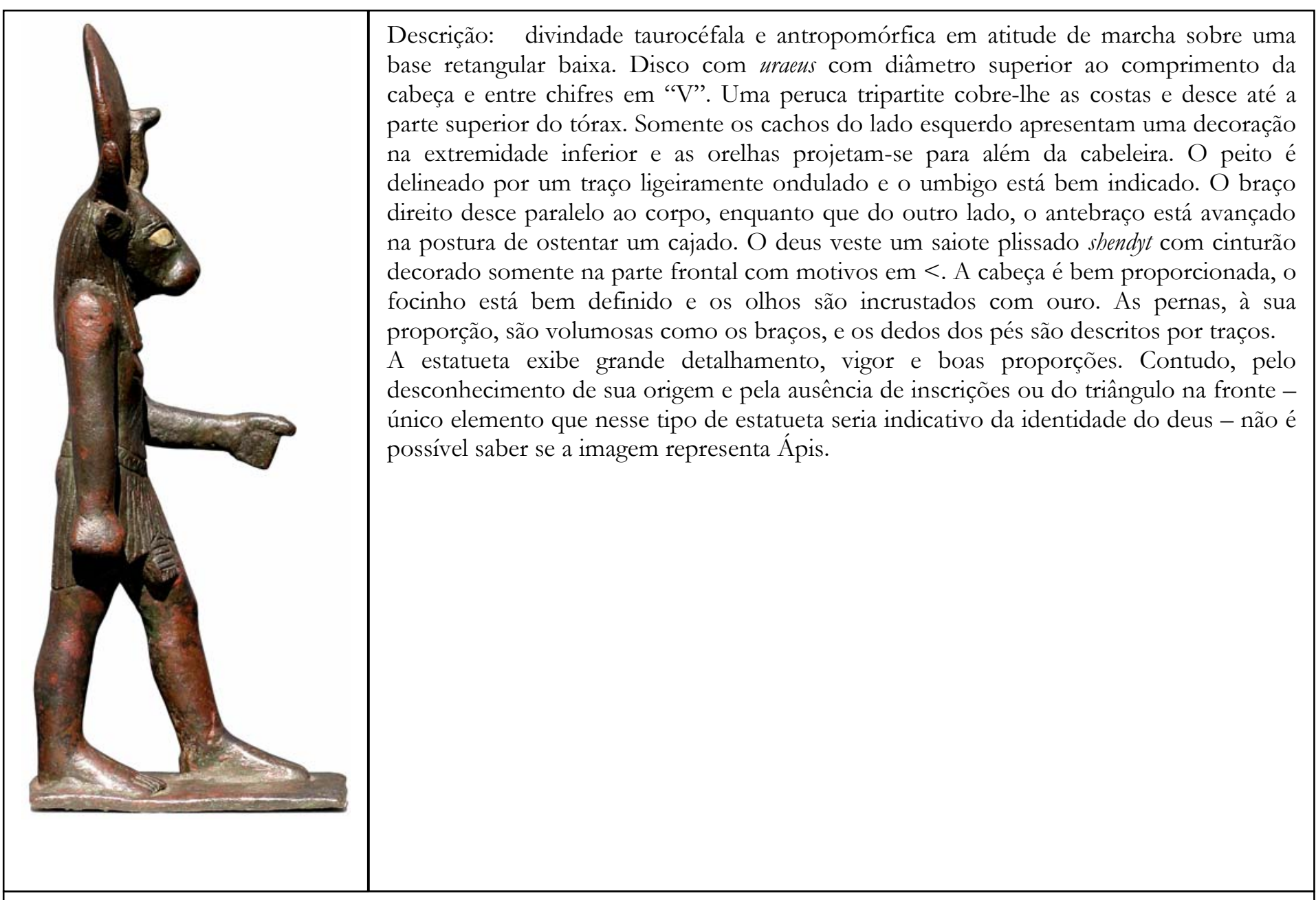

Bibliografia sobre o referido bronze:

W. Arnold Meijer in Carol A.R. Andrews, J. van Dijk Objects for Eternity, pp. 198-199, nº 3.18. 


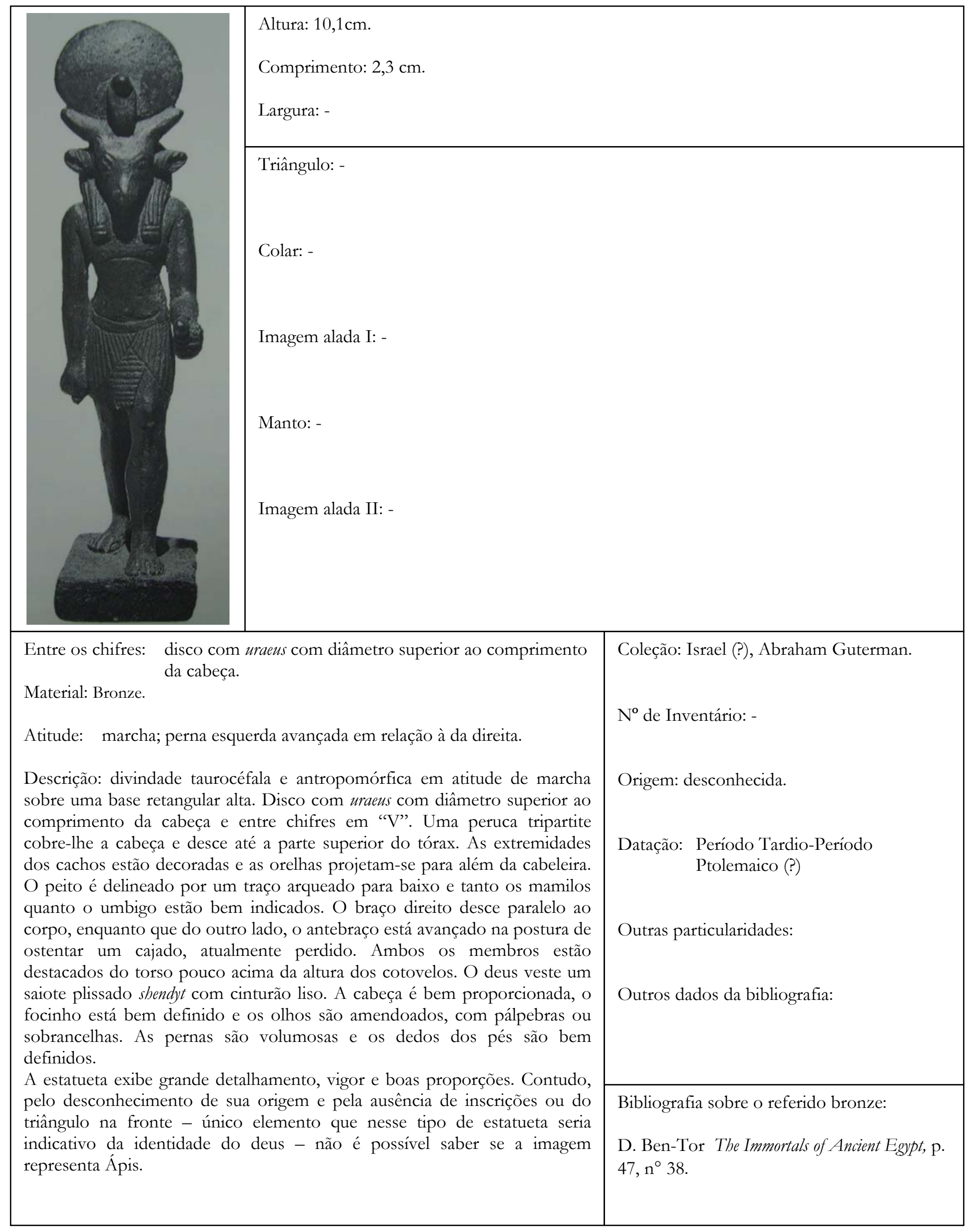




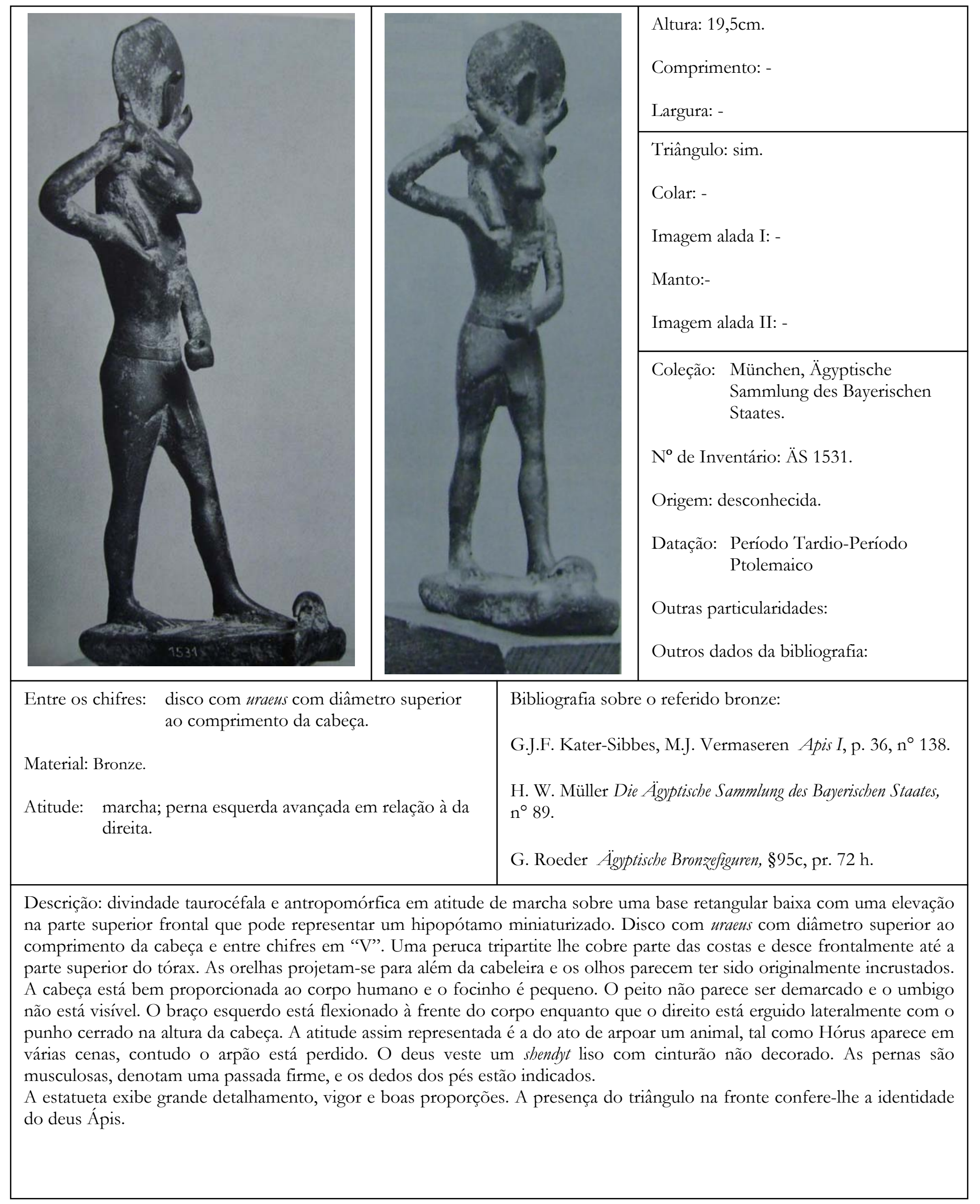




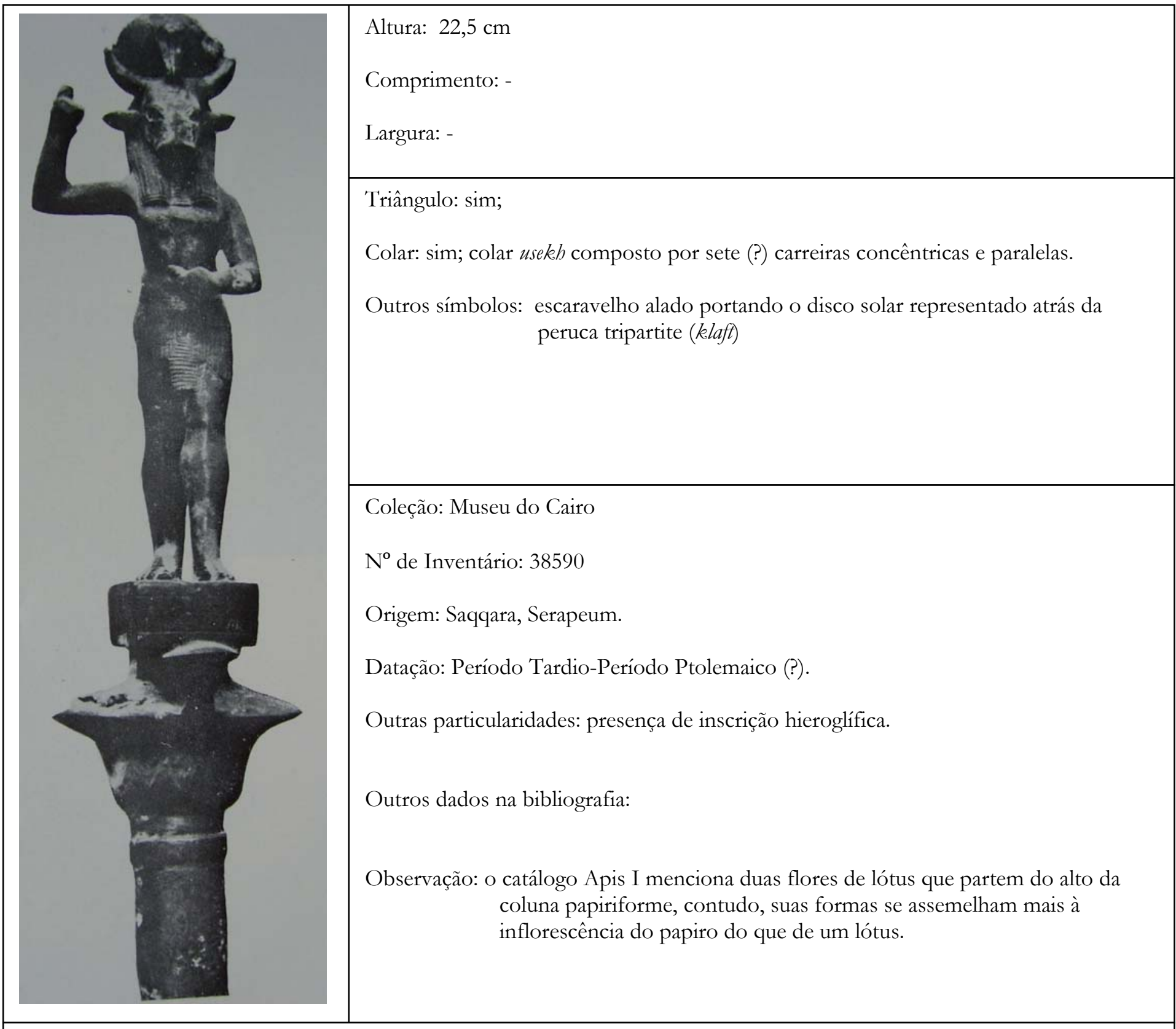

Entre os chifres: disco com uraeus elíptico cujo. comprimento é inferior ao da cabeça.

Material: Bronze

Atitude: marcha; perna da esquerda avançada em relação à da direita.

Descrição: representação antropomórfica taurocéfala de Ápis sobre base retangular alta, com inscrições. Esta está assentada em uma elevação sobre uma coluna papiriforme, de onde partem dois motivos decorativos - atrás e à frente - também no modelo de uma flor de papiro. Está vestido com um saiote shendyt plissado com cinturão e à cabeça leva uma peruca tripartite (klaft) volumosa com cachos detalhados. Entre os chifres em crescente aberto inscreve-se um disco elíptico com uraeus bem destacada e cuja altura é inferior ao comprimento da cabeça. Na fronte possui, como é de costume, um triângulo invertido, e os olhos amendoados e com pálpebras estão posicionados à frente da cabeça. O focinho e a cabeça são largos e as orelhas projetam-se para além dos limites da peruca. O corpo é bem moldado: as pernas têm formas vigorosas, com panturrilhas volumosas e os pés são apresentados com detalhe. O braço esquerdo vem à frente, com o punho localizado na altura do umbigo, e o direito está erguido paralelamente à linha da base com o antebraço elevado em certa inclinação. O respectivo punho também está fechado e pela postura presume-se que a imagem portasse uma lança ou arpão. 
O torso é esguio, as linhas do peito são sugeridas e a cintura é estreitada. O cinturão do saiote desce exibindo uma curvatura que acompanha o ventre sobre a qual o umbigo possivelmente está indicado.

A imagem é de uma esmerada elaboração e sua identificação a Ápis é comprovada tanto pela inscrição à frente da base quanto pela representação do triângulo na fronte. Por sua atitude, e pelos motivos decorativos que emergem da coluna papiriforme sugerindo a forma de um barco, é possível que esta representação esteja associada à imagem de Hórus na mesma atitude e golpeando um hipopótamo, que no caso encarnaria Seth. O artefato possivelmente constituía a extremidade de um cetro ou objeto ritualístico.

Bibliografia sobre o referido bronze:

G.J.F. Kater-Sibbes, M. J. Vermaseren Apis I, p. 9, n² 24, pr. XIX n²4. 


\begin{tabular}{|c|c|c|}
\hline A & \multicolumn{2}{|c|}{$\begin{array}{l}\text { Altura: } 12 \mathrm{~cm} \text { (sem pinos de fixação); } 1 \mathrm{~cm} \text { (base) } \\
\text { Comprimento: } 4,1 \mathrm{~cm} \text { (base). } \\
\text { Largura: } 1,8 \mathrm{~cm} \text { (base) }\end{array}$} \\
\hline ia) $\frac{3}{20}$ & \multicolumn{2}{|l|}{$\begin{array}{l}\text { Triângulo: sim. } \\
\text { Colar: - } \\
\text { Imagem alada I: - } \\
\text { Manto: - } \\
\text { Imagem alada II: - }\end{array}$} \\
\hline (1) & \multicolumn{2}{|c|}{$\begin{array}{l}\text { Coleção: privada. } \\
\text { No de Inventário: - } \\
\text { Origem: desconhecida. } \\
\text { Datação: Período Tardio-Período Ptolemaico. } \\
\text { Outras particularidades: } \\
\text { Outros dados da bibliografia: }\end{array}$} \\
\hline \multicolumn{2}{|c|}{$\begin{array}{l}\text { Entre os chifres: disco com diâmetro superior ao } \\
\text { comprimento da cabeça. }\end{array}$} & $\begin{array}{l}\text { Bibliografia sobre o referido bronze: } \\
\text { E. Doetsch-Amberger Osiris-Apis, pp.39-45. }\end{array}$ \\
\hline \multicolumn{3}{|c|}{$\begin{array}{l}\text { Descrição: divindade taurocéfala e antropomórfica em atitude de marcha sobre uma base retangular alta com inscrições e } \\
\text { pinos de fixação na sua parte inferior. Disco com diâmetro muito superior ao comprimento da cabeça e entre chifres em } \\
\text { crescente. A fronte é decorada com um triângulo invertido. Uma peruca tripartite cobre-lhe a cabeça e desce até a parte } \\
\text { superior do tórax e as orelhas projetam-se para além da cabeleira. O peito é modelado com esmero e o umbigo está bem } \\
\text { indicado. Ambos os braços descem paralelamente junto ao corpo e só se destacam deste em sua parte superior. O deus veste } \\
\text { um saiote plissado shendyt com cinturão estreito. A cabeça é bem proporcionada, o focinho está bem definido com as narinas } \\
\text { e boca, e os olhos são cuidadosamente delineados. As pernas são volumosas e vigorosas e os dedos dos pés estão bem } \\
\text { modelados. } \\
\text { A estatueta apresenta boas proporções e grande detalhamento nas suas partes. A inscrição na base e a presença de um } \\
\text { triângulo na fronte conferem à imagem divina a identidade de Ápis. }\end{array}$} \\
\hline
\end{tabular}




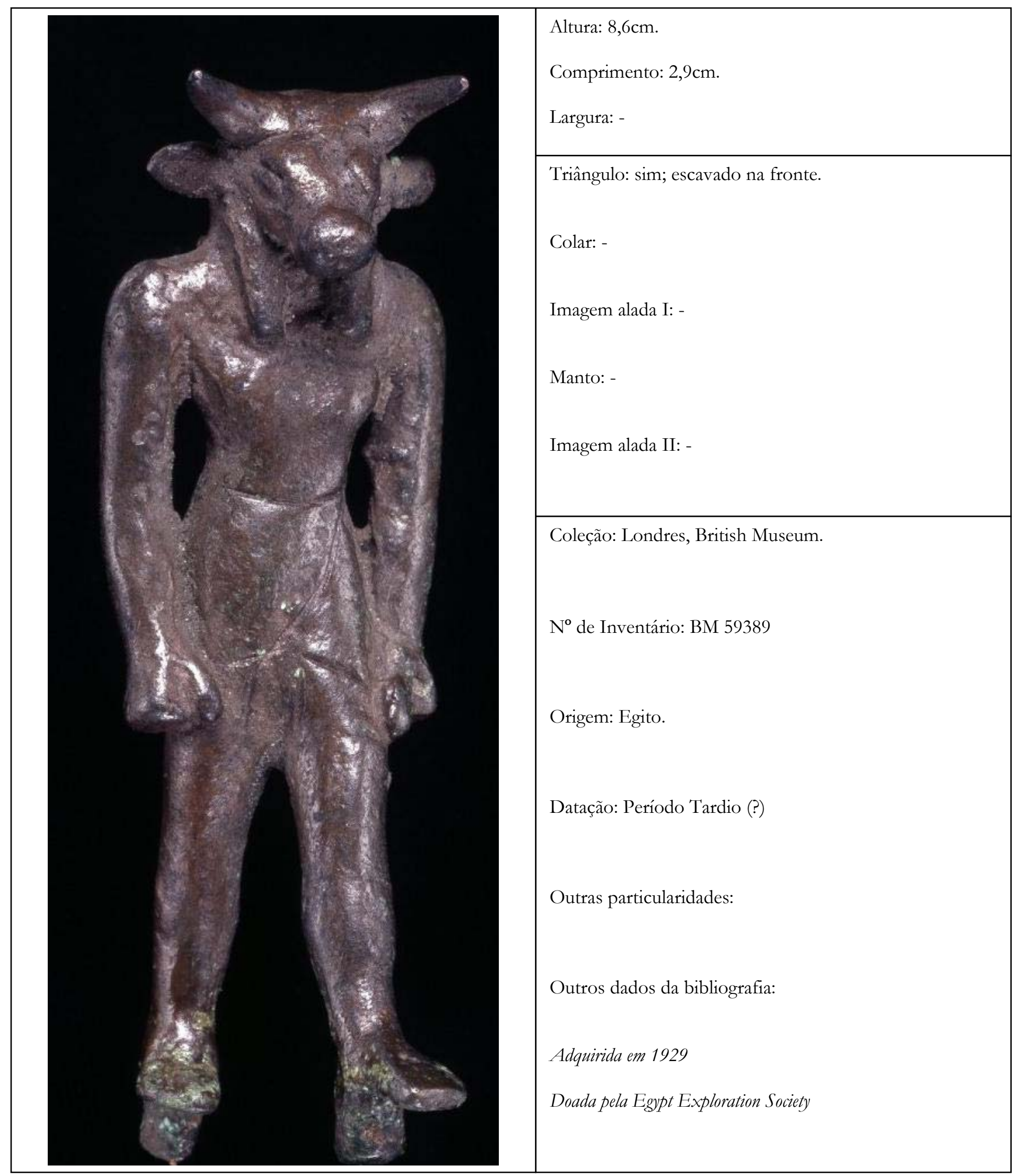


Entre os chifres: -

Material: liga de cobre.

Atitude: marcha; perna esquerda avançada em relação à da direita.

Descrição: divindade taurocéfala e antropomórfica em atitude de marcha, sem base e com pinos para fixação abaixo dos pés. Chifres em "V" desprovidos do símbolo solar. Uma peruca tripartite estreita e curta cobre-lhe as costas, desce até a parte superior do tórax e deixa as longas orelhas à mostra, projetando-se lateralmente para além da cabeleira. O peito se sobressai sutilmente em relação à barriga desprovida de umbigo. Os ombros são largos, dando maior vigor aos braços fortes que descem acompanhando o corpo, do qual estão destacados na sua parte mediana. O deus veste um saiote shendyt liso sem cinturão. A cabeça é bem proporcionada, o focinho sem narinas e boca está bem definido e os olhos são amendoados. As pernas são volumosas como os braços, pouco torneadas e os dedos dos pés não estão descritos.

Ainda que sumária quanto aos detalhes, a figurinha exibe vigor e boas proporções. Apesar de não ostentar um disco com uraeus, símbolo que não é exclusivo de Ápis, sua identidade como este touro é confirmada pelo triângulo exposto na fronte.

Bibliografia sobre o referido bronze:

http://www.britishmuseum.org/research/search the collection database/search object details.aspx?objectid=155001\&par tid $=1 \&$ searchText $=$ apis\&from $A D B C=$ ad\&toADBC $=$ ad\&numpages $=10 \&$ orig $=\% 2$ fresearch $\% 2$ fsearch the collection data base.aspx\&currentPage $=14$ 


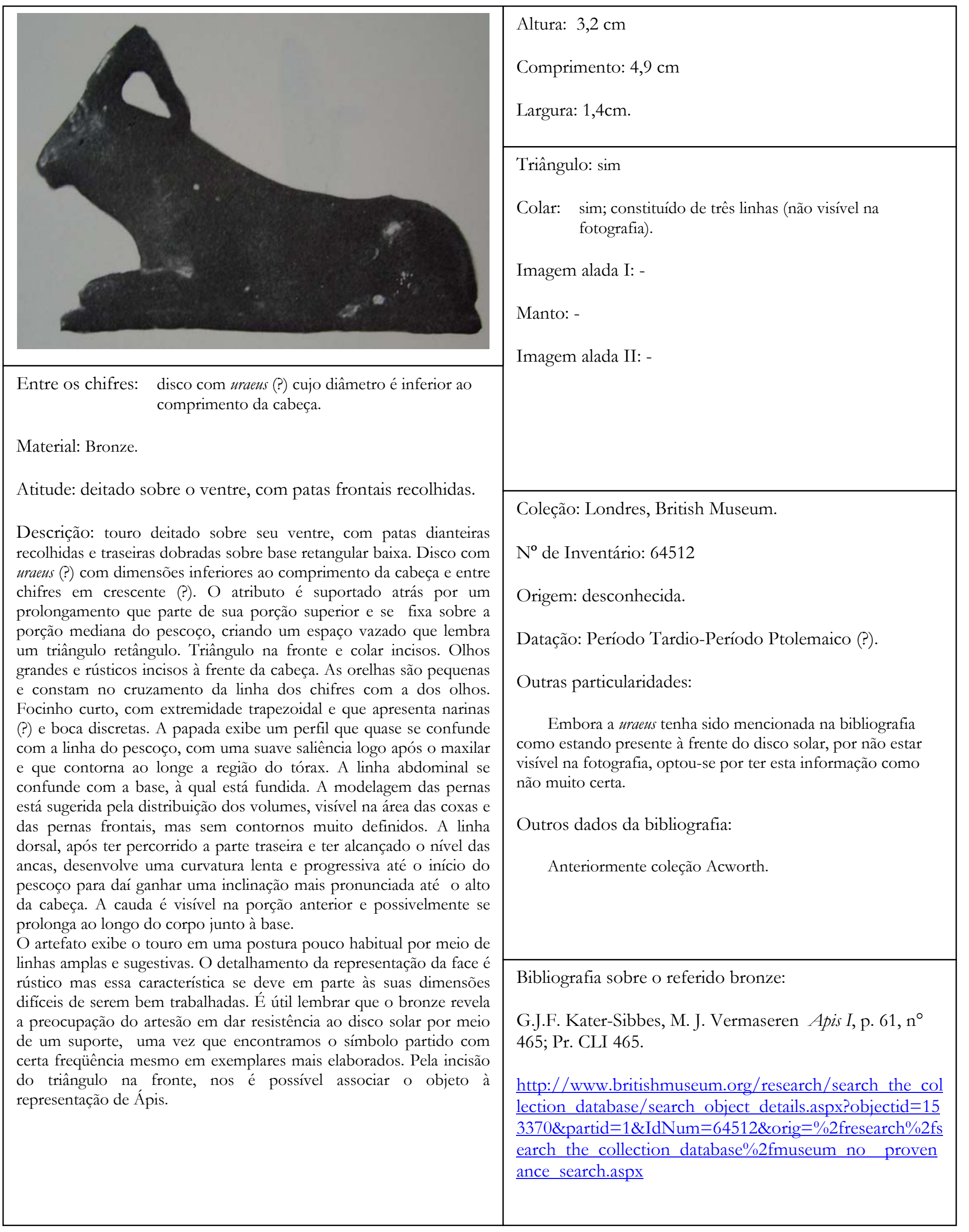




\begin{tabular}{|c|c|}
\hline & $\begin{array}{l}\text { Altura: } 3,5 \mathrm{~cm} \text { (sem pino de fixação) } \\
\quad \text { Altura do pino de fixação traseiro: } 1,5 \mathrm{~cm} \\
\text { Comprimento: } 7 \mathrm{~cm} \\
\text { Largura: - }\end{array}$ \\
\hline $\begin{array}{l}\text { Entre os chifres: - } \\
\text { Material: bronze? } \\
\text { Atitude: bovino deitado sobre o ventre com pernas dianteiras } \\
\text { recolhidas e as traseiras flexionadas. } \\
\text { Descrição: bovino deitado sobre base com laterais e frente retas } \\
\text { e perpendiculares e porção final curva acompanhando a silhueta } \\
\text { da parte traseira do animal. As laterais desta exibem um sulco } \\
\text { que parece percorrer todo o seu perímetro. Protuberância não } \\
\text { identificada no alto da fronte que pode ser a serpente uraeus. } \\
\text { Chifres quebrados (?). Olhos bem indicados, incisos e } \\
\text { direcionados para frente em uma cabeça com expressões } \\
\text { delicadas e projetada para além das pernas dianteiras recolhidas. } \\
\text { Orelhas na região da nuca e na linha superior aos olhos. Papada } \\
\text { com protuberância convexa abaixo do pescoço que depois } \\
\text { ganha feição de um declive em direção ao peito. Não se } \\
\text { distingue nem a linha do abdômen nem o sexo, uma vez que } \\
\text { estes, assim como as pernas, estão fundidos à base sem } \\
\text { qualquer detalhamento. No entanto, nota-se os volumes das } \\
\text { pernas traseiras e dianteiras recolhidas nas suas respectivas } \\
\text { posições. A cauda possivelmente está repousada sobre a base, } \\
\text { no lado direito, e a linha que se desenvolve dela até as ancas é } \\
\text { reta, ascendente e em um ângulo de } 45^{\circ} \text {. Logo depois, ela } \\
\text { continua a ascensão mas de forma mais suave até o alto da } \\
\text { cabeça. } \\
\text { O artefato está em ótimo estado de preservação e exibe } \\
\text { volumes trabalhados, mesmo que seus detalhes omitam } \\
\text { particularidades presentes em outras imagens de Ápis. }\end{array}$ & $\begin{array}{l}\text { Coleção: Paris, Musée du Louvre. } \\
\mathrm{N}^{\mathrm{o}} \text { de Inventário: N } 5134 \\
\text { Origem: desconhecida } \\
\text { Datação: Período Tardio-Período Ptolemaico (?). } \\
\text { Outras particularidades: } \\
\quad \text { Havia dois pinos de fixação: dianteiro quebrado. } \\
\text { Outros dados na ficha do museu: } \\
\quad \text { Patine genre Serapeum } \\
405 \\
\text { K } 5390 \\
\text { AE } 002853\end{array}$ \\
\hline Bibliografia sobre o referido bronze: & \\
\hline
\end{tabular}




\begin{tabular}{|c|c|}
\hline & $\begin{array}{l}\text { Altura: } 4,1 \mathrm{~cm} \\
\text { Diâmetro da base: } 6,5 \mathrm{~cm} \\
\text { Largura: - }\end{array}$ \\
\hline - & $\begin{array}{l}\text { Triângulo: - } \\
\text { Colar: - } \\
\text { Imagem alada I: - } \\
\text { Manto: - } \\
\text { Imagem alada II: - }\end{array}$ \\
\hline $\begin{array}{l}\text { Entre os chifres: - (?) não é possível afirmar pela fotografia } \\
\text { Material: Bronze ? } \\
\text { Atitude: Bovino deitado sobre seu ventre, com pata dianteira } \\
\text { esquerda esticada e a direita recolhida. } \\
\text { Descrição: Bovino deitado sobre seu ventre no alto de uma } \\
\text { calota, com pata dianteira esquerda esticada e as demais } \\
\text { recolhidas. A cauda, direcionada para frente, é espessa e } \\
\text { desenha uma curva sobre a base. A cabeça, um tanto pequena } \\
\text { para a corpulência do animal, está erguida como se este } \\
\text { observasse atentamente a algo, mas suas feições não estão } \\
\text { muito trabalhadas - possivelmente devido às reduzidas } \\
\text { dimensões do artefato. Entretanto, o focinho é bem modelado } \\
\text { e as orelhas parecem espelhar o mesmo esmero. Sobre a cabeça } \\
\text { há uma elevação difícil de se reconhecer - chifres ? Da nuca } \\
\text { parte uma linha descendente relativamente constante que se } \\
\text { acentua depois das ancas e continua desenhando a cauda. As } \\
\text { pernas procuram formas naturais e os volumes do corpo são } \\
\text { bem visíveis principalmente nas coxas e na região das costelas. } \\
\text { A papada é formada, grosso modo, por duas retas que se } \\
\text { encontram no início do pescoço, formando um ângulo aberto, e } \\
\text { unem assim a parte inferior do maxilar à região do peito. } \\
\text { A figurinha é elaborada, encontra-se em ótimo estado de } \\
\text { conservação e fixada a uma base moderna. }\end{array}$ & $\begin{array}{l}\text { Coleção: Paris, Musée du Louvre. } \\
\text { No de Inventário: E } 4430 \\
\text { Origem: ? (não mencionada na ficha do museu) } \\
\text { Datação: Período Tardio-Período Ptolemaico (?) } \\
\text { Outras particularidades: } \\
\qquad \text { das indicações da fotografia ou da ficha do museu. } \\
\text { Outros dados na ficha do museu: } \\
\text { AE00836 } \\
\text { Reserve des colonnes } \\
\text { D } 3262\end{array}$ \\
\hline Bibliografia sobre o referido bronze: & \\
\hline
\end{tabular}




\begin{tabular}{|c|c|}
\hline & $\begin{array}{l}\text { Altura: } 3,5 \mathrm{~cm} \\
\text { Comprimento da base: } 5,1 \mathrm{~cm} \\
\text { Largura: - }\end{array}$ \\
\hline & $\begin{array}{l}\text { Triângulo: - } \\
\text { Colar:- } \\
\text { Imagem alada I:- } \\
\text { Manto:- } \\
\text { Imagem alada II: - }\end{array}$ \\
\hline $\begin{array}{l}\text { Entre os chifres: traços de uma uraeus. } \\
\text { Material: Bronze ? } \\
\text { Atitude: bovino deitado sobre seu ventre com patas recolhidas. } \\
\text { Descrição: Bovino deitado sobre seu ventre, com patas } \\
\text { recolhidas e repousando em uma base retangular alta sem } \\
\text { inscrições. A cauda aparentemente desenha uma curva sobre a } \\
\text { coxa da perna direita. A cabeça, direcionada para frente, ergue- } \\
\text { se sobre um pescoço largo e comprido. O focinho é afinado, } \\
\text { lembrando as estatuetas de vacas, e os olhos arredondados. As } \\
\text { orelhas estão bem visíveis e encontram-se na intersecção da } \\
\text { linha dos olhos com aquela dos chifres. Estes são volumosos na } \\
\text { sua base mas estão quebrados pouco acima dela. A papada } \\
\text { desenvolve quase que um percurso linear descendente desde } \\
\text { cima, tendo uma ligeira saliência no fim do pescoço e outra, um } \\
\text { pouco mais pronunciada, na região do peito. Da nuca parte } \\
\text { uma linha descendente até o início do pescoço, a partir de onde } \\
\text { descreve uma paralela à base até às ancas, para assim descer } \\
\text { com a cauda. As pernas dianteiras são magras e as traseiras } \\
\text { estão fundidas ao corpo. } \\
\text { A figurinha, apesar do pescoço desproporcional e das pernas } \\
\text { traseiras não muito trabalhadas, procura formas harmoniosas e } \\
\text { certa expressividade à cabeça. Suas superfícies estão bastante } \\
\text { oxidadas, o que também pode ter comprometido a definição de } \\
\text { suas linhas. }\end{array}$ & 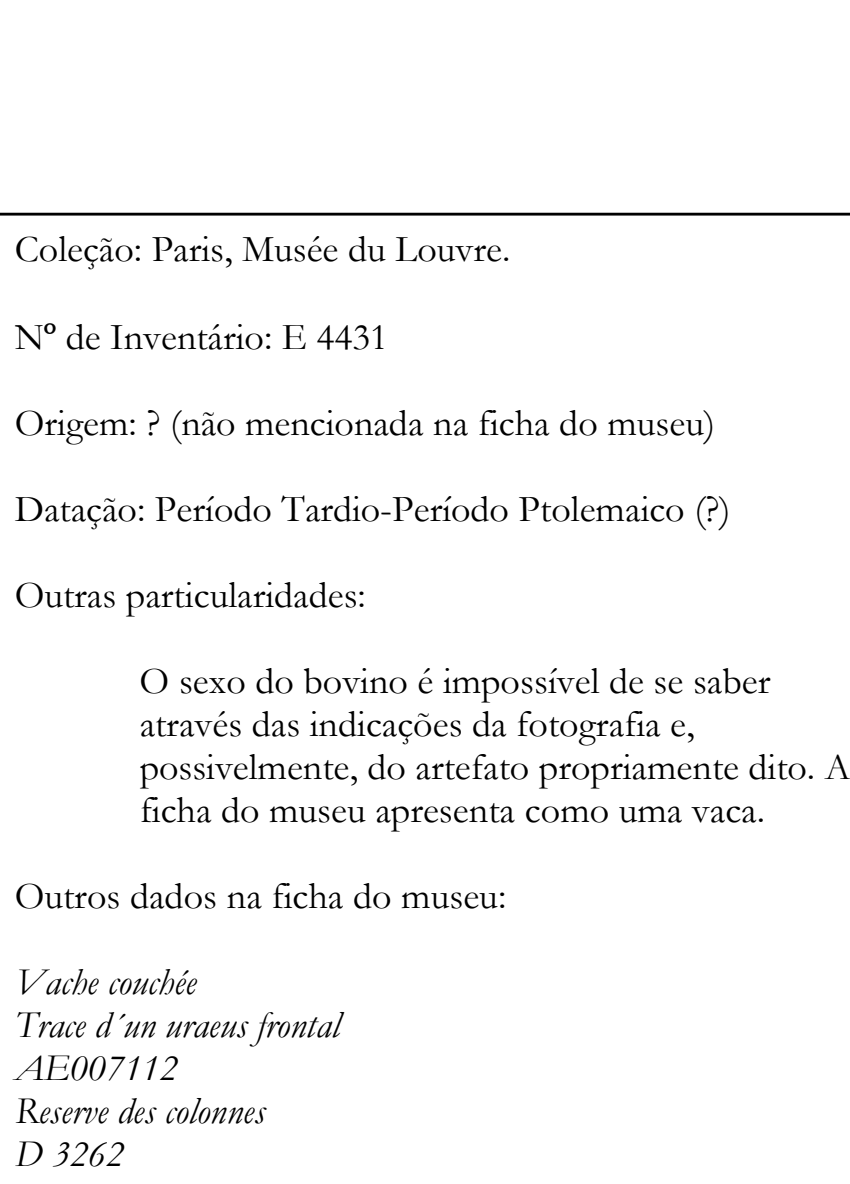 \\
\hline Bibliografia sobre o referido bronze: & \\
\hline
\end{tabular}




\begin{tabular}{|c|c|}
\hline & $\begin{array}{l}\text { Altura: ? } \\
\text { Comprimento da base: } 4,6 \mathrm{~cm} \\
\text { Largura da base: } 2,5 \mathrm{~cm}\end{array}$ \\
\hline & $\begin{array}{l}\text { Triângulo: - } \\
\text { Colar: - } \\
\text { Imagem alada I: - } \\
\text { Manto: - } \\
\text { Imagem alada II: - }\end{array}$ \\
\hline $\begin{array}{l}\text { Entre os chifres: - } \\
\text { Material: Bronze ? } \\
\text { Atitude: bovino deitado sobre seu ventre com patas recolhidas } \\
\text { Descrição: Bovino deitado sobre seu ventre, com patas } \\
\text { recolhidas e repousando em uma base em forma de ferradura } \\
\text { alongada alta sem inscrições. A cauda aparentemente desenha } \\
\text { uma ampla curva sobre a coxa da perna direita. A cabeça e } \\
\text { pescoço estão quebrados assim como seus chifres. A linha que } \\
\text { se desenvolve do início do pescoço e dos ombros e que aí se } \\
\text { encontra mais elevada, encontra um declive um pouco mais } \\
\text { pronunciado para percorrer o dorso numa inclinação constante } \\
\text { e, logo após as ancas, adquirir outra queda pronunciada para } \\
\text { percorrer a extensão da cauda. Ainda que muito oxidadas, } \\
\text { pode-se observar os volumes da musculatura das pernas } \\
\text { dianteiras ao passo que as particularidades das traseiras estão } \\
\text { mais imperceptíveis por estarem fundidas ao corpo. } \\
\text { A figurinha procura espelhar certas particularidades do bovino } \\
\text { quando deitado mas suas superfícies estão demasiadamente } \\
\text { oxidadas para se perceber maiores detalhes. Embora esteja } \\
\text { classificada como uma vaca na ficha do museu, sem maiores } \\
\text { informações é difícil se precisar. O artefato está fixo a uma } \\
\text { base moderna. }\end{array}$ & $\begin{array}{l}\text { Coleção: Paris, Musée du Louvre. } \\
\text { No de Inventário: E } 5927 \\
\text { Origem: ? (não mencionada na ficha do museu) } \\
\text { Datação: Período Tardio-Período Ptolemaico (?). } \\
\text { Outras particularidades: } \\
\text { Outros dados na ficha do museu: } \\
\text { Vache couchée } \\
\text { Tête a recoller } \\
\text { Cornes cassées } \\
\text { AE007113 } \\
\text { Reserve des colonnes } \\
\text { Xxxx } \\
\text { D } 3262\end{array}$ \\
\hline \multicolumn{2}{|l|}{ Bibliografia sobre o referido bronze: } \\
\hline
\end{tabular}




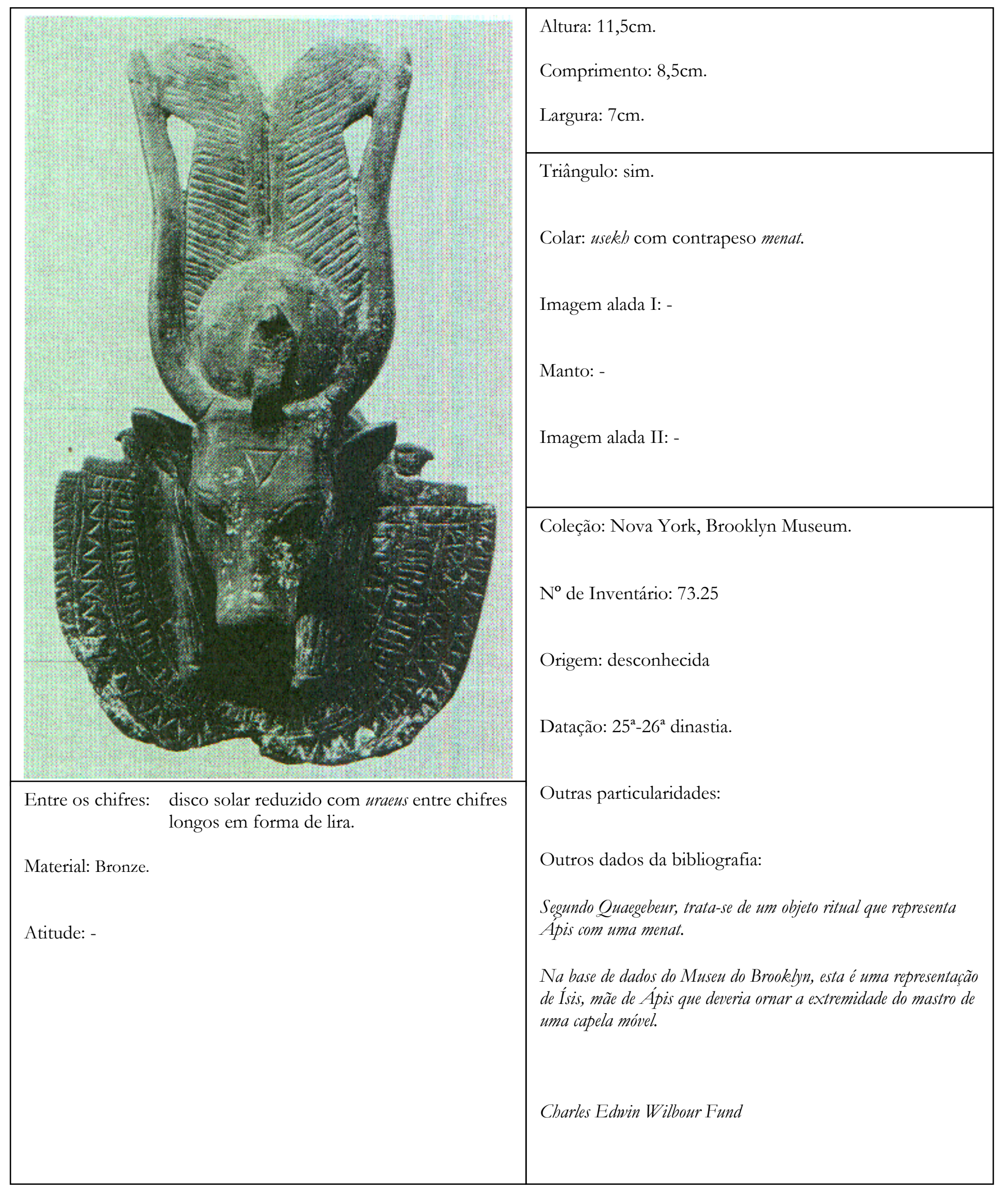




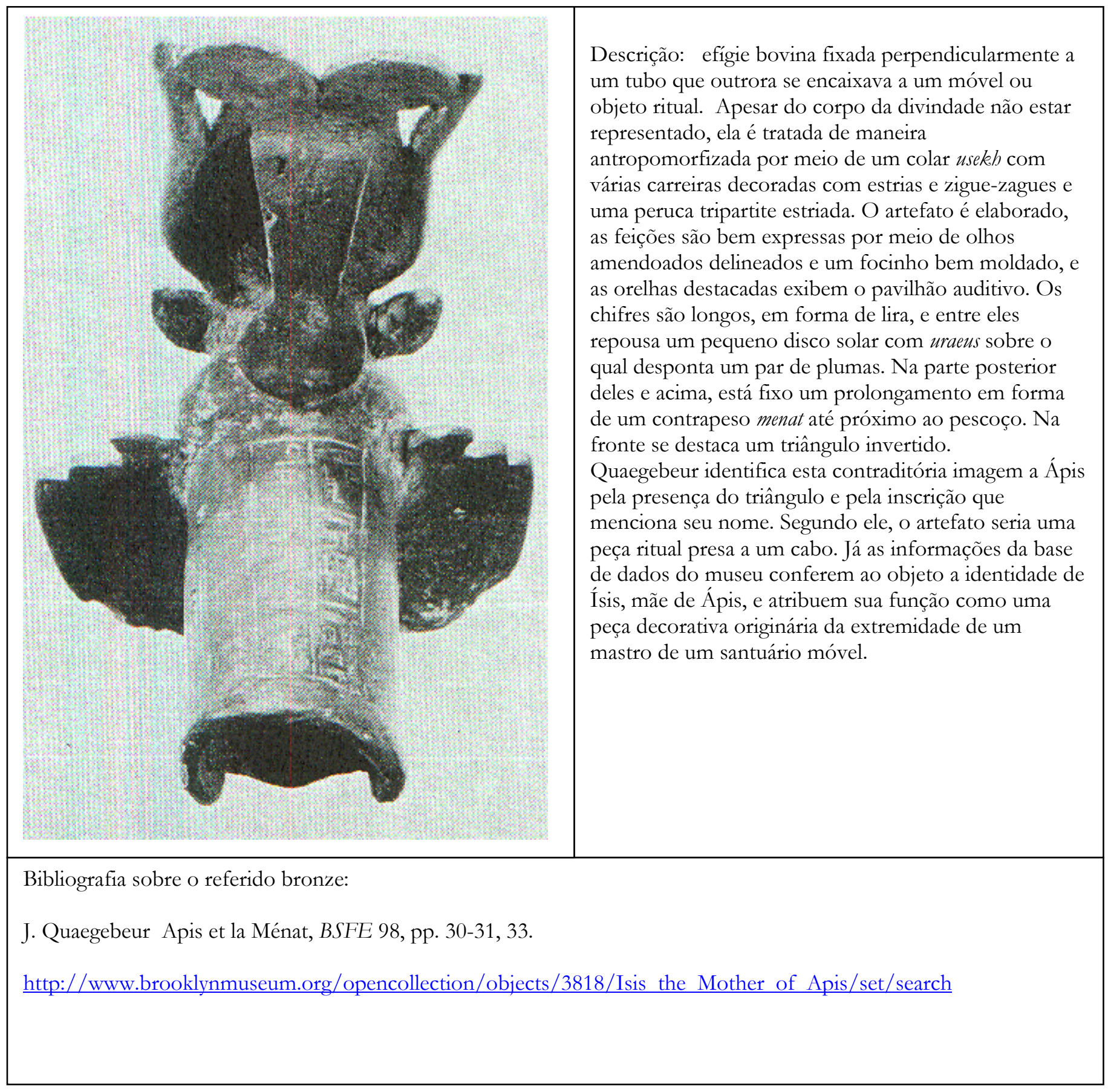

